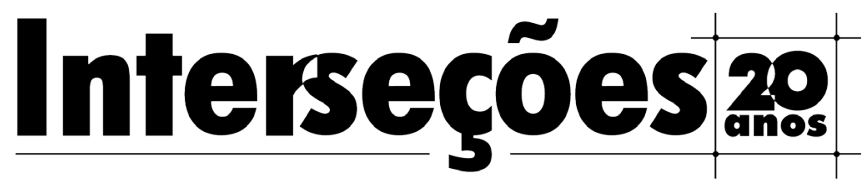

REVISTA DE ESTUDOS INTERDISCIPLINARES 


\section{UNIVERSIDADE DO ESTADO DO RIO DE JANEIRO}

Reitor

Prof. Ruy Garcia Marques

\section{Vice-Reitora}

Profa. Maria Georgina Muniz Washington

Sub-Reitora de Graduação

Profa. Tania Maria de Castro Carvalho Netto

Sub-Reitor de Pós-Graduação e Pesquisa

Prof. Egberto Gaspar de Moura

Sub-Reitora de Extensão e Cultura

Profa. Elaine Ferreira Torres

Centro de Ciências Sociais

Prof. Domenico Mandarino

Instituto de Ciências Sociais

Profa. Maria Claudia Pereira Coelho

Prof. Ronaldo de Oliveira Castro

Programa de Pós-Graduação em Ciências Sociais

Profa. Helena Bomeny (Coordenação Geral)

Prof. Paulo D'Avila Filho (Coordenação Adjunta)

Profa . Cecília Loreto Mariz (Coordenação Acadêmica) 


\section{Interseções 20 \\ REVISTA DE ESTUDOS INTERDISCIPLINARES}

ano 21 número 1

abril de 2019

Programa de Pós-Graduação em Ciências Sociais Universidade do Estado do Rio de Janeiro 


\section{Interseções \\ Revista de Estudos Interdisciplinares}

Interseções: revista de estudos

interdisciplinares é uma publicação organizada pelo Programa de Pós-Graduação em Ciências Sociais (PPCIS) da Universidade do Estado do Rio de Janeiro (UERJ). Seu objetivo é divulgar estudos baseados na interdisciplinaridade das ciências humanas, considerada indispensável para a reflexão sobre a realidade sociocultural dinâmica, cambiante e complexa do mundo contemporâneo.

\section{Editores}

Helena Bomeny, Maria Claudia Coelho e Paulo D’Avila

\section{Assistente Editorial}

Thayz Guimarães

\section{Estagiária}

Mayra Chomski

\section{Revisão de Texto}

Dayse Lúcia Mendes

\section{Tradução}

Marcelo Burgos

\section{Diagramação}

Sigaud \& Torres Gestão e Capacitação Empresarial

Publicação Quadrimestral - 2019.1

\section{Conselho Editorial}

Anália Torres (Instituto Universitário de Lisboa)

Bernardo Ferreira (Universidade do Estado do Rio de Janeiro)

Cecília Loreto Mariz (Universidade do Estado do Rio de Janeiro)

Carlos Aurélio Pimenta de Faria (Pontifícia Universidade Católica de Minas Gerais)

Cynthia Sarti (Universidade Federal de São Paulo)

Clara Araújo (Universidade do Estado do Rio de Janeiro)

Clara Cristina Jost Mafra (Universidade do Estado do Rio de Janeiro) in memoriam

Clarice Ehlers Peixoto (Universidade do Estado do Rio de Janeiro)

Claudia Barcellos Rezende (Universidade do Estado do Rio de Janeiro)

Guy Bellavance (Universidade de Quebec)

Hector Leis (Universidade Federal de Santa Catarina)

Helio R. S. Silva (Pontifícia Universidade Católica do Rio Grande do Sul)

Ítalo Moriconi (Universidade do Estado do Rio de Janeiro)

João Trajano Sento-Sé (Universidade do Estado do Rio de Janeiro)

José Machado Pais (Universidade de Lisboa)

José Reginaldo Gonçalves (Universidade Federal do Rio de Janeiro)

Josué Pereira da Silva (Universidade Estadual de Campinas)

Jurandir Freire Costa (Universidade do Estado do Rio de Janeiro)

Leonardo Avritzer (Universidade Federal de Minas Gerais)

Luiz Eduardo Soares (Universidade do Estado do Rio de Janeiro)

Luiz Flavio Costa (Universidade Federal do Rio de Janeiro)

Maria Josefina Gabriel Sant'Anna (Universidade do Estado do Rio de Janeiro)

Maria Luiza Heilborn (Universidade do Estado do Rio de Janeiro)

Marjo de Theije (Universidade Livre de Amsterdã)

Maurício Tenório-Trillo (Universidade de Chicago)

Myrian Sepúlveda dos Santos (Universidade do Estado do Rio de Janeiro)

Nélida Archenti (Universidad de Buenos Aires)

Paulo Henrique Novaes Martins de Albuquerque (Universidade Federal de Pernambuco)

Ricardo Benzaquen de Araújo (Pontifícia Universidade Católica do Rio de Janeiro) "in memoriam"

Roberto DaMatta (Pontifícia Universidade Católica do Rio de Janeiro)

Sergio Costa (Universidade Livre de Berlim)

Sidney Chalhoub (Universidade Estadual de Campinas)

Susana Durão (Universidade de Lisboa)

Valter Sinder (Universidade do Estado do Rio de Janeiro)

CATALOGAÇÃO NA FONTE

I61 Interseções: Revista de Estudos Interdisciplinares. - Ano 21, n.1 (2019)- . - Rio de Janeiro: UERJ, NAPE, 1999-

Anual (1999), Semestral (2000), Quadrimestral (2019)

Publicação do Programa de Pós-Graduação em Ciências Sociais da UERJ.

ISSN 2317-1456

1. Ciências humanas - Periódicos. 2. Ciências Sociais - Periódicos. I. Universidade do

Estado do Rio de Janeiro.

$\operatorname{CDU}(30) 05$

UERJ / REDE SIRIUS / PROTAT

Indexação:

Índice de Ciências Sociais do IUPERJ;

CLASE - Citas Latinoamericas en Ciencias Sociales y Humanidades;

LATINDEX - Sistema regional de información en linea para revistas científicas de America

Latina, el Caribe, España y Portugal;

EBSCO;

OPEN EDITION / Revues.org;

Cengage-Learning

Homepage: http://www.e-publicacoes.uerj.br/index.php/intersecoes/index 


\section{Sumário}

\section{Artigos}

A reconfiguração da sociologia no Brasil: expansão institucional e mobilidade docente.......7 Jacob Carlos Lima

DOI: $10.12957 /$ irei.2019.42300

Comida, imigrações e imaginários urbanos em cidades globais 49

Carla Pires Vieira da Rocha; Carmen Sílvia Rial

DOI: $10.12957 /$ irei.2019.42303

Participação e democratização da segurança pública no Brasil em perspectiva comparada: os casos de Rio de Janeiro e Pará 70

João Trajano Sento-Sé; Leandro Marinho

DOI: $10.12957 /$ irei.2019.42304

Razões da evasão: abandono escolar entre jovens no Brasil 99

André Salata

DOI: $10.12957 /$ irei.2019.42305

Em um dia qualquer: violência, simpatia e carisma pelas tramas das audiências de custódia em Cuiabá

Clark Mangabeira

DOI: $10.12957 /$ irei.2019.42306

A estética da desregulação da violência doméstica em Marina Colasanti 147 Carlos Magno Gomes

DOI: $10.12957 /$ irei.2019.42308

\section{Memoriais}

Memorial

Maria Claudia Coelho

DOI: 10.12957/irei.2019.42312

Memorial

Claudia Barcellos Rezende

DOI: 10.12957/irei.2019.42313 
Memorial ....................................................................................2 216

Clarice Ehlers Peixoto

DOI: $10.12957 /$ irei.2019.42314

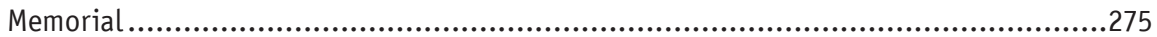

Myrian Sepúlveda dos Santos

DOI: $10.12957 /$ irei.2019.42315 


\section{Contents}

\section{Articles}

The reconfiguration of sociology in Brazil: institutional expansion and academic

Mobility. .7

Jacob Carlos Lima

DOI: $10.12957 /$ irei.2019.42300

Food, inmigrations and urban imaginaries in global cities 49

Carla Pires Vieira da Rocha; Carmen Sílvia Rial

DOI: $10.12957 /$ irei.2019.42303

The experiences of the state public safety councils: Rio de Janeiro and Pará in a comparative perspective 70

João Trajano Sento-Sé; Leandro Marinho

DOI: 10.12957/irei.2019.42304

Reasons for dropping out: school abandonment by the brazilian youth 99

André Salata

DOI: $10.12957 /$ irei.2019.42305

On any given day: violence, congeniality and charisma throughout the networks of the custody hearings in Cuiabá.....

Clark Mangabeira

DOI: 10.12957/irei.2019.42306

The esthetics of domestic violence deregulation in Marina Colasanti. 147

Carlos Magno Gomes

DOI: 10.12957/irei.2019.42308

\section{Memorials}

Memorial.

Maria Claudia Coelho

DOI: 10.12957/irei.2019.42312

Memorial 193

Claudia Barcellos Rezende

DOI: 10.12957/irei.2019.42313 
Memorial .........................................................................................2 216

Clarice Ehlers Peixoto

DOI: 10.12957/irei.2019.42314

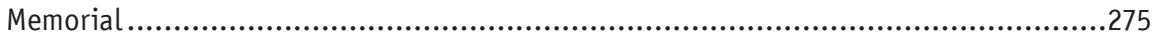

Myrian Sepúlveda dos Santos

DOI: $10.12957 /$ irei.2019.42315 


\section{Artigos}

\section{A reconfiguração da sociologia no Brasil: expansão institucional e mobilidade docente ${ }^{1}$}

Jacob Carlos Lima*

\section{Resumo}

Este artigo analisa a reconfiguração do campo da Sociologia no Brasil, tendo como recorte a expansão da graduação e da pós-graduação a partir dos anos 1980, que resultou num crescimento sem precedentes da pesquisa social no país. Esse processo se consolidou com a normatização da avaliação da pós-graduação, bem como com a implantação de políticas de fomento à formação e pesquisa e, a partir de 2003, de programas de expansão das universidades públicas, com novas universidades, novos campi, institutos federais e maior democratização do acesso a estudantes de baixa renda, cotistas e outros. Nesse período, houve uma forte renovação geracional propiciada, de um lado, pela abertura de novas vagas nas universidades públicas decorrentes de programas de expansão, como o PROUNI, e, de outro, pela aposentadoria de um número expressivo de professores que participaram da montagem e organização da pós-graduação de Sociologia em diferentes regiões do país. Esse conjunto de situações levou a um processo que estamos chamando de "nacionalização" do campo da Sociologia no Brasil. Nacionalização no sentido da construção de uma cultura acadêmica não mais restrita a pequenos grupos e regiões, mas à sua generalização pelo país de uma forma cada vez mais conectada com o desenvolvimento da disciplina internacionalmente. Para demonstrar essa afirmação utilizamos alguns indicadores: os dados do CCGE, que, por sua vez, utiliza dados da Plataforma Sucupira da Capes e da RAIS sobre número de cursos e titulados no mestrado e doutorado, assim como a situação diante do mercado de trabalho no período 1996-2014. Foram levantados também os cursos de graduação ativos no país a partir de 1933 e seu crescimento até 2018 através do site e-mec do Ministério da Educação. Utilizamos ainda a Plataforma Sucupira da Capes, para obter dados dos docentes disponíveis em todos os programas credenciados da área.

1 Uma versão preliminar deste texto foi apresentada no FÓRUM SBS /ANPOCS Internacionalização da Sociologia Brasileira: desafios e perspectivas, no $41^{\circ}$ Encontro Anual da ANPOCS em Caxambu (MG), outubro de 2018, mesa que se propunha a discutir algumas das questões aqui colocadas.

* Jacob Carlos Lima é professor titular no Departamento de Sociologia da Universidade Federal de São Carlos, é Doutor em Sociologia pela Universidade de São Paulo (1992), com Pós-doutorado no Department of Urban Studies and Development do Massachusetts Institute of Technology (EUA-2001). E-mail: calimajb@gmail.com. 


\section{Palavras-chave}

Sociologia no Brasil. Graduação e Pós-Graduação em Sociologia e Ciências Sociais. Institucionalização do campo da Sociologia.

\section{Abstract}

The article analyzes the reconfiguration of the sociology field in Brazil, from the expansion of undergraduate and graduate studies starting from the 1980s, which resulted in an unprecedented growth of social research in the country. This process was consolidated with the standardization of the graduate evaluation, as well as the implantation of development policies towards graduation and research. Moreover, since 2003, with the programs of public university expansion - new universities, new campuses, federal institutes of technical education - and the democratization of access to low-income students. During this period, there was a strong generational renewal promoted, on one hand, by the opening of new vacancies in public universities because of expansion programs, like PROUNI, and, on the other, the retirement of a significant number of professors and researches who participated in the organization of the graduate sociology studies in different areas of the country. This set of situations has led to a process we are calling the "nationalization" of the sociology field in Brazil. Nationalization in the sense of building an academic culture no longer restricted to small groups and areas, but to its generalization in the country in a more connected way with the development of the discipline internationally. In order to demonstrate this, we have used some indicators: the CCGE data, which, in turn, uses data from the Capes and RAIS Sucupira Platform, regarding the number of courses and master's and doctorate degrees, as well as the situation in the work market during the 1996-2014 period. The undergraduate courses active in the country, from 1933 and their growth until 2018, were obtained through the website of the Ministry of Education. We also used the Capes Sucupira Platform to obtain data regarding the faculty available and all accredited programs in the field.

\section{Keywords}

Sociology in Brazil. Under-Graduation and Graduation in Sociology and Social Sciences. Institutionalization of the Sociology Field.

Este texto objetiva discutir a reconfiguração do campo da Sociologia no Brasil, tendo como recorte a expansão da graduação e da pós-graduação a partir dos anos 1980, que resultou num crescimento sem precedentes da pesquisa social no país. Esse processo se consolidou com a normatização 
da avaliação da pós-graduação (que estabeleceu critérios de titulação e produção acadêmica), bem como com a implantação de políticas de fomento à formação e pesquisa e, a partir de 2003, de programas de expansão das universidades públicas, com novas universidades, novos campi, institutos federais e maior democratização do acesso a estudantes de baixa renda, cotistas e outros. Resultou dessa política o crescimento de cursos de graduação e pós-graduação e um mercado de trabalho com novas oportunidades de carreira aos titulados na área, num contexto de crescimento econômico e de implementação de políticas sociais.

Nesse período, houve uma forte renovação geracional propiciada, de um lado, pela abertura de novas vagas nas universidades públicas decorrentes de programas de expansão, como o PROUNI, e, de outro, pela aposentadoria de um número expressivo de professores que participaram da montagem e organização da pós-graduação de Sociologia em diferentes regiões do país. A nova geração destaca-se pela qualificação em centros nacionais e internacionais, refletindo-se numa maior atualização teóricometodológica, que propiciou uma maior padronização nos conteúdos ensinados, na formação de quadros e no estabelecimento de uma cultura acadêmica marcada pela publicação regular, na participação, seja em eventos acadêmicos nacionais e internacionais da disciplina, seja em redes nacionais e transnacionais de pesquisa. Essa renovação foi acompanhada pelo deslocamento geográfico dos doutores recém-concursados, rumo a departamentos e programas de pós-graduação localizados em diferentes regiões do país.

Esse conjunto de situações, e esta é nossa hipótese, levou a um processo que estamos chamando de "nacionalização" do campo da Sociologia no Brasil. Nacionalização no sentido da construção de uma cultura acadêmica não mais restrita a pequenos grupos e regiões, mas à sua generalização pelo país de uma forma cada vez mais conectada com o desenvolvimento da disciplina internacionalmente. A formação dos quadros da pós-graduação, ainda marcada pela presença dos programas pioneiros, diversifica-se cada vez mais através da abertura de cursos em todo o país com qualidade certificada por órgãos de regulação e fomento, como a Capes e o CNPq, baseando-se em critérios amplamente discutidos no campo, com seus consensos e conflitos. Embora ainda permaneça fortemente concentrada nos estados de São Paulo e Rio de Janeiro, a formação em Sociologia e Ciências Sociais está presente praticamente em todos os estados da federação, sendo que apenas a região Norte ainda não está plenamente atendida. 
A abertura de cursos de graduação e pós em novos campi, ou mesmo sua expansão nos demais, a partir de 2003, implicou deslocamentos espaciais numa dimensão ímpar, considerando os novos postos de trabalho abertos que canalizaram a demanda dos titulados sem vinculação institucional. Isto colocou novos desafios para se pensar a carreira de sociólogodocente-pesquisador em espaços sem tradição acadêmica ou de pesquisa, situação similar à existente, embora em menor escala, com a expansão das universidades federais havida na década de 1970. Essa expansão implicou a mobilidade espacial dos docentes e se verificou em dois momentos: na formação e na construção da carreira acadêmica. No primeiro caso, existe uma diversidade resultante da existência de cursos de pós-graduação nos locais de origem da formação graduada, o que mudou substancialmente nas últimas décadas. No segundo caso, vincula-se à inserção na carreira universitária em universidades públicas, privadas ou em atividades não acadêmicas. No caso da construção da carreira em uma universidade pública, a mobilidade fica mais evidente em seu início, tendendo depois à permanência em uma única universidade dada as especificidades da carreira. A partir daí essa mobilidade se manifesta mais na realização de pós-doutorados e na atuação como professores visitantes no país ou no exterior.

A pós-graduação, por sua vez, propiciou um diferencial na profissionalização do sociólogo, profissionalização aqui discutida nos limites da academia. Dados apresentados pela Capes apontam para uma situação positiva dos profissionais pós-graduados no mercado de trabalho no período de 2009 a 2014.

Neste quadro, procuramos apresentar alguns indicadores acerca dos cursos existentes e da composição do corpo docente dos programas de pósgraduação e sua diversificação. Os dados apontam essa mobilidade, mas não permitem verificar sua dimensão, uma vez que a pós-graduação filtra a entrada em favor de pesquisadores com maior produção ou engajamento na pesquisa, o que não é um impedimento em regiões com menor tradição acadêmica, mas represa nas demais. Além disso, a aposentadoria de um grande número de docentes que estiveram no início da institucionalização da pós-graduação não implicou necessariamente saída da pós-graduação, o que permite a transmissão de experiências e a manutenção de uma continuidade na formação e na pesquisa e uma certa complementação geracional. 
Entretanto, devemos lembrar que, durante a década de 1990, as universidades públicas enfrentaram grandes dificuldades em sua manutenção e expansão, em função de políticas de redução de gastos públicos e secundarização do ensino público enquanto política de governo. Com isso, a substituição de docentes ficou abaixo das necessidades, criando um gap geracional a partir dos concursos. Esse gap não aparece tanto a partir da participação docente na pós-graduação, exigindo um estudo mais extensivo acerca da composição dos departamentos de Sociologia e Ciências Sociais no país, o que não foi possível fazer para este texto.

Alguns indicadores dessa reconfiguração foram empregados nesta pesquisa: os dados do $\mathrm{CCGE}^{2}$, que, por sua vez, utiliza dados da Plataforma Sucupira da Capes e da RAIS sobre número de cursos e titulados no mestrado e doutorado, assim como a situação diante do mercado de trabalho no período 1996-2014. Foram levantados também os cursos de graduação ativos no país a partir de 1933 e seu crescimento até 2018 através do site e-mec do Ministério da Educação. Utilizamos ainda a Plataforma Sucupira da Capes, para obter dados dos docentes disponíveis em todos os programas credenciados da área. De forma complementar, selecionamos três departamentos de Sociologia e/ou Ciências Sociais com dados disponíveis on-line para complementação das informações acerca da mobilidade espacial docente.

Por fim, finalizamos com algumas observações sobre o campo da Sociologia e das Ciências Sociais no contexto das mudanças e lutas disciplinares na configuração da carreira.

\section{A graduação e a pós-graduação em Sociologia}

Podemos dizer que os tempos heroicos da disciplina, a partir dos cursos pioneiros de graduação e pós-graduação em Sociologia, foram encerrados com a reforma universitária de 1968, com a expansão do ensino superior privado e a instalação do novo formato da pós-graduação. O caráter ensaístico e as pesquisas que se tornaram canônicas na Sociologia brasileira nos seus primeiros 30 anos deram lugar então a uma cultura acadêmica marcada pela apresentação de resultados de pesquisa em seminários e

\footnotetext{
${ }^{2}$ CCGE (2016) - Centro de Gestão e Estudos Estratégicos. Mestres e doutores 2015 - Estudos da demografia da base técnico-científica brasileira.
} 
congressos nacionais e internacionais e sua publicação sistemática. A massificação do ensino superior veio acompanhada de um forte crescimento da comunidade acadêmica e de novos padrões de competição e cobrança de produção bem como de acesso a fontes de financiamento. Um processo sem volta que resultou ora em críticas ao produtivismo exacerbado dos órgãos de avaliação e fomento ora no reconhecimento de uma maior democratização no acesso da formação e mesmo da atuação profissional. O campo da Sociologia, antes restrito a pequenas comunidades de pesquisadores no Rio de Janeiro e São Paulo, deu lugar a uma vigorosa comunidade nacional de pesquisadores com crescente reconhecimento internacional pela qualidade da produção e formação ${ }^{3}$.

De 1933 a 1964, tivemos a abertura de 21 cursos de graduação em Sociologia e Política ou Ciências Sociais distribuídos em alguns estados da Federação. São Paulo concentrou a maioria com seis cursos, seguido pelo Rio de Janeiro com quatro, Rio Grande do Sul com três, Minas Gerais com dois, três no Nordeste (UFPE, UFBA, UFCG), um no Pará, um em Goiás e um no Paraná (Quadro 1). De certa forma, nesse período já podemos falar de uma formação distribuída nacionalmente, mas sem pesquisa de referência, que no geral se manteve de forma mais efetiva em São Paulo (ALMEIDA, 1987).

Quadro 1 - Cursos de graduação em Sociologia e/ou Ciências Sociais 1933-1964

\begin{tabular}{|c|c|c|c|}
\hline $\mathbf{N}^{\mathbf{0}}$ & Instituição & Município & $\begin{array}{c}\text { Ano de } \\
\text { fundação }\end{array}$ \\
\hline 01 & $\begin{array}{c}\text { Fundação Escola de Sociologia e } \\
\text { Política }\end{array}$ & São Paulo (SP) & 1933 \\
\hline 02 & USP & São Paulo (SP) & 1934 \\
\hline 03 & UFRJ (Universidade do Brasil) & Rio de Janeiro (RJ) & 1939 \\
\hline 04 & PUCRS & Porto Alegre (RS) & 1940 \\
\hline 05 & UFPR & Curitiba (PR) & 1940 \\
\hline
\end{tabular}

\footnotetext{
${ }^{3}$ Vários autores destacam esse período de formação com certa nostalgia de um passado idílico, no qual a universidade formava pessoas integrais, imbuídas da interdisciplinaridade do conhecimento. Pertinente enquanto uma crítica à burocratização e ao produtivismo do período posterior, não se considera, porém, o caráter extremamente restrito da universidade naquele período e mesmo da produção sociológica, limitada a um conjunto pequeno de textos canônicos. Sobre isso, vejam-se Leis (2000) e Perlatto (2017).
} 


\begin{tabular}{|c|c|c|c|}
\hline $\mathbf{N}^{\mathbf{0}}$ & Instituição & Município & $\begin{array}{c}\text { Ano de } \\
\text { fundação }\end{array}$ \\
\hline 06 & $\begin{array}{c}\text { UERJ (Universidade do Distrito } \\
\text { Federal) }\end{array}$ & Rio de Janeiro (RJ) & $1941(1953)^{4}$ \\
\hline 07 & UFMG & Belo Horizonte (MG) & 1941 \\
\hline 08 & UFBA & Salvador (BA) & 1941 \\
\hline 09 & PUCCAMP & Campinas (SP) & 1942 \\
\hline 10 & UFJF & Juiz de Fora (MG) & 1948 \\
\hline 11 & UFPE & Recife (PE) & 1950 \\
\hline 12 & UFPA & Belém (PA) & 1954 \\
\hline 13 & PUCRIO & Rio de Janeiro (RJ) & 1955 \\
\hline 14 & UNISINOS & São Leopoldo (RS) & 1958 \\
\hline 15 & UFRGS & Campina Grande & 1962 \\
\hline 16 & UFCG & (PB) & 1959 \\
\hline 17 & UFG & Goiânia (GO) & 1962 \\
\hline 18 & UNESP & Maráília (SP) & 1963 \\
\hline 19 & UNESP & São Paulo (SP) & 1964 \\
\hline 20 & PUCSP & Niterói (RJ) & 1964 \\
\hline 21 & UFF & & \\
\hline
\end{tabular}

Fonte: e-mec-MEC.

Nota: Não se consideram cursos abertos e fechados nesse período. O ano refere-se à autorização de funcionamento, o que nem sempre significou o início efetivo das atividades.

\footnotetext{
${ }^{4}$ Segundo Almeida (1987), a Universidade do Distrito Federal foi criada por iniciativa de Anísio Teixeira, então Secretário Municipal de Educação no governo de Pedro Ernesto em 1935, com quatro escolas: Escola de Filosofia e Letras; Instituto de Educação; Escola de Economia e Direito e Escola de Ciências. Buscava reproduzir o modelo da USP em São Paulo, com a proposta de uma universidade como "lugar de atividade científica livre e produção cultural desinteressada" (p.46). O contexto político da sua criação, entretanto, não foi favorável à sua continuidade. A partir da união de lideranças católicas conservadoras e o Ministério da Educação, o projeto foi abandonado e a reitoria entregue a Alceu de Amoroso Lima, que preparou o seu fechamento, que ocorreu em 1939. Em dezembro de 1950, foi criada a Universidade do Distrito Federal, atual UERJ, a partir de lei municipal. Embora com o mesmo nome, resultou da junção da Faculdade de Ciências Econômicas do Rio de Janeiro, da Faculdade de Direito do Rio de Janeiro, da Faculdade de Filosofia do Instituto La-Fayette e da Faculdade de Ciências Médicas. A Faculdade de Filosofia do Instituto La-Fayette, criada em 1939, em maio de 1941 teve a autorização de funcionamento do curso de Ciências Sociais, que iniciou suas atividades em 1953. (UERJ. A Universidade. Apresentação. Histórico) (emec-MEC).
} 
Na pós-graduação, tínhamos praticamente dois programas no sistema anterior de mestrados e doutorados tutoriais, ambos em São Paulo 5 . Esses programas não pressupunham disciplinas, mas poderiam exigir a presença em seminários, dependendo do professor orientador. No mais, as atividades exigidas eram a organização de estudos e a pesquisa individualizada devidamente orientada. A partir de 1965, com o Parecer CFE no 977/65, aprovado em dezembro daquele ano, o modelo de pósgraduação norte-americano, com mestrados e doutorados, disciplinas e áreas de concentração, foi regulamentado, embora já houvesse cursos nesse formato.

A Universidade São Paulo e a Escola de Sociologia e Política foram as pioneiras na área (Quadro 2), sendo que a primeira se adequou ao novo formato em 1971, e a Escola de Sociologia Política manteve a forma tutorial até 1986, quando encerrou seu mestrado e doutorado, no momento em que a Capes passou a regular a pós-graduação no país, autorizando o funcionamento dos cursos (BARREIRA; CORTES; LIMA, 2018).

\section{Quadro 2 - Cursos de Pós-graduação em Sociologia e/ou Ciências Sociais 1933-}

1971

\begin{tabular}{|c|c|c|c|c|c|}
\hline & Instituição & Cidade & $\begin{array}{l}\text { Ano de } \\
\text { início }\end{array}$ & $\begin{array}{c}\text { Produção } \\
\text { no formato } \\
\text { pré-reforma } \\
\text { de } 1971\end{array}$ & $\begin{array}{c}\text { Desdobramentos } \\
\text { posteriores }\end{array}$ \\
\hline 1 & $\begin{array}{l}\text { Fundação } \\
\text { Escola de } \\
\text { Sociologia e } \\
\text { Política de } \\
\text { São Paulo }\end{array}$ & $\begin{array}{c}\text { São } \\
\text { Paulo }\end{array}$ & $\begin{array}{c}\text { MS 1943- } \\
1986 \\
\text { DR } 1945- \\
1986\end{array}$ & $\begin{array}{c}244 \text { (até 1986) } \\
82 \text { (até 1986) }\end{array}$ & $\begin{array}{l}\text { O programa manteve } \\
\text { o formato anterior } \\
\text { à reforma e foi } \\
\text { desativado em } 1986 . \\
\text { Escola Pós-Graduada } \\
\text { mantém cursos lato } \\
\text { sensu em Ciências } \\
\text { Sociais (2016). }\end{array}$ \\
\hline
\end{tabular}

\footnotetext{
${ }^{5}$ Segundo Sucupira (1980: 3): “a ideia de cursos de doutorado surge, pela primeira vez, com a Reforma Francisco Campos, em 1931. O Estatuto das Universidades Brasileiras (Decreto n? 19.851, de 11 de abril de 1931) previa o doutoramento de tipo europeu, com defesa de tese, 'atendidas outras exigências regulamentares dos respectivos institutos'. Por sua vez, o Decreto n? 19.852, também de 11 de abril de 1931, que dispunha sobre a organização da Universidade do Rio de Janeiro, criava cursos regulares de doutorado no campo do direito e das ciências exatas e naturais. Tais cursos constituíam, de fato, uma pós-graduação, que hoje denominamos stricto sensu".
} 


\begin{tabular}{|c|c|c|c|c|c|}
\hline & Instituição & Cidade & $\begin{array}{l}\text { Ano de } \\
\text { início }\end{array}$ & $\begin{array}{l}\text { Produção } \\
\text { no formato } \\
\text { pré-reforma } \\
\text { de } 1971\end{array}$ & $\begin{array}{c}\text { Desdobramentos } \\
\text { posteriores }\end{array}$ \\
\hline 2 & $\begin{array}{l}\text { Universidade } \\
\text { de São Paulo }\end{array}$ & $\begin{array}{c}\text { São } \\
\text { Paulo }\end{array}$ & $\begin{array}{c}1934 \\
\text { (primeira } \\
\text { tese em } \\
\text { 1945; } 1^{\mathrm{a}} \\
\text { dissertação } \\
\text { defendida } \\
\text { em } 1953\end{array}$ & $\begin{array}{c}25 \\
\text { dissertações } \\
\text { (Até 1970) } \\
20 \text { teses (até } \\
\text { 1970) }\end{array}$ & $\begin{array}{c}\text { Adotou o novo } \\
\text { formato a partir de } \\
1971 .\end{array}$ \\
\hline
\end{tabular}

Fonte: Sociologia USP, 2017.

Dados fornecidos pela Escola de Sociologia e Política de São Paulo (2014).

A reforma educacional de 1968 decorreu da preocupação da ditadura militar com a autonomia técnica e científica do país, e a pós-graduação se tornou uma política para atingir esses objetivos, assim como também a expansão do ensino superior privado e estatal. A reforma pressupunha a organização e expansão do sistema de universidades federais e do sistema privado empresarial, a articulação das atividades de ensino e pesquisa praticamente inexistente, a abolição das cátedras vitalícias, a introdução do regime departamental e de carreira acadêmica, com o ingresso e a progressão docente vinculados à titulação acadêmica, e, por fim, a criação de uma política nacional de pós-graduação, através de planos nacionais de pós-graduação ${ }^{6}$.

No período pós-1965 até 1980, foram criados 15 mestrados ${ }^{7}$, embora nem sempre voltados apenas à Sociologia, como nos casos da UFBA, que era de Ciências Humanas, e da UFPE, que era integrado com Economia, situação similar ao de Campina Grande, e ainda o da ESALQ-USP, em Piracicaba, de Ciências Sociais Rurais com Economia e Sociologia, que não sobreviveu ${ }^{8}$ (Gráfico 1).

\footnotetext{
${ }^{6}$ Para uma análise da reforma educacional de 1968, veja-se Saviani (2008).

7 Sobre experiências anteriores de pós-graduação na área, veja-se Barreira, Cortês e Lima (2018).

${ }^{8}$ Foi criado na ESALQ-USP, em 1966, o Mestrado em Ciências Sociais Rurais com as áreas de concentração em Administração, Economia e Sociologia Rural. Em 1975, Economia Rural e Sociologia Rural constituíram mestrados separados. O mestrado em Sociologia Rural foi extinto em 1981 por conflitos políticos internos com o afastamento de professores.
} 
Gráfico 1 - Mestrados 1967-1980

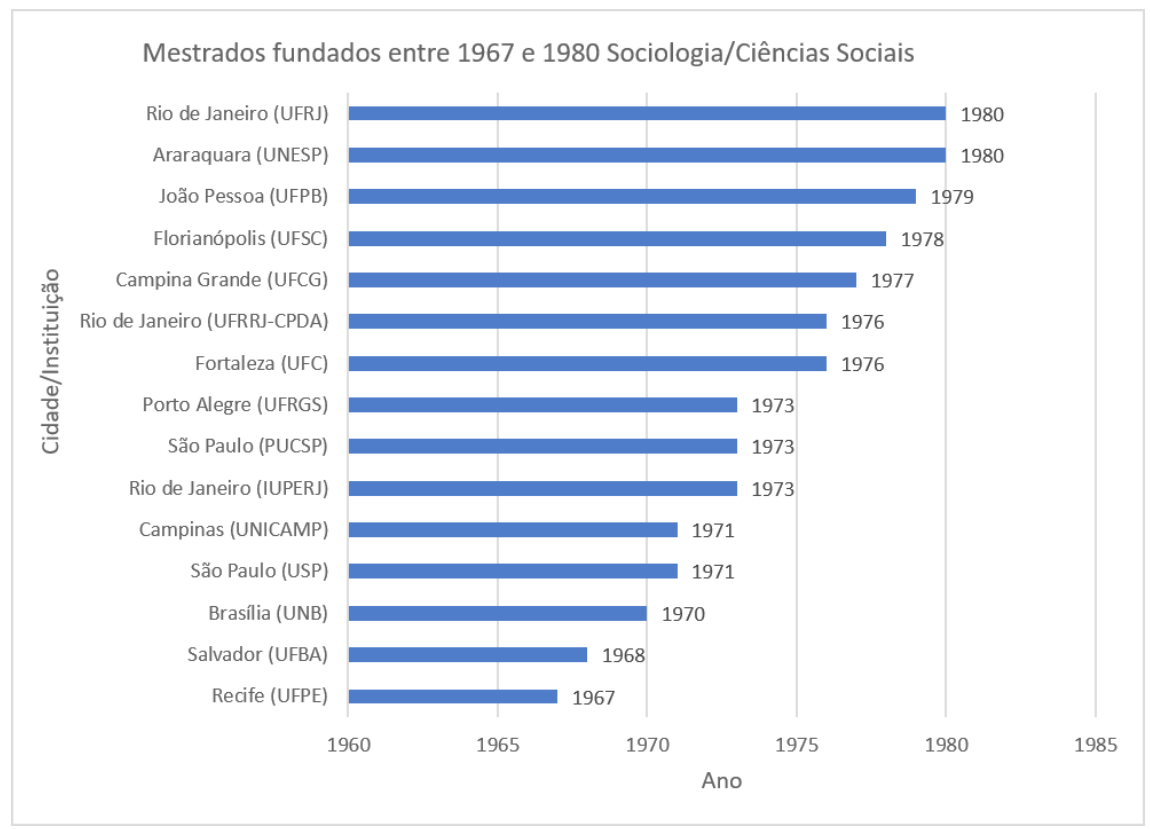

Fonte: Elaborado pelo autor a partir de dados da Capes (MEC-SESU, 2017).

Nota: A data de aprovação dos programas nem sempre coincide com seu funcionamento efetivo.

Os doutorados, com exceção da USP, tiveram início nos anos 1980, sendo que até 1990 seu número se restringia a cinco programas. Isso irá explicar que parte dos titulados, nesse período, obteve sua formação no exterior, vindo a compor o corpo docente da pós-graduação em expansão. Ilustrativo desse fato foi a composição dos credenciados do programa da UnB desde sua formação em 1970 até os anos 1990 (Gráfico 2).

\footnotetext{
${ }^{9}$ Farias e Tavolaro (2017) destacam os docentes que compuseram os quadros do Departamento de Sociologia e da pós-graduação em vários momentos e da sua titulação doutoral.
} 


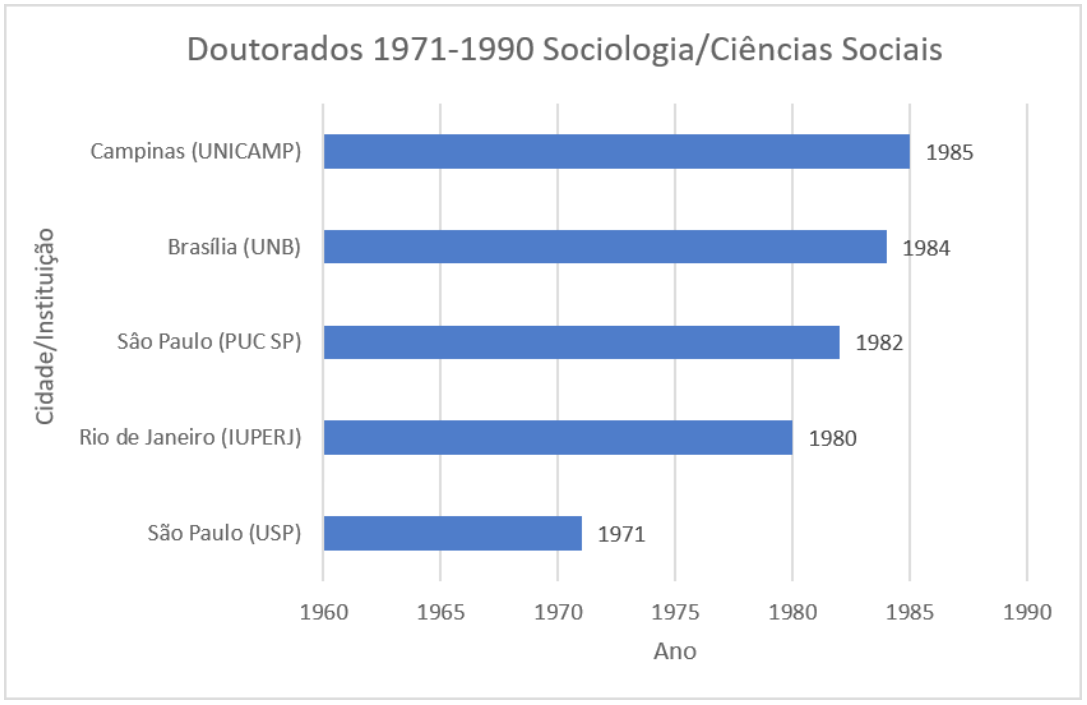

Fonte: Elaborado pelo autor a partir de dados da Capes (MEC-SESU, 2017).

A expansão das universidades federais e da pós-graduação provocou um primeiro deslocamento de docentes e pesquisadores para as diversas regiões do país, atraídos pelos novos postos de trabalho e um salário maior. Foi o caso, principalmente, das universidades do Norte e Nordeste, que receberam uma grande quantidade de docentes de todo o país e mesmo estrangeiros. Entre outros casos, podemos citar o da Universidade Federal do Acre, que, na década de 1970, por ser uma fundação, pagava salários mais altos que as universidades autárquicas, e outro, mais expressivo, da Universidade Federal da Paraíba, que, em função de um reitor que tinha sido presidente do CNPq e próximo aos militares, conseguiu investimentos que tornaram a Universidade o segundo maior orçamento entre as federais, atraindo docentes-pesquisadores nacionais e estrangeiros e investindo na expansão da graduação e pós-graduação. Nesse período foram criadas duas pós-graduações na Paraíba na área: o mestrado de Sociologia Rural em Campina Grande e o mestrado em Ciências Sociais em João Pessoa.

No âmbito da graduação, o período do regime militar promoveu a expansão de cursos privados em Ciências Sociais, mas que em sua maioria não sobreviveram. Alguns se mantiveram por mais de dez anos, mas a maioria fechou por não interessar às mantenedoras. Mesmo sendo cursos considerados "baratos", dada a baixa demanda, não são lucrativos (Quadro 3). 
Quadro 3 - Expansão da graduação em Ciências Sociais 1965-1985

\begin{tabular}{|c|c|c|c|c|c|}
\hline $\mathbf{N}^{\circ}$ & Instituição & Cidade & $\mathbf{1 9 6 0}$ & $\mathbf{1 9 7 0}$ & $\mathbf{1 9 8 0}$ \\
\hline 01 & Fundação Santo André & Santo André (SP) & 1966 & & \\
\hline 02 & UnB & Brasília (DF) & 1967 & & \\
\hline 03 & UERN & Mossoró (RN) & 1967 & & \\
\hline 04 & UFC & Fortaleza & 1968 & & \\
\hline 05 & Unimontes & Montes Claros (MG) & 1968 & & \\
\hline 06 & UFSC & Florianópolis (SC) & & 1972 & \\
\hline 07 & UEL & Londrina (PR) & & 1973 & \\
\hline 08 & UFRN & Natal (RN) & & 1974 & \\
\hline 09 & UFPI & Teresina (PI) & & & 1984 \\
\hline
\end{tabular}

Fonte: Elaborado pelo autor com dados do e-mec MEC, 2017.

Como esse dado inclui apenas os cursos ativos, apenas nove cursos novos foram registrados, que se somariam aos 21 existentes anteriormente (seis privados). Entretanto, dados do MEC, de 1973, computam a existência de 75 cursos, sendo que destes 49 estariam no Sudeste, o que permite ter uma ideia da dimensão da expansão do ensino privado após 1968 e de sua mortalidade (I PNPD 1975-1979). Em 1985, existiam apenas 30 cursos no país. Cerca de 45, aproximadamente, foram abertos a partir de 1965 e fechados posteriormente ${ }^{10}$. É interessante observar que a repressão política do período não impediu o aumento do número de cursos, embora tenha perseguido alunos e professores.

As crises econômicas e políticas nos estertores do regime militar inibiram novos investimentos nas universidades federais, provocando uma degradação da infraestrutura, greves generalizadas, comprometendo a permanência de docentes e impactando no desenvolvimento do ensino da graduação e pós-graduação ${ }^{11}$.

Mesmo assim, devemos destacar a implementação de políticas de capacitação docente pela CAPES e CNPq a partir do I PNPG - Plano Nacional de Pós-Graduação -1975-1979, para a titulação docente nos programas do Sudeste do país e do exterior, aumentando a mobilidade de

\footnotetext{
${ }^{10}$ Não conseguimos dados acerca do número de cursos abertos e desativados no período.

${ }^{11}$ A primeira universidade federal em São Paulo foi a UFSCar, no interior do Estado. Apenas a partir de 2003 outras universidades federais foram criadas em São Paulo, a Unifesp e a UFABC.
} 
docentes-pesquisadores. Além disso, tiveram início os encontros anuais da ANPOCS (1977), que marcaram o início dos congressos nacionais de forma sistemática, possibilitando maior visibilização da produção acadêmica do setor, até então muito restrita (BARREIRA; CORTÊS; LIMA, 2018). No início dos anos 1980, retornam do exterior os primeiros docentes titulados através do PICD, em grande parte vinculados a universidades do Norte-Nordeste, atraídos para o Sul-Sudeste e Distrito Federal por melhores condições de trabalho e acesso à pesquisa e à pós-graduação.

Na década de 1980, a pós-graduação em Sociologia teve um crescimento discreto com apenas quatro novos cursos de mestrado (UFMG, UFS, UFRN, UFSCar). Nos anos 1990 foram abertos 10 novos mestrados e 11 doutorados, mudando a configuração espacial da formação na área, apesar da falta de investimentos nas universidades federais.

\section{A expansão no período pós-2003}

A expansão do período 2003-2012 resulta de um conjunto de políticas públicas tendo no REUNI a sua versão mais completa. O programa, criado em 2007, integrava o Plano Nacional de Educação e resultou na criação de 18 novas universidades federais e 173 campi em cidades do interior do país. Resultou na mobilização e deslocamentos de docentes, em sua maioria titulados como doutores, para todas as regiões do país, criando novas demandas de pesquisa e financiamentos. Nos institutos federais, o crescimento foi maior ainda: das 140 escolas existentes no país em 2002, foram construídas mais 500 unidades, que passaram a integrar 644 campi. Em grande parte deles, a disciplina Sociologia está presente e, em alguns casos, com cursos de graduação em Ciências Sociais.

$\mathrm{Na}$ graduação temos agora uma nova situação decorrente dessa expansão. São 120 cursos, sendo 109 presenciais e majoritariamente em universidades públicas, com licenciaturas e bacharelados em todas as regiões do país (Tabela 1). 
Tabela 1 - Cursos de graduação em Sociologia e Ciências Sociais 1933-2017

\begin{tabular}{|c|c|c|c|c|c|c|}
\hline Tipo de instituição & $\begin{array}{c}\mathbf{1 9 3 3 -} \\
\mathbf{1 9 6 4}\end{array}$ & $\begin{array}{c}\mathbf{1 9 6 5 -} \\
\mathbf{1 9 8 5}\end{array}$ & $\begin{array}{c}\mathbf{1 9 8 6} \\
\mathbf{2 0 0 2}\end{array}$ & $\begin{array}{c}\mathbf{2 0 0 3 -} \\
\mathbf{2 0 1 7}\end{array}$ & EaD & Total \\
\hline Públicas & 16 & 08 & 20 & 49 & 01 & $\begin{array}{c}94 \\
(78,3 \%)\end{array}$ \\
\hline $\begin{array}{c}\text { Confessionais/sem } \\
\text { fins lucrativos }\end{array}$ & 05 & 01 & - & 01 & - & $07(5,8 \%)$ \\
\hline Privadas & - & - & 02 & 07 & 10 & $\begin{array}{c}19 \\
(15,8 \%)\end{array}$ \\
\hline Total & 21 & $\begin{array}{c}09 \\
(42,8 \%)\end{array}$ & $\begin{array}{c}22 \\
(71 \%)\end{array}$ & $\begin{array}{c}57 \\
(109,6 \%)\end{array}$ & 11 & $\begin{array}{c}120 \\
(100 \%)\end{array}$ \\
\hline
\end{tabular}

Fonte: e-mec-MEC; IES.

Nota: Apenas cursos ativos em setembro de 2017. O cálculo considera a licenciatura e o bacharelado na mesma instituição como um único curso. Algumas universidades ou escolas privadas têm autorização para o funcionamento do curso ativo, mas não significa que estejam funcionando. Para minimizar a diferença ente os autorizados e os em funcionamento, entramos no site de cada instituição privada.

Na pós-graduação, na avaliação quadrienal de 2013-2016, 53 programas foram avaliados, sendo que destes 31 com mestrados e doutorados, um apenas com doutorado, 19 mestrados acadêmicos e dois mestrados profissionais (sendo que dois mestrados e dois doutorados foram descredenciados). Depois da avaliação, até 2018, foram aprovados mais quatro doutorados (UFPel, UFSM, UFF, UFRRJ) e um mestrado (UFMAImperatriz).

$\mathrm{O}$ crescimento da área comparativamente às áreas de Antropologia e Ciência Política, que compõem no país as Ciências Sociais stricto sensu, ilustra o crescimento da área dentro da pós-graduação brasileira. Entre 1996-2014, houve um crescimento de $145 \%$ no número de mestrados e 166,7\% no de doutorados (Tabela 2). 
Tabela 2 - Número e percentagem de programas de mestrado em 2014 e taxa de crescimento entre 1996 e 2014, por áreas do conhecimento

\begin{tabular}{|c|c|c|c|c|}
\hline \multirow{2}{*}{$\begin{array}{c}\text { Classificação } \\
\text { áreas na } \\
\text { Capes }\end{array}$} & \multirow{2}{*}{$\begin{array}{c}\text { Área do } \\
\text { conhecimento }\end{array}$} & $\begin{array}{c}|c| \\
\text { Número } \\
\mathbf{( 2 0 1 4 )}\end{array}$ & $\mathbf{\%}(\mathbf{2 0 1 4})$ & $\begin{array}{c}\text { Crescimento } \\
\text { (\%) 1996-2014 }\end{array}$ \\
\hline 80 & Total & 3.620 & 100,00 & 204,97 \\
\hline 29 & Sociologia & 49 & 1,35 & 145 \\
\hline 38 & $\begin{array}{c}\text { Ciência } \\
\text { Política }\end{array}$ & 37 & 1,02 & 270 \\
\hline 53 & Antropologia & 23 & 0,64 & 130 \\
\hline
\end{tabular}

Fonte: CGEE - Mestres e doutores 2015 - Estudos da demografia da base técnicocientífica brasileira (Organização Social supervisionada pelo Ministério da Ciência, Tecnologia, Inovações e Comunicações (MCTIC) - dados Coleta Capes/ Plataforma Sucupira e RAIS.

A área de Ciência Política foi a que mais cresceu (270\%), seguida pela Sociologia (145\%) e pela Antropologia (130\%), acompanhando uma tendência de autonomização das chamadas Ciências Sociais stricto sensu e a profissionalização de seus quadros (Tabela 3).

Tabela 3 - Número e percentagem de programas de doutorado em 2014 e taxa de crescimento entre 1996 e 2014, por áreas do conhecimento

\begin{tabular}{|c|c|c|c|c|}
\hline \multirow{2}{*}{$\begin{array}{c}\text { Classificação } \\
\text { áreas na } \\
\text { Capes }\end{array}$} & $\begin{array}{c}\text { Área do } \\
\text { conhecimento }\end{array}$ & $\begin{array}{c}\text { Número } \\
\mathbf{( 2 0 1 4 )}\end{array}$ & $\mathbf{\%}(\mathbf{2 0 1 4})$ & $\begin{array}{c}\text { Crescimento } \\
\text { (\%) 1996-2014 }\end{array}$ \\
\hline 80 & Total & 1954 & 100,0 & 210,2 \\
\hline 19 & Sociologia & 32 & 1,64 & 166,7 \\
\hline 44 & $\begin{array}{c}\text { Ciência } \\
\text { Política }\end{array}$ & 17 & 0,87 & 466,7 \\
\hline 51 & Antropologia & 15 & 0,77 & 200,0 \\
\hline
\end{tabular}

Fonte: CGEE - Mestres e doutores 2015 - Estudos da demografia da base técnicocientífica brasileira (Organização Social supervisionada pelo Ministério da Ciência, Tecnologia, Inovações e Comunicações (MCTIC)- dados Coleta Capes/ Plataforma Sucupira e RAIS).

Esse percentual do crescimento no mestrado refletiu-se no aumento da titulação na Sociologia (145\%), ficando atrás da Ciência Política (466,7\%) e da Antropologia (200\%), conforme Tabela 4. 
Tabela 4 - Número e percentagem de títulos de mestrado concedidos no Brasil no ano de 2014 e taxa de crescimento entre 1996 e 2014, por áreas do conhecimento

\begin{tabular}{|c|c|c|c|c|}
\hline \multirow{2}{*}{$\begin{array}{c}\text { Classificação } \\
\text { Áreas na } \\
\text { Capes }\end{array}$} & \multirow{2}{*}{$\begin{array}{c}\text { Área do } \\
\text { conhecimento }\end{array}$} & $\begin{array}{c}|c| \\
\text { Número } \\
\mathbf{( 2 0 1 4 )}\end{array}$ & \% (2014) & $\begin{array}{c}\text { Crescimento } \\
\text { (\%) 1996-2014 }\end{array}$ \\
\hline 80 & Total & 50.206 & 100,00 & 378,97 \\
\hline 26 & Sociologia & 646 & 1,29 & 145 \\
\hline 46 & $\begin{array}{c}\text { Ciência } \\
\text { Política }\end{array}$ & 351 & 0,70 & 303,45 \\
\hline 54 & Antropologia & 255 & 0,51 & 193,10 \\
\hline
\end{tabular}

Fonte: CGEE - Mestres e doutores 2015 - Estudos da demografia da base técnicocientífica brasileira (Organização Social supervisionada pelo Ministério da Ciência, Tecnologia, Inovações e Comunicações (MCTIC) - dados Coleta Capes/ Plataforma Sucupira e RAIS).

Os dados da Sociologia refletem a consolidação da área e uma preocupação de manter o crescimento em níveis sustentáveis, num momento em que a pós-graduação está disseminada por todo o país, com exceção dos estados do Acre, Rondônia, Amapá e Roraima.

A realização do mestrado e doutorado, consecutivamente, aponta uma preocupação com a formação para a carreira acadêmica num momento de expansão das possibilidades de emprego, de mudanças na carreira docente das universidades públicas, nas quais o título de doutor passou a ser condição de ingresso, com políticas governamentais de incentivo à pós-graduação com financiamentos para os programas e bolsas para parte significativa dos alunos. Nesse período, a trajetória de formação nos três níveis representou cerca de $34 \%$ dos titulados e que, em certa medida, foram absorvidos pela expansão do mercado acadêmico e não acadêmico no país, seja nas universidades públicas, no ensino privado e outras atividades beneficiadas igualmente com o crescimento econômico e das políticas sociais (Tabela 5). 
Tabela 5 - Número de indivíduos que receberam títulos de mestrado no período 1996-2010 e número e proporção destes que também obtiveram título de doutorado no período 1996-2014, por área do conhecimento

\begin{tabular}{|c|c|c|c|c|}
\hline $\begin{array}{c}\text { Classificação } \\
\text { áreas na } \\
\text { Capes }\end{array}$ & $\begin{array}{c}\text { Área do } \\
\text { conhecimento }\end{array}$ & $\begin{array}{c}\text { Titulados } \\
\text { no } \\
\text { mestrado } \\
\text { no período } \\
\mathbf{1 9 9 6 - 2 0 1 0} \\
\text { (A) }\end{array}$ & $\begin{array}{c}\text { Titulados no } \\
\text { mestrado no período } \\
\text { 1996-2010 que } \\
\text { também titularam } \\
\text { no doutorado no } \\
\text { período 1996-2014 } \\
\text { (B) }\end{array}$ & $\begin{array}{c}\text { Proporção } \\
\text { (\%) (B/A) }\end{array}$ \\
\hline 80 & Total & 371.586 & 113.520 & 30,6 \\
\hline 21 & Antropologia & 1.801 & 768 & 42,6 \\
\hline 33 & Sociologia & 5.934 & 2.020 & 34,0 \\
\hline 47 & $\begin{array}{c}\text { Ciência } \\
\text { Política }\end{array}$ & 2.309 & 666 & 28,8 \\
\hline
\end{tabular}

Fonte: CGEE - Mestres e doutores 2015 - Estudos da demografia da base técnicocientífica brasileira (Organização Social supervisionada pelo Ministério da Ciência, Tecnologia, Inovações e Comunicações (MCTIC)- dados Coleta Capes/ Plataforma Sucupira e RAIS).

A titulação de mestrado e doutorado entre 1996-2010 na área foi mais expressiva com um crescimento de $486,9 \%$, praticamente igual à média da pós-graduação brasileira. Nesta, a Antropologia ficou na dianteira, seguida pela Sociologia e Ciência Política. A situação se altera no cômputo dos títulos de doutorado no período, com a Ciência Política e a Antropologia na dianteira (Tabela 6).

Tabela 6 - Número e percentagem de títulos de doutorado concedidos no Brasil no ano de 2014 e taxa de crescimento entre 1996 e 2014, por área do conhecimento

\begin{tabular}{|c|c|c|c|c|}
\hline \multirow{2}{*}{$\begin{array}{c}\text { Classificação } \\
\text { das áreas na } \\
\text { CAPES }\end{array}$} & \multirow{2}{*}{$\begin{array}{c}\text { Área do } \\
\text { conhecimento }\end{array}$} & \multicolumn{3}{|c|}{ Doutores: número de títulos } \\
\hline & & $\begin{array}{l}\text { Número } \\
\text { (2014) }\end{array}$ & \% (2014) & $\begin{array}{l}\text { Crescimento } \\
\text { (\%) 1996-2014 }\end{array}$ \\
\hline 80 & Total & 16.729 & 100,0 & 486,2 \\
\hline 11 & Sociologia & 358 & 2,14 & 486,9 \\
\hline 51 & Antropologia & 101 & 0,60 & 621,4 \\
\hline 53 & Ciência Política & 95 & 0,57 & $1.800,0$ \\
\hline
\end{tabular}

Fonte: CGEE - Mestres e doutores 2015 - Estudos da demografia da base técnicocientíficos brasileira (Organização Social supervisionada pelo Ministério da Ciência, Tecnologia, Inovações e Comunicações (MCTIC)- dados Coleta Capes/ Plataforma Sucupira e RAIS). 
É interessante destacar que nesse período cresceu significativamente a procura de profissionais na área de Antropologia e Ciência Política, o que favoreceu o investimento na formação pós-graduada nessas disciplinas. O mesmo aconteceu com a Sociologia, com um crescimento mais contido, embora nesses títulos estejam incluídos o título de "Ciências Sociais", que pode estar vinculado a qualquer uma das três disciplinas.

Um dado interessante nesse crescimento é a relação graduação-pósgraduação. Como vimos anteriormente, são 109 os cursos de graduação em Ciências Sociais, Sociologia, Sociologia e Política, presenciais e à distância em funcionamento no país. A esse número agregam-se 12 cursos de Antropologia e 19 de Ciência Política (3 à distância), num total aproximado de 140 cursos de graduação da área de Ciências Sociais stricto sensu. Na pósgraduação, esse número aumenta 39\%, chegando a 230 cursos, conforme Tabela 7.

Tabela 7 - Cursos de pós-graduação em Ciências Sociais stricto sensu

\begin{tabular}{|c|c|c|c|c|c|}
\hline & $\begin{array}{c}\text { Total de } \\
\text { cursos }\end{array}$ & Mestrados & Doutorados & $\begin{array}{c}\text { Mestrados } \\
\text { profissionais }\end{array}$ & $\begin{array}{c}\text { Doutorados } \\
\text { profissionais }\end{array}$ \\
\hline $\begin{array}{c}\text { Sociologia } \\
\text { e Ciências } \\
\text { Sociais }\end{array}$ & 89 & 49 & 38 & 02 & \\
\hline $\begin{array}{c}\text { Antropologia e } \\
\text { Arqueologia }\end{array}$ & 59 & 36 & 22 & 01 & 01 \\
\hline $\begin{array}{c}\text { Ciência Política } \\
\text { e Relações } \\
\text { Internacionais }\end{array}$ & 82 & 40 & 24 & 17 & 01 \\
\hline & 230 & 125 & 84 & 20 & \\
\hline
\end{tabular}

Fonte: Capes (Plataforma Sucupira).

Esse quadro evidencia uma característica da pesquisa no Brasil: estar majoritariamente vinculada às universidades públicas, e à pós-graduação como condição para sua realização. A expansão das universidades e a titulação dos docentes pressiona a abertura de novos programas como forma de acomodação dos docentes-pesquisadores contratados. O caráter aberto das profissões das Ciências Sociais possibilita a incorporação de profissionais de outras áreas, e a pós-graduação funciona, em certa medida, como porta de entrada. É comum formados em Direito, Comunicação, Arquitetura, Economia, Administração e outras áreas complementarem sua formação em Sociologia ou Ciências Sociais e atuarem profissionalmente na 
área. Ao contrário de profissões estabelecidas, como Engenharia, Medicina e Direito, que estabelecem barreiras de entrada e controle sobre o mercado, nas Ciências Sociais, assim como nas Ciências Humanas em geral, esse controle é difuso, havendo competição de titulados em várias disciplinas por posições no mercado (BONELLI, 1994).

\section{A pós-graduação e o mercado de trabalho}

Numerosos trabalhos acerca da relação titulação/mercado de trabalho têm sido produzidos pela Capes como forma de ilustrar que a pós-graduação atua positivamente na inserção dos profissionais em empregos mais bem remunerados ${ }^{12}$. A ideia de formação continuada, da busca de formação mais abrangente, tem sido utilizada como elemento explicativo dessa inserção. Entretanto, na área de Sociologia, devemos considerar que o mercado é formado pelo ensino, pesquisa e extensão, majoritariamente em instituições estatais, ONGs e movimentos sociais, universidades e faculdades privadas.

Nas escolas privadas, nota-se que a qualificação funciona mais como garantia de manutenção do conceito e status de universidade e/ ou faculdade a partir das exigências do MEC de um número mínimo de professores titulados. Notícias recorrentes de dispensas em massa de docentes dessas instituições ocorrem com frequência e, com a crescente incorporação dessas escolas por grandes grupos empresariais nacionais e internacionais, a tendência é aumentar a busca de redução de custos e maior lucratividade, com prejuízo do ensino e da pesquisa. Aumenta-se o número de alunos por turmas, reduz-se o número de professores e exigências de titulação. A aprovação recente pelo MEC que as atividades (40\%) na graduação sejam feitas por $\mathrm{EaD}^{13}$, assim como a aprovação pela Capes, também no final do governo, da pós-graduação stricto sensu via $\mathrm{EaD}$, atendendo aos interesses empresariais, tende a precarizar a atividade docente, comprometer sua qualificação e reduzir ainda mais as atividades de pesquisa nessas instituições.

\footnotetext{
${ }^{12}$ Utilizamos aqui os dados sistematizados do CCGE, que, por sua vez, sistematizam dados da Capes da RAIS sobre o mercado de trabalho dos egressos de cursos de pós-graduação.

${ }^{13}$ G1 - 31/12/2018. Graduação presencial poderá ter até 40\% de aulas a distância. Até então, o limite máximo fixado pelo MEC era de $20 \%$ da carga horária. (GLOBO. G1).
} 
Segundo Baltar e Baltar (2017), o perfil do sociólogo tem se confundido com o de professor universitário, embora a demanda por profissionais de Sociologia tenha se mantido regular. Mas essa não tem sido a ênfase da formação que desconsideraria as especificidades da profissão fora da academia. Mesmo assim, a pós-graduação na área faz diferença em termos de emprego.

A pesquisa do CCGE com mestres e doutores titulados a partir de 1996 (Tabela 8), tendo como referência os anos de 2009 e 2014, indica alguns números positivos acerca da situação de mercado dos portadores de títulos de mestres e doutores. No caso dos mestres em Sociologia, houve um crescimento de $47,52 \%$ dos empregados formais, embora com uma variação mínima, positiva, da taxa de formalização desses empregos de 64,3\% para 64,4\%, ao contrário dos titulados em Antropologia e Ciência Política, cujas taxas ficaram negativas. Esse número pode indicar empregos PJ ou de consultorias informais, que não são computados (Tabela 9).

Tabela 8 -Número de mestres (1) titulados no Brasil a partir de 1996, empregados (2) em 2014, por áreas do conhecimento

\begin{tabular}{|c|c|c|c|c|}
\hline \multirow{2}{*}{$\begin{array}{c}\text { Classificação } \\
\text { áreas na } \\
\text { Capes }\end{array}$} & \multirow{2}{*}{$\begin{array}{c}\text { Área do } \\
\text { conhecimento }\end{array}$} & $\begin{array}{c}\text { Número } \\
\mathbf{( 2 0 1 4 )}\end{array}$ & \% (2014) & $\begin{array}{c}\text { Crescimento } \\
\text { (\%) 2014/2009 }\end{array}$ \\
\cline { 3 - 5 } & Total & 16.729 & 100,0 & 486,2 \\
\hline 80 & Sociologia & 4.141 & 1,41 & 47,52 \\
\hline 22 & $\begin{array}{c}\text { Ciência } \\
\text { Política }\end{array}$ & 1.845 & 0,63 & 60.71 \\
\hline 60 & Antropologia & 893 & 0,30 & 52,65 \\
\hline
\end{tabular}

Fonte: CGEE - Mestres e doutores 2015 - Estudos da demografia da base técnicocientífica brasileira (Organização Social supervisionada pelo Ministério da Ciência, Tecnologia, Inovações e Comunicações (MCTIC)- dados Coleta Capes/ Plataforma Sucupira e RAIS), p.123.

Notas:

(1) A população de mestres considerada a cada ano é formada pelo conjunto dos indivíduos que obtiveram títulos de mestrado (acadêmico ou profissional) no Brasil durante o período que vai de 1996 até o referido ano. Foram, no entanto, extraídos dessa população os indivíduos que vieram a também obter título de doutorado até o referido ano. Indivíduos que obtiveram mais de um título de mestrado no período foram considerados apenas uma vez. Nesses casos, a primeira titulação é a que foi tomada em consideração.

(2) A situação de emprego é aferida no dia 31 de dezembro do ano sob análise, de acordo com os registros da RAIS do mesmo ano. 
Tabela 9 -Taxa de emprego (1) formal em 2009 e em 2014 de titulados em programas de mestrado (2) no Brasil a partir de 1996, por área do conhecimento

\begin{tabular}{|c|c|c|c|c|}
\hline \multirow{2}{*}{$\begin{array}{c}\text { Classificação } \\
\text { áreas }\end{array}$} & Área do & \multicolumn{3}{|c|}{ Mestres taxa de emprego formal } \\
\cline { 3 - 5 } & conhecimento & $\mathbf{2 0 0 9}$ & $\mathbf{2 0 1 4}$ & Diferença 2014/2009 \\
\hline 80 & Total & 66,7 & 65,8 & $-0,84$ \\
\hline 37 & Sociologia & 64,3 & 64,4 & 0,1 \\
\hline 40 & Ciência Política & 65,1 & 62,5 & $-2,6$ \\
\hline 78 & Antropologia & 47,0 & 45,8 & $-1,1$ \\
\hline
\end{tabular}

Fonte: CGEE - Mestres e doutores 2015 - Estudos da demografia da base técnicocientífica brasileira (Organização Social supervisionada pelo Ministério da Ciência, Tecnologia, Inovações e Comunicações (MCTIC) - dados Coleta Capes/ Plataforma Sucupira e RAIS).

Notas metodológicas (1) e (2) na Tabela 8.

No caso dos doutores, a taxa de crescimento no período foi maior que a dos mestres pelas exigências dos concursos das universidades públicas do título de doutor para a entrada na carreira. O crescimento da taxa de doutores entre 1996 e 2014 foi de 62,42\%, com uma taxa de emprego formal maior de 77,87\%, em 2009, e 78,57 em 2014, com uma variação positiva de $0,70 \%$ (Tabelas 10 e 11).

Tabela 10 - Número de doutores (1) titulados no Brasil a partir de 1996, empregados (2) em 2014, por áreas do conhecimento

\begin{tabular}{|c|c|c|c|c|}
\hline \multirow{2}{*}{$\begin{array}{c}\text { Classificação } \\
\text { áreas }\end{array}$} & \multirow{2}{*}{$\begin{array}{c}\text { Área do } \\
\text { conhecimento }\end{array}$} & $\begin{array}{c}\text { Número } \\
\mathbf{( 2 0 1 4 )}\end{array}$ & \% (2014) & $\begin{array}{c}\text { Crescimento (\%) } \\
\text { 2014/2009 }\end{array}$ \\
\hline 80 & Total & 16.729 & 100,0 & 486,2 \\
\hline 9 & Sociologia & 3.120 & 2,46 & 62,42 \\
\hline 52 & Ciência Política & 676 & 0,53 & 111,91 \\
\hline 53 & Antropologia & 649 & 0,51 & 74,46 \\
\hline
\end{tabular}

Fonte: CGEE - Mestres e doutores 2015 - Estudos da demografia da base técnicocientífica brasileira (Organização Social supervisionada pelo Ministério da Ciência, Tecnologia, Inovações e Comunicações (MCTIC) - dados Coleta Capes/ Plataforma Sucupira e RAIS).

Notas metodológicas (1) e (2) na Tabela 8. 
Tabela 11 -Taxa de emprego (1) formal em 2009 e em 2014 de titulados em programas de doutorado (2) no Brasil a partir de 1996, por área do conhecimento

\begin{tabular}{|c|c|c|c|c|}
\hline \multirow{2}{*}{$\begin{array}{c}\text { Classificação } \\
\text { áreas }\end{array}$} & Área do & \multicolumn{3}{|c|}{ Doutores: taxa de emprego formal } \\
\cline { 3 - 5 } & conhecimento & $\mathbf{2 0 0 9}$ & $\mathbf{2 0 1 4}$ & Diferença 2014/2009 \\
\hline 80 & Total & 74,77 & 75,47 & 0,71 \\
\hline 17 & Ciência Política & 75,59 & 80,48 & 4,88 \\
\hline 27 & Sociologia & 77,87 & 78,57 & 0,70 \\
\hline 67 & Antropologia & 65,72 & 65,69 & $-0,04$ \\
\hline
\end{tabular}

Fonte: CGEE - Mestres e doutores 2015 - Estudos da demografia da base técnicocientífica brasileira (Organização Social supervisionada pelo Ministério da Ciência, Tecnologia, Inovações e Comunicações (MCTIC) - dados Coleta Capes/ Plataforma Sucupira e RAIS).

Notas metodológicas (1) e (2) na Tabela 8.

Em termos de remuneração, a diferença entre mestres e doutores é substancial, mas indica a forte presença das instituições públicas e suas carreiras, assim como no caso de instituições privadas os salários decorrentes de regimes de trabalho específicos com carreiras, em geral, formalizadas (caso de universidades confessionais e outras fortemente estabelecidas no mercado). No caso do ensino privado, o salário é composto, em grande parte dos casos, pela soma de atividades em diversas escolas ao mesmo tempo (Tabela 12).

Tabela 12 -Remuneração (1) mensal média de mestres (2) titulados no Brasil a partir de 1996, por área do conhecimento, 2009 e 2014 (R\$ de 12/2014)

\begin{tabular}{|c|c|c|c|c|}
\hline \multirow{2}{*}{$\begin{array}{c}\text { Classificação } \\
\text { áreas }\end{array}$} & \multirow{2}{*}{$\begin{array}{c}\text { Área do } \\
\text { conhecimento }\end{array}$} & \multicolumn{3}{|c|}{$\begin{array}{c}\text { Mestres: Remuneração mensal média (R\$ } \\
\text { constantes de 12/4) }\end{array}$} \\
\cline { 3 - 5 } & & $\mathbf{2 0 0 9}$ & $\mathbf{2 0 1 4}$ & Diferença 2009/2014 \\
\hline 80 & Total & 8.880 & 9.719 & 9,4 \\
\hline 07 & Ciência Política & 13.185 & 13.078 & $-0,8$ \\
\hline 50 & Sociologia & 6.913 & 7.710 & 11,5 \\
\hline 68 & Antropologia & 6.518 & 6.833 & 4,8 \\
\hline
\end{tabular}

Fonte: CGEE - Mestres e doutores 2015 - Estudos da demografia da base técnicocientífica brasileira (Organização Social supervisionada pelo Ministério da Ciência, Tecnologia, Inovações e Comunicações (MCTIC) - dados Coleta Capes/ Plataforma Sucupira e RAIS).

Notas metodológicas (1) e (2) na Tabela 8. 
Tanto para mestres como para doutores, a variação salarial foi positiva, $11,5 \%$ para mestres e 16,7\% para doutores, decorrente das negociações salariais das universidades federais no período e da política deliberada de valorização da titulação de doutorado (Tabela 13).

Tabela 13 - Remuneração (1) mensal média de doutores (2) titulados no Brasil a partir de 1996, por área do conhecimento, 2009 e 2014 (R\$ de 12/2014)

\begin{tabular}{|c|c|c|c|c|}
\hline \multirow{2}{*}{$\begin{array}{c}\text { Classificação } \\
\text { áreas }\end{array}$} & \multirow{2}{*}{$\begin{array}{c}\text { Área do } \\
\text { conhecimento }\end{array}$} & \multicolumn{3}{|c|}{$\begin{array}{c}\text { Doutores: Remuneração mensal média (R\$ } \\
\text { constantes de 12/2014) }\end{array}$} \\
\cline { 3 - 5 } & & $\mathbf{2 0 0 9}$ & $\mathbf{2 0 1 4}$ & Diferença 2009/2014 \\
\hline 80 & Total & 11.733 & 13.861 & 18,1 \\
\hline 13 & Ciência Política & 13.616 & 14.998 & 10,2 \\
\hline 40 & Sociologia & 11.565 & 13.499 & 16,7 \\
\hline 65 & Antropologia & 10.309 & 12.471 & 21,0 \\
\hline
\end{tabular}

Fonte: CGEE - Mestres e doutores 2015 - Estudos da demografia da base técnicocientífica brasileira (Organização Social supervisionada pelo Ministério da Ciência, Tecnologia, Inovações e Comunicações (MCTIC) - dados Coleta Capes/ Plataforma Sucupira e RAIS).

Notas metodológicas (1) e (2) na Tabela 8.

\section{A pós-graduação e a mobilidade espacial-institucional}

Feita a caracterização da expansão e institucionalização da área de Sociologia e da importância da pós-graduação para o mercado de trabalho, passaremos a apresentar alguns dados referentes à formação de docentes, sua mobilidade espacial e geracional a partir de sua atuação na pósgraduação. Essa mobilidade é ilustrativa da "nacionalização" da área e consolidação do campo, como afirmamos anteriormente, padronizando em grande medida a formação e a profissionalização, tendo como recorte o mercado de trabalho acadêmico.

Vamos apresentar alguns gráficos especificados regionalmente. Para efeito de comparação, juntamos a região Sudeste (Minas Gerais e Espírito Santo) com a Centro-Oeste. Rio de Janeiro e São Paulo aparecem separadamente por concentrarem, respectivamente, o maior número de programas de pós-graduação no país, o que marcou a configuração do campo da Sociologia historicamente.

No Rio de Janeiro, a formação dos docentes vinculados à pós-graduação concentra-se em programas do próprio Estado. A UFRJ é a mais endógena, 
com 52,7\% dos credenciados formados na própria instituição. Com a crise do IUPERJ em 2009, seus docentes e titulados se distribuíram por outros programas, com presença marcante na PUCRio (8 dos 14 docentes) e na UERJ-Ciências Sociais (PPCIS), em que representam 1/3 dos credenciados. Os titulados no Estado, em seus diversos programas, representam 61,6\% dos docentes-pesquisadores que atuam na pós-graduação. USP e Unicamp são as únicas instituições de fora do Estado a ter um número relevante de titulados, assim como os titulados no exterior, embora em sua maioria anteriores a 2000.

No Estado, a UENF apresenta maior diversidade de formação, assim como o CPDA da UFRRJ, com destaque aos formados no próprio programa com uma característica temática e interdisciplinar. O novo programa do IESP-UERJ Sociologia, por sua vez, destaca-se pelo número de titulados no exterior. Dos 11 titulados (outubro 2018) no exterior, cinco foram depois do ano 2000. Na UENF, dos 21 credenciados, outros representam cinco formados na própria instituição, dois na UFMG, dois na UFJF, um na PUCRio (Gráfico 3).

Gráfico 3 - IES de Titulação/ IES de atuação (PPG)

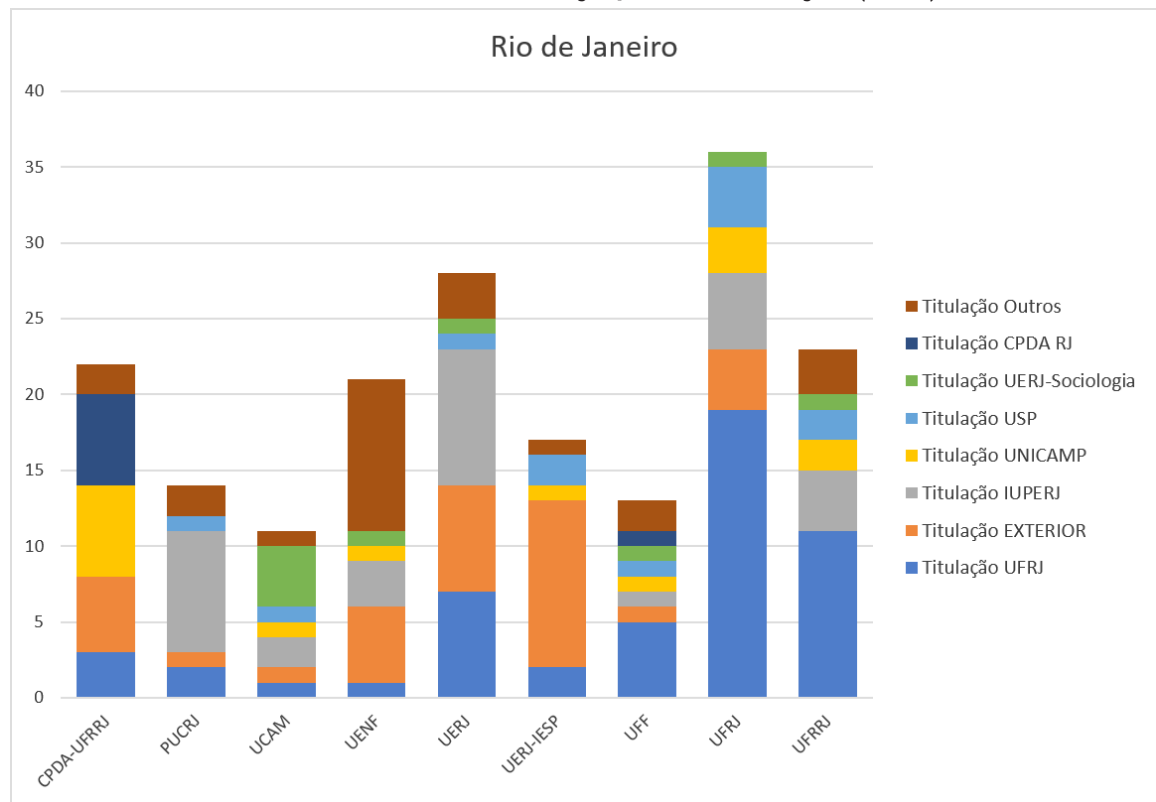

Fonte: Elaborado pelo autor a partir dos sites dos PPGs (2018). 
São Paulo apresenta o maior índice de endogenia do país, com os titulados permanecendo na instituição de formação ou no estado de origem. A USP titulou 41,7\% dos docentes atuantes na pós-graduação, seguida da Unicamp, com os dois programas da área, além de outras titulações com $28,6 \%$, seguida pela PUCSP com $11,6 \%$. As três universidades representando 81,9\% (Gráfico 4).

\section{Gráfico 4 - IES de titulação/ IES de atuação}

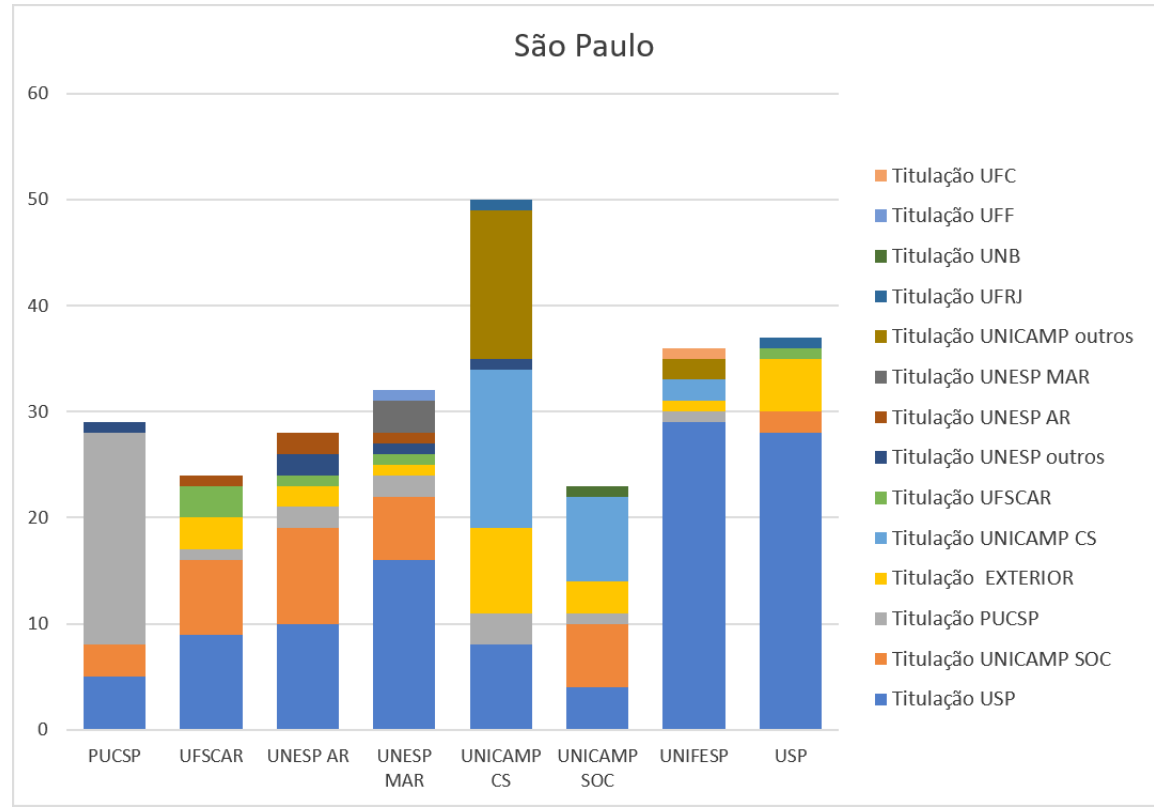

Fonte: Elaborado pelo autor a partir dos sites dos PPGs (2018).

Os programas da USP, PUCSP e Unicamp são os mais endógenos, com a maioria dos seus credenciados sendo formados no próprio programa e/ou instituição. Isto se explica pelo pioneirismo dos programas dessas instituições na área, no caso da USP e PUCSP, assim como da Unicamp, com dois programas, um disciplinar e o outro interdisciplinar ${ }^{14}$. Na UNIFESP,

\footnotetext{
${ }^{14}$ O Programa de Ciências Sociais da Unicamp, com apenas o doutorado, foi organizado para atender inicialmente às três áreas disciplinares que abriram seus mestrados - a Sociologia, a Política e a Antropologia. Posteriormente, foram criados programas disciplinares completos, com mestrado e doutorado, e mantido o de Ciências Sociais, que incorporou docentes das três áreas e mais áreas afins, como Economia, Demografia (presente na proposta original) e Educação.
} 
resultado da expansão das federais com um campus de humanidades na cidade de Guarulhos, região metropolitana de São Paulo, dos seus 36 docentes credenciados no Programa de Ciências Sociais, 29 foram titulados na USP, absorvendo os titulados que se encontravam em outras instituições e/ou atividades. Nos demais, UFSCar e Unesp - Araraquara e Marília -, a titulação pela USP e Unicamp, embora dominante, já divide espaço com formados em seus próprios programas e outros do Estado de São Paulo e exterior.

Nas outras regiões do país nota-se uma maior diversificação da formação, com a predominância crescente de programas consolidados regionalmente.

No Sul, os titulados na UFRGS se destacam numericamente no próprio programa e na UFSM e, em menor escala, nos demais programas do Estado. Em seguida, vem a Unicamp majoritariamente nos estados do Paraná e Santa Catarina, assim como a USP e a PUCSP. Deve-se considerar o caráter mais recente dos doutorados na região em termos comparativos, principalmente com São Paulo. Mesmo assim, a formação no próprio Sul tem sido crescente, destacando-se a UFRGS, a UFPR e a UFSC. É forte ainda a presença dos formados no exterior. Entre as universidades estaduais do Paraná (UEL, UEM e Unioeste) e a UFSC, predomina a formação nas universidades paulistas, como USP, Unicamp e PUCSP (Gráfico 5).

\section{Gráfico 5 - SUL IES de Titulação e IES de institucionalização na pós-graduação}

Região Sul

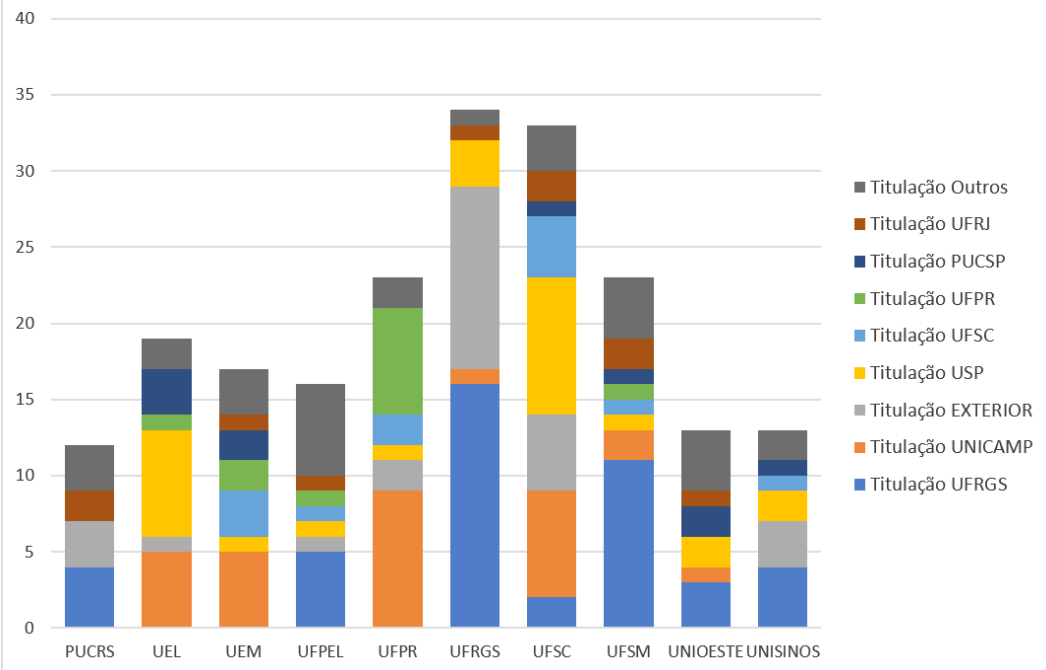

Fonte: Elaborado pelo autor a partir dos sites dos PPGs (2018). 
No Nordeste, a formação é bem diversificada, embora os programas tradicionais tendam a predominar em seus estados. No Ceará, a UFC é responsável pela maioria dos titulados em seu programa e no da UECE. Em Pernambuco, a UFPE titulou a maioria dos docentes da Fundação Joaquim Nabuco, situação similar à da Unifesp, em São Paulo, com a expansão da instituição. O programa da própria UFPE - que ainda tem um número significativo de titulados no exterior, embora seja a geração titulada até 2000 - tem uma presença significativa na maioria dos programas da região. A UFBA, com doutorado mais recente, tem seus titulados no próprio programa, pela USP e no exterior, assim como presença destacada na UFRB.

No total, a maioria dos titulados obtiveram seus títulos fora da região de origem. Cerca de $58 \%$ dos docentes foi titulado no exterior. USP, Unicamp, PUCSP, UFRJ, UFRGS e UnB, UFPe e UFC titularam cerca de $22 \%$ do total (Gráfico 6).

Gráfico 6 - Nordeste IES de Titulação e IES de institucionalização na pósgraduação

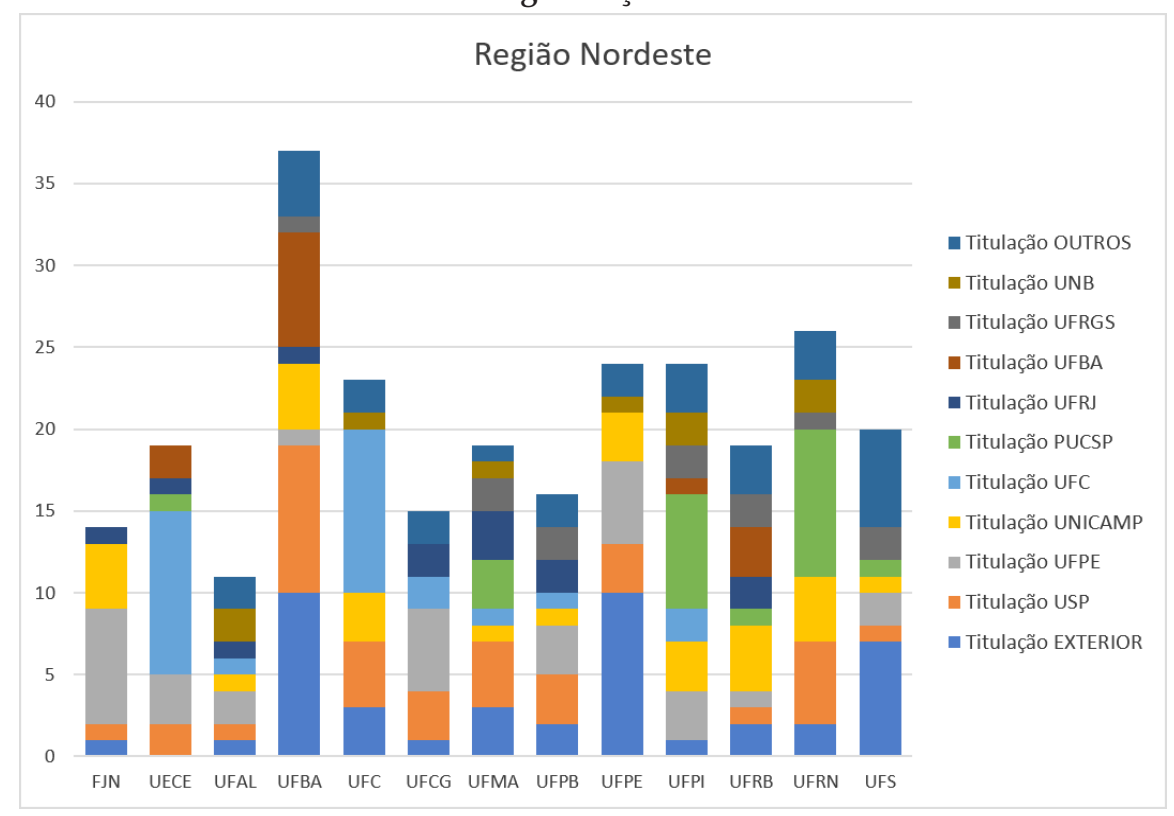

Fonte: Elaborado pelo autor a partir dos sites dos PPGs (2018). 
No Sudeste (excluídos São Paulo e Rio de Janeiro) e Centro-Oeste, a UnB tem credenciados em seu programa $50 \%$ dos docentes titulados na própria instituição e também no programa da UFG. Em Minas, a UFMG tem 60\% titulados em seu próprio programa, mas não possui número significativo de titulados em outros programas do Estado. Unicamp, USP, IUPERJ, Unesp e UFRJ têm uma presença mais significativa. Deve-se considerar a juventude dos programas da região, principalmente em MT e MS, recém-criados, e programas ainda com graus distintos de consolidação, como UFES, UVV, UFU, UFJF e PUC Minas (Gráfico 7).

\section{Gráfico 7 - IES de Titulação e IES de institucionalização na pós-graduação}

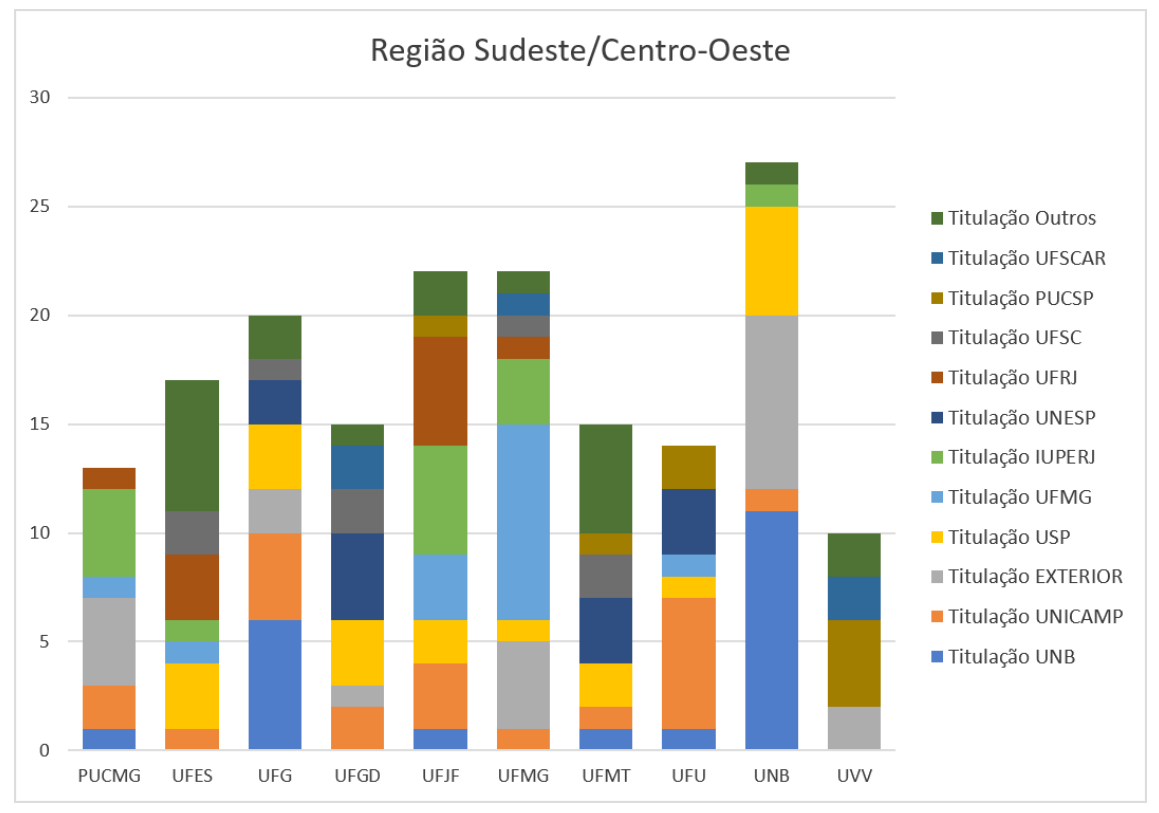

Fonte: Elaborado pelo autor a partir dos sites dos PPGs (2018).

A região Norte tem apenas dois programas disciplinares, o mais antigo na UFPA e o da UFAM. Na UFPA, destacam-se ainda os formados no exterior no período anterior a 2000, em seguida, os formados pela própria instituição, embora a maioria no programa interdisciplinar do NAEA, o Programa de Pós-Graduação em Desenvolvimento sustentável do Trópico Úmido, que chegou a integrar o Comitê de Avaliação da Área de Sociologia até os anos 1990, posteriormente solicitando sua passagem para o comitê interdisciplinar (Gráfico 8). No conjunto, a maioria dos titulados fez seus 
doutorados em outras regiões do país, principalmente na USP, Unicamp, UFRJ.

Gráfico 8 - IES de Titulação e IES de institucionalização na pós-graduação

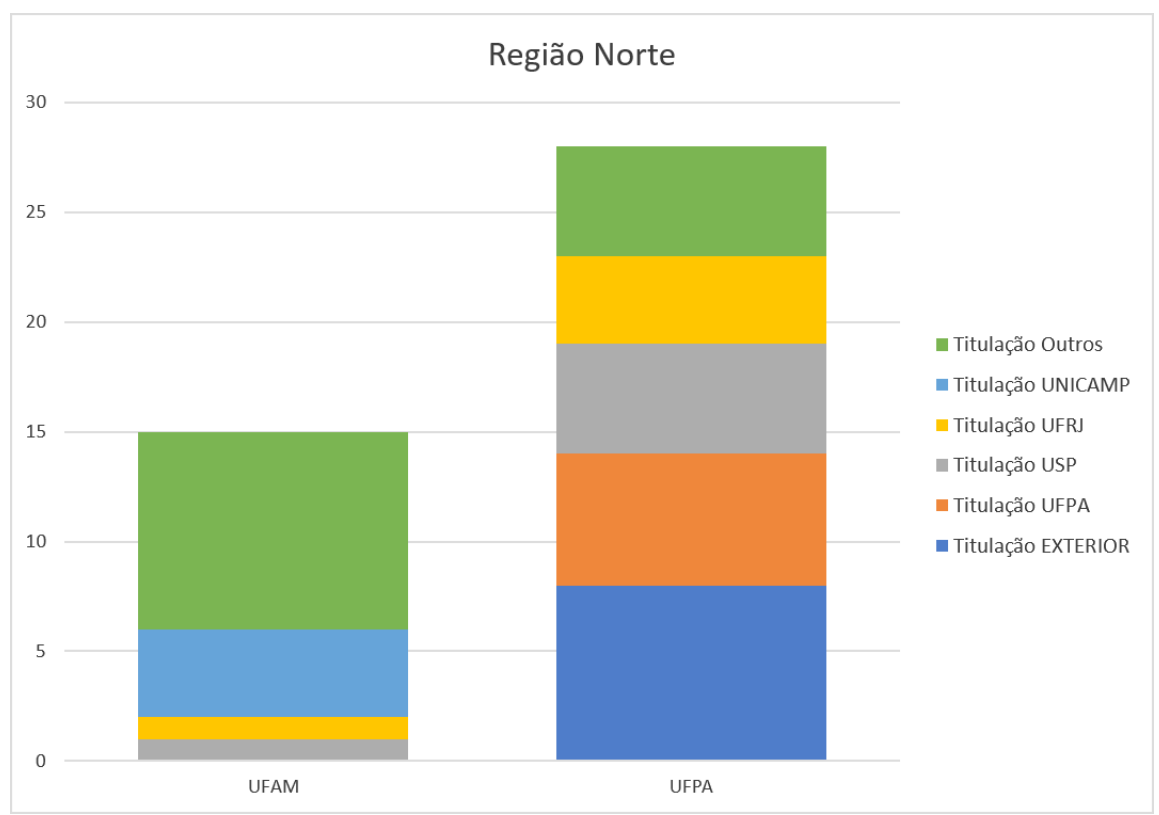

Fonte: Elaborado pelo autor a partir dos sites dos PPGs (2018).

O que fica evidente em todas as regiões é a maior diversidade nas formações fora dos estados de São Paulo e Rio de Janeiro, acompanhando a expansão da formação no país. Entretanto, na pós-graduação, com as exigências de produção e a permanência de professores aposentados como credenciados, ainda é significativa a formação doutoral no exterior e nos programas mais antigos, como USP, Unicamp, PUC e IUPERJ, que abriram essa formação no país, como veremos a seguir.

\section{A mobilidade geracional na pós-graduação}

A formação de doutores da última década tem provocado um grande impacto na pós-graduação, embora haja um relativo equilíbrio geracional, com a presença de professores aposentados que permanecem atuando. Esse equilíbrioé fundamental para a manutenção da qualidade desses programas, evitando os gaps geracionais existentes nos departamentos, os quais, ao 
mesmo tempo que dinamizam e trazem novas perspectivas e linhas de pesquisa, comprometem a continuidade de outras que, em várias situações, caracterizaram a formação e a pesquisa em determinados programas. É importante ressaltar que tempo de titulação não significa tempo de atuação na pós-graduação ou mesmo na universidade, dado que a renovação dos departamentos com o crescimento dos concursos públicos a partir de 2004 se deu a partir de mais de uma década de restrições a novas contratações. Com isso, os gráficos demonstram uma tendência a um equilíbrio que nem sempre reflete o caráter de renovação dos departamentos.

Assim, nas regiões Nordeste, Sul, Sudeste e Centro-Oeste, os gráficos apresentam uma curva gaussiana, demonstrando a dominância de docentes de meio de carreira (Gráficos 9 a 11).

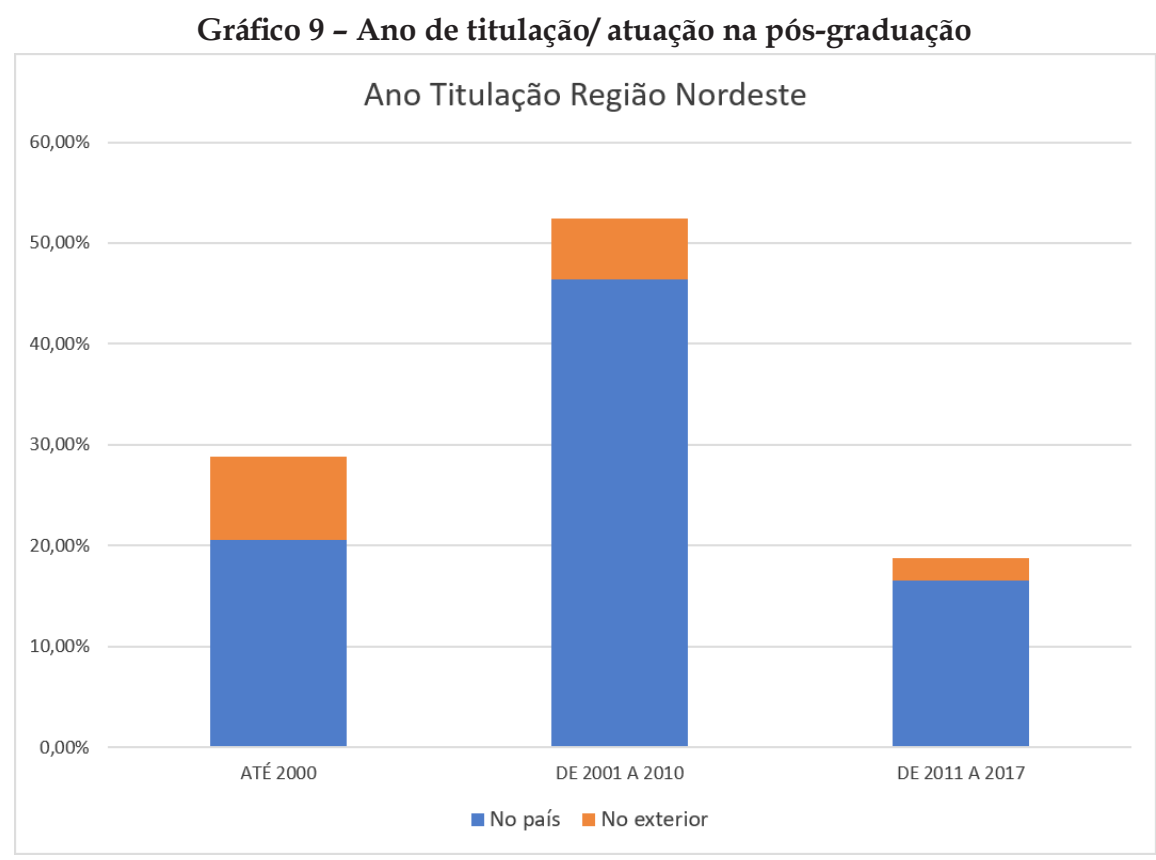

Fonte: Elaborado pelo autor a partir dos sites dos PPGs (2018). 
Gráfico 10 - IES de Titulação e IES de institucionalização na pós-graduação

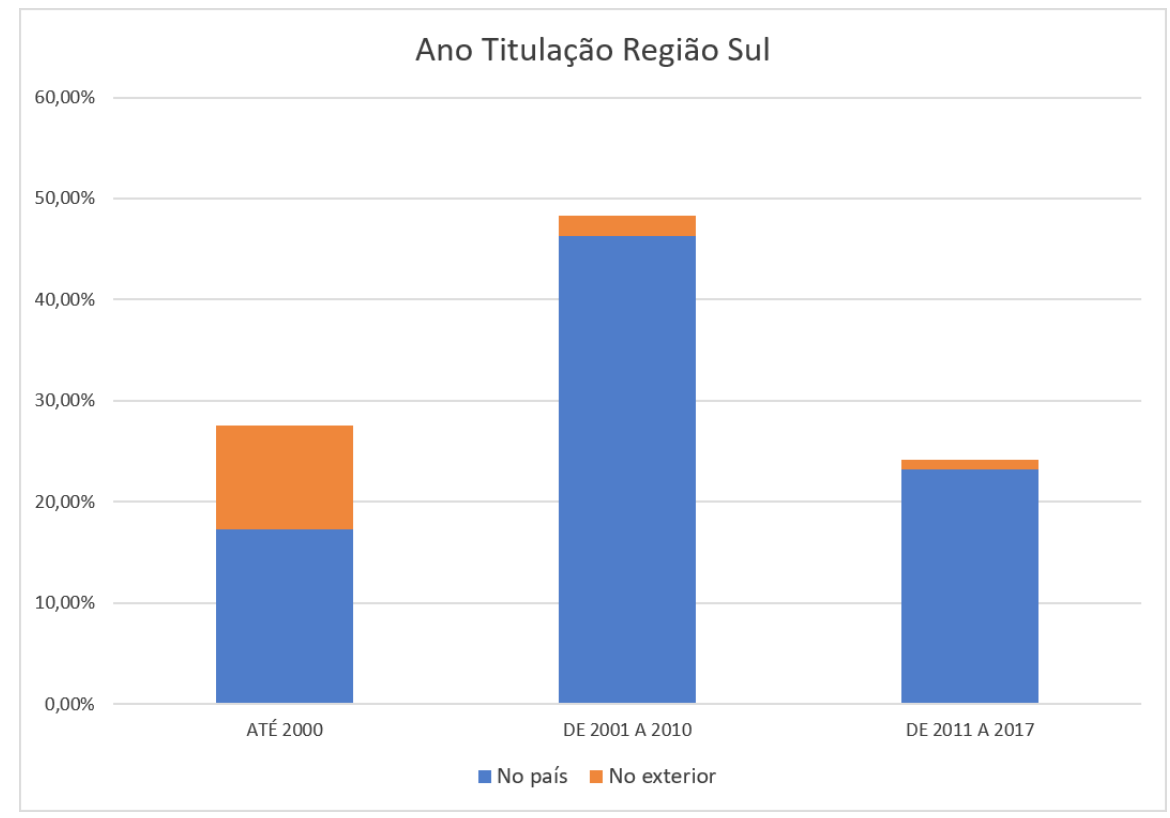

Fonte: Elaborado pelo autor a partir dos sites dos PPGs (2018).

Gráfico 11 - IES de Titulação e IES de institucionalização na pós-graduação Ano Titulação Sudeste/Centro-Oeste

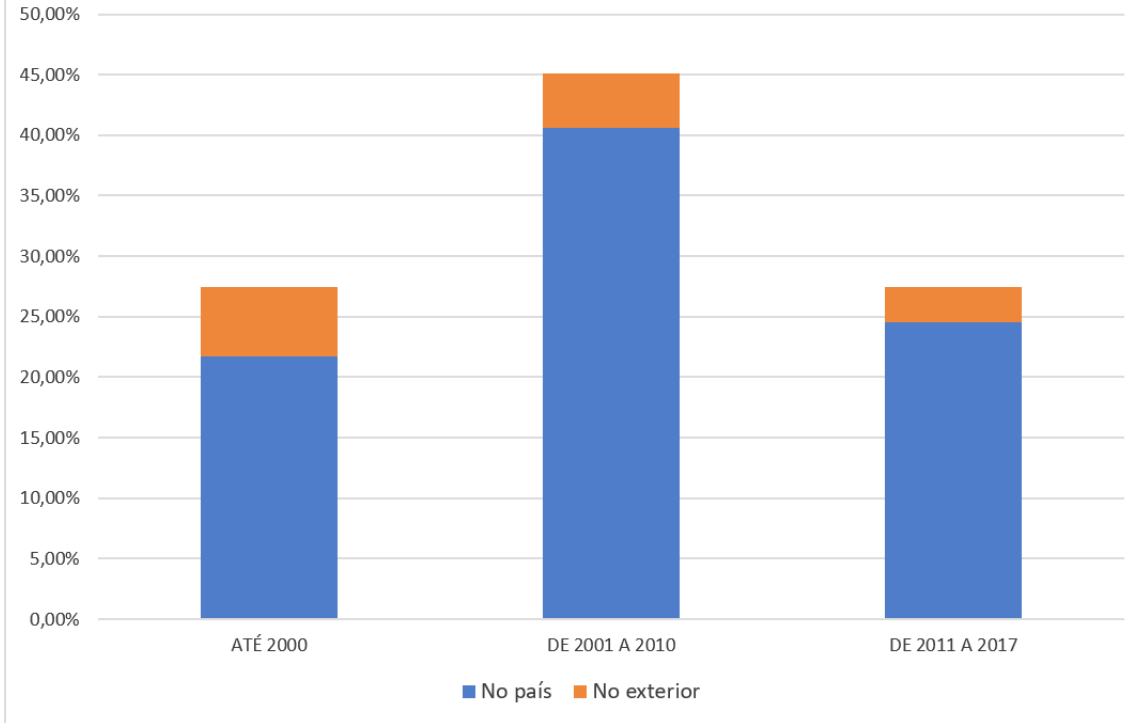

Fonte: Elaborado pelo autor a partir dos sites dos PPGs (2018). 
Essa curva se altera um pouco na região Norte e no Rio de Janeiro, embora por motivos diferentes: no Norte, com apenas dois programas existentes, indica a entrada mais restrita de novos credenciados; no Rio de Janeiro, a competitividade e a existência de uma massa crítica consolidada apontam para uma renovação mais lenta, embora contínua (Gráficos 12 e 13).

Gráfico 12 - IES de Titulação e IES de institucionalização na pós-graduação

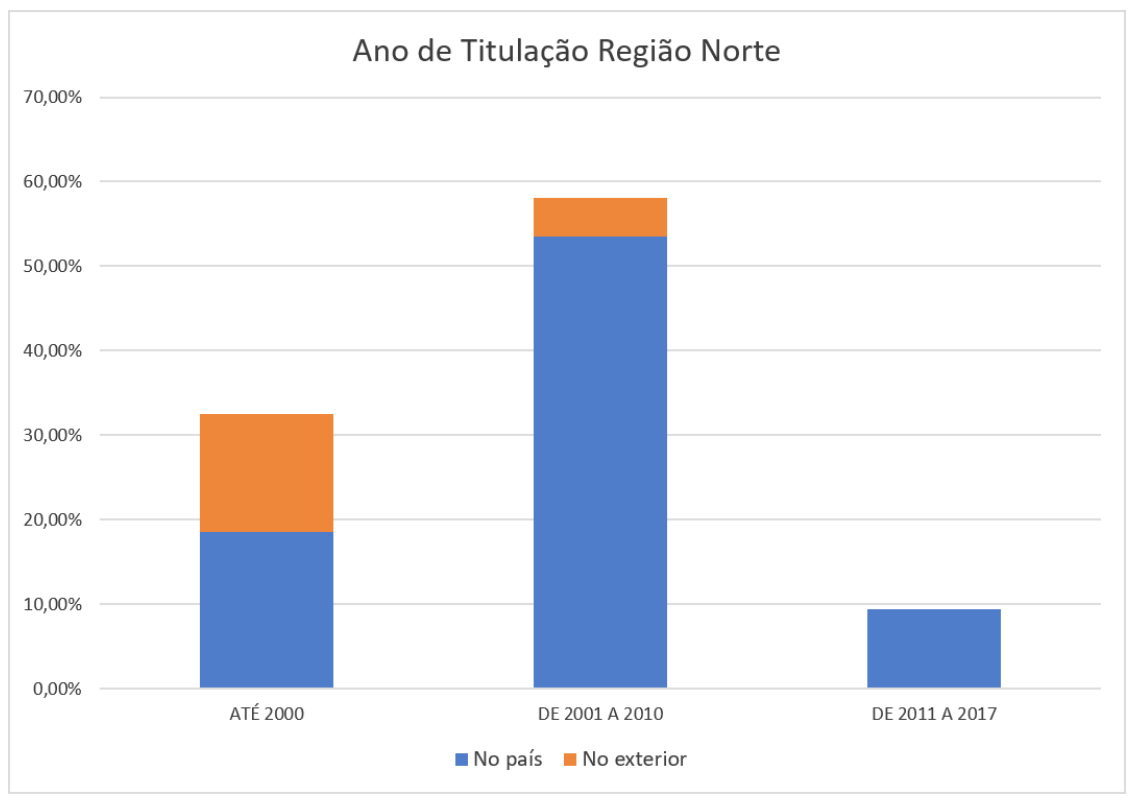

Fonte: Elaborado pelo autor a partir dos sites dos PPGs (2018). 


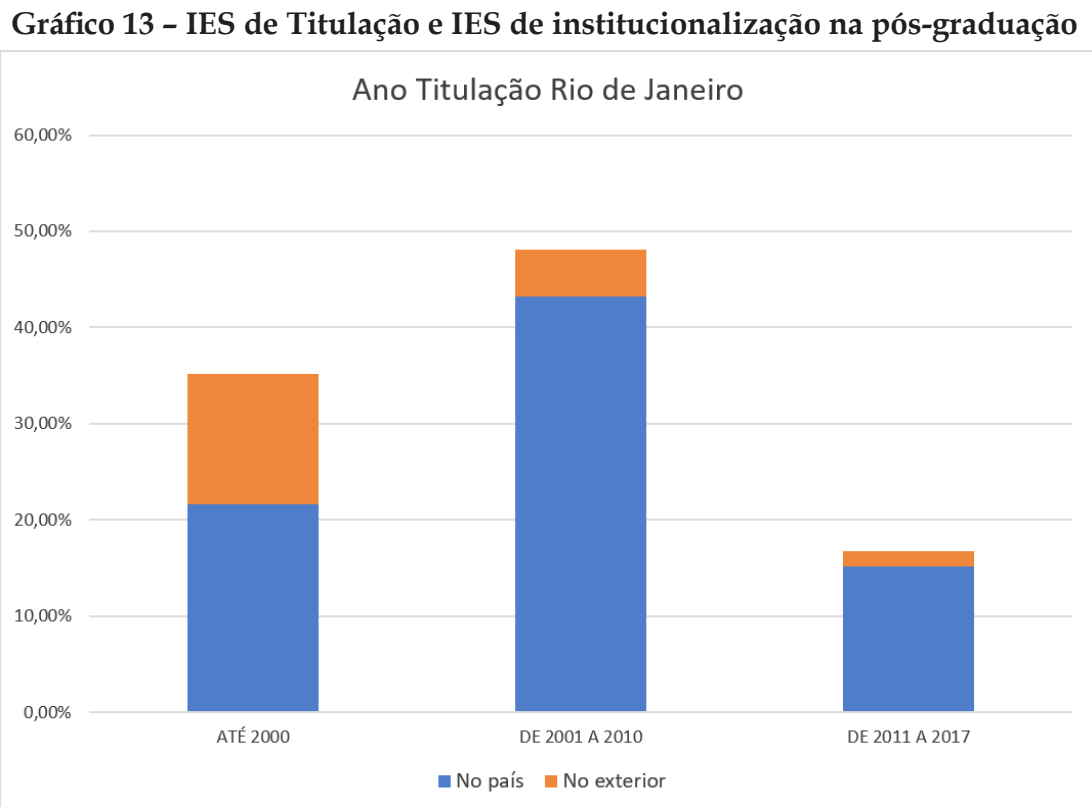

Fonte: Elaborado pelo autor a partir dos sites dos PPGs (2018).

São Paulo aparece fora da curva, por motivos similares ao do Rio de Janeiro, mas aprofundados. Grande parte dos docentes presentes no início da pós-graduação continuam atuando e, mesmo com certa renovação, os titulados até o ano 2000 ainda representam 50\% do total (Gráfico 14). 


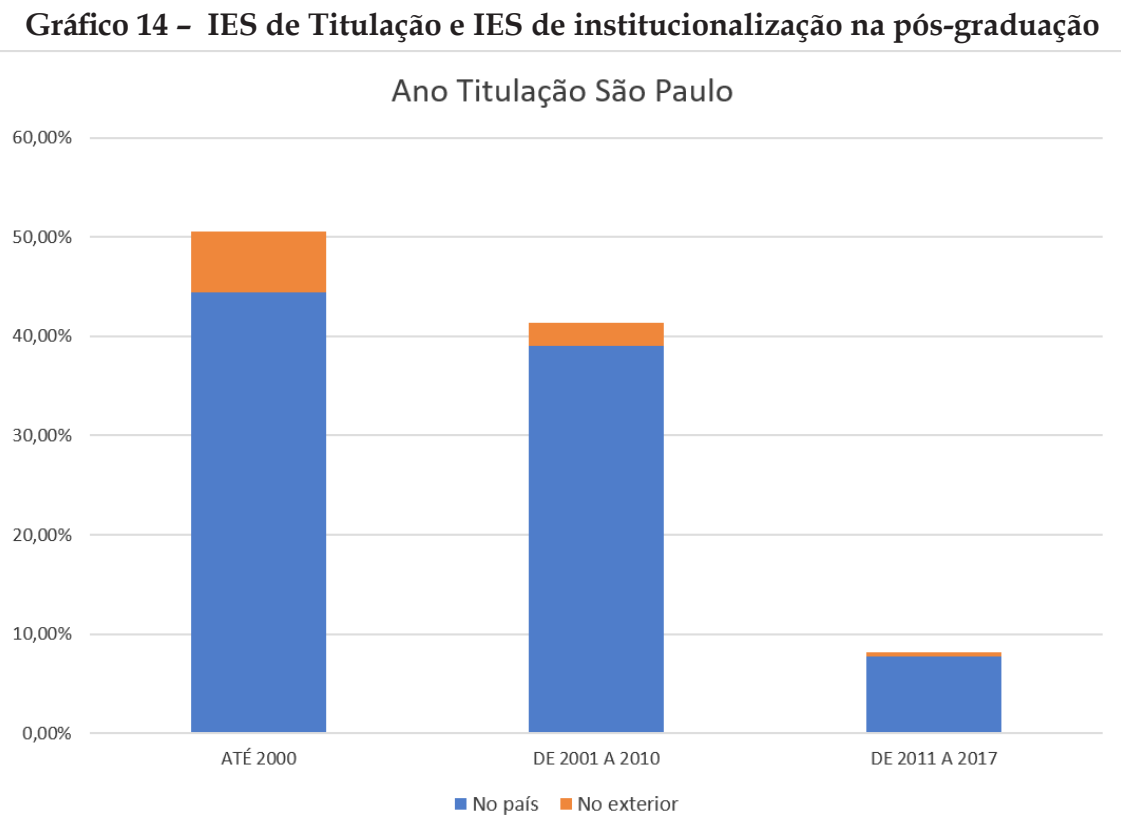

Fonte: Elaborado pelo autor a partir dos sites dos PPGs (2018).

Os dados apresentados sobre a mobilidade geracional na pós-graduação, que apontam para a renovação dos quadros, discreta, mas constante, talvez aparecessem de forma mais distinta e radical se considerássemos os docentes envolvidos nos programas interdisciplinares. Estes se multiplicam principalmente em novos campi sem uma configuração disciplinar consolidada, havendo ora propostas inovadoras em termos de ensino e pesquisa, ora uma forma de juntar pesquisadores com temáticas próximas.

\section{Sociologia, Ciências Sociais e Interdisciplinaridade}

Uma das questões que vêm sendo debatidas na Capes já há algum tempo é a necessidade de revisão de alguns critérios de avaliação para que se continue efetivamente fazendo a discriminação, a partir de indicadores, da excelência dos programas de pós-graduação. Isso aconteceu na década de 1990 com a implementação do Qualis periódico e a mudança de conceitos para notas, além do fato de a maioria dos programas de pós-graduação da área terem atingido padrões de qualidade equivalentes. 
Além desse padrão já atingido, a expansão das últimas décadas deu visibilidade ao que historicamente foi construído no Brasil, como o "campo" das Ciências Sociais, originalmente agrupando três disciplinas com níveis distintos de consolidação e profissionalização: a Sociologia, a Ciência Política e a Antropologia. Isso se tornou o formato dominante nos cursos de graduação em Ciências Sociais, o mesmo acontecendo no início da pósgraduação, embora nesse início já esteja presente uma disciplinarização nas três áreas. A Sociologia, fortemente majoritária, tornou-se sinônimo de Ciências Sociais e também passou a ter, principalmente na pós-graduação, programas disciplinares e, posteriormente com a inclusão da disciplina no ensino médio, cursos de licenciatura e mesmo bacharelado na graduação.

Em entrevista realizada na década de 1990 acerca dos últimos 20 anos das Ciências Sociais no Brasil da época, Elisa Reis destacava a positividade das disputas no campo das Ciências Sociais e sua delimitação disciplinar. Para ela, esse processo resultou do crescimento e da institucionalização da profissão, que foi desvinculando a sobreposição existente entre a Sociologia e a Ciência Política, que muitas vezes se confundiam. Essa situação aconteceu menos entre a Sociologia e a Antropologia, que tiveram percursos institucionais similares, por exemplo, na criação da Sociedade Brasileira de Sociologia (1950) e da Associação Brasileira de Antropologia (1953) ${ }^{15}$.

Na Sociologia, como nas outras disciplinas, segundo afirma Reis, Reis e Velho (1991:246), “a natureza racionalizante da ciência implica numa percepção da postura metódica e disciplinar como recurso analítico. A disciplinaridade funciona como uma convenção, não como uma convicção ou imposição".

As lutas no campo científico movimentam-se entre as regras do jogo construídas em cada campo, o capital simbólico e o reconhecimento que estabelecem essas regras. Um campo é definido a partir dos objetos de disputas que o caracterizam, imperceptível para quem não o integra, e pressupõe que seus integrantes incorporem o habitus que torne compreensíveis leis, regras do jogo e objetos de disputa (BOURDIEU, 1983; 1983a: 89).

No Brasil não foi diferente, e nesse combate a Sociologia foi acusada indiretamente de imperialismo diante das demais. Peirano (2000:19) afirma que a Antropologia foi tratada por muito tempo como uma costela

${ }^{15}$ Sobre a criação das associações, veja-se Lima e Cortês (2013). 
da Sociologia; Forjaz (1997) destaca a influência da Sociologia francesa na Sociologia brasileira e a indistinção entre Sociologia Política e Ciência Política como fatores de inibição do desenvolvimento da Ciência Política - situação que se altera com a instituição do sistema de pós-graduação a partir do final dos anos 1960 e o financiamento por instituições norteamericanas (1997).

Mas os conflitos do campo se distribuem internamente na Sociologia. Nas últimas avaliações da Capes, questiona-se a queda de programas tradicionais na área e que formaram boa parte do campo, dos docentes e pesquisadores na pós-graduação brasileira. Por muito tempo, alguns cursos consolidados funcionaram sem considerar muito os processos avaliatórios que passaram a regular a formação pós-graduada com a expansão do ensino superior. Essa situação começou a ser alterada a partir de 2003, com a maior formalização da avaliação e cobrança aos programas do atendimento aos critérios estabelecidos pela área e o crescimento da pósgraduação, provocando uma maior institucionalização que, por sua vez, levou a críticas à burocratização ou mesmo à neoliberalização da academia, com o privilegiamento do produtivismo presente numa avaliação fundada principalmente em dados quantitativos. Entretanto, ao lado desse movimento de institucionalização, com a polêmica acerca de como e o que avaliar, houve também maior democratização da avaliação, com maior participação dos coordenadores de programas no estabelecimento do documento de área, assim como discussões e seminários da coordenação com a área.

Outra disputa presente no comitê de Sociologia está entre os programas disciplinares e os interdisciplinares de Ciências Sociais e que tipo de formação seria mais adequada. Isto ocorre em parte pela diversidade assumida pelos programas de Ciências Sociais na pós-graduação, que funcionam ora de forma temática, integrando as três disciplinas em torno de uma proposta, ora como cursos que formam nas três disciplinas, sendo que, no geral, o orientador dirige as pesquisas para uma delas. Como foi dito, com a expansão das universidades e da pós-graduação, as áreas de Ciência Política e Antropologia expandiram fortemente seus programas disciplinares. A partir da existência de um número de docentes considerados adequados pelos documentos das áreas, cursos disciplinares foram criados. Nos cursos ou programas de Ciências Sociais, ora existe uma predominância da Sociologia, ora não existem condições institucionais para abertura de cursos disciplinares. Numa terceira vertente, mantêm-se propostas integrativas de interdisciplinaridade. 
Além disso, houve um crescimento no período de 1996-2014 de 736,4\% nos doutorados interdisciplinares (92 em 2014) e 715,6\% nos mestrados (261, em 2014). Na Câmara II da Coordenação Sociais e Humanidades da Capes, estes de certa forma ampliaram as propostas de interdisciplinaridade das Ciências Sociais, incluindo disciplinas como Economia, História, Direito, Geografia. Na Câmara II, alguns dos programas poderiam ser considerados de Ciências Sociais ampliados, ficando em questão a especificidade e a manutenção da proposta das Ciências Sociais stricto sensu, modelo ainda vigente.

Seguem alguns exemplos de programas que estão na Câmara de Sociais e Humanidades da Área Interdisciplinar da Capes. Percebe-se que a maioria dos programas interdisciplinares está em universidades novas ou campi novos de universidades já existentes. Na ausência de um corpo docente com formação disciplinar, a interdisciplinaridade surge mais como opção de ter um programa, ou curso, do que efetivamente uma proposta diferenciada em grande parte dos casos. Isto considerando a vinculação pesquisa-pós-graduação que exige que os doutores estejam em cursos de pós como forma de acesso a determinados recursos.

Mesmo em cursos mais antigos e ou consolidados, nota-se que os titulados dos cursos interdisciplinares, ao solicitarem financiamento de pesquisa e ou bolsas de capacitação, terminam por destacar a formação disciplinar como forma de acesso, por não existir a opção Interdisciplinar, ou talvez pela dificuldade de se criar uma. O mesmo ocorre no mercado de trabalho acadêmico. Quando os concursos são na mesma universidade de titulação, esta é incorporada entre as titulações aceitas. Em outras situações isso não ocorre. Alguns exemplos dos cursos interdisciplinares podem ser assim agrupados: Cultura e Sociedade; Ciências Sociais e Humanas; Interdisciplinar em Humanidades; Sociedade e Território; Políticas Públicas; Memória e Patrimônio; Estudos latino-americanos (Quadro 4).

Quadro 4 - Programas que integram a Câmara de Sociais e Humanidades da Coordenação da Área Interdisciplinar - Selecionados pela proximidade dos Programas de Ciências Sociais stricto sensu

\begin{tabular}{|c|c|c|c|}
\hline Nome do curso & Nível & Instituição & Estado \\
\hline Sociologia e Direito & $\begin{array}{l}\text { Mestrado/ } \\
\text { Doutorado }\end{array}$ & UFF & RJ \\
\hline Cultura e Territorialidades & Mestrado & UFF & RJ \\
\hline Estudos de Cultura e Território & Mestrado & UFT & TO \\
\hline Dinâmicas Territoriais e Cultura & Mestrado & UNEAL & AL \\
\hline
\end{tabular}




\begin{tabular}{|c|c|c|c|}
\hline Nome do curso & Nível & Instituição & Estado \\
\hline Sociedade, Cultura e Fronteiras & $\begin{array}{l}\text { Mestrado/ } \\
\text { Doutorado }\end{array}$ & UNIOESTE & PR \\
\hline Relações Étnico-Raciais & Mestrado & CEFET & RJ \\
\hline $\begin{array}{l}\text { Relações Étnicas e } \\
\text { Contemporaneidade }\end{array}$ & Mestrado & UESB & BA \\
\hline Estudos Étnicos e Africanos & $\begin{array}{l}\text { Mestrado/ } \\
\text { Doutorado }\end{array}$ & UFBA & BA \\
\hline $\begin{array}{c}\text { Família na Sociedade } \\
\text { Contemporânea }\end{array}$ & $\begin{array}{l}\text { Mestrado/ } \\
\text { Doutorado }\end{array}$ & UCSAL & BA \\
\hline $\begin{array}{l}\text { Estudos Interdisciplinares sobre } \\
\text { Mulheres, Gênero e Feminismo }\end{array}$ & $\begin{array}{l}\text { Mestrado/ } \\
\text { Doutorado }\end{array}$ & UFBA & BA \\
\hline $\begin{array}{c}\text { Interdisciplinar em Ciências } \\
\text { Humanas }\end{array}$ & Mestrado & UFFS & $\mathrm{BA}$ \\
\hline Ciências Humanas & $\begin{array}{c}\text { Mestrado } \\
\text { Profissional }\end{array}$ & UFVJM & $\begin{array}{l}\text { BA/ } \\
\text { MG }\end{array}$ \\
\hline $\begin{array}{c}\text { Interdisciplinar em Ciências } \\
\text { Humanas }\end{array}$ & Doutorado & UFSC & SC \\
\hline $\begin{array}{l}\text { Interdisciplinar em Ciências } \\
\text { Humanas e Sociais Aplicadas }\end{array}$ & Mestrado & $\begin{array}{l}\text { UNICAMP- } \\
\text { Limeira }\end{array}$ & $\mathrm{SP}$ \\
\hline Interdisciplinar em Humanidades & Mestrado & UNILAB & $\mathrm{CE}$ \\
\hline Ciências Humanas & Mestrado & UEA & $\mathrm{AM}$ \\
\hline Ciências Sociais e Humanas & Mestrado & UERN & $\mathrm{RN}$ \\
\hline Ciências Humanas e Sociais & $\begin{array}{l}\text { Mestrado/ } \\
\text { Doutorado }\end{array}$ & UFABC & $\mathrm{SP}$ \\
\hline Humanidades, Culturas e Artes & $\begin{array}{l}\text { Mestrado/ } \\
\text { Doutorado }\end{array}$ & UNIGRANRIO & RJ \\
\hline Ciências da Sociedade & Mestrado & UFOPA & PA \\
\hline $\begin{array}{c}\text { Processos e manifestações } \\
\text { culturais }\end{array}$ & $\begin{array}{l}\text { Mestrado/ } \\
\text { Doutorado }\end{array}$ & FEEVALE & RS \\
\hline $\begin{array}{c}\text { Diversidade Cultural e Inclusão } \\
\text { Social }\end{array}$ & $\begin{array}{l}\text { Mestrado/ } \\
\text { Doutorado }\end{array}$ & FEEVALE & RS \\
\hline Sociedade e Cultura na Amazônia & $\begin{array}{l}\text { Mestrado/ } \\
\text { Doutorado }\end{array}$ & UFAM & $\mathrm{AM}$ \\
\hline $\begin{array}{c}\text { Dinâmicas Territoriais e Sociedade } \\
\text { na Amazônia }\end{array}$ & Mestrado & UNIFESSPA & PA \\
\hline Cultura e Sociedade & Mestrado & UFMA & MA \\
\hline $\begin{array}{l}\text { Estudos de Cultura } \\
\text { Contemporânea }\end{array}$ & $\begin{array}{l}\text { Mestrado/ } \\
\text { Doutorado }\end{array}$ & UFMT & MT \\
\hline
\end{tabular}




\begin{tabular}{|c|c|c|c|}
\hline Nome do curso & Nível & Instituição & Estado \\
\hline Sociedade e Desenvolvimento & Mestrado & UNESPAR & PR \\
\hline Desenvolvimento e Sociedade & Mestrado & UNIARP & SC \\
\hline $\begin{array}{c}\text { Práticas Socioculturais e } \\
\text { Desenvolvimento Social }\end{array}$ & Mestrado & UNICRUZ & RS \\
\hline
\end{tabular}

Fonte: Capes - Plataforma Sucupira (janeiro 2019).

Sem dúvida, as fronteiras das Ciências Sociais nem sempre são identificáveis, o que também ocorre nas ciências de forma geral. Entretanto, como afirmam Reis, Reis e Velho (1997:245), ao se referirem à teoria social clássica, na medida em que formulações transcendem os limites de uma disciplina, elas estimulam o desenvolvimento de novas especializações que provocam o avanço do conhecimento. Isso não é uma recusa à interdisciplinaridade inerente à própria formação da Sociologia e à importância dessa interdisciplinaridade na formação, mas de se evitarem as generalizações excessivas ou o discurso filosofante que às vezes perpassam as justificativas da formação do sociólogo, como se a profissionalização fosse apenas uma questão secundária para os estudantes e profissionais.

\section{Concluindo}

Os dados aqui apresentados fornecem um painel da institucionalização da Sociologia, tendo a formação pós-graduada como eixo. Busquei demonstrar a construção do campo e sua "nacionalização", não no sentido restritivo do nacional, mas de sua expansão territorial de construção de uma comunidade acadêmica e profissional na área.

Para isto destaquei a expansão da formação graduada e pós-graduada e as questões que se colocam a partir dessa expansão. Uma delas é a existência de um número maior de cursos de pós-graduação comparativamente à graduação, considerando a área de Ciências Sociais stricto sensu, mas destacando a constituição da formação disciplinar da Sociologia, e as lutas presentes no campo das Ciências Sociais. Uma forma de responder a essa questão é atribuir o caráter complementar da formação em Sociologia e Ciências Sociais para algumas profissões como Direito, Educação, História, Economia, Jornalismo, Filosofia, Medicina e outras, nas quais os titulados tendem a permanecer. Uma outra encontra-se na descoberta da vocação, fazendo com que migrem a partir da formação pós-graduada. Como a titulação pós-graduada se sobrepõe à graduada nas humanidades, isso é 
relativamente comum. No Ensino Médio, levantamento realizado em 2012 indicava que apenas $19,42 \%$ dos professores com formação em Sociologia ou Ciências Sociais ministravam a disciplina, o que refletia o caráter recente da obrigatoriedade da Sociologia, por um lado, e por outro a pouca atração exercida pelo magistério entre os formados na área ${ }^{16}$.

A formação em Sociologia e Ciências Sociais se distribui por todo o país com padrões de qualidade significativo, o que é ilustrativo da maior presença da Sociologia brasileira em fóruns mundiais. Isso se deu a partir de uma capacitação docente propiciada dentro e fora do país, que se institucionalizou e consolidou. A prevalência da avaliação da pósgraduação pela Capes, na qual a pesquisa e as publicações tiveram um papel determinante, se constituiu instrumento importante para a "nacionalização" dessa formação e atuação.

Através dos programas de pós tentei apresentar o processo de mobilidade docente entre as regiões do país. Os dados nesse sentido restringem-se apenas à pós-graduação dada a dificuldade de levantamento de dados sobre docentes dos departamentos de Sociologia ou de Ciências Sociais nem sempre on-line, assim como dos docentes dos Institutos Federais que também tiverem forte expansão. Isto permitiria um panorama mais completo da mobilidade espacial e geracional. Com as novas universidades e campi, houve uma incorporação de profissionais graduados em todo o país, o que é ilustrado com os dados acerca de sua incorporação pelo mercado de trabalho nas universidades públicas e privadas e mesmo fora do âmbito acadêmico. Outra questão relevante é o impacto dessa mobilidade nas cidades e regiões para onde os pesquisadores se deslocam, assim como os processos de consolidação que não duram menos que 10 anos, mas isso é assunto para uma próxima pesquisa.

Por fim, vale retomar a questão da crise econômica e das mudanças políticas dos últimos dois anos, que tem significado uma profunda regressão em termos de investimentos e de perspectivas do desenvolvimento científico e tecnológico. Além disso, temos as ameaças concretas à

\footnotetext{
${ }^{16}$ Bodart e Silva (2016) afirmam que o censo apresenta diversos problemas de preenchimento e que esses números devem ser relativizados. Em pesquisa que realizaram em todo o país, o número é bem maior: 76, 7\%, mas foi realizado em um blog destinado a professores da área, o que também limita seu alcance. Mesmo assim, com a retirada da obrigatoriedade das Ciências Sociais com a reforma do Ensino Médio em 2017, deve acrescentar novos dados acerca da busca pelo magistério entre formados na área.
} 
universidade e sua autonomia pela radicalização de um discurso moralistareligioso que vai na contramão das conquistas das últimas décadas. Num artigo publicado em 1958, Florestan Fernandes destacava uma percepção negativa da Sociologia no período por setores conservadores da sociedade, vista então como "uma ameaça aos fundamentos emocionais e morais da ordem estabelecida", sendo que tudo que fosse entendido como sociológico deveria ser "repelido como fonte de perigos reais ou potenciais para os costumes ou a mentalidade do povo brasileiro" (1977[1958], p.57-58). Após 60 anos, assistimos à repetição desse discurso. A Sociologia, mais uma vez, é penalizada pelo obscurantismo que se espraia pela sociedade, reforçando a ignorância acerca da disciplina e de suas possibilidades.

\section{Referências}

ALMEIDA, M.H.T.

(1987). Castelos na Areia: Dilemas da Institucionalização das Ciências Sociais no Rio de Janeiro (1930-1964). BIB, Rio de Janeiro, n. 24. p. $41-60,2^{\circ}$ semestre.

BALTAR, R; BALTAR, C.S.

(2017). A Sociologia como profissão. Revista Brasileira de Sociologia, v. 05, n. 10, p.259289, maio/ago.

BARREIRA, I.F; CORTES, S.V.; LIMA, J.C.

(2018). A Sociologia fora do eixo: diversidades regionais e campo da pós-graduação no Brasil. Revista Brasileira de Sociologia, v. 06, n. 13, p.76-103, maio/ago.

BODART, C.N; SILVA, R.S.

(2016). 0 perfil do professor brasileiro de Sociologia do ensino médio e sua percepção da condição docente. Inter-Legere - Revista de Pós-Graduação em Ciências Sociais da UFRN, Natal no 18, p. 168-189.

BONELLI, M. G.

(1994). 0 mercado de trabalho dos cientistas sociais. Revista Brasileira de Ciências Sociais, São Paulo, v. 09, n.25, p. 110-126.

BOURDIEU, P.

(1983). 0 campo científico. In: ORTIZ, R. (Org.). Sociologia. São Paulo: Ática, 1983. p. 122155.
BOURDIEU, P.

(1983a) Algumas propriedades dos Campos. In: BOURDIEU, P. Questões de sociologia. Rio de Janeiro, Editora Marco Zero, p. 89-94.

CCGE.

(2016). Mestres e doutores 2015 - Estudos da demografia da base técnico-científica brasileira. Brasília, DF, Centro de Gestão e Estudos Estratégicos. Disponivel em: <https://www.cgee.org.br/ documents/10182/734063/Mestres_ Doutores_2015_Vs3.pdf> Acesso em: 15 mar. 2018.

DS. Departamento de Sociologia USP. Disponível em: <http://sociologia.fflch.usp.br/pos/ apresentacao $>$

e-MEC. Ministério da Educação. Disponível em:< emec.mec.gov.br>

FARIAS, E.; TAVOLARO, S.B.F.

(2017). A prática da Sociologia na UnB: da abertura de horizontes intelectuais aos anseios de renovação. In: BOMENY, $H$. (org.). Ensino de Sociologia na graduação: perspectivas e desafios. São Paulo: SBSAnnablume, p.77-109.

FERNANDES, F.

(1977[1958]). 0 padrão de trabalho científico dos sociólogos brasileiros. In FERNANDES, F. $A$ Sociologia no Brasil. Petrópolis, Vozes. 
FORJAZ, M.C.S.

(1997). A emergência da Ciência Política no Brasil: aspectos institucionais. Revista Brasileira de Ciências Sociais, v. 12 n. 35, p. 101-120.

GLOB0. G1. Educação. Disponível em: <https://g1.globo.com/educacao/ noticia/2018/12/31/graduacao-presencialpodera-ter-ate-40-de-aulas-a-distancia. ghtml>

ICS. Instituto de Ciências Sociais. Disponível em: <http://www.ics.uerj.br/site/index.php/ institucional/apresenta\%C3\%A7\%C3\%A30. html>

LIMA, J.C.; CORTÊS, S.V.

(2013). A Sociologia no Brasil e a interdisciplinaridade nas ciências sociais. Civitas, Porto Alegre, v. 13, n. 3, p. 416-435, set.-dez.

MEC-SESU.

(1965). Parecer no 977/65. Definição dos cursos de pós-graduação. Relator Newton Sucupira. Disponivel em: <https://www.capes.gov. $\mathrm{br} /$ images/stories/download/legislacao/ Parecer_CESU_977_1965.pdf> Acesso em: 17 ago. 2018.

PEIRAN0, Mariza G. S.

(2000). A Antropologia como ciência social no Brasil. Etnográfica, v. 4, n. 2, p. 219-232.

PERLATTO, F.

(2017). Sociologia e Ciências sociais na graduação: especialização \& imaginação interdisciplinar. In: BOMENY, H. Ensino de Sociologia na graduação: perspectivas e desafios. São Paulo, SBS-Annablume, p.145170.
REIS, E.P.

(1991). Reflexões transversas sobre transdisciplinaridade e ensino de Ciências Sociais. In: BOMENY, H; BIRMAN, P. As assim chamadas Ciências Sociais. Rio de Janeiro, UERJ-Relume Dumará, p. 243-249.

REIS, E.P; REIS, F.W.; VELHO, G.

(1997). As Ciências Sociais nos últimos 20 anos: três perspectivas. Revista Brasileira de Ciências Sociais, v. 12 n. 35, p.7-28.

LEIS, H.R.

(2000). A tristeza de ser sociólogo no século XXI. Dados, v.43 n.4, p. 737-760.

SAVIANI, D.

(2008). Cadernos Cedes, Campinas, v. 28, n. 76, p. 291-312, set. /dez.

SUCUPIRA, N.

(1980). Antecedentes e primórdios da pósgraduação. Forum educ., Rio de Janeiro, 4 (4), p. 3-18, out./dez.

UERJ. A Universidade. Apresentação. Disponível em: $\quad<$ http://www.uerj.br/a-uerj/auniversidade $>$

UERJ. A Universidade. Histórico. Disponível em: <http://www.uerj.br/a-uerj/a-universidade>

\section{Recebido em}

março de 2019

\section{Aprovado em}

março de 2019 


\title{
Comida, imigrações e imaginários urbanos em cidades globais $^{1}$
}

\author{
Carla Pires Vieira da Rocha* \\ Carmen Sílvia Rial**
}

\begin{abstract}
Resumo
0 texto explora a comida na constituição de imaginários urbanos a partir de imigrantes em cidades globais, levando em conta o caso da cidade de Amsterdã (Países Baixos), e é fio condutor do período atual da globalização e correlativa intensificação de diferentes fluxos. Ressalta a heterogeneidade das migrações contemporâneas e mostra como o cosmopolitismo, visto sobretudo a partir de uma dinâmica de diversidade cultural, torna-se um conceito fundamental para compreender como vêm se constituindo determinados imaginários urbanos, em especial aqueles associados à comida.
\end{abstract}

\section{Palavras-chave}

Comida. Imigrações internacionais. Imaginários urbanos.

\section{Abstract}

The text explores the food in the conformation of urban imaginaries from immigrants in global cities, considering the case of the city of Amsterdam (Netherlands) and the current period of globalization and correlative intensification of different flows as the guiding thread. It highlights the heterogeneity of contemporary migrations and shows how cosmopolitanism, seen mostly from a dynamic of cultural diversity, becomes a fundamental concept to understand how certain urban imaginaries have been constituted, especially those associated with food.

\section{Keywords}

Food. International Immigrations. Urban Imaginaries.

\footnotetext{
${ }^{1}$ O presente trabalho foi realizado com apoio da CAPES, Coordenação de Aperfeiçoamento de Pessoal de Nível Superior - Brasil, no âmbito do Programa Capes/ NUFFIC.

* Carla Pires Vieira da Rocha é pós-doutoranda no Programa de Pós-Graduação em Ciências Humanas da Universidade Federal de Santa Catarina (UFSC). Doutora em Ciências Humanas (UFSC). E-mail: carlapvrocha@gmail.com.

** Carmen Sílvia Rial é professora dos programas de Antropologia e de Pós-Graduação em Ciências Humanas da Universidade Federal de Santa Catarina (UFSC). Doutora em Antropologia.E-mail: rial@cfh.ufsc.br.
} 


\section{Introdução}

“Todas as sociedades viveram no e pelo imaginário. Digamos que todo real seria 'alucinado' (objeto de alucinações para indivíduos e grupos) se não fosse simbolizado, isto é, coletivamente representado."

Marc Augé

Na época atual, ao observarmos a relação entre comida e imigração, o papel dos imaginários urbanos assume cada vez mais relevância. À medida que os processos relativos à globalização vêm se materializando nos centros urbanos, configurando as denominadas cidades globais (SASSEN, 1998, 2010), distintos imaginários são constituídos, articulando-se, inclusive, aos projetos migratórios de imigrantes. Um exemplo desse panorama é o que ocorre com imigrantes transnacionais em Amsterdã. Mas assim como as motivações para migrar são diversas, os imaginários urbanos também são múltiplos. Ao analisarmos o quadro de Amsterdã e imigrações com grande ênfase em aspectos culturais, conjuntamente a noções de cosmopolitismo, a comida aparece como um elemento expressivo para se compreender como vêm se configurando tais imaginários nesse contexto.

O presente texto baseia-se em uma pesquisa etnográfica realizada com imigrantes de variadas nacionalidades na cidade de Amsterdã (Países Baixos), entre abril de 2015 e março de 2016, cujo foco foi voltado para compreender como o período atual da globalização vem ressoando na constituição de estilos de vida, imaginários e práticas cotidianas de imigrantes transnacionais nessa cidade, com proeminência aquelas relativas à alimentação. A pesquisa evidenciou quedeterminadosimaginários urbanos não apenas ganham relevância para compreender a heterogeneidade das migrações contemporâneas como também a constituição de certas práticas relativas à alimentação, conforme será abordado ao longo do texto².

\footnotetext{
${ }^{2}$ A pesquisa incluiu vinte e três entrevistas com homens e mulheres de idades entre 21 e 54 anos, provenientes de camadas médias em seus países de origem. Esses países compreendiam Brasil, Jamaica, França, Suíça, Alemanha, Costa do Marfim, Espanha, Curaçao, Itália, Venezuela, Portugal, Rússia e Áustria. O período de permanência desses indivíduos na cidade, à data da entrevista, variava de dois meses a vinte e sete anos. A pesquisa resultou na tese de doutorado intitulada Comida em uma cidade global: práticas alimentares de imigrantes transnacionais em Amsterdã, disponível em: https://repositorio.ufsc.br/xmlui/handle/123456789/178589.
} 


\section{Imigrantes em Amsterdã: imaginários urbanos em uma cidade global}

As migrações internacionais têm sido impulsionadas por distintas motivações. O enfoque nos imaginários urbanos contribui para a compreensão do que vem constituindo tais mobilidades e, em especial, ao considerarmos os significados da desterritorialização aí envolvidos. Como chama a atenção Canclini ${ }^{3}$, os imaginários aparecem como um componente necessário, tornando-se importantes para estabelecer relações tanto de localização quanto de deslocalização dos sujeitos, consistindo ainda não apenas como representação simbólica do que ocorre, mas também como um lugar de elaboração de insatisfações e desejos.

Canclini (2010) também observa que os imaginários nutriram toda a história do urbano. Defendendo ponto de vista complementar e fundamental para nossa abordagem, Linder e Meissner (2019) argumentam que os imaginários urbanos formam parte de nossas vidas diárias e estão em todos os lugares, abrangendo turismo, marcas (rótulos) atribuídos a uma cidade, arte, arquitetura, planejamento, policiamento, velhas e novas mídias, entre diversas possibilidades a serem destacadas. Nessa mesma ótica, Linder e Meissner (2019), reportando ao pensamento de autores que no século 20 fundamentaram a teoria crítica sobre espaço e urbanismo, como Georg Simmel, Walter Benjamin, Kevin Lynch, Michel de Certeau, Henri Lefebvre e Edward Soja (embora com diferentes perspectivas epistemológicas), defendem que os imaginários urbanos desempenham um papel igualmente definidor para o espaço da cidade, ao mesmo tempo que interligam estruturas e signos, mentes e corpos, fatos e subjetividades, realidades e virtualidades. Podemos ainda aludir ao pensamento de Edward Soja (2010) e sua definição de imaginários urbanos, no sentido de que tais imaginários estão sempre em transição, refletindo transformações nos campos interconectados da cultura, política, economia, natureza e tecnologia. Segundo esse autor, os imaginários urbanos são "os mapeamentos mentais ou cognitivos da realidade urbana e as grades interpretativas através das quais pensamos, experimentamos, avaliamos e decidimos agir nos lugares,

\footnotetext{
${ }^{3}$ Entrevista realizada por Alicia Lindón, Diálogo con Néstor García Canclini ¿Qué son los imaginarios y cómo actúan en la ciudad? 23 de febrero de 2007, Ciudad de México. Revista eure. v. XXXIII, n. 99, p. 89-99, Santiago de Chile, 2007.
} 
espaços e comunidades em que vivemos" (SOJA, 2000: 324 apud LINDER; MEISSENER, 2019).

Algumas cidades ao redor do mundo vêm concentrando uma quantidade expressiva de imigrantes e igualmente uma diversificação nesse sentido. É o caso, sobretudo, daqueles centros urbanos que se enquadram na definição de cidades globais, uma vez que materializam com maior relevo os processos relacionados à globalização em curso. Dentre essas cidades, destacamos o caso de Amsterdã.

Conforme sinalizam Çinar e Bener (2007), a apreensão de uma cidade passa por compreender as formas pelas quais os limites que configuram as cidades são produzidos, disseminados, institucionalizados, contestados e negociados em várias situações da vida urbana diária que constituem e reproduzem continuamente a imaginação coletiva. Ao buscarmos compreender o que faz de Amsterdã um destino migratório a partir de imigrantes que ali chegaram há vinte cinco anos ou então em datas mais recentes, indubitavelmente entram em cena perspectivas diversas com relação à cidade. Tais perspectivas são também filtradas pelas histórias de vida desses indivíduos que englobam a realidade de seus países de origem, principalmente no período de emigração. Entretanto, por mais filtradas que devam ser as percepções da cidade em virtude da realidade anterior de cada um desses indivíduos e não obstante esse centro urbano estar imerso em uma dinâmica de mudanças resultantes da globalização vigente, sua configuração nutre alguns imaginários reiterados continuamente, mesmo diante de mudanças emergentes, como será abordado mais adiante. Tais imaginários também colaboram para que indivíduos alimentem expectativas em torno de seus projetos de vida nesse centro urbano, em especial, para aqueles cuja mobilidade tem forte ênfase em aspectos culturais.

Amsterdã é a cidade mais populosa dos Países Baixos e é considerada uma porta de entrada de imigrantes das mais diversas proveniências desde longa data. De acordo com dados oficiais, computando imigrantes de primeira e segunda geração, cerca de 178 nacionalidades estariam ali representadas 4 . Dados estatísticos municipais de 2014 revelam que o total dessas populações $(411.092)^{5}$ chega a ser superior ao número de holandeses

\footnotetext{
${ }^{4}$ My first month: all you need to know and note. Expatcenter Amsterdam, 11 ed. Jan, 2015.

${ }^{5}$ A composição étnica da cidade em 2012 era de 49,5\% neerlandeses e 50,5\% estrangeiros. Pessoas de origem não europeia constituíam ao todo $34,9 \%$ da população e $52,6 \%$ de pessoas menores de 18 anos de idade.
} 
$(400.093)^{6}$. Devido à imigração em larga escala proveniente, principalmente, de Suriname, Marrocos e Turquia, há uma estimativa de que em poucos anos pessoas de origem não europeia se tornarão o grupo étnico dominante na cidade ${ }^{7}$. Mais recentemente, além de estarem se diversificando as regiões de origem dos imigrantes nessa capital, ancoradas no transnacionalismo, as imigrações têm agora um alcance mais global, como nunca visto anteriormente (CASTLES; MILLER, 1993).

A capital holandesa é também considerada um dos principais centros financeiros da Europa, polo importante de globalização da economia. Enquanto cidade global, essa capital está alinhada a um campo de cidades que se tornaram mais facilmente acessíveis por meio das finanças (dinheiro), comunicações (viagens) e informação (radiodifusão, publicações, mídia). Nas palavras de Sassen (2010), o caráter internacional das cidades globais não está associado apenas à sua infraestrutura de telecomunicações ou empresas internacionais, mas ainda aos muitos ambientes culturais onde seus trabalhadores circulam. A exemplo de outros centros urbanos intensamente marcados pelos processos globais, essa é uma capital onde se cruzam muitos turistas, imigrantes, estudantes e valores diversos.

Nas narrativas construídas sobre Amsterdã, históricas ou contemporâneas, tanto a partir de seus órgãos oficiais quanto as dos atores sociais, e aqui focalizamos nos sujeitos dessa pesquisa, ganha proeminência a que a inscreve como cidade cosmopolita, sobretudo pela mistura de diferenças, em que pessoas, mercadorias, ideias e culturas do mundo todo se encontram e interagem. Tal contexto dá razão a uma multiplicidade de imaginários. Entretanto, como nos recorda Canclini (ibid.), quando se trata de imaginários urbanos, não é importante apenas o que define uma cidade, mas também como os indivíduos se situam com relação às várias cidades que podem estar contidas sob o mesmo nome, já que cada habitante fragmenta e conjetura sobre o que não vê, sobre o que desconhece, evidenciando ainda que não há saberes totalizadores ou formas absolutas nesse sentido. Conforme sinalizado, em meio às motivações que levaram esses sujeitos a direcionarem seus projetos migratórios para Amsterdã, avultam certas imagens/narrativas relacionadas à cidade. Nos relatos, "aberta", "multicultural" e "tolerante" são termos correntemente associados

${ }^{6}$ Disponível em: http:/ /www.ois.Amsterdã.nl/english/ Acesso em: jul. 2016.

${ }^{7}$ As populações com número mais vultoso na cidade são marroquinos (73.311), surinameses (67.490) e turcos (42.211). 
a essa capital ${ }^{8}$. Nas entrevistas ou conversas informais com imigrantes, e inclusive com mais de um indivíduo nascido na Holanda, não foi raro haver narrativas fazendo distinção bastante contundente entre essa capital e as demais cidades do país, avaliadas como de população mais conservadora, acima de tudo, no que diz respeito a noções de "liberdade". Mas a metrópole ainda se constrói a partir de uma série de características importantes de serem levadas em conta, no intuito de contornar como se constituem imaginários relativos a essa cidade, transformando-a em um destino migratório significativo dentro do continente europeu e mesmo em uma perspectiva mais global. Como ressalta Canclini (ibid.), uma cidade é sempre heterogênea e isso decorre, entre outras razões, dos muitos imaginários que a habitam.

A noção de tolerância também constitui muitas narrativas sobre o país, mais particularmente a capital, e acompanha a sua trajetória histórica ${ }^{9}$. Tal narrativa associada à cidade é constantemente reafirmada em panfletos turísticos, na fala de diversos imigrantes e principalmente a partir dos discursos oficiais ${ }^{10}$. Cabe citar o website e materiais impressos do governo ou mesmo algumas instituições, como o museu histórico da cidade, onde se pode constatar as referidas narrativas em tópicos presentes em sua exposição permanente. Na época atual, as narrativas constituídas a partir da noção de tolerância social são sobretudo associadas às políticas migratórias e também à política liberal do país com relação à homossexualidade, drogas, prostituição, eutanásia e aborto ${ }^{11}$.

\footnotetext{
${ }^{8}$ A referida tolerância associada à Amsterdã reporta a raízes bem mais antigas. Entre alguns fatores que têm contribuído para perpetuar imaginários nesse sentido, destaca-se o fato de o país ser o primeiro a legalizar a eutanásia (2001) e o casamento entre pessoas do mesmo sexo (2001), o fato de o aborto ser considerado uma prática igualmente legal, custeado pelo governo independentemente da razão envolvida, e também a legalização da prostituição e das drogas consideradas leves (haxixe e maconha).

${ }^{9}$ No passado, Amsterdã já atraía imigrantes, entre os quais muitos judeus e protestantes que buscavam refúgio, após serem perseguidos em seus próprios países. Além disso, conforme o material impresso referido, a qualidade de tolerância reporta a raízes bem mais antigas e deve-se também ao fato de que a construção de relações com indivíduos de outros contextos culturais sempre foi vista e valorizada pelos Amsterdammers (cidadãos de Amsterdã) como uma forma de ampliar as possibilidades de trocas, o que incluía facilitar o comércio e promover o avanço econômico. Com relação a esse aspecto, vale lembrar que desde o período das primeiras explorações europeias, as rotas de comércio, também funcionavam como redes internacionais de comunicação, baseadas não somente em trocas comerciais, mas também culturais.

${ }^{10}$ Ver em: http://www.iamsterdam.com/en/visiting/about-amsterdam.

${ }^{11}$ O país é o primeiro a legalizar a eutanásia (2001) e o casamento entre pessoas do mesmo sexo
} 
A ideia de capital da liberdade também dá razão a narrativas sobre Amsterdã expressas em particular a partir de seus órgãos oficiais. Exemplo disso é o Red Light District (distrito da luz vermelha) - bairro que centraliza a prostituição legalizada e também o comércio e atividades em torno do tema (sex shops, cinema, casas de shows eróticos e também o museu do sexo). A tolerância por parte do governo ao consumo e comércio de drogas leves, ainda sob condições restritas, é outro exemplo. Há cerca de 400 coffe shops dispersos pelos diferentes bairros da cidade. No que se refere às narrativas sobre a cidade a partir de seus órgãos oficiais, essas ainda giram em torno da alta qualidade de vida atribuída àquele contexto. Contribuem para esse quadro vários fatores, como uma área urbana com mais de quarenta parques, vasta oferta de programação cultural, a referência positiva de suas universidades, baixas taxas de desemprego com relação a outras capitais do mesmo continente, uma cultura do ciclismo como meio de transporte e vinculada diretamente à noção de estilo de vida saudável e ainda significativos investimentos na área ambiental, visando à reputação de capital mais sustentável da Europa.

No que se refere às narrativas constituídas a partir dos sujeitos da pesquisa, essas também apontam Amsterdã como um local privilegiado para se viver, em especial na conjuntura vigente, em que a discrepância de condições entre diferentes partes do mundo reflete faces do período atual da globalização, como as que incidem, inclusive, no desencadeamento de certas modalidades de movimentos migratórios. Atribuindo também os padrões globais de imigração ao impacto desigual da globalização, Price e Benton-Short (2008) argumentam que, ao invés de uma superfície plana, a globalização teria produzido dezenas de planaltos e regiões-pico, sendo as cidades globais vistas como refletoras da disparidade e desigualdade da globalização. Nessa imagem, as cidades globais estariam acima dos terrenos circunvizinhos, nos picos mais altos, atuando como centros de comando e controle da economia global, ligadas umas às outras pelos fluxos de capital, tecnologia, informação e comércio. Em consequência de tal modelo, essas cidades se tornariam um ponto de atração para imigrantes, sobretudo para aqueles à procura de emprego, oportunidades e serviços.

Embora imaginários associados a Amsterdã, como os referidos, vão ao encontro de expectativas nutridas por muitos imigrantes que buscam a

(2001). Com relação ao aborto, além de ser uma prática igualmente legal, o governo custeia as respectivas despesas, independentemente da motivação envolvida. 
cidade como destino, podendo ser enquadradas como favoráveis aos planos desses sujeitos, mudanças de ordem mais ampla vêm afetando esse contexto. A Holanda é um dos países integrantes da União Europeia e, como resultado das regras impostas paulatinamente pela comunidade, o país sofreu uma série de mudanças que se refletiram em sua capital, muitas das quais são percebidas de maneira pouco positiva por imigrantes, em particular, pelos que estão há mais de dez anos residindo na capital. Na percepção desses indivíduos, essas mudanças vêm sendo mais significativas nos últimos anos e têm incidido em redimensionamentos diversos, abarcando os planos econômico, social, político e cultural. Inevitavelmente, esse novo cenário trouxe implicações que ressoaram em seus estilos de vida e também em certos imaginários relativos à cidade, conforme pode ser identificados nos seguintes relatos:

Há 25 anos atrás, Amsterdã era socialmente alternativa, era uma cidade muito social, onde se podia viver e deixar viver. Havia os hippies que queriam estar debaixo do sol no Vondelpark. Agora não tem nada a ver com isso. Imagina encontrar uma pessoa toda nua no Vondelpark? Mudou também porque, antes, o que ganhava era o partido social. O governo que está agora é um governo de direita - a Holanda agora é muito mais capitalista. A mudança socioeconômica e política mudou muitíssimo e o país tem mudado nos últimos cinco anos também por causa do terrorismo, com a forma de radicalização de muitas das religiões. Mudou e a gente já não se sente mais tão cômoda e segura como antes. Se és homossexual na rua já não te sentes tão seguro, tem havido uma série de maus-tratos que os homossexuais no país têm tido que suportar, muito mais que antes. As gerações novas que estão aqui não sabem como era antes, era muito melhor; para eles, era muito melhor, muito mais aceitável. E a quantidade de imigrantes que não puderam se integrar a uma sociedade liberal, como a sociedade holandesa, porque não tiveram este ajuste, vieram com a mentalidade conservadora e a religião. Antes, havia mais aceitação para outro tipo de cultura. A questão é quando começaram com a introdução do euro e a Holanda começou a pertencer à comunidade europeia. A pressão política internacional que lhe deram foi muito forte com as drogas, por exemplo. A Holanda teve que começar a fechar as portas e eliminar coffe shops ${ }^{12}$. Eras prostituta, podias vender-te na rua atrás de uma

${ }^{12}$ Estabelecimentos de venda e consumo de drogas leves (maconha e haxixe) de maneira legalizada. 
janela, eras tua própria chefe. Se quisesses fumar tua maconha no parque, fumavas no parque, desde que não perturbasses as pessoas, que o problema fosse teu e não dos outros. Não tinha aquele problema de drogas, não havia a quantidade de junkees (viciados em drogas) que se via na Alemanha, por exemplo. Agora se vê uma quantidade de armas que estão conseguindo, antes não se via. Eu gostava mais como era antes, era melhor que agora. (Marisa, imigrante da Venezuela, 45 anos, há 25 anos em Amsterdã).

Antes, havia tudo e tudo era fácil. Tudo, significa dizer viver tranquilo, sem problemas. Se não tens trabalho podes comprar coisas, te dão dinheiro, te dão isso, aquilo. Mas quando trocou o milênio e os florins para euro, a vida se tornou muito difícil. Antes eu ganhava 2000 florins e podia economizar, comprar um carro e muitas cosias. Mas, no momento, 1700 euros, é dizer que são quase 3000 florins. Hoje, isso é nada. (Pablo, imigrante da Espanha, 40 anos, há 26 anos em Amsterdã).

Mas, apesar das modificações apontadas com relação à Amsterdã, diversos indivíduos ainda a consideram um local, em muitos aspectos, diferenciado positivamente para estabelecer seus projetos de vida ${ }^{13}$. Tal diferenciação possivelmente justifique os contínuos deslocamentos para essa capital. Embora esses não sejam um fato novo, como já foi acenado, tem havido uma certa mudança na receptividade a imigrantes nesse contexto, em ação alinhada com o quadro de políticas migratórias mais rígidas no qual muitos países do continente europeu vêm se inscrevendo, em especial, a partir dos ataques terroristas enfrentados nos últimos anos ${ }^{14}$.

\footnotetext{
${ }^{13} \mathrm{O}$ que a noção de projeto procura é dar conta da margem seletiva de escolha que indivíduos e grupos têm em determinado momento histórico de uma sociedade. Por outro lado, procura ver a escolha individual não mais apenas como uma categoria residual da explicação sociológica, mas sim como elemento decisivo para a compreensão de processos globais de transformação da sociedade. Visa também focalizar os aspectos dinâmicos da cultura, preocupando-se com a produção cultural, enquanto expressão de atualização de códigos em permanente mudança. Ou seja, os símbolos e os códigos não são apenas usados, são também transformados e reinventados, com novas combinações e significados. Entendo projeto como Schutz o definiu - conduta organizada para atingir fins específicos (Schutz, 1971). O sujeito da ação pode ser um indivíduo, um grupo ou uma categoria social. Chama-se a atenção para a importância da dimensão consciente da ação em que o sujeito se organiza para a realização de projetos definidos. (VELHO, 2003, p. 107; grifos do autor)

${ }^{14}$ Sobretudo no período posterior ao atentado às torres gêmeas em Nova York (EUA), no ano de 2001, as políticas migratórias na Holanda começaram a sofrer modificações paulatinas. Os dois ataques terroristas em Paris no ano de 2015 (o primeiro na sede do jornal Charles Hebdo e o segundo, em diferentes locais da cidade simultaneamente) e os demais em Bruxelas, Istambul, Nice e Berlim, em 2016, vêm colaborando para acirrar as referidas modificações.
} 
Como foi evidenciado, os imaginários urbanos também perfazem os deslocamentos humanos. Na conjuntura atual, as migrações têm sido provocadas por questões sociais, ambientais, políticas, econômicas e também têm sido concebidas como possibilidade de se vivenciar e explorar aspectos culturais relacionados ao país de destino. Tal panorama reflete o caráter cada vez mais heterogêneo desses movimentos e também que a imigração consiste em um processo não necessariamente negativo e dramático, mas como possibilidade de se construir novas subjetividades (VAILATI; RIAL, 2016). Em cidades como Amsterdã, cujos traços vêm sendo cada vez mais demarcados pelos processos relativos à globalização, emergem imaginários urbanos diversos. Dentre esses imaginários, os relativos à comida e cosmopolitismos a ela associados são significativos para compreender como a comida é um aspecto central nos processos migratórios pela persistência de padrões alimentares tanto quanto pela introdução de novos itens na paisagem local e também como vêm se constituindo imaginários urbanos em cidades globais, como será abordado a seguir.

\section{Paisagem alimentar, imigrações e imaginários cosmopolitas em Amsterdã}

Assim como os movimentos humanos têm sido potencializados alterando significativamente o ethnoscape global, vem ocorrendo uma intensificação dos fluxos de mercadorias e, consequentemente, o redimensionando de inúmeras paisagens alimentares ao redor do planeta ${ }^{15}$. Ao serem

Durante várias décadas, os holandeses abraçaram o multiculturalismo e a tolerância étnica com bastante afinco. No entanto, nos últimos anos, o multiculturalismo relacionado às políticas migratórias vem dando lugar a uma abordagem integracionista mais rigorosa (NELL; RATH, 2009). Essa nova abordagem alinha-se com as vigentes em outros países da Europa e mesmo com os Estados Unidos, onde vem se evidenciando o estreitamento cada vez mais progressivo das suas fronteiras geográficas, no que se refere à acolhida de imigrantes. Na Europa, a situação também vem sendo agravada com a problemática associada à crise dos refugiados antes referida. Portanto, no contexto atual, ao mesmo tempo em que se intensificam os movimentos humanos impulsionados por dinâmicas associadas à globalização, em resposta, nacionalismos e xenofobia, baseados em noções de identidade e segurança nacional, atuam como o outro lado da moeda, configurando uma problemática crescente em torno das migrações internacionais contemporâneas que não se resumem ao continente europeu.

${ }^{15}$ Fazemos referência à noção de Appadurai (1990), quando sinaliza um caminho para se compreender a globalização em suas dimensões culturais apontando uma tensão entre homogeneização e heterogeneização. $\mathrm{O}$ autor defende que a nova economia cultural global tem de ser pensada como uma ordem complexa, repleta de justaposições e relacionada a certas deslocações fundamentais entre a economia, a cultura e a política. Propõe assim explorar tais 
consideradas sobretudo as últimas décadas do século $\mathrm{XX}$ e inícios do século XXI, a intensificação desses fluxos têm colocado novos parâmetros para se pensar a alimentação, sobretudo em contextos urbanos. É sabido que o fenômeno alimentar não se resume ao caráter biológico, abarcando aspectos de ordem cultural, econômica, ambiental, psicológica, ética. Do mesmo modo, a desterritorialização de artigos alimentares não significa apenas um reordenamento de paisagens alimentares, incidindo ainda na reconfiguração de dietas, na ressignificação de muitos alimentos e na constituição de imaginários.

A maior circulação de itens alimentares está cada vez menos atrelada aos movimentos humanos. À medida que imaginários globais relacionados à comida ganham maior disseminação, em particular através do mediascape, evidencia-se uma amplitude no desenvolvimento de paladares cosmopolitas nos mais distintos contextos ${ }^{16}$. Ao direcionarmos o olhar para Amsterdã, o enfoque na diversidade de imigrantes naquele contexto é um fator também determinante para se refletir sobre a sua paisagem alimentar e, consequentemente, em como a configuração dessa paisagem ressoa não apenas nas práticas relacionadas à alimentação de imigrantes transnacionais a partir daquele contexto, como também na constituição de imaginários urbanos relacionados à comida, sobretudo aqueles de viés cosmopolita.

Assim como outras capitais marcadas por forte afluxo migratório, Amsterdã pode ser vista como uma cidade altamente diversificada, tanto no que se refere à sua paisagem de pessoas (ethnoscape) quanto à sua paisagem alimentar. Nos últimos anos, refletindo a dinâmica da globalização atual, ambos os fluxos (pessoas e comidas) intensificaram-se.

deslocações, por meio da relação entre cinco planos ou dimensões de fluxos culturais globais: Paisagem étnica (ethnoscapes), Paisagem tecnológica (technoscapes), Paisagem financeira (financialscapes), Paisagens midiáticas (mediascapes), Paisagens ideológicas (ideascapes).

${ }^{16}$ Hoje, a comunicação relativa à comida vem sendo amplamente estimulada através das paisagens midiáticas em âmbito global. Nessas paisagens, a comida se transformou em um fenômeno de comunicação visual. No Brasil, por exemplo, é possível identificar o crescente número de páginas nos cadernos de gastronomia dos diferentes jornais, assim como o lançamento de variados livros e revistas especializados no assunto. Em âmbito mais amplo, destaca-se a efervescência de programas de culinária nos mais variados formatos. O Master Chef é um caso ilustrativo. Criado no Reino Unido em 1990 e relançado no ano de 2005, esse programa de televisão tornou-se um fenômeno global. Além do Brasil, onde chegou à quarta edição em 2017, e de outros países da América do Sul, o programa ainda ganhou versões em outros 40 países, incluindo a América do Norte, Europa, Oceania, Ásia e África. Já na internet, de maneira similar ao que ocorre nas mídias convencionais, não é difícil constatar a difusão ampla de receitas, imagens, textos ou vídeos relativos à comida em sites especializados no tema e também em publicações pessoais: blogs, YouTube e outras redes sociais, como Instagram e Facebook. 
Tomando como ponto de partida o bairro Osdorp-Midden, representativo da diversidade migratória em Amsterdã, é possível ter uma ideia inicial de como se configura a paisagem alimentar de Amsterda ${ }^{17}$. Entre suas múltiplas possibilidades de provimento no campo alimentar, incluindo atender à parcela de suas populações imigrantes, estão os mercados turcos, padaria marroquina, açougues holandês e muçulmano, mercados surinameses, mercearias asiáticas, supermercados e também a presença de uma filial do Hema, cadeia de lojas das mais tradicionais da Holanda que igualmente oferta itens alimentares. Ainda compõem aquela área da cidade restaurantes com culinárias de outros países, além da Holanda, entre os quais, Suriname, China, Turquia e Líbano. Além disso, entre outros comércios diversos, sorveterias, confeitarias e cafeterias contribuem para diversificar a oferta alimentar do bairro.

Em anos mais recentes, mais particularmente na última década, houve algumas modificações mais expressivas nas ofertas alimentares desse bairro. Redes transnacionais alimentares, como McDonald's, Subway e KFC (Kentucky Fried Chicken), somente em período bastante recente chegaram a essa região da cidade. A abertura dessas redes coincidiu com outras mudanças na dinâmica urbana de Amsterdã. Tais mudanças também podem ser associadas à conjuntura vigente de intensificação de fluxos em âmbito global e que se refletem de maneira muito significativa na cidade em sentido mais amplo, como a potencialização da sua ethnoscape (APPADURAI, 1990), a presença de demais cadeias alimentares e empresas transnacionais e fluxos culturais de outra natureza.

É possível afirmar que o universo de ofertas presente nesse bairro reproduz em uma escala menor a paisagem alimentar da cidade. Tanto ali como em outras áreas da cidade, grandes redes de supermercados disputam consumidores com os pequenos mercados e mercearias étnicos, ao incrementarem suas gôndolas com produtos voltados para atender à diversificada demanda migratória. A ênfase recai sobre ingredientes e condimentos relacionados a culinárias dos grupos de imigrantes mais numerosos na cidade (turcos, marroquinos, indonésios e surinameses). Mas esses supermercados também ofertam itens para o preparo das culinárias chinesa, mexicana, japonesa, indiana, italiana, vietnamita, brasileira, entre outras possibilidades. A variedade de itens inclui desde algas, tortillas a

\footnotetext{
${ }^{17}$ A escolha deste bairro como ponto de partida deve-se ao fato de ter sido a referência inicial para o desenvolvimento da pesquisa em questão.
} 
condimentos, molhos indianos, massas italianas, cereais andinos, azeites de oliva importados de Portugal, Grécia, Espanha, Líbano, entre uma série de outros produtos. Percorrendo os corredores dos principais supermercados da cidade, é possível observar ainda como os fluxos em torno da comida são constituídos de produtos que vão muito além dos industrializados ${ }^{18}$. No Jumbo, por exemplo, uma das redes de supermercados mais populares na cidade, se pode optar entre itens similares, mas de diferentes proveniências, como bananas importadas da Colômbia, Costa Rica ou Panamá. Afora essas grandes redes de comércio, nos mercados turcos ou nas feiras de rua, podese encontrar desde mangas, abacates, abacaxi, kiwi, entre outras variedades de frutas cultivadas, sobretudo em países de clima tropical, a legumes e verduras de origens diversas.

Em paralelo, os mercados asiáticos, conhecidos na cidade como tocos, são também uma alternativa bastante popular para a atender à demanda de muitos alimentos utilizados não somente por imigrantes asiáticos, mas também por sul-americanos ou africanos. Além de especiarias asiáticas, é possível encontrar variedades de carne, mandioca, bacalhau, assim como cereais e temperos distintos.

A paisagem alimentar de Amsterdã também contempla algumas comunidades de imigrantes nem tão representativas no país, tais como a de brasileiros. Comércios como Finalmente Brasil ou Casa Brasil Portugal, situados na Kinkerstraat (rua que concentra grande parte de comércios relativos a comidas étnicas na cidade), oferecem um sortimento de produtos. Lá, brasileiros/as encontram erva para preparo de chimarrão ou para tererê, cafés, farinha de mandioca, polvilho, polpas de frutas, sucos, carnes a vácuo para feijoada e diversos outros itens importados do Brasil. Os produtos são ainda disponibilizados via comércio eletrônico, tornando possível o seu acesso em demais cidades do país e mesmo da Europa.

Para vários imigrantes entrevistados nessa capital, incorporar a diversidade na vida cotidiana, isto é, adotar hábitos culturais alheios em outro país é visto como desafio positivo, uma possibilidade de novas experiências ou aprendizados, e a comida é concebida como fator-chave nesse sentido. Levando em conta o ponto de vista desses indivíduos, expectativas relacionadas a experiências culturais são centrais para entender como os referidos fluxos ecoam nas suas práticas alimentares e também na

\footnotetext{
${ }^{18}$ As principais redes de supermercado na cidade são Dirk, Lidl, Jumbo e Albert Heijn, sendo que as duas primeiras são consideradas as mais acessíveis no quesito preço.
} 
construção de imaginários urbanos relativos à constituição de seus estilos de vida nesse contexto.

A comida também aparece refletida em imaginários relativos ao movimento migratório, conforme se pode observar através de alguns exemplos. Para Martina (27 anos $)^{19}$, imigrante da Argentina e há dez meses em Amsterdã, sua motivação para emigrar deveu-se ao fato de estar "obcecada" e "fascinada" pelo mundo em geral, o que, em suas palavras, não significa descontentamento com o país natal, e sim "a necessidade de aprender coisas novas" e "ter algum estímulo constante". Considerando isso, resume sua motivação para emigrar ao que pondera ser central nesse sentido: "Necessito ver outras culturas, comer outras comidas, falar outro idioma, conhecer outra gente".

O relato de Antônia (31 anos), italiana que morou por dez anos na China antes de emigrar para Amsterdã, também ressalta a dimensão cultural relativa ao movimento migratório e as expectativas fomentadas nessa direção:

Eu quero descobrir mais, eu não quero voltar para o lugar de onde vim, ninguém quer voltar para trás, a gente quer ir mais longe, não fisicamente, mas em termos de experiência [...]. Eu gosto de estar com pessoas de diferentes países, falar inglês e isso é um pouco difícil na Itália [...]. Eu quero comprar alguma comida de outro país e, dependendo de onde você mora na Itália, não é algo muito fácil.

Nesse relato, a comida também é imaginada como algo equiparável em relevância ao domínio de um novo idioma, ou seja, como um meio de se interagir com um novo contexto e, acima de tudo, como possibilidade de se situar no mundo a partir da incorporação de uma experiência nesse domínio. Contudo, ainda que por diferentes razões a apropriação da paisagem alimentar de Amsterdã esteja voltada sobretudo para perpetuar hábitos relacionados aos países de origem desses imigrantes e o consumo de itens associados a outras culturas alimentares se restrinja muitas vezes apenas a um plano imaginário, a sua diversidade vai ao encontro das já mencionadas expectativas nutridas com relação à imigração e ao que essa pode representar também em termos de acúmulo de capital cult.

Um exemplo de como a ampla gama de produtos associados às diferentes

${ }^{19}$ Os nomes foram trocados com o intuito de preservar a identidade das/os interlocutores. 
culturas culinárias contribui para a constituição de certos imaginários urbanos nutridos por sujeitos desterritorializados é o argumento da imigrante vinda da Itália (referida anteriormente), ao relatar sobre o quanto escassa concebia a diversidade de produtos alimentares onde habitava, na região da Sicília:

Eu me sinto feliz de ter escolhas; quando você mora em uma cidade onde você pode comprar frutas que vêm do Marrocos, da Índia, da Indonésia, isso quer dizer que esta cidade está aprovisionando essas pessoas também. Quer dizer que você está morando em uma cidade multicultural e eu gosto disso.

Mas alguns dos imaginários associados a Amsterdã poderiam ser igualmente associados a Sidney, Nova Iorque, Londres, Buenos Aires, Bangkok, São Paulo ou demais cidades consideradas multiculturais e cosmopolitas, sobretudo em decorrência da grande concentração de imigrantes de variadas origens. As narrativas seguintes talvez contribuam de maneira mais eficaz para ilustrar especificidades da capital holandesa e, consequentemente, imaginários urbanos peculiares desse contexto:

Parece-me que Amsterdã é muito privilegiada porque é uma cidade pequena, não é uma metrópole [...]. Tens tudo em Londres, tens tudo em Paris, tens tudo em Nova Iorque, mas são cidades muito grandes, necessitas de um dia para ir de ponta a ponta. Em Amsterdã, ao contrário, em quinze minutos podes estar onde quiseres na cidade e, no centro, consegues tudo o que queres; em uma quadra encontras coisas de mais de cem países, de diversas culturas e todas perto umas das outras [...]. Amsterdã em si é uma bolha com todos os tipos de culturas muito próximas umas das outras. Então, o turco está muito perto do marroquino, do ganês, do judeu [...] somos todos vizinhos. Há o que te repara a roupa, o outro tem um bar, o outro tem a mercearia. Há o supermercadinho do turco, do marroquino, do libanês, o do que te vende os temperos. Já o que te veste vem do Brasil e o que te faz as unhas vem da Tailândia. Isso faz com que encontres tudo. Se queres comer comida tailandesa hoje, por exemplo, e não queres ir a um restaurante tailandês, vais conseguir os ingredientes na esquina da tua casa (Marisa, imigrante da Venezuela, 45 anos, há 25 anos em Amsterdã).

Eu considero Amsterdã um lugar mais rico, reúne vários tipos de comida, é um lugar mais acessível. Em Nova Iorque, para 
encontrar produtos ou comidas étnicas, você tem que ir a diferentes áreas étnicas. Em Amsterdã, está tudo misturado. Esta é uma das razões pelas quais eu gosto de viver aqui. Não é separado, não é segregado. Tudo está misturado. O povo pobre mora junto com o povo rico. Você não sabe se esta é uma casa social ou não. E você olha para o supermercado está tudo misturado também ( $\mathrm{Liz}$, imigrante da Jamaica, 54 anos, há 16 anos em Amsterdã).

Nesses relatos, se algumas particularidades enaltecem Amsterdã com relação a demais capitais de paisagem progressivamente globalizada, dando vazão à constituição de certos imaginários, é importante lembrar que a crescente busca de comidas associadas a culinárias de outros países, além de não ganhar expressão apenas nesse centro urbano, remonta a períodos bem anteriores. Notando não ser novidade o fato de muitas pessoas consumirem comidas estrangeiras, seja porque consideram algo excitante, interessante, exótico ou sedutor, Wilk (2010) ainda observa que, por centenas de anos, familiaridade e conforto com essa modalidade de comida têm constituído parte do repertório de sofisticação em muitas civilizações, sendo um dos aspectos essenciais através dos quais se distingue o "educado", "experiente" (grifos nossos) e seu capital cultural.

Nessa ótica, portanto, a comida é considerada um elemento simbolicamente valorizado em termos de distinção social, e o gosto não é uma escolha idiossincrática, mas algo ligado à detenção de capitais econômico, social e cultural (BOURDIEU, 2003). Nesses termos, é possível também afirmar que, se a neofobia pode representar um dos aspectos desafiadores de se lidar com a comida em condição migratória, na conjuntura atual, em que a neofilia tem sido bastante estimulada sobretudo através das mídias comunicativas (mediascape), a constituição de imaginários cosmopolitas em torno da comida é cada vez mais favorecida ${ }^{20}$.

No caso de Amsterdã, a proliferação de tais imaginários é fomentada a partir de diferentes contextos. A principal rede de supermercados holandesa, Albert Heijn, é um exemplo em tal sentido; na sua revista semanal impressa, em páginas do seu site e também através de mala direta via internet, publica várias receitas promovendo produtos relacionados às mais diversas culinárias. Esse exemplo também evidencia o quanto a cozinha, em sua condição de negócio, mobiliza uma força econômica relevante. Em

${ }^{20}$ A neofobia é concebida como medo de experimentar comidas novas; já a neofilia se define como o desejo pelo novo (FISCHLER, 1995). 
tal medida, promover a neofilia, enquanto desejo de experimentar novas sensações de gosto através de uma variedade de cozinhas, tem sido um meio de se ampliar um público consumidor, através do incremento da indústria foodie e de seus componentes (mercados para ingredientes, aulas de culinária, publicações, turismo alimentar, etc.) (WILK, 2010).

Como chamam a atenção Çinar e Bender (2007), na vida cotidiana, a imaginação coletiva opera através de um vasto campo de experiência coletiva envolvendo viagens, interações e práticas comunicativas de pessoas dentro de uma cidade, experiências que funcionam para tecer uma sensação de conexão no espaço e, por sua vez, para imaginar a cidade como um único lugar. Nessa mesma linha de pensamento, Appadurai (1990) observa que o mediascape (paisagens midiáticas) é um desencadeador da produção de imaginários e de comunidades imaginadas por indivíduos desterritorializados ao redor do mundo.

No âmbito dos fluxos relacionados à alimentação, além das mídias convencionais e de seu papel na difusão de determinados imaginários relacionados à comida, e no que diz respeito a alguns imigrantes em Amsterdã, o compartilhamento de imagens e textos relacionados a esse tema, em especial através das redes sociais, além de evidenciar que o consumo visual da comida, em certas situações, passa a ter mais relevância que a tomada alimentar (RIAL, 1992), pode ser concebido como um meio pelo qual esses indivíduos também vêm fundando e dando visibilidade aos seus imaginários cosmopolitas nessa cidade. Isso inclui comer novas comidas, frequentar restaurantes relacionados a outras culturas alimentares, adotar hábitos referentes a outros contextos culturais além do holandês, conviver com indivíduos de nacionalidades distintas e, consequentemente, com hábitos alimentares variados.

O mundo de hoje é, inegavelmente, cada vez mais cosmopolita; assim como gostos e cozinhas a serem consumidas são mais abrangentes, cresce o número de pessoas atentas a notícias provenientes do mundo todo e eventos globais cobertos pela mídia ou então influenciadas por outras tendências universais (APPADURAI; BRECKENRIDGE, 1988) ${ }^{21}$. Levando isso em conta, é possível afirmar que cidades como Amsterdã, caracterizadas por um caráter fortemente global, transnacional e multiétnico, favorecem ou mesmo potencializam determinados cosmopolitismos através do consumo

\footnotetext{
${ }^{21}$ Seguindo mesma linha de pensamento, Appiah (2006) observa que, mesmo enraizados em locais específicos, indivíduos estão interagindo com o mundo cosmopolita da migração, nomadismo e diáspora.
} 
alimentar, o que também repercute na constituição de seus imaginários urbanos.

Há diferentes abordagens sobre cosmopolitismo. Vertovec (2002) defende compreendermos tal concepção como algo de viés múltiplo e não restrito somente a indivíduos de classe alta e da cultura ocidental, mas também àqueles outros, cujas vozes desempenham um papel na produção de espaços cosmopolitas ${ }^{22}$. Ao nos concentrarmos no eixo comida/cosmopolitismos, também são profícuas as considerações de Johnston, Baumann e Cairns (2010), quando notam que, de modo similar ao nacionalismo, cosmopolitismo pode ser entendido não apenas como uma política filosófica abstrata, mas como construção social formada pela banalidade dos atos e interações diários, incluindo o cozinhar e o comer.

Já para Hannerz (1990), cosmopolitismo está ligado a um estado de espírito, uma orientação que implica vontade de interagir com o outro, um querer mergulhar em outras culturas ou mesmo ser livre para fazê-lo. Entretanto, ao enfocarmos na ideia de um cosmopolitismo alimentar, é certo que comer a comida alheia não significa necessariamente empatia, tolerância ou envolvimento com o outro. Um exemplo disso é o atual crescimento do consumo de comida Halal em todo o mundo, mais expressivamente em países da Europa e Estados Unidos, sem haver uma correlação com o aumento da população muçulmana e ocorrendo simultaneamente com a expansão da islamofobia nesses mesmos países ${ }^{23}$. Como chama a atenção Wilk (2010), até em contextos multiétnicos, há certos limites em termos do que os indivíduos estão dispostos a tolerar, e isso fica mais óbvio quando atentamos para as inúmeras e crescentes reações à globalização expressas com xenofobia, rejeição, busca de pureza e autenticidade. Tal ponto de vista também evidencia que consumidores de produtos culturais estrangeiros não necessariamente internalizam os valores, ideologias ou estilos de

\footnotetext{
${ }^{22}$ Segundo Vertovec e Cohen (2002), teses de que o cosmopolitismo estaria disponível apenas para uma elite ou por quem tem recursos necessários para viajar, aprender outras línguas e absorver outras culturas repercutem em ataques frequentes a este conceito. Ainda que não discorde totalmente de argumentos nesse sentido, sobretudo no que diz respeito a uma grande maioria para quem o cosmopolitismo nunca foi uma opção, Vertovec e Cohen (2002) reportam ao pensamento de Poole (1999), a fim de ressaltar que, no mundo contemporâneo, as diversidades cultural e linguística têm sido onipresentes e a capacidade de se comunicar e entender culturas alheias está disponível, pelo menos potencialmente, para muitos.

${ }^{23} \mathrm{Na}$ comida Halal, os alimentos são preparados segundo preceitos do Islamismo, o que envolve diversas regras relativas ao consumo da carne como também de vegetais e cereais. Os preceitos incluem a forma de abate e alimentação do animal, formas de cultivo dos vegetais e cereais ou mesmo de embalar os produtos.
} 
vida supostamente contidos nesses produtos (INDA; ROSALDO, 2002). $\mathrm{Na}$ mesma perspectiva, mesmo que alimentos sejam vendidos em escala global, esses são sempre filtrados por códigos simbólicos de determinados mercados culturais nacionais (WARDE, 2010). Portanto, tomando ainda como exemplo a comida Halal, isso significa que, em diversos países e para muitos indivíduos, em vez de ter seu consumo atrelado a determinados preceitos, essa tem sido concebida apenas como mais uma opção de comida rápida e preço acessível.

A partir dessas considerações, é possível depreender que a comida atua como um desencadeador de imaginários urbanos, sobretudo ao observarmos a conjuntura atual marcada por uma significativa intensificação de fluxos diversos. Em tal perspectiva, noções de cosmopolitismo são centrais para compreender como se vem articulando a relação entre a comida e imaginários urbanos entre imigrantes, em especial, para aqueles cujas experiências de natureza cultural são impulsionadoras de sua mobilidade, como é o caso de muitos em Amsterdã.

\section{Considerações finais}

No panorama atual, quando se intensificam os processos relacionados à globalização, as heterogeneidades que atravessam os movimentos migratórios vêm sistematicamente impondo novas questões para se refletir sobre esses fenômenos, dentre as quais se exaltam aquelas relativas aos imaginários urbanos. De modo igual, as práticas que acompanham ou se desenvolvem ao longo desses movimentos são delineadas pelo contexto migratório, no qual se inscrevem. Assim como emigrar não se restringe a um deslocamento no espaço físico, a comida cada vez menos se resume ao ato alimentar, abrangendo visões de mundo, concepções de estilo de vida, possibilidades de comunicação e interconexão, e também imaginários urbanos.

Ao traçarmos como os processos vinculados ao período atual da globalização vêm ganhando expressão e demarcando práticas relacionadas à alimentação de imigrantes transnacionais em uma cidade global - no caso, Amsterdã -, o enfoque nos imaginários associados a essa cidade foram fundamentais para compreender o que vêm perfazendo esses deslocamentos, como indivíduos desterritorializados se relacionam com esse contexto urbano e com suas práticas cotidianas, destacando-se as alimentares. 
Para imigrantes em Amsterdã, em cujo deslocamento aspectos culturais ganham realce, o cosmopolitismo, visto sobretudo a partir de uma dinâmica de diversidade cultural, torna-se um conceito fundamental para compreender como vêm se constituindo determinados imaginários urbanos associados a Amsterdã e, consequentemente, na configuração de imaginários relativos à comida. Mesmo diante das progressivas mudanças nesse centro urbano, exigindo muitas vezes que esses indivíduos reformulem seus estilos de vida, imaginários urbanos, sobretudo aqueles associados a cosmopolitismos, em certa medida, seguem dando ancoragem aos seus projetos de vida em uma cidade global.

\section{Referências}

APPADURAI, Arjun; BRECKENRIDGE, Carol.

(1988). Why Public Culture? Public Culture, v. 1, n. 1, p. 5-9. Durhan, USA.

APPADURAI, Arjun.

(1990). Disjuncture and Difference in the Global Cultural Economy. In: WILLIAMS, Patrick; CHRISMAN, Laura. Colonial Discourse and Post-Colonial Theory. N.Y.: Columbia University Press. p. 324- 339.

APPIAH, Kwane A.

(2006). Cosmopolitanism: ethics in a world of strangers. New York: W. W. Norton \& Co.

BOURDIEU, Pierre.

(2003). A Economia das Trocas Simbólicas. São Paulo: Editora Perspectiva.

CANCLINI, Néstor García.

(2010). Imaginários Urbanos. 4 ed. Buenos Aires: Eudeba.

CASTLES, Stephen; MILLER, Mark J.

(1993). The age of migration: international population movements in the modern world. Londres/Nova York: MacMillan Press.

ÇINAR, Alev; BENDER, Thomas.

(2007). Introduction. The City: Experience, Imagination, and Place. In: ÇINAR, Alev; BENDER, Thomas (eds.). Urban imaginaries: locating the modern city. Minneapolis/ London: University of Minnesota Press.
FISCHLER, Claude.

(1995). El (h)omnivoro: el gusto, la cocina y el cuerpo. Barcelona: Anagrama.

HANNERZ, ULf.

(1990). Transnational Connections. Culture, People and Places. Londres: Sage.

INDA, Jonathan; ROSALD0, Renato.

(2002). Introduction. In: INDA, Jonathan; ROSALD0, Renato (eds.). The Anthropology of Globalization: A Reader. Malden: MA-0xford, Blackwell. p. 1-36.

JONSTON, Josée; BAUMANN, Shyon; CAIRNS, Kate.

(2010). The Nacional and the cosmopolitan in cuisine: Constructing America through Gourmet Food writing. In: IGLIS, David, GIMLIN, Inglis. The globalization of food. New York: Berg. p. 161-185.

LINDNER, Christoph; MEISSNER, Miriam.

(2019). Urban imaginaries in theory and practice. In: LINDNER, Christoph; MEISSNER, Miriam (Eds.).The Routledge Companion to Urban Imaginaries. Abingdon, Oxon: New York, NY: Routledge.

LINDÓN, Alicia.

(2007). Diálogo con Néstor García Canclini ¿Qué son los imaginarios y cómo actúan en la ciudad? Entrevista realizada por Alicia Lindón, 23 de febrero de 2007, Ciudad de 
México. Revista eure. v. XXXIII, n. 99, p. 8999, Santiago de Chile.

NELL, Liza; RATH, Jan.

(2009). Introduction. In: NELL, Liza; RATH, Jan (eds.). Ethnic Amsterdam: Immigrants and Urban Change in the Twentieth Century. Amsterdam: Amsterdam University Press. p. 11-22.

PRICE, Marie; BENTON-SHORT, Lisa.

(2008). Urban immigrant gateways in a globalizing world. In: PRICE, Marie; BENTONSHORT, Lisa (eds.). Migrants to the metropolis: the rise of immigrant gateway cities. Syracuse, N.Y.: Syracuse University Press. p. 23-50.

RIAL, Carmen.

(1992). Ça se passe comme ça chez les fast-food: étude anthropologique de la restauration rapide. (Tese de doutorado apresentada à Université de Paris V - Sorbonne).

ROCHA, Carla Pires Vieira da.

(2017). Comida em uma cidade global: práticas alimentares de imigrantes transnacionais em Amsterdã. (Tese doutorado apresentada à Universidade Federal de Santa Catarina, Centro de Filosofia e Ciências Humanas, Programa de Pós-Graduação Interdisciplinar em Ciências Humanas - Florianópolis). Disponivel em: <https://repositorio.ufsc.br/ xmlui/handle/123456789/178589>

SASSEN, Saskia.

(1998). As cidades na economia mundial. São Paulo: Nobel.

SASSEN, Saskia. (2010). Sociologia da globalização. Porto Alegre: Artmed.
VAILATI, Alex; RIAL, Carmen.

(2016). Introduction. In: VAILATI, Alex; RIAL, Carmen (orgs.). Migration of rich immigrants: gender, ethnicity and class. London: Palgrove MacMillan. p. 1-11.

VELHO, Gilberto.

(2003). Projeto e metamorfose: antropologia das sociedades complexas. 3.ed. Rio de Janeiro: Jorge Zahar Ed.

VERTOVEC, Steven; COHEN, Robin.

(2002). Introduction: Conceiving Cosmopolitanism. In: VERTOVEC, Steven; COHEN, Robin (eds). Conceiving cosmopolitanism: theory, context and practice. 0xford: 0xford University Press. p. $1-22$.

WARDE, Alan.

(2010). Globalization and the Challenge of Variety: A Comparison of Eating in Britain and France. In: IGLIS, David; GIMLIN, Inglis. The globalization of food. New York: Berg. p. 227-242.

WILK, Richard.

(2010). Difference on the menu: neophilia, neophobia and globalization. In: IGLIS, David; GIMLIN, Inglis. The globalization of food. New York: Berg, 2010. p. 185-196.

\section{Recebido em}

março de 2018

\section{Aprovado em}

março de 2019 


\title{
Participação e democratização da segurança pública no Brasil em perspectiva comparada: os casos de Rio de Janeiro e Pará ${ }^{1}$
}

\author{
João Trajano Sento-Sé * \\ Leandro Marinho**
}

\begin{abstract}
Resumo
A partir de um estudo de caso em perspectiva comparada dos conselhos estaduais de segurança pública do Rio de Janeiro e do Pará, este trabalho pretende compreender como dentro de um mesmo setor de políticas públicas contextos diferentes tendem a gerar instituições com desenhos e estruturas distintas. Para tanto, foram observados os respectivos modelos de organização, os padrões de interação Estado/sociedade civil em seu funcionamento, o grau de institucionalização e de desenvolvimento, a capacidade de incidência sobre a política de segurança pública e os principais problemas enfrentados em seu histórico.
\end{abstract}

\section{Palavras-chave}

Conselhos. Segurança pública. Participação. Rio de Janeiro. Pará.

\begin{abstract}
Based on a comparative case study of Pará's and Rio de Janeiro's state public safety council, this work intends to understand how, within the same sector of public policies, different contexts tend to generate institutions with different designs and structures. In order to do so, we have observed the respective organizational models, the State/civil society interaction
\end{abstract}

\footnotetext{
${ }^{1}$ Uma primeira versão deste artigo foi apresentada por Leandro Marinho no III Encontro Internacional Participação, Democracia e Políticas Públicas, ocorrido entre 30/05/2017 e 02/06/2017, na Universidade Federal do Espírito Santo (UFES). Agradecemos a toda organização do evento e, em especial, aos debatedores e comentadores que participaram da sessão em que o referido trabalho foi apresentado.

* João Trajano Sento-Sé é professor Associado do Instituto de Ciências Sociais da Universidade do Estado do Rio de Janeiro (UERJ, Rio de Janeiro, Brasil) e pesquisador do Laboratório de Análise da Violência da UERJ. Possui doutorado e mestrado em Ciência Política pelo Instituto Universitário de Pesquisas do Rio de Janeiro (IUPERJ, Rio de Janeiro, Brasil). E-mail: joaotrajano@uol.com.br.

** Leandro Marinho é doutorando e mestre pelo Programa de Pós-Graduação em Ciências Sociais (PPCIS) da Universidade do Estado do Rio de Janeiro (UERJ, Rio de Janeiro, Brasil) e pesquisador do Laboratório de Análises da Violência da Universidade do Estado do Rio de Janeiro (LAV/UERJ). Possui graduação em Ciências Sociais pela Pontifícia Universidade Católica do Rio de Janeiro (PUC, Rio de Janeiro, Brasil). E-mail: marinhos.leandro@gmail.com.
} 
patterns and how they operate, the degree of institutionalization and development, the ability to influence public safety policy and the main problems faced in its history..

\section{Keywords}

Councils. Public Safety. Participation. Rio de Janeiro. Pará.

\section{Impasses e avanços dos conselhos de segurança pública}

Historicamente, uma das chaves de interpretação das mazelas e limites da instauração de uma ordem liberal no Brasil reside num argumento dualista segundo o qual vivemos sob um Estado forte, tentacular e opressor, que manieta e controla uma sociedade débil, apática e carente de virtudes e solidariedade. Esse argumento aparece de diferentes maneiras nos clássicos que trataram de modo pioneiro os processos de formação social e política do Brasil, mas se estendem até os dias atuais, ecoando como uma espécie de paradigma em ramos diversos de nossa produção intelectual. É interessante observar que essa percepção geral não se restringe ao mundo acadêmico, sendo incorporada como desafio a ser enfrentado por muitos atores no campo político propriamente dito. Nessa vertente, instituir uma ordem liberal democrática corresponderia a redefinir essa espécie de marca de origem, o que tem sido tentado com alguma frequência.

Tal investida pode ser vista como uma das marcas do último processo de redemocratização por que o país passou. Como se sabe, a partir dos anos 1980, novas formas de interação entre sociedade civil e Estado começaram a ser construídas no Brasil. Deu-se, então, um processo inédito em nossa história republicana, pelo qual a criação de canais capazes de mitigar a opacidade do Estado e torná-lo mais aberto à intervenção da sociedade se tornou um dos pontos centrais da agenda política. Isso tudo, cabe enfatizar, no contexto de exaustão de um regime de exceção e da movimentação que resultou na eleição de uma Assembleia Constituinte em 1986.

Um movimento importante, nesse sentido, deu-se com a institucionalização, em diferentes níveis de governo, de espaços dedicados à articulação entre membros dessas duas esferas, Estado e sociedade civil, em torno de processos deliberativos sobre políticas, sinalizando uma resposta às demandas por participação que emergiam de diversos movimentos sociais. Esses espaços passaram a ser denominados pela literatura brasileira 
especializada "instituições participativas", conceito formulado para se referir a instâncias de atuação política não vinculadas diretamente ao Estado. A importância dada a elas é diretamente proporcional ao reconhecimento do caráter problemático e à precariedade das soluções dadas à tensão entre representação e participação nas democracias contemporâneas (AVRITZER, 2008, p. 49)2.

Aolongo das últimas décadas, garantidas por dispositivos constitucionais e por legislações regulamentadoras que condicionam o repasse de verbas para as respectivas áreas de atuação, as instituições participativas proliferaram. Elas tiveram significativa expansão nos mais distintos campos de intervenção governamental (saúde, educação, assistência social, etc.), pelos municípios e estados brasileiros, alcançando, ainda no governo FHC e, de forma mais acentuada, durante os dois governos Lula (PT), expressão nacional ${ }^{3}$. Essa ampliação resultou num grande volume de experiências descentralizadas com a participação da sociedade civil na elaboração, implementação e gestão de políticas públicas, fazendo do Brasil, até então considerado um país de baixa propensão associativa e escassas formas de participação (KOWARICK, 1973; SINGER; BRANDT, 1980), uma referência nos debates internacionais sobre o tema.

Segundo Avritzer (2008), seria possível afirmar que há hoje no Brasil uma "infraestrutura da participação" diversificada tanto em sua forma quanto em seu desenho. Segundo ele, as instituições participativas no Brasil contemporâneo conheceram basicamente três modelos de desenho institucional: a) desenho participativo de baixo pra cima, por exemplo, os orçamentos participativos; b) desenho de partilha do poder, observado em conselhos gestores e de direitos; e, por fim, c) desenho de ratificação

${ }^{2}$ De acordo com Avritzer (2009 apud AVRITZER, 2008, p. 45), instituições participativas são "formas diferenciadas de incorporação de cidadãos e associações da sociedade civil na deliberação sobre políticas". Embora "diferenciadas", essas formas de participação política constituem instituições políticas na medida em que, assim como as instituições mais tradicionais (parlamento, partidos, etc.), envolvem um conjunto de normas e procedimentos que organizam a ação social e política (POWELL; DIMAGGIO, 1991; HELMKE; LEVITSKI, 2006).

${ }^{3}$ Há de se lembrar que o Partido dos Trabalhadores (PT) foi um agente importante na implementação de instâncias participativas, sobretudo, desde a emergência do famigerado Orçamento Participativo em Porto Alegre, em 1999. Quando chegou à presidência, em 2003, com o ex-presidente Luiz Inácio Lula da Silva, o partido também propiciou "novos repertórios de interação Estado-sociedade" (ABERS; SERAFIM; TATAGIBA, 2014) ao introduzir ativistas de distintos movimentos sociais em seu governo, ampliando significativamente o número de conselhos na esfera nacional, nas mais diversas áreas. 
pública, tal como os planos diretores. Seguindo essa tipologia, interessa neste trabalho atentar para o segundo modelo de desenho institucional, representado pelos conselhos gestores, numa área de atuação específica: a segurança pública.

Para além das particularidades relativas ao seu desenho, que por conta de seu caráter interinstitucional os discrimina também de outros tipos de conselhos, como os conselhos populares ou os conselhos de "notáveis" (os primeiros compostos exclusivamente por membros da sociedade civil e os segundos restritos a especialistas em determinado tema), os conselhos gestores podem ser diferenciados das demais estruturas participativas pelo modo como a participação é garantida. Nessas formações colegiadas em particular, a participação se dá a partir da representação por meio de associações, organizações e entidades atuantes e/ou que gozem de reconhecimento na área em questão.

O número bastante expressivo de conselhos existentes hoje no contexto brasileiro indica que essa ferramenta tem sido percebida como uma das grandes apostas para o aprimoramento de práticas participativas em nosso país. Ao fim da década de 1990, pesquisa realizada pelo IBGE (1999) já constatava a existência de quase 27 mil conselhos distribuídos em praticamente todos os municípios brasileiros, havendo, em média, 4,9 conselhos por município. Contudo, apesar desse alastramento, o qual se convencionou chamar de "febre conselhista", muitos autores têm chamado atenção para as limitações e problemas envolvidos nesses colegiados, como a resistência do Estado para reconhecer a efetividade desses espaços, as desigualdades de recursos e de poder de influência nos processos decisórios entre seus membros, a falta de capacitação dos conselheiros (sobretudo aqueles vinculados a instâncias da sociedade civil), o caráter apenas consultivo de muitos conselhos, dentre outras questões (TEIXEIRA, 1996; CARVALHO, 1998; TATAGIBA, 2003; FUKS; PERISSINOTTO; SOUZA, 2004; GOHN, 2006).

Não obstante exista hoje uma vasta literatura nas ciências sociais brasileiras sobre o tema da participação, havendo distintos enfoques de acordo com as áreas, instituições e atores analisados, há ainda dentro desse campo alguns domínios que necessitam de maior investimento analítico sobre suas dinâmicas e sua operacionalidade. Esse é o caso, por exemplo, dos conselhos gestores que atuam no campo da segurança pública e dos direitos humanos. 
No campo da segurança pública, apesar de algumas iniciativas precursoras $^{4}$, a implementação sistemática de conselhos se deu mais tardiamente, se tomarmos como referência outras áreas, como saúde, educação e assistência social, por exemplo. É necessário ter em mente, contudo, que nesse setor específico, com frequência identificado à repressão e à reprodução de mecanismos de dominação social, as relações entre Estado e sociedade civil sempre foram marcadas por um alto grau de tensão. Por um lado, a gestão da área sempre foi compreendida por seus responsáveis como um exercício exclusivo do Estado e de suas instituições especializadas no uso da força. Some-se a isso a arraigada cultura corporativa desses setores, refratários a quaisquer mudanças que pudessem ir de encontro aos seus interesses e aos seus modos consagrados de atuação (SOARES, 2000; RATTON, 2007).

Por outro lado, no campo da sociedade civil organizada, verificava-se uma franca hostilidade aos operadores da segurança pública, cultivada por grande parte da militância associativa, tornando mais difíceis as possibilidades de diálogo. Além disso, o próprio nível de organização dos grupos civis engajados nesse domínio se apresentava como uma dificuldade adicional, uma vez mais em comparação com a mobilização em outros setores. Foi somente na passagem da década de 1990 para os anos 2000, após um agudo crescimento dos índices de criminalidade e da sensação de insegurança, que organizações oriundas da sociedade civil conseguiram, por meio de campanhas, protestos, formulação de propostas, dentre outras atividades, exercer maior influência no debate público acerca do tema (PAVEZ; TOLEDO; GONÇALVES, 2009).

Concomitantemente, na esfera estatal, foi possível perceber o advento de uma nova compreensão sobre administração da segurança pública a partir de dois episódios. No nível mais abrangente, a criação do Programa Nacional de Segurança Pública (2000) e, posteriormente, o lançamento do Primeiro Plano Nacional de Segurança Pública (2003) simbolizaram a inserção dessa matéria na agenda do Governo Federal e a construção de um discurso sobre segurança pública no âmbito nacional (SENTO-SÉ, 2011). No nível das cidades, o surgimento de iniciativas de gestão municipal e intermunicipal,

\footnotetext{
${ }^{4}$ Os primeiros conselhos a operar estritamente no campo da segurança pública com a participação da sociedade civil, ambos de cunho comunitário, surgiram nos estados do Paraná e de São Paulo, oriundos de iniciativas distintas. Enquanto no Paraná os conselhos emergiram de grupos organizados da sociedade civil, nas cidades de Londrina (1982) e Maringá (1983), em São Paulo, os conselhos comunitários surgiram a partir de um Decreto Estadual (1985) regulamentado pelo então governador Franco Montoro.
} 
como o Fórum Metropolitano de Segurança Pública, criado em 2001 pelos municípios que compõem a região metropolitana de São Paulo, representou a incorporação dos municípios ao debate. Como observado por Rodrigues, Lázaro e Sento-Sé (2014), em todos esses empreendimentos a participação da sociedade civil e sua cooperação junto às autoridades públicas aparecem como uma dimensão estratégica importante para o planejamento das políticas relativas à segurança.

A despeito desses esforços, no plano federal, somente alguns anos mais tarde, a participação cidadã obteve espaço na agenda política. Mais precisamente, isso se deu em 2009, quando foi realizada a Primeira Conferência Nacional de Segurança Pública e, a partir daí, foi reformulado o Conselho Nacional de Segurança Pública (Conasp). Diferentemente daquilo que ocorreu em outros setores, como o de política urbana e o de desenvolvimento agrário, as duas iniciativas não foram produto de demandas da sociedade civil nem tampouco de determinações estratégicas do Governo Federal. Segundo Abers, Serafim e Tatagiba (2014, p. 344), o ocorrido foi resultado da atuação de um pequeno número de atores do Estado - com destaque para aqueles vinculados à Secretaria Nacional de Segurança Pública (SENASP) -, comprometidos com uma perspectiva participativa e que almejavam a criação de redes de relações entre potenciais parceiros, de maneira a superar a mútua hostilidade que até então caracterizara o campo.

Já no contexto municipal (e local), verificou-se, ao longo da última década e meia, um aumento no número de experiências associativas via conselhos, principalmente após a oficialização da regra segundo a qual a existência de conselhos municipais de segurança pública constitui-se uma das condições para os municípios receberem recursos do Fundo Nacional de Segurança Pública ${ }^{5}$. Num esforço inicial, no contexto dos preparativos para a realização da já mencionada Primeira Conferência Nacional de Segurança Pública, a SENASP apurou a existência de 545 conselhos de segurança em funcionamento distribuídos em 22 unidades federativas, sendo 447 conselhos comunitários, 64 municipais, 10 estaduais e 3 conselhos classificados como "outros".

Quatro anos depois, tendo como base os dados colhidos pela SENASP, Rodrigues, Lázaro e Sento-Sé (2014) empreenderam uma tentativa de atualizar o status dos conselhos de segurança pública no Brasil a partir de contatos realizados diretamente com os conselheiros. Apenas 62 conselhos

${ }^{5}$ Lei Federal No 12.681 , de 2012. 
responderam à investida, que foi marcada pela grande dificuldade em acessar informações atualizadas e os próprios representantes dos conselhos (idem, p. 121). De acordo com os autores, esse resultado expressa a grande volatilidade do campo e a baixa institucionalidade dos colegiados, além de apontar para a grande dependência do "espontaneismo intermitente" de suas lideranças (idem, p. 120).

Já levantamento recente feito pelo IBGE, a Pesquisa de Informações Básicas Municipais (MUNIC), realizada em 2014, revelou que dos 5.570 municípios brasileiros, 691 possuíam conselhos municipais de segurança pública e 480 tinham pelo menos um conselho comunitário de segurança pública naquele ano. Utilizando-se de uma metodologia distinta, na qual a coleta de informações se deu a partir da aplicação de questionários a personagens-chave, todos representantes de instâncias governamentais da municipalidade previamente identificados e selecionados, a pesquisa demonstrou que entre 2006 e 2014 o percentual de municípios com esse tipo de conselhos teve um pequeno acréscimo, subindo de $8 \%$ para $12,4 \%$.

Embora distintas e de caráter incipiente, essas pesquisas apontam para a existência de um universo conselhista no país no campo da segurança pública que, sem dúvida, não é irrelevante. Ao contrário, não constitui exagero algum afirmar que se trata de um terreno bastante fértil à investigação científica. No entanto, não há como escapar à constatação de que muito pouco foi feito para o estudo dos diferentes tipos de colegiados que atuam nessa área. É preciso, porém, ressalvar que, como indicado por Rodrigues, Lázaro e Sento-Sé (2014, p. 119), os obstáculos que se apresentam na abordagem dos personagens que compõem esses espaços não são poucos: informações desencontradas e/ou desatualizadas sobre os conselhos e seus conselheiros, o que impede ou pelo menos dificulta a sua localização; ausência de estrutura mínima (como telefones ou endereços de e-mail institucionais); dependência da militância de algumas lideranças isoladas, que raramente conseguem transformar seus esforços na institucionalização desses canais. Portanto, a escassez de pesquisas que se verifica é menos um produto da ausência de interesse pelo tema e mais uma dificuldade de aproximação do campo.

Além de escassos, os trabalhos dos quais se tem notícia no campo das ciências sociais, em sua maioria, têm seu foco voltado às experiências nos limites comunitários (para ficar em alguns exemplos: MACAULAY, 2005; SENTO-SÉ; FERNANDES, 2005; PATRÍCIO, 2013; SENTO-SÉ; SANTOS; FERREIRA, 2012; BUENO et al., 2016). Os parcos estudos que fogem a essa 
dimensão estão nos registros de Protásio e Listgarten (2010), que analisaram o Conselho de Defesa Social de Minas Gerais; Delano de Souza (2011), que estuda o Conselho Municipal de Defesa Social de Contagem; UFRJ (2013), que realizou um diagnóstico dos Conselhos Estaduais de Segurança Pública e de Direitos Humanos; e, por fim, Poncioni e Silva (2016), que analisaram tanto os conselhos comunitários (CCSs) como o Conselho de Segurança Pública do Estado do Rio de Janeiro (Consperj).

$\mathrm{O}$ presente trabalho busca se inscrever nesse último conjunto de investigações e se dispõe, justamente, a uma tentativa de contribuir para uma melhor compreensão dos mecanismos de participação existentes no setor de segurança pública. Pretendemos analisar, por meio de estudo de caso e em perspectiva comparada, os conselhos estaduais de segurança pública de dois estados brasileiros: Pará e Rio de Janeiro. $\mathrm{O}$ argumento que permeia a análise que aqui se faz a partir dos conselhos estaduais de Pará e Rio de Janeiro é o de que dentro de um mesmo setor de políticas públicas, dotado de um padrão específico de relações entre Estado e sociedade civil, contextos diferentes tendem a gerar desenhos institucionais e estruturas igualmente distintas que, por sua vez, podem gerar formas de interação e participação díspares entre si. A escolha por esses conselhos específicos se justifica por três motivos diversos, mas interligados. Em primeiro lugar, optou-se por privilegiar os conselhos que operam na esfera estadual tendo em vista a diminuta quantidade de pesquisas nessa direção. A escolha por Pará e Rio de Janeiro, por sua vez, se explica por duas razões. Primeiramente, trata-se de dois estados pertencentes a regiões bastante diferentes entre si, o que implica históricos e contextos de segurança pública singulares. A segunda razão tem a ver com as próprias características dos conselhos, que, ao serem escrutinadas e comparadas, evidenciarão divergências e convergências, aproximações e distanciamentos.

Finalmente, o terceiro motivo. Este estudo é produto de algumas experiências das quais tivemos a oportunidade de participar em diferentes projetos de pesquisa. $\mathrm{O}$ primeiro deles foi realizado a partir do convênio ${ }^{6}$ estabelecido entre o Ministério da Justiça/PNUD e a Fundação Guimarães Rosa e o Laboratório de Análise da Violência da UERJ (LAV-UERJ). Tratase do projeto "Avaliação da Implementação dos Conselhos de Segurança no Brasil". Nessa iniciativa, que resultou na produção de um extenso relatório

\footnotetext{
${ }^{6}$ Resultado do Edital BRA/04/029 - Segurança Cidadã; Pensando a Segurança Pública, Edital de Convocação n 002/2015 pelo Ministério da Justiça, Secretaria Nacional de Segurança Pública e Programa das Nações Unidas para o Desenvolvimento.
} 
e de um artigo científico intitulado "Quatro experiências e um modelo: conselhos de segurança e participação política" (SENTO-SÉ et al., 2016, no prelo), foram investigadas as diferentes formas de experiências conselhistas em quatro estados brasileiros - Rio de Janeiro, Pará, Bahia e Paraná - nos quais obtivemos acesso a um material bastante extenso e estimulante.

O segundo projeto, de que um de nós tomou parte, foi executado no âmbito do Instituto de Estudos da Religião (ISER) e se dedicou a analisar as dinâmicas dos homicídios na Baixada Fluminense. Os resultados alcançados estão expostos no relatório final intitulado "Homicídios na Baixada Fluminense: Estado, mercado, criminalidade e poder" (RODRIGUES et al., 2017, no prelo). Em ambos os projetos os conselhos estaduais de segurança pública foram objeto de análise e fontes preciosas de informações ${ }^{7}$. No primeiro caso, tanto o Conselho Estadual do Rio de Janeiro quanto o do Pará foram estudados. No segundo caso, como a investigação dizia respeito a uma região fluminense, levou-se em consideração apenas o colegiado do Rio de Janeiro, obviamente. Dada a riqueza de informações encontradas e levando em consideração os motivos explicitados anteriormente, pareceu interessante a ideia de reunir e sistematizar os dados coletados sobre esses fóruns.

Finalmente, cabe mencionar que um dos autores foi conselheiro no Rio de Janeiro, no primeiro biênio de funcionamento do Consperj. O trabalho que aqui se apresenta, por conseguinte, não é resultante de um projeto específico, mas é um recorte, dentre muitos possíveis, a partir de experiências em iniciativas díspares. Trata-se, na verdade, de mais um resultado decorrente de um já longo programa de pesquisa dedicado ao tema, desenvolvido no âmbito do LAV-UERJ.

Buscando aprimorar os conhecimentos sobre o funcionamento dos conselhos de segurança pública mencionados, foram observados os respectivos modelos de organização, os padrões de interação entre sociedade civil e Estado em seu funcionamento, o grau de institucionalização de cada conselho, a capacidade de ingerência sobre a política de segurança pública e as formas possíveis da participação e as percepções de atores da sociedade civil sobre a efetividade desses espaços. Para tanto, foram analisadas todas as peças normativas que modelaram a criação e formação dos conselhos. Além

\footnotetext{
${ }^{7}$ Agradecemos os responsáveis e instituições vinculados a esses projetos pela possibilidade de utilizarmos informações e reflexões obtidas a partir deles para a feitura deste artigo. Esclarecemos, desde já, que não há qualquer coincidência ou superposição entre o presente artigo e os respectivos relatórios de pesquisa.
} 
disso, com o intuito de confrontar a normatividade formal às dinâmicas práticas, utilizamos o método da observação participante em reuniões de ambos os conselhos e realizamos entrevistas com roteiros semiestruturados com alguns de seus membros. Foram acompanhadas reuniões ordinárias dos colegiados e realizadas entrevistas com atores-chave representantes da sociedade civil e de órgãos do Estado com representação nos conselhos.

$\mathrm{O}$ restante do trabalho está organizado em duas partes. $\mathrm{Na}$ primeira, serão apresentadas as considerações acerca do Conselho Estadual de Segurança Pública do Pará (CONSEP). A segunda tratará do conselho fluminense, o Consperj - Conselho de Segurança Pública do Rio de Janeiro. Ao fim desta exposição serão tecidas as considerações finais, em caráter provisório e um tanto ensaístico, sobre ambas as experiências e sobre comparações possíveis entre elas.

\section{0 Conselho Estadual de Segurança Pública do Pará (CONSEP)}

A criação do Conselho Estadual de Segurança Pública do Pará (Consep) data do ano de 1996 e se deu por meio de lei estadual, sancionada pelo então governador do estado Almir Gabriel (PSDB). Seu surgimento ocorre em um contexto político que coincide com a emergência de diversos conselhos gestores no Brasil (GOHN, 2001), em que pese o fato de que experiências do tipo no campo da segurança pública ainda fossem bastante escassas e impensáveis na maioria dos estados brasileiros. À época apenas cinco estados previam conselhos estaduais de segurança pública em suas respectivas legislações, sendo que somente em três houve algum registro de atividade.

O contexto específico da segurança pública no Pará, naquele momento, é igualmente relevante. Como destaca Debert (2000), em trabalho seminal sobre o processo de mobilização de diferentes atores no campo da segurança pública no Estado do Pará, durante a década de 1990, vivia-se então um grande esforço de aproximação entre as instituições do sistema de justiça criminal e a sociedade civil. Foram encampadas iniciativas como o Projeto Povo (Policiamento Ostensivo Volante) e a Companhia Especial de Polícia Assistencial (CEPAS), ambas pela Polícia Militar, e o programa "Ministério Público e a comunidade", idealizado pelo MP paraense, por exemplo. Neste mesmo período foi instituída também a Ouvidoria do Sistema de Segurança Pública do Pará, que teve como sua primeira dirigente máxima uma das mais respeitadas ativistas do campo dos direitos humanos no Pará, 
Rosa Marga Rothe, uma das lideranças da Sociedade Paraense de Defesa dos Direitos Humanos (SPDDH), instituição que até hoje goza de grande prestígio no Estado e no país 8 .

Nessa conjuntura, a formação do conselho de segurança pública paraense foi uma das medidas adotadas pelo então Secretário de Segurança Pública e mentor da proposta, no bojo da reformulação das políticas para o setor no Estado. Segundo o ex-gestor Paulo Sette Câmara, entrevistado para este estudo, havia uma necessidade imperativa de se estabelecer uma nova concepção de segurança pública que não se restringisse apenas à polícia. Assim, durante sua gestão, foi instituído também - pela mesma lei que criou o Consep e a Ouvidoria9--, o Sistema de Segurança Pública do Estado do Pará (hoje denominado SIEDS), dedicado a promover a integração entre as instituições responsáveis pela área, incluindo a Ouvidoria e o Conselho. Neste espírito, o Consep seria a principal ferramenta do sistema que se inaugurava, de forma a atuar como um órgão superior de deliberação colegiada e a ser uma instância que contaria com a participação do poder público e da sociedade civil. Conforme salientou em entrevista, o Conselho deveria operar como um espaço de diálogo entre representantes dessas duas esferas visando à criação de alternativas para a segurança pública:

(...) nós fizemos uma revolução aqui que você não tem noção. A minha ideia era ter conselho paritário, com a sociedade civil forte. Aí lancei quais eram as que eu achava: a Sociedade dos Direitos Humanos, a Ordem dos Advogados, a Criança e o Adolescente e o CEDENPA. (...) A ideia era que a gente conseguisse buscar caminhos pra segurança pública, mostrar que a segurança era maior do que a polícia. (...) Gente, o objetivo disso é ver se a gente consegue conhecer o outro lado, vocês não conhecem o outro lado, tá na hora de conhecer as posições de cada qual. Então, qualquer proposta, qualquer decisão que sair daqui vai ser uma decisão discutida entre os lados. (Depoimento de Paulo Sette Câmara)

Logo nos primeiros meses de funcionamento do novo sistema, no entanto, um trágico acontecimento quase pôs em cheque suas pretensões. Em abril de 1996, dezenove trabalhadores rurais sem terra foram assassinados pela Polícia Militar paraense durante protesto contra a demora na desapropriação

${ }^{8}$ Não obstante instituída por lei em 1996, a Ouvidoria só passou a operar a partir do fim de 1997.

${ }^{9}$ Lei n ${ }^{0} 5.944$, de 2 de fevereiro de 1996. 
de terras no Estado. O episódio ficou internacionalmente conhecido como o "Massacre de Eldorado dos Carajás", em referência ao município no qual aconteceu. Sem entrar em maiores detalhes sobre o ocorrido, o ex-Secretário de Segurança Pública paraense revelou que à época teria colocado seu cargo à disposição, mas teria sido convencido pelo governador a continuar no exercício de suas funções, com a garantia de respaldo aos seus projetos.

Dentro desse conturbado contexto, o Conselho Estadual de Segurança Pública paraense deu início ao seu processo de autoconstrução. Embora definido formalmente, restava ainda estabelecer de que maneira o colegiado exerceria as funções e atividades que lhes foram atribuídas. Diante dos precedentes verificados em outros Estados, onde previsões legais não significaram o imediato ou até mesmo a concretização do efetivo funcionamento de conselhos, e tendo em conta as já mencionadas tensões que constituem o campo da segurança pública, esta era uma preocupação justificável. No entanto, se mesmo antes do episódio de Eldorado dos Carajás as autoridades políticas já se mostravam favoráveis à iniciativa capitaneada pelo próprio Secretário de Segurança, posteriormente, a necessidade de respostas aos protestos da sociedade civil organizada ante o acontecido não só tornou inadiável o compromisso firmado como também o impulsionou. Deste modo, em poucos meses o Conselho elaborou seu regimento interno peça fundamental ao funcionamento de qualquer instituição -, submeteu-o à Consultoria-Geral do Estado e obteve a aprovação do governador, que homologou a proposta por meio de decreto ${ }^{10}$. A seguir serão descritos e analisados os seus aspectos principais e as tensões que se verificam em sua rotina.

\subsection{Da estrutura ao funcionamento: como opera o Consep}

Diferentemente da grande maioria dos conselhos do tipo que atuam nos Estados, municípios ou no âmbito local, seu regimento prevê que o Consep disponha de caráter normatizador e deliberativo, além de ter autonomia para fiscalizar e avaliar a política de segurança pública do Estado. A estrutura do Conselho comporta quatro órgãos principais: i) o Plenário ou o Colegiado Pleno, órgão mais importante do Conselho, em que são realizadas as deliberações; ii) a Secretaria Executiva, responsável pela parte

${ }^{10}$ Parecer n ${ }^{0}$ 343/95 da Consultoria-Geral do Estado, publicado em 29 de julho de 1996 e 1555 de, 09 de agosto de 1996. 
administrativa e pelo funcionamento do fórum; iii) a Ouvidoria do Sistema, que deve efetuar o controle das instituições que constituem o sistema de segurança pública do Pará; iv) e a Comissão de Controle de Segurança Pública, a quem compete o acompanhamento da aplicação de recursos, análise e divulgação de estatísticas, dentre outras funções.

A presidência do colegiado cabe ao Secretário de Segurança Pública e Defesa Social, que detém o direito a um "voto de qualidade", enquanto a vice-presidência é reservada a um dos membros oriundos da sociedade civil, a despeito de o regimento interno determinar a realização de eleição para este último cargo. Segundo foi possível apurar com alguns conselheiros que foram entrevistados durante o trabalho de campo, esta seria uma concessão estabelecida por meio de um "acordo de cavalheiros" entre as partes envolvidas. Interpretada positivamente pelos membros do colegiado, se por um lado essa manobra indica uma tentativa de equilíbrio entre Estado e sociedade civil - já que, na ausência do presidente, seus poderes são transferidos ao vice-presidente - por outro ela também aponta para a possibilidade da prevalência de acordos informais diante de mecanismos democráticos formalmente instituídos.

Como ocorre na composição de outros colegiados, inclusive no Rio de Janeiro, os membros titulares do plenário que devem representar as entidades do Estado são definidos previamente. Diferentemente do que se verifica na instituição fluminense, no entanto, como se verá mais adiante, no conselho paraense mesmo os representantes da sociedade civil são definidos de forma prévia. Ou seja, a titularidade institucional do Conselho é toda ela estabelecida a priori, ainda que as entidades que representam a sociedade civil organizada disponham de autonomia para indicar seus membros titulares e suplentes. Esse é um ponto importante a se destacar porque atesta uma hierarquização prévia das entidades da sociedade civil, e a definição, por parte do poder público, daquelas que estão abalizadas para ter assento no Conselho.

Todos os conselheiros têm suplentes no Consep, à exceção dos membros natos. De acordo com o Secretário Executivo, encarado como um dos pilares do Conselho por exercer a função praticamente desde a sua fundação, esta teria sido uma estratégia da qual o então Secretário de Segurança teria lançado mão para evitar que os membros natos enviassem suplentes ao invés de comparecer eles próprios às reuniões. Segundo esse raciocínio, a presença das autoridades máximas das instituições do Sistema Estadual de Segurança Pública e Defesa Social do Estado do Pará (SIEDS) conferiria 
legitimidade ao Conselho e às suas deliberações.

Certamente uma das experiências mais consolidadas no país no campo da segurança pública, o Consep foi pioneiro também por adotar uma estrutura tripartite, garantindo assentos ao poder público, à sociedade civil e aos trabalhadores da área de segurança pública. Isto, porém, não se refletiu em uma paridade entre esses segmentos. Desde a sua primeira aparição em peças legislativas, o Conselho tem em sua composição uma assimetria em termos de representação que tende a privilegiar o Estado em detrimento da sociedade civil e das entidades representantes de trabalhadores da segurança pública.

Atualmente, de acordo com o $\S 1^{\circ}$ do Art. $4^{\circ}$ da Lei $N^{\circ} 7584$, de 28 de dezembro de 2011, o colegiado pleno do Consep é composto por dezesseis membros, distribuídos da seguinte maneira: i) representando os órgãos públicos integrantes do SIEDS, na qualidade de membros natos, estão sete membros - o Secretário de Estado de Segurança Pública e Defesa Social; o Comandante-Geral da Polícia Militar do Estado; o Comandante-Geral do Corpo de Bombeiros Militar; o Delegado-Geral da Polícia Civil do Estado; o Diretor-Superintendente do Departamento de Trânsito do Estado do Pará; o Superintendente do Sistema Penitenciário do Estado; e o Diretor-Geral do Centro dePerícias Científicas "Renato Chaves"; ii) representando a sociedade civil, há quatro entidades - a Ordem dos Advogados do Brasil, seção Pará (OAB-PA); a Sociedade Paraense de Defesa dos Direitos Humanos (SDDH); o Centro de Defesa da Criança e do Adolescente (CEDECA); e o Centro de Defesa do Negro do Pará (CEDENPA); iii) um membro representa as entidades de classe dos órgãos do SIEDS; iv) além de todos os integrantes elencados, compõem o Consep também dois deputados estaduais, um representante do Ministério Público Estadual e um representante do Poder Judiciário Estadual - estas duas últimas instituições integram o colegiado desde que manifestem interesse em participar ${ }^{11}$.

As corregedorias internas da Polícia Militar e da Polícia Civil do Pará e a Ouvidoria do SIEDS também compõem o Conselho, podendo ter direito a voz, sem, contudo, ter direito a voto. Dentre as funções do Consep está a

\footnotetext{
${ }^{11}$ De acordo com o secretário executivo do Consep, inicialmente, não havia vagas previstas ao Poder Legislativo. Elas foram criadas a partir de uma negociação política, quando da submissão do projeto de lei que deu origem ao conselho à assembleia legislativa paraense. Foram criadas duas vagas para que houvesse a possibilidade de haver um representante da situação e outro da oposição. No caso dos assentos destinados ao Ministério Público e ao Poder Judiciário, estes foram incluídos pela primeira vez a partir da Lei № 7584, de 28 de dezembro de 2011, que reestruturou a Secretaria de Estado de Segurança Pública e Defesa Social (SEGUP).
} 
organização dos processos eleitorais para as escolhas dos integrantes dos colegiados dos corregedores e do ouvidor do sistema de segurança pública paraense. Somando-se os representantes do SIEDS, do Poder Legislativo, do Ministério Público e do Poder Judiciário, o Estado conta com dois terços dos membros do Conselho (11), ao passo que a sociedade civil dispõe de quatro vagas para sua representação e os trabalhadores dos órgãos da segurança pública apenas uma. Na visão dos conselheiros provenientes da sociedade civil, essa desproporcionalidade tem comprometido a sua capacidade de atuar de maneira propositiva e de fazer frente aos representantes do Estado.

(...) cresceu a representatividade, digamos, dos órgãos instituídos, ao contrário da sociedade civil. Então hoje, nós inclusive vivemos uma situação em que a sociedade civil é minoritária no conselho. (...) quando a gente vai pro embate, que precisa votar, a gente sempre vai perder. Nós sempre temos perdido nos últimos tempos porque a gente está minoritário. (Entrevista com a representante do CEDENPA e Vice-Presidente do CONSEP)

Como salientado nesse trecho, a desigualdade na representação entre Estado e sociedade civil torna-se mais evidente justamente nos momentos de deliberação. De acordo com a representante do CEDENPA, que também é a vice-presidente do conselho, os conselheiros derivados dos quadros do Estado invariavelmente se articulariam para votar em bloco e fazer valer a sua superioridade numérica. Isso foi confirmado por outros conselheiros e assumido como "parte do jogo", no qual as "articulações" são válidas. Tal situação se agravaria ainda pelas "dissidências" que vez ou outra ocorrem por parte da Ordem dos Advogados e das entidades de classe. Essas últimas, inclusive, são percebidas como ambíguas, isto é, ao mesmo tempo em que são reconhecidas como associações de trabalhadores e, portanto, em tese, pertencentes à sociedade civil organizada, por sua postura de apoio ao Estado, em alguns momentos, elas também são vistas como parte integrante deste último.

Apesar da ambiguidade naquele que seria o terceiro segmento do colegiado, é interessante perceber como do ponto de vista dos próprios conselheiros existe uma clara cisão entre "eles" e "nós". Essa divisão teria se tornado ainda mais forte após a posse de um general do Exército como titular da pasta de segurança pública, em 2014. Tido pelas organizações não governamentais que integram o colegiado como incompatível com as demandas do campo, a postura do general diante da Secretaria representaria 
um afastamento entre Estado e sociedade civil, entre "eles" e "nós". Na prática, porém, apesar das disputas e assimetrias, as regras estabelecidas e as dinâmicas envolvidas num espaço deliberativo impelem os atores envolvidos no Consep à interdependência, mesmo que ela se materialize em alguns momentos sob a forma de concorrência. Em se tratando de uma instituição participativa, mesmo que os desígnios das autoridades governamentais e dos agentes do estado prevaleçam, isto só pode acontecer por meio de um canal oficial e legítimo de diálogo entre as esferas.

Em contrapartida, é preciso ressaltar que, se tomarmos a oposição que nos é dada a partir dos depoimentos colhidos entre representantes do Estado e da sociedade civil, é necessário reconhecer que as condições em que se dão os embates no âmbito do colegiado não propiciam equilíbrio de poder entre as partes envolvidas. A representação numérica da qual dispõe a sociedade civil influencia diretamente as deliberações do conselho. Há propostas sendo avaliadas que sugerem uma reformulação no regimento interno do conselho, visando conceder à sociedade civil mais vagas, incorporando grupos como o movimento LGBTTs e os movimentos feministas. Essa reformulação só será possível se for alcançada, em votação, a maioria absoluta. Nesse sentido, a atual estrutura pode se constituir como um obstáculo e acabar se tornando um vetor para a continuidade de uma assimetria estrutural.

Em termos mais concretos de operacionalidade, o Consep se reúne ao menos duas vezes ao mês, em datas predefinidas pelo próprio colegiado, que elabora e põe em votação um calendário semestral de encontros, posteriormente publicado em Diário Oficial. Pode haver reuniões extraordinárias, mas estas dependem de convocação do presidente do conselho, o que geralmente não ocorre. As reuniões são conduzidas pelo secretário executivo, responsável pela elaboração e leitura de todas as atas, que devem ser aprovadas no primeiro momento da congregação. Em seguida, todos os expedientes recebidos e expedidos pelo Consep são comunicados a todos os conselheiros. Em momento posterior, devem ser debatidos os pontos de pauta que foram definidos previamente, na reunião anterior, e comunicados a todos os conselheiros, mesmo os que porventura foram faltosos. Por fim, reserva-se um momento derradeiro para intervenções que não estejam em pauta.

Há ainda um momento à parte, reservado a intervenções que venham de participantes que não sejam membros do conselho, geralmente oriundos da sociedade civil. Esse momento é denominado "Momento da Cidadania" 
e consiste em conceder o direito a voz, mediante solicitação e deliberação prévia por parte do conselho, a qualquer cidadão que queira se manifestar sobre "assunto de notória repercussão". Muito embora não haja previsão legal para esse momento específico das reuniões do conselho, é interessante perceber como para além da forma tradicional de participação - que se dá por meio de representação entre os membros do colegiado - há ainda esse outro elemento externo, cuja atuação é regulada por normas informais e singulares.

É necessário dizer, arrematando as considerações sobre a experiência do Conselho Estadual do Pará, que a participação da sociedade civil carece de maior investimento. Isso porque, além de ser proporcionalmente reduzida e ser representada por atores institucionalmente determinados de maneira prévia, como já assinalamos, seus titulares são constrangidos pelo próprio regimento e modo de operação dos encontros do Conselho. Isto certamente está em relação direta, embora não explique de todo, com o fato de que as informações sobre as atividades do Conselho, como horário de reuniões, resoluções e a própria existência do mesmo, não possuem nenhum tipo de divulgação. Apenas os membros do colegiado têm acesso a esse material. Isso conflita com o previsto no art. 15 do regimento interno do Conselho, que determina que as sessões Plenárias do CONSEP devem ser abertas ao público, havendo transparência em relação às "pautas e datas previamente divulgadas pelos meios de comunicação de massa, sendo facultado o direito de voz a qualquer cidadão presente às mesmas".

Apesar disso, segundo diferentes conselheiros ouvidos, o Conselho tem conseguido, talvez como nenhum outro no Brasil, interferir nas políticas de segurança - ainda que de forma relativamente tímida -, sendo considerado um importante passo na consolidação do diálogo como ferramenta imprescindível às ações do Estado.

(...) o CONSEP ele tem sido um avanço pra gente sem sombra de dúvida. A gente tem condição de discutir, de trazer algumas questões, que são questões que não são discutidas. Então, às vezes ele já foi melhor, às vezes ele tá mais ou menos... Eu diria que ele agora está mais ou menos, ele já foi melhor, por exemplo, no início, com o Sete Câmara, que tinha uma posição mais aberta, ele foi melhor com outros presidentes que já passaram por aqui, que tinham a posição mais aberta. Esse atual presidente não sei se deu pra perceber mas ele é meio durão, ele tem como é que eu posso dizer, tradição militar, né? (Entrevista com conselheiro do Consep representante da sociedade civil) 
A capacidade de ingerência do Consep, é bom notar, é antes de tudo uma consequência de seu caráter deliberativo, prerrogativa incomum aos conselhos que atuam na área, como já mencionado. Um exemplo do que se afirma pode ser verificado na criação do chamado "Grupo de Acompanhamento da Letalidade e Mortalidade", que funciona no interior do Conselho e cuja atuação consiste em monitorar mortes cometidas por policiais no Estado e as investigações decorrentes. Esse grupo foi responsável por sugerir a produção de um relatório circunstanciado por parte do policial que utilizar arma de fogo em serviço, o qual deve ser enviado para análise do colegiado. Embora não tenhamos subsídios suficientes para estimar qualquer desdobramento dessa medida, cabe notar que, ao menos no espírito da deliberação, há o aceno para alguma espécie de mecanismo de controle do Conselho sobre o uso da força pelas agências policiais. Cabe observar e acompanhar os passos futuros a partir dela.

De acordo com a vice-presidente do Conselho, o maior desafio do Consep seria justamente dirimir a distância ainda existente entre as deliberações que resultam da atividade do Conselho e a efetivação dessas nas práticas das instituições do sistema de segurança pública paraense. O principal obstáculo à redução ou até mesmo à extinção dessa distância seria a longa tradição de práticas autoritárias, sobretudo da Polícia Militar. Ou seja, a despeito de sua longevidade e do investimento institucional, o Consep parece lidar, ainda hoje, com obstáculos bem conhecidos desde o início do debate sobre a criação de fóruns dessa natureza.

(...) A prática autoritária permanece. Eu acho que ela é muito forte, ela faz parte da formação. Essa distância entre a resolução, as deliberações e a execução, né... Quem vai executar somos nós, né, quem vai executar lá na frente. Essa distância permanece muito grande e eu acho que a questão da prática autoritária ainda é muito forte no sistema. (Entrevista com a representante do CEDENPA e Vice-Presidente do CONSEP)

Mas se o "passo seguinte", isto é, a execução das deliberações tomadas no conselho parece ser o problema maior no Consep, no caso do Consperj há questões de fundo a serem enfrentadas. A próxima sessão analisará, em perspectiva comparada, o histórico e o funcionamento do Conselho Estadual do Rio de Janeiro. 


\section{0 Conselho de Segurança Pública do Estado do Rio de Janeiro - CONSPERJ}

Desde meados da década de 1970, o Rio de Janeiro tem sido representado como uma espécie de espaço metonímico da violência urbana brasileira. As mudanças no padrão da criminalidade que se deram a partir dos anos 1950, apesar de terem atingido todas as grandes cidades brasileiras, ganharam maior notoriedade na capital fluminense (MISSE, 1999). O aumento dramático da violência que se sucedeu nas décadas seguintes, verificado nos altos índices de criminalidade e de sensação de insegurança, combinado a um grau singular de organização criminal e a grande visibilidade de uma ex-capital federal, sede de grandes empresas de comunicação e centro turístico reconhecido nacional e internacionalmente, fizeram com que o Rio de Janeiro passasse a ser percebido como a "mais perigosa" das "cidades perigosas" (ibidem), rótulo depois estendido a toda região metropolitana e, no limite, a todo o Estado.

Nesse processo, o contexto fluminense tornou-se objeto de diversas iniciativas encampadas tanto por parte do Estado, por meio de políticas públicas, quanto por parte da sociedade civil, através da atuação de universidades, instituições e organizações não governamentais na produção de pesquisas, debates, projetos, etc. Até o fim do século XX, no entanto, a implementação efetiva de uma agenda participativa em campo tão sensível não passava de uma ideia distante, a exemplo do que ocorria na maior parte dos estados brasileiros, muito embora já estivesse prevista legalmente ${ }^{12}$.

Apenas em 1999, quando da eleição de Anthony Garotinho (PDT) ao governo do Estado, a ideia de criação de conselhos de segurança foi retomada na pauta do debate político. O novo governador, que havia feito da segurança pública uma de suas principais plataformas de campanha,

\footnotetext{
${ }_{12}$ Na esteira da Constituição Federal de 1988, a Carta Constitucional do Rio de Janeiro, promulgada no ano seguinte, previa em capítulo dedicado à segurança pública a criação de um Conselho Comunitário de Defesa Social, que, contando com a representação de instituições da sociedade civil, deveria assessorar os órgãos de segurança pública. Embora seja denominado "comunitário", esse fórum não possui relação com os atuais conselhos comunitários. Ao contrário do primeiro, estes últimos não estão limitados a uma única instituição e atuam para além da estrutura estatal. Alguns anos antes, iniciativa similar foi realizada durante o mandato de Leonel Brizola (1983-1986), com a criação do primeiro Conselho de Segurança Pública de que se tem notícia no Estado. Entretanto, além de não haver registros sobre o seu efetivo funcionamento, ao que tudo indica o colegiado funcionava como uma espécie de conselho de "notáveis" (SENTO-SÉ, 1998; RODRIGUES; LÁZARO; SENTO-SÉ, 2014).
} 
ainda nos primeiros meses de seu mandato criou o Conselho de Segurança Pública do Rio de Janeiro (Consperj), por meio do Decreto Estadual 25.172 de 03 de janeiro, e os Conselhos Comunitários de Segurança (CCSs), por meio da Resolução No 263, de 26 de julho. Mas, apesar da pronta iniciativa, ambos os projetos não prosperaram durante o governo em questão.

Os conselhos comunitários foram criados em várias áreas da cidade do Rio de Janeiro, concomitantemente à prática dos chamados cafés da manhã comunitários. Em ambas as iniciativas, conselhos e cafés da manhã, normalmente promovidos em batalhões da Polícia Militar do Estado, o espírito predominante era o de aproximar a população da polícia, quebrando o gelo histórico das relações entre ambas e melhorando a imagem da segunda junto à opinião pública. Contudo, após essa breve vaga inicial, os conselhos comunitários passaram por um processo de esvaziamento, que se estendeu até 2004, quando, já sob novo governo, o Instituto de Segurança Pública do Rio de Janeiro (ISP) passou a coordenar todas as ações relativas a esses colegiados e os institucionalizou.

Já o Conselho Estadual foi instituído apenas formalmente. A despeito de seu marco legal, o órgão só passou a funcionar efetivamente quase quinze anos após a sua criação. De acordo com Poncioni e Silva ${ }^{13}$ (2016), o real funcionamento do Consperj só foi possível após um longo período de diálogo entre a Secretaria de Estado de Segurança do Rio de Janeiro (SESEG), representada por sua Subsecretaria de Educação, Valorização e Prevenção da Secretaria de Segurança, que exerceu papel de liderança no processo, e entidades, organizações e movimentos sociais atuantes no campo. As conversas travadas entre as referidas partes foram fundamentais para que o Conselho deixasse de existir apenas legalmente e operasse a partir de um desenho tripartite.

Essas ações resultaram na reestruturação do colegiado pelo Decreto n. ${ }^{\circ} 43.752$, de 11 de setembro de 2012, que alterou principalmente suas competências e composição. O Conselho passou a ser definido como um órgão "propositivo na definição de estratégias e diretrizes relacionadas à Política Estadual de Segurança" (Parágrafo I, Art. $3^{\circ}$ do supracitado decreto), e dentre suas atribuições passaram a constar prerrogativas importantes, tais como o acompanhamento da aplicação e execução de recursos destinados à segurança pública; a promoção da intersetorialidade entre os órgãos estaduais da área; o desenvolvimento de estudos; o auxílio

${ }^{13}$ Silva foi, inclusive, membro suplente do Consperj durante dois anos. 
ao ISP na articulação dos conselhos comunitários, aos quais foi garantido um assento no Consperj, na vaga das instituições representantes da sociedade civil; e o recebimento, encaminhamento e acompanhamento de denúncias relacionadas à ação das forças de segurança do Estado. As reuniões foram tornadas públicas, salvo deliberações em contrário, e ficou determinado que quaisquer novas alterações no regimento interno só poderiam ocorrer com a presença de $2 / 3$ dos conselheiros e por meio da obtenção de maioria simples.

Deste modo, podemos dizer que, diferentemente do caso paraense e dos próprios conselhos comunitários institucionalizados no Rio de Janeiro, o conselho estadual de segurança pública fluminense não pode ser entendido pura e simplesmente como um espaço "inventado" pelo Estado (PATRÍCIO, 2013). Embora tenha sido criado legalmente pelo Estado como parte de um projeto de governo e mediante a liderança da pasta estadual competente, o diálogo estabelecido entre agências do Estado e atores da sociedade civil impede que o processo seja tomado como expressão de uma vontade única. Somente a partir de um intenso e demorado processo de negociação, mobilizado tanto por entidades e movimentos sociais quanto por atores da própria Secretaria de Segurança, o Consperj pôde enfim iniciar o seu funcionamento. Isto demonstra que apenas com o comprometimento de agentes de ambas as esferas com a agenda em questão foi possível a institucionalização de uma instância participativa de cunho estadual no campo da segurança pública. A efetivação do CONSPERJ dependeu de movimentos de convergência, não partindo apenas do Estado para a sociedade ou da sociedade para o Estado.

É importante ter em mente que as circunstâncias em que o Conselho foi criado eram extremamente favoráveis. O ano de 2012 foi o ápice da popularidade e do prestígio do programa de unidades de polícia pacificadora (as UPPs). Pautado pela proposta de estabelecer uma relação de proximidade polícia/moradores das favelas onde tais unidades eram implantadas, o programa abriu para a Secretaria de Segurança do Estado uma perspectiva bastante positiva para mudanças no campo do policiamento. Assim como ocorreu no Pará, portanto, também no Rio de Janeiro o Conselho Estadual é criado numa atmosfera em que as perspectivas de inflexão nas abordagens convencionais no campo da segurança davam o tom na condução da pasta pelos seus respectivos titulares e auxiliares diretos. Diferentemente do que ocorreu no estado da região Norte, porém, nenhum caso traumático que conspurcasse os propósitos reformistas ocorreu naquele momento, 
propiciando um processo de implantação menos marcado pelo sentido de urgência e mais sujeito a debates e ajustes de rota.

\subsection{Das normas à operacionalidade: aprofundando os conhecimentos sobre o Consperj}

Com nova estrutura, o Conselho de Segurança Pública do Rio de Janeiro iniciou suas atividades somente no início de 2013, ampliando suas competências e se tornando um fórum propositivo. Como ressaltado por Poncioni eSilva (2016) eSento-Séet al. (2016, no prelo), boa parte do seu tempo de existência foi tomado em longas discussões sobre as suas atribuições e sobre a construção do seu regimento interno. Assim, dada a sua incipiência, é necessário ressaltar que quaisquer avaliações sobre o seu funcionamento ou desempenho tendem a ser precipitadas, sobretudo, tendo em conta que o órgão opera em um campo no qual a participação ainda constitui uma novidade para vários atores e muitos ainda o enxergam com desconfiança. Não é o que se pretende fazer aqui. Diversamente, compreende-se que um exame de alguns aspectos da estrutura e das atividades desse órgão possa oferecer reflexões importantes e contribuir para subsidiar investigações futuras.

Na composição do Consperj há a Plenária, seu órgão máximo, em que são formuladas e aprovadas as propostas de autoria do conselho; a Presidência e a Vice-Presidência, que cabem, respectivamente, ao Secretário de Segurança e a um membro a ser indicado por ele, podendo este ser um conselheiro ou não; a Mesa Diretora, que se constitui como um grupo interno que pode agir paralelamente ao colegiado para discutir o seu planejamento estratégico, sendo composta pelo presidente, pelo vicepresidente e pelos coordenadores dos grupos temáticos; e a Comissão Permanente de Ética, responsável por acompanhar o exercício do mandato e das funções dos conselheiros, cuja composição se dá pelo vice-presidente e mais seis conselheiros, dos quais dois devem ser representantes do poder público, dois representantes da sociedade civil e dois representantes dos trabalhadores da área de segurança pública. Há ainda os Grupos Temáticos e as Comissões Temporárias. Estas últimas são comitês especiais que podem ser criados para estudo e elaboração de propostas sobre temas específicos, devendo ser compostas por três conselheiros eleitos pela Plenária, respeitada a paridade na representação. Já os primeiros dispõem caráter permanente e visam promover debates sobre a gestão pública do campo. Há quatro grupos 
temáticos, criados coletivamente e definidos em regimento para atuar em frentes distintas: Articulação dos Conselhos Comunitários; Estudos, Acompanhamento e Avaliação das Políticas de Segurança Pública; Direitos Humanos; Legislação, Orçamento, Modernização e Desenvolvimento. Segundo a Secretária Executiva do Conselho quando da realização da pesquisa ${ }^{14}$, esses grupos ainda não conseguiram estabelecer uma rotina de atividades e, consequentemente, não chegaram a formular propostas.

Tal como o Consep, o Consperj opera, atualmente, em modelo tripartite, sendo o primeiro Conselho Estadual de Segurança do país a incluir representantes da sociedade civil e dos trabalhadores da área de segurança na proporção estabelecida pela $1^{\text {a }}$ Conferência Nacional de Segurança, de 2009. O Conselho é composto por 30 membros e 30 suplentes, os quais exercem seus mandatos por dois anos, cabendo a possibilidade de uma reeleição. Doze vagas são reservadas à sociedade civil (sendo uma destinada aos conselhos comunitários - CCSs), nove aos representantes de entidades de trabalhadores da área de segurança pública e os demais assentos são disponibilizados ao poder público. Em comparação com o colegiado paraense, há algumas diferenças na forma como os assentos no Consperj são definidos.

Se no primeiro caso as entidades que representam a sociedade civil são definidas previamente, desde a fundação do Conselho, na experiência fluminense estas são selecionadas por meio de processo eleitoral aberto, convocado por meio de edital, o que ocorre também para o preenchimento das vagas destinadas às organizações representativas de trabalhadores da área de segurança pública. Em relação ao poder público, a escolha dos membros ocorre por indicação dos respectivos órgãos e/ou instituições públicas, não havendo obrigatoriedade para que estes sejam os seus dirigentes máximos, ao contrário do que ocorre no Pará. Na prática, isso tem se refletido na baixa participação dos membros titulares dessas instituições.

A previsão de um assento para os Conselhos comunitários no Consperj indica a tentativa de se firmar alguma interlocução entre a instância participativa que atua no âmbito estadual e os espaços participativos circunscritos aos limites comunitários, iniciativa que não se verifica no estado paraense, o que é considerado por muitos atores algo positivo.

${ }^{14}$ As pesquisas que subsidiaram este artigo foram realizadas durante o ano de 2016. 
(...) já é um avanço. E a gente acredita que as lutas elas são lutadas gradualmente. Nós vamos conseguindo essas lutas e vamos conseguindo a vitória. A gente faz articulações. (...) Eles têm sido bem receptivos, têm nos entendido, têm respeitado bastante os conselhos comunitários do Estado, têm respeitado muito, estão sensíveis a nossa problemática no Conselho... Entende-se também que nós estamos na ponta... A gente tá falando sobre uma política de segurança, a gente tá falando dos conselhos, que é independente de governo. Hoje o governador é A, amanhã pode ser B e os conselhos vão continuar. (Entrevista com conselheiro do Consperj representante da sociedade civil)

Contudo, há problemas nessa tentativa de diálogo que decorrem da atuação dos conselheiros e mesmo da forma como ela se estabeleceu. Quando do momento de criação da vaga destinada aos CCSs, os conselhos comunitários reivindicaram mais seis assentos, visando à representação de cada uma das Risps (Regiões Integradas de Segurança Pública), divisões territoriais implementadas pela Secretaria de Segurança para a atuação das polícias fluminenses - ao todo são sete. À época, gestores da Seseg alegaram que, caso a solicitação fosse atendida, a paridade do Conselho estaria comprometida, já que a sociedade civil passaria a ter quase o dobro de representação em relação aos outros segmentos (PONCIONI; SILVA, 2016, p. 199). Essa reivindicação perdura até os dias de hoje e suscita ainda muitos debates, conforme frisado em entrevista pelo próprio representante dos CCSs, quando da realização da pesquisa de campo, de maneira que muitos conselheiros comunitários não concebem o Consperj como um espaço legítimo de participação cidadã, chegando até mesmo a evitá-lo.

(...) hoje a gente também tá nessa luta pra que cada região integrada de segurança pública, cada Risp tenha o seu representante, porque são regiões diferentes do Estado, cada uma tem a sua particularidade, tem a sua particularidade. Então as demandas às vezes são diferentes, a demanda que é no Rio de Janeiro é diferente da Baixada, do Sul Fluminense ou da Região dos Lagos ou do Interior. Então a gente vê essa necessidade, porque isso foi uma grande briga dos conselhos, já que nós, enquanto conselho, estamos desde 1999 atuando, sendo parceiros da Secretaria de Segurança, levando as nossas demandas, nossas preocupações quanto à questão de segurança do Estado. (..) a gente já tá na militância há muito mais tempo. (Entrevista com conselheiro representante dos CCSs no Consperj) 
A contenda tem como pano de fundo uma discussão importante sobre o foco da atuação do Consperj. Como ressaltado pelo mesmo conselheiro citado, que também é integrante de um CCS atuante em São João de Meriti, cidade da Baixada Fluminense, as atividades e as próprias discussões do Consperj ainda são muito restritas à capital do Estado. De fato, as entidades que representam a sociedade civil, em sua maioria, têm sua origem e atuam na cidade do Rio de Janeiro, o que inevitavelmente condiciona em parte o diálogo travado com o poder público. Além disso, ao promover, desde a sua reativação, seus encontros no prédio que abriga a Secretaria de Segurança, localizado no centro do Rio, o Conselho tende a limitar a participação do público que não reside na metrópole fluminense. Diante disso, representantes da sociedade civil propuseram reuniões regulares em outras regiões do Estado como uma maneira de levar o Conselho até as áreas aonde tradicionalmente não ia. A proposta inovadora tem se concretizado desde o início de 2016 por meio de reuniões itinerantes trimestrais pelas regiões integradas de segurança pública, nas quais o espaço mantém-se aberto à participação, através do direito a voz, de moradores e representantes de entidades locais.

Naquilo que diz respeito aos trabalhadores de segurança pública, é preciso salientar que a sua participação também não se dá conforme o que se esperava quando a estrutura do Conselho fora imaginada de forma tripartite. Isto se deve a dois motivos principais. Em primeiro lugar, é bastante difícil que todos os assentos destinados a esse segmento sejam preenchidos pelo simples motivo de que ainda há poucas entidades que representem os agentes dessa área. Em segundo lugar, de acordo com integrantes do Conselho que foram entrevistados, as poucas organizações desse meio são parcamente engajadas quando se trata do Consperj. Muitos consideram que este seria um espaço em que os policiais seriam apenas alvo da hostilidade da sociedade civil e no qual não haveria um diálogo profícuo com as autoridades governamentais.

Outro aspecto que chama atenção no contraste com o Conselho estadual paraense está nas instituições e órgãos pertencentes ao poder público que constituem o Consperj. No Consep, as instituições da referida esfera que possuem representação no plenário são basicamente aquelas que compõem o sistema de justiça criminal, à exceção da Assembleia Legislativa do Estado. No Rio de Janeiro, o Conselho Estadual de Segurança Pública abriga, para além dessas instituições, secretarias de Estado que podem contribuir com o tema, a saber: Casa Civil, Assistência Social e Direitos Humanos, Educação, 
Cultura, Esporte e Lazer e Saúde. Embora tal iniciativa possa ser vista com bons olhos, a participação e o engajamento dos atores responsáveis por essas pastas até o momento também têm sido aquém do esperado, como pôde ser observado nas reuniões que foram acompanhadas ou tiveram a participação de pesquisadores do presente programa. De qualquer maneira, a inclusão de outros órgãos para além daqueles que constituem o sistema de justiça criminal pode ser entendida como um indicativo de uma concepção de segurança pública mais ampla, que compreende que o campo não está restrito às instituições que tradicionalmente são a ele associadas e, nesse sentido, há uma diferença que não pode ser desconsiderada na comparação entre o Consperj e o Consep.

Além disso, não raro, a participação de atores representantes de pastas como as de Educação, Cultura e Assistência Social, por exemplo, áreas em que a relação entre Estado e sociedade civil organizada tende a ser menos hostil, têm possibilitado algumas articulações entre estes e representantes de entidades civis na formulação de propostas de intervenção do conselho que possuam caráter interinstitucional. Essas situações específicas são exemplos, dentre outros, de como se desenvolvem as relações entre Estado e sociedade civil no âmbito interno do Consperj. Se no conselho do Pará percebemos uma clara cisão entre representantes da sociedade civil, por um lado, e atores vinculados ao Estado, por outro, as conexões e tensões no Consperj parecem ser presididas por outras lógicas. Não são incomuns as situações em que atores de diferentes segmentos se articulam em desacordo ou mesmo em confronto com outros grupos igualmente heterogêneos do ponto de vista de seu lugar de representação. Ou seja, a definição de posicionamentos e de identidades tende a ser mais dinâmica e menos marcada, ainda que tendências de alinhamento sejam observadas ao longo dos debates.

Por fim, é importante ressaltar que, diversamente daquilo que se dá no Pará, as atividades do Conselho Estadual de Segurança Pública são publicizadas, por meio do website do colegiado. Nele é possível ter acesso às peças legais que normatizam o Conselho, ao seu histórico, às atividades que são desenvolvidas, aos grupos temáticos que o compõem, dentre outras informações. Ainda que seja pouco conhecido, trata-se de uma ferramenta que tem potencial para estimular a participação da sociedade e que, portanto, não pode ser desprezada, sobretudo, quando se leva em conta o fato de que as instituições participativas no Brasil continuam a ser relativamente desconhecidas, à exceção daqueles que de alguma maneira já estão engajados politicamente. 


\section{Conclusão}

Este trabalho pretendeu apresentar as estruturas, as composições, o histórico e as formas de funcionamento de duas experiências distintas de colegiados estaduais atuantes no campo da segurança pública. Procurouse pensar também como se dão as formas de participação e as percepções dos atores da sociedade civil em relação à efetividade dos respectivos conselhos. A análise indica que mais estudos precisam ser empreendidos para uma melhor compreensão das dinâmicas envolvidas na participação em instâncias participativas no campo da segurança pública. Por outro lado, foi possível perceber como contextos distintos no Rio de Janeiro e Pará geraram instituições com desenhos variados quanto à composição e alcance de intervenção do Estado, o que se traduz em estruturas e operacionalidades bastante distintas. Ademais, as próprias formas de participação variaram conforme o caso. Enquanto no Pará as reuniões são restritas aos membros, a despeito do regimento interno, no Rio de Janeiro há em curso reuniões itinerantes que propiciam a participação de quaisquer cidadãos por meio do direito a voz, estabelecendo diálogo para além das situações formais que se verificam nas sessões do colegiado.

Se no contexto paraense o massacre de Eldorado dos Carajás e a decorrente pressão da sociedade civil impulsionaram ainda mais uma iniciativa que já era capitaneada pelo próprio Secretário de Segurança Pública, no Rio de Janeiro, a cooperação entre instâncias da sociedade civil e agentes do Estado foi importante para que o Consperj saísse do papel e se tornasse uma instituição efetivamente existente. No entanto, enquanto no caso paraense emergiu uma instância deliberativa, no caso fluminense vimos surgir um conselho propositivo com grandes restrições quanto a sua ingerência na política de segurança pública. Ao passo em que no Consep, os membros representantes da sociedade civil veem a própria existência do Conselho como um importante passo em direção à maior democratização do campo da segurança pública, os conselheiros do Rio de Janeiro acreditam que há muito ainda a evoluir para reconhecer ganhos efetivos por sua criação.

Há, portanto, a sensação compartilhada de que a participação via conselhos no campo da segurança pública é um projeto inacabado, que ainda necessita de aprimoramento e de maior tempo de prática, para que sejam estabelecidas rotinas e desfeitas desconfianças e dicotomias que impõem posturas mais beligerantes e tensionadas entre os diferentes atores. Destaque-se também o papel que a existência dos conselhos desempenha no processo de reconhecimento da alteração do estatuto da segurança pública 
como campo de encampação de políticas específicas. Tradicionalmente, a segurança esteve associada a questões puramente do Estado e de produção de ordem a partir de um status quo previamente definido. A disseminação da experiência "conselhista" pode concorrer para a consagração da ideia de segurança vinculada ao conjunto mais amplo de direitos de cidadania, quer dizer, bens sociais que devem ser providos democraticamente a todos os membros da sociedade. $\mathrm{O}$ árduo caminho a ser percorrido nesse processo é certamente parte da explicação do caráter tardio que essa fórmula é incorporada na segurança pública. As barreiras para a incorporação de princípios como de equidade, isonomia e cooperação dialógica fazem parte das dificuldades a serem enfrentadas.

Espera-se que com este trabalho tenha sido possível compreender minimamente as questões implicadas no funcionamento de instâncias participativas em terreno tão delicado. Investigações futuras podem aprofundar os temas aqui levantados e provocar novas reflexões, necessárias ao entendimento dos novos contornos da democracia no Brasil.

\section{Referências}

ABERS, Rebecca; SERAFIM, Lizandra; TATAGIBA, Luciana.

(2014). Repertórios de Interação EstadoSociedade em um Estado Heterogêneo: A Experiência na Era Lula. DADOS - Revista de Ciências Sociais, Rio de Janeiro, vol. 57, n. 2, pp. 325-357.

AVRITZER, Leonardo.

(2008). Instituições participativas e desenho institucional: algumas considerações sobre a variação da participação no Brasil democrático. Opinião Pública, Campinas, vol. 14, no 1, Junho, p.43-64.

(2009). Participatory Institutions in Democratic Brazil. Baltimore: John Hopkins University Press.

BUENO, Samira; ASTOLI, Roberta; PEKNY, Ana Carolina; JARDIM, Lucas.

(2016). Excluir para legitimar: a disputa dos significados da segurança pública nas políticas de participação em São Paulo. In OLIVEIRA Jr., Almir. Instituições participativas no âmbito da segurança pública: programas impulsionados por instituições policiais. Rio de Janeiro, IPEA.
CARVAlHo, Maria do Carmo A. A.

(1998). Participação social no Brasil hoje. São Paulo: Instituto Pólis, 27p.

DEBERT, Guita Grim. Ministério público no Pará. (2009). In SADEK, Maria Tereza. Justiça e cidadania no Brasil. Rio de Janeiro, Centro Eldenstein de Pesquisas Sociais.

HELMKE, Gretchen; LEVITSKY, Steven.(Orgs.). (2006). Informal Institutions \& Democracy: lessons from Latin America. Baltimore: John Hopkins University Press.

IBGE.

(1999). Pesquisa de Informações Básicas Municipais.

KOWARICK, Lucio.

(1973). Capitalismo e Marginalidade na América Latina. Rio de Janeiro: Paz e Terra.

MACAULAY, Fiona.

(2005). Parcerias entre Estado e sociedade civil para promover a segurança do cidadão no Brasil. Sur-Revista internacional de direitos humanos, Ano 2; n 2, p. 146/173. 
MISSE, Michel.

(1999). Malandros, Marginais e Vagabundos \& a Acumulação Social da Violência no Rio de Janeiro. Rio de Janeiro: IUPERJ [Tese de Doutorado em Sociologia].

PONCIONI, Paula; SILVA, Anderson Moraes de Castro e.

(2016). Instituições participativas de segurança no Rio de Janeiro. In OLIVEIRA Jr., Almir. Instituições participativas no âmbito da segurança pública: programas impulsionados por instituições policiais. Rio de Janeiro, IPEA.

\section{PATRÍCI0, Luciane.}

(2013). Participação nas políticas públicas de segurança: uma etnografia comparada de conselhos comunitários de segurança pública no RJ e no DF. Encontro Internacional Participação, Democracia e Políticas Públicas: aproximando agendas e agentes. São Paulo, UNESP.

PAVEZ, Thais R.; TOLED0, Demétrio G. C. de e GONÇALVES, Renata R.

(2009). Redes Sociais, Mobilização e Segurança

Pública: Evolução da Rede de Atores da Segurança Pública no Processo Preparatório da 1a Conferência Nacional de Segurança Pública. Brasília, Ministério da Justiça.

POWELL, Walter; DIMAGGIO, Paul.

(1991). The new institutionalism in organizational analysis. The University of Chicago Press.

PROTÁSIO, Gilberto; LISTGARTEN, Silvia.

(2010). Governança da sociedade no Conselho de Defesa Social de Minas Gerais: potencialidades de aprimoramento da democracia participativa e da conexão entre políticas de defesa social com as de desenvolvimento econômico e social. Revista eletrônica Del Rey, vol. 1, n. 1, Janeiro/Junho. Disponivel em: <http://www.fdr.edu.br/ revista/edicoesVolume1.asp>

RATTON, José Luiz et al.

(2007). Polícia, democracia e sociedade. São Paulo: Ed. Lumen Juris.

RODRIGUES, André; LÁZARO, Márcio; SENTO-SÉ, João Trajano de Lima.
(2014). Conselhos de segurança pública no Brasil. Notas de um campo a ser explorado. Revista Brasileira de Segurança Pública, v. 8, p. 110.

SENTO-SÉ, João Trajano Lima.

(1998). Imagens da Ordem, Vertigens do Caos. 0 Debate Sobre as Políticas de Segurança Pública no Rio de Janeiro, nos Anos 80 e 90. Arché Interdisciplinar. Rio de Janeiro, v. VII, n.19, p. 41-73.

SENTO-SÉ, João Trajano de Lima; FERNANDES, Otair.

(2005). A Criação do Conselho Comunitário de Segurança de São Gonçalo. In: SENTO-SÉ, João Trajano. (Org.). Prevenção da Violência. 0 Papel das Cidades. Rio de Janeiro: Civilização Brasileira. p. 255-281.

SENTO-SÉ, João Trajano de Lima; SANTOS, Anastácia Cristina; FERREIRA, Thiago. (2012). Os conselhos comunitários de segurança pública do Rio de Janeiro. Institucionalização e participação. Desigualdade \& Diversidade (PUCRJ), v. 11, p. 99-114.

SINGER, Paul; BRANDT, Vinicius Caldeira (Orgs). (1980). São Paulo: O Povo em Movimento. Petrópolis: Editora Vozes.

SOARES, Luiz Eduardo.

(2000). Meu casaco de general. 500 dias no front da segurança pública do Rio de Janeiro. São Paulo, Cia. das Letras..

TEIXEIRA, Elenaldo Celso.

(1996). Movimentos Sociais e Conselhos. In: A participação popular nos conselhos de gestão. Cadernos ABONG, n. 15, julho.

UFRJ.

(2013). Diagnóstico dos Conselhos Estaduais de Segurança Pública e de Direitos Humanos. Brasília: Ministério da Justiça, Secretaria Nacional de Segurança Pública (SENASP), 376 p.: il. Coleção Pensando a Segurança Pública; v. 3.

\section{Recebido em}

outubro de 2017

\section{Aprovado em}

fevereiro de 2019 


\title{
Razões da evasão: abandono escolar entre jovens no Brasil $^{1}$
}

André Salata*

\section{Resumo}

Apesar da expansão do sistema de ensino do país nas últimas décadas, assim como a meta de tornar compulsória e universal a frequência escolar também de jovens com idade correspondente ao Ensino Médio, entre estes ainda há uma parcela significativa que não frequenta a escola. 0 artigo tem como objetivo estudar os principais fatores associados à evasão escolar de jovens entre 15 e 17 anos de idade. Mais especificamente, analisamos o efeito da origem socioeconômica dos jovens, assim como de sua situação de trabalho, sobre as chances de evasão. Para isso, utilizamos dados provenientes da PNAD (IBGE) de 2015 e, também, do suplemente de 2006, a partir dos quais rodamos estatísticas descritivas e modelos logit multivariados. Os resultados alcançados evidenciam o forte efeito do background domiciliar e do trabalho intensivo - com carga horária acima de 20 horas semanais - sobre as chances de evasão, mas colocam dúvidas sobre as leituras que tomam a eventual necessidade de trabalhar como principal mediadora do efeito da origem social sobre a evasão de jovens.

\section{Palavras-chave}

Evasão Escolar. Ensino Médio. Origem Social. Trabalho. Desigualdades Sociais.

\begin{abstract}
Notwithstanding the expansion of the Brazilian's educational system in the last decades, as well as its goal of making compulsory and universal the school attendance of young people with a high school age, among these there is still a significant proportion that do not attend school. Thus, the article aims to study the main factors associated with school dropout among young people between 15 and 17 years of age. More specifically, we analyze the effects of the socioeconomic origin of young people, as well as their work situation, on the chances of evasion. Besides, we explore some data regarding the attested reasons for them to dropout school. We work with data from the National Household Sample Survey (PNAD) of
\end{abstract}

\footnotetext{
${ }^{1}$ Este trabalho é produto de projeto de pesquisa financiado pelo Conselho Nacional de Desenvolvimento Científico e Tecnológico (CNPq) por meio de uma bolsa de produtividade em pesquisa (PQ-nível 2), e foi desenvolvido no âmbito da Rede Observatório da Dívida Social das Universidades Católicas da América Latina (REDODSAL).

* André Salata é doutor em Sociologia, professor do Programa de Pós-Graduação em Ciências Sociais da Pontifícia Universidade Católica do Rio Grande do Sul (PUCRS) e bolsista de produtividade em pesquisa do CNPq. E-mail: andre_salata@yahoo.com.br.
} 
2015, and also from the PNAD 2006 supplement, from which we run descriptive statistics and multivariate logit models. The results corroborate the strong effect of family background and intensive work (with a workload of more than 20 hours per week) on the chances of dropout, but raise questions on the readings that take the possible need to work as the main mediator of the effect of social origin on youth evasion.

\section{Keywords}

School Dropout. High School. Social Origin. Employment. Social Inequalities.

\section{Introdução}

Em novembro de 2009 foi promulgada a emenda constitucional $n^{0} 59$, que determinava a ampliação da obrigatoriedade e gratuidade do ensino a todas as etapas da educação básica no Brasil, dos quatro aos dezessete anos de idade, prevendo sua implantação progressiva até o ano de 2016. Desse modo, a matrícula escolar obrigatória no Brasil, que até então ia dos 6 aos 14 anos de idade - o que corresponde ao Ensino Fundamental -, foi estendida também para as faixas etárias que correspondem à Pré-Escola (4-5 anos) e ao Ensino Médio (15-17 anos). O Plano Nacional de Educação (PNE), por sua vez, em consonância com a emenda constitucional $n^{\text {a }} 59$, entre suas 20 metas previa, justamente, universalizar, até 2016, o atendimento escolar da população de 4 a 5 (primeira meta) e de 15 a 17 anos (terceira meta), além de garantir a matrícula escolar de toda a população de 6 a 14 anos (segunda meta).

Se, por um lado - segundo dados de 2015, provenientes da Pesquisa Nacional por Amostra de Domicílios (PNAD), do Instituto Brasileiro de Geografia e Estatística (IBGE) -, a universalização das matrículas entre 6 e 14 anos já pode ser tomada como uma realidade (ficando em torno de $98 \%$ ), por outro lado, para as crianças de 4 a 5 anos, e também para os jovens de 15 a 17 anos de idade, o percentual dos que frequentam a escola girava, ainda em 2015, em torno de 85\%. Ou seja, há ainda muitos obstáculos para que aquelas metas, traçadas no PNE e promulgadas pela emenda constitucional $\mathrm{n}^{\circ} 59$, sejam alcançadas.

Neste artigo, estaremos interessados na faixa etária de 15 a 17 anos, tendo como objetivo identificar os principais fatores que ainda levam muitos desses jovens a não frequentar a escola, assim como suas motivações para não o fazerem. Tomaremos como foco principal a relação entre origem social e frequência à escola para os jovens naquela faixa etária, que idealmente 
corresponderia ao Ensino Médio, procurando analisar a força dessa relação, assim como os mecanismos e motivações que poderiam explicá-la, como a eventual necessidade de trabalhar.

Para isso, faremos uso dos dados da PNAD 2015 - a partir dos quais trabalharemos com modelos logit multivariados -, do suplemento da PNAD 2006 sobre educação - que traz informações sobre as motivações dos jovens para não frequentarem a escola - e, também, dos dados da PNAD 1995, a fim de elaborar uma breve análise descritiva das tendências observadas nas duas últimas décadas no que diz respeito à frequência escolar de crianças e jovens no Brasil. O presente artigo, dessa maneira, ao analisar a relação entre origem social e situação escolar, se insere tanto no campo dos estudos sobre estratificação social quanto no debate acerca da evasão escolar.

O trabalho se encontra organizado em cinco seções, além desta introdução. Na primeira delas procuramos oferecer um panorama geral da frequência à escola de crianças e jovens no Brasil das duas últimas décadas, além de estabelecer um diálogo com parte da bibliografia sobre o tema. $\mathrm{Na}$ seção subsequente, fazemos uma breve revisão a respeito das principais causas da evasão, assim identificadas pela literatura. Posteriormente, na seção seguinte, apresentamos as hipóteses a serem testadas, os dados, as variáveis e as técnicas utilizadas. Na outra seção, fazemos uso de modelos logit multivariados, a fim de identificar os principais fatores associados à evasão de jovens de 15 a 17 anos no Brasil, com atenção especial para as características de origem social e situação de trabalho; nessa seção também trazemos alguns dados a respeito das motivações dos jovens para não frequentarem a escola. Finalmente, nas conclusões, refletimos acerca dos principais resultados encontrados, à luz das questões previamente colocadas.

\section{Frequência à escola entre jovens de 15 a 17 anos no Brasil}

A escolaridade alcançada pelos indivíduos é, conforme já amplamente demonstrado por inúmeros estudos, no Brasil e no exterior, uma variávelchave para a explicação das desigualdades na sociedade contemporânea, constituindo-se fator crucial para as chances de os indivíduos conseguirem emprego, para o status da ocupação obtida e, também, para os rendimentos auferidos a partir da mesma (MENEZES-FILHO;FERNANDES;PICCHETTI, 2007). Assim, o tempo de permanência na escola é um elemento marcante no processo de reprodução das desigualdades, de modo que, quanto mais anos de estudo acumulados antes de o indivíduo deixar a escola, melhor 
tende a ser sua posição no mercado. Quanto mais cedo o jovem abandona a escola, por outro lado, maiores suas desvantagens na disputa pelas posições e recursos distribuídos pela sociedade (HASENBALG, 2003).

Mas não é somente em termos individuais que a evasão escolar traz prejuízos. Em um sentido mais coletivo, ela prejudica a própria acumulação de capital humano do país, colocando obstáculos a um desenvolvimento econômico de longo prazo (SCHULTZ, 1961). Além disso, a evasão também pode ser relacionada a diversos outros problemas sociais, tais como desemprego, pobreza, dependência da assistência pública, problemas de saúde, criminalidade, apatia política e social etc. (DE WITTE et al., 2013). Assim, é também do interesse coletivo que os indivíduos estendam sua permanência na escola, como condição necessária - mas não suficiente para um maior acúmulo de anos de estudo.

O Gráfico 1 traz o percentual de indivíduos que estudam, por idade (entre 10 e 30 anos), nas duas últimas décadas no Brasil. ${ }^{2}$

\section{Gráfico 1 - Percentual de Indivíduos que Estudam, por Idade (10 a 30 anos) -} Brasil, 1995, 2006 e 2015

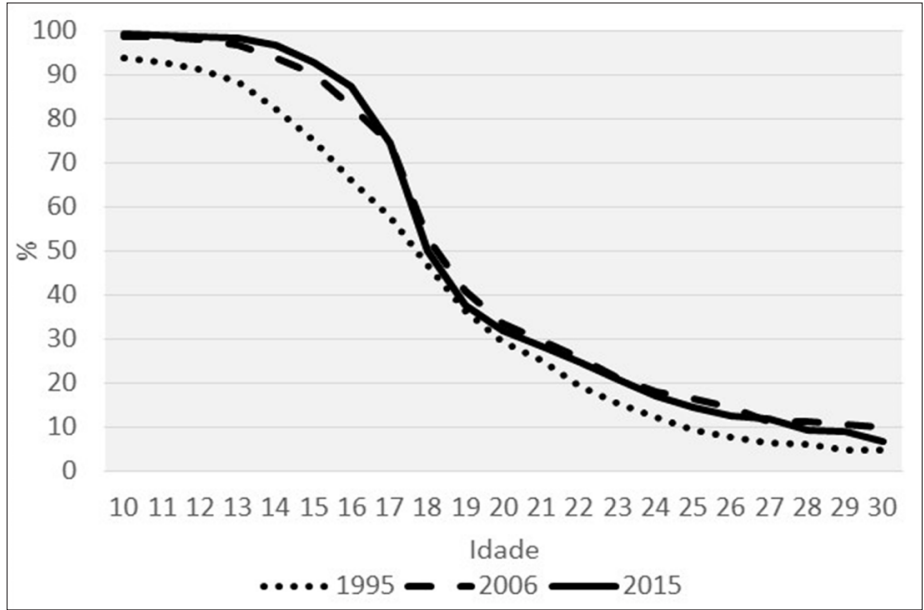

Fonte: Pesquisa Nacional por Amostra de Domicílios (PNAD-IBGE), 1995, 2006 e 2015. Tabulação: próprio autor.

Em primeiro lugar, notamos uma tendência clara e esperada em todo período que diz respeito à redução do percentual de estudantes conforme

\footnotetext{
${ }^{2}$ A fim de padronizarmos a amostra, excluímos as áreas rurais da região Norte, que foram incluídas nas PNADs apenas a partir de 2004. Além disso, a razão de utilizarmos os dados de 2006, e não de 2005 (que dividiria de modo mais exato as duas décadas tratadas), é que para aquele ano há um suplemento sobre educação, a partir do qual posteriormente iremos extrair informações relevantes para este artigo.
} 
crescem os anos de idade. Esse movimento, no entanto, não é linear. Até por volta dos 14 anos é bem reduzida a proporção de crianças e jovens fora da escola; a partir dessa idade, e principalmente quando chegamos em torno dos 16 anos, a frequência à escola cai de modo acentuado, desacelerando apenas por volta dos 20 anos. Verificamos, portanto, que a faixa etária tratada neste artigo, dos 15 aos 17 anos, é crucial nesse processo, já que é ali que um movimento mais proeminente de afastamento em relação à escola começa a ser observado.

Constatamos que desde 1995 houve melhoras nesse sentido, já que a frequência à escola passou a ser maior para todas as idades, principalmente entre os mais jovens (até 18 anos), o que ilustra uma tendência a deixarem a escola mais tarde. Mais especificamente, para a faixa etária que nos interessa aqui (15-17 anos), o percentual de jovens que não estudava cai de $33 \%$, em 1995, para 14\% em 2015. Em termos absolutos, em 2015 havia no Brasil, aproximadamente, 1.5 milhão de jovens nessa faixa etária fora da escola. ${ }^{3}$

No entanto, como pode ser visto no Gráfico 2 , as propensões a continuar na escolar variam bastante de acordo com o estrato socioeconômico dos jovens.

Gráfico 2 - Percentual de Indivíduos que Estudam, por Idade (10 a 30 anos), por Quintis de Renda Domiciliar Per Capita - Brasil, 2015

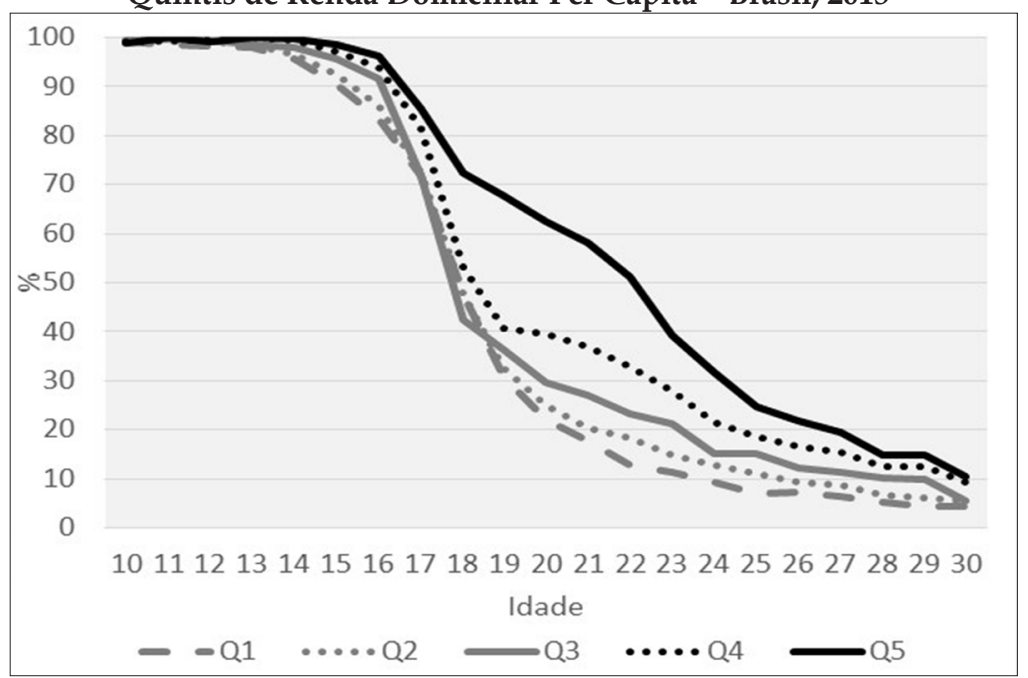

Fonte: Pesquisa Nacional por Amostra de Domicílios (PNAD-IBGE), 2015.

Tabulação: próprio autor

\footnotetext{
${ }^{3}$ Apesar de não termos dados longitudinais, e por isso não podermos afirmar que os jovens que não estavam estudando no momento da pesquisa não iriam voltar à escola, temos boas razões para acreditar que essa interrupção levará a prejuízos de aprendizado e, em muitos casos, ao abandono definitivo, reduzindo os anos de estudo alcançados pelo indivíduo.
} 
Ao dividir a população pelos quintis de rendimento domiciliar per capita, o Gráfico 2 ilustra as diferenças socioeconômicas nas propensões a continuar estudando, de acordo com a idade. Fica evidente, conforme esperado, que os jovens provenientes dos quintis mais elevados tendem a estudar até idades muito mais avançadas do que os jovens dos quintis mais baixos.

É interessante notar que essas desigualdades começam a se manifestar entre os 15 e 17 anos de idade, tornando-se mais acentuadas entre os 19 e 25 anos. Com efeito, se pensarmos na reprodução das desigualdades enquanto um processo de acúmulo de vantagens e desvantagens ao longo do ciclo de vida (HASENBALG; SILVA, 2003), a faixa etária correspondente ao Ensino Médio se mostra um momento crucial. Constatamos, por exemplo, que enquanto no primeiro quintil $17 \%$ dos jovens entre 15 e 17 anos não estudavam em 2015, no quintil mais rico esse percentual caía para $7 \%$.

Desse modo, apesar de a evolução recente ser positiva, há ainda um considerável percentual de jovens entre 15 e 17 anos de idade fora da escola, especialmente entre as camadas socioeconômicas inferiores.

\section{Pesquisas anteriores sobre evasão}

O tema da evasão escolar tem sido objeto de intenso debate no campo da Sociologia e, também, da Educação. Desde meados do século passado, diversos estudos consistentes têm sido elaborados a fim de procurar melhor compreender esse fenômeno, com foco nas possíveis causas que levam muitos jovens a deixar a escola antes de completarem determinado nível de estudo. Apesar das enormes dificuldades encontradas para tratar desse tema, dada a sua complexidade, podemos afirmar que há certo acúmulo de conhecimento acerca do mesmo, de modo que a maior parte das pesquisas sobre esse tópico, a despeito de sua heterogeneidade e resultados algumas vezes incongruentes, convergem em alguns pontos relevantes (HUNT, 2008).

Primeiramente, no entanto, é preciso lembrar que há ainda certa disputa acerca da definição desse fenômeno, ou seja, sobre o que entendemos por evasão escolar. Como bem colocado por Dore e Lüscher (2013), poderíamos relacioná-lo a fatores muito diversos, tais como a saída do aluno de uma instituição, a sua saída do sistema de ensino como um todo, a não conclusão de certo nível de escolaridade, o abandono definitivo da escola, o afastamento temporário em relação à mesma etc. Neste artigo, como já deve 
estar claro, focamos no afastamento - temporário ou definitivo - do jovem em relação ao sistema de ensino. ${ }^{4}$

Em relação às convergências encontradas na bibliografia, destaco três pontos centrais. O primeiro deles é a constatação de que a evasão escolar não é resultado de uma decisão pontual e facilmente localizada no tempo e espaço, mas sim fruto de um processo de média ou longa duração (FINN, 1989; WEHLAGE, 1989; LAMBORN et al., 1992). A evasão deve ser entendida como etapa final de um processo de desengajamento do estudante em relação à vida escolar, tanto do ponto de vista acadêmico que se expressa no baixo rendimento e maior repetência - quanto social expresso na fragilidade dos laços estabelecidos naquele espaço em relação a outras redes nas quais os estudantes estão inseridos.

O segundo ponto de convergência é o reconhecimento de que são inúmeros os fatores que condicionam os indivíduos a permanecer ou abandonar a escola. Entre as causas desse fenômeno, podemos encontrar fatores psicológicos, características individuais adscritas, atributos da família de origem, padrões de comportamento e atividades dentro da escola, características das próprias instituições de ensino, qualidades da vizinhança onde o jovem reside, condições do mercado de trabalho, entre outros (DE WITTE et al., 2013).

Dada a complexidade do fenômeno em foco, modelar seus determinantes se torna uma tarefa bastante árdua. De acordo com Rumberger (1983), relações de causalidade poderiam ser mais facilmente inferidas para fatores exógenos - como background familiar, localização geográfica e atributos individuais adscritos -, já que esses seriam fixos e determinados bem antes do momento da evasão. Já para fatores endógenos ${ }^{5}$ - como habilidades acadêmicas, aspirações, rendimento escolar, entre outros -, como esses tendem a ocorrer concomitantemente ao processo de evasão, seria muito mais difícil estabelecer tais relações.

Ainda de acordo com Rumberger (1983), a fim de determinar a magnitude dos efeitos de cada um desses fatores sobre a probabilidade de

\footnotetext{
${ }^{4}$ Com os dados que utilizamos, provenientes da PNAD, seria inviável estabelecer tais distinções. Desse modo, trabalhamos com o conceito de evasão como a condição do jovem que não frequentava a escola no momento da pesquisa. O fenômeno aqui mensurado, portanto, engloba tanto o abandono - situação na qual o jovem se matriculou em determinada série no início do ano letivo, tendo posteriormente deixado de frequentar a escola naquele ano quanto a evasão propriamente dita - quando o jovem que foi à escola em um dado ano não chega nem mesmo a se matricular no início do ano letivo seguinte (BARROS, 2017).

${ }^{5}$ Utilizo aqui a diferenciação estabelecida pelo próprio Rumberger (1983), entre fatores endógenos e exógenos.
} 
evasão, haveria duas estratégias possíveis: trabalhar somente com fatores exógenos, o que permitiria verificar os efeitos totais dos mesmos; ou inserir também fatores endógenos, que em grande medida exercem a função de mediadores entre as variáveis exógenas e a variável dependente. Nessa segunda estratégia, como resultado, temos os efeitos líquidos dos fatores exógenos e endógenos. Dado o interesse da presente pesquisa e a natureza dos dados em mãos, em nossa análise trabalharemos somente com fatores exógenos.

Chegamos, assim, ao terceiro ponto de convergência dos estudos sobre o tema, que se refere ao peso daqueles inúmeros fatores sobre as chances de evasão. A esse respeito ainda há muitas divergências, até mesmo em função das diferentes realidades que os estudos se dedicaram a analisar. No entanto, e apesar dessas divergências, há alguns resultados que aparecem com certa constância nessas pesquisas.

Segundo Rumberger (2001), ${ }^{6}$ o background familiar tem se mostrado o elemento mais relevante para predizer a evasão, destacando-se a escolaridade dos pais, os rendimentos, as condições de moradia, a estrutura familiar e a localização geográfica. Como a origem social está relacionada à localização geográfica em nível nacional e, em grande medida, condiciona o local de moradia no nível intramunicipal, ela é capaz de condicionar o acesso dos jovens à escola por meio da oferta disponível de unidades escolares e vagas. Entretanto, mesmo quando as variáveis geográficas são mantidas constantes, o nível socioeconômico da família de origem tende a se mostrar um dos fatores explicativos mais importantes sobre a evasão.

Diversos mecanismos causais poderiam ser imaginados a fim de explicar a relação entre o background domiciliar e as chances de evasão.

Sobre o efeito do nível de rendimentos da família de origem, é possível que jovens moradores de domicílios com menos recursos econômicos apresentem maiores chances de evasão, entre outras razões, em função da maior necessidade de complementarem a renda domiciliar. Nessa leitura, haveria uma estreita relação entre o background econômico, a eventual necessidade de o jovem complementar o orçamento familiar por meio de seu trabalho, e o consequente desengajamento em relação à esfera escolar. Aqui, o trabalho do jovem seria um dos principais mediadores entre a situação econômica familiar e a evasão, sendo a insuficiência de renda a causa última desse fenômeno, já que tornaria muito altos os custos de

\footnotetext{
${ }^{6}$ Para uma revisão sistemática dos resultados de pesquisas anteriores sobre o tema, ver também De Witte et al. (2013).
} 
dedicar-se exclusivamente à escola para os jovens provenientes de famílias com menor aporte econômico.

Entre as razões mencionadas pela literatura para o efeito do nível educacional da família de origem, poderíamos reduzir as explicações a dois tipos: aquelas que focam no papel da socialização e aquelas que têm na racionalidade o seu princípio. Entre as últimas, encontra-se a ideia de que pais mais escolarizados teriam maior conhecimento acerca da importância da escola, e por isso seus filhos apresentariam menores chances de evasão; já para o primeiro tipo de explicação, familiares mais ou menos escolarizados serviriam como modelos de papéis sociais, a partir dos quais os jovens desde sua infância - internalizariam a relevância da escola, seu valor e a possibilidades de obter sucesso via sistema escolar. Além disso, jovens provenientes de famílias com maior escolaridade tenderiam a apresentar maior familiaridade com a cultura escolar, melhor desempenho, menores chances de repetência e, consequentemente, maior engajamento escolar e menor propensão à evasão.

Ainda, entre os fatores de cunho institucional, características ligadas às escolas (rede de ensino, composição dos alunos, razão professor/alunos, estrutura física, qualidade dos professores conforme percebida pelos alunos e o clima escolar) e à vizinhança (recursos no local, influência dos pares, modelos de papel social e oportunidades de emprego) também se mostram relevantes. Já entre os fatores de cunho individual, que em grande medida fazem a mediação entre os fatores institucionais e a permanência ou evasão, destacam-se o desempenho acadêmico, a troca de escolas, a frequência às aulas, a disciplina do estudante dentro da escola, as aspirações educacionais e ocupacionais, a repetência e, finalmente, o sexo do estudante - de modo que mulheres apresentam menor tendência à evasão. ${ }^{7}$

É importante lembrar que comportamentos fora da escola também estão diretamente ligados às chances de evasão, tais como a gravidez precoce, o matrimônio e a participação no mercado de trabalho. Sobre o trabalho dos jovens, em outros países tem sido constatado que seu efeito sobre as chances de evasão, no sentido de aumentá-las independentemente dos demais fatores, é condicionado pelo tipo de emprego, estabilidade e, principalmente, pela intensidade da ocupação. Resultados de pesquisas conduzidas em outros países mostram que, enquanto jovens com carga horária de trabalho mais baixa (até 15 ou 20 horas semanais) chegam a ter

\footnotetext{
${ }^{7}$ Quanto ao efeito de raça, identificamos algumas divergências na literatura (DE WITTE et al., 2013).
} 
resultados escolares superiores aos jovens que não trabalham, aqueles com carga horária de trabalho mais elevada (acima de, aproximadamente, 20 horas semanais) tendem a apresentar pior desempenho escolar e maiores chances de evasão (WARREN, 2003, 2002; MCNEAL, 1997).

Duas possíveis explicações têm sido aventadas para o efeito de trabalhar sobre as chances de evasão (WARREN, 2002). A primeira delas, e mais convencional, é o modelo de "soma-zero", que assume que o tempo e a energia empregados no trabalho são subtraídos do tempo e energia que seriam gastos em atividades relacionadas à escola (presença nas aulas, estudo, preparação para provas, atividades extraclasse etc.) caso o jovem não trabalhasse. Quanto maior a carga horária de trabalho, menos tempo e energia ficariam disponíveis para as atividades escolares, o que acabaria por prejudicar o desempenho escolar, o engajamento do jovem na escola e, consequentemente, aumentaria suas chances de evasão.

Uma abordagem alternativa, denominada por Warren (2002) de "orientação primária", tem como fundamento não a alocação de recursos escassos (tempo e energia), mas sim fatores psicológicos e sociais que condicionariam a escolha dosjovens entre a escola e o trabalho. O pressuposto básico aqui é que estudantes cuja orientação estivesse mais voltada à escola tenderiam a apresentar melhor rendimento escolar, não importando sua situação de trabalho. Já estudantes com uma orientação menos voltada à escola tenderiam a obter um rendimento escolar menos satisfatório, independentemente de trabalharem ou não. A situação de trabalho, por sua vez, seria mero sintoma, resultante da importância conferida à escola (versus trabalho) pelo jovem, não havendo, portanto, uma relação causal direta entre as horas despendidas no trabalho e o rendimento escolar e/ou as chances de evasão.

Apesar de suas diferenças, de algum modo ambas as abordagens assumem haver também uma relação entre a entrada do jovem no mercado de trabalho e o background familiar. Na abordagem da "somazero", podemos argumentar, o ato de trabalhar estaria mais relacionado à carência de recursos econômicos e à necessidade de complementar o orçamento familiar, e atuaria como uma variável mediadora entre aquela carência, o pior desempenho escolar e a maior chance de evasão. $\mathrm{Na}$ segunda perspectiva, da "orientação primária", a entrada no mercado de trabalho seria - assim como a evasão -, mais consequência do que causa do pior rendimento escolar. Este último, por sua vez, seria em grande medida condicionado pela origem social, especialmente pelo nível educacional do núcleo familiar. 


\section{Hipóteses, dados e métodos}

No Brasil, quando comparamos com a extensa bibliografia internacional, constatamos uma carência de estudos mais abrangentes sobre o tema, em especial a respeito da evasão no Ensino Médio (SILVA, 2016; DORE; LÜSCHER, 2013). Como consequência, temos pouco conhecimento acumulado sobre os fatores associados à evasão escolar e o peso de cada um para a explicação e esclarecimento daquele fenômeno. ${ }^{8}$

Entre os estudos já realizados no país, muitos já apontaram as condições de vida da família de origem - ou nível socioeconômico -, a escolaridade da mãe, o tamanho e o tipo de família como alguns dos principais fatores explicativos da permanência na escola (BRANDÃO, 1983; LOPEZ DE LEON; MENEZES-FILHO, 2002). Uma leitura frequente sobre o fenômeno no país é que a evasão escolar seria fruto, principalmente, da necessidade de os jovens entrarem no mercado de trabalho a fim de colaborar com o orçamento familiar por meio do rendimento auferido (ARROYO, 1993; MEKSENAS, 1998). ${ }^{9}$ Tal abordagem se faz presente, também, em reportagens publicadas em jornais e revistas de grande circulação e na imprensa de um modo geral, que nos últimos anos chegou a dedicar um importante espaço ao tema da evasão escolar de jovens. ${ }^{10}$

Com efeito, o principal objetivo da análise conduzida neste trabalho é identificar os principais fatores associados à evasão escolar de jovens entre

\footnotetext{
${ }^{8}$ Para uma revisão mais abrangente da bibliografia nacional sobre o tema, ver Tavares Júnior, Santos e Maciel (2017).

${ }^{9}$ O estudo de Neri (2009), ao tratar das motivações de crianças e jovens para abandonar a escola, destaca o desinteresse pela mesma como a principal razão para a evasão e, apesar de suas limitações, oferece um interessante contraponto àquelas leituras mais voltadas à necessidade de trabalhar como explicação central daquele fenômeno.

${ }^{10}$ Exemplos de reportagens publicadas nos últimos anos sobre esse tema podem ser encontrados em:

- “Com evasão escolar empacada, país levaria 200 anos para incluir jovens”. Folha de São Paulo (17/10/2017). Disponível em: < http://www1.folha.uol.com.br/educacao/2017/10/1927604com-evasao-escolar-empacada-pais-levaria-200-anos-para-incluir-jovens.shtml>.

- "Brasil tem 2,5 milhões fora da escola; trabalho é principal razão para abandono". Gazeta do Povo (15/08/2017). Disponível em: <http://www.gazetadopovo.com.br/ educacao/brasil-tem-25-milhoes-fora-da-escola-trabalho-e-principal-razao-para-abandono7g4ljozkru2w9y6wu1hjag3gc>.

-"Por que o jovem não conclui o Ensino Médio?". Carta Educação (04/08/2016). Disponível em: <http://www.cartaeducacao.com.br/reportagens/por-que-o-jovem-nao-conclui-oensino-medio/ $>$.

- "Brasil encara a batalha para prosperar no ensino médio". El País (23/02/2018). Disponível em: < https://brasil.elpais.com/brasil/2018/02/22/politica/1519256346_754753.html>.
} 
15 e 17 anos no Brasil contemporâneo. Mais especificamente, perguntamos qual o peso do perfil socioeconômico da família de origem desses jovens, e de sua participação no mercado de trabalho, sobre as chances de não frequentar a escola? Além disso, indagamos em que medida a eventual necessidade de trabalhar faria a mediação entre a origem social e a frequência à escola? Com o intuito de fornecer resposta a essas questões, testaremos as seguintes hipóteses:

Hipótese 01: mesmo quando mantemos constantes as características individuais, geográficas e de estrutura familiar, o nível de rendimentos e, principalmente, o nível de escolaridade da família de origem ainda se mostram muito relevantes para explicar as chances de evasão.

Hipótese 02: o fato de o jovem trabalhar eleva suas chances de evasão, especialmente quando o trabalho exige uma carga horária mais intensiva.

Hipótese 03: a situação de trabalho do jovem explica uma parcela significativa do efeito da origem socioeconômica sobre as chances de evasão.

Como vimos, há boas razões teóricas, em grande medida confirmadas por estudos empíricos já realizados, para acreditarmos que a origem social dos jovens seja um dos fatores mais relevantes a fim de explicar suas chances de evasão. Além disso, pesquisas anteriormente desenvolvidas mostram que a situação de trabalho dos jovens, quando exige uma carga horária mais intensiva, tende a influenciar positivamente as chances de abandono. No entanto, lançamos dúvidas sobre a ênfase de alguns estudos nacionais sobre a suposta necessidade de trabalho como importante mediador entre os efeitos de classe de origem e a frequência à escola.

A fim de testar nossas hipóteses, trabalharemos com modelos logit multivariados, tendo as chances de evasão escolar como variável dependente. O Quadro 1 descreve as variáveis utilizadas nos modelos: 
Quadro 1 - Descrição das Variáveis Utilizadas nos Modelos

\begin{tabular}{|c|c|c|c|}
\hline Variáveis & Descrição & Tipo & Categorias \\
\hline \multicolumn{4}{|l|}{ Dependente } \\
\hline Evasão & $\begin{array}{l}\text { Indica se o indivíduo não } \\
\text { frequentava a escola na } \\
\text { época da pesquisa }\end{array}$ & Dummy & $\begin{array}{l}\text { 0-Não frequenta } \\
\text { 1-Frequenta }\end{array}$ \\
\hline \multicolumn{4}{|l|}{ Independentes } \\
\hline Idade & Idade em anos & Dummies & $\begin{array}{l}0-15 \text { anos } \text { (referenda) } \\
1-16 \text { anos } \\
2-17 \text { anos }\end{array}$ \\
\hline Região & $\begin{array}{l}\text { Região geográfica de } \\
\text { residência }\end{array}$ & Dummies & $\begin{array}{l}0 \text { - Nordeste (referência) } \\
1 \text { - Norte } \\
2 \text { - Sudeste } \\
3 \text { - Sul } \\
4 \text { - Centro-Oeste }\end{array}$ \\
\hline Localização & $\begin{array}{l}\text { Tipo de área da } \\
\text { residência }\end{array}$ & Dummies & $\begin{array}{l}0 \text {-Rural \{referência) } \\
1 \text { - Urbano não } \\
\text { metropolitano } \\
2 \text { - Urbano metropolitano }\end{array}$ \\
\hline Sexo & $\begin{array}{l}\text { Indicadora de sexo } \\
\text { feminino }\end{array}$ & Dummy & 0-Masculino 1-Feminino \\
\hline Cor & $\begin{array}{l}\text { Indicadora de pretos e } \\
\text { pardos }\end{array}$ & Dummy & $\begin{array}{l}\text { 0-Brancos } \\
\text { 1-Pretos e pardos }\end{array}$ \\
\hline $\begin{array}{l}\text { Tipo de } \\
\text { família }\end{array}$ & $\begin{array}{l}\text { Indicadorade famiia } \\
\text { monoparental }\end{array}$ & Dummy & $\begin{array}{l}0 \text { - Não-monoparental } \\
\text { 1-Monoparental }\end{array}$ \\
\hline $\begin{array}{l}\text { Número de } \\
\text { filhos }\end{array}$ & $\begin{array}{l}\text { Número de filhos com } \\
\text { até } 13 \text { anos de idade no } \\
\text { domicilio }\end{array}$ & Discreta & Número de filhos \\
\hline Escolaridade & $\begin{array}{l}\text { Maior escolaridade } \\
\text { (em anos) entre chefe e } \\
\text { cônjuge (quando houver) }\end{array}$ & Discreta & $\begin{array}{l}\text { Anos de estudo } \\
\text { completos }\end{array}$ \\
\hline Renda & $\begin{array}{l}\text { Renda mensal domiciliar } \\
\text { per capita (sem } \\
\text { considerar a renda } \\
\text { proveniente do trabalho } \\
\text { do jovem, quando } \\
\text { houver), dividida por } 100\end{array}$ & Contínua & $\begin{array}{l}\text { Renda em reais }\{\mathrm{RS}) \text {, } \\
\text { dividida por } 100\end{array}$ \\
\hline Trabalho & $\begin{array}{l}\text { Indica se o jovem } \\
\text { trabalha, e qual sua carga } \\
\text { horária semanal }\end{array}$ & Djmmies & $\begin{array}{l}0 \text { - Não trabalha } \\
\text { (referência) } \\
1 \text { - Trabalha (até } 20 \text { horas) } \\
2 \text { - Trabalha (mais de } 20 \\
\text { horas) }\end{array}$ \\
\hline
\end{tabular}

\section{Fonte: Elaborado pelo autor.}


Entre as variáveis independentes temos, primeiramente, um conjunto de dummies indicadoras de idade, que servirão como controle. Esperamos que idades mais avançadas estejam associadas a maiores chances de evasão. Em seguida, temos duas variáveis que visam capturar os efeitos da localização geográfica do domicílio: a região geográfica e o tipo de área - se rural, urbana não metropolitana ou urbana metropolitana. Os eventuais efeitos dessas variáveis servem como bons indicadores de possíveis deficiências na oferta de escolas e vagas, assim como da atratividade do mercado de trabalho nessas áreas.

Duas variáveis dizem respeito a características individuais adscritas, quais sejam, o sexo e a cor dos jovens. Se na literatura internacional, como vimos, há muitas discordâncias sobre o efeito de raça, é comum o resultado de que mulheres apresentem menores chances de evasão. Já as variáveis do tipo de família e número de filhos trazem a composição do domicílio para nossa análise, o que, segundo aquela literatura, tem se mostrado uma informação bastante relevante. Assim, é esperado que jovens provenientes de famílias ${ }^{11}$ com mais filhos e/ou monoparentais apresentem maiores desvantagens, já que tendencialmente receberiam menos atenção dos responsáveis (SILVA, 2003).

A variável de renda indica o nível de recursos econômicos da família de origem dos jovens, como de praxe na bibliografia sobre estratificação e desigualdades. Neste artigo estaremos trabalhando com a renda domiciliar per capita da residência dos mesmos, dividida por 100 - a fim de facilitar a leitura dos coeficientes do modelo. A fim de melhor capturar esse efeito da origem social, o cálculo da renda domiciliar per capita foi realizado sem considerar a eventual renda proveniente do trabalho do jovem. Já o nível de escolaridade da família de origem é mensurado a partir das informações dos responsáveis. Mais precisamente, utilizaremos os anos de estudo completos para o responsável pelo domicílio ou seu cônjuge (quando houver), considerando apenas aquele que apresentar maior escolaridade. De acordo com os pressupostos teóricos já mencionados, esperamos que, quanto menor o aporte de recursos econômicos e culturais, maiores sejam as chances de evasão.

Finalmente, nossa última variável independente indica não somente se o jovem trabalha, mas também a sua carga horária semanal, discriminando

\footnotetext{
${ }^{11}$ Apesar de nos referirmos muitas vezes às famílias, na verdade toda a análise é realizada a partir de informações do domicílio, que por vezes pode abrigar mais de uma família.
} 
entre indivíduos que trabalham até 20 horas e aqueles cuja carga horária fica acima de 20 horas semanais. Espera-se que o trabalho tenha efeito positivo sobre as chances de evasão, mas que, assim como verificado para outros países, esse efeito não seja linear, mostrando-se presente principalmente entre os jovens com carga horária semanal mais extensa. Como vimos, os eventuais efeitos do trabalho sobre a frequência à escola poderiam ser explicados em função da alocação de tempo e energia na ocupação em detrimento dos estudos, ou, então, como indicador do grau de centralidade atribuído pelos jovens e/ou suas famílias à escola em relação ao trabalho (WARREN, 2003).

Quanto ao recorte utilizado, trabalhamos somente com jovens entre 15 e 17 anos, que é a idade em que idealmente deveriam cursar o Ensino Médio. Além disso, para sermos capazes de considerar a origem social dos mesmos, tivemos que limitar nossa amostra aos jovens que estivessem no papel de filhos no domicílio, o que reduz o número de casos a quase $95 \%$ do total de jovens naquela faixa etária. ${ }^{12}$ Finalmente, restringimos nossa análise aos jovens que ainda não haviam completado o Ensino Médio, pois entendemos que não estar frequentando a escola tendo completado o mesmo é um fenômeno distinto da evasão antes de completar aquele nível de ensino.

\section{Resultados}

A fim de estimar as chances de evasão de acordo com as variáveis dependentes e assim testarmos nossas hipóteses, trabalhamos com modelos logit multivariados. ${ }^{13}$

Foram rodados seis modelos aninhados. ${ }^{14}$ Primeiramente, temos o modelo nulo, que inclui apenas a constante; já o "Modelo 1" adiciona a idade; o "Modelo 2" incorpora as variáveis geográficas; o "Modelo 3" traz também as variáveis individuais; o "Modelo 4" adiciona as informações de estrutura familiar; o "Modelo 5" inclui os indicadores de recursos econômicos e culturais da família de origem; finalmente, o "Modelo 6"

\footnotetext{
${ }^{12}$ Esse recorte, sem dúvidas, traz limitações à nossa análise, cujos resultados devem então ser tratados com cautela.

${ }^{13}$ Para uma exposição mais detalhada sobre este tipo de modelo, ver Powers e Xie (2008).

${ }^{14}$ Para rodar os modelos, fizemos uso dos pesos amostrais, sem, no entanto, realizar a expansão da amostra. Assim, os testes de hipóteses foram realizados com o número real de casos da amostra.
} 
adiciona as variáveis indicadoras de trabalho do jovem e sua eventual carga horária semanal. A Tabela 1 traz os coeficientes de cada um desses modelos, em razões de chance. ${ }^{15}$

Tabela 1 - Modelos Logit: razões de chance $[\exp (b)]$ para a evasão de jovens entre 15 e 17 anos de idade- Brasil, 2015

\begin{tabular}{|c|c|c|c|c|c|c|c|}
\hline Variáveis & Mod 0 & Mod 1 & Mod 2 & Mod 3 & Mod 4 & Mod 5 & Mod 6 \\
\hline Idade (16) & $\ldots$ & $1,610^{* * *}$ & $1,603^{* * *}$ & $1,614^{* * *}$ & $1,640^{* * *}$ & $1,653^{* * *}$ & $1,543^{* * *}$ \\
\hline Idade (17) & $\ldots$ & $3,008^{* * *}$ & $3,028^{* * *}$ & $2,988^{* * *}$ & $3.098^{* * *}$ & $3,099 * * *$ & $2,633^{* * *} 8$ \\
\hline Norte & $\ldots$ & $\ldots$ & $0,822+$ & $0,818+$ & $0,819+$ & 0,982 & 0,961 \\
\hline Sudeste & $\ldots$ & $\ldots$ & $0,785^{* *}$ & $0,849+$ & 0,897 & 1,129 & 1,054 \\
\hline Sul & $\ldots$ & $\ldots$ & 1,059 & $1,202+$ & $1,277^{*}$ & $1,641^{* * *}$ & $1.482^{* * *}$ \\
\hline Centro-Oeste & $\ldots$ & $\ldots$ & 0,981 & 1,014 & 1,079 & $1,5528^{* * *}$ & $1,370-$ \\
\hline Urbano & $\ldots$ & $\ldots$ & $0,759^{* *}$ & $0,791^{* *}$ & $0,799 *$ & $1203+$ & $1218^{*}$ \\
\hline $\begin{array}{c}\text { Urbano } \\
\text { metropolitano }\end{array}$ & $\ldots$ & $\ldots$ & $0,616^{* * *}$ & $0,636^{* * *}$ & $0,632^{* * *}$ & 1,111 & 1,160 \\
\hline Feminino & $\ldots$ & $\ldots$ & $\ldots$ & $0,537^{* * *}$ & $0,530^{* * *}$ & $0,520^{* * *}$ & $0,574^{* * *}$ \\
\hline $\begin{array}{l}\text { Pretos e } \\
\text { Pardos }\end{array}$ & $\cdots$ & $\cdots$ & $\ldots$ & $1,327^{* * *}$ & $1,246^{* *}$ & 1,005 & 1,013 \\
\hline Monoparental & $\ldots$ & $\ldots$ & $\ldots$ & $\ldots$ & $1,777^{* * *}$ & $1,329 * * *$ & $1,304^{* * *}$ \\
\hline $\begin{array}{l}\text { Número de } \\
\text { filhos }\end{array}$ & $\cdots$ & $\cdots$ & $\cdots$ & $\cdots$ & $1,230^{* * *}$ & $1,107^{* * *}$ & $1.100^{* * *}$ \\
\hline Escolaridade & $\ldots$ & $\ldots$ & $\ldots$ & $\ldots$ & $\ldots$ & $0,877^{* * *}$ & $0,877^{* * *}$ \\
\hline Renda & $\ldots$ & $\ldots$ & $\ldots$ & $\ldots$ & $\ldots$ & $0,943^{* * *}$ & $0,944^{* * *}$ \\
\hline $\begin{array}{c}\text { Trabalho (até } \\
20 \mathrm{~h})\end{array}$ & $\ldots$ & $\cdots$ & $\ldots$ & $\cdots$ & $\cdots$ & $\ldots$ & $0,805+$ \\
\hline $\begin{array}{c}\text { Trabalho } \\
\text { (mals de } 20 \mathrm{~h} \text { ) }\end{array}$ & $\ldots$ & $\cdots$ & $\ldots$ & $\cdots$ & $\ldots$ & $\ldots$ & $2,962^{* * *}$ \\
\hline Constante & $0.106^{* * *}$ & $0.060^{* * *}$ & $0.088^{* * *}$ & $0.088^{* * *}$ & $0.046^{* * *}$ & $0.152^{* * *}$ & $0,142^{* * *}$ \\
\hline $\mathrm{N}$ & 13.557 & 13.557 & 13.557 & 13.557 & 13.557 & 13.557 & 13.557 \\
\hline $\log N$ & -2487830 & -2419806 & -2402343 & -2366102 & -2324539 & -2206539 & -2149088 \\
\hline Model X² & $\ldots$ & $136048^{* * *}$ & $170974^{* * *}$ & $243456^{* * *}$ & $326582^{* * *}$ & $562582^{* * *}$ & $677484^{* * *}$ \\
\hline LLR test & $\ldots$ & $\ldots$ & $34926^{* * *}$ & $72482^{* * *}$ & $83126^{* * *}$ & $236000^{* * *}$ & $114902^{* * *}$ \\
\hline $\mathrm{df}$ & 0 & 2 & 8 & 10 & 12 & 14 & 16 \\
\hline
\end{tabular}

Fonte: Pesquisa Nacional por Amostra de Domicílios (PNAD-IBGE), 2015.

Tabulação: próprio autor.

$+\mathrm{p}<=0,10 * \mathrm{p}<=0,05 *{ }^{*} \mathrm{p}<=0,01 * * * \mathrm{p}<=0,001$

Conforme pode ser verificado na parte inferior da tabela, todos os modelos apresentam poder de explicação significativamente maior que o

${ }^{15}$ Para obter as razões de chance, são calculados os exponenciais dos coeficientes dos modelos. 
modelo nulo. Além disso, o ajuste de cada um deles é significativamente melhor que aquele do modelo imediatamente anterior. Visando testar nossas hipóteses, estaremos especialmente interessados nos coeficientes dos "Modelo 5"- que inclui as informações de recursos econômicos e culturais - e, posteriormente, do "Modelo 6" - que adiciona a variável de trabalho.

Olhando primeiramente para o "Modelo 5", vemos que, conforme esperado, a idade apresenta forte efeito positivo sobre as chances de evasão, dado que jovens com 17 anos têm chances maiores que jovens de 15 anos de estarem fora da escola. ${ }^{16}$ A região de moradia também influencia significativamente nas chances de evasão ${ }^{17}$, de modo que, quando comparado com a região Nordeste (categoria de referência), moradores da região Sudeste, Sul e Centro-Oeste apresentam chances maiores. Além disso, morar em área urbana aumenta significativamente (em 20\%) as chances de evasão. ${ }^{18}$ Uma possível explicação para parte desses efeitos de região - com exceção do parâmetro relativo ao Centro-Oeste - e área poderia estar no maior poder de atratividade do mercado de trabalho sobre os jovens em regiões economicamente mais dinâmicas, elevando as chances de evasão. Essa interpretação, entretanto, é apenas em parte corroborada a partir das alterações desses parâmetros no "Modelo 06", quando inserimos a variável indicadora de trabalho, o que reduz os coeficientes relativos às regiões Sul e Sudeste, mas não aqueles indicadores de áreas urbanas.

Em conformidade com a bibliografia sobre o tema, as mulheres apresentam chances $48 \%$ menores de evasão do que os homens. Já a raça dos jovens, no entanto, passa a não exercer efeito significativo sobre as chances de evasão quando inserimos as variáveis de renda e escolaridade no modelo, estando esse resultando em consonância com parte da literatura internacional. A estrutura familiar, conforme esperado, tem efeito significativo sobre as chances de evasão. Para jovens em famílias monoparentais, estas são 32\% maiores; e a cada filho a mais no domicílio as chances aumentam em $10 \%$.

Finalmente, devemos olhar para os efeitos das variáveis indicadoras de recursos econômicos e culturais da família de origem. Mesmo mantendo

${ }^{16} \mathrm{~A}$ fim de interpretar as razões de chance em termos percentuais, basta aplicar a seguinte fórmula: $(\mathrm{x}-1)^{\star} 100$.

${ }^{17} \mathrm{O}$ teste para a significância estatística dos 4 parâmetros de região, em conjunto, rejeita a hipótese nula com $\mathrm{p}<0.001$.

${ }^{18}$ A moradia em região metropolitana, em relação a áreas rurais, também aumenta estas chances. No entanto, o coeficiente não se mostra significativo. 
constantes as demais variáveis do modelo, cada ano a mais de escolaridade do responsável reduz as chances de evasão em 13\%. Em relação aos rendimentos domiciliares, a cada 100 reais a mais de renda per capita, as chances de evasão diminuem em aproximadamente $6 \%$. Assim, encontramos efeitos fortes e significativos das informações de origem familiar sobre as chances de evasão.

A fim de melhor interpretarmos esses efeitos, faremos uso de probabilidades preditas a partir dos parâmetros do "Modelo 5". O gráfico abaixo traz as probabilidades para evasão (eixo vertical), de acordo com valores de renda domiciliar per capita (eixo horizontal) e escolaridade do responsável (discriminando cada uma das linhas). ${ }^{19}$ Desse modo, enquanto que a inclinação das retas representa graficamente o efeito da renda, a distância estre as mesmas ilustra o efeito da escolaridade.

Gráfico 3 - Modelos Logit: probabilidades preditas para a evasão de jovens entre 15 e 17 anos de idade, de acordo com escolaridade do responsável e renda familiar - Brasil, 2015

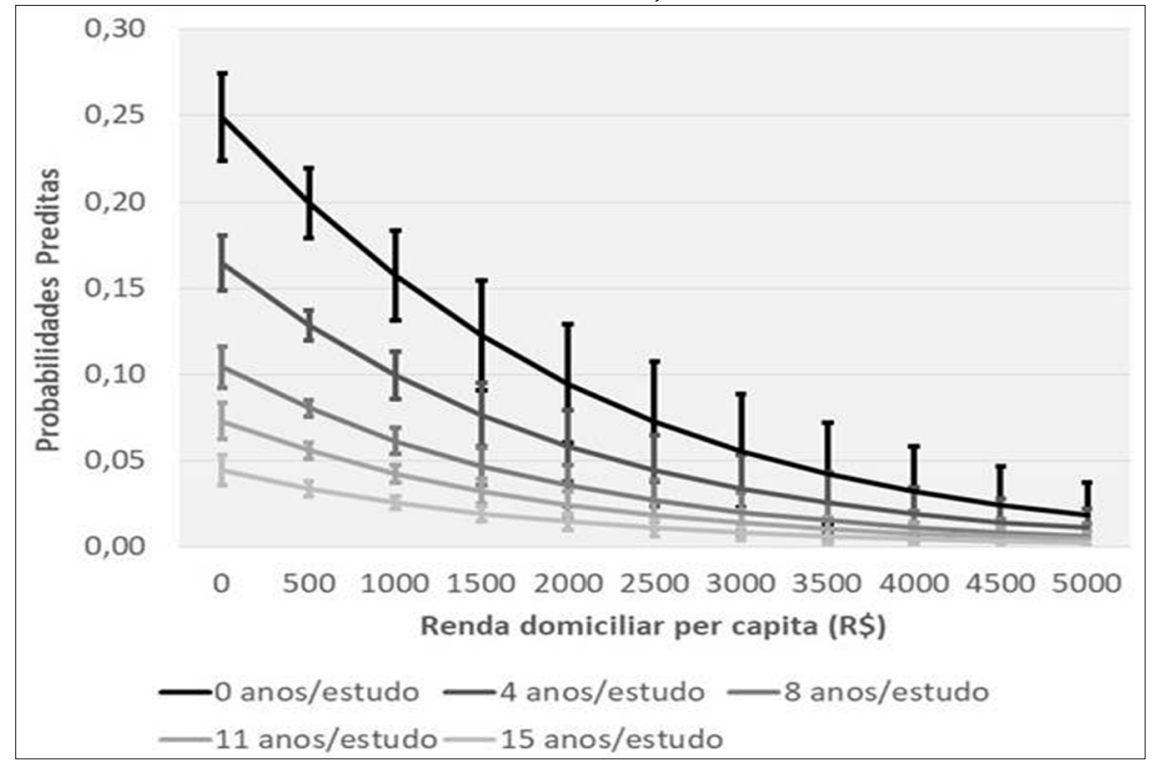

Fonte: Pesquisa Nacional por Amostra de Domicílios (PNAD-IBGE), 2015. Tabulação: próprio autor.

${ }^{19}$ Além disso, o gráfico também traz os intervalos de confiança $(90 \%)$ para cada uma das estimativas, representados pelos traços verticais cruzando as linhas. 
No Gráfico 3, podemos enxergar de modo mais claro os enormes efeitos que os recursos econômicos e culturais da família de origem exercem sobre as probabilidades de evasão dos jovens, mesmo quando mantemos constantes as demais variáveis. ${ }^{20}$ Além disso, e conforme esperado para esse tipo de modelo, as probabilidades não são lineares, de modo que as influências de renda e escolaridade variam de acordo com os valores da outra variável.

Segundo o modelo que estimamos, um jovem cujo responsável com maior escolaridade não tenha nem ao menos 1 ano de estudo completo, e cujo domicílio onde reside tenha renda per capita próxima de zero, tem probabilidade de 0,25 de não estar estudando. Para o mesmo nível de rendimentos, essa probabilidade cai para menos de 0,05 , caso a escolaridade do responsável seja de 15 anos, o que expressa o acentuado efeito do capital cultural sobre a evasão, e que pode ser visualizado na distância vertical que separa as linhas no campo mais à esquerda do gráfico. Conforme caminhamos em direção às famílias com maior aporte de rendimentos, na parte mais à direita, no entanto, a tendência observada é de redução acentuada da probabilidade de evasão para todos os perfis. Assim, mesmo que o responsável não tenha completado nenhum ano de estudo, a probabilidade de evasão é baixíssima, de 0,018, caso a renda per capita esteja em $\mathrm{R} \$ 5.000,00$. Portanto, como esperado, os efeitos das variáveis de background domiciliar são acentuados e se fazem sentir de modo mais proeminente entre os jovens com maiores probabilidades de evasão.

Os resultados até então analisados já são suficientes para corroborar nossa primeira hipótese de que os recursos econômicos e culturais da família de origem dos jovens apresentam forte influência sobre suas chances de evasão, independentemente das outras variáveis (individuais, geográficas e de estrutura familiar) também inseridas no modelo. Também já foi possível identificar os principais fatores que têm impacto naquelas chances, destacando-se, para além de escolaridade e renda, o número de filhos na família, a presença ou não de um cônjuge, o sexo e a região geográfica de residência.

Analisando agora os coeficientes do "Modelo 06", vemos, primeiramente,

\footnotetext{
${ }^{20}$ Para o cálculo das probabilidades preditas, os valores das demais variáveis foram fixados em suas respectivas médias. É importante lembrar, portanto, que o gráfico representa os efeitos de escolaridade e renda sobre indivíduos "médios" nas demais variáveis do modelo, e que os resultados apresentados seriam distintos caso fixássemos aquelas variáveis em valores diferentes.
} 
que o trabalho com carga horária menos intensa (até 20 horas) não eleva as chances de evasão. Pelo contrário, o fato de o jovem trabalhar com carga horária menos intensa está associado a uma chance $20 \%$ menor de evasão (resultado significativo ao nível de $p<=0,100$ ). Por outro lado, o fato de o jovem trabalhar mais de 20 horas por semana aumenta suas chances de evasão em 196\%. Ou seja, corroborando nossa segunda hipótese, e assim como também verificado em outros países (WARREN, 2003), o efeito de trabalhar sobre a frequência à escola é acentuado, mas se faz presente apenas para aqueles com carga horária mais elevada.

Na literatura sobre o tema encontramos algumas hipóteses explicativas para o fato de o trabalho tendencialmente elevar as chances de evasão apenas quando se trata de uma carga horária intensiva (D`AMICO, 1984; STEINBERG et al., 1993; McNEAL, 1997). A mais comum delas é a de que se, por um lado, trabalhos mais intensivos acabariam por fazer uso de tempo e energia que poderiam ser empregados em atividades escolares, por outro lado, a experiência de trabalho em si exigiria e cultivaria qualidades também valorizadas no universo escolar, como disciplina, perseverança e atitude colaborativa, por exemplo. Assim, até certo ponto, a experiência de trabalho poderia caminhar junto ao bom rendimento escolar, tornando-se prejudicial somente nos casos de carga horária mais intensiva, quando seus efeitos negativos anulariam os positivos.

Retomando a discussão apresentada anteriormente, vimos que uma das possíveis explicações para o efeito das características socioeconômicas da família de origem sobre a evasão seria a necessidade de trabalho dos jovens em famílias menos abastadas, a fim de complementar a renda domiciliar. Voltando à Tabela 1, no entanto, os coeficientes do nosso "Modelo 6" mostram que, mesmo quando inserimos uma variável indicando a situação de trabalho do jovem e a sua carga horária, os efeitos de escolaridade e renda continuam sendo significativos; mais do que isso, eles se mantêm praticamente inalterados em relação ao modelo anterior, o qual não incluía a variável trabalho, não sendo estatisticamente significativa a pequena diferença observada. ${ }^{21}$

Tal resultado pode ser tomado como evidência de que apenas uma parcela muito pequena, ínfima, e não significativa, dos efeitos de recursos econômicos e culturais da família de origem se dá por meio de uma suposta

${ }^{21} \mathrm{O}$ mesmo não acontece com os coeficientes de sexo e de região geográfica, que tendem a diminuir; o que pode ser tomado como evidência de que parte dos efeitos dessas variáveis passa pela variável indicadora de trabalho. 
pressão para que o jovem trabalhe. De tal modo, podemos afirmar que a maior parte do efeito da família de origem sobre a frequência à escola passa ao largo da participação dos jovens no mercado de trabalho.

Visando melhor analisar os efeitos do trabalho sobre a evasão, e também sua relação com os rendimentos e escolaridade da família de origem dos jovens, o Gráfico 4 traz mais algumas probabilidades preditas. Primeiramente, criamos três tipos socioeconômicos: Baixo (renda per capita de $\mathrm{R} \$ 500,00$ e 4 anos de estudo), Médio (renda per capita de $\mathrm{R} \$ 1.500,00$ e 8 anos de estudo) e Alto (renda per capita de $\mathrm{R} \$ 3.000,00$ e 12 anos de estudo). Em seguida, calculamos as probabilidades de evasão para cada um desses perfis, de acordo também com a situação de trabalho dos jovens. ${ }^{22}$

\section{Gráfico 4 - Modelos Logit: probabilidades preditas para a evasão de jovens} entre 15 e 17 anos de idade, de acordo com situação de trabalho e perfil socioeconômico da família - Brasil, 2015

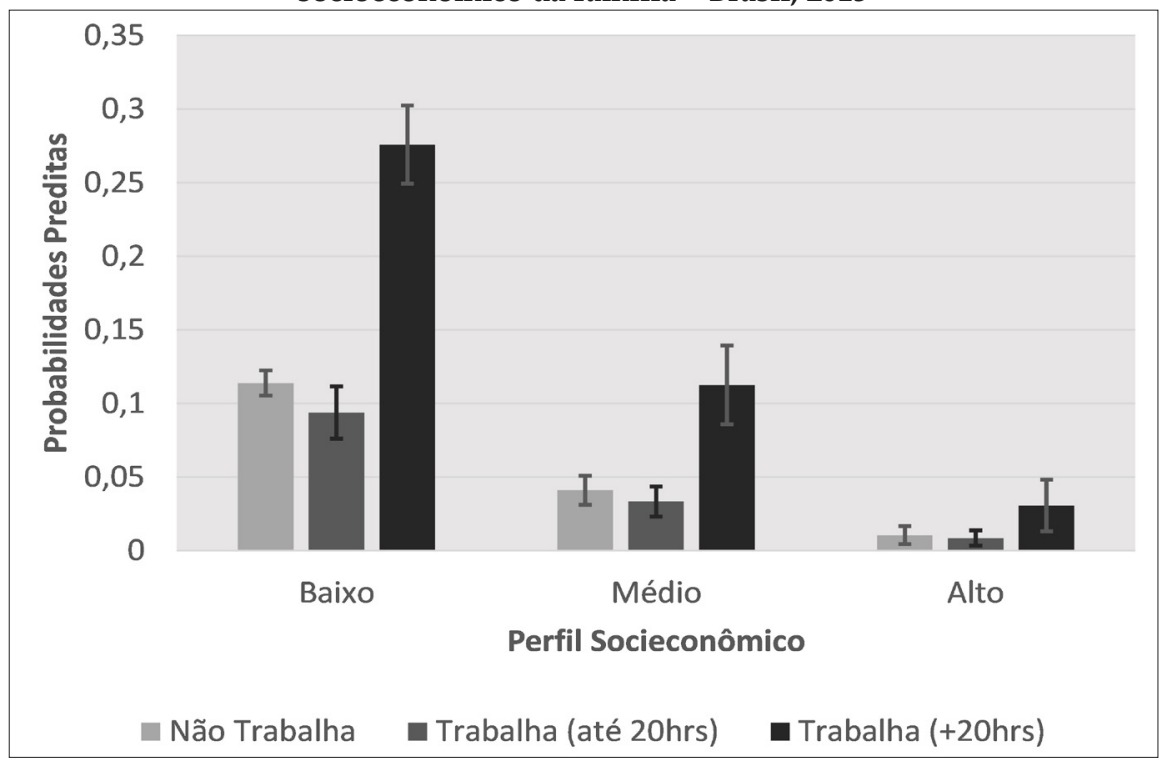

Fonte: Pesquisa Nacional por Amostra de Domicílios (PNAD-IBGE), 2015. Tabulação: próprio autor.

A diferença de altura entre as barras de um mesmo cluster (Baixo, Médio ou Alto) expressa graficamente o efeito de trabalhar e da carga horária de

\footnotetext{
${ }^{22}$ Para o cálculo das probabilidades preditas, os valores das demais variáveis foram fixados em suas respectivas médias.
} 
trabalho, e as diferenças de barras com a mesma coloração, entre os clusters, representam o efeito do nível socioeconômico. ${ }^{23}$

Alguns resultados ficam mais claros e evidentes a partir do gráfico. Primeiramente, que tanto o nível socioeconômico quanto o trabalho intensivo (mais de 20 horas semanais) possuem efeitos agudos sobre a probabilidade de evasão, de modo que esses efeitos se somam, atuam concomitantemente, não sendo possível tomar o trabalho como variável mediadora entre o background familiar e a evasão. Segundo, que o efeito do trabalho com carga horária elevada é consideravelmente maior para os jovens provenientes de famílias com perfil socioeconômico mais baixo, cujas probabilidades de abandono são mais altas. A título de ilustração, vemos que um jovem de perfil socioeconômico "Baixo" teria probabilidade de evasão na ordem de 0,11 ; e que esta saltaria para 0,27 caso o mesmo jovem trabalhasse com carga horária superior a 20 horas semanais. Finalmente, que mesmo quando comparamos situações semelhantes de trabalho, com carga horária análoga, continua havendo diferenças marcantes e significativas entre jovens provenientes de famílias com perfis socioeconômicos distintos. Por exemplo, entre os jovens que não trabalham, a probabilidade de evasão fica em 0,11 para o perfil "Baixo", 0,04 para o perfil "Médio", e 0,01 para o perfil "Alto".

Deste modo, se os resultados alcançados trazem evidências suficientemente fortes para corroborar as duas primeiras hipóteses anteriormente lançadas por nós, o mesmo não pode ser dito em relação à terceira. $\mathrm{O}$ fato de o jovem trabalhar, mesmo que de modo intensivo, não explica parcela significativa do efeito da origem socioeconômica sobre as chances de evasão. Na verdade, ambos os efeitos, de background familiar e de situação de trabalho, são acentuados e se somam, não sendo possível afirmar nem que a situação de trabalho seja um importante mediador entre nível socioeconômico e evasão, e nem que sua relação com esse fenômeno seja espúria, resultante dos efeitos combinados do background sobre as duas.

\section{Motivações da evasão}

Com o objetivo de melhor compreender os fatores associados à evasão, assim como os mecanismos através dos quais aqueles exercem seus efeitos

${ }^{23}$ Além disso, o gráfico também traz os intervalos de confiança $(90 \%)$ para cada uma das estimativas, representados pelos traços verticais na parte superior das barras. 
sobre a ação dos jovens, outro tipo de informação relevante pode ser as motivações alegadas pelos indivíduos para não estarem frequentando a escola (RUMBERGER, 1983). Felizmente, no ano de 2006, a PNAD trouxe também um suplemento em que era perguntado qual o principal motivo para a pessoa não frequentar a escola (se este fosse o caso). ${ }^{24}$

Entre as opções de resposta dadas aos entrevistados, constavam 16 possibilidades, que então agregamos em 5 categorias, conforme o Quadro 2:

Quadro 2 - Possíveis motivos para não frequentarem a escola

\begin{tabular}{|c|l|}
\hline Demanda & - Falta de documentação \\
(incapacidade) & - Não tem quem o(a) leve \\
& - Expunça ou incapacidade \\
\hline Demanda & - Concluiu a série ou curso desejado \\
(motivação) & - Não quis frequentar escola ou creche \\
\hline & - Os pais ou responsáveis não querem que frequente \\
\hline Demanda (renda/ & - - Tjudar nos afazeres domésticos \\
trabalho) & - Falta de dinheiro para as despesas escolares \\
& - Os pais ou responsáveis preferem que trabalhe \\
\hline & - Falta de transporte escolar \\
\hline Oferta & - Não existe escola ou creche perto de casa \\
\hline Outros motivos & - Falta de vaga na escola ou creche \\
\hline
\end{tabular}

Fonte: Elaborado pelo autor.

A primeira categoria diz respeito a jovens que não frequentavam a escola por algum impedimento específico, como doença, falta de documentação etc. A segunda diz respeito à não frequência escolar por falta de motivação dos próprios jovens ou de seus responsáveis. A terceira categoria se refere aos jovens que não frequentavam a escola em função de limitações financeiras e/ou necessidade de trabalhar, incluindo trabalho doméstico. A quarta engloba as razões voltadas a limitações de oferta, como a falta de vagas, escolas e transporte. Finalmente, a quinta e última categoria agrega os casos não contemplados pelas anteriores.

\footnotetext{
${ }^{24} \mathrm{O}$ entrevistado não era necessariamente o jovem, o que sem dúvida pode gerar algum viés nas respostas obtidas. Por esta razão, tais dados devem ser analisados com cautela.
} 
O Gráfico 5 traz a frequência percentual das motivações para jovens entre 15 e 17 anos não frequentarem a escola no Brasil, distribuídas pelos quintis de renda domiciliar per capita.

Gráfico 5 - Motivações para a evasão de jovens entre 15 e 17 anos de idade, por quintis de renda domiciliar per capita - Brasil, 2006

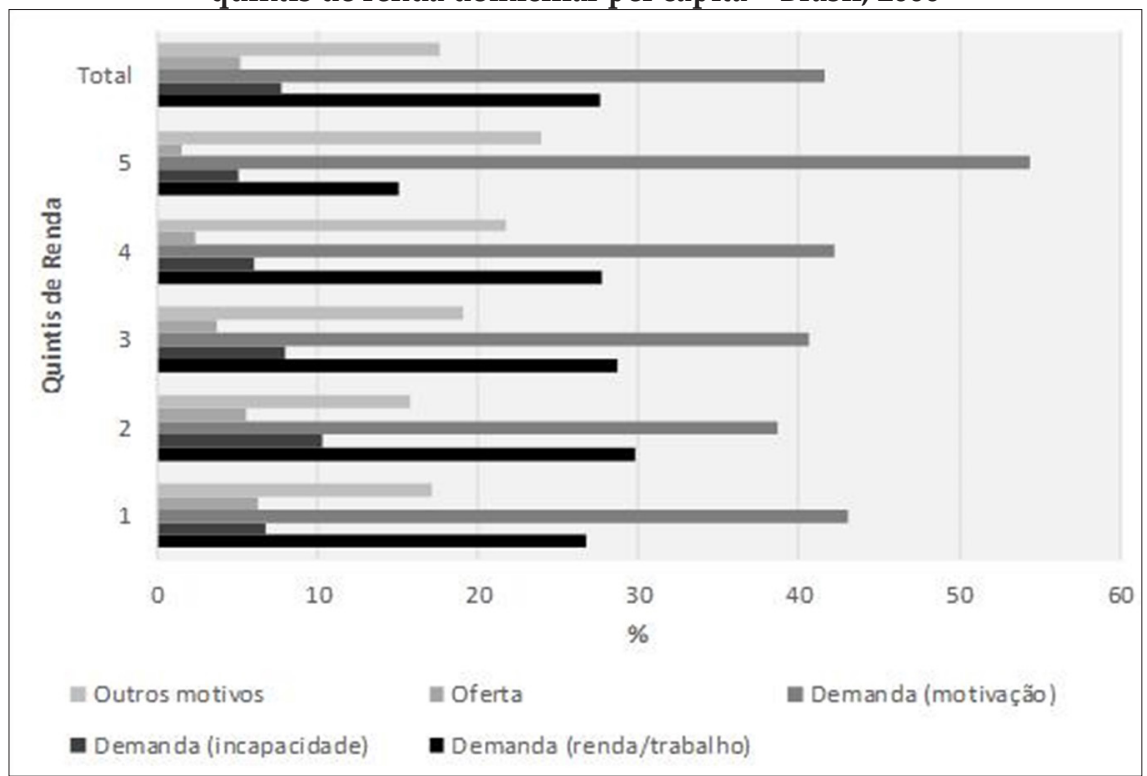

Fonte: Pesquisa Nacional por Amostra de Domicílios (PNAD-IBGE), 2006. Tabulação: próprio autor.

Um primeiro ponto a ser observado é o elevado percentual de respostas na categoria residual "outros motivos", o que imediatamente chama atenção para a complexidade desse fenômeno, a dificuldade de categorização desses motivos e, assim, as limitações metodológicas dessa abordagem.

No agregado total, o motivo mais citado para a evasão dos jovens é a falta de motivação, englobando mais de $41 \%$ dos casos. Em seguida, temos as limitações de rendimentos e necessidade de trabalhar, com $27 \%$. Outros motivos não englobados pelas demais categorias, por sua vez, correspondem a $17 \%$ dos casos. As incapacidades foram citadas por $7 \%$ dos entrevistados, e as deficiências na oferta escolar por aproximadamente 5\% dos mesmos. O padrão observado é semelhante para todos os quintis de renda, com exceção do quintil mais rico, em que o percentual de evasão em função de renda/trabalho é substantivamente menor, e o de evasão 
em virtude de falta de motivação é maior. Além disso, há uma tendência, também, de elevação da categoria residual entre os quintis mais ricos. Mas, de um modo geral, as razões alegadas para a evasão são semelhantes para todos os quintis, destacando-se, em primeiro lugar, a falta de motivação e, posteriormente, as carências econômicas e/ ou a necessidade de trabalhar.

É importante mencionar que, dentro dessas grandes categorias predominantes - Demanda (motivação) e Demanda (renda/trabalho) -, há razões que se destacam pela sua frequência. Dentro da primeira categoria, quase $85 \%$ da sua frequência se deve à resposta "não quis frequentar escola ou creche", e quase $15 \%$ à resposta "concluiu a série ou curso desejado". Já no interior da segunda, quase $80 \%$ de sua frequência se deve à resposta "trabalhar ou procurar trabalho", aproximadamente $10 \%$ a "ajudar nos afazeres domésticos", e os outros 10\% restantes à "falta de dinheiro para as despesas escolares". Destarte, as categorias agregadas representam bem, respectivamente, a falta de motivação e a entrada no mercado de trabalho como razões para não frequentar a escola.

Assim, se, por um lado, deficiências na oferta parecem responder por uma minoria dos casos, por outro, as limitações econômicas das famílias e, sobretudo, a falta de motivação para frequentar a escola aparecem como as principais razões alegadas para a evasão entre jovens de 15 e 17 anos de idade. Tais resultados reforçam, em certa medida, aqueles extraídos a partir dos modelos logit anteriormente apresentados, nos quais as variáveis de origem familiar (indicadoras de volume de recursos econômicos e culturais) e a situação de trabalho apresentaram efeitos acentuados sobre as chances de evasão. Em sua maioria, os jovens deixam de frequentar a escola não por dificuldades de acesso, mas sim por falta de motivação e, ainda, pela inserção no mercado de trabalho.

Resultados semelhantes a esses foram encontrados em outros países, onde também a falta de motivação se mostrou a razão mais frequentemente mencionada para a evasão (RUMBERGER, 2001). Desse modo, seria plausível imaginarmos que o enorme efeito da origem social sobre as chances de evasão, verificado nos modelos rodados, se dê mais através de sua influência sobre as motivações dos jovens e/ou seus responsáveis do que por meio das restrições objetivas impostas aos mesmos - o que vai ao encontro dos resultados obtidos no "Modelo 06", quando a inserção da variável de participação no mercado de trabalho pouco altera os efeitos das variáveis de capital econômico e cultural. 


\section{Conclusões}

Iniciamos este artigo mencionando a emenda constitucional $n^{\circ}$ 59, de 2009, que tornava a educação básica obrigatória e gratuita dos quatro aos dezessete anos de idade no Brasil, assim como a terceira meta do PNE, que visava universalizar, até 2016, o atendimento escolar para jovens entre 15 e 17 anos de idade. Como vimos, no entanto, ainda em 2015 aproximadamente 15\% dos jovens nessa faixa etária não frequentavam a escola. Nos perguntamos, então, qual seria o peso da origem social e da situação de trabalho sobre as chances de os jovens não frequentarem a escola, e em que medida o efeito da primeira seria mediado pela segunda.

Em consonância com a literatura sobre o tema, brevemente revisada neste artigo, os resultados por nós alcançados tornam evidente o importante papel exercido pelas características socioeconômicas da família de origem sobre as chances de evasão dos jovens. Mesmo quando controlamos por variáveis individuais, geográficas e relativas à composição familiar, o volume de capital econômico e cultural da família de origem exerce forte efeito sobre as chances de os jovens não frequentarem a escola. Vimos também que o fato de o jovem trabalhar, independentemente de seu background domiciliar, eleva significativamente sua chance de evasão, mas apenas quando a carga horária de trabalho é mais intensa. E, finalmente, verificamos que a situação de trabalho não explica parte significativa do efeito de background familiar sobre a evasão escolar.

De tal modo, o modelo teórico empregado por parte da bibliografia nacional, endossado também em reportagens publicadas nos meios de comunicação em massa, e que toma a participação no mercado de trabalho como um dos principais mediadores entre o background familiar e a evasão, deve ser problematizado. De acordo com os resultados alcançados, a situação de trabalho não poderia ser tomada como variável mediadora entre nível socioeconômico e evasão, de modo que ambas são causas assaz importantes, porém pouco relacionadas, da evasão entre jovens. É verdade que jovens com origem em famílias de menor capital cultural e econômico, assim como jovens que trabalham de modo mais intensivo, apresentam chances mais elevadas de evasão; mas, sendo a relação entre background familiar e situação de trabalho menos estreita do que normalmente imaginado, não é a eventual necessidade de trabalhar que explica o efeito da origem social sobre a evasão. Seus efeitos, na verdade, se somam.

Logo, há mecanismos para além da necessidade de trabalhar que são 
os principais responsáveis pela relação entre o background familiar e as chances de evasão. Fora as pressões materiais mais imediatas, é preciso reconhecer a capacidade daquele background condicionar as expectativas, atitudes e preferências dos jovens, assim como sua experiência escolar. Se a evasão deve ser encarada como o ponto de chegada de um longo processo (FINN, 1989), o efeito da origem social dos estudantes sobre a experiência escolar dos mesmos e o modo como esta, por sua vez, é também capaz de estimular ou não um maior engajamento por parte dos jovens devem ser considerados (BRANDÃO et al., 1983).

Ao utilizar os dados do suplemento da PNAD 2006, também fomos capazes de verificar as principais motivações alegadas para a evasão, quais sejam: a entrada no mercado de trabalho, e, principalmente, a falta de motivação dos jovens ou de seus familiares pela continuidade dos estudos. Tais resultados dão suporte àqueles alcançados por meio dos modelos logit, dado que tornam evidente a importância da demanda, muito maior que as deficiências na oferta, para explicar a evasão dos jovens atualmente. Mais do que isso, também nos ajudam a refletir a respeito dos mecanismos por meio dos quais a origem social dos jovens condiciona suas decisões (e/ou de suas famílias) sobre a frequência à escola, indicando que seus efeitos passam mais pelas preferências e motivações do que pelas restrições imediatamente impostas aos jovens.

Conforme já atestado pela literatura internacional a esse respeito, há uma miríade de causas e fatores explicativos para a evasão, muitos deles relacionados entre si, e por isso sendo tão difícil alcançarmos um nível mais satisfatório de compreensão desse fenômeno. Com efeito, para melhor compreender os mecanismos que fazem a mediação entre esses dois polos (origem e frequência à escola) no país, modelos mais completos deverão ser testados, incluindo também as chamadas variáveis endógenas, referentes às aspirações e expectativas dos jovens, seu histórico escolar, a instituição onde estudam etc. ${ }^{25}$ Afinal, como outros trabalhos já identificaram, a evasão é apenas o ponto de chegada de um longo processo.

Apesar de suas limitações, no entanto, o presente estudo tem o mérito de realizar uma análise mais ampla sobre a evasão escolar de jovens no país, revelando não apenas alguns dos principais entraves à expansão da escolarização dos jovens de 15 a 17 anos, mas, ao mesmo tempo, lançando luz

\footnotetext{
${ }^{25}$ Alguns estudos realizados no país, ainda que limitados a um recorte geográfico mais específico, já caminharam nesta direção, como Shirasu e Arraes (2016) e Soares (2015).
} 
sobre um momento decisivo no processo de reprodução das desigualdades. Se não é uma eventual necessidade de trabalhar, supostamente derivada do background social menos abastado de grande parcela da população, o principal motivo a afastar os jovens do sistema de ensino, e nem supostas deficiências na oferta em si, precisamos olhar para dentro das escolas, a fim de encontrar maneiras de torná-las mais atrativas - vis-à-vis o mercado de trabalho - e incentivar o engajamento dos jovens, especialmente para aqueles mais sujeitos à evasão, de modo a melhorar a permanência dos mesmos.

\section{Referências}

ARROY0, Miguel G.

(1993). Educação e Exclusão da Cidadania. In: BUFFA, Ester.; ARROYO, Miguel G.; NOSELLA, Paolo. (orgs.). Educação e Cidadania: quem educa o cidadão. São Paulo: Cortez, p. 31-80.

BARROS, Ricardo Paes de.

(2017). Políticas Públicas para Redução do Abandono e Evasão Escolar de Jovens. São Paulo: Insper. Disponível em: <http:// gesta.org.br/wp-content/uploads/2017/09/ Politicas-Publicas-para-reducao-doabandono-e-evasao-escolar-de-jovens.pdf > Acesso em: 12 fev. 2018.

BRANDÃ0, Carlos Rodrigues.

(1983). Casa de Escola: cultura camponesa e educação rural. Campinas: Papirus.

BRANDÃo, Zaia; BAETA, Anna Maria Bianchini; DA ROCHA, Any Dutra Coelho.

(1983). Evasão e repetência no Brasil: a escola em questão. Rio de Janeiro: Achiamé.

D'AMIC0, Ronald.

(1984). Does employment during high school impair academic progress? Sociology of education, v.57, n.3, p. 152-164. Disponivel em: <http://www.jstor.org/ stable/2112599?seq=1\#page_scan_tab_ contents> Acesso em: 22 fev. 2018.

DE WITTE, Kristof et al.

(2013). A critical review of the literature on school dropout. Educational Research Review, v.10, p. 13-28. Disponível em: <http://www. sciencedirect.com/science/article/pii/
S1747938X13000286> Acesso em: 15 mar. 2017.

DORE, Rosemary; LÜSCHER, Ana Zuleima.

(2013). Permanência e evasão na educação técnica de nível médio em Minas Gerais. Cadernos de Pesquisa, v.41, n.144, p.772789. Disponivel em: <http://publicacoes.fcc. org.br/ojs/index.php/cp/article/view/73>. Acesso em: 10 abr. 2017.

FINN, Jeremy D.

(1989). Withdrawing from school. Review of educational research, v.59, n.2, p.117-142. Disponivel em: <http://rer.sagepub.com/ content/59/2/117.short>. Acesso em: 25 fev. 2017.

HASENBALG, Carlos.

(2003). A Transição da Escola para o Trabalho. In: HASENBALG, Carlos.; SILVA, Nelson Valle. Origens e Destinos. Desigualdades Sociais ao Longo da Vida. Rio de Janeiro: Topbooks, p.147-172.

HASENBALG, Carlos. SILVA, Nelson Valle. (2003). Origens e Destinos: desigualdades sociais ao longo da vida. Rio de Janeiro: Toobooks, p.55-84.

HUNT, Frances.

(2008). Dropping out from school: a cross country review of literature. Create Pathways to Acess Research Monograph, n०16. United Kingdom: Centre for International Education, School of Education, University of Sussex, 2008. Disponivel em: <https://eric. 
ed.gov/?id=ED504047> Acesso em: 20 jan. 2018.

LAMBORN, Susie; NEWMANN, Fred; WEHLAGE, Gary.

(1992). The significance and sources of student engagement. In: NEWMANN, Fred (org.). Student engagement and achievement in American secondary schools. Nova York: Teachers College Press, p.11-39.

LOPES DE LEON, Fernanda L.; MENEZES-FILHO, Naércio Aquino.

(2002). Reprovação, avanço e evasão escolar no Brasil. Pesquisa e Planejamento Econômico, Rio de Janeiro, v.32, n.3, p.417451. Disponivel em: <http://repositorio.ipea. gov.br/handle/11058/4286>. Acesso em: 12 fev. 2017.

MCNEAL Jr., Ralph B.

(1997). Are students being pulled out of high school? The effect of adolescent employment on dropping out.Sociology of Education, v.70, n.3, p. 206-220. Disponivel em: http://repositorio.ipea.gov.br/ handle/11058/4286>. Acesso em: 20 fev. 2018.

MEKSENAS, Paulo.

(1998). Sociologia da Educação: introdução ao estudo da escola no processo de transformação social. 9. ed. São Paulo: Loyola.

MENEZES-FILHO, Naércio; FERNANDES, Reynaldo; PICCHETTI, Paulo.

(2007). Educação e queda recente da desigualdade no Brasil. In: BARROS, Ricardo Paes; FOGUEL, Miguel Nathan; ULYSSEA, Gabriel. (orgs.). Desigualdade de renda no Brasil: uma análise da queda recente. Rio de Janeiro, IPEA, p. 185-304. Disponível em: $\quad<$ http://repositorio.ipea.gov.br/ handle/11058/3249> Acesso em: 25 out. 2012.

NERI, Marcelo.

(2009). 0 Tempo de Permanência na Escola e a Motivação dos Sem-Escola. Rio de Janeiro: FGV/IBRE, CPS.. Disponivel em < http://www. cps.fgv.br/ibrecps/TPE/TPE_Motiva\%C3\%A7 $\%$ C3\%B5esEvas\%C3\%A3oEscolar_Sumario. pdf>. Acesso em: 19 out. 2017.
POWERS, Daniel; XIE, Yu.

(2008). Statistical Methods for Categorical Data Analyses. Bingley: Emerald..

RUMBERGER, R. W.

(1983). Dropping out of high school: The influence of race, sex, and family background. American Educational Research Journal. v.20, n.2, p.199-220. Disponível em: <http://aer. sagepub.com/content/20/2/199.abstract> Acesso em: 15 jan. 2017.

\section{RUMBERGER, Russell W.}

(2001). Why students drop out of school and what can be done. Paper presented at conference on Dropouts in America: How Severe is the Problem? What Do We Know about Intervention and Prevention, in Harvard University. Disponivel em: <https:// escholarship.org/uc/item/58p2c3wp.pdf> Acesso em: 20 jan. 2017.

SCHULTZ, Theodore. W.

(1961). Investment in Human Capital. The American Economic Review, v.51. n.1, p.117. Disponivel em: <http://www.jstor.org/ stable/1818907> Acesso em: 05 dez. 2016.

SHIRASU, Maitê Rimekká; ARRAES, Ronaldo de Albuquerque.

(2016). Determinantes da Evasão e Repetência Escolar. In: Anais do XLIII Encontro Nacional de Economia da ANPEC - Associação Nacional dos Centros de Pós-graduação em Economia. Disponivel em: < https://www.anpec.org.br/ encontro/2015/submissao/files_I/i12-85f3c 3774c3d65741cb278e01e61db39.pdf> Acesso em: 10 fev. 2017.

SILVA, Nelson do Valle.

(2003). Expansão Escolar e Estratificação Educacional no Brasil D. In HASENBALG, C.; SILVA, N.V (Orgs.) Origens e Destinos: desigualdades sociais ao longo da vida. Rio de Janeiro. Toobooks. p. 105-147.

SILVA, Wander Augusto.

(2016). Evasão Escolar no Ensino Médio no Brasil. Educação em Foco, n.19. p.1334. Disponível em: <http://revista.uemg. $\mathrm{br} /$ index.php/educacaoemfoco/article/ view/1910> Acesso em: 04 dez. 2017. 
SOARES, Tufi M. et al.

(2015). Fatores Associados ao Abandono Escolar no Ensino Público em Minas Gerais. Educação e Pesquisa, v.41, n.3, p.757-772, 2015. Disponivel em: <http://www.journals. usp.br/ep/article/view/105654> Acesso em: 05 fev. 2017.

STEINBERG, Laurence; FEGLEY, Suzanne; DORNBUSCH, Sanford M.

(1993). Negative impact of part-time work on adolescent adjustment: Evidence from a longitudinal study. Developmental Psychology, v.29, n.2, p. 171-180. Disponivel em: < http:// psycnet.apa.org/record/1993-29060-001> Acesso em: 21 fev. 2018.

TAVARES JÚNIOR, Fernando; DOS SANTOS, Joan Rosa; DE SOUZA MACIEL, Maurício.

(2017). Análise da Evasão no Sistema Educacional Brasileiro. Revista Pesquisa e Debate em Educação, v.6, n.1, p.73-92. Disponivel em: http://www.revistappgp. caedufjf.net/index.php/revista1/article/ view/142 Acesso em: 10 fev. 2018.

WARREN, John Robert; LEE, Jennifer C.

(2003). The impact of adolescent employment on high school dropout: Differences by individual and labor-market characteristics.
Social Science Research, v.32, n.1, p.98128. Disponivel em: <https://www. sciencedirect.com/science/article/pii/ S0049089X02000212 > Acesso em: 19 fev. 2018.

WARREN, John Robert. (2002). Reconsidering the relationship between student employment and academic outcomes: a new theory and better data. Youth \& Society, v.33, n.3, p.366-393. Disponivel em: <http://journals.sagepub.com/doi/abs/ 10.1177/0044118X02033003002> Acesso em: 24 fev. 2018

WEHLAGE, Gary G. et al.

(1989). Reducing the risk: Schools as communities of support. Philadelphia: Falmer Press.

\section{Recebido em}

fevereiro de 2018

\section{Aprovado em}

setembro de 2018 


\title{
Em um dia qualquer: violência, simpatia e carisma pelas tramas das audiências de custódia em Cuiabá
}

Clark Mangabeira*

\begin{abstract}
Resumo
0 presente trabalho objetiva apresentar uma visão etnográfica dos bastidores das audiências de custódia e da carceragem onde os flagranteados são acomodados, a partir da visão dos profissionais sobre os acusados, e de uma audiência tomada como metonímia das demais, a partir das categorias de violência, carisma e simpatia. 0 fio condutor são as imagens construídas dos flagranteados nas trajetórias de idas e vindas no âmbito das relações que estabelecem. 0 foco são os dizeres, minúcias e idiossincrasias que compõem a realidade social e emotiva da carceragem e de uma audiência de custódia do fórum de Cuiabá.
\end{abstract}

\section{Palavras-chave}

Violência. Carisma. Simpatia. Sistema penitenciário.

\begin{abstract}
This work aims to present an ethnographic view of the backstage of custody hearings and of the incarceration where those caught in the act are accommodated, based on the professionals' view of the defendants, and of a hearing used as a metonymy of the others, based on the categories of violence, charisma and congeniality. The guiding thread is the images constructed of those caught in the act in the trajectories of comings and goings within the scope of the relationships they establish. The focus are the words, minutiae and idiosyncrasies that make up the social and emotional reality of incarceration and of a custody hearing in the Cuiabá forum..
\end{abstract}

\section{Keywords}

Violence. Charisma. Congeniality. Prison system.

\footnotetext{
* Clark Mangabeira é doutor em Antropologia Social pelo Museu Nacional/UFRJ, é professor adjunto do Departamento de Antropologia e do Programa de Pós-Graduação em Antropologia Social da Universidade Federal de Mato Grosso - UFMT. E-mail: clarkufmt@gmail.com; mangabeira.clark@gmail.com.
} 
- Seu nome completo, jovem?

- Primeiramente, eu queria falar um negócio pro senhor... Eu menti meu nome...

- Aí sim! Você deu um nome frio lá?

- Me perdoa...

- Se arrependeu de dar o nome falso lá?

- Arrependi.

- Esse nome Mauro Silva ${ }^{1}$ é o frio, qual é o quente?

- João Silva. Eu queria chegar na frente do senhor para poder falar.

- Colocou seu dedo na máquina, chegou ao seu nome! Você tem passagem, João? Um monte, né?

- Tenho, mas eu tava tranquilo já. Faz tempo que eu não aprontava. E nesse caminho agora, eu não aprontei. O rapaz me deu o telefone dele pra mim trocar em droga, só que eu demorei, entendeu? Eu demorei. Aí ele chamou a polícia para mim. Aí quando eu voltei, a polícia estava esperando eu já. Eu não roubei, eu tinha parado de roubar...

- Quanto anos mais ou menos de condenação você tem?

- Tá tudo pago, dezessete, mas tá tudo pago. Graças a Deus. Dessa condenação minha de dezessete, eu tirei oito anos já. Tá tudo pago.

- É, mas parece que já tem um decreto de prisão preventiva seu pra sair, com decisão do juiz, lá do executivo de pena...

- Mas o que é que eu tenho que fazer? Se eu ir lá, que que eu tenho que fazer?

- Ser preso. Pra ver depois, a Defensoria vai discutir o que vai haver lá, porque você está sendo preso, por que eu não sei, pode estar descumprindo as medidas, tem que ver o porquê...

- Não tô não! Tô indo certinho!

- Você usa droga também? Pasta base?

- Sim.

$* * *$

Desde 24 de julho de 2015, quando foi promulgada a resolução 9/2015 do Tribunal de Justiça do Estado de Mato Grosso (Resolução n. 9/2015/ TP do Egrégio Tribunal de Justiça do Estado de Mato Grosso e Resolução 213 do CNJ, com fundamento no artigo $5^{\circ}$, inciso XXXV da Constituição Federal - Princípio da Inafastabilidade da Jurisdição - e Art. $7^{\circ}$, item 5, da Convenção Americana de Direitos Humanos - Pacto de San José da

\footnotetext{
${ }^{1}$ Todos os nomes foram alterados a fim de garantir o anonimato dos envolvidos.
} 
Costa Rica -, promulgada por meio do Decreto Presidencial n. 678, de 06 de novembro de 1992), a princípio (visto que, atualmente, outras varas também começaram a realizar audiências de custódia), a $11^{\circ}$ Vara Criminal do Tribunal de Justiça do Estado de Mato Grosso em Cuiabá, tem atuado na realização de audiências de custódia com os flagranteados: indivíduos que cometem delitos são transladados das delegacias de polícia para o fórum e submetidos a uma audiência de custódia no prazo máximo de vinte e quatro horas contadas a partir da prisão em flagrante. Na audiência, o juiz decide acerca da manutenção ou não do cerceamento da liberdade do acusado, bem como averigua a integridade física e mental do mesmo.

O objetivo da audiência de custódia passou a ser, na prática, consequentemente, decidir sobre a legitimidade e a necessidade da prisão, otimizando-se o serviço do Poder Judiciário, pois flagranteados que, antes da implementação das audiências de custódia, ficavam inseridos na malha burocrática do Estado por meses à espera das audiências introdutórias dos processos, atualmente, no prazo legal de vinte e quatro horas, em Cuiabá, tem seus casos analisados por um Juiz de Direito no tocante à restrição da liberdade, garantindo-se ao acusado direitos humanos básicos, tal qual preconizado na Constituição de 1988 e no Pacto de São José da Costa Rica, de 1969.

Nesse sentido, meramente legal, burocrático e objetivo, a seara da audiência de custódia, no plano do Direito, esgota-se imediatamente como um instituto garantidor dos direitos humanos dos flagranteados, bem como se trata, política e mediatamente, de um instrumento de esvaziamento dos presídios, visto que é preconizada a aplicação de medidas alternativas ao cárcere, a fim de se combater a superlotação das cadeias. Em tese, a averiguação casuística da necessidade da prisão traduz-se em uma ponderação individual sobre a trajetória do flagranteado e sobre a "real" periculosidade do indivíduo e a gravidade do seu ato, tensionando-se a decisão do juiz, a partir do contexto global do sujeito, na direção de uma possibilidade mais conveniente que não a cadeia.

Paralelamente, para além dos meandros jurídicos da audiência em si, a malha estatal destinada à custódia, em Cuiabá, introduziu o "Projeto Renascer", fruto de parceria entre a $11^{\circ}$ Vara Criminal e a Secretaria de Estado de Justiça e Direitos Humanos de Mato Grosso, a partir do qual o flagranteado, antes da audiência, é submetido a atendimento médico e psicológico, exame de corpo de delito, identificação civil e à assistência social. O objetivo é fornecer ao juiz competente, através de um documento 
preenchido antes das audiências, uma "visão global do acusado" a fim de que, por exemplo, no caso de alvará de soltura com medidas cautelares, o acusado tenha encaminhamentos determinados pelo juízo no sentido de qualificação profissional e educacional, assistência social (albergues e inclusão em programas assistenciais), medidas de saúde e acompanhamento dos casos de vício em drogas e/ou álcool etc.; ou, no caso de reclusão em presídio, o flagranteado seja encaminhado à equipe técnica de saúde e aos agentes ressocializadores com seus dados integrais, de modo a facilitar o trabalho da instituição de ressocialização. O intuito do "Projeto Renascer" é promover a inclusão do flagranteado nas redes municipal e estadual de saúde, trabalho e educação como tentativa de prevenir e combater a reincidência, em especial no caso dos réus primários com alvará de soltura.

Antes da audiência, a dinâmica do Projeto Renascer opera na tentativa de, primeiro, qualificar a situação do flagranteado de maneira a auxiliar o juiz na sua decisão, e, segundo, como "meio de passagem" entre a carceragem do fórum e a audiência, um local de apaziguamento do flagranteado conforme delineado na voz de um dos psicólogos atendentes: "aqui, o custodiado pode chorar, colocar pra fora o que está sentindo, e resumir a sua situação". O ponto nevrálgico dos atendimentos é a deteç̧ão de doenças infectocontagiosas, das situações de risco em que os flagranteados se encontram (se usuários de drogas, se possuem documentação civil etc.), o primeiro atendimento psicológico para análise do histórico do sujeito, a fim de servir de base para decisões mais apuradas do juiz, e o exame de corpo de delito, para constatar ou não qualquer violência que o custodiado tenha sofrido. Posteriormente, o flagranteado encontra-se com a defensoria pública ou advogado de defesa, a fim de preparar-se para a audiência.

Como momentos demarcados da trajetória do sujeito na malha judiciária e jurídica, os trâmites do Projeto Renascer e da audiência de custódia aparecem como dois átimos cruciais do processo do flagranteado até a sentença final condenatória ou absolutória. São momentos de demarcação de qualidades do custodiado, de primeira definição das suas idiossincrasias como indivíduos/delinquentes/cidadãos, seja na direção de continuação do processo penal, com o flagranteado preso ou não, seja na de terminar o escrutínio penal, nos casos em que houver quaisquer erros que envolvam a situação delinquente, com o consequente relaxamento da prisão em flagrante.

Anteriores à acusação formal, ao oferecimento da denúncia, consideramse bastidores do Judiciário o trâmite até a audiência de custódia e esta 
incluída, na medida em que exercem sua força agenciadora sobre o ato delinquente, sobre sua qualidade de gerador de prisão e sobre a trajetória pregressa do flagranteado, definindo-se o microuniverso da efetivação ou não da prisão preventiva ou de outras medidas cautelares. Enquanto bastidores, as realidades e "teias de significados" (GEERTZ, 1978, p. 15) que engendram a audiência de custódia e as ações do Projeto Renascer possuem uma eficácia elementar sobre - e apenas sobre - a prisão em flagrante, definindo-se, assim, primeiro, um continuum específico, com começo, meio e fim, esgotando-se sua realidade no momento da decisão do juiz sobre a privação de liberdade; e, segundo, uma resolução de um conflito prévio ao mérito da futura ação penal, a ser iniciada com o oferecimento da denúncia: a validade ou não da prisão em flagrante. Consequentemente, nesses bastidores, as dinâmicas dos envolvidos evidenciam possibilidades semânticas de percepção dos sentidos dos direitos e da criminalidade a partir de uma configuração específica, definida entre a chegada do autuado ao fórum, vindo da delegacia como preso em flagrante, e o resultado da audiência.

Nesse sentido, objetiva-se apresentar uma noção etnográfica de tais bastidores do Judiciário a partir da visão dos profissionais sobre os acusados, culminando no estudo de caso de uma audiência de custódia, cujas minúcias, falas, silêncios, emoções e ações compõem o clímax do trabalho do Projeto Renascer, àquela anterior. $\mathrm{O}$ fio condutor são os discursos e as imagens construídas dos flagranteados nas idas e vindas no âmbito do Renascer, com finalização na audiência de custódia de João Silva, dada como metonímia do coletivo de audiências.

A cena anterior de abertura é o diálogo inicial, gravado pelo próprio Poder Judiciário e disponibilizado para pesquisa, entre o flagranteado João Silva e o juiz que presidiu a audiência de custódia. Silva apresentou-se usando uma máscara médica, cirúrgica, devido à suspeita de tuberculose, percebida em atendimento feito anteriormente, na seara do Projeto Renascer.

Tendo sido recolhido pela polícia, Silva foi encaminhado ao fórum de Cuiabá às 8 horas da manhã do dia da sua audiência. Ao chegar, foi revistado pelo agente penitenciário responsável e acomodado em uma das celas nas quais ficam os flagranteados à espera das audiências de custódia, que começam por volta das 14 horas.

Por volta das 10 horas, Silva foi encaminhado às salas do Projeto Renascer. Fez exame de corpo de delito, identificação civil (quando foi 
descoberto seu verdadeiro nome) e foi atendido por enfermeiras, momento no qual foi detectada a suspeita de tuberculose e lhe dada a máscara médica. Em seguida, apresentou-se para o atendimento diante do assistente social e da psicóloga relatando o ocorrido, como se sentia e um breve retrospecto do seu passado. Fruto desse relato, foi transcrito um documento - o Plano Individualizado de Atendimento (PIA) - que passou a integrar o conjunto levado ao juiz, juntamente com o Auto de Prisão em Flagrante e a Certidão de Antecedentes Criminais.

Nesse trâmite, algemado, Silva foi levado de sala em sala sob o olhar atento dos agentes penitenciários, visto que a logística do atendimento do Renascer é da responsabilidade da Secretaria de Justiça e Direitos Humanos. O protocolo de segurança para quem está nas dependências da carceragem inclui aprendizagem sobre, por exemplo, "manter-se com as costas na parede" enquanto há trânsito dos custodiados, a fim de evitar ser surpreendido pela ação de algum custodiado. Em geral, ao meio-dia, todos os custodiados recebem alimentação e, então, aguardam o começo das audiências.

Segundo a fala dos agentes penitenciários, há três momentos bem demarcados de sociabilidade e comportamento nesse período na carceragem e no Renascer: primeiro, ao chegar e ao serem acomodados, após a revista, nas celas, os agentes indicam que "eles se acham! Ficam olhando com cara de mau, com raiva, tentando nos intimidar". Posteriormente, quando há o atendimento no Renascer, "aí eles viram santinhos...choram e se desesperam na frente do psicólogo e do assistente (social) e sabem que fizeram a coisa errada", retornando ao primeiro comportamento tão logo voltam à cela. Já na audiência, "são os coitados! Os inocentes! E dizem isso para o juiz! Não fizeram nada de errado".

Nessa dinâmica interacional com os agentes penitenciários e com a equipe do Renascer, a percepção destes acerca dos autuados aponta na direção de que os flagranteados surgem como "manipuladores" da própria imagem, alternando performances, inclusive emotivas, em momentos variados. A cada "momento performático", a violência efetivamente praticada aparece menos como fruto dos atos, já que, muitas vezes, tanto a equipe do Renascer quanto os agentes penitenciários ignoram as minúcias do crime supostamente cometido enquanto lidam com os flagranteados nos protocolos de atendimento imediato, e mais como um contexto comum de comunicação, substantivada na vida dos flagranteados e precipitada na interação com a equipe técnica, que pretende combatê-la e controlá-la. 
A violência é contextual, pois o dito e o sabido são que todos que por ali passam são violentos, independentemente do caso em si. Nas dinâmicas da carceragem, os ditos dizem menos sobre os fatos e mais sobre as vidas possíveis e vividas.

Enquanto contexto, o plano de fundo da violência, que perpassa a prática do Renascer e o lócus da carceragem, alcançando a audiência de custódia, é uma lógica comunicativa na medida em que estabelece uma classificação a priori sobre quem está ali, definindo-o como "violento" e impregnando-o de uma identidade estabelecida nos limites da carceragem e do fórum, advinda desde sua prisão em flagrante pela autoridade policial. Ademais, trata-se de uma identidade reificada por uma prática/ato criminosa latente, vívida, visto que são presos em flagrante. Sob essa classificação, as ações e interações estabelecem-se, do lado dos agentes penitenciários e da equipe do Renascer, como uma atitude acusatória por excelência, a partir da qual emergem os "bandidos".

Segundo Howard S. Becker (2008), em seus estudos sobre comportamentos desviantes, a categoria desvio surge não como qualidades de um ato/sujeito, mas como produto de um processo relacional que envolve interações específicas e processos de acusação. Para além de uma rotulação, o desvio traduz-se a partir de uma reação das pessoas a comportamentos particulares, em uma lógica bidimensional pendular entre aqueles que criam e impõem as regras e aqueles que as infringem, surgindo o desviante como elemento já previsto nas próprias normas.

No microcosmos da carceragemenas interações do Renascer, as categorias bandido ou violento, impostas de antemão, apresentam-se já definidas na interação concreta a partir de uma interação abstrata com os criminosos que virtualmente ocuparão os bancos da carceragem. Independentemente do resultado da audiência, mesmo que venha a ser solto, o sujeito que anteriormente passou pela carceragem foi tratado concretamente como criminoso, bandido, violento, definido na interação concreta com a equipe técnica e agentes a partir da virtualização interacional abstrata que designa que, ao estar ali, preso em flagrante, a violência é o plano contextual de existência daquela trajetória.

Nas teias de relações dos bastidores do Judiciário, portanto, aparece a categoria que Michel Misse (2010) chama de sujeição criminal. O rótulo de "bandido" é produzido pelo contato com a polícia e com as leis penais, aparecendo inclusive a moralidade pública como um contexto em contradição ao qual o bandido se forma (MISSE, 2010, p. 17). Ele se torna 
um agente (i)moral, ao qual são atribuídas práticas negativas e socialmente desaprováveis, e que ensejam uma reação moral proporcionalmente incisiva em relação ao ato praticado àquele sujeito que o praticou: a readequação à moral e à sociedade que o acusa e, no extremo, a eliminação física do mesmo.

Paralelamente, o sujeito sujeitado criminalmente surge com uma "subjetividade essencialmente criminosa" (MISSE, 2010, p. 19), potencialmente irrecuperável. São sujeitos que são criminalizados e não os cursos de suas ações:

Trata-se de um sujeito que "carrega" o crime em sua própria alma; não é alguém que comete crimes, mas que sempre cometerá crimes, um bandido, um sujeito perigoso, um sujeito irrecuperável, alguém que se pode desejar naturalmente que morra, que pode ser morto, que seja matável. No limite da sujeição criminal, o sujeito criminoso é aquele que pode ser morto. (MISSE, 2010, p. 21).

Surge, portanto, na perspectiva dos agentes da lei e, principalmente, dos agentes penitenciários, primeiro, a violência como contexto comunicativo e classificatório, e, segundo, a categoria violento/criminoso/bandido como definição acusatória de sujeição criminal - política, emocional e estética na interação concreta com o "desviante" em questão, montado nas rotinas, protocolos e interações - virtuais e concretas - com o flagranteado, dado como provavelmente violento, e visto que a sujeição criminal começa no plano da interação social contextual (MISSE, 2010). Nesse sentido, os momentos performáticos registrados pelos agentes penitenciários fazem sentido dentro da lógica classificatória dada previamente, sendo, portanto, dramas interacionais para, em um primeiro momento, atestar uma periculosidade praticamente irrecuperável performática diante dos demais custodiados e da equipe (quando os autuados agem com "cara de mau"), e, em um segundo momento, escamotear a pretensa realidade delitiva que os levaram até ali (quando afirmam inocência), tudo dentro da lógica comunicativa de violência dada pelo contexto da prisão em flagrante.

Por outro lado, a lógica classificatória e comunicativa que a violência imprime, de antemão, pela ocupação do espaço e da temporalidade da carceragem, aos custodiados, parece fazer desvelar, nestes, uma ação específica com fins à liberdade ante a ameaça da prisão preventiva. Aquelas diversas performances, por um lado, visam a atender e confirmar a identidadejá dada - violentos/marginais - pela localização na malhajurídica 
e enquanto uma categorização política dada em um contexto de interação entre acusados e acusadores (BECKER, 2008); e, de outro, o estabelecimento de uma forma de sociabilidade, para os custodiados, que encarna a (re) definição daquela identidade dada de antemão. Nessas malhas de tramas, os "bandidos" aparecem como sujeitos essencialmente maus, moralmente condenáveis pelo pessoal da carceragem e potencialmente configuráveis em bandidos que não só podem, como devem ser presos. Há uma preparação para o palco moral do julgamento, visto que "o crime é definido primeiramente no plano das moralidades que se tornaram hegemônicas e cuja vitória será inscrita posteriormente nos códigos jurídicos" (MISSE, 2010, p. 22).

Para Gilberto Velho (2008), a violência é parte das relações sociais "e é parte constituinte da própria natureza desta sociedade cujo universo de representações não só expressa como produz a desigualdade e a diferença" (VELHO, 2008, p. 147). As ações dos custodiados dentro do sistema do Renascer e da carceragem, portanto, envolvem a dinamização da lógica da violência na sua qualidade comunicativa, ainda que seja uma violência abstratamente considerada pela simples presença do sujeito na carceragem, uma violência que se atualiza com a entrada do custodiado no sistema via prisão em flagrante.

Por violência, entende-se a dimensão relacional que deriva da categoria desvio, ou seja, o descumprimento de regras estabelecidas para proteção da ordem pública e individual, socialmente montadas e moralmente moldadas, a partir do qual o sujeito adentra na malha jurídica. Assim, continuar, a partir do possível delito que levou ao flagrante, o contato violento dentro da carceragem com os agentes penitenciários é agenciar, minimamente, a categorização por estes imposta aqueles, confirmando-se a expectativa de plausibilidade de violência que ensejou o trajeto para a audiência de custódia. Se, desde o flagrante, impõe-se a identidade de bandido (ou qualquer sinônimo desta), o primeiro momento de enfrentamento e demarcação desse status dá-se perante os agentes penitenciários, com a consequente confirmação, para si, daquela identidade impositiva e imposta. Em outras palavras,

Impor a uma pessoa um único destino e uma identidade (uma patologia; uma classificação; um atributo essencial distintivo) fabricada com preconceitos corresponde a destruir sua liberdade, e aprisioná-la em uma única e invariável possibilidade de ser. A pessoa passa a ser prisioneira de uma imagem, uma identidade, 
uma palavra: "o problemático", "o louco", "o drogado", "o bipolar", "o agressivo", "o criminoso", "o traficante”, “o ladrão”, "a vadia", "a maluca", "a desajustada", aquela que "é assim mesmo" e "sempre foi assim" etc. As palavras variam, mas o artigo - "o" ou "a" - permanece atestando o caráter imutável da classificação (SOARES, 2011, p. 47).

$\mathrm{Na}$ imposição dessa identidade criminosa, não se diferenciando os agentes dos atos delituosos e os erroneamente encarcerados, os delitos mais e menos graves, dentro do sistema do Renascer e da carceragem, a manutenção daquela parece tornar-se uma condição sine qua non da sociabilidade na relação com os agentes penitenciários, metonimicamente considerados como a encarnação das regras cuja infringência definiu a identidade criminosa dos custodiados. A "cara de mau", a atitude agressiva, os possíveis xingamentos e os demais comportamentos são menos efetivações para si, e sim construções para outrem, dentro de um limite de expectativa razoavelmente imposto desde a apreensão do sujeito, e que este próprio pode assumir publicamente ao tornar-se indiferente ao status negativo a ele associado: "impor-se pelo medo é uma das formais mais elementares e universais de operar o poder em condições de desconfiança recíproca" (MISSE, 2010, p 26).

Na condição desse status negativo, o flagranteado representa um perigo aos outros, perigo este associado a uma subjetividade própria derivada de um "carisma de valor negativo" (MISSE, 2010, p. 27), intrínseco a sua realidade de sujeito. Consequentemente, esse carisma negativo impulsiona os sujeitos criminais na direção de maior aceitabilidade e performance de si como "bandido" diante dos outros e para outros, e pelos outros os construindo assim. O carisma negativo revela-se como um valor de diferenciação entre aqueles que são sujeitados criminalmente e aqueles que não o são, cidadãos com identidade social, em tese, distante das margens da violência, entre acusados e acusadores no contexto de moralidades aceitas socialmente.

Paralelamente, longe dos agentes penitenciários, com a assistência social e psicológica da equipe do Renascer, o choro, a lamúria, o nervosismo, as explicações e os demais comportamentos mais passivos aparecem como signos não apenas de uma performance no sentido de construção da inocência diante da rede estatal, mas também, e principalmente, como a segunda via da relação de violência de imposição daquela identidade criminosa. Tal comportamento parece não ser a negação da identidade criminosa, 
nem o oposto das atitudes de dentro da carceragem, mas outro momento do continuum identitário imposto desde o flagrante, no qual, inclusive, há possibilidades de tentativas de transmutação do carisma de caráter negativo em positivo (MISSE, 2010, p. 30), manuseando-se a interação no sentido de readequá-la minimamente à ordem legítima, a fim de se tentar reduzir a expectativa negativa já amplamente disseminada sobre o sujeito criminalizado.

De acordo com Velho (2003), a ideia de negociação de realidade leva em consideração a relação com o(s) outro(s) especificamente delineada, a partir da qual o repertório - no caso, identitário - ao alcance do sujeito é passível de manipulação. A percepção de que o outro pode entendê-los, compreendê-los, parece deslocar a atribuição identitária criminosa para uma seara não mais de primeiro plano, na qual era necessária sua confirmação para outrem, mas para um segundo plano, a partir do qual novas relações acontecem; um segundo plano construído por sobre a violência enquanto contexto definidor e interativo prioritário, em que a atuação performática da inocência ou da tristeza florescem, independentemente da veracidade delas ou não.

Enquanto um processo complexo, conflituoso e multifacetado, a negociação da realidade, na perspectiva dos custodiados em contato com a equipe do Renascer e mesmo diante do juiz na audiência que julgará a possibilidade de liberdade, precipita novamente a violência estabelecida desde a prisão em flagrante: não é (somente) porque querem demonstrar que são inocentes - embora, às vezes o sejam - que os custodiados agem emotivamente e passivamente, a fim de atestar aquela inocência, diante de psicólogos, assistentes sociais e juízes; é porque são reconhecidos e passaram a se autoidentificar como violentos, não mais tendo que confirmar externamente a identidade violenta lhes imposta pelos agentes representantes da força na/da lei na carceragem e na delegacia, que o comportamento do choro ou do nervosismo acontece, sendo passível de experimentação; exatamente na medida em que a violência lhes imprimiu a identidade, o nervosismo, mesmo mínimo, nessas novas interações com novos interlocutores mais afastados do poder de polícia (assistência social, enfermeiras, psicólogos etc.), é plausível de ocorrência. Em outras palavras, é porque, agora, percebem que todos creem na violência identitária dos sujeitos acusados, que a possibilidade de inocência pode aparecer; é devido ao fato de que agora entendem que os consideram violentos - afinal, estão na carceragem presos em flagrante - que, diante dos psicólogos, uma 
catarse emotiva efetiva-se, sedimentando a identidade criminosa imposta para os próprios acusados, independentemente da violência ou não de fato praticada.

Trata-se de um segundo nível de violência - para além da do fato que levou o custodiado à carceragem e da caracterização violenta dada por terceiros. Uma metaviolência, fruto da identidade imposta, e, pela catarse, normalmente verificada nas conversas, absorvida pelo autuado, encarnada enquanto um bandido, seja ele de fato um ou não:

Várias possibilidades são vetadas a essa pessoa de cuja identidade,
em alguma medida, nós - escola, família, condomínio, médicos,
comunidade - tomamos posse, de antemão e independentemente
do que ela mesma queira. Esse é o ponto de impacto de ações
externas que reduzem a liberdade do ser. Aí incide uma força
poderosa e castradora: eis a violência operando, fazendo seu
trabalho sujo, talvez imperceptível para quem observa de fora,
mas profundamente doloroso e marcante para quem o sofre
(SOARES, 2011, p. 47).

Assim, se a possibilidade da percepção da inocência já aparece abstratamente vetada para o custodiado, a entrega ao desespero é, ato contínuo violento, uma reafirmação da identidade violenta a ele dada, e mantida anteriormente, por ele, para outrem. No caso em tela, por exemplo, Silva, diante do juiz, reforça que "estava tranquilo", que fazia tempo "que eu não aprontava. E nesse caminho agora, eu não aprontei". Ora, para além do fato de que Silva sabe que o juiz possui seus antecedentes criminais, usar essa informação diante do mesmo parece ser fruto do entendimento de si e para si de que, naquele contexto interativo, ser violento lhe é uma identidade imposta estabelecida. Daí, para além de tentar demonstrar ao juiz sua trajetória mais "tranquila" e tentar, assim, a liberdade, reafirmando que já cumprira suas penas, a metaviolência aparece na própria introspecção de que não os atos, o em julgamento e os anteriores, são/foram criminosos, mas que sua trajetória resplandece delinquente. Atos e fatos perdem espaço para o criminoso presencialmente atestando-se criminoso pela sua identidade construída, principalmente, pelos outros. Consequentemente, as reações emotivas surgem como nível da percepção de si fruto daquela identidade imposta, e não apenas como mera performance tendente à definição de inocência.

Por fim, a violência, enquanto marca identitária fruto de interações na seara jurídica, é tão afirmativa que o resultado do atendimento no Renascer, 
os múltiplos planos de identificação e documentação culminam no Plano Individualizado de Atendimento, que seguirá para o juiz para municiá-lo na decisão pela liberdade ou prisão preventiva. Consolida-se o resultado das diversas interações em um documento, um ato classificatório da pessoa (e não do fato praticado), em tese fundamental para a decisão magistrada, mas que parece ser outra marca, agora concreta, das diversas contextualizações pela qual passou o custodiado desde a prisão.

- Da sua prisão até agora, teve alguma violação dos seus direitos?

- Não, nada.

- Com a palavra, doutora promotora...

- Nenhum questionamento, obrigada.

- Doutora defensora...

- O João está sendo acusado de roubo de celular. O senhor pode dizer o que aconteceu? Foi encontrado algum celular com você?

- Não! Não acharam nada comigo! O rapaz que está acusando eu chamou eu para pegar uma droga para ele. Aí, me deu dez reais. Eu fui e peguei a droga. Aí, nós fumamos, o dinheiro dele acabou e ele disse "você pode vender meu celular lá? Vende lá o celular pra nós fumar". Aí nessa eu peguei o celular dele e fui lá vender, entendeu? Aí demorei muito, porque ninguém estava querendo comprar. Aí nisso ele chamou a polícia. Aí quando eu voltei, a polícia já estava esperando eu já. Só que aí eu devolvi o celular dele, devolvi tudo. Só que mesmo assim, me indiciaram. Não teve roubo. Não teve nada.

- Você acredita que ele disse que foi roubado por você por quê?

- Porque ele ficou com medo de perder o telefone... e não usar a droga.

- Tá certo. Sem mais perguntas.

$[\ldots]$

- Promotora, com a palavra.

- Meritíssimo juiz, o flagrante encontra-se em ordem também em relação a esse autuado, razão pela qual o Ministério Público pugna pela sua homologação. O Parquet entende ainda que é o caso de conversão da prisão em flagrante em preventiva em razão do seguinte: trata-se de roubo majorado pelo concurso de agentes. São duas vítimas, a ordem pública se faz necessária de ser mantida nos termos do artigo 312 do Código de Processo Penal. A vida pregressa do autuado lhe é deveras desfavorável, tendo ele ainda condenação anterior por crime transitado em julgado, de modo que se atende ao artigo 313, inciso II, do mesmo estatuto. A pena cominada ao 
ilícito também autoriza a segregação, atendendo ao artigo 313, inciso I, do Código de Processo Penal. O autuado praticou ilícito contra a vítima Paulo e contra a vítima Gustavo, embora Paulo não o tenha reconhecido, a vítima Gustavo o reconheceu com absoluta certeza como sendo o autor do ilícito. O Ministério Público entende ainda que o fato de ele ter mentido seu nome perante a autoridade policial, embora tenho dito o nome verdadeiro agora em juízo, configura sim o ilícito de falsa identidade, de modo que também se vê ameaçada a aplicação da lei penal. Por todo exposto, o Parquet espera ver convertida a prisão flagrante em preventiva. É como manifesto.

- Defesa, com a palavra...

- Excelência, trata-se de Auto de Prisão em Flagrante contra João Silva. $\mathrm{O}$ acusado foi ouvido nesta audiência, oportunidade em que narrou os fatos de forma bastante semelhante ao que narrou na delegacia, negando ter cometido o referido assalto e relatando que a vítima o teria acusado de roubo porque teria pedido a ele para buscar droga, em troca de um celular, e quando viu este nas mãos da polícia, em tempo de tê-lo de volta e com medo de uma represália, teria dito que o referido bem teria sido roubado. É importante salientar que nenhuma arma de fogo foi encontrada com o acusado, nem tampouco a res furtiva. Resta somente a palavra da vítima. Encarcerá-lo preventivamente com base apenas em seus antecedentes é medida de injustiça. A defesa entende que não estão presentes os requisitos autorizadores da preventiva e que deve ser dada ao acusado a liberdade provisória. E em não sendo este o entendimento de Vossa Excelência, que lhe seja imposta qualquer uma das cautelares elencadas do artigo 319, como tornozeleira eletrônica ou coisa do tipo, já que o mesmo, reitero, não infringe nenhum dos requisitos ensejadores da preventiva. Encerro.

No mesmo dia da audiência de Silva, houve outras cinco. A dinâmica leva, em média, doze minutos até a decisão do magistrado. Depois do atendimento na carceragem e das dinâmicas do Renascer, e após o almoço, Silva aguardou o chamado dos agentes a fim de seguir para a antessala do Sala de Audiência, onde o juiz, a promotora e a defensora esperavamno. Sem algemas, apenas com a máscara cirúrgica, sentou-se e começou a sessão.

Em todo o percurso pelos bastidores, da chegada do custodiado ao fórum ao final da audiência de custódia, com o consequente encaminhamento do autuado à liberdade ou ao presídio, o tom da discussão sobre a violência em primeiro plano, do ato, e, em segundo, da própria pessoa do acusado 
- gira em torno do cotidiano dos fatos e da trajetória do sujeito, do dia a dia no qual a realidade delituosa, em tese, ocorreu. Segundo um dos juízes que atuam na custódia, "aqui é a criminalidade mais básica, do dia a dia, mais simples, e temos que conversar nesse tom".

De acordo com Veena Das (2007), a narração e a análise de eventos devem ser escrutinadas na medida em que se vinculam ao cotidiano, nas cavidades da vida ordinária, enquanto um fenômeno atrelado à singularidade das vidas a ele conectadas. Nesse sentido, Das (2007) concebe a ordinariedade da violência, na qual os atos violentos devem ser percebidos - e narrados - em uma linguagem rotineira e ordinária, intrínseca das relações. A violência praticada pelos flagranteados deve ser, portanto, percebida como uma linguagem do plano ordinário de vivência e construção de si - a partir de si e dos outros -, na qual a trajetória do acusado é avaliada e reavaliada pelo mesmo e pelos interlocutores em contextos específicos, considerandose perspectivas singulares.

Na esteira de Das (2007), a audiência de custódia é uma zona de fluxos e refluxos de narrativas e estéticas na qual o evento delitivo é narrado de diversas maneiras, revisitado na tentativa de concebê-lo sempre na sua ordinariedade, seja a pragmática, seja a jurídica, a fim de estabelecer, por fim, a possibilidade ou não da liberdade.

Nesse jogo de interações, de um lado, a relação dos agentes do Estado, em especial da defesa, com o autuado em tela, João Silva, estabelece a ordinariedade pragmática do evento, tratando-o narrativamente isolado da linha da trajetória do custodiado. Ao ser indagado, Silva conta o fato a partir da sua própria perspectiva, enquanto e apenas como um evento vivido - e, deste modo, uma violência ordinária, acontecida, isolada. $\mathrm{O}$ foco recai sobre o que aconteceu, como aconteceu, sobre o evento em si, mundanamente considerado dentro da esfera de ação pretérita. Consequentemente, Silva narra o fato destacando que "não houve roubo", mas um mal-entendido.

Por outro lado, as interações entre os agentes do Estado estabelecem uma estética narrativa que realocam o evento dentro da trajetória do custodiado, estabelecendo a violência não como uma qualidade do fato, mas como uma virtualidade do flagranteado, reforçando a identidade estabelecida na carceragem. A discussão passa a ser de uma temporalidade que se irradia, a partir do evento, para trás (há um mandado de prisão contra Silva por outros delitos) e para frente (pela ordem pública, o Ministério Público considera a prisão necessária, bem como uma nova acusação por falsa identidade). O evento delitivo, encarado, na perspectiva dos agentes da lei, como algo 
rotineiro devido à trajetória do acusado, estabelece a discussão da violência sob o condão da ordinariedade jurídica da pessoa, de maneira que é a qualidade de Silva, suas idiossincrasias, que determinam a potencialidade delitiva e a periculosidade, independentemente do fato em análise (ponto, inclusive, destacado pela defesa na tentativa de convencer pela liberdade).

Da interação entre juiz, Ministério Público e defesa, Silva torna-se espectador, pois já participara no que lhe era devido, primeiro, com suas "qualidades" de potencial criminoso tendo sido registradas por terceiros nos documentos que o acompanharam - PIA, auto de prisão em flagrante, ficha criminal etc. -, elementos que compõem o ato classificatório da pessoa; segundo, narrando o evento nas fendas da sua ordinariedade, visto que o sujeito aparece como o limite de experimentação do mundo (DAS, 2007), de modo que o assalto é perspectivamente analisado por Silva.

Já juiz, Ministério Público e defesa, entre si, interagem de forma diversa, a partir do jargão jurídico, definindo o futuro de Silva. Enquanto na relação com o autuado, o fato é verificado como um evento pessoal (BARTH, 2000, p. 131), a partir da perspectiva sincrônica de narrativa e memória; na relação entre os agentes estatais, consideram-se a trajetória do autuado e a potencialidade diacrônica de uma carreira criminal, sendo esta a esfera relevante para a concessão ou não da liberdade. Entre ambas as versões, surge Silva, identificado de antemão como violento/criminoso/bandido, cuja prisão ou liberdade depende não apenas do acontecido, mas das identidades, narrativas, influências e virtualidades que pairam sobre ele dentro do processo nesses bastidores do Judiciário.

Nesse contexto, surge a simpatia como uma categoria micropolítica emotiva de construção de relações que pode ajudar na compreensão das interações que se estabelecem entre os membros do Judiciário e o acusado. Candace Clark (1997) designa a simpatia como uma das "colas" da sociedade, através da qual uma pessoa se conecta com outra. Caso não haja simpatia por outrem, não se estabelece nenhuma relação. Ademais, a simpatia pode, ao mesmo tempo, estabelecer diferenças hierárquicas entre quem "oferece simpatia" e quem "recebe a simpatia", entre simpatizantes e simpatizados, através das quais o simpatizado reage a uma possível atitude emocional do simpatizante, sabendo exatamente como, quando e onde pedir simpatia como parte de uma economia socioemocional específica, e sabendo que está hierarquicamente inferior ao simpatizante devido ao contexto de necessitar de simpatia. De forma direta, consequentemente, Clark (1997) entende simpatia como uma forma de interação social e um 
antídoto para a tristeza da vida, um "ingrediente de apego" (CLARK, 1997, p. 11) das relações sociais enquanto parte do código moral das mesmas, uma "emoção social" que conecta atores sociais (CLARK, 1997, p. 31).

No caso de Silva, enquanto simpatizado em atividade, o choro e as tentativas de buscar, diante do juiz, o relaxamento da prisão parecem se enquadrar exatamente no papel ativo de quem está hierarquicamente subordinado ao contexto, ao papel de quem depende de simpatia para se ver livre da situação problemática. A narrativa do evento por Silva, com detalhes e emocionalmente construída desde a revelação da mentira sobre o nome, tentando fazer-se como um sujeito não criminoso, pretende despertar a simpatia necessária entre dois sujeitos em hierarquias distintas para eles se conectarem em prol da liberdade de Silva. A dinâmica da relação entre defesa e juiz, que conversam com Silva, e mesmo diante do Ministério Público, que não pergunta nada sobre o evento ocorrido e apenas se manifesta juridicamente sobre o caso em si, transmuta-se na atitude de Silva de tentar despertar simpatia com sua sinceridade. Mesmo na seara mais ampla dos relatos dos agentes que demarcam as atitudes dos acusados que passam pelo Renasce e pela carceragem, estar diante do juiz como inocentes, e diante do psicólogo e do assistente social como "bonzinhos", emocionalmente abalados, faz parte do papel do simpatizado de se construir na interação com o simpatizante, a fim de tentar escapar do caráter negativo da sujeição criminal a que está enquadrado de antemão. Nesse jogo, entrando em choque o evento e a construção da pessoa, é naquelas teias de narrativas que a resolução do ato se resolve.

Enfim, portanto, em silêncio, Silva recebe a decisão, o ato resolutório do tópico, clímax de todo o bastidor, do trabalho iniciado na carceragem, passando pelo Renascer, e da própria audiência de custódia. Nesse microcosmo, o foco não é o mérito jurídico do fato, mas a efervescência identitária de Silva em sua trajetória de vida. A prisão ou a liberdade operam como signos que confirmam ou redesignam a vida do sujeito, contudo sempre o classificando e configurando-o a partir do evento considerado dentro da sua ordinariedade, do cotidiano dos caminhos de Silva. Restam silêncios e futuros, possíveis e impossíveis, continuados para além do bastidor, quando a ação penal for instaurada e novos méritos, questões, performances e perspectivas forem acrescentadas na malha jurídica do caso. Até lá, é a liberdade ou a prisão o mote da classificação mais geral de vidas e fatos, resolvidas pela e na audiência de custódia. 
- Olha, primeiro, a doutora promotora solicitou, então temos que abrir um processinho contra você, porque você usou um nome falso lá na delegacia, isso é um crime previsto no artigo 307 do Código Penal. Em segundo lugar, a vítima te reconheceu no roubo. Até averiguar essa situação, você vai ter que ficar recolhido. E tem um mandado de prisão seu lá na Execução Penal, vai ter que ser averiguada essa situação também, tá?...

- Então... eu vou ficar preso então?

- Não tem como sair, tá? Pode levar ele.

\section{Referências}

BAILEY, F. G.

(1983). The Tactical Uses of Passion. An essay on power, reason and reality. Ithaca and London: Cornell University Press.

BARTH, Fredrik.

(2000). 0 guru, o iniciador e outras variações antropológicas. Rio de Janeiro: Contra Capa Livraria.

BECKER, Howard S.

(2008). Outsiders. Rio de Janeiro: Zahar.

CLARK, Candace.

(1997). Misery and company: sympathy in everyday life. Londres: The University of Chicago Press.

DAS, Veena.

(2007). Life and Words: Violence and the descent into the ordinary. Berkeley: University of California Press.

GEERTZ, Clifford.

(1978). A Interpretação das Culturas. Rio de Janeiro: Jorge Zahar Ed.

LIMA; RATTON; AZEVEDO (orgs.).

(2014). Crime, polícia e justiça no Brasil. São Paulo: Contexto.
MISSE, Michel.

(2010). Crime, sujeito e sujeição criminal: aspectos de uma contribuição analítica sobre a categoria "bandido". Lua Nova, n.79, pp.15-38.

SOARES, Luiz Eduardo.

(2011). Justiça: pensando alto sobre violência, crime e castigo. Rio de Janeiro: Nova Fronteira.

VELH0, Gilberto.

(2003). Projeto e metamorfose: antropologia das sociedades complexas. Rio de Janeiro: Jorge Zahar Ed.

VELH0, Gilberto.

(2008). Individualismo e cultura: notas para uma antropologia das sociedades complexas. Rio de Janeiro: Jorge Zahar Ed.

\section{Recebido em}

agosto de 2018

\section{Aprovado em}

fevereiro de 2019 


\title{
A estética da desregulação da violência doméstica em Marina Colasanti
}

Carlos Magno Gomes*

\section{Resumo}

Este artigo apresenta um estudo acerca das regulações de gênero que normatizam a violência doméstica pela análise da obra Contos de amor rasgados (1986), de Marina Colasanti. Partimos do conceito de revisão paródica, de Linda Hutcheon, para identificar a caricatura da masculinidade como uma forma de deslocamento das normas de gênero. De acordo com os estudos acadêmicos de Judith Butler, Henrietta Moore, Lia Zanotta Machado e Rita Laura Segato, apresentamos a violência de gênero e o excesso de masculinidade como práticas de controle moral e físico da mulher. Especificamente, investigamos como são representados os valores morais atrelados à questão da honra e à crise identitária das personagens masculinas.

\section{Palavras-chave}

Violência doméstica. Antropologia de gênero. Literatura contemporânea.

\begin{abstract}
This article presents a study about gender regulations that make domestic violence normative from the analysis of Contos de Amor Rasgados (Torn Love Tales) (1986), by Marina Colasanti. We are working with the concept of parodic revision by Linda Hutcheon to identify the caricature of masculinity as a form of displacement of gender norms. According to academic studies by Judith Butler, Henrietta Moore, Lia Zanotta Machado and Rita Laura Segato, we present the gender violence and the excess of masculinity as practices of moral and physical control over women. Specifically, we investigate how moral values bound to the question of honor and the identity crisis of masculine characters are represented.
\end{abstract}

\section{Keywords}

Domestic Violence. Gender Anthropology. Contemporary Literature.

\footnotetext{
* Carlos Magno Gomes é professor de Teoria Literária vinculado ao PROFLETRAS e ao PPGL da UFS. Doutor em Literatura pela UnB (2004). Pesquisador bolsista CNPq e membro do GT da ANPOLL A mulher na literatura.E-mail: calmag@bol.com.br.
} 


\section{Apresentação}

Os estudos feministas questionam as regulações sociais que estão por trás da violência contra a mulher como as normas simbólicas de imposição da masculinidade, e a estrutura de exploração do corpo feminino como uma extensão do desejo masculino. Em muitos casos, a regulação do corpo feminino é mantida por abusos físicos e privações sociais em sistemas de torturas e de constantes ameaças. No Brasil, a Lei Maria da Penha (2006) e a Lei do Feminicídio (2015) punem os agressores com mais rigor e foram criadas, a partir da luta das mulheres, para conter esses crimes e proteger as vítimas. Todavia, a recorrência dessas agressões indica que devemos ir além da aplicação de penas mais severas e medidas protetoras, pois os valores simbólicos que atravessam esses crimes são construídos coletivamente e extrapolam as fronteiras da legislação em vigor ${ }^{1}$.

No contexto familiar, a recorrência do assédio moral, do cárcere privado e das agressões físicas, que, quase sempre, antecedem o feminicídio, reforçam valores morais que estão centrados em uma contradição social que reconhece a liberdade da mulher ao mesmo tempo em que veicula discursos de domínio do corpo feminino como parte do exercício da masculinidade. Tais práticas são tipificadas como violência doméstica e são reconhecidas pela população brasileira, como comprova a pesquisa do Instituto Patrícia Galvão (BRASIL, 2014) acerca da percepção da sociedade sobre violência e assassinatos de mulheres. Esse levantamento traz diversos dados acerca de como homens e mulheres percebem a dimensão social do feminicídio. Os resultados foram catalogados, no ano anterior, em mais de 100 municípios das cinco regiões brasileiras, envolvendo diversas classes sociais conforme a renda familiar per capita.

Entre as constatações da vulnerabilidade feminina, destacamos que $70 \%$ dos entrevistados acreditam que a mulher está mais sujeita à violência de gênero em casa (BRASIL, 2014, p. 19). Essa percepção denuncia o reconhecimento da violência como uma forma de controle e punição da companheira no espaço familiar. Para $85 \%$ dos participantes dessa pesquisa, "as mulheres que denunciam seus parceiros correm mais risco de sofrer assassinato" (BRASIL, 2014, p. 05). Infelizmente, tais dados dão sinais da

\footnotetext{
${ }^{1}$ Este texto traz os resultados de uma pesquisa de pós-doutorado desenvolvida junto ao Programa de Pós-Graduação em Antropologia Social da UnB (2016-2018), supervisionada pela Profa. Dra. Lia Zanotta Machado, acerca do feminicídio na literatura brasileira, com financiamento do CNPq.
} 
violência doméstica como uma epidemia social.

Tal prática está atrelada às normas sociais simbólicas que primam pela valorização da força e da virilidade masculina como marcas da normatização do corpo do homem. No espaço doméstico, a ideia de posse do corpo da mulher e a agressividade masculina dão o ritmo das agressões que, em muitos casos, provocam lesões fatais que podem chegar ao feminicídio. Retomando dados da pesquisa anterior, identificamos o homicídio feminino como uma das punições mais praticadas por homens obsessivos. Para 92\% dos entrevistados, as mulheres que sofrem violência doméstica com frequência estão sujeitas a serem assassinadas (BRASIL, 2014, p. 35).

Essa percepção acerca da violência contra a mulher reforça que não estamos diante de casos isolados, mas de comportamentos que se repetem diariamente. De acordo com os estudos antropológicos e feministas de Rita Laura Segato (2005, p. 270), os crimes de gênero "não são obra de desvios individuais, doentes mentais ou anomalias sociais, mas de expressões de uma estrutura simbólica profunda que organiza nossos atos e nossas fantasias e confere-lhes inteligibilidade". O reconhecimento dessa estrutura que regula a violência contra a mulher nos convida a identificar as normas dessa perversa forma de punição feminina.

Essa violência também pode ser identificada nas representações estéticas por meio de duas perspectivas: aquelas que repetem a temática sem reflexões críticas; ou aquelas que retomam essas representações com o intuito de questionar e/ou denunciar as formas de controle do corpo feminino. Por exemplo, nas narrativas realistas do século XIX e XX, a violência contra a mulher é descrita como parte da normatização da moral patriarcal, identificada na representação de personagens masculinas ciumentas e possessivas que punem suas esposas, quando desconfiam que são traídas, como representado nos romances Dom Casmurro (1899), de Machado de Assis, e São Bernardo (1934), de Graciliano Ramos. Essas narrativas registram a violência doméstica pelo prisma masculino, segundo o qual a punição é naturalizada para valorizar e respaldar a moral e a masculinidade do agressor.

Em contrapartida, ainda durante o século XX, essa normatização de gênero passou a ser questionada pelos textos de autoria feminina, como em O quinze (1930), de Rachel de Queiroz, com uma protagonista que rompe com um namorado, após se recusar a repetir o "destino de mulher" e ser submissa às ordens do marido; e Perto do coração selvagem (1944), de Clarice 
Lispector, que traz uma jovem em formação que rompe com os papéis tradicionais de menina, moça e mulher obediente para viver sua liberdade.

Além desses romances, destacamos alguns contos contemporâneos que deslocam o privilégio masculino para detalhar o quanto a mulher é vítima de uma estrutura perversa de controle e punição, como em "Venha ver do pôr de sol" (1970), de Lygia Fagundes Telles, e "A língua do P" (1974), de Clarice Lispector. Nesses contos, o desnudamento das engrenagens de violência fica mais explícito, denudando "paradigmas culturais" que estão por trás da violência contra a mulher (GOMES, 2014).

Diante das especificidades e contradições que dão sustentação a essa violência, identificadas tanto na sociedade como nas narrativas da literatura brasileira, este artigo abre o debate sobre as regulações e normas que dão sustentação à violência doméstica pela interpretação dos valores morais masculinos, descritos na obra Contos de amor rasgados (1986), de Marina Colasanti. Esse livro é composto por minicontos que exploram temas como paixão, amor, infidelidade, ciúme, entre outros, próprios do cotidiano de um casamento, descrevendo também a violência sofrida pela mulher nesse espaço, com destaque para o cárcere privado e para o feminicídio. Especificamente, investigamos os valores sociais da "questão da honra" como justificativa para o assassinato da esposa no casamento. Para isso, analisaremos o assédio psicológico e a traição imaginária, no conto "Para que ninguém a quisesse", e a crise de masculinidade em "Com a honra no varal".

Esses minicontos desmascaram a estrutura social que condena as mulheres a punições e ao feminicídio pela crise de masculinidade e subjetividade de um marido traído. Para nossa análise, recorremos a uma base teórica interdisciplinar, respaldada pelos estudos antropológicos. Partiremos das contribuições feministas para a ampliação dos sentidos da violência contra a mulher, levando em conta que essa violência é parte de outra, estrutural, hegemônica e reproduzida pelas normas sociais. Dentro dos estudos acerca da normatização das regras de gênero, debateremos sobre as desregulações, propostas de Judith Butler (2014), a obsolescência da honra familiar, articulada por Lia Zanotta Machado (2014), e a crise de masculinidade, identificada por Henrietta Moore (2000). 


\section{A estrutura da violência de gênero}

A agressão contra a mulher é parte de uma complexa rede de valores que dão sustentação aos diferentes tipos de violência doméstica e nos convida a uma reflexão sobre as causas de sua recorrência, pois nos interessa analisar se se trata da manutenção de uma norma simbólica ou de um desvio de comportamento individual. Em outras palavras, está em jogo analisar se essa violência é representada como ruptura ou como uma continuidade nos textos de Marina Colasanti. Tais questionamentos fazem parte de uma estratégia de revisão dos valores sociais que fundamentam a violência de gênero. Em tal empreitada, precisamos entender como os mecanismos morais são incorporados às práticas sociais.

Por fazer parte dessas práticas, a violência contra a mulher precisa ser analisada pelo duplo movimento que a impulsiona: as instâncias das regulações e as operações de poder. Tanto seu campo simbólico quanto a maneira como ela se repete socialmente são relevantes para uma visão mais ampla dos valores que dão sustentação a esse ato. Judith Butler propõe um deslocamento do imaginário simbólico para as normas culturais generificadas da imposição do poder masculino, visto que a norma é um produto cultural que se mantém pela citação, isto é, "somente pela virtude de seu poder repetido de conferir realidade, é que a norma é constituída como uma norma" (BUTLER, 2014, p. 267).

Diante das tensões entre a "legitimação dos valores iguais de gênero" e os "valores de longa duração dos códigos relacionais da honra", destacamos a questão da honra como um contrato simbólico do casamento que reforça as desigualdades de gênero (MACHADO, 2014, p. 111). A crise de masculinidade faz parte desse repertório e é antecedida por uma crise da representação, que tem como pano de fundo "conflitos e estratégias sociais ligadas" aos modos de representação (MOORE, 2000, p. 41). Tanto a honra familiar como a crise de masculinidade fazem parte desses conflitos sociais que precisam ser mais bem debatidos.

No Brasil, a violência contra a mulher vem de longa data e é parte da cultura patriarcal herdada de uma sociedade excludente e extremamente controladora e disciplinadora. Logo, como parte de normas coletivas, essa violência "não é exterior ao seu campo de aplicação", pois "é produzida na produção desse campo" (BUTLER, 2014, p. 267). Ao reconhecermos a violência como uma norma, realizada dentro do campo de regulação de gênero, pretendemos fazer uma reflexão sobre os subsídios simbólicos que 
insistem em aprisionar a mulher a valores masculinos.

Portanto, estamos diante de um debate que perpassa a questão da violência como parte do imaginário de controle patriarcal para se reestruturar por meio de reflexões acerca dos conceitos de sexo/gênero e poder que confirmam que há "relações desiguais de gênero", quando identificamos o elogio masculino da força e da agressividade (MACHADO, 2014, p. 124). Para desnudar as sutilezas com que a violência é regulada, tentamos fugir de categorias homogeneizantes, quando pensamos em causas e contextos e quando buscamos compreender as relações de poder, pois os valores relacionados ao patriarcado também estão se adaptando aos novos contextos. Segundo Wânia Pasinato, o patriarcado "sofreu transformações para garantir sua sobrevivência num mundo em que os papéis sociais de gênero estão mudando em velocidade vertiginosa" (PASINATO, 2011, p. 237).

Outro aspecto usado culturalmente para invisibilizar essa violência está relacionado à relativização do assédio sexual como exercício da masculinidade. Minimizar a responsabilidade do agressor faz parte do repertório popular. Tal comportamento pode ser identificado nas interpretações da violência sexual, nas quais a mulher ainda é vista como "culpada", quando sorriu, ou usou uma roupa mais sensual, "dando oportunidade" ao violador de agir. Tal forma de relativização se enquadra como parte das tênues fronteiras entre o assédio e a fantasia masculina, que estão relacionadas aos processos de representação "tanto individual como social" (MOORE, 2000, p. 43).

Além disso, em volta dessa estreita fronteira entre violência e fantasia, repete-se um discurso de medo das mulheres que passa pela valorização do poder masculino no qual "o temor e medo das mulheres, ou o sentimento de culpa das mulheres foram construídos reciprocamente pela legitimação do poder de gênero instaurado legalmente de controle e castigo dos homens, com a recíproca culpabilização das mulheres" (MACHADO, 2014, p. 108). Portanto, a violência de gênero é parte de um campo de luta em que velhos padrões são impostos "de maneira transversal", nos quais o corpo feminino é mantido aprisionado ao desejo do homem (PASINATO, 2011, p. 239).

Questionando essa regulação de gênero, a ficção de Marina Colasanti nos proporciona uma densa reflexão acerca das normas que dão sustentação, especificamente, à violência doméstica. Sua literatura é construída por um modelo paródico de revisão dos papéis tradicionais que brincam com valores morais e sociais. Tal particularidade de revisar 
e deslocar o imaginário masculino opressor e a submissão feminina revela uma "literatura pós-moderna", atravessada por "questões ideológicas e políticas" por priorizar representações caricatas da masculinidade tradicional. Essa literatura, em que feminismo e desregulação de gênero se misturam, faz parte das estratégias estéticas dos textos pós-modernos, conforme nos ensina Linda Hutcheon (1993, p. 05). Na continuidade deste artigo, identificamos as particularidades da estética de desregulação de gênero, de Marina Colasanti.

\section{As regras da violência doméstica}

A literatura de Marina Colasanti é marcada por um olhar feminista que desloca valores patriarcais e verdades hegemônicas acerca das relações matrimoniais. Seu universo familiar é um espaço de descentramento e de questionamento das identidades femininas submissas. Seus clássicos infantis da coletânea Doze reis e a moça no labirinto do vento (1978) trazem sátiras do imaginário dos contos de fadas com propostas de revisão da história da mulher. Essas narrativas descrevem protagonistas donas de suas histórias, que procuram seus parceiros e se afastam deles quando se sentem oprimidas. Elas não aceitam o destino de viver à sombra de um príncipe, pois rompem com as regulações próprias do gênero feminino: obediente, submissa e esposa.

Nessas representações literárias, que revisam o imaginário dos contos de fadas, Marina Colasanti desregula as normas de gênero, a partir do modelo paródico de narrar, pois retoma representações femininas homogêneas para deslocá-las para espaços de liberdade. Esse modelo literário é retomado, de forma particular, em Contos de amor rasgados, pois são privilegiadas as descrições irônicas de homens condicionados a repetir apenas as normas do controle e de punição. Essas personagens masculinas, ridicularizadas por atitudes patéticas, são expostas como parte de uma estrutura social, mas com particularidades subjetivas que expõem a estética de desregulação de gênero.

Essa coletânea de minicontos pode ser vista como uma revisão feminista da violência doméstica, uma vez que traz homens vazios e sem rumo após o ato de violência. Historicamente, esses contos antecipam o debate sobre os direitos da mulher, que foram reconhecidos pela Constituição Federal de 1988, mas só ganharam espaço na legislação brasileira após a criação das Leis Maria da Penha (2006) e do Feminicídio (2015), que são exemplos de 
lutas e conquistas feministas.

Além disso, esse livro tem a proeza de questionar o imaginário da honra masculina a partir da representação da crise de identidade de homens sensíveis que se veem desnudados diante de seus atos de punição. Ao deslocar a lógica simbólica do criminoso, Marina Colasanti abre o espaço literário para um debate mais amplo acerca dos valores masculinos, sem cair nos clichês. Sua estética traz uma reflexão acerca da contradição do casamento, calcado em valores obsoletos, como a honra, em oposição ao processo civilizatório que ampliou o "debate em torno da desigualdade social entre os sexos", pois não é o marido, "enquanto indivíduo", que concede a liberdade a uma mulher. "Ela se fundamenta na estrutura da própria sociedade" (ELIAS, 1994, 184).

Partindo dessa abordagem, exploraremos as particularidades do texto literário pós-moderno para argumentar como a violência doméstica é regulada por regras sociais que visam ao controle da sexualidade feminina. Os contos da coletânea Contos de amor rasgados trazem personagens sem nomes, marcados pelos papéis de gênero engendrados na cultura patriarcal, centrada nas regulações de gênero que primam pela moral masculina. Partimos para a identificação do modelo paródico na análise da traição imaginária no miniconto "Para que ninguém a quisesse", que retrata a proporcionalidade do aumento da violência por meio da vigilância do corpo da esposa.

O conto se inicia narrando o cotidiano de um casal, expondo o ciúme doentio do marido, que vai aniquilando a autoestima da mulher e o prazer entre eles. O marido impõe um severo controle ao corpo da esposa por medo de ter sua honra manchada socialmente. O convívio com amigos e a participação em festas ficam para trás, quando ele se sente ameaçado pela beleza da mulher, dando início à tortura psicológica. Especificamente, esse tipo de violência é consequência de uma "ameaça imaginária", que faz parte da regulação de gênero, visto que "esposas são muitas vezes espancadas por infidelidades imaginárias, o que torna a violência e a ameaça de violência mais eficaz como meio de controle social" (MOORE, 2000, p. 39).

A ameaça imaginária produz duras normas de controle do corpo da mulher e do confinamento em cárcere privado. No conto, a imposição do controle é vertical, não há espaço para a voz da mulher. Temos acesso ao discurso disciplinador do marido: "mandou que descesse a bainha dos vestidos e parasse de se pintar" (COLASANTI, 2010, p. 111). Esse controle é um dos primeiros passos do homem em crise com seus valores pessoais e 
sociais, relevando contradições de diferentes discursos, coexistentes em um mesmo espaço (MOORE, 2000, p. 27).

No segundo momento, o marido passa a controlar o comportamento social da esposa, visto que a primeira imposição não foi suficiente para reaver sua confiança. Ele passa a impedir que ela explore sua silhueta, exigindo que "eliminasse os decotes, jogasse fora os sapatos de saltos altos" (COLASANTI, 2010, p. 111). Nesse caso, temos um narrador que não dá voz à mulher, mas ironiza a postura masculina de generificar o corpo feminino apenas como extensão dos seus medos e receios. O ciúme doentio vai aniquilando, aos poucos, a autoestima da mulher e o prazer entre eles.

Sem liberdade, sem reconhecimento das regras básicas para uma boa convivência e sem o respeito às normas sociais, o casamento fica vulnerável, pois o "autocontrole" deixa de ser praticado por esse marido, que não respeita hábitos internalizados pela civilização para praticar normas obsoletas de conduta social (ELIAS, 1994, 106). Em um relacionamento com desconfianças, a falta de civilidade transforma a ausência de autocontrole em imposições sem limites. Tal incapacidade é produtora de violência e está relacionada à "administração que outras pessoas fazem de si mesmas enquanto indivíduos marcados por gênero" (MOORE, 2000, p. 39).

Ao construir um homem tão obcecado pelo controle do corpo da mulher, Colasanti reforça que o descontrole masculino nasce do contrato simbólico de que o casamento dá direito de posse do corpo feminino. Diante da insegurança e do ciúme, o desespero do marido se torna evidente, quando resolve amputar a beleza da esposa: "pegou a tesoura e tosquiou-lhe os longos cabelos" (COLASANTI, 2010, p. 111). Essa ação desnuda a violência descomedida do assédio psicológico masculino. Nesse caso, vai além do assédio, pois se trata de tortura.

Ao descrever um homem em crise, desconfiado e em vigilância de uma traição imaginável, essa narrativa abre uma reflexão acerca do controle imposto por maridos ciumentos. Em seus estudos sobre a representação do corpo feminino na literatura brasileira, Elódia Xavier reconhece que a autoria feminina, nas últimas décadas do século XX, passa a questionar o "corpo disciplinado", quando desloca esteticamente "esquemas predeterminados, e repressores" (2007, p. 59).

No conto de Colasanti, esse deslocamento acontece quando a esposa não corresponde à imposição do marido. Se, antes, havia uma vida social, se ela podia acompanhá-lo em encontros com amigos, aos poucos esse comportamento passa a ser visto como perigoso para o marido inseguro. 
Com essa visão, esse conto questiona a violência própria do padrão patriarcal que só aceita mulheres submissas ao desejo exclusivo do marido. Tal exclusividade é excessiva e doentia, mas aceita socialmente quando se trata de relações familiares.

Com o ato final de cortar os cabelos da esposa, eliminando a última marca feminina desta, o marido também lhe corta a possibilidade de vida social. Depois de aprisioná-la aos seus ciúmes doentios, a esposa entra em depressão e passa a viver em silêncio, confundindo-se com as sombras da casa: "E continuou andando pela casa de vestido de chita, enquanto a rosa desbotava sobre a cômoda" (COLASANTI, 2010, p. 112). Com isso, a personagem feminina se opõe a seguir as normas do marido, pois, mesmo sem romper de forma definitiva, ela opta por manter sua construção de feminino e se nega a ser essa mulher controlada.

Além do questionamento do corpo disciplinado, esse conto retoma o debate acerca do espaço do lar no imaginário da mulher. Como parte da estrutura opressora, a casa, representada nesse conto, deixa de ser uma "casa protetora", para ser usada como uma "casa jaula", quando passa a ser o berço da clausura, imposta pelo marido (XAVIER, 2012, p. 41).

Com essas marcas estéticas de denúncia da opressão do corpo da mulher, essa narrativa questiona a regulação de gênero e expõe as contradições desse processo, pois há dois momentos - um de liberdade da mulher e outro de controle e punição. Essa mudança de comportamento é justificada pela falta de segurança que o marido passa a ter, registrando outras posições identitárias que ameaçam o casamento, uma vez que "os indivíduos constituem seu sentido de si mesmos - suas autorrepresentações como sujeitos - por referência a várias posições de sujeito frequentemente contraditórias entre si e não a uma posição singular de sujeito" (MOORE, 2000, p. 23). Tais contradições estão presentes na construção de uma masculinidade opressora e de uma feminilidade resistente.

Esteticamente, o modelo paródico pode ser identificado nos excessos de controle e de vigilância masculinos que beiram à loucura. Tal opção estética pode ser vista "como estratégia de denúncia", pois traz a paródia como uma forma estética de deslocar as posições tradicionais de gênero e "brinca com a justificativa da questão da honra como motivo do feminicídio" (GOMES, 2015, p. 210).

Tais comportamentos são descritos proporcionalmente ao aumento do ciúme e à diminuição da confiança na esposa. Como visto, a casa vai se transformando em uma prisão à medida que a insegurança masculina 
aumenta. Com o cárcere privado, resta à mulher o silenciamento para não perder referência ao seu corpo sensual e exuberante. Portanto, o tom irônico da narrativa denuncia a tentativa de naturalização do corpo da mulher como uma extensão da masculinidade. Isso é frustrado pela resistência da esposa que prefere o silêncio e não interage com aquele tipo de regulação.

No plano ideológico, o modelo paródico de Colasanti desloca as regras de lugar e aponta a frustração masculina como consequência para a violência doméstica. Esse tipo de representação reforça o debate acerca da criminalização da violência doméstica por se tratar de crimes do espaço privado e íntimo dos casais. Para Lia Zanotta Machado, a desqualificação desse crime, como de "bagatela" ou de esfera íntima, reafirma a fronteira da casa como um "espaço de poder desigual e de violência" (MACHADO, 2014, p. 124). Ao denunciar o território da casa como um espaço de tortura, o modelo literário abre debate acerca das sutilezas desse crime e da importância de rejeitarmos todas as formas de assédio moral e psicológico nas relações matrimoniais.

Na sequência, demonstraremos como o modelo literário de Colasanti vai além do deslocamento do excesso de masculinidade e da representação da "traição imaginável" para questionar os valores morais por trás do feminicídio.

\section{A punição como regulação moral}

O modelo paródico de Colasanti é retomado nas cenas que descrevem o feminicídio em Contos de amor rasgados. Esse crime é ironicamente questionado por ser descrito como parte de regulação de gênero que visa punir o desrespeito à "ordem do pai" (PASINATO, 2011, p. 230). As cenas dessa violência estão presentes em "Com a honra no varal", que desnuda normas simbólicas e sociais em torno da honra masculina e da fidelidade feminina, pois expõe as contradições do sujeito masculino em crise com valores próprios da honra familiar (MACHADO, 2014, p. 107).

Nesse texto, temos uma mulher infiel, aprisionada e assediada até a hora da morte, dando destaque para a tortura psicológica. Esse modelo literário abre o debate sobre a normatização do feminicídio como uma regulação, visto que a estrutura de gênero é mais uma vez questionada pelo olhar paródico de Colasanti, que descreve cenas mecânicas de um homem que tenta se vingar da esposa infiel, mas que é surpreendido por valores civilizatórios antes de concluir seu crime. 
Desde o título, "Com a honra no varal", destaca a questão da honra masculina como norte dos valores matrimoniais. No intuito de punir a esposa, ele a mantém em cárcere privado com a ameaça de matá-la, pois passa a planejar a morte dela. O crime premeditado explicita a vingança como o único código de honra possível. Conforme denota o título, a roupa suja e a honra masculina devem ser limpas e expostas socialmente. Nesse caso específico, em volta da honra família, há cobranças relacionadas "à honestidade, isto é, fidelidade ou virgindade das mulheres e que produzia, como contraparte, a submissão e a vergonha das e nas mulheres" (MACHADO, 2014, p. 107).

Ao descrever a esposa encarcerada, esse conto retrata uma estrutura de gênero que destina os sombrios territórios do sacrifício feminino como parte dos contratos sociais. No universo ficcional, a representação do feminicídio está atrelada à regulação do controle do corpo da mulher. A metáfora da necessidade de lavar a roupa reforça a obrigatoriedade de limpar a honra do marido traído. Essa restauração se dá por meio do prazer que ele passa a ter, ao executar um crime premeditado: "preparando-se para abrir o nicho na parede, não tinha dúvida: a esposa adúltera seria emparedada viva" (COLASANTI, 2010, p. 185).

Essa narrativa revela um marido que planeja os mínimos detalhes daquela execução. Ele se prepara para enterrar, viva, sua companheira, a mulher está "trancada no banheiro" e "aguardava seu destino", enquanto isso ele "esmerava-se no acerto justiceiro" (COLASANTI, 2010, p. 185). No contexto familiar, não cabe à mulher o papel de ser infiel. A regulação de gênero patriarcal expurga esse comportamento e prega a punição como um ato simbólico de justiça moral.

Tal representação retoma a discussão das posições masculinas hegemônicas que reservam à mulher o controle pela cultura "da honra familiar e da honra masculina", pregando comportamentos de fidelidade ou virgindade das mulheres, que reforçam moralmente, "como contraparte, a submissão e a vergonha das e nas mulheres" (MACHADO, 2014, p. 107). Além disso, o conto ironiza a satisfação do marido, que tenta limpar sua honra com o castigo fatal, demonstrando alívio ao saber que a mulher será punida: "Ele antegoza o prazer que virá nos dias futuros" (COLASANTI, 2010, p.185).

Nesses casos, não só os valores pessoais estão em jogo, mas há um padrão cultural a ser respeitado: a valorização da honra. O modelo paródico de Colasanti expõe um sujeito masculino que executa um assassinato 
a partir da ideia de limpeza e de pôr ordem moral na família. Ao jogar com esses valores, o texto literário expõe uma crise entre valores pessoais e coletivos. Tal crise é "resultado do conflito entre estratégias sociais que estão intimamente ligadas a esses modos de representação" (MOORE, 2000, p. 41). A traição é vergonhosa para um homem, por isso a vingança é explorada como alívio pessoal de justiça.

Todavia, no modelo literário de Colasanti, esse alívio é colocado de sobreaviso, pois o agressor hesita em matar sua esposa quando pensa na futura desorganização da casa. Quando o homem vingativo deixa de pensar no sacrifício, ele passa a perceber o quanto a mulher é importante para a estrutura organizacional da casa desarrumada, pois ninguém "pôs a mesa", "nenhum almoço o espera" e descobre, "junto à cama descomposta, ninho de sujos panos embolados, que ninguém troca ou lava, onde ninguém, além dele, se deita" (COLASANTI, 2010, p.184).

Com esse quadro de dependência da mulher, de forma humorada, o conto retoma a ideia de punição e passa a explorar a possibilidade do cárcere, já que reconhece que pode deixar a mulher presa na parede, mas com a possibilidade de saída, trocando os tijolos que iam enterrá-la por "fechar a abertura apenas com uma porta" (COLASANTI, 2010, p.184). Com essa reviravolta na mente do criminoso, o modelo literário volta a deslocar os valores de lugar e expõe, de forma cômica, como a vingança é patética. Ao brincar com um sujeito masculino em crise com sua agressividade, esse conto reforça sua postura feminista de questionamento da brutalidade masculina, responsável pela "maior parte dos homicídios de mulheres" que são cometidos em espaços domésticos "por seus parceiros íntimos ou conhecidos" (PASINATO, 2011, p. 242).

Com a desistência do assassinato por questões práticas da vida doméstica, "Com a honra no varal", no plano estético, expõe o riso como uma marca paródica, que ecoa como uma grande piada desse tipo de regulamentação. Tal contraste entre o crime planejado e a desistência por uma questão prática reforça o quanto a violência contra a mulher é um código de defesa de valores ancestrais ultrapassados. Isso acontece porque a honra tornase obsoleta diante das necessidades básicas dos sujeitos civilizados, visto que "o processo civilizador, a despeito da transformação e aumento das limitações que impõe às emoções, é acompanhado permanentemente por tipos de libertação dos mais diversos" (ELIAS, 1994, p. 184).

Para Rita Segato, esse tipo de violência reforça os valores morais de uma comunidade, já que o corpo feminino, sacrificado por um homem 
desonrado, poderá ser mais facilmente "naturalizado pela comunidade" (SEGATO, 2005, p. 278). Por esse prisma, o conto revisa o sistema punitivo, compartilhado coletivamente. O exagero da cena tenta sintetizar, de forma satírica, o quanto a estrutura de gênero é cega e fascista ao propor o sacrifício da mulher adúltera. Com essa visão, o texto literário parodia o feminicídio por defesa da honra, opondo-se a um padrão cultural de controle e posse do corpo da mulher. Esse questionamento é condizente com as obras pósmodernas de autoria feminina que primam pela revisão de valores morais mantidos para beneficiar o sujeito masculino (HUTCHEON, 1993, p. 09).

$\mathrm{Na}$ representação literária, destacamos que está em jogo o fato de a personagem masculina ser traída pela necessidade de ter uma mulher para executar as tarefas domésticas. Esse jogo que o conto propõe com um marido indeciso é uma estratégia estética de reflexão acerca dos conflitos sociais entre civilidade e feminicídio. Infelizmente, na contemporaneidade, nos casos de violência doméstica, tal brutalidade não está restrita à ficção de autoria feminina e muitos homens estão deixando de lado as conquistas do processo civilizador para resgatar códigos obsoletos de honra. Isso é evidente para $56 \%$ dos/as brasileiros/as, entrevistados/as pelo Instituto Patrícia Galvão, ao afirmarem conhecer homens que cometeram violência contra uma companheira ou ex-companheira (BRASIL, 2014, p. 56).

Como uma estética da desregulação da violência, esse modelo paródico traz a visão do quanto a violência de gênero é praticada como parte de contratos imaginários, que rejeitam o processo civilizatório. Ela é cometida por maridos em crise com sua honra e pelos valores morais obsoletos para a legislação brasileira. No conto, a mulher é punida por um marido possessivo e ciumento, que explora a ameaça de assassinato como uma força de punição e vingança. Todavia, a fragilidade desse sujeito, traído por questões de civilidade, expõe a mecanização da honra como uma forma de punição. Ao construir personagens masculinas que raciocinam, Colasanti desnuda a barbárie da violência doméstica, ironizando a obsolescência da honra que motiva o ato mecânico do feminicídio.

\section{Considerações finais}

Ao identificarmos, no texto literário de Colasanti, o modelo paródico de revisão da violência de gênero, constatamos o deslocamento de valores morais, pautados pela questão da honra masculina, em confronto direto com questões civilizatórias. Em comum, essas narrativas explicitam o 
fascismo das regulações de gênero por meio de atos e normas que castigam e culpam as mulheres que estão fora dos padrões familiares conservadores. Suas personagens masculinas são exibidas com dúvidas acerca de normas próprias do processo civilizatório, mesmo depois de cometer crimes contra suas esposas. Nesse processo representacional, a crise de masculinidade está articulada por uma "crise identitária", exposta pela negação da masculinidade opressora (MOORE, 2000, p. 43).

Tal modelo estético desloca a postura punitiva dos agressores para posições subjetivas que expõem os contratos simbólicos por trás da violência de gênero. Em "Para que ninguém a quisesse", a traição imaginária ganha uma versão trágica de uma mulher que vai se transformando em um zumbi à medida que o controle aumenta. Essa estética da desregulação é reforçada pela caricatura do marido obsessivo. A imagem deformada desse homem agressor é uma forma de revisão da regulação do feminino, pois expõe o "excesso" dos processos normativos de gênero (BUTLER, 2014, p. 272).

Quando narra o feminicídio em "Com a honra no varal", Colasanti vai adiante e desloca o assassino para uma crise de valores educacionais. A personagem masculina desse conto entra em crise com os valores civilizatórios. Ele desiste de assassinar a esposa para manter sua casa organizada e ficar livre das preocupações domésticas. Tal opção cômica ridiculariza a questão de honra como um dos princípios reguladores da violência doméstica, expondo o quanto ela é obsoleta diante de valores sociais mais amplos.

Nos dois contos analisados, o texto literário ironiza e contesta práticas sociais, pois, por meio da paródia, se opõe a discursos institucionais que "produzem a alta tolerância em relação à violência contra as mulheres" (MACHADO, 2014, p. 124). Essa tolerância é um desafio a ser superado pela sociedade brasileira, assombrada por tantos casos de feminicídios nos últimos anos. Um dos caminhos é o aumento de penas para os crimes domésticos, conforme constata a pesquisa do Instituto Patrícia Galvão, quando identifica que $85 \%$ da população brasileira acreditam que os agressores/assassinos de mulheres não têm penas condizentes com seus crimes (BRASIL, 2014, p. 50).

Como reflexão final, reconhecemos o modelo literário de revisão de Colasanti como uma tradução feminista, pois se trata de uma estética pós-moderna que tanto desregula as questões de gênero como apresenta uma performance ideológica de resistência. Essa estética desmascara a normatização de gênero para expor os meandros das práticas sociais 
opressoras e relativizadas nos espaços domésticos. Tal tessitura literária é consolidada pelo ritmo paródico de sua narrativa que desloca o fixo e o hegemônico por meio do irônico e o do caricato.

\section{Referências}

BRASIL.

(2014). Pesquisa sobre a Percepção da sociedade sobre violência e assassinato de mulheres. São Paulo: Data Popular e Instituto Patrícia Galvão.

BUTLER, Judith.

(2014). Desregulando gênero. Cadernos Pagu, vol. 42, p. 249-274, Campinas.

COLASANTI, Marina.

(2010). Contos de amor rasgados. 3. ed. Rio de Janeiro: Record.

ELIAS, Norbert.

(1994). O processo civilizador. 2. ed. Rio de Janeiro: Jorge Zahar Ed.

GOMES, Carlos Magno.

(2014). 0 femicídio na ficção de autoria feminina brasileira. Estudos Feministas, v. 22, n. 3, p. 781-794, Florianópolis.

GOMES, Carlos Magno.

(2015). “Ecos sociais do homicídio de mulheres na narrativa contemporânea". In: KAMITA, Rosana; FONTES, Luísa (Orgs.). Mulher $e$ literatura: vozes consequentes. Florianópolis: Mulheres, p. 197-214.

HUTCHEON, Linda.

(1993). La política de la parodia postmoderna. Traducción del inglés por Desiderio Navarro. Revista Criterios. La Habana, edición especial, p. 187-203. Disponivel em: http://www. criterios.es/pdf/hutcheonpolitica.pdf. Acesso em 15 de mai. de 2017.
MACHAD0, Lia Zanotta.

(2014). “0 medo urbano e a violência de gênero". In: MACHAD0, Lia Zanotta; BORGES, Antonádia Monteiro; MOURA, Cristina Patriota de.(Orgs.). A cidade e o medo. Brasília: Verbena/Francis, p. 103-125.

M00RE, Henrietta.

(2000). Fantasias de poder e fantasias de identidade: gênero, raça e violência. Cadernos Pagu, v. 14, p. 13-44, Campinas.

PASINATO, Wânia.

(2011). Feminicídios e as mortes de mulheres no Brasil. Cadernos Pagu, v. 37, p. 219-246, Campinas.

SEGATO. Rita Laura.

(2005). Território, soberania e crimes de segundo Estado: a escritura nos corpos das mulheres de Ciudad Juarez. Estudos Feministas, v. 13, n. 2, p. 265-285, Florianópolis.

XAVIER, Elódia.

(2007). Que corpo é esse? 0 corpo no imaginário feminino. Santa Catarina: Mulheres.

XAVIER, Elódia.

(2012.) A casa na ficção de autoria feminina. Florianópolis: Mulheres.

\section{Recebido em}

julho de 2017

\section{Aprovado em}

fevereiro de 2018 


\section{Memorial $^{1}$}

Maria Claudia Coelho

Quando me perguntam sobre textos ou autores marcantes na minha trajetória, respondo sempre: "Simmel e 'A Metrópole e a Vida Mental"". Vindo de uma graduação em História na PUC-Rio, concluída em 1985, fui apresentada à obra de Georg Simmel em um curso de Antropologia Urbana oferecido pelo Prof. Gilberto Velho em 1986, no primeiro ano do meu Mestrado no PPGAS do Museu Nacional da UFRJ. O refinamento da passagem entre os níveis "macro" e "micro" da vida social - ali expressos na articulação entre as características da vida na metrópole e o surgimento da subjetividade blasé - definiu a linha-mestra central da minha atuação intelectual como professora e pesquisadora.

O programa daquele curso entrelaçava a obra de Georg Simmel às reflexões de Richard Sennett e Christopher Lasch sobre o narcisismo contemporâneo, realçando assim as possibilidades de construção das dimensões "íntimas" - e, naquele momento inicial da minha formação, "íntimo" podia significar "subjetividade", "emoções", " psiquismo" e outras categorias deste vasto (e algo indefinido) campo semântico que parecia abarcar um sem-fim de aspectos da experiência individual. O que me fascinava era aquilo que, creio, encanta a todo antropólogo em formação: descobrir a sociedade e a cultura nos espaços recônditos da "natureza" e do "indivíduo".

Perceber, assim, que os sentimentos de vazio e absurdo que definem o indivíduo moderno podem ser entendidos como se originando das condições de vida na modernidade, ou que o descrédito das convenções sociais pode ser retraçado historicamente por meio de uma reflexão sobre a importância atribuída ao mundo público, pautou toda a linha de reflexão que desenvolvi no mestrado em Antropologia Social no Museu Nacional. A linha de Antropologia Urbana criada por Gilberto Velho, com sua combinação entre a antropologia interpretativista e a sociologia interacionista, apresentava naquela época uma forma típica de construção de objetos de pesquisa: a etnografia de grupos urbanos voltada para a

\footnotetext{
${ }^{1}$ Este memorial foi defendido em 12 de abril de 2018. A banca examinadora foi composta pelos Profs. Helena Bomeny (presidente), Otávio Velho, Luiz Fernando Dias Duarte, Myriam Moraes Lins de Barros e Ceres Víctora.
} 
análise de seus "ethos" e "visão de mundo".

Àquela época, eu convivia intensamente com estudantes de teatro, e sua forma de estar no mundo me impressionava muito, em particular aquilo que me parecia um paradoxo insolúvel: como conciliar a certeza de cada um de que teria sucesso na profissão de ator se o mundo à sua volta lhes mostrava que pouquíssimos conseguiriam? De onde cada um deles tirava a certeza de que estaria entre os eleitos?

Esse paradoxo esteve no cerne da minha dissertação de mestrado, intitulada "Teatro e Contracultura: um estudo em antropologia social" e defendida em 1989. Nela, realizei uma etnografia de uma escola de teatro, na qual entrelacei duas questões principais: a análise do individualismo que, em sua versão exacerbada, conduzia ao sujeito blasé de Simmel e ao sujeito narcísico de Sennett e Lasch; e a discussão sobre as rupturas e continuidades da contracultura naquele mundo artístico.

Havia naquele universo um cultivo de noções como "alternativo" ou "cabeça aberta", bem como uma crítica à "burguesia" e ao "sistema", que a mim, nascida em 1964 e conhecendo o movimento contracultural por caminhos bibliográficos, parecia atestar uma permanência de seu ideário. Entretanto, quando conversava com amigos mais velhos sobre essa percepção, encontrava, na melhor das hipóteses, uma benevolência complacente, ancorada na célebre citação "o sonho acabou".

Formulei então uma hipótese. Se, por um lado, não podia deixar de dar crédito àquela autoridade que provinha da experiência de meus amigos que haviam vivido as décadas de 60 e 70 na sua juventude, por outro lado não podia compreender como não percebiam o quanto havia permanecido daquele ideário. Como conciliar essas duas divergências de percepção? A hipótese que desenvolvi na conclusão foi de que a experiência vivida não lhes permitia perceber a dimensão de continuidade que havia ali, fazendo com que seu próprio desencanto acentuasse a dimensão de ruptura com aquilo que para eles fora sonho, projeto de vida; por outro lado, o contato meramente bibliográfico com aquele período não permitia a mim perceber as diferenças de intensidade e vitalidade, o que fazia com que eu acentuasse a dimensão de continuidade entre a contracultura dos anos 60 e 70 e os meus jovens estudantes de teatro de fins dos anos 80. Minha "solução de conciliação" foi de que estávamos diante de uma versão pálida do ideário contracultural, afetado em sua essência por aquele narcisismo contemporâneo: mudar a si não mais para mudar o mundo, mas como um projeto em si mesmo. 
A dissertação produziu algumas de minhas primeiras publicações - um artigo nas "Comunicações" do Museu Nacional, em um número editado por Gilberto Velho sobre estilos de vida jovens; um texto na Ciência Hoje sobre as categorias "mana" típicas do universo teatral; e um comentário sobre as semelhanças entre as profissões do ator e do antropólogo nos Cadernos de Teatro d'O Tablado. O tema, contudo, não se esgotou aí, e foi um belo reencontro orientar, vinte anos depois, a tese de doutorado de Ana Amélia Brasileiro Medeiros Silva sobre a criação teatral em monólogos, com forte inspiração teórica na obra de Georg Simmel.

Essa incursão inicial pelo mundo teatral deixou marcas profundas, tanto do ponto de vista das escolhas teóricas quanto do ponto de vista dos interesses temáticos. Do ponto de vista teórico, ficou o fascínio pelos interacionistas: a metáfora do theatrum mundi, do mundo como um palco, da vida como teatro, do indivíduo como ator, me acompanha desde então. Os atores - aqui não mais como metáfora para o sujeito em sociedade, mas como escolha profissional - continuaram a me impressionar: seu modo de vida, seu jeito de olhar para o mundo, o universo em que vivem, permaneceram comigo, tendo constituído o objeto de minha tese de doutorado, realizado no IUPERJ no período de 1991 a 1994.

Ao longo dessa fase inicial de minha formação, durante o mestrado e o doutorado, atuei como professora no Departamento de Comunicação Social da PUC-Rio (iniciando logo após concluir a graduação, em 1986) e, alguns anos depois, como professora da Faculdade de Comunicação Social da UERJ (iniciando em 1993). Nessas primeiras inserções profissionais, lecionei a disciplina de Teoria da Comunicação, estruturada em dois semestres. No primeiro, o programa girava, essencialmente, em torno da cultura como comunicação; no segundo, a problemática central eram as teorias da comunicação de massa.

O tema do ator se encontrou, por ocasião da formulação do projeto para o doutorado, com as teorias da comunicação de massa. Da preocupação interacionista com o "mundo artístico teatral" passei para o universo televisivo, e em particular para a temática da fama. Para a fama convergiam os interesses pelo ator e pela comunicação de massa, o que levou à elaboração de minha tese de doutorado, defendida no IUPERJ em 1994 sob orientação do Prof. Luiz Eduardo Soares: "Anonimato e Celebridade: a condição individual e a experiência da fama".

A tese aborda a experiência da fama sob uma tríplice perspectiva: sua representação nos discursos da comunicação de massa, em particular os 
discursos cinematográficos; sua percepção por aqueles que a vivem na posição do fã, utilizando como dados cartas enviadas a atores e atrizes de televisão; e sua experiência por aqueles que a vivem como ídolos, com base em entrevistas em profundidade.

A análise dos discursos cinematográficos baseou-se em um conjunto de sete filmes que abordam a fama, em um continuum analítico que partia das histórias cujo personagem central é o fã; prosseguia para narrativas em torno do desejo de ser famoso; avançava para filmes sobre ídolos e terminava com uma história sobre ostracismo. Tomando por base a visão tão recorrente no campo da antropologia da comunicação de massa de que a indústria cinematográfica é uma instância discursiva de onde emergem os mitos contemporâneos, sugeri que o "mito da fama", tal como narrado nesse conjunto de histórias, é marcado pela melancolia e pela tristeza; longe de estar associado ao glamour, ao sucesso e à felicidade, como sugere o senso comum, a fama é retratada como uma experiência de frustração, solidão, loucura e morte.

O exame da experiência do anonimato, tal como expressa pelos fãs em suas cartas, colocou em relevo dois aspectos: seu anseio pela singularização e o recurso ao discurso amoroso para falar de seus sentimentos pelo ídolo. $\mathrm{O}$ anseio pela singularização pode ser sintetizado na necessidade de saber-se único, expressa na recorrência à expressão "sou seu fã número 1" para falar da força de sua adoração. Há, aí, contudo, um paradoxo, com a recorrência do desejo de evidenciar-se único tornando os fãs ainda mais parecidos entre si, em uma espécie de paroxismo da tensão entre massificação e individualização que ocupou tantos teóricos da comunicação de massa.

O segundo ponto - o recurso ao discurso amoroso - chamou-me a atenção por duas razões: sua recorrência e sua aparente inadequação. Digo "inadequação" do ponto de vista de um observador distanciado, uma vez que o ideal da relação amorosa, ao menos no Ocidente moderno, é marcado pela reciprocidade e exclusividade, ou seja, tudo aquilo que a relação fã-ídolo, por definição, não pode ser. Se é assim, por que o fã fala de amor para seu ídolo? Busquei uma resposta combinando teorias sobre carisma (Charles Lindholm), sobre comunicação de massas (Edgar Morin) e sobre emoções (Marcel Mauss). A hipótese que elaborei então foi a de que o carisma e o amor seriam experiências subjetivamente vizinhas, que compartilhariam um desejo de fusão com o objeto da adoração/do amor, sendo, porém, objeto de valorações diferenciadas pela comunicação de massa, com o sujeito fascinado sendo retratado como louco e doentio 
e o sujeito apaixonado ocupando o lugar do herói moderno. Ora, se o fã consome essas narrativas, e se elas são um "modelo para a interpretação da experiência", entender o que sente com base nessas narrativas é fonte de profundo desconforto emocional. Se, por outro lado, a expressão dos sentimentos é, como dizia Mauss, uma maneira de explicar o que se sente para si mesmo, então expressar o fascínio pelo sujeito carismático sob a forma do enamoramento seria uma maneira de enxergar a si mesmo sob uma luz mais favorável, nesse movimento alcançando também aquela singularização típica do amor moderno.

A terceira parte da tese inverte a perspectiva e aborda a experiência da fama do ponto de vista do ídolo, sua relação com os fãs, com o assédio e, principalmente, com a exposição à própria imagem. Emerge daí uma percepção da fama como algo essencialmente assimétrico: se o anseio central do fã que envia uma carta a seu ídolo falando de seus sentimentos é por uma resposta, por algo que lhe assegure de que foi lido, o estabelecimento de uma reciprocidade de qualquer natureza é justamente aquilo que o sujeito famoso nega. De certa forma, ainda que sem o saber, nega por que disso depende sua fama. Como afirma Elias Canetti em suas reflexões sobre a celebridade em Massa e Poder:

\footnotetext{
“Enquanto alguém se preocupa com os donos das bocas que dizem nomes, enquanto as recruta, as corrompe, as incita ou fustiga, ainda não é totalmente célebre. Neste caso, ele está apenas preparando as bases para o seu futuro exército de sombras. Uma vez atingida, a glória pode permitir-se não ter preocupações com os demais, sem que perca nada com isso". (1983: 442)
}

Mas ser célebre não coloca o sujeito apenas diante do dilema do que fazer com aquele que o distingue com sua adoração, mas também diante do dilema do que fazer consigo mesmo diante dessa adoração. A experiência da fama se assemelha a uma casa de espelhos circense, em que o sujeito é incessantemente submetido a um sem-fim de imagens de si mesmo, todas elas diferentes, em alguma medida distorcidas. Como saber, então, quem se é? O que fazer com tantos olhares que, se por um lado envaidecem, por outro aprisionam?

A sugestão da tese é de que a experiência da fama é uma espécie de panóptico pelo avesso: de um lado, incontáveis sujeitos que olham para um só, sem serem vistos; de outro, um sujeito que é visto, sem ver ninguém. É porque a negação da reciprocidade do olhar é, simultaneamente, estratégia 
de "interacionismo aplicado", empregada conscientemente pelos atores para evitar a aproximação do fã, e recurso teórico para explicarmos a essência da relação fã-ídolo: são olhares que se evitam, ao invés de, na metáfora maior da relação amorosa, olhares que se cruzam.

A tese se transformou em meu primeiro livro, publicado pela Editora da Fundação Getúlio Vargas em 1999, sob o título A Experiência da Fama individualismo e comunicação de massa. Publiquei também diversos artigos, no Brasil, na Inglaterra e em Portugal, abordando facetas diversas das condições do anonimato e da celebridade, e orientei diversos trabalhos sobre temas conexos, entre eles as teses de doutorado de Patricia Coralis, sobre o "culto" a Judy Garland, e de Geraldo Condé, sobre o imaginário da felicidade na comunicação de massa.

Olhando retrospectivamente, pouco mais de vinte anos depois, a tese parece ter concluído um ciclo intelectual e institucional. Três anos depois de terminar o doutorado, realizei um duplo movimento de reorientação profissional: saí da PUC, em uma opção pela dedicação exclusiva na UERJ, ingressando no Programa de Incentivo à Produção Científica (PROCIÊNCIA) em 1997, do qual participo ininterruptamente até hoje, em sete períodos consecutivos; e, internamente à UERJ, transferi-me para a área de Antropologia do então Departamento de Ciências Sociais do IFCH.

Mas, como sabemos, os interesses intelectuais não se encerram abruptamente, ainda que sob uma perspectiva imediata pareçam configurar uma ruptura. Olhando para essa primeira fase, reconheço duas questões que até hoje me acompanham, em cursos, orientações e projetos de pesquisa. A primeira delas está dada em primeiro plano, esboçada já no primeiro parágrafo desse memorial: o problema das configurações contemporâneas da subjetividade moderna, nessa primeira fase concentrado nas obras de Georg Simmel, Richard Sennett e Christopher Lasch. Posteriormente, a esses autores iriam se somar Sigmund Freud e Norbert Elias.

A segunda questão é a atenção, ali ainda embrionária, para as emoções como objeto de estudo das ciências sociais. Na tese, ela está presente na análise do discurso amoroso das cartas dos fãs, em que a leitura de Marcel Mauss das emoções como uma linguagem em que o sujeito explica aos outros e a si mesmo como se sente é referência essencial. Naquele momento, contudo, o estudo das emoções estava ainda subordinado à preocupação com a experiência subjetiva do indivíduo na moderna sociedade de massas, em particular a tensão entre singularização e massificação.

O interesse em estudar as emoções se fez presente aí também em um 
curso oferecido pelo Prof. Luiz Eduardo Soares em 1991, cujo programa combinava um conjunto de referências sobre violência. Lembro até hoje das discussões travadas em sala de aula, em particular pelo ecletismo das escolhas bibliográficas, que combinavam Elias Canetti, Bruno Bettelheim e Michael Taussig (e os cito somente para dar uma ideia da largueza do escopo disciplinar). O curso, para além do interesse pelos textos em si, deixou em mim uma marca profunda: o desconforto com a filiação estrita a matrizes disciplinares rígidas.

Entre esses textos, havia um que se tornaria referência crucial para o projeto de pesquisa que formulei dez anos depois: “Massacre Justo”, de Jack Katz. Esse artigo está presente em minha trajetória intelectual de diversas maneiras: como âncora de inquietações de pesquisa, como bibliografia de cursos oferecidos e como objeto de meus interesses como tradutora. Mora ao lado de "A Metrópole e a Vida Mental" no espaço destinado aos textos imprescindíveis.

Peço agora licença para uma primeira e breve digressão. Em 1998, logo após realizar aquele duplo movimento de reinserção institucional, iniciei uma formação em psicanálise no Círculo Psicanalítico do Rio de Janeiro. A proposta de formação do CPRJ segue o modelo continuado, não havendo uma "conclusão" propriamente dita, ao menos em termos oficiais. Frequentei o Círculo durante cerca de quatro anos, cursando praticamente todo o módulo sobre a obra de Freud e participando de diversas atividades em torno de questões da clínica psicanalítica contemporânea.

Foi nessa época que travei contato com os textos freudianos sobre cultura: O Mal-Estar na Civilização, Psicologia de Grupo e Análise do Ego, Totem e Tabu. Naquele momento, o exercício da clínica psicanalítica se afigurava, para mim, como uma possibilidade concreta de atuação profissional. A academia, contudo, falou mais alto, e hoje - ou pelo menos até esse momento - o saldo principal daquela experiência foi o estreitamento do diálogo interdisciplinar entre antropologia, sociologia e psicanálise, com a formulação de um programa de curso que ofereço regularmente na graduação e na pós-graduação intitulado “Teorias da Modernidade”, em que discuto as teses de Georg Simmel, Sigmund Freud e Norbert Elias sobre a modernidade. Abordo-as como "diagnósticos sombrios da falta e do vazio" em torno de três configurações subjetivas: o sujeito blasé, o homo clausus e o sujeito narcísico. Essas três teses me servem também de âncora para discutir o problema teórico que subjaz àquele fascínio que exerce 
sobre mim, até hoje, "A Metrópole e a Vida Mental": as articulações entre a sociedade e o indivíduo.

Da obra de Norbert Elias, elejo um texto para fazer companhia a "A Metrópole e a Vida Mental" e "Massacre Justo" na minha lista dos "dez mais": A Solidão dos Moribundos. Nele se encontram o problema teórico da articulação indivíduo-sociedade e a questão da dimensão social das emoções, com foco na experiência da solidão. Mas esse pequeno livro tem lugar tão central ainda por uma outra razão: me impressiona muitíssimo a conjugação entre razão e afeto presente no ato em si de lê-lo. Não creio que seja possível compreender a tese ali exposta sem se deixar comover profundamente e não tenho lembrança de alguma outra obra de teoria social que me tenha marcado de maneira tão indelével no plano mesmo da sensibilidade.

O projeto de pesquisa com o qual ingressei no PROCIÊNCIA, em 1997, tinha como objeto as trocas de presentes, encaradas como uma forma de linguagem. Três interlocuções se conjugaram aí: a formação em Antropologia, por meio do Ensaio sobre a Dádiva; as diversas incursões ao COPPEAD da UFRJ, realizadas ao longo dos anos 1990, em convites para discutir as trocas de presentes como uma forma de consumo; e a "conversa" contínua com a área de sociolinguística interacional do Departamento de Letras da PUC-Rio, que despertou então em mim um interesse ainda hoje vitalizado pela interface entre os estudos da interação e os estudos da linguagem.

Dois textos estruturaram aquele primeiro projeto, que tinha como objetivo discutir o ato de presentear como uma forma de comunicação: o Ensaio sobre a Dádiva e um capítulo do livro Humiliation, de William Ian Miller. O Ensaio, para um projeto sobre a dádiva, é referência por demais óbvia, cuja inclusão dispensa maiores explicações (embora, como veremos adiante, sua riqueza de opções teóricas não permita essa saída tão fácil de jogar com a cumplicidade do leitor em relação à centralidade do Ensaio para a teoria antropológica). Já o texto de Miller, para fazer justiça ao efeito que exerceu sobre mim, exige uma atenção mais detida.

Esse efeito começa já no título: "Requiting the Unwanted Gift". Ao começar a ler, me deparei com um primeiro obstáculo: não sabia o significado do verbo "to requite". Pesquisando, encontrei dois campos semânticos distintos. O primeiro remetia para "retribuir, recompensar"; o segundo sugeria "revidar, castigar". 
Fiquei fascinada por esse duplo sentido do termo, ainda mais pela impossibilidade de traduzi-lo preservando a ambivalência proposital do autor. Porque é disso mesmo que trata o texto: o que fazer diante de um presente que não desejávamos receber? Devemos retribuí-lo ou revidá-lo?

É porque, segundo Miller, todo presente traz em si um potencial de insulto, sendo suas regras, portanto, uma gramática, "tão complexa quanto a própria linguagem", e exigindo do falante uma "competência" análoga àquela que dele se espera no plano linguístico.

$\mathrm{O}$ texto de Miller foi, para mim, um divisor de águas, abrindo um sem-fim de possibilidades para a análise da dádiva: seu entendimento como uma forma de linguagem (me permitindo assim dar continuidade à interlocução com os colegas da sociolinguística interacional); sua aplicação das ideias de Marcel Mauss às sociedades complexas, retirando assim o Ensaio do seu lugar, para mim, até então restrito a uma referência canônica do pensamento antropológico; o potencial de insulto da dádiva (rompendo assim com a visão do senso comum que a associa à coesão dos vínculos sociais); e a articulação das trocas materiais com a emergência de diversos sentimentos associados, entre outros aspectos da vida social, à hierarquia. Sem dúvida alguma: "Requiting the Unwanted Gift" e o Ensaio sobre a Dádiva moram também na prateleira imaginária onde habitam as minhas leituras indispensáveis.

Esse primeiro projeto sobre a dádiva produziu alguns textos, não por acaso direcionados para a área de estudos sobre a linguagem: um capítulo de livro sobre a expressão das identidades de gênero por meio das trocas de presentes, de orientação teórica fortemente interacionista, publicado em uma coletânea organizada por Liliana Bastos e Luiz Paulo Moita Lopes, colegas da área de Linguística; e um artigo publicado em dossiê organizado por Maria das Graças Dias Pereira na revista Palavra, editada pelo Departamento de Letras da PUC-Rio, sobre a elaboração da face (com base na conceituação elaborada por Erving Goffman) por meio das trocas materiais.

Mas a discussão da dádiva como uma forma de linguagem, longe de esgotar meu interesse pelo tema, só fez abrir novas possibilidades analíticas. O levantamento bibliográfico realizado descortinou uma profusão de referências bibliográficas que era, para mim, inimaginável quando iniciei a pesquisa. Assim, findo o primeiro projeto, elaborei uma segunda proposta para concorrer a novo período no PROCIÊNCIA. Nela, o foco estava na dádiva como expressão de sentimentos. 
A pesquisa bibliográfica me havia revelado a existência de duas formas principais de tratamento da dádiva, recortadas ao longo de um eixo relativo à natureza dos grupos pesquisados. A primeira forma diz respeito ao estudo dos sistemas de troca em sociedades tribais que tem, como referências basilares, evidentemente, os Argonautas e o Ensaio sobre a Dádiva, e prossegue para, entre outros, as obras de Claude Lévi-Strauss e Maurice Godelier. A segunda é encontrada nos estudos sobre sistemas de troca em sociedades urbanas, dos quais há uma profusão, como o estudo de David Cheal realizado em Winnipeg, no Canadá, o trabalho de Joy Hendry sobre as embalagens japonesas, os estudos de Mayfair Yang e Yunsiang Yan sobre a China e o próprio texto já citado de William Ian Miller sobre os Estados Unidos contemporâneos.

À primeira forma, cujo objeto preferencial são as sociedades tribais, chamei "sistêmica", em uma tentativa de realçar aquele que me parecia um traço distintivo de suas abordagens: a preocupação com a identificação de regras implícitas ou inconscientes que orientariam as maneiras de dar e receber presentes. Já a segunda forma, voltada para as sociedades urbanas, não teria esse mesmo caráter, estando mais orientada para a dimensão interacional e emocional das práticas do presentear.

O segundo projeto sobre a dádiva, desenvolvido de 2000 a 2003, teve como foco a expressão de sentimentos por meio dos objetos trocados. Esse projeto foi desenvolvido já no Departamento de Ciências Sociais do IFCH, no âmbito da linha de pesquisa "Transformações da Intimidade", de cuja criação participei juntamente com Luiz Eduardo Soares e Claudia Barcellos Rezende. Data já desse momento a preocupação com a reflexão sobre os limites e possibilidades de construção das emoções como um objeto das ciências sociais - novo eixo central de minhas pesquisas, cursos e orientações, o qual substituiu a conjugação entre o objeto "ator" e as teorias da comunicação de massa pela qual vinha então pautando minha atuação intelectual.

Desde então, a Antropologia das Emoções passou a ser meu foco. Acoletânea Languageand the Politics of Emotion, organizada pelas antropólogas norte-americanas Catherine Lutz e Lila Abu-Lughod, é o texto basilar dessa trajetória. Sua introdução esboça um mapa do campo de estudos sobre as emoções, identificando três vertentes: o essencialismo, característico dos estudos de orientação "psi", baseado na ideia, como o nome sugere, de que as emoções teriam uma essência universal; o historicismo, voltado para a investigação das transformações históricas da vida emocional; e o 
relativismo, espécie de variação sincrônica do historicismo, comprometido com a noção de uma "construção cultural" das emoções. Contra esse pano de fundo, as autoras formulam sua proposta teórica: o contextualismo, baseado na noção de "discurso" de Michel Foucault. Para elas, as emoções somente poderiam ser entendidas no contexto de sua elocução, informando sobre a natureza da relação existente entre os interlocutores e tendo, portanto, um papel "micropolítico".

Essa noção de "micropolítica" das emoções orientou aquele que considero o principal resultado desse segundo projeto sobre a dádiva: um texto, originalmente publicado em coletânea organizada por Gilberto Velho e Karina Kuschnir, sobre as trocas de presentes entre patroas e empregadas domésticas.

Esse texto analisa um conjunto de dados obtidos em entrevistas em profundidade realizadas com mulheres de camadas médias da Zona Sul do Rio de Janeiro, todas elas "patroas" de empregadas domésticas, sobre os presentes que dão a suas empregadas e/ou recebem delas. Inclui também, em uma tentativa de comparação, alguns relatos de empregadas domésticas, obtidos de forma bem menos sistemática, sobre os presentes que recebem de suas patroas e/ou dão a elas.

O foco da análise gira em torno da gratidão, entendida, tal como sugere Simmel, como um sentimento que estabelece hierarquia, inferiorizando aquele que o sente. Para Simmel, a gratidão teria "um gosto de servidão".

O rendimento analítico da gratidão para entender a natureza da relação patroa-empregada doméstica por meio das trocas de presentes nas quais (não) se engajam está na identificação de uma espécie de "regateio". Falando sobre os presentes que dão a suas empregadas, as patroas descrevem, como a empregada "ideal" para presentear, aquela que "fica muito agradecida". Por outro lado, dizem não esperar e, no limite, não querer, qualquer retribuição material pelos presentes que dão.

As empregadas, por sua vez, não demonstraram, nas conversas comigo, qualquer gratidão pelos presentes que recebem. Ao contrário, muitas vezes os desvalorizam, considerando-os de valor ínfimo ou "desatentos" em relação a seus gostos e características individuais. Não demonstram, também, qualquer desejo de retribuição, com os presentes que eventualmente dão a suas patroas se parecendo mais com aquele "revide" de que falava Miller.

Uma entrevistada, que trabalhava como acompanhante de um senhor idoso, me contou uma história que é uma síntese perfeita desse "regateio" em torno da gratidão. Na casa em que trabalhava, havia uma outra 
acompanhante, recém-contratada, com quem se revezava, e uma cozinheira, que trabalhava na casa há muitos anos. Essa nova acompanhante deu à patroa, por ocasião de seu aniversário, uma cafeteira, paga a prestações. A patroa ficou indignada e confidenciou à cozinheira (que contou à minha entrevistada) que a moça era "muito metida" por ter lhe dado um presente daquele valor. Minha entrevistada contou a história com um traço de rancor, e arrematou: "eu? Eu só dou a ela meias de três reais, porque isso ela aceita".

A história tem, sem dúvida, uma tonalidade cruel. Talvez por isso mesmo, seja um excelente "drama" para pensar a função da gratidão nessa relação. Ora, de um lado temos um "doador" hierarquicamente superior em uma relação trabalhista, que dá presentes que sabe não poderem ser retribuídos por objetos de valor monetário aproximadamente equivalente, e que não deseja qualquer retribuição. Mas, no lugar de uma dádiva material, anseia por uma retribuição em outra "moeda": o despertar da gratidão do outro, suscitada pela imposição de um estado de dívida, causado justamente pela impossibilidade de retribuir. Se a gratidão, como sugere Simmel, tem um "gosto de servidão", então suscitar no outro esse sentimento cumpriria a função subjetiva de assegurar-se de sua superioridade hierárquica.

Ora, é justamente o reconhecimento desse lugar inferiorizado que as empregadas parecem recusar à patroa, ao não demonstrarem qualquer gratidão e, ainda mais, ao "revidarem" os presentes caros com "meias de três reais", em um agenciamento da troca em que "aceitam", empiricamente, retribuir com menos, mas negando-se, no plano subjetivo, a se sentirem gratas.

Se, como dizia Mauss, a dádiva dramatiza a natureza da relação existente entre doador e receptor, a gratidão estaria aqui no cerne da gramática emocional que regula essas trocas, realizando aquele trabalho micro político discutido por Lutz e Abu-Lughod. Em um plano macro, temos a relação trabalhista tal como definida no universo legal brasileiro; em um plano intermediário, temos indivíduos singulares desempenhando os papéis sociais definidos naquela relação (a "patroa" e a "empregada"); e, no plano subjetivo, temos uma negociação emocional em torno do dar/ receber gratidão, em que uma espera, como retribuição, a aceitação de uma dívida impagável que confirmaria sua superioridade, dívida essa negada pela outra por meio da dádiva que vem sob a forma de um revide.

Esse texto, juntamente com um conjunto de trabalhos produzidos ao longo do desenvolvimento dos projetos sobre a dádiva, foi posteriormente 
publicado em meu segundo livro, intitulado $O$ Valor das Intenções - dádiva, emoção e identidade (Editora da Fundação Getúlio Vargas). O interesse pela relação entre dádiva e emoções se expressou também na orientação da dissertação de Lucas Rehen, que tratou da troca de hinos no universo do Santo Daime como um "sistema de dádiva" associado a uma gramática emocional característica dessa forma de religiosidade.

Para além da exploração da temática da dádiva, esses projetos deixaram como resultado uma inquietação intelectual: o trabalho político e moral realizado pelas emoções. E aqui, o encontro com dois outros textos foi fundamental: The Anatomy of Disgust, também de William Ian Miller, e Misery and Company, de Candace Clark. O primeiro trata do nojo e do desprezo como "emoções de demarcação de status"; o segundo discute a compaixão como um sentimento assimétrico, capaz de estabelecer uma hierarquia entre aquele que dá e aquele que recebe compaixão.

Estamos aqui, evidentemente, diante de um conjunto de sentimentos dotado de uma fecunda capacidade micropolítica, na medida em que suas condições de surgimento - sua "gramática" - dramatiza relações hierárquicas: a gratidão, a compaixão, o desprezo e o nojo. Essa foi a questão que orientou os projetos apresentados a seguir ao PROCIÊNCIA: "Violência, Alteridade e Emoção: percepções da violência no Rio de Janeiro" e "Moral, Alteridade e Sentimentos: percepções da violência", desenvolvidos de 2003 a 2009.

Esses projetos tiveram por objetivo discutir as gramáticas emocionais associadas a experiências de vitimização em uma modalidade específica da violência urbana: os assaltos a residências. Realizei um conjunto de entrevistas em profundidade com casais que haviam tido a experiência de serem assaltados em suas residências, tendo, entre os objetivos originais, o interesse pelo marcador "gênero" como eixo de comparação entre a forma de vivenciar a condição de vítima. Entre as publicações resultantes do projeto, há duas que gostaria de comentar aqui de forma mais detida.

A primeira é o artigo "Narrativas da Violência: a dimensão micropolítica das emoções", publicado na revista Mana em 2010. Nesse texto, procuro conjugar o conceito de "representação" à análise da gramática emocional presente nessa experiência de vitimização. Para tanto, inventario em primeiro lugar as representações dos assaltantes tal como presentes nos relatos dos assaltos: para os entrevistados, os assaltantes são "sujos", "bagunceiros", "pobres" e "ignorantes". Esses atributos são mencionados em meio a expressões de desprezo e compaixão que surgem, por exemplo, 
como comentários sobre a suposta incapacidade dos assaltantes de reconhecerem o valor dos objetos a serem roubados (preferindo coisas de baixo valor a outras cujas marcas não sabem reconhecer), ou como substitutos da raiva ou do medo.

A chave analítica utilizada para compreender essa gramática emocional conjuga as teses de William Miller e Candace Clark sobre o desprezo e a compaixão como "emoções demarcadoras de status" com a análise de Jack Katz, no texto "Massacre Justo", sobre a relação entre raiva e humilhação em relatos de agressores em experiências de assassinatos. Nesse artigo, de forte inspiração interacionista, Katz parte da leitura que o futuro assassino faz das atitudes da vítima e mostra a recorrência de uma percepção de que a vítima coloca em xeque um "bem supremo", central para a definição da identidade do assassino: o bebê que não para de chorar desafia a autoridade paterna, o vizinho que estaciona em frente à garagem ameaça o direito à propriedade, o marido que obriga a mulher a queimar seus livros questiona a igualdade de gênero. Essa dimensão cognitiva se associaria, na experiência típica dessa "cena", a um sentimento de humilhação que toma conta do assassino, parecendo defini-lo para sempre. Essa humilhação, intolerável no momento, transmuta-se então em raiva, uma espécie de "humilhação pelo avesso" (no entendimento de Katz), sentimento igualmente holista que se apossa do assassino, levando à agressão física que restauraria a ordem supostamente ameaçada pela vítima.

Katz sugere, assim, haver uma dinâmica emocional entre os sentimentos da humilhação e da raiva, capaz de explicar as razões de uma agressão que parece marcada pela desproporção entre a atitude da vítima e a reação do agressor. Nos relatos que colhi, a experiência da vitimização nos assaltos a residências começa de maneira semelhante, com sentimentos de medo e impotência levando à raiva. Entretanto, a "definição da situação" é distinta daquela dos relatos analisados por Katz: meus entrevistados avaliam que uma reação física à agressão de que são alvo é inadequada, por arriscada ou inviável. Surgem, então, em lugar dela, sentimentos de desprezo, expressos muitas vezes sob a forma de ironia ou deboche em relação aos assaltantes, ou de compaixão, como se os assaltantes fossem merecedores de pena por não terem escolha na vida a não ser assaltar.

Desprezo e compaixão formariam, assim, um outro complexo emocional com a raiva, em uma relação de substituição que realizaria um trabalho subjetivo de restauração de uma ordem hierárquica que a subjugação pela violência teria vindo ameaçar. A principal contribuição teórica do texto é 
a discussão relativa à importância de se analisar as emoções sob a forma de "complexos" ou "dinâmicas", ou seja, dar atenção à maneira como os sentimentos se articulam uns aos outros, ao invés de pensa-los isoladamente. Discuti esse ponto brevemente no livro Antropologia das Emoções, publicado em co-autoria com Claudia Barcellos Rezende, comparando-o ao complexo emocional formado pelo amor e pelo ciúme, cujas características variam em função do contexto cultural e da organização social do casamento (se monogâmico ou poligâmico).

O segundo texto decorrente dos projetos sobre a vitimização em assaltos a residências foi publicado em 2012 na revista Sexualidade, Salud y Sociedad, editada pelo Centro Latino-Americano em Sexualidade e Direitos Humanos (CLAM) da UERJ. Nele, recorto um segundo eixo analítico do mesmo conjunto de depoimentos: as marcas de gênero presentes nessa experiência da vitimização. O ponto fundamental é o tema do controle de si, que aparece sob forma diametralmente oposta no caso de homens e mulheres.

Os casais entrevistados parecem realizar uma espécie de "divisão sexual do trabalho emocional": um permanece "calmo", suas ações visando proteger a todos, enquanto o outroéo "vulnerável" que precisa ser protegido. As versões dessa "calma" e dessa "vulnerabilidade" são matizadas, não se superpondo a-historicamente aos papéis de gênero, recortados por um eixo geracional que parece facultar divisões diversas desse "trabalho emocional" entre os gêneros. Há, contudo, uma "linha de corte" essencial, relativa a qual o sentimento que precisa ser controlado. Nos homens, o sentimento perigoso a ser controlado é a raiva; nas mulheres, o sentimento que ameaça é o medo. Assim, o homem que "salva" a situação o faz por ser capaz de conter sua raiva; mas, quando é a mulher que faz o papel de "calma", é seu medo que ela controla. Assim, o homem "calmo" tem, subjacente a essa imagem de si, uma percepção de ser sujeito de agressões. A mulher "calma", por sua vez, entende a si mesma como sujeita a agressões.

Ora, gênero e controle são apontados, desde o trabalho seminal de Catherine Lutz sobre a etnopsicologia ocidental, como eixos organizadores da visão das emoções no Ocidente moderno. As emoções participariam, nessa etnopsicologia, de duas oposições estruturantes: emoção-razão e emoção-alheamento. Na primeira, a emoção é o polo negativo, por sua associação ao descontrole, atributo do feminino; na segunda, é o polo positivo, por sua relação com o controle, prerrogativa do masculino. Na segunda oposição, a valoração se inverte, com a emoção, ainda atribuída ao feminino, sendo associada a uma capacidade empática, de compadecimento 
e envolvimento com a dor do outro; já o masculino seria o lugar da frieza, da indiferença, em que princípios abstratos teriam precedência sobre situações concretas de sofrimento.

Ao gênero e ao controle vem se somar, apenas dois anos depois na obra de Lutz, o poder como um terceiro eixo fundamental. Assim, faria parte das estratégias da dominação masculina a representação do feminino como perigoso e vulnerável devido, justamente, a seu descontrole emocional. As conclusões de minha pesquisa estabelecem, assim, um diálogo com essa tríade gênero-controle-poder, sugerindo a fecundidade de nos perguntarmos quais as emoções-alvo da necessidade de controle, em um nuançar dessa gramática emocional atravessada pelas diferenças de gênero.

A temática da violência, que orientou o período de 2003 a 2009 em minha trajetória como pesquisadora, teve desdobramentos paralelos: a participação em dois projetos de pesquisa sobre temas correlatos.

O primeiro deles foi o projeto "Juventude e Violência no Rio de Janeiro", coordenado por Ignacio Cano com apoio da FINEP. Minha colaboração para o projeto consistiu em analisar um conjunto de entrevistas sobre percepções e experiências da violência realizadas com jovens em quatro situações distintas: jovens em cumprimento de medidas socioeducativas; jovens escolarizados; jovens em processo de retorno à escola; e jovens sem qualquer tipo de vínculo institucional. Como resultado, publiquei em 2014, em coautoria com João Trajano Sento-Sé, um estudo comparativo sobre essas trajetórias enfocando, entre outros aspectos, a dimensão temporal da maneira como esses jovens refletiam (ou não) sobre seu futuro, com base em uma distinção entre "sonho" e "projeto".

O segundo projeto, coordenado por Helena Bomeny e com a participação de João Trajano Sento-Sé, contou com o apoio da FAPERJ e enfocou a violência nas escolas do Rio de Janeiro sob a perspectiva de professores da rede pública. Três foram os pontos analisados: a) a "alterização" da violência, ou seja, sua atribuição a um outro - outra escola, outro período, outros alunos; b) um "deslizamento semântico" entre a "violência" e a "indisciplina", ao ponto de uma eventual indistinção entre ambas; e c) a "autoridade docente", tema inserido espontaneamente pelos entrevistados como chave para a compreensão da violência, sugerindo assim a centralidade da "autoridade" para a definição de si do professor, uma vez que "violência" parecia ser aquilo que ameaçava a autoridade docente no espaço escolar. Como principais resultados dessa pesquisa, publicamos dois artigos em coletâneas editadas em Portugal, respectivamente por João 
Sebastião e por Susana Durão: "Violência nas Escolas Públicas do Rio de Janeiro: notas exploratórias sobre a autoridade docente e as percepções da violência" e "Projeto 'Escola Segura': autoridade, legalidade e policiamento em escolas públicas do Rio de Janeiro".

Acredito, contudo, que entre os resultados de um projeto não se contam somente publicações. Além de orientações e novos programas de curso, há também novas ideias, inspirações possíveis para outros projetos. Dessa pesquisa, uma inquietação me ficou: o problema do lugar das emoções como fonte da autoridade. Essa questão foi abstraída de uma passagem de uma entrevista em que a diretora de uma escola conta ter enfrentado fisicamente, sozinha, um rapaz que insistia em traficar dentro da escola sob sua responsabilidade, ameaçando jogá-lo do alto de uma escada. O relato impressiona pela coragem e suscita a pergunta: de onde vem a força para tal enfrentamento? Qual o lugar do afeto, do senso de responsabilidade para com seus alunos, do desejo de protege-los, nessa atitude ao mesmo tempo audaz e insensata em uma cidade como o Rio de Janeiro?

Essa questão, de resto canônica nos estudos sobre autoridade, presente por exemplo na discussão weberiana sobre a autoridade carismática ou nas teses malinowskianas sobre a separação entre autoridade e afeto nas sociedades bilineares, ressurge mais tarde em minha trajetória intelectual com a emergência de um novo campo de investigação: o policiamento, com ênfase, justamente, no exercício da autoridade policial.

Antes, contudo, de eleger esse novo campo de investigação, elaborei um projeto de natureza bibliográfica: "Emoção e Interação na Teoria Social Contemporânea" (2009-2012). A alteração de formato - da investigação baseada em um campo empírico para a reflexão bibliográfica - se deveu à percepção de que a sequência de projetos até então desenvolvidos deixara um conjunto de "fios soltos", problemas teóricos que se encontravam de certa forma "esgarçados" em meio aos campos específicos. O projeto tinha dois objetivos principais: no plano geral, explorar os limites e possibilidades da construção das emoções como um objeto das ciências sociais; e, no plano específico, examinar a maneira como a sociologia de inspiração interacionista se ocupava das emoções.

O projeto teve como principal resultado a organização e tradução do volume Estudos sobre Interação - textos escolhidos, publicado pela EdUERJ em 2013. Do volume consta também uma "Apresentação", na qual discuto dois problemas articulados: a) o escopo do social no projeto teórico interacionista; e b) a forma como a fronteira indivíduo-sociedade é traçada 
nesse estilo sociológico.

O volume é composto por sete textos, principiando com quatro textos de autores clássicos: "A Tríade", de Georg Simmel; "A Sociedade como Interação Simbólica", de Herbert Blumer; "As Boas Pessoas e o Trabalho Sujo", de Everett C. Hughes; e "Exclamações Reativas", de Erving Goffman. Em seguida, incluí dois textos de autores contemporâneos de filiação interacionista: "Trabalho Emocional, Regras de Sentimento e Estrutura Social", de Arlie Hochschild, e o já citado "Massacre Justo", de Jack Katz. O volume se encerra com um texto de comentário sobre a obra de Goffman: "Goffman: um teórico social sistemático", de Anthony Giddens.

A escolha dos textos foi orientada, de certa forma, pela proposta de realização deum passeioteórico pela sociologia interacionista.Impressionoume, desde os primeiros contatos com essa literatura, a abrangência dos fenômenos que podiam ser tratados sob essa orientação, que podiam incluir, em Simmel, um sujeito se embelezando diante do espelho ou, em Goffman, um indivíduo que conversa consigo mesmo. Parecia-me que os interacionistas levavam a extremos a exploração da fronteira indivíduosociedade, criando paradoxos instigantes, como postular a existência do social na experiência da solidão.

Nessa sociologia, o "indivíduo" não é algo fácil de definir. Se, por um lado, continua sendo o polo excluído contra o qual a sociologia demarca sua singularidade disciplinar, por outro lado os interacionistas flertam com as possibilidades de "colonizar" áreas cada vez mais amplas da experiência individual. Na "Apresentação", discuto o traçado desses limites, com foco no problema da "formação de três", que abordo sob uma perspectiva comparativa entre a "tríade" de Simmel e o "complexo de Édipo" de Freud. A comparação é "boa para pensar" aquele problema do escopo do social, pois, se Simmel e Freud concordam que é o terceiro que instaura a sociedade, dirigem o foco para aspectos diferentes dessas formações: o primeiro olha para a natureza dessa forma social, o segundo se interessa pela dinâmica psíquica que constitui o sujeito.

O livro - tanto na argumentação exposta na "Apresentação" quanto em sua concepção geral - avança até a sociologia interacionista das emoções, por meio dos conceitos de "trabalho emocional" e "regras do sentimento", propostos por Arlie Hochschild, em desdobramento da conceituação de Goffman sobre o gerenciamento da expressão do sentimento, e por meio da análise da relação entre interação e emoção nas cenas de agressão empreendida por Jack Katz. 
O período de realização desse projeto foi também um momento de realização de uma síntese da trajetória até aqui percorrida, bem como de consolidação de uma nova forma de atuação intelectual. A síntese aparece na publicação de dois livros em parceria com Claudia Barcellos Rezende, com quem desenvolvi, ao longo desses anos, a área de antropologia das emoções na UERJ: Antropologia das Emoções (Editora da FGV, 2010) e Cultura e Sentimentos - ensaios em antropologia das emoções (Editora Contracapa/ FAPERJ, 2011). O primeiro é um volume de introdução ao campo da antropologia das emoções, em que discutimos as oposições naturezacultura e indivíduo-sociedade em relação à construção das emoções como objeto de estudo das ciências sociais; expomos as principais vertentes teóricas da área; e examinamos a dimensão micropolítica das emoções. O segundo reúne um conjunto de textos de autoria de pesquisadores com quem mantínhamos interlocução regular, em particular em bancas e congressos, e de orientandos nossos que haviam desenvolvido suas teses e dissertações na área de antropologia das emoções.

A nova forma de atuação intelectual foi o início de um trabalho regular de organização de grupos de trabalho e mesas-redondas em reuniões de associações científicas, sempre voltados para a exploração das possibilidades de análise socio-antropológica das emoções. Em um primeiro momento, os GTs foram realizados no âmbito da ANPOCS, em parceria com Octavio Bonet (UFRJ), e voltados para uma interlocução com a área da Antropologia da Saúde (2007-2009).

A partir de 2010, esse tipo de atuação se expandiu, com o estabelecimento de novas interlocuções e com a participação em reuniões de outras associações científicas, no Brasil e no exterior. Foram realizados GTs em parceria com Cynthia Sarti (UNIFESP) e Ceres Víctora (UFRGS) no âmbito da ANPOCS; com Mariana Sirimarco (Universidade de Buenos Aires) e Ana Spivak L’Hoste (UNSAM) na Reunião de Antropologia do Mercosul e no Congresso Argentino de Antropologia Social; com Antónia Lima (ISCTE/ UL) no Congresso Luso-Afro-Brasileiro; e com Susana Durão (ICS/Lisboa e UNICAMP) na Associação Brasileira de Antropologia, na Associação Europeia de Antropologia Social, na Sociedade Internacional de Etnologia e Folclore e na Associação Portuguesa de Antropologia.

Essa expansão, contudo, não significou apenas um incremento dessa forma de atuação profissional. Atrelada a isso, houve também uma reorientação intelectual dos grupos e mesas propostos. Chamei a essa reorientação, em trabalho publicado nos Anais da Reunião Brasileira de 
Antropologia de 2010, de uma análise do trabalho realizado pelas emoções na cena pública, com a construção de novos objetos de pesquisa em Antropologia das Emoções, tais como os movimentos sociais, o policiamento, as transformações políticas, as instituições e os universos profissionais. Meu próprio trabalho anterior, sobre as emoções em episódios de vitimização em formas da violência urbana, ganhou novo significado, inserindo-se nessa nova direção. Como resultados desse esforço de reflexão, publiquei dois dossiês em parceria com Ceres Víctora: o primeiro sobre experiências de vitimização (tendo ainda como co-organizadoras Cynthia Sarti e Jane Russo) e o segundo sobre movimentos sociais, corpo e autoridade. Encontrase também no prelo um dossiê organizado em parceria com Susana Durão e intitulado "Emoções, Política e Trabalho", que reúne dez textos de autoria de pesquisadores brasileiros, argentinos e portugueses, apresentados ao longo de aproximadamente seis anos de trabalho conjunto de organização de atividades em reuniões científicas com foco intelectual constante.

O trabalho de orientação de teses, dissertações e monografias foi fortemente influenciado por essa abertura de novos temas em Antropologia das Emoções, conforme expresso nas teses de Bruno Zilli sobre trajetórias de militantes LGBT e de Nelson Mugabe sobre a jocosidade na sociabilidade LGBT; de Raquel Brum Fernandes sobre gestão de projetos sociais para a juventude; de Marília Loschi sobre o lugar das emoções na emissão de sentenças judiciais; de Johana Pardo sobre gramáticas emocionais em presídios; de Verônica Rocha sobre risco e emoção nos esportes radicais; de Fabio Rios sobre a relação entre a concepção arquitetônica dos estádios de futebol e a experiência emocional do torcedor; e de Eduardo Oliveira sobre a gramática emocional do exílio. As articulações entre emoções, corpo e saúde/doença estiveram presentes também nas teses de Ester Juer sobre o discurso médico sobre os hormônios femininos e de Bianca Sophia sobre transtornos alimentares.

E aqui peço licença para uma segunda e também breve digressão. Foi também nessa época que uma outra modalidade de atuação institucional teve início, com o projeto de criação do Instituto de Ciências Sociais da UERJ.

Quando me transferi para a área de Ciências Sociais da UERJ, seu desenho institucional era de um Departamento existente no âmbito do Instituto de Filosofia e Ciências Humanas. Fui Coordenadora do Programa de Pós-Graduação em Ciências Sociais no biênio 2005-2006, Sub-Chefe do 
Departamento de Ciências Sociais no biênio 2009-2010 e Coordenadora da Graduação em Ciências Sociais por um período de seis meses em 2011.

Em 2011, o então Departamento de Ciências Sociais decidiu propor à Universidade sua transformação em Unidade Acadêmica, ganhando assim maior autonomia do ponto de vista de sua inserção no organograma institucional. Em parceria com Ronaldo Oliveira de Castro, fui responsável pela elaboração do projeto. Após uma longa tramitação de quase três anos, a criação do Instituto foi aprovada pelo Conselho Universitário em abril de 2014. Em agosto do mesmo ano, fui indicada pelos colegas para dirigir o Instituto em um mandato pró-tempore, em composição com Ronaldo Oliveira de Castro.

Em outubro de 2015, compus com Ronaldo Castro a chapa candidata ao primeiro mandato eleito do ICS, cargo no qual me encontro no momento em que redijo esse memorial.

Entendo que essa função excede em muito sua definição corriqueira como "cargo administrativo". Há alguns anos atrás, conversando com o Prof. Ricardo Benzaquen, meu professor na graduação e no doutorado e, por ocasião dessa conversa, meu supervisor em um estágio de pós-doutorado, ele comentou o modo como via as diferenças geracionais entre nós dois. Disse-me ele: "a sua geração vive fazendo projetos de captação de recursos e montando redes internacionais de pesquisa. Na minha geração, a habilidade mais valorizada era a institution building".

Esse olhar distanciado sobre nossas diferenças geracionais caiu como um raio. "Se ele tem razão e essa habilidade era mais valorizada na geração dele do que na minha", pensei então, "nasci na geração errada". Porque, mesmo com todo o desprestígio de que é alvo, hoje, o trabalho administrativo nas Universidades, entendido muitas vezes como "mera burocracia", considero a parceria com Ronaldo Castro na criação e consolidação do ICS, à qual nos dedicamos juntos há vários anos, uma realização profissional de envergadura idêntica, se não maior, do que aquelas das quais resultaram livros e artigos.

O conjunto de projetos até então desenvolvidos produziu três problemas teóricos maiores. O primeiro é o trabalho realizado pelas emoções em fenômenos da esfera pública, como uma questão mais geral ligada à constituição do campo da Antropologia das Emoções. O interesse pela abordagem sociológica interacionista das emoções gerou duas indagações mais específicas: a configuração das gramáticas emocionais geradas por 
relações de poder e autoridade e o papel das emoções na coesão dos vínculos sociais e na promoção da conformidade do indivíduo às normas.

O tema das relações entre poder, autoridade e emoção embasou o projeto seguinte desenvolvido para o Prociência: "Autoridade, Poder e Gramáticas Emocionais" (2012-2015), que conjugava a análise interacionista das emoções com a atividade policial como "campo empírico" de investigação (conjugando o projeto anterior sobre os interacionistas com um projeto então recém-aprovado pela FAPERJ sobre o exercício da autoridade policial). O objetivo específico era analisar as dimensões cognitiva e emocional do exercício da/submissão à autoridade policial, procurando examinar de que maneira concepções de "poder", "autoridade", "legalidade" e "violência" se articulavam a gramáticas emocionais específicas naquilo a que chamamos de "cenas" de exercício de autoridade. Como campo, elegemos as blitzen da Operação Lei Seca no Rio de Janeiro, combinando assim a observação participante com a realização de entrevistas em profundidade com policiais e cidadãos que tivessem sido parados nessas blitzen.

$\mathrm{O}$ projeto teve como resultados principais dois textos. O primeiro, em parceria com João Trajano Sento-Sé, Anderson Silva e Bruno Zilli, foi publicado na revista Análise Social, em 2013. Nele, examinamos o modo como os policiais relatam sua atuação nas operações da Lei Seca, com ênfase na maneira como dizem fazer valer sua autoridade, imposta sem o recurso aos signos mais ostensivos do policiamento - armas e fardas -, utilizando, em vez deles, o controle emocional, a demonstração de conhecimentos legais e, principalmente, a polidez. Um elemento usualmente estranho às cenas de interação entre policiais e cidadãos apareceu também: uma certa jocosidade por parte dos cidadãos, recebida sem maior incômodo pelos policiais. A análise dos dados conjugou teorias da autoridade, teses sobre a relação entre polidez e violência e análises clássicas do riso para propor uma interpretação dessa forma de exercício da autoridade, mostrando como a polidez substitui aí a violência na imposição da autoridade, reforçada pela imperturbabilidade diante do riso dos cidadãos, em uma negociação velada sobre "quem pode mais".

O segundo artigo, em parceria com João Trajano Sento-Sé, Raquel Brum Fernandes e Fabio Rios, foi publicado na Revista Brasileira de Ciências Sociais em 2016. Nele, invertemos o foco e analisamos a mesma "cena interacional" do ponto de vista dos cidadãos. A análise das emoções relatadas revelou a recorrência de uma percepção da sujeição à autoridade policial como uma forma de "desrespeito" capaz de suscitar sentimentos como medo ou 
vergonha.

Para além da análise das emoções, contudo, chamou-nos a atenção uma certa congruência encontrada entre a descrição dos policiais de sua própria atuação e os relatos dos entrevistados a respeito. Para nós, acostumados a relatos caudalosos de conflitos entre policiais e cidadãos, não apenas no registro da vivência cotidiana, mas também no plano das divergências discursivas, foi surpreendente perceber uma certa "concordância" quanto à polidez adotada pelos policiais no trato com os cidadãos. E mais: surpreendeu-nos, a princípio, nossa própria "decepção" com a ausência dos conflitos esperados, como se não soubéssemos o que fazer com dados de aparência tão "harmoniosa".

A chave para resolver nossa dificuldade analítica veio das reflexões de Norbert Elias, desenvolvidas em Os Estabelecidos e os Outsiders, a respeito do lugar do conflito nas ciências sociais. Partindo de uma reflexão sobre o conceito durkheimiano de "anomia", Elias discute as dificuldades teóricas da sociologia com os fenômenos "nômicos", ou seja, a dificuldade de lidar com aquilo que parece transcorrer conforme o esperado. Concluímos o texto, assim, examinando nosso desapontamento inicial com os dados como uma expressão desse amor das ciências sociais pelo conflito, que nos teria deixado, em um primeiro momento, paralisados diante dos dados. E mais: sugerimos também que essa dificuldade com dados harmoniosos, encontrados em fenômenos envolvendo a atividade policial no Rio de Janeiro, poderia ser uma pista para a reflexão em torno da própria agenda de pesquisa sobre policiamento nas Ciências Sociais, fortemente orientada pelo tema do desrespeito para com os direitos humanos.

Nessa mesma época, teve início uma parceria intelectual com Susana Durão. Da conjugação entre seus interesses sobre o policiamento e minha atuação na área de Antropologia das Emoções surgiu um projeto sobre o Grupo Cultural AfroReggae (GCAR). Trabalhando a partir de dados coletados por Susana, publicamos juntas em 2012, na Revista de Antropologia da USP, um texto em que analisamos um conjunto de pequenas histórias recorrentemente contadas no material midiático produzido pelo e sobre o GCAR, as quais tratamos como "fábulas", ou seja, como narrativas que tinham uma "moral". Essa "moral" era relativa ao problema da "responsabilidade para com o outro", contando sempre uma mesma história: o rapaz negro e pobre que, tendo como inimigo a polícia, sobrevive aos perigos da sedução pelo tráfico ou da morte prematura, desenvolvendo com isso um senso de responsabilidade por outros igualmente ameaçados. 
Trata-se, assim, de um "sobrevivente", que se oporia ao "mártir", figuras icônicas, respectivamente, da esperança e da utopia. Concluímos nossas reflexões discutindo o papel do sentimento de esperança no engajamento político, entendido como o tempo do "ainda não" (como discute Vincent Crapanzano), ou seja, de transformações não factuais, mas factíveis.

Faço agora a última digressão. Em paralelo a essa trajetória como professora e pesquisadora e à minha atuação na criação do Instituto de Ciências Sociais da UERJ, desenvolvi um conjunto de atividades na área de editoração e tradução.

Edito a revista Interseções, publicada pelo Programa de Pós-Graduação em Ciências Sociais (PPCIS), desde 2005. A revista tem 35 números publicados, sendo 13 no formato on-line, adotado a partir de 2010. Há dois anos, Interseções entrou para o extrato considerado "qualificado" pela CAPES na área de Sociologia (área de avaliação do PPCIS), recebendo classificação como "B1". Tivemos também recentemente projeto de financiamento aprovado pela FAPERJ.

Em 2008, fui convidada por Italo Moriconi, então diretor da Editora da UERJ, para integrar a Comissão da Coleção "Comenius", série de publicações voltada para a preparação de volumes de orientação didática para a graduação. Como desdobramento dessa participação, propus à EdUERJ a organização de um reader com textos de sociologia interacionista, que resultou no volume acima citado Estudos sobre Interação.

A atividade de tradução é, para mim, inspirada na leitura de um artigo de Greg Smith em que o autor discute o impacto, sobre a sociologia norteamericana, das traduções sistemáticas da obra de Georg Simmel por Albion Small, referindo-se à tradução como uma forma de "ação social". Entendo que traduzir, ou fazer traduzir, é muito mais do que "democratizar" o acesso a obras estrangeiras (embora essa não seja uma função menor). Trata-se de uma reflexão/intervenção sobre o próprio campo, uma vez que os contatos intelectuais que travamos na graduação, nossos "anos de formação", se sedimentam intelectualmente à maneira de uma "socialização primária intelectual" (parafraseando livremente Peter Berger). Assim, traduzir e, com isso, facultar o contato dos estudantes de graduação com textos centrais das matrizes intelectuais da cena internacional é uma maneira de participar da discussão sobre projetos de formação em Ciências Sociais no Brasil.

Guiada por essa reflexão, propus a Italo Moriconi um segundo projeto de tradução: Writing Culture, marco bibliográfico de fundação da antropologia 
pós-moderna norte-americana, lançado originalmente em 1986 e até então inédito em português. Italo se entusiasmou com a ideia e em 2017 a EdUERJ lançou, em parceria com a Papéis Selvagens, A Escrita da Cultura, em tradução minha que traz também uma "Apresentação à Edição Brasileira" de minha autoria.

O lançamento do livro foi um momento de rara gratificação profissional. Em meio à devastação que a crise econômica vem produzindo na UERJ, promovemos a aula inaugural do Programa de Pós-Graduação em Ciências Sociais com a presença de George Marcus, co-organizador do livro, em mesa composta também por Luiz Eduardo Soares e por mim, com mediação de Valter Sinder. A comunidade acadêmica prestigiou em peso nossa iniciativa editorial, nosso Programa e nossa Universidade, com um auditório lotado de colegas, de outras instituições e da casa, alunos e exalunos, da graduação e da pós-graduação.

Penso nesse evento como um momento incomum de síntese profissional, em que a atividade de "institution building" se conjugou a uma atuação intelectual como tradutora e pesquisadora. Porque não se tratava apenas do lançamento do livro ou da organização da mesa: o mais importante de tudo foi ver o Instituto de Ciências Sociais da UERJ como sede do evento.

$$
* * *
$$

Retorno agora ao terceiro problema teórico abstraído dos projetos sobre a construção das emoções como objeto da sociologia interacionista: o papel das emoções na coesão dos vínculos sociais e na promoção da conformidade do indivíduo às normas. Esse é a questão que orienta o projeto de pesquisa que ora desenvolvo: “Interação e Gramáticas Emocionais: o fenômeno do bullying". O projeto se encontra em fase de realização e análise de entrevistas. Os dados de que já dispomos sugerem fios de continuidade em relação a dois projetos anteriores: a pesquisa sobre a violência nas escolas e a pesquisa sobre as narrativas da violência em assaltos a residências. Do primeiro, recupero o "deslizamento semântico" então encontrado entre a "violência" e a "indisciplina", que aqui parece ser reproduzido sob a forma de um esboroamento da fronteira entre bullying e "violência", sugerindo a existência de um campo semântico mais amplo em que a "violência" faria as vezes de mediadora entre o bullying e a "indisciplina".

Do segundo projeto, ressalto a presença de uma dinâmica emocional muito semelhante àquela encontrada entre as vítimas de assaltos a residências, com a raiva decorrente da humilhação provocada pelo bullying sendo muitas vezes negada e substituída por expressões de pena ou 
desprezo. Arrisco aqui a hipótese - ainda preliminar - de que esse complexo emocional formado por humilhação-raiva-desprezo-compaixão poderia ser tomado como típico das experiências de vitimização, constituindo-se assim em uma gramática emocional da vitimização.

Com o projeto sobre bullying entrando já na fase de análise de dados, começo a entreter ideias para o próximo projeto. Em junho de 2017, proferi uma palestra no Programa de Pós-Graduação em Antropologia Social da UFRGS, a convite da Profa. Ceres Víctora, intitulada "As Emoções e o Trabalho Intelectual". Nela, procurei rastrear o lugar das emoções no trabalho de campo, fazendo essa "história" convergir para duas questões: o lugar da nostalgia (Berliner, 2015) e do pessimismo (Kalberg, 1987) nos projetos disciplinares, respectivamente, da antropologia e da sociologia, e o papel das emoções como mola propulsora da produção de conhecimento em si. Procurei, ao final da palestra, esboçar uma provocação sobre o "ideal asséptico" do universo acadêmico- intelectual que concebe as emoções como "poluidoras", capazes de conspurcar o exercício de uma atividade descrita essencialmente como racional (como, de resto, a maior parte dos universos profissionais e, por que não, dos fenômenos da vida pública, conforme já discutido acima).

Apesar de ainda em estado embrionário, arrisco um "anúncio": um próximo projeto de pesquisa sobre o lugar das emoções na produção de conhecimento (e um certo diálogo com o lugar das emoções na instituição "academia" será, creio, inevitável). Nesse novo objeto, se entrelaçam três questões que abstraio como resultado teórico geral dessa trajetória: a micropolítica das emoções, os complexos emocionais e a relação entre emoção e tempo. Assim: qual o lugar das emoções nas disputas por prestígio e qual o lugar dessas disputas na produção do conhecimento? De que forma se conjugam raiva, vergonha, inveja e, por que não, amizade, amor, respeito na dinâmica competição/cooperação que rege o trabalho intelectual? E de que modo as percepções sobre trajetórias profissionais e concepções de sucesso/fracasso, em seu entrelaçamento com a história das políticas de avaliação científica, não comportam dimensões nostálgicas, esperançosas, ansiosas, pessimistas ou mesmo entediadas?

É, possivelmente, um tanto heterodoxo falar de futuro em um memorial. Mas a nostalgia, marca afetiva possível da relação com o passado, tem, como apontam seus estudiosos, uma relação paradoxal com o tempo. Se por um lado é lamento por uma perda, por outro é sentimento do presente no qual, por meio de uma idealização do passado, projetamos um futuro 
possível. Na nostalgia, há um elemento de esperança.

E recontar a própria história não seria uma forma, entre outros sentidos possíveis, de assenhorear-se de si?

$$
* * *
$$

Há muito reflito sobre os temas de meus projetos: por que passei da dádiva para a violência? Acalento haver uma resposta possível nas próprias obras de inspiração seminal. Marcel Mauss, ao final do Ensaio sobre a Dádiva, diz serem a festa e a guerra as duas formas possíveis de relação entre grupos humanos: "Dois grupos de homens que se encontram podem fazer apenas duas coisas: ou (...) lutar ou tratar-se bem". Essa é também a visão de Claude Lévi-Strauss, em sua tese sobre a exigência imperiosa da troca para a constituição do social, abstraída a partir da análise do ritual francês da troca de vinhos, quando afirma que aos parceiros resta escolher entre a cordialidade e a hostilidade, uma vez que a indiferença é somente uma possibilidade mítica de ordem lógica. Seriam, assim, violência e dádiva, as duas faces da mesma moeda?

Concluo com um brevíssimo exercício de etnografia urbana. Conjugamse aqui dois encantamentos: a observação dos fragmentos da vida urbana, da forma aleatória e casual como se oferecem à nossa atenção, e o fascínio pelo minimalismo antropológico, do qual a análise do ritual francês da troca de vinhos é para mim o melhor exemplo da literatura antropológica. Afinal, reconhecer em uma regra banal de etiqueta o princípio constitutivo da sociedade traduz a essência da vocação antropológica - uma descrição que não é vocação última, mas sim expressão do amor pelo reconhecimento, nos menores detalhes do cotidiano, das grandes questões da existência humana.

Estou voltando de uma caminhada, esperando em uma esquina para atravessar. É cedo, mas já está escuro. Vejo dois meninos, 14 e 10 anos talvez, esperando a poucos metros de mim. Um rapaz se aproxima deles e começa a gritar. Ouço, um pouco espantada, o teor da "conversa": "Tu me dá isso aí?", grita o rapaz. "Isso aí" é uma garrafa térmica que o menino mais velho leva na mão. Fico atenta, observando para ver se seria o caso de tentar intervir. O menino, aturdido, entrega a garrafa. O rapaz grita: "Posso ficar com isso? Tu tá me dando?" Os meninos aquiescem. O rapaz tem uma caixinha na mão. Exige, oferecendo as balas: "Pega um aí!". E duas, três vezes: "Pega outro, porra! Pega mais!". Os dois obedecem, mudos. O rapaz se afasta e, antes que eu possa falar com os meninos, volta e grita novamente: "Pega mais um!"

Pergunto a eles se está tudo bem e se posso acompanha-los. Dizem 
que sim, ainda meio aturdidos, e atravessamos a rua juntos. Do outro lado da calçada, um segurança de uma loja e uma senhora se aproximam. Revoltados, perguntam o que o rapaz havia feito. Querem chamar a polícia. Digo para não fazerem isso, que não havia sido um roubo. $\mathrm{O}$ segurança se irrita: "é claro que foi!". O menino recusa e desdenha: "era só um brinde". Vou andando com eles e, de passagem, o mais velho tira as balas das mãos do outro ("me dá essa porcaria aqui") e as joga em uma lata de lixo. Pouco adiante, dispensa a minha "escolta": "nós moramos logo ali".

E então? Foi roubo ou não? A cada amigo a quem proponho a pergunta, em cada círculo que a conto, uma acalorada discussão. As opiniões variam, ninguém fica indiferente.

Uma intimidação, uma extorsão, uma tentativa canhestra de transformála em "troca" pela imposição da "retribuição": as balas pela garrafinha. A encenação da troca pelo rapaz parece caricaturar a tese da tríplice obrigação: obrigatório dar a garrafinha, obrigatório receber as balas.

As várias "definições da situação" - foi roubo ou não foi? - nos servindo aqui não só como ferramenta analítica, mas também como dados etnográficos, pois que os personagens da cena não chegam a um acordo. Chamar a polícia ou não? Para quê, diz o menino, era só um brinde.

Brindes - os tipos de valor e a relação com a forma de aquisição do objeto. Nenhum valor de troca (brindes não são comprados), baixo valor de uso (brindes são supérfluos), nenhum valor de vínculo (brindes são impessoais). Será possível roubar um brinde?

As balas jogadas fora: a recusa óbvia, raivosa, da dádiva. O que ele me tirou não tem valor. O que ele me deu é lixo.

Reencontro aqui meus temas entrelaçados, síntese perfeita de tudo o que me fascina: a vinheta urbana, o minimalismo antropológico, a incerteza da situação, a negociação dos sentidos, a confusão dos sentimentos, aturdimento, impotência, raiva.

Foi troca ou foi roubo? Dádiva ou violência?

$$
* * *
$$

Um pós-escrito: Luiz Eduardo Soares, sempre orientador, foi o leitor da primeira versão desse memorial. Entre suas sugestões, a inclusão de um breve comentário sobre a crise na UERJ, em suas palavras uma institution deconstruction, que parece estar atingindo seu ápice no momento em que redijo esse texto.

O que significa escrever um memorial em um período assim? O que é rememorar uma trajetória na qual a "construção institucional" ocupa papel 
tão central em época tão ameaçadora?

Norbert Elias, em seu texto "Os Pescadores e o Turbilhão", utiliza uma história de Edgar Allan Poe para expor duas formas de lidar com as crises. Dois irmãos, náufragos em um bote, veem a embarcação se aproximar perigosamente de um redemoinho. Um está paralisado de medo, encolhido no fundo do barco. O outro observa ao redor, em busca de uma salvação, e percebe que formas cilíndricas flutuam por mais tempo antes de serem engolidas. Há tonéis à volta do barco, e ele tenta convencer o irmão de que devem saltar e se agarrar a eles, para aguardar que o redemoinho perca a força. Apavorado, o irmão não escuta. $\mathrm{O}$ pescador então salta sozinho e sobrevive agarrado a um tonel.

Duas atitudes possíveis diante da crise: "envolvimento", ou seja, se deixar engolir pelas circunstâncias, sem a distância crítica capaz de conduzir ao diagnóstico e à busca de soluções; ou "observação", olhar para a crise que nos engolfa, compreende-la como se de fora, e incorporar essa observação à condução da vida no momento mesmo em que estamos ameaçados de submergir.

Se há hoje algum consenso na UERJ, é que jamais se viu crise assim. O medo, o desamparo, o abandono permeiam o cotidiano. Em uma conjuntura como essa, o esforço da memória é crucial. Retraçar o caminho percorrido, perceber conexões entre escolhas muito afastadas entre si no tempo, identificar continuidades e compreender o papel das rupturas, são, todas elas, maneiras de reiterar um compromisso, de afirmar uma crença profunda no potencial transformador da teoria social sobre o mundo, tanto mais essencial quanto maior o drama. Lembrar para não submergir.

Em um contexto de crise abissal, escrever um memorial é entreter uma relação de otimismo com o futuro.

Rio de Janeiro, 10 de julho de 2017.

\section{Referências}

BERLINER, David.

(2015). "Are Anthropologists Nostalgist?". In:

CLARK, Candace.

0 . Angé e D. Berliner (orgs.). Anthropology

(1997). Misery and Company - sympathy in everyday life. Chicago \& London: The and Nostalgia. New York and Oxford: Berghahn Books, pp. 17-34.

CANETTI, Elias.

(1983). Massa e Poder. São Paulo: University of Chicago Press.

CRAPANZAN0, Vincent.

(2004). Imaginative Horizons - an essay in Melhoramentos; Brasília: UnB. literary-philosophical anthropology. Chicago \& London: The University of Chicago Press. 
ELIAS, Norbert. (2001). A Solidão dos Moribundos. Rio de Janeiro: Jorge Zahar.

ELIAS, Norbert.

(1998). "Os Pescadores e o Turbilhão". In: Envolvimento e Alienação. Rio de Janeiro: Bertrand Brasil.

ELIAS, Norbert e Scotson, John L. (2000). Os Estabelecidos e os Outsiders. Rio de Janeiro: Jorge Zahar.

KALBERG, Stephen.

(1987). "The Origin and Expansion of Kulturpessimismus: the relationship between public and private spheres in early twentieth century Germany". Sociological Theory, Vol. 5, fall, pp. 150-165.

KATZ, Jack.

(2013). "Massacre Justo". In: Maria Claudia Coelho (org.). Estudos sobre Interação - textos escolhidos. Rio de Janeiro: EdUERJ.

LÉVI-STRAUSS, Claude.

As Estruturas Elementares do Parentesco.

LINDHOLM, Charles.

(1993). Carisma. Rio de Janeiro: Jorge Zahar.

LUTZ, Catherine.

(1988). Unnatural Emotions - Everyday Sentiments on a Micronesian Atoll \& Their Challenge to Western Theory. Chicago: The University of Chicago Press.

LUTZ, Catherine e ABU-LUGHOD, Lila. (orgs.) (1990). Language and the Politics of Emotion. New York, Cambridge University Press.
MAUSS, Marcel.

(1980). “A Expressão Obrigatória dos Sentimentos". In: S. Figueira (org.). Psicanálise e Ciências Sociais. Rio de Janeiro: Francisco Alves, pp.56-63.

MAUSS, Marcel.

(1974). "Ensaio sobre a Dádiva". In: Sociologia e Antropologia. São Paulo: EPU, pp. 37-184.

MILLER, William Ian.

(1997). The Anatomy of Disgust. Cambridge: Harvard University Press.

MILLER, William Ian.

(1993) "Requiting the Unwanted Gift". In: Humiliation. Ithaca and London: Cornell University Press.

MORIN, Edgar.

(1984). Cultura de Massas no Século XX. vol. 1. Rio de Janeiro: Forense-Universitária.

SIMMEL, Georg.

(1987). "A Metrópole e a Vida Mental". In: VELH0, Otávio G. (org). o Fenômeno Urbano. Rio de Janeiro: Ed. Guanabara.

SIMMEL, Georg.

(1964). "Faithfulness and Gratitude". In: Kurt H. Wolff (org.). The Sociology of Georg Simmel. New York: Free Press, pp. 379-395.

SMITH, Greg.

(2004). Instantâneos 'sub specie aeternitatis' - Simmel, Goffman e a sociologia formal. In: GASTALD0, Edison (org.). Erving Goffman desbravador do cotidiano. Porto Alegre: Tomo Editorial, pp. 47-80. 


\section{Memorial $^{1}$}

Claudia Barcellos Rezende

"Para uma pessoa com alguma imaginação, o passado está em constante mudança." José Eduardo Agualusa, A sociedade dos sonhadores involuntários

O conceito de experiência traz consigo uma temporalidade implícita. Minha vivência do presente é informada pelo vivi no passado e pelo que espero do futuro. Mas a narrativa da experiência, como diz Bruner (1986) na sua introdução ao volume The Anthropology of Experience, é distinta da vivência em si. Ao narrar o que vivi, seleciono elementos e tons de acordo com o contexto de expressão. Nas palavras de Halbwachs (1990), a memória é seletiva e é o presente que interfere no que é rememorado do passado.

As formas de expressão da experiência são também culturalmente criadas. A biografia como modelo em que fatos e estados se sucedem no tempo, em relação de causa e efeito, impõe um ordenamento linear da experiência distinto do seu caráter fragmentado e incoerente, com intencionalidades nem sempre claras. Para usar a expressão de Bourdieu (2006), é uma ilusão que, no entanto, torna-se uma forma cultural de narrar a experiência.

Neste modelo em que o indivíduo é o centro de referência, o acaso aparece muitas vezes para explicar a tomada de rumos e escolhas, como mostrou Mariza Peirano (1992) em seu estudo sobre a trajetória de alguns intelectuais brasileiros. Argumenta Becker (1995) que as menções ao acaso desviam o foco do que ele chama de intercontigência - a dependência das ações das outras pessoas. Minhas decisões e ações esbarram sempre nas ações de outras pessoas. Se a agência é uma capacidade universal de buscar realizar projetos, seguindo a concepção de Sherry Ortner (2006), ela está sempre inserida em relações de poder, mesmo quando aparentam ser apenas laços de solidariedade.

Faço este pequeno arrazoado teórico pois é nele que me baseio para a escrita deste memorial. Este texto é uma versão reduzida daquela submetida

\footnotetext{
${ }^{1}$ Este memorial foi defendido em 19 de abril de 2018. A banca examinadora foi composta pelos Profs. Helena Bomeny (presidente), Luiz Fernando Dias Duarte, Myriam Moraes Lins de Barros, Yvonne Maggie e Peter Fry.
} 
à UERJ como parte da do processo de promoção para professora titular. Apesar de pequenas mudanças, mantive o presente específico no qual escrevi o texto original, setembro de 2017, período de crise aguda da UERJ quando sua própria existência esteve ameaçada. Rememoro minha trajetória então em um momento e para um público específico - para colegas que farão parte de uma banca de avaliação. Ordeno acontecimentos, escolhas e sensações de um modo mais coerente e distinto do que foi a experiência em si. Destaco aqui os temas e questões que me interessaram e atravessaram minha formação e atuação como docente e pesquisadora. Embora eu seja o fio condutor, preferi privilegiar as pessoas e o conjunto de relações que amarram e interferiram nos meus caminhos, sem deixar de lado, contudo, a minha agência ${ }^{2}$.

\section{Deslocamentos}

O deslocamento fez parte intensamente dos meus primeiros trinta anos de vida. Nasci nos Estados Unidos, quando meu pai fazia doutorado em Física. Vim para o Brasil quando tinha dois anos e meio e moramos no Rio, base da família até os seis anos. Por conta do percurso acadêmico do meu pai, passei seis meses em Campinas e depois nos estabelecemos em Recife, onde vivi até o final de minha graduação em Ciências Sociais. Neste meio tempo, estivemos duas vezes nos Estados Unidos, em períodos de quase dois anos, em função de um pós-doutorado do meu pai e depois do doutorado de minha mãe, que é musicista e compositora. Assim, as escolhas dos meus pais afetaram não apenas onde eu morei - e com quem e como me relacionava - como também meu modo de ver o mundo.

Quando mais tarde descobri a antropologia, achei que ela traduzia, enquanto um campo de conhecimento, uma forma de olhar que eu desenvolvi muito cedo. Lembro-me de voltar da primeira estadia nos Estados Unidos quando eu tinha dez anos, com a nítida percepção de que cada lugar - Rio, Recife, Santa Barbara na California - tinha suas regras e valores próprios. Enquanto os americanos faziam fila no refeitório da escola, naquela época, para ser atendido na cantina da escola em Recife era preciso falar mais alto.

Antes de descobrir a antropologia, tinha certeza de que gostaria de

\footnotetext{
${ }^{2}$ Faço ao longo do texto referência a algumas publicações, cujos dados completos estão no meu currículo Lattes: http://lattes.cnpq.br/2464920090343673.
} 
estudar a sociedade e seus problemas. Minha escola, que era da congregação religiosa marista, fazia visitas frequentes a comunidades pobres e orfanatos, o que me impactava muito. Revendo papéis para escrever este texto, encontrei uma carta escrita no $3^{\circ}$ ano do $2^{\circ}$ grau na qual dizia querer ajudar a resolver os problemas do Nordeste. Em que pese o idealismo da idade, estava lá o desejo de combinar sociologia com psicologia social para trabalhar junto às pessoas, escutá-las e auxiliá-las.

Entrei para o curso de ciências sociais na Universidade Federal de Pernambuco em 1982. Ao final do primeiro período, minha família se mudou mais uma vez para a California para o doutorado de minha mãe e durante dois anos, cursei disciplinas na Universidade da California, em Santa Barbara (UCSB). De início, estranhei muito a estrutura acadêmica lá, inteiramente distinta do modelo de grade curricular fixa e pré-definida dos cursos no Brasil. Na UCSB, os alunos ingressavam na universidade, não em um curso específico, tendo que fazer disciplinas de todas as grandes áreas, até se concentrarem em uma específica. A única exigência eram duas disciplinas de redação em inglês, que marcaram profundamente meu estilo de escrita. Depois de dois termos acadêmicos em que repliquei o que fazia em Recife, consegui experimentar outras áreas, bem como disciplinas eletivas de antropologia de títulos muito 'exóticos' para mim - sociedade tradicional chinesa, caçadores e coletores, ecologia cultural. De um modo pouco refletido, havia me aproximado da antropologia que, em Recife, me fora completamente desconhecida.

Voltei dos Estados Unidos em 1984, já resolvida a concentrar meus estudos nesta área. Mas na UFPE na época, a área mais forte no departamento de ciências sociais era sociologia, portanto não cursei tantas eletivas em antropologia quanto gostaria. Também fui estagiária de Silke Weber e bolsista de iniciação científica de Heraldo Souto Maior, ambos sociólogos, com quem aprendi a analisar dados quantitativos. Analisei tabelas de uma pesquisa feita em 1963 sobre um programa de educação via rádio para o campo do primeiro governo Arraes. Por conta da ditadura, estes dados haviam ficado guardados durante vinte anos sem análise. Desta pesquisa surgiu minha monografia, para a qual mergulhei no estudo das Ligas Camponesas da década de 60, muito mobilizada mais uma vez pelas ideias de intervenção social.

Minha mudança para a antropologia urbana aconteceu por conta da orientação de Gilberto Velho no mestrado, iniciado em 1987. Como fazer pós-graduação já era um caminho natural na família, escolhi o Programa de 
Pós-Graduação em Antropologia do Museu Nacional, na época referência no país e localizado no Rio, onde já moravam minhas irmãs e avós. Gilberto era conhecido do meu pai e por isso fiz contato com ele sobre uma possível orientação. Até então, não tinha ideia do que gostaria de estudar no mestrado. De alguma forma, o interesse pelo campesinato ficou para trás junto com a minha vida em Recife.

O trabalho com Gilberto foi responsável não só pela guinada para os estudos urbanos, mas também pelo fortalecimento de uma perspectiva teórica mais voltada para o indivíduo. Ter sido sua aluna significou, como foi para outros orientandos dele, o contato com as obras de Simmel, com a fenomenologia de Schutz e o aprofundamento do interacionismo simbólico que eu já conhecia de Recife. A preocupação com as formas das interações aliada ao modo como os indivíduos mobilizam códigos e significados em um contexto tão diversificado quando o urbano foi uma herança fundamental da síntese realizada por Gilberto. Ele foi também um modelo de professor e orientador, sempre presente, atencioso e rigoroso ao mesmo tempo, postura que me marcou em diversas situações da vida acadêmica.

Por sugestão sua, pesquisei formas de sociabilidade entre jovens de camadas médias. Juventude já era um tema pesquisado por outras orientandas suas, como Silvia Fiuza e Maria Claudia Coelho, que veio a se tornar amiga próxima e parceira de trabalho na UERJ. Entrevistei adolescentes sobre suas relações na escola e com a família, buscando entender para eles o sentido de ser jovem. Tomando o conceito de juventude enquanto construção histórica e cultural, ser jovem significava passar por mudanças que afetavam "suas cabeças". Ser "cabeça aberta" - estar disposto a experimentar situações novas no lazer e na paquera - era um valor e podia às vezes contrastar com pais mais controladores. Assim, aparecia já na dissertação uma preocupação com a construção de identidade, interesse que eu aprofundaria mais tarde.

Além da orientação de Gilberto, que depois se transformaria numa grande amizade, tive no mestrado contato pela primeira vez com os campos da antropologia das emoções e do corpo/saúde/doença, através de disciplinas dadas por Luiz Fernando Dias Duarte. Fascinava-me perceber como experiências tão individuais como os sentimentos e as aflições corporais ganhavam contornos culturalmente específicos. No curso sobre emoção, a bibliografia era em grande parte francesa, diferente dos autores americanos que viria a usar mais tarde. Ainda que minha dissertação não tenha se detido nestes aspectos, os temas das emoções, corpo, saúde e 
doença retornariam na minha trajetória alguns anos depois, mantendo-se até hoje como meus interesses.

Terminei o mestrado em maio de 1989, já com os planos de doutorado na Inglaterra bem delineados. Continuei próxima aos meus amigos e professores da UFPE. Na época, Roberto Aguiar, professor de sociologia, incentivava seus ex-alunos a fazerem doutorado na London School of Economics, onde ele mesmo havia se formado. A antropologia naquela universidade era renomada - afinal Malinowski havia ensinado lá, ainda que nenhum professor na época fizesse pesquisa urbana "em sociedades complexas", como Gilberto me alertava. Pesou a favor da universidade inglesa meu desejo de viver fora, na Europa, desta vez sem a companhia da família. Mesmo não vendo esta opção com bons olhos, Gilberto me pôs em contato com Joanna Overing, especialista em sociedades ameríndias, que aceitou me orientar.

Cheguei em Londres em setembro de 1989, muito curiosa para conhecer os ingleses. Não esqueço o comentário feito por minha amiga Popy Maia de Recife, que me buscou no aeroporto e disse que os ingleses botavam coleiras em suas crianças e deixavam seus cachorros soltos! Se logo conheci outros brasileiros com visões semelhantes sobre a reserva e frieza dos locais, fiquei fascinada com a diversidade de origens dos colegas que habitavam o mesmo dormitório que eu. Os meses iniciais foram assim uma experiência intensa de cosmopolitismo, que reforçaram meu olhar etnográfico e o desejo de pesquisar os ingleses.

O início foi também o contato com a estranheza de me ver como estudante de terceiro mundo. Ao chegar soube que, por ser aluna estrangeira, teria que fazer um ano de mestrado, como forma de assegurar meu conhecimento dos clássicos da antropologia britânica. Esta exigência me causou a princípio muita indignação, pois já tinha mestrado, com pesquisa de campo e dissertação defendida, enquanto os colegas ingleses iam direto da graduação para o doutorado. Mas as disciplinas deste primeiro ano ofereceram também a oportunidade de não apenas consolidar aquelas leituras como também de conhecer os expoentes britânicos contemporâneos, em particular Marilyn Strathern e Henrietta Moore, que foi minha professora e acrescentou as questões de gênero aos meus interesses. Ganhei uma bagagem de leitura de etnografias de todas as partes do mundo, abrangência que não tinha e que contribuiu imensamente para uma desconstrução radical de muitas noções que ainda eram pouco problematizadas. A orientação de Joanna, americana radicada na Inglaterra, colaborava ainda mais para estes questionamentos, 
fundamental para meu estudo sobre um tema muito próximo pessoalmente - a amizade.

Inicialmente, pretendia fazer um estudo comparativo das relações familiares nas camadas médias em Londres e no Rio de Janeiro. Mas mudei de objeto logo no primeiro ano, por conta dos comentários estereotipados sobre os ingleses. Já havia morado nos EUA e percebido como as dinâmicas de amizade lá eram bem distintas das que eu conhecia em Recife e no Rio. Resolvi então estudar o que significava amizade para jovens ingleses brancos de camadas médias residentes em Londres, mantendo o corte de classe que havia estudado no mestrado e escolhendo uma etapa de vida distinta - o início da vida profissional. Embora já convivesse com colegas ingleses nas disciplinas do doutorado, realizei trabalho de campo durante um ano, conversando e interagindo em situações de sociabilidade com uma rede de pessoas unidas por laços de amizade.

Enquanto encontrava muita receptividade de ingleses que achavam o estudo importante, deparei-me com muita resistência de colegas e professores no departamento na LSE. Como Gilberto Velho me avisara, questionavam as limitações de um trabalho de campo feito em Londres, ao contrário da preferência por aldeias remotas que renderiam uma observação participante mais "completa" da vida local. Entendi também que havia um desconforto com uma inversão no modelo de relação de pesquisa mais conhecido para eles - o "encontro colonial". Os ingleses tradicionalmente os pesquisadores - eram tomados como objeto de estudo por uma brasileira - tradicionalmente um ser exótico pela combinação entre gênero e origem cultural e nacional, experiência que apresento no artigo "A amiga brasileira: amizade e trabalho de campo em Londres", publicado em 1995 nas Comunicações do PPGAS. Apesar desta resistência, alguns professores valorizaram o ineditismo do estudo e fui convidada após a tese a contribuir com o verbete sobre amizade para a Enciclopédia de Antropologia Social e Cultural em 1996.

A tese de doutorado, defendida no final de 1993, foi uma etnografia em moldes mais clássicos, falando de como as pessoas estudadas viviam - como eram suas casas, com quem viviam, onde trabalhavam, como se divertiam no tempo de lazer, sempre usando a amizade como recorte de aproximação. Analisei as concepções de amizade apresentadas pelos ingleses pesquisados, articulando-as a noções de pessoa, gênero e classe social. Percebi que mesmo este último conceito, tão caro na sociologia, ganhava significados nativos bem distintos e cruciais para entender como 
são as pessoas e como podem se relacionar enquanto amigos. Comparei também os laços de amizade com as relações amorosas e familiares, buscando entender pelo contraste a singularidade dos amigos.

As publicações a partir da tese vieram alguns anos depois, já incorporando a comparação que eu viria a fazer posteriormente com meu estudo sobre amizade no Rio de Janeiro e que comentarei mais adiante. Mas gostaria aqui de apontar como vários temas explorados na tese - amizade e a relação com as ideias de intimidade e confiança, o contraste com a família, a importância da classe e do gênero - apareceriam depois em minhas pesquisas futuras e principalmente como o interesse teórico no conceito de pessoa se tornou norteador de minha trajetória intelectual. Através das ideias de identidade, emoção, subjetividade e corpo, tenho explorado desde então facetas do conceito de pessoa em contextos sociais e culturais distintos.

\section{Criando raízes}

Retornei ao Rio de Janeiro no fim de 1993. Se o início da temporada em Londres havia sido muito empolgante e em algum momento considerei ficar por lá, já no final dos quatro anos tinha muitas saudades da vida no Brasil, em particular do modo como as pessoas se relacionam. Voltei decidida a trabalhar aqui. Consegui uma bolsa recém-doutor do CNPq para atuar no departamento de antropologia no Instituto de Filosofia e Ciências Sociais (IFCS) da UFRJ.

Na época, fiz contato com Yvonne Maggie, que havia criado recentemente o Programa Raça e Etnicidade, financiado pela Fundação Rockfeller, com o objetivo de reunir pesquisadores estrangeiros e brasileiros que estudavam a temática em diversos contextos socioculturais. Nos dois anos de bolsa no IFCS, colaborei com Yvonne e Peter Fry no Programa. Um dos resultados deste período foi a coedição com Yvonne da coletânea Raça como Retórica, em 2002, reunindo os textos apresentados pelos pesquisadores participantes do Programa Raça e Etnicidade. Neles, as categorias de raça e etnicidade não aparecem de forma fixa, mas são acionadas em certos contextos e relações, como retórica de diferença. Tanto no Brasil como em outros países, há relações de poder complexas subjacentes ao modo de manipular estes termos, demarcando sempre hierarquias raciais e sociais.

O convívio com estes estudiosos introduziu a dimensão da raça nas minhas preocupações teóricas. Como disse Yvonne uma vez, depois que se começa a estudar raça, ela nunca desaparece do nosso olhar. Pesquisei 
durante três anos as relações entre empregadas domésticas e patroas, buscando entender como as percepções sobre raça apareciam nas suas falas e nas suas relações. Explorei também como a categoria empregada adquiria representações específicas, muitas vezes negativas, discutidas em meu artigo "A empregada na televisão: uma análise de representações", publicado em 1997 nos Cadernos de Antropologia e Imagem. Apesar do foco na questão racial, a amizade surgiu como tema importante nos dados pesquisados, uma vez que figurava sempre como modelo ideal de relação entre patroas e empregadas. Este dado contrastava de forma marcada com a separação nítida entre amizade e trabalho que encontrei em Londres, comparação que explorei em dois capítulos para as coletâneas The Anthropology of Friendship (1999) e Mediação, cultura e cidadania (2001).

Neste período, participei também durante dois anos de uma rede de pesquisa sobra gênero, raça e etnicidade na América Latina coordenada por Marisa Navarro e Susan Bourque, então professoras respectivamente de Dartmouth College e Smith College. Em colaboração com Márcia Lima, discuti a articulação entre gênero, raça e classe na sociedade brasileira tomando como exemplo as representações em torno das empregadas domésticas, análise desenvolvida no artigo "Linking gender, class and race in Brazil", publicado em 2004 na revista Social Identities. Esta experiência contribuiu para a percepção de que estas variáveis se interpenetram sempre - o que atualmente é apresentado como interseccionalidade - e se a dimensão de classe já havia sido significativa no doutorado, sua análise em associação com raça e gênero torna-se fundamental.

Este estágio de pós-doutorado foi também meu início à docência. Ainda que tenha oferecido disciplinas de "Introdução à antropologia" para diversos cursos de graduação, foi no IFCS que tive de enfrentar o desafio de encarar turmas grandes que lá estavam para cursar uma obrigatória externa, em geral com pouca motivação. Também co-orientei bolsistas de iniciação científica no Núcleo da Cor, coordenado por Yvonne Maggie. Vejo assim este tempo no IFCS como um momento de introdução à vida acadêmica, que viria se consolidar com minha entrada na UERJ em 1996.

Fiz concurso para o departamento de ciências sociais da UERJ em uma fase de renovação de quadros da universidade. Naquela época, buscavase mudar a fama de "escolão" que a UERJ teve por muitos anos. Pouco antes de mim, outros colegas com doutorado recente haviam entrado no departamento, com o objetivo não apenas de fortalecer a pesquisa na instituição como também de reverter a alta taxa de evasão dos estudantes 
de graduação. O Programa de Pós-Graduação em Ciências Sociais (PPCIS) contava apenas com o mestrado, recém criado em 1994. Para estimular a pesquisa e a dedicação exclusiva, que não existia como regime de trabalho, foi criado o programa ProCiência, no qual eu ingressaria em 1997 permanecendo até hoje.

Retomei o tema da amizade em meu primeiro projeto de pesquisa, intitulado "Amizade e hierarquia: princípios conflitantes?" (1997-2000). A presença da amizade como ideal na relação entre patroas e empregadas domésticas contrastava com o que ouvi dos ingleses estudados em Londres, onde era mantida à parte da esfera do trabalho. Em contraste com os ingleses, encontrei no Rio certa surpresa com meu tema de estudo - porque estudar uma relação tão 'fácil' e tão comum entre os brasileiros? A partir desta diferença, resolvi pesquisar o tema nos moldes do que havia feito no doutorado, com foco em histórias das relações, buscando entender quais os significados dados para amizade no Rio de Janeiro. De forma semelhante ao estudo inglês, examinei como a experiência subjetiva da amizade está articulada a um nível mais amplo de representações sobre diferenças sociais, reforçando muitas vezes marcas de distinção social. Com a participação de bolsistas PIBIC na realização de entrevistas, ampliei o recorte social estudado - pessoas de camadas médias, porém com idades e raças distintas: jovens universitários negros e brancos e homens e mulheres na faixa dos quarenta anos, funcionários de uma empresa estatal.

Com os dados desta pesquisa e do estudo do doutorado, publiquei o livro Os significados da amizade: duas visões de pessoa e sociedade, em 2002. Discuti como amizade era definida em Londres e no Rio de Janeiro, o que era considerado problemático em cada contexto, como era diferenciada de relações familiares e amorosas e, por fim, como classe, raça e religião afetavam ou não vínculos entre amigos. Minha proposta era menos realizar uma comparação explicita - feita só na conclusão - do que usar cada material etnográfico para iluminar o outro. Em ambos os contextos, amizade surge relacionada a concepções de pessoa e ao modo de estabelecer relações, mas com ênfases e sentidos diversos. Em Londres, o foco do discurso era o self, sua revelação e a manutenção ou não de sua autonomia. Expor o self "verdadeiro" - espontâneo, não contido pela polidez, emotivo - acontecia em contextos restritos, como entre amigos próximos. A polidez era manejada distintamente por pessoas de origem social diferentes, dificultando assim a amizade entre elas. No Rio de Janeiro, o destaque recaía sobre a escolha do outro, cujas intenções deveriam ser "boas", desinteressadas, para 
tornar-se assim "de confiança". Aqui a ideia de "verdade" da pessoa não remetia a uma emotividade espontânea, mas a querer o bem do outro e a sua disposição de contribuir para isso. Neste sentido, a amizade poderia se desenvolver entre pessoas de classe e religião diferentes, mais como um ideal do que prática de fato.

Ao longo desta pesquisa, deparava com referências constantes ao modo brasileiro de fazer amizade, principalmente nas relações com estrangeiros ou em experiências de vida no exterior. Propus então um pequeno subprojeto, "A construção de identidades e alteridades através da amizade", em 1999, para o Programa PIBIC da UERJ. Juntamente com os bolsistas de iniciação científica, examinei as narrativas sobre amizade de jovens que viveram um ano no exterior através de programas de intercâmbio escolar. Este material apontou para uma mudança na autopercepção enquanto brasileiro/a, a partir do modo de estabelecer relações de amizade no exterior, motivando assim a elaboração do projeto seguinte para o ProCiência "Somos ocidentais? Um estudo da construção de identidade nacional entre intelectuais", desenvolvido entre 2000 e 2003.

Este projeto surgiu também da minha própria experiência enquanto estudante de doutorado na Inglaterra e do meu convívio com outros brasileiros na mesma situação. Foi neste período que percebi a relatividade de uma série de categorias identitárias e principalmente da plasticidade do significado de ser brasileiro, ao mesmo tempo em que experimentei um aguçamento do meu sentido de pertencimento ao Brasil. Tive que reinterpretar e lidar com a expectativa de que brasileiros são sempre expansivos e afetuosos, a imagem da sensualidade onipresente da mulher brasileira, a percepção de não ser branca e nem ocidental e a imposição de que, por vir de um país subdesenvolvido, eu precisava refazer meu mestrado.

O foco teórico do projeto, que se desdobrou no estudo seguinte "Os elos do pertencimento: identidade nacional e subjetividade" (2003-2007), estava assim no conceito de identidade e especificamente na construção de identidade nacional. Partindo da visão mais corrente nas ciências sociais de que as identidades, longe de serem unidades essencializadas, são elaboradas continuamente de acordo com o contexto, busquei compreender, entre pessoas que tinham realizado seus doutorados no exterior, como a experiência de ser estrangeiro em países europeus e nos Estados Unidos afetou sua auto-percepção enquanto brasileiros, bem como seu modo de pensar o Brasil. Entrevistei professores universitários no Rio de Janeiro, a 
maioria na área de humanas, que haviam vivido fora do país no final da década de 1980 e início dos anos 90.

Os artigos publicados a partir destes projetos deram forma ao livro Retratos do estrangeiro: identidade brasileira, subjetividade e emoção, publicado em 2009. Nele discuto como a imagem do brasileiro emotivo, que compõe narrativas de Paulo Prado, Sergio Buarque de Hollanda e Gilberto Freyre, acompanhou a experiência de vida dos entrevistados, ganhando novos significados. Se entre estes autores clássicos a emotividade era ambígua - positiva como calor humano e negativa por ser irracional, para os entrevistados ela era valorizada como algo que distinguia os brasileiros positivamente dos locais, principalmente no modo de fazer amizade. A identidade brasileira, mais aguçada naquele contexto, era entendida de forma estereotipada: a emotividade, o gosto pelo futebol, samba, feijoada. Mas a relação com a brasilidade não era unívoca, pois marcava em várias situações a dificuldade de ser reconhecido nas universidades locais como igual, levando os entrevistados a se distanciarem deste estereótipo. Eram, portanto, identificações móveis, de natureza afetiva, que se manifestavam com força maior na condição de ser um estudante estrangeiro.

Ao longo destes anos, orientei vários alunos com temas relacionados, direta ou indiretamente, às minhas pesquisas. Se a orientação de bolsista PIBIC fazia parte dos meus projetos de pesquisa, na pós-graduação o desafio era estimular a autonomia de cada um mantendo o diálogo com as minhas especialidades. Assim, das seis teses de doutorado que orientei, duas estudaram as relações entre o jovem e sua família (Márcia Stengel e Fernanda Sansão Ramos), três analisaram processos de construção de identidade (Guilherme Nogueira, Danielle Ellery e Carlos Costa Luz) e uma examinou a articulação entre corpo e amizade em uma comunidade naturista (Luiz Fernando Rojo). De forma semelhante, as orientações de mestrado voltaram-se para relações de gênero, construção de identidade (nacional, de trabalhador, de raça, de jovem), relações de amizade e relações amorosas, emoção e consumo. Algumas destas foram, por sua vez, desdobramentos de monografias e orientações de iniciação científica.

Os temas de pesquisa também se refletiram nas disciplinas eletivas que ofereci na graduação e na pós-graduação. Em ambos os níveis, o curso "Individuo e sociedade" foi ocasião para explorar construções do conceito de pessoa, de identidade e de emoção, bem como teorias que articulam os planos micro e macro da vida social. Discuti os significados da amizade e seu contraste com as relações familiares nas eletivas de "Organização social 
e parentesco". Através das disciplinas "Cultura brasileira" e "o Negro no Pensamento Social Brasileiro", pude discutir as construções de identidade brasileira e as relações raciais como parte deste processo.

Destaco aqui o interesse específico pelas emoções como eixo transversal aos projetos de pesquisa que desenvolvi nestes anos. A pesquisa sobre amizade revelava articulações distintas entre pessoa e emoção em Londres e no Rio, de tal forma que, ao contrário de lá, aqui amizade podia referir-se a uma relação e a um sentimento que pode existir em interações de trabalho, como, por exemplo, entre empregadas e patroas. No estudo sobre identidade brasileira, elas figuravam tanto como elementos das representações sobre brasilidade, como na qualificação da experiência de vida no exterior.

A reflexão teórica sobre emoção se desenvolveu também nas disciplinas dadas na pós-graduação e na graduação, muitas em parceria com Maria Claudia Coelho, amiga dos tempos do mestrado no Museu Nacional e agora colega de departamento. Juntas, publicamos o livro Antropologia das emoções, em 2010, e a coletânea Cultura e Sentimentos: ensaios em antropologia das emoções, em 2011. O primeiro apresenta de forma sintética e introdutória, as principais questões em torno do estudo antropológico das emoções, como as tensões entre o que é biológico e universal e o que é particular e cultural, bem como sua dualidade enquanto experiência individual e social ao mesmo tempo. Discutimos também o potencial micropolítico das emoções e os contornos da experiência emotiva na modernidade ocidental. O segundo volume reúne estudos de parceiros e ex-alunos de pós-graduação, orientandos nossos, que tomaram os sentimentos ora como foco de atenção, ora como recorte analítico para discutir gênero, religião, política, entre outros. Aqui o esforço foi contribuir para a construção de um campo brasileiro de antropologia das emoções.

Este trabalho de construção de um campo se desdobrou em dois outros níveis, dentro e fora da UERJ. Em congressos nacionais - como nas Reuniões Brasileira de Antropologia, nos encontros da ANPOCS - e internacionais como nas Reuniões de Antropologia do Mercosul, apresentei trabalhos e organizei, em alternância com Maria Claudia, grupos de trabalho e mesas redondas sobre cultura e emoção. Dentro da Uerj, criamos em 2007 o Núcleo de Antropologia das Emoções (NANTE) como atividade de extensão. Através de mini-cursos, alunos de pós-graduação debatiam suas pesquisas bem como filmes com alunos de graduação e participantes externos a UERJ. Se em função de cargos administrativos que eu e Maria Claudia ocupamos nesta época tivemos que encerrar o núcleo, o interesse em uma abordagem 
antropológica das emoções se mantem nas orientações e disciplinas que damos e nos projetos de pesquisa, ainda que eu tenha deslocado minha ênfase para o conceito de subjetividade, como discuto a seguir.

\section{Maternidade}

Em 2004, nasceu meu filho Sebastião. A gravidez veio já aos 39 anos e trouxe com ela muitas questões em torno da experiência física e subjetiva de gestar um bebê, articulada aos sentidos de maternidade. Neste período, a amizade e a identidade nacional, questões tão caras para mim anteriormente, já se colocavam como temas bem explorados.

Assim, em 2007, resolvi transformar a gravidez em objeto de estudo no projeto "A experiência da gravidez: corpo, subjetividade e parentesco", que recebeu apoio também do $\mathrm{CNPq}$ através de bolsa de produtividade. Era um tema pouco estudado em si - havia vários trabalhos sobre as novas tecnologias reprodutivas que recortavam aspectos e momentos específicos da gravidez, mas não o período como um todo. Assim, este projeto, que teve continuidade nos períodos seguintes, se propôs a investigar como este processo que ocorre no corpo é vivenciado de acordo com significados e práticas culturais. Enquanto processo situado no corpo das mulheres, diz respeito às questões de gênero - o lugar social das mulheres, a importância da maternidade na construção de papéis e subjetividades femininas e as relações de gênero na família. Enquanto processo que reproduz sujeitos, a gravidez põe em foco não apenas conceitos de pessoa, mas a constituição de laços familiares. Em última instância, a gravidez tem sido não só um objeto de reflexão em si mas também meio privilegiado para analisar a relação entre pessoa, subjetividade e parentesco.

Para este projeto pesquisei mulheres em sua primeira gestação, casadas, com idades em torno de 30 anos, brancas, de camadas médias, com formação universitária e residentes na zona sul do Rio de Janeiro. Realizei entrevistas e trabalho de campo em um grupo de gestantes em 2008. Neste ano, realizei um pós-doutorado na UFRJ, tendo Myriam Lins de Barros como interlocutora. O diálogo com ela foi extremamente rico e produtivo: discuti com ela questões da pesquisa de campo e analisei o material que estava colhendo, destacando o que era interessante e diferente de outras gerações. Dos três eixos do projeto - corpo, subjetividade e parentesco, este último foi o que menos apareceu, ainda que nossas discussões tenham levantado questões que busquei desenvolver posteriormente. 
Nesta etapa, a dimensão das emoções na experiência da gravidez e o foco na preparação para o parto foram os temas que tiveram maior desenvolvimento entre as mulheres estudadas. No artigo "Um estado emotivo: representação da gravidez na mídia", publicado nos Cadernos Pagu em 2011, analisei a representação da gestação na mídia e no senso comum enquanto período de "maior emotividade", ao mesmo tempo em que se demanda às mulheres a manutenção de um controle de si. A questão do autocontrole se manifesta também através da frequente menção aos sentimentos de ansiedade e medo em torno do parto e pós-parto expresso nos encontros do grupo de gestantes, tema que desenvolvi em alguns artigos, em especial "Em torno da ansiedade: subjetividade, mudança e gravidez" publicado na revista Interseções em 2012.

Aprofundei a dimensão do parentesco nos períodos seguintes do Prociência (2009-2012, 2012-2015), também com apoio de bolsas de produtividade do $\mathrm{CNPq}$, investigando especificamente o modo de pensar o pertencimento familiar a partir da gravidez. Com os bolsistas de iniciação científica, realizei um novo conjunto de entrevistas com um recorte mais diversificado de mulheres: brancas e negras, residentes nas zonas sul e norte do Rio de Janeiro, casadas, com idades em torno de 30 anos e formação universitária. Como apresento no artigo "The experience of pregnancy: subjectivity and social relations", publicado na Vibrant em 2012, a participação da família de origem no cotidiano da gravidez é bem mais atuante do que em gerações anteriores, como aquelas estudadas por Tania Salem e Maria Isabel Almeida. O casal é uma unidade significativa, na qual presença do homem na gestação e parto é tomada como dada. Ao mesmo tempo, a maternidade para estas mulheres surge como projeto cuidadosamente escolhido e planejado que, contudo, assusta pelas mudanças que trará às suas vidas profissionais, conjugais e à sua autonomia.

Esta segunda etapa da pesquisa sobre gravidez teve dois desdobramentos. Primeiro, produziu um questionamento sobre o lugar da família na construção do pertencimento de um modo mais geral e deu origem a um projeto de auxílio para pesquisa, financiado pelo Edital Universal do CNPq em 2009. Reunindo pesquisas de doutorandos que estudavam a elaboração de identidade racial entre negros de camadas médias, a construção de identidade profissional entre jovens vestibulandos e a presença da subjetividade no processo de administração da indústria cinematográfica, além do meu projeto sobre gravidez e família, examinamos como as relações de parentesco norteavam processos identitários nestes diferentes contextos. 
Segundo, suscitou meu desejo de realizar outro estágio pós-doutoral, desta vez fora do país, na Universidade de Edimburgo, em diálogo com Janet Carsten, referência nos estudos de parentesco. Com bolsa Estágio Sênior da Capes, passei onze meses na Escócia entre 2013 e 2014, com o objetivo de analisar em profundidade todas as entrevistas já realizadas. Este estágio me colocou novamente diante da antropologia britânica, com sua tradição de etnografias globais e agora com novos debates teóricos de natureza mais filosófica. As conversas com Janet e Maya Mayblin, professora também do departamento de antropologia, bem como a presença nos seminários semanais que este organizava, contribuíram muito para pensar teoricamente os processos de constituição do parentesco revelados nos meus dados de pesquisa.

Como resultado, escrevi dois artigos que discutem especificamente a gravidez como momento de (re)construção do parentesco, que está longe de ser justificado apenas pelo compartilhamento de substâncias biológicas. Em "Nomes que (des)conectam: gravidez e parentesco no Rio de Janeiro", publicado na revista Mana em 2015, apresento como, através da escolha dos sobrenomes, os casais avaliam suas próprias relações com as famílias de origem e decidem qual sobrenome transmitir ao bebê, o que constrói tanto conexões quanto desconexões. De modo semelhante, em "Imaginando o bebê esperado: parentesco, raça e beleza no Rio de Janeiro", publicado na revista Etnográfica em 2016, quando as gestantes imaginam a aparência física do bebê, fazem uma lista dos traços físicos desejados e não desejados, ambos remetidos às características familiares que são muitas vezes associadas à raça e etnicidade. Ao mesmo tempo em que projetam uma continuidade entre gerações, marcam também singularidades e distanciamentos. Assim, mesmo quando a questão implica as próprias 'substâncias biológicas', o compartilhamento enquanto base do parentesco é visto de forma seletiva, ajustando-se a projetos do casal que podem desejar continuar certa identidade étnica e posição social familiares ou, ao contrário, afastar-se destas através da ascensão social.

Ao retornar da Escócia, participei do projeto Gênero efamília, coordenado por Clara Araújo e financiado pela Faperj, que realizou um extenso survey sobre os temas no estado do Rio de Janeiro. Analisei uma pequena parte dos dados estatísticos a partir das variáveis gênero e geração, experiência metodológica que não tinha desde minha graduação. Neste trabalho, que resultou em um capítulo na coletânea Entre a casa e o trabalho: gênero e família no Rio de Janeiro, organizada por Clara Araújo e Andréa Gama e publicada 
em 2017, destaca-se a permanência da maternidade como papel social valorizado para mulheres, tanto por elas e pelos homens, enquanto que o trabalho tem significado principalmente se for referido ao sustento da família. Esta opinião é mais pronunciada nas gerações mais velhas do que nas mais novas, que mesmo assim ainda valorizam significativamente a experiência de ter filho.

Nestes anos, percebi um crescimento nos estudos sobre parto, tema que já aparecia nas minhas entrevistas enquanto um evento projetado e temido. Além disso, frequentemente ouvia relatos espontâneos de parto quando falava no tema da minha pesquisa. Assim, elaborei o projeto "Histórias de parto: pessoa e parentesco", iniciado em 2015 e ainda em desenvolvimento no presente. Desta vez, contudo, estruturei a pesquisa de campo de forma comparativa: entrevistei um grupo de mulheres com mais de 60 anos, que tiveram seus filhos na década de 1980, e outro mais jovem, com idades entre 35 e 45 anos que tiveram filho nos últimos quatro anos. A proposta de comparação vem da percepção, já nas pesquisas anteriores, da disseminação recente dos discursos de humanização do parto, daí meu desejo de ouvir mulheres mais velhas que pariram antes do surgimento deste movimento de crítica à obstetrícia tradicional.

Por conta de uma greve docente de cinco meses em 2016, pude realizar dezesseis entrevistas - sete com mulheres mais velhas e nove com o grupo mais jovem. Estou em processo de analisar as narrativas, que contam um pouco sobre as gestações e detalham mais os partos. Ao contrário do que imaginei inicialmente, as histórias mencionam pouco o parentesco, seja em termos de referências à constituição dos laços, seja pela participação da família no momento do parto. Em compensação, desponta de forma fundamental a relação com o médico e o hospital em todo o processo.

A partir de um trabalho apresentado em Lisboa em 2016, no Congresso Internacional de Estudos de Gênero, destaco aqui algumas diferenças entre as duas gerações de mulheres. As mais velhas se casaram e tiveram mais filhos e mais cedo do que as mais jovens. A maternidade veio com o parto, momento em que "conheceram" os bebês. O trabalho aparece para as mais velhas como um foco importante das narrativas, mas seus relatos das gestações e partos incluem os maridos de forma mais pontual, sugerindo uma divisão de trabalho na qual cabia às mulheres principalmente $o$ cuidado dos filhos e da casa.

Entre as mulheres mais jovens, enfatizo o caráter planejado das gestações, que vieram depois dos 30 anos. O ideário do parto humanizado aparece 
como fator de influência na escolha do médico e do tipo de parto, que exigiu programação financeira, uma vez que muitos destes não aceitam planos de saúde. A maternidade foi para quase todas vivida já a partir da gravidez. Os maridos figuram o tempo todo nas narrativas, desde as decisões sobre a gravidez como também as ações e escolhas em torno do parto.

Seja naquelas experiências vistas como problemáticas ou nos partos considerados bons e tranquilos, é a negociação da mulher com a equipe médica - o obstetra especialmente mas também anestesistas, pediatras e enfermeiras - o fio condutor das narrativas. O que diferencia as duas gerações neste aspecto é a crítica feita pelas mais jovens a procedimentos médicos em consonância com as propostas do parto humanizado e o planejamento do parto de forma detalhada. Estas narrativas refletem, por sua vez, experiências de gênero a partir de um segmento social específico em termos de raça, classe e escolaridade, que também se revela na vivência do sistema médico-hospitalar. Esta interseção entre estes marcadores sociais produz assim os eixos dentro dos quais estas experiências tornam-se significativas, em um esforço de articular a dimensão da vivência subjetiva aos contextos de relações sociais e de poder mais amplos nos quais ela se insere.

Por conta das pesquisas sobre gravidez e parto, orientei três dissertações de mestrado em torno destes temas, discutindo de forma mais aguda os processos de medicalização da gestação. As duas orientações de mestrado em andamento também têm como foco as experiências corporais - a tatuagem e a violência racial. Tenho participado de muitas bancas, de qualificação e defesa, em torno da gravidez e do parto, bem como de grupos de trabalho em congressos nacionais e internacionais. Nestas ocasiões, vejo a crescente militância em torno dos direitos das mulheres aos partos que elas desejam, traço presente também nas dissertações que orientei. Posiciono-me sempre a partir de um olhar que problematiza tanto visões essencializantes das mulheres - na ideia de que parir está na sua natureza - e certas críticas feitas pela "medicina baseada em evidências", por ver a própria ideia de "evidência" como longe de ser autoevidente.

O estudo de uma experiência corporal inserida nos sistemas de saúde me aproximou dos trabalhos feitos por Rachel Aisengart Menezes, da UFRJ, e Waleska Aureliano, colega de departamento da UERJ. Juntas, elaboramos o projeto "Gestão do corpo e subjetividades contemporâneas", que recebeu apoio do CNPq através do Edital Universal em 2016. Nossa proposta é discutir a formação de subjetividades contemporâneas, por meio de 
diferentes modos de gestão dos cuidados corporais, em três contextos: na gravidez e no parto, no adoecimento e tratamento para câncer e no processo do morrer, em decorrência de avanço de doença degenerativa. Partimos da visão de que estes modos de gestão do corpo se constituem através de discursos presentes em instituições e campos de saber que são acionados tanto por profissionais quanto por sujeitos que vivenciam as situações apontadas. O objetivo, portanto, do estudo destas formas de percepção e de lidar com o corpo é contribuir para uma análise da subjetividade enquanto uma construção cultural e historicamente específica.

Assim, se nas primeiras pesquisas que fiz logo após o doutorado, o eixo estava nos conceitos de pessoa e de identidade, agora o foco está na subjetividade e na experiência, que envolve o corpo. Se meu interesse sempre esteve no sujeito, esteve sempre também nas relações sociais nas quais ela ou ele estão inseridos, relações estas marcadas por diferenças de poder de caráter mais ou menos institucionalizado. Não vejo uma mudança de abordagem, mas sim um movimento de buscar conceitos em torno de como o sujeito vive na sociedade. O conceito de pessoa, abordado inicialmente por Mauss (1974) e retomado na década de 80 (por exemplo, Carrithers et al 1985, Kondo 1990), sustentou um amplo leque de estudos sobre como estar e agir no mundo adquire significados muitos distintos em épocas, sociedades e culturas diferentes. Na década de 90 nas formulações de Giddens (1991) e Hall (1998), as questões em torno da identidade despontaram com força, referindo-se aos sentidos subjetivos que o sujeito atribui às formas de pertencimentos coletivos. Atravessando ambos estão as emoções, como modos culturalmente elaborados de sentir e reagir às pessoas e ao mundo, que como propõem Lutz e Abu-Lughod (1990), falam mais da vida social do que de estados interiores. O deslocamento para o conceito de subjetividade veio de um desejo de encontrar um conceito que incluísse a emoção e fosse além, explicando como grupos de pessoas interpretam e agem de modos distintos. Com as definições de Ortner (2007), a noção de subjetividade inclui não só os afetos e modos de pensar, mas também o modo de agir, a prática social. E é enquanto ser em movimento que agrego a estas ferramentas o conceito de experiência, elaborado por Bruner (1986), que permite a análise de como eventos vividos são percebidos e significados pelos indivíduos. 


\section{0 ensino e os sonhos antigos}

Se minhas pesquisas articulam muito do que fiz e faço na universidade e fora dela, há alguns aspectos da minha trajetória como docente que são menos vinculados a elas e que gostaria de comentar aqui. Volto lá atrás para o começo, para a minha história familiar. Sou filha de dois professores universitários. Cresci com meu pai tirando dúvidas de matemática e física, sua área, o que era um desafio para ele conseguir me explicar conceitos tão básicos para ele. Com minha mãe, tive apoio às aulas de piano que fazia, com sua atenção meticulosa às passagens e dedilhados difíceis. Ela foi também a primeira leitora dos meus textos, me alertando sempre para o encadeamento das ideias e cuidado com a repetição de palavras. Além do que ganhei deles em termos de aprendizado, tive também desde cedo duas pessoas dedicadas a ensinar como modelos. Quando entrei na universidade, nos tempos em que pretendia resolver os problemas do Nordeste, me via fazendo isso através da educação. Se a ambição social arrefeceu, minha escolha pelo ensino se mostra cada vez mais apaixonada.

Quando comecei a dar aula, ainda no IFCS, me sentia muito tímida e nervosa diante das turmas grandes de "Introdução à antropologia", vindas de outros cursos. Mas vencida a estranheza inicial com cada turma, gostava muito de ver que certas discussões empolgavam e faziam os alunos repensarem suas ideias. Desde aquela época, o curso de "Introdução à antropologia" tem sido um espaço de desafio que frequentemente gosto de encarar: como apresentar para alunos que ingressam na universidade o que é antropologia? São turmas grandes, agitadas com a novidade de estar fora da escola. Ao mesmo tempo, sei que há questões como as formas sutis de etnocentrismo e o relativismo no modo de entender corpo, emoção, gênero que impactam muito os alunos, tirando-lhes o chão muitas vezes, razão porque gosto também de dar a obrigatória de "Antropologia Biológica" no quarto e quinto períodos do curso. Em que acreditar então, perguntam eles? Nestes vinte e poucos anos, tenho acompanhado como etnocentrismo e relativismo se tornaram noções já familiares desde o ensino médio e tenho tido que pensar exemplos e questões diferentes do que usava no início. Pois o desafio continua a ser não só introduzi-los a como também seduzi-los pela antropologia.

Mas ai surge outro problema:como apresenta-los às teorias antropológicas ao longo de sua história, já a partir do segundo período? Desde que entrei na Uerj, tenho dado recorrentemente a disciplina obrigatória "Teoria 
antropológica I" (evolucionismo, Boas e Escola de Cultura e Personalidade, Malinowski e Evans-Pritchard). Como tive pouca teoria antropológica na graduação, tomei para mim a tarefa de dar aos alunos uma boa formação teórica. Muito rapidamente descobri que ao chegar ao final do curso, os alunos já não lembravam mais destes autores e seus conceitos e debates teóricos. Já organizei o conteúdo de maneiras diversas, por escolas ou por temas, e ainda assim não tenho certeza se venho sendo bem sucedida, pois acho que parte do problema está em ser apresentado à teoria muito cedo no curso. Com frequência, ofereço a eletiva "Teoria da cultura" como forma de relembrar autores, preencher lacunas e sistematizar um pouco da história da antropologia. Sem dúvida, também nas outras eletivas mais próximas aos temas de pesquisa, busco transmitir aos alunos a necessidade de perceber nas diversas situações do cotidiano as questões teóricas debatidas por autores clássicos e contemporâneos das ciências sociais.

Acho que o desafio de ensinar antropologia está mais na graduação do que na pós-graduação. Na pós, a proposta é fortalecer a formação e desenvolver a pesquisa. Por isso talvez, em um programa de pós-graduação com mais de vinte professores, não disputo tanto a oferta de disciplinas na pós. Mesmo quando dou cursos obrigatórios como "Teoria antropológica" e "Metodologia Qualitativa" (um programa de fato teórico-metodológico) na pós-graduação, o tom é distinto - com certeza recupero debates teóricos mas já pressuponho que não são desconhecidos aos alunos. Nas disciplinas eletivas, nas quais tenho enfatizado a importância de articular as dimensões micro e macro sociais da vida cotidiana, realçando como construções de subjetividade e discursos emotivos acompanham organizações sociais e relações de poder mais amplas, vejo-me trocando ideias com interlocutores, alunos que já desenvolvem suas pesquisas e suas próprias reflexões.

Nesse sentido, o trabalho de orientar monografias de fim de curso é sempre muito interessante, pois é a chance que os alunos têm ao final da graduação de sistematizar o que aprenderam dentro de um tema e recorte específicos que eles escolhem. Nas vinte monografias que orientei, os assuntos são variados, mas acompanham de certa forma minhas pesquisas. Há tempos atrás, quando ensaiamos uma reforma curricular, pensamos em transformar a monografia em eletiva, como forma de facilitar a conclusão do curso para aqueles que não pensam em pós-graduação. Os alunos rechaçaram a proposta com veemência e entendi a importância daquele primeiro exercício de autonomia e autoria. 
Também penso nas orientações de iniciação científica como forma de fazer escolhas, não apenas de aprender a fazer pesquisa. Sempre pedi aos alunos que selecionem um subcampo específico dentro do meu projeto, de modo que eles recortem o grupo a ser pesquisado de acordo com seus interesses. Por isso também, ainda que com roteiros de entrevista traçados por mim, inserimos questões relacionadas às suas preocupações. Neste sentido, minha experiência de orientar bolsistas é ao mesmo tempo de ensino e troca. Mesmo que em fase de aprendizado de conceitos, questões teóricas e mapeamento do campo de estudo, eles são interlocutores importantes. Muitas ideias desenvolvidas e apresentadas em artigos surgiram dos nossos debates em torno dos dados das pesquisas de campo.

Ser professora e orientadora mesclam para mim troca intelectual e afetiva e é com certeza atividade que me realiza profundamente. Se já tinha um sonho antigo de trabalhar como educadora, foi na UERJ com todas as suas particularidades que o transformei em realidade. Vejo como ao longo dos anos, o curso de graduação se consolidou e aperfeiçoou, refletido não apenas no aumento significativo de formandos e na queda na taxa de evasão que existia quando entrei. Cada vez mais alunos participam de pesquisas durante sua graduação, tanto com bolsas de iniciação científica como pelo programa de estágio voluntário, e muitos destes prosseguem para o mestrado e doutorado, seja no PPCIS ou em outros programas. Considerando o fato de que nossos alunos costumam vir de segmentos sociais em que são muitas vezes os primeiros da família a entrar na universidade, este trabalho é motivo de muito orgulho e por isso gera tanta angústia no tempo presente de descaso da UERJ. Mais do que a perda de recursos, temos perdido alunos...

\section{Desafios}

Neste memorial, privilegiei as atividades que me identificam como professora e pesquisadora. Realizei também atividades administrativas variadas, como coordenação da área de antropologia e decurso de graduação, chefia do departamento de antropologia, após a criação do Instituto de Ciências Sociais em 2014, e coordenação adjunta de pós-graduação em dois momentos do PPCIS. Embora tenham sido oportunidades importantes de conhecer e compreender melhor o funcionamento da UERJ enquanto instituição, é, contudo, no ensino e na pesquisa que vejo minha contribuição fundamental. 
Como desafios futuros, considero importante principalmente ter conexões mais próximas com grupos de pesquisa de outras instituições nacionais e internacionais. Este é tanto um desejo pessoal como também uma necessidade institucional. Para o PPCIS principalmente, a internacionalização, através de pesquisas, convênios e publicações em revistas estrangeiras, é um aspecto a ser mais desenvolvido para que possamos melhorar nossa avaliação junto a Capes. E com certeza, a ampliação dos horizontes de pesquisa será sentida no ensino da graduação, contribuindo assim para um ganho de qualidade do curso de ciências sociais. Se por certa timidez faço pouco este movimento, as parcerias internacionais para mim ajudam a manter o olhar mais cosmopolita e também questionador que foi tão importante no meu doutorado. É através destes diálogos que trocamos não apenas dados etnográficos distintos, mas concepções diversas do que é uma contribuição teórica nova, como pude aprender nas minhas tentativas recentes de publicar artigos em revistas americanas e inglesas.

Fecho este texto, como não poderia deixar de ser, falando do que significa olhar para trás no presente em que vivemos na Uerj, a partir do qual tornase custoso pensar no futuro. Começar a escrevê-lo me gerou muita angústia: afinal, porque estou pensando em progredir na carreira se a própria instituição parece ameaçada? Como falar de perspectivas futuras quando temos um governo que nos trata como se não existíssemos? Quero acreditar que uma universidade que está entre as melhores no país e na América Latina não pode acabar assim. Diante dos danos já causados pela falta de investimentos e pagamentos que afetaram o calendário acadêmico, uma das nossas maiores tarefas agora será recuperar os alunos que perdemos e continuar mostrando ao grande público a força da instituição enquanto centro de ensino e pesquisa. Do mesmo modo que, olhando para a Uerj na qual ingressei, creio ter contribuído para sua transformação ao longo destes anos na referência que se tornou, tenho que continuar trabalhando para mantê-la assim, viva e importante. No momento, é este meu maior desafio. 


\section{Referências}

BECKER, Howard.

(1995). "Foi por acaso": reflexões sobre a coincidência. Anuário Antropológico 93, p. 155-173

BOURDIEU, Pierre.

(2006). A ilusão biográfica. In: AMAD0, Janaina \& FERREIRA, Marieta M. (orgs.). Usos $e$ abusos da história oral. $8^{a}$ ed. Rio de Janeiro, Fundação Getúlio Vargas.

BRUNER, Edward.

(1986). Experience and its Expressions. In: TURNER, Victor W. e BRUNER, Edward M. (org.). The Anthropology of Experience. Chicago, University of Chicago Press. p. 3-30.

CARRITHERS, Michael, COLLINS, Steven \& LUKES, Steven (orgs).

(1985) The category of the person: anthropology, philosophy, history. Cambridge, Cambridge University Press.

GIDDENS, Anthony.

(1991). Modernity and Self-Identity: self and society in the late modern age. Cambridge, Polity Press.

HALBWACHS, Maurice.

(1990). A memória coletiva. São Paulo, Vértice.
HALL, Stuart.

(1998). A identidade cultural na pósmodernidade. São Paulo, DP\&A.

KONDO, Dorinne.

(1990). Crafting Selves: Power, Gender and Discourses of Identity in a Japanese Workplace. Chicago, The University of Chicago Press.

LUTZ, Catherine A.\& ABU-LUGHOD, Lila. (orgs.) (1990). Language and the Politics of Emotion. Cambridge e Paris, Cambridge University Press e Maison des Sciences de l'Homme.

MAUSS, Marcel.

(1974). Uma categoria do espírito humano: a noção de pessoa, a noção do "eu". Sociologia e Antropologia, vol. 1. São Paulo, EDUSP.

ORTNER, Sherry B.

(2006). Anthropology and social theory: culture, power, and the acting subject. Durham e Londres, Duke University Press.

PEIRAN0, Mariza.

(1992). Artimanhas do acaso. Anuário Antropológico/89, pgs 9-21. 


\section{Memorial $^{1}$}

Clarice Ehlers Peixoto

\section{Memoriale}

Palavra que remete à noção de memória, lembrança, recordação, remissão ao passado. Aqui, trata-se de reconstituir minha trajetória profissional, delineada pelo meu perfil acadêmico. Nesta difícil tentativa de esboçar meu autorretrato profissional é impossível não vincular eventos e circunstâncias pessoais e familiares que marcaram minhas escolhas e que foram determinantes nas opções profissionais, dando sentido à minha identidade acadêmica.

Diria que este exercício é semelhante ao de folhear um álbum de retratos no qual cada imagem ali fixada rememora os eventos extraquadro que ela aciona. Inspirada nessas imagens fugirei do modelo regular de memorial para aciona-las, recompondo os fragmentos da minha memória na linha do tempo ${ }^{2}$.

A primeira imagem do meu álbum relembra a experiência infantil de passar três dias na aldeia Munduruku, no baixo Tapajós, com meus dois irmãos menores. As fotografias mostram as crianças pescando no rio Cururu com o padre franciscano da missão, meus irmãos e meninos indígenas e com mulheres e crianças indígenas em frente à missão. Parecemos felizes neste lugar paradisíaco, mas eu estava apavorada nesse meu primeiro e último contato com indígenas.

\footnotetext{
${ }^{1}$ Este memorial foi defendido em 24 de abril de 2018. A banca examinadora foi composta pelo Profs. Helena Bomeny (presidente), Sylvia Caiuby Novaes, Myriam Lins de Barros, Luiz Flavio de Carvalho Costa, Marco Antônio Gonçalves.

${ }^{2}$ Peço desculpas pela qualidade das fotografias. São fotos de família que esmaeceram com o tempo.
} 

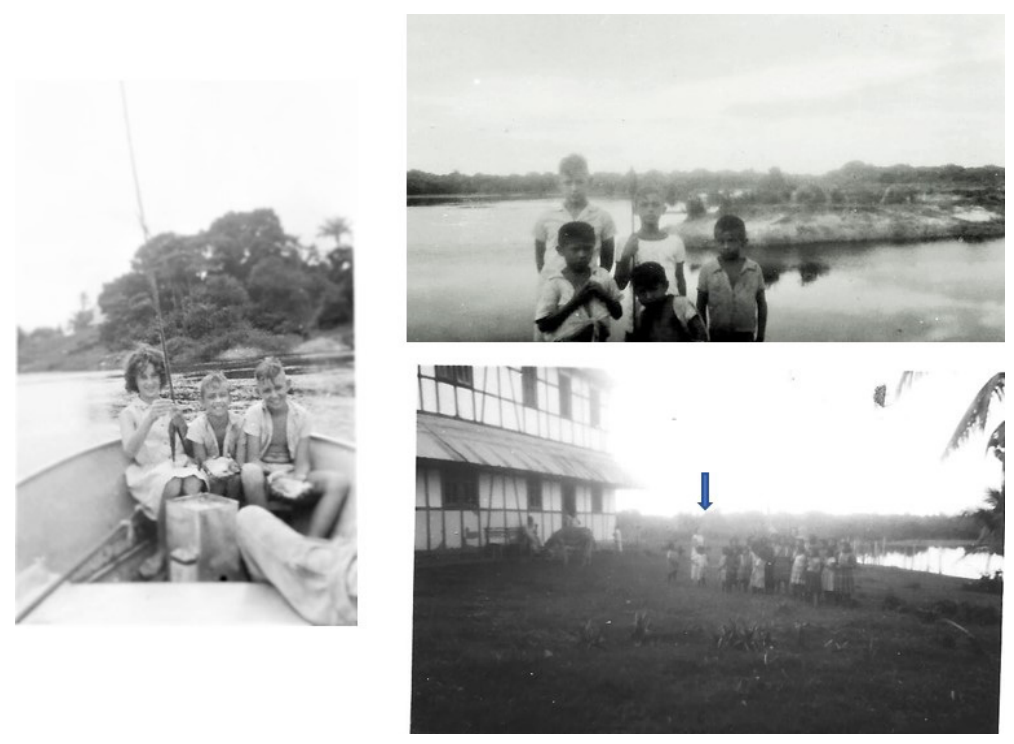

Cercada de índios por todos os lados

Filha de militar da Aeronáutica. Em 1960 vivíamos em Belém do Pará e meu pai trabalhava no Correio Aéreo Nacional (CAN), cuja função era promover a integração entre as populações ribeirinhas e as missões religiosas das aldeias indígenas com as cidades de Santarém e Belém, transportando víveres, medicamentos e pessoas provenientes de todos os recantos da Amazônia. Em uma dessas viagens, ele nos levou para conhecer "índios de verdade" e, aos dez anos de idade voltei da aldeia com a certeza de nunca mais queria ver "índio", pois, para uma menina 'branca', a experiência não foi nada agradável. Muito diferente daquilo que narram nossos pais fundadores sobre os primeiros contatos e primeiros olhares em terras longínquas. Essas imagens guardadas no baú da memória me fizeram entender, muitos anos mais tarde, porque sempre me distanciei da etnologia.

\section{De como cheguei à sociologia}

Até os vinte anos de idade morei em vilas militares Brasil afora. 1964 morava em Brasília, em 1968 no Galeão. Dois momentos da nossa história que marcaram profundamente as minhas escolhas, a começar pelo curso clássico. Colégio Estadual André Maurois, turno noturno, sob a direção da professora Henriette Amado, cuja orientação pedagógica era um 
aprendizado marcado pela leitura, pelo questionamento e pelo debate com liberdade e responsabilidade. Liberdade que não existia do outro lado dos muros da escola. Tempos de efervescência política, de manifestações e passeatas. Tempos de violência, prisão e morte. De medo, ao percorrer o longo trajeto entre a vila militar do Galeão (onde muitos ruídos assombravam) e a escola do Leblon. De alívio ao entrar em sala de aula onde outras visões de mundo e maneiras de pensar me eram reveladas, e quando acompanhava os colegas nas manifestações no centro da cidade onde podia expressar meus constrangimentos. Dois mundos, duas maneiras de pensar a sociedade e de tratar os brasileiros.

As dúvidas, inquietações e temores me levaram à sociologia, 1969. A difícil escolha pelo curso de Sociologia e Política da PUC/RJ, em detrimento do IFCS/UFRJ, deve-se ao desmantelamento deste com o exílio e os expurgos de vários professores, alguns dentre eles se transferiram para a PUC. E claro, a pressão familiar para não entrar para um "antro de subversivos" ${ }^{\prime \prime}$.

Uma nova janela para ler o mundo se abria com os cursos de sociologia, política e antropologia e o mergulho nessas literaturas totalmente proibidas nesta época: Marx, Althusser, Weber, Marta Harnecker, entre outros. A sede por esse conhecimento me levava a aventuras próprias da literatura policial. Onde adquirir esses livros proibidos em uma cidade sitiada? Endereço sussurrado entre os colegas: Livraria Ler, rua México 31 - sobreloja. Era certamente a melhor em ciências sociais. A aquisição era bem 'camuflada': eu escrevia o título do livro em um papel e entregava ao Fabiano, o simpático vendedor que nos acobertava. Dias depois voltava para pega-lo, no fundo da livraria, já encapado com papel branco ou de embrulho. Sair dali com um livro "subversivo" na mochila, e seguir de ônibus para a vila militar do Galeão, era muito arriscado. Mais ainda escondê-lo dentro de casa. Estudava de madrugada para ninguém ver do que se tratava.

A certeza dessa primeira escolha foi sedimentada com a experiência de viver no sertão nordestino, em 1970-19714. Um corte na formação

\footnotetext{
${ }^{3}$ Mesmo sem gostar da minha escolha, meu pai a respeitou e me levava de carro (do Galeão para rua Marquês de Olinda) para fazer as provas de vestibular já que elas começavam cedo. Eram tempos de muita manifestação estudantil na porta do IFCS. Palavras de ordem, bandeiras e convites para aderir à luta contra a ditadura. Meu pai assistia essa "baderna dos subversivos"! Daí a pressão para desistir da universidade pública e optar pela universidade privada. Difícil não ceder quando não se tem autonomia financeira e se vive rodeada de militares por todos os lados!

${ }^{4}$ 1970. Recém-casada acompanhei o marido em seu primeiro trabalho como engenheiro na construção da usina hidroelétrica de Paulo Afonso.
} 
universitária e a convicção de uma retomada futura. Paulo Afonso (BA), construção da usina hidroelétrica e o impacto de uma acentuada desigualdade social. No interior do território murado da usina existia a mesma estrutura hierárquica expressa nas vilas militares: o "bairro dos engenheiros" e o "bairro dos operários". Fora dos muros da usina, a pobreza sertaneja. Dentro, o verde do sistema de irrigação onde 'tudo que se planta dá' (até uvas e figos), do outro lado dos muros da CHESF a aridez e a secura da terra, a falta de água e de alimentos. Contraste avassalador!

Feira de Paulo Afonso, de quinta a domingo
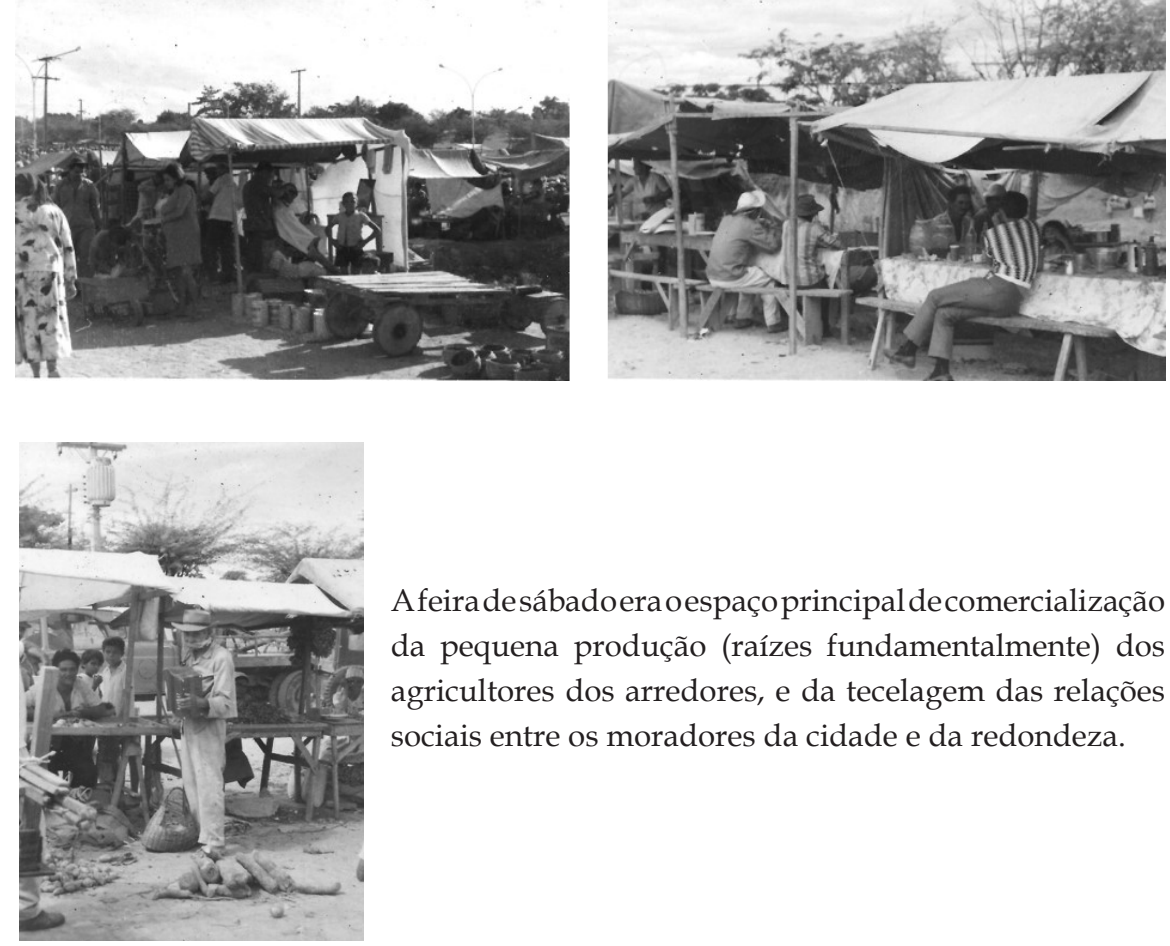

Afeiradesábadoeraoespaço principaldecomercialização da pequena produção (raízes fundamentalmente) dos agricultores dos arredores, e da tecelagem das relações sociais entre os moradores da cidade e da redondeza.

Julho de 1975, diploma de sociologia em mãos e a convicção de que seguiria os caminhos da pesquisa social. O IBGE recrutava pesquisadores para uma pesquisa nacional sobre as condições de vida e nutricionais da população brasileira - ENDEF (Estudo Nacional de Despesa Familiar). Durante os três primeiros anos trabalhei junto à presidência da instituição ${ }^{5}$

5 O coordenador do ENDEF era um militar reformado da marinha que havia cursado sociologia no EUA e se tornou fã da sociologia funcionalista de Paul Lazarsfeld - austríaco que migrou para os EUA na década de trinta, professor na Universidade de Columbia, e criou o 
em uma equipe interdisciplinar, cujo trabalho principal era analisar as informações qualitativas contidas nas páginas finais dos questionários. Nossos relatórios sobre alimentação, moradia, saúde, educação e condições locais analisavam as impactantes realidades sociais de 55 mil municípios brasileiros. Não à toa tiveram suas páginas carimbadas com 'confidencial' e foram engavetados. Eram tempos de ditadura militar e os relatórios nunca mais saíram das gavetas.

Selecionamos as áreas de 'bolsões de pobreza' no país. Mapas em mãos, seguimos para algumas dessas regiões com o objetivo de aprofundar o conhecimento sobre as precárias condições de vida dessas populações que viviam em Campos, São João da Barra e Barra de Itabapoana na região norte do Rio de Janeiro, e Jequié no sudoeste da Bahia ${ }^{6}$.

Em Campos ficamos impactadas com as condições de vida e de trabalho dos cortadores de cana, principalmente das crianças. Paralelamente ao trabalho oficial ali realizado, Maria Tereza Ramos de Oliveira (socióloga) e eu realizamos uma pesquisa focalizada nas condições de vida dos moradores de uma favela que se criava ao longo da rodovia ${ }^{7}$.
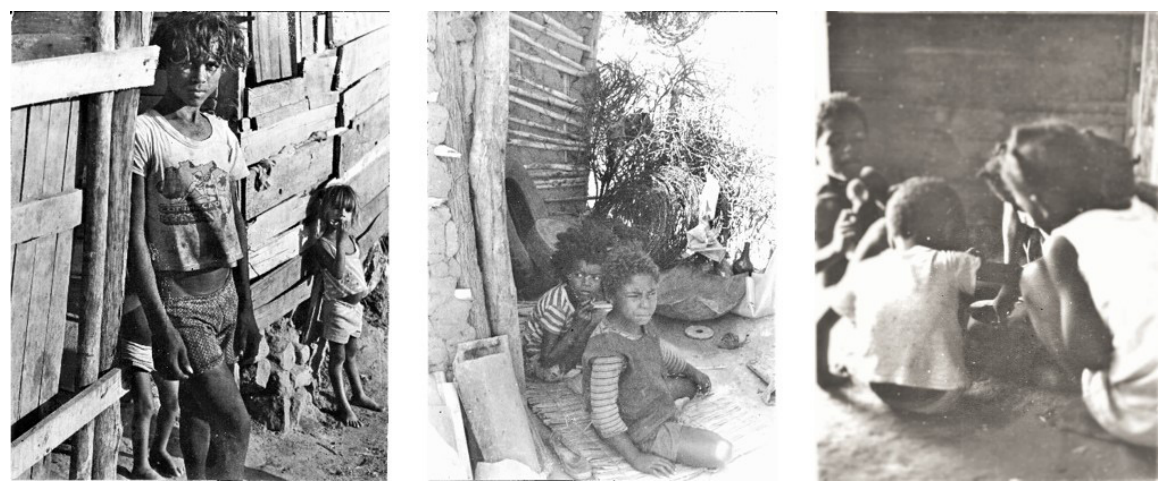

As fotografias são mais reveladoras sobre as condições de vida dessas crianças, muitas delas cortadoras de cana, do que o texto dos relatórios do ENDEF.

Bureau of Applied Social Research para desenvolver um novo estilo de sociologia: burocrática, técnica e empírica. Ele formou o trio funcionalista, junto com Talcott Parsons e Robert Merton, que dominou a sociologia americana nas décadas de quarenta e cinquenta do século passado.

${ }^{6}$ Só participei da pesquisa no norte fluminense. A direção do IBGE cancelou o trabalho de campo nas outras regiões.

7 Cortadores de cana. Um estudo de caso. ENDEF/IBGE, mimeografado, 57pp, 1978. Arquivado. 


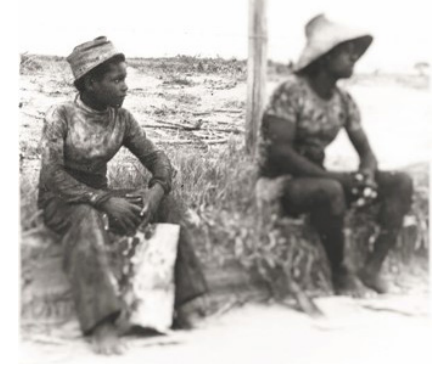

Dois adolescentes. Corpos cansados no final do dia de trabalho. Sem tempo para a escola e para as brincadeiras.

Corpos cobertos de fuligem da queimada da cana, que nunca desgruda da pele.

As páginas seguintes desse álbum apresentam flashes das pesquisas ibegeanas realizadas pelo departamento de Indicadores Sociais (1977-1988) para o qual fui transferida. Participei de estudos sobre habitação popular no Rio de Janeiro (Loteamentos clandestinos na Baixada Fluminense e Favelas do Rio de Janeiro ${ }^{8}$ ) e de grandes pesquisas nacionais: 'A questão social: um estudo sobre relações entre Estado e conflitos sociais no Brasil'; 'Questão agrária: um estudo de experiências de assentamento' (convênio com BNDES); 'Saneamento Básico no Brasil'.

1981-1983. 'Favelas do Rio de Janeiro' ${ }^{9}$ tinha por objetivo repensar as questões sobre marginalidade \& habitação popular. Tempos de contexto social e político ditatorial, tendo à frente do Ministério do Interior o coronel militar Mario Andreazza, mentor do Projeto Rio no âmbito do Promorar/ BNH. Os dois primeiros capítulos do relatório estão voltados para uma discussão sobre conceituação e delimitação da questão, e análise do período 1950-1970 (Leeds \& Leeds 1978; Valladares 1978; Perlman 1977; Santos 1981). Os dois últimos capítulos são fruto de pesquisa etnográfica intensa, e tensa, para entender dois processos de desfavelização: na favela do Jacarezinho e

\footnotetext{
${ }^{8}$ O governo federal lançou um novo projeto de construção de casas populares e de urbanização de favelas. No Rio de Janeiro, a área do complexo da Maré foi a escolhida. Nossa pesquisa acompanhou todo o processo de cadastramento e seleção das famílias que seriam deslocadas para a Vila do João, recém construída. Incluímos nesse projeto um estudo sobre o sistema de transações imobiliárias recém-criado pela Associação de Moradores do Jacarezinho para entender as estratégias locais de comercialização das moradias.

${ }^{9}$ Não publicado, 302pp, 1983. Equipe: Jane Souto de Oliveira (coord.), Clarice Peixoto, David Vetter, Elza Rodrigues, Helena Castello Branco, Lilian Neumayer. Apesar de arquivado pelo IBGE apresentamos os resultados da pesquisa em congressos e distribuímos inúmeras cópias aos pesquisadores desse campo.
} 
no conjunto de favelas da Maré (construção da Vila do João).
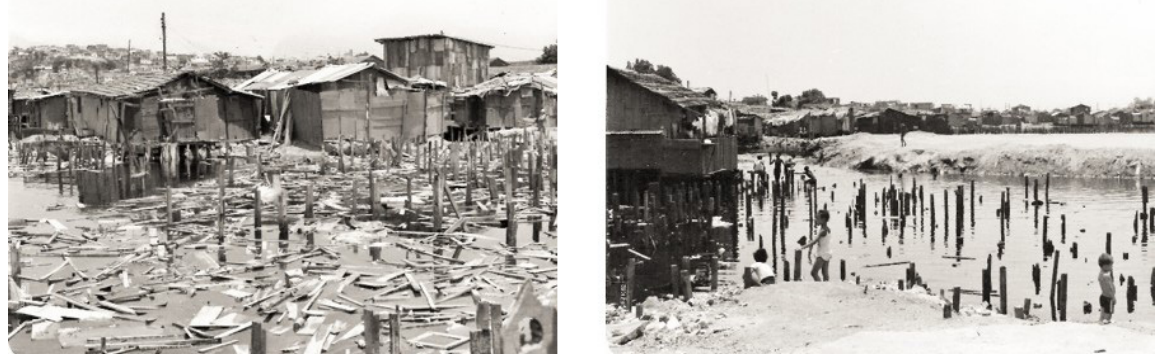

Dezembro de 1982. Palafitas da Maré. Nas águas poluídas da baía de Guanabara as crianças brincavam e se banhavam.
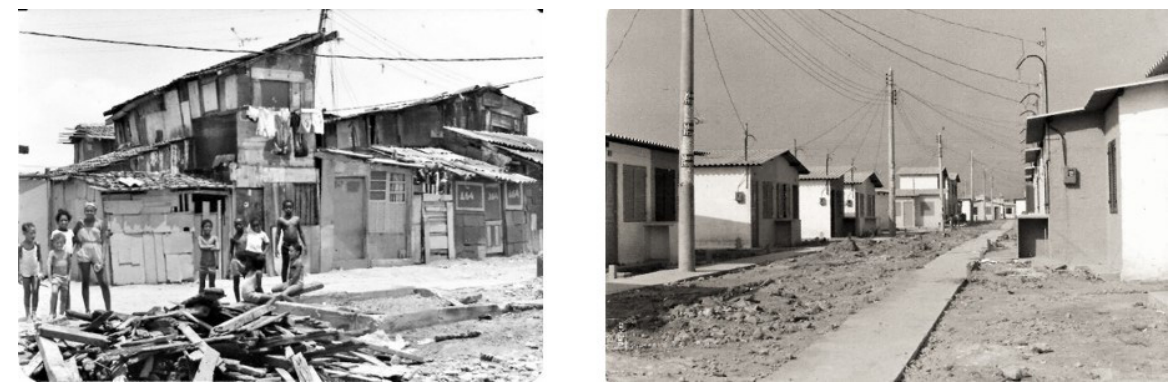

O presente e o sonho do futuro - Vila do João: casas de alvenaria, relógio de luz, água limpa e encanada e banhos de chuveiro!

Durante um ano acompanhamos o processo de cadastramento e de deslocamento dos moradores das palafitas de Nova Holanda para a área contígua onde se construía a Vila do João. Ainda que se tratasse de uma desfavelização outorgada por meio da intervenção estatal, para muitos moradores significava um corte com o estigma da marginalidade e com a identidade de favelado. Nesse período, as famílias viveram dias de expectativa e ansiedade, aguardando o sorteio e a cor da pintura do barraco que indicava o setor para onde seriam deslocadas. A grande preocupação era com o esfacelamento das redes de solidariedade e de apoio familiar. Nosso relatório finaliza com a pergunta: "Não deixa de ser pertinente a indagação quanto às perspectivas de execução das etapas previstas e ainda não realizadas ${ }^{10}$. Passado o período eleitoral, e face à presente crise

${ }^{10}$ Até o fechamento do relatório (1983) os moradores da Vila do João ainda não tinham os
carnês de pagamento das novas moradas e, portanto, não eram efetivamente proprietários do 
econômica, haverá condições de se levar adiante um projeto de tal vulto?". (1983: 289).

Meu interesse pelo estudo das desigualdades sociais, orientado por uma metodologia antropológica, só aumentava.

1984-1985. A pesquisa 'A questão social: um estudo sobre relações entre Estado e conflitos sociais no Brasil'11 surgiu a partir de nossas inquietações derivadas tanto dos relatórios qualitativos da pesquisa ENDEF quanto dos rumos políticos do país. Desenvolvida no interior de um órgão público, nesse período ditatorial, ela foi fundamentalmente um estudo de perspectiva histórica - análise das políticas econômicas e sociais brasileiras desde a primeira república -, que procurou compreender o modo específico de intervenção do Estado face às pressões da 'questão social'. Nosso ponto de vista era que as intervenções estatais constituíam um processo de controle social que "tende a regular e até mesmo prevenir os conflitos decorrentes de participações diferenciadas nos processos de produção e de reprodução". O trabalho não apresenta uma análise econômica da política social brasileira, pois "a indagação central esteve o tempo todo remetida à questão dos direitos sociais e da cidadania". (1985, p. II-III). Arquivado.

1986-1987. 'A questão agrária: um estudo de experiências de assentamento $^{\prime 12}$ foi realizada em convênio com o BNDES e tinha por objetivo analisar alguns assentamentos rurais financiados pelo programa Finsocial/BNDES. Novamente retornamos à pesquisa de campo, acompanhados por dois pesquisadores do BNDES. Nossos relatórios finais foram dissonantes: o do BNDES indicava o fim do programa porque considerava que os investimentos do banco não tinham retorno financeiro dada a 'incompetência' dos pequenos agricultores, e o do IBGE apontava para as falhas desse programa que não considerava a adaptação à uma nova terra com clima diverso daquele no qual viviam e produziam, ao desconhecimento do uso de agrotóxicos em terras não produtivas, entre outros elementos. O acordo foi desfeito e o relatório desapareceu, mas

imóvel que ocupavam.

${ }^{11}$ Mimeografado, 221pp. Equipe coordenada por Marina Teixeira: Clarice Peixoto, Cleber Felix, $\mathrm{M}^{\mathrm{a}}$ das Graças Mangueira Este, $\mathrm{M}^{\mathrm{a}}$ Helena Beozzo.

${ }^{12}$ Não publicado, s/n. de pag. Pesquisa solicitada pelo BNDES para 'descobrir' porque o seu programa de assentamento rural não dava retorno financeiro em determinadas áreas. $\mathrm{O}$ objetivo do banco era abandonar esses programas e os pequenos agricultores ali assentados. Duas áreas de pesquisa: São José da Boa Morte/RJ e Abapan/PR. Fiz parte da equipe do Paraná junto com $\mathrm{M}^{\mathrm{a}}$ das Graças M. Este, José Luis Petruccelli e dois técnicos do BNDES. 
ficaram as imagens da nossa pesquisa que buscava entender as razões da baixa produtividade nesse assentamento compulsório ${ }^{13}$, e evitar que o programa Finsocial abandonasse esses pequenos produtores.
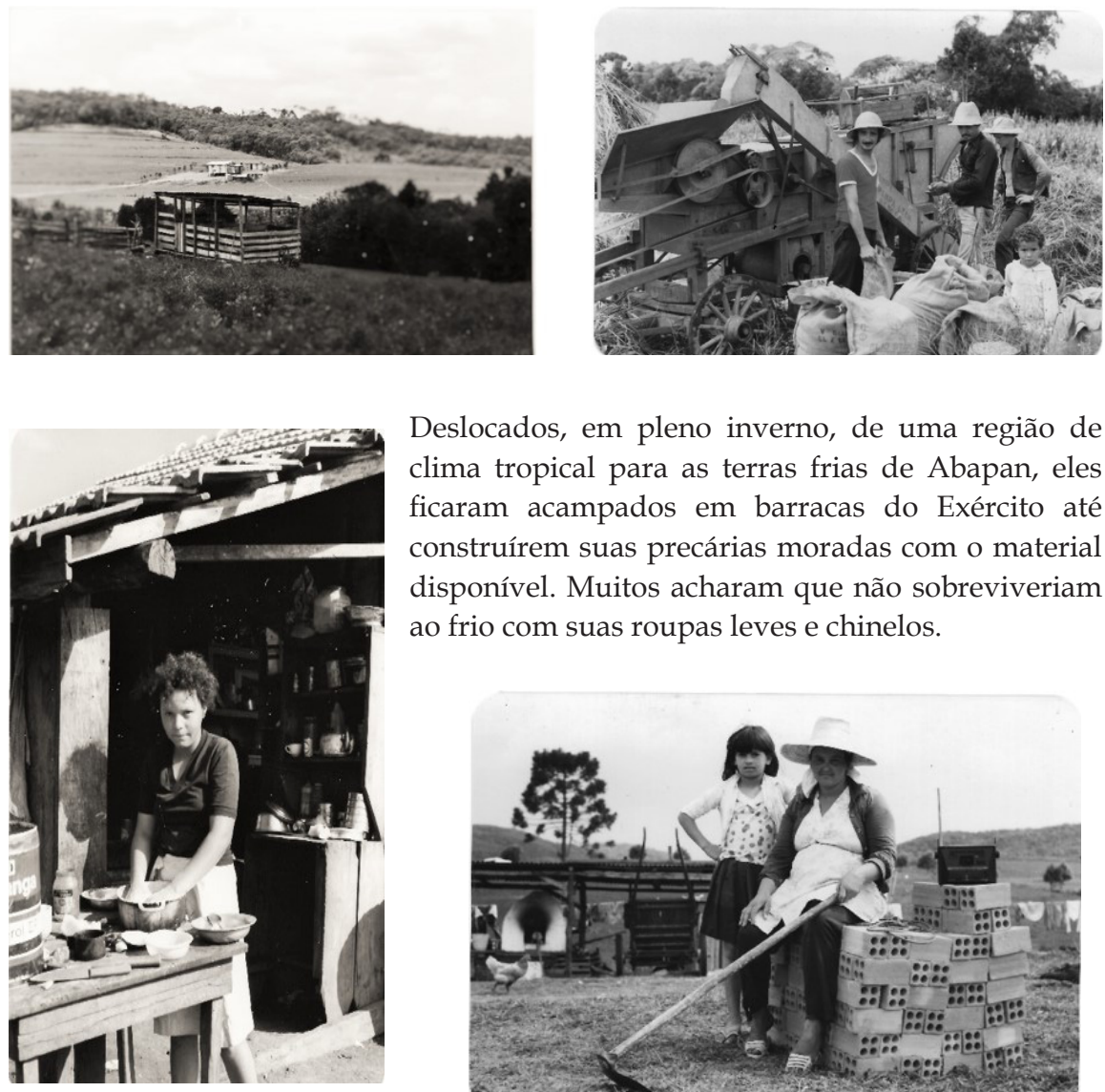

Deslocados, em pleno inverno, de uma região de clima tropical para as terras frias de Abapan, eles ficaram acampados em barracas do Exército até construírem suas precárias moradas com o material disponível. Muitos acharam que não sobreviveriam ao frio com suas roupas leves e chinelos.

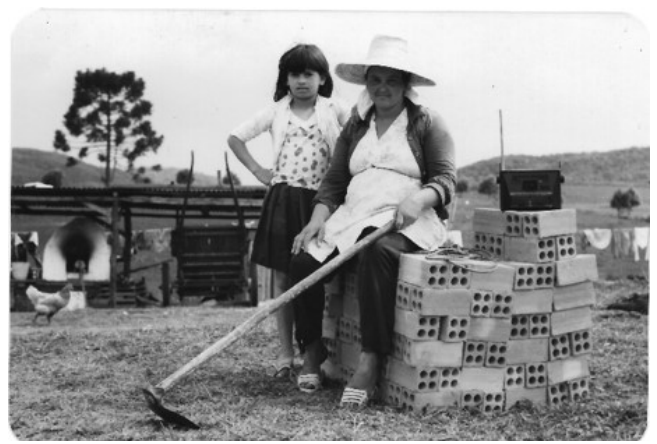

Até aqui era significativa a participação de sociólogos e antropólogos nas pesquisas ibegeanas, o que assegurava um peso maior às informações qualitativas. Nelas, a etnografia complementava e dava suporte aos dados estatísticos - observação direta, entrevistas, conversas dirigidas e fotografias ${ }^{14}$ - e permitia atualizar conceitos e categorias aplicados nas

${ }^{13}$ Essas famílias foram retiradas das ilhas do rio Paraná para a construção da usina de Itaipu. Elas praticavam a agricultura de subsistência em terras férteis e foram deslocadas para o noroeste do Paraná, para terras que eram de pastagem degradada, improdutivas. O Programa financiava, entre outros incrementos, agrotóxicos pesados que eles não sabiam usar.

${ }^{14}$ Nessas viagens de pesquisa eu sempre levava uma câmera fotográfica e meu interesse 
grandes enquetes.

1987-1988. 'Saneamento Básico no Brasil' foi a primeira pesquisa do IBGE sobre essa questão, e a última da qual participei. Como coordenadora, eu criei uma equipe multidisciplinar para entrevistar as prefeituras e empresas de prestação de serviços de grandes e pequenas cidades brasileiras, indagando sobre que tipo de informações necessitavam para a melhoria dos serviços de abastecimento de água, esgotamento sanitário, drenagem urbana, limpeza urbana e coleta de lixo. Rodamos o Brasil e com essas informações em mãos elaboramos um questionário a ser aplicado em 5. 507 municípios brasileiros. Questionário pronto, tarefa cumprida.

O IBGE dava nova direção às suas pesquisas, agora dirigidas apenas para as análises estatísticas produzidas pela instituição, e cortou brutalmente os financiamentos para a pesquisa de campo etnográfica. Estava na hora de partir. A série Ibegeana termina por aqui.

Página virada.

\section{A guinada para a antropologia}

Nessas pesquisas de campo ibegeanas buscávamos inspiração na literatura sócio antropológica. Olivro Os parceiros do Rio Bonito, de Antonio Candido, foi decisivo na escolha pela antropologia e pelo mestrado no Museu Nacional. Em 1980 fiz o concurso sem ter ideia de quem eram nossos antropólogos brasileiros ${ }^{15}$. Na banca, três antropólogos de renome - Francisca Keller, Otávio Velho e Gilberto Velho - nomes que eu nunca ouvira falar! Tenho certeza de que fui aprovada porque sabia fazer pesquisa e, naquele tempo, o concurso exigia uma pesquisa de campo sobre um dos temas propostos no edital. Meu interesse pela questão da desigualdade social permanecia, e foi acentuado com a realização da pesquisa 'Favelas do Rio de Janeiro' e a efervescência dos estudos sobre habitação popular/favelas, principalmente os de Lícia Valladares e Carlos Nelson dos Santos. Assim, optei por um tema nesse campo.

Ingressei no mestrado com um projeto para estudar as favelas da Tijuca

não estava voltado apenas para as clássicas fotos de viagens (paisagens, etc.); sempre achei importante registrar as situações sociais estudadas, mesmo que não constassem dos textos escritos e que, nessa época, ainda não soubesse como analisar a riqueza de informações que as imagens revelavam.

${ }^{15} \mathrm{Na}$ graduação fui aluna de Manoel Diegues Jr. e Alba Zaluar que me fizeram conhecer M. Mauss, B. Malinowski, F. Boas, Radcliffe-Brown entre outros pais fundadores da disciplina. 
(Borel, Formiga e Casa Grande), considerando-as como vilas operárias posto que próximas à fábrica de cigarros Souza Cruz e de algumas indústrias têxteis. Pesquisa inspirada naquelas desenvolvidas por meu orientador José Sérgio Leite Lopes. Mas, abandonei o projeto logo no primeiro ano ao retornar das férias familiares em Fernando de Noronha.

1980. Fernando de Noronha ainda era território federal, administrado pelo Exército, e cuja população civil era bem maior do que a militar, e vivendo sob o jugo desta ${ }^{16}$. Diria que era um laboratório daquilo que o país vivia nesses tempos de ditadura ${ }^{17}$. O que me interessava era perceber os elementos que circunscreviam esse mundo militar para entender a lógica do sistema hierárquico e disciplinar ali implantado no período da administração militar: 1942-1986. Tratava-se, assim, de uma situação bastante particular: uma ilha-prisão transformada em ilha-quartel e que, por isso, congregava elementos característicos de ambas as situações, deixando marcas e lembranças nas coisas e nas pessoas.

Nessa época, a forma que o sistema de dominação assumiu em Fernando de Noronha apresentava algumas especificidades relacionadas diretamente à sua condição ambígua de território livre e unidade militar. Entretanto, o fato de ser uma área de segurança nacional - assim determinada por ser um ponto estratégico do território nacional - já conferia aos militares maior legitimidade para o exercício do poder, que se manifestava tanto na configuração das relações de trabalho quanto na esfera da reprodução social dos moradores. Nesse sentido, o sistema de governo implantado pelos militares ao longo de décadas funcionava como uma rede de disposições que, intervindo na vida cotidiana dos moradores civis, controlava diretamente a moradia, a escola e o hospital, a produção e a distribuição dos alimentos, a comunicação com o continente (telefonia e correios) e o direito de ir e vir (controle das listas de passageiros nos aviões da FAB), entre outros.

Se os militares habitavam casas construídas no estilo vila militar - um bairro para os oficiais, outro para os militares subalternos - os muitos moradores civis viviam em moradias precárias, ou antigos casarões malconservados. O privilégio maior, evidentemente, era do coronelgovernador.

\footnotetext{
${ }^{16}$ Fernando de Noronha foi território federal de 1942 a 1988. A Constituição de 1988 reintegrou Noronha ao Estado de Pernambuco como Parque Nacional Marinho.

${ }^{17}$ Lugar de prisão política até final dos anos setenta, nesta ilha isolada e distante do continente eram cometidas todas as atrocidades contra seus prisioneiros, diziam os moradores.
} 


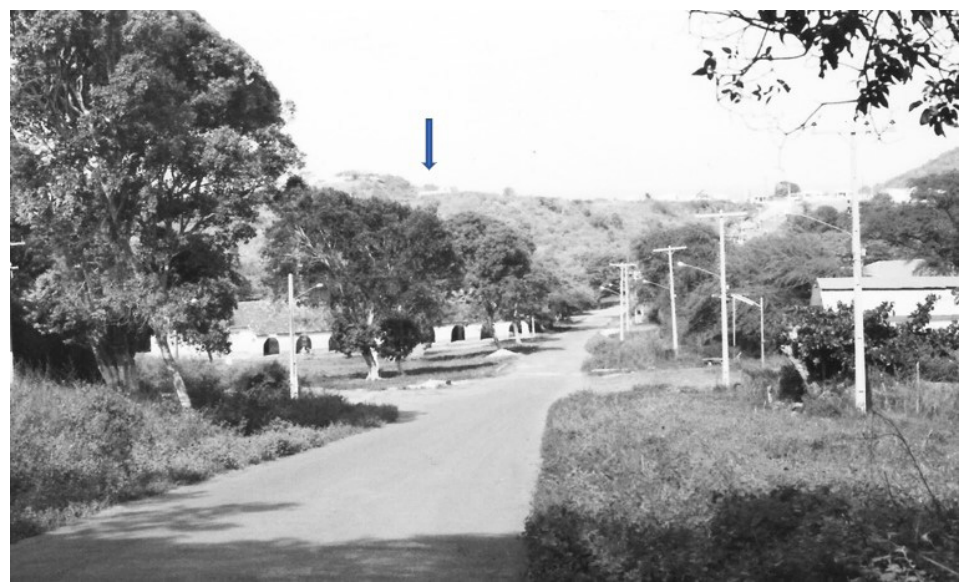

No alto da colina, a casa do coronel-governador e uma vista de $360^{\circ}$ para todos os bairros da ilha. Um maravilhoso panóptico!

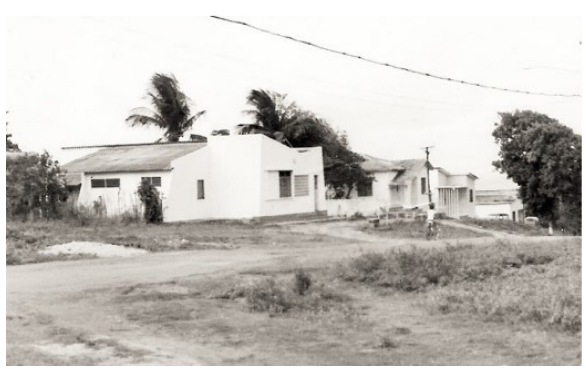

Vila dos Oficiais. Casas de alvenaria: sala, três quartos, varanda, dependências e quintal.

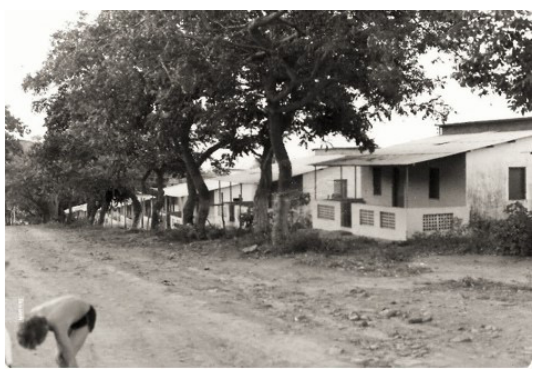

Vila de militares subalternos. Casas de alvenaria: sala, dois quartos, varanda, dependências, sem quintal!

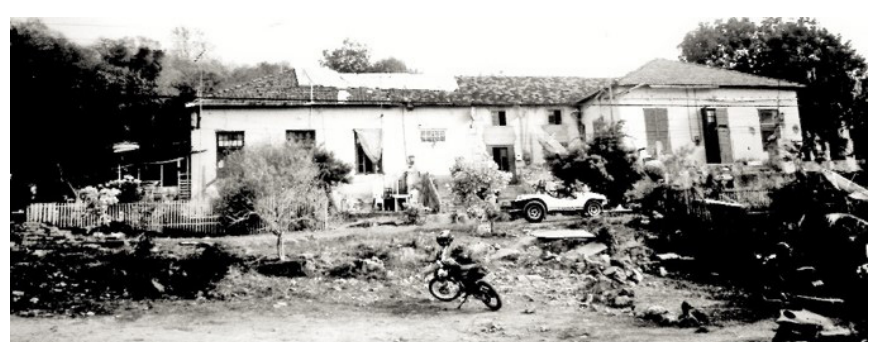

Vila do Boldró. Casarão antigo, transformado em cortiço para abrigar vários moradores civis.

Dentre eles Salviano, o mais antigo pescador de Noronha.

Todos os seus filhos também eram pescadores. 
Janeiro 1980. Primeiro encontro com Salviano.

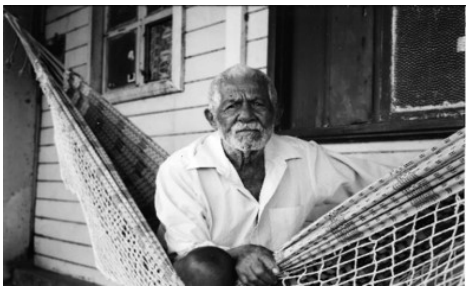

Pedi permissão para a entrevista. Achou

que eu era jornalista e ele queria fazer várias

denúncias sobre o controle da produção

pesqueira pelos militares, e o direito de ir e vir ao continente.

'Não sou jornalista, sou antropóloga'.

"Antropófoga? Pode se retirar".

Voltei a ser socióloga, já que ele conhecia um pouco melhor esse ofício.

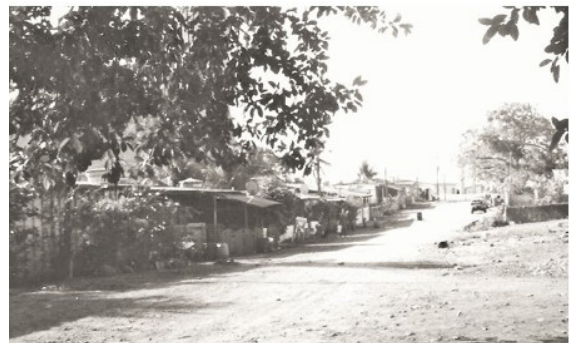

Floresta Velha. Casas mais precárias de moradores civis.

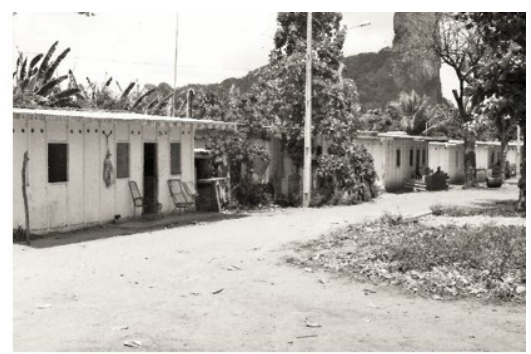

Vila do Trinta. De moradores que trabalhavam para a administração territorial: os 'recibados'.

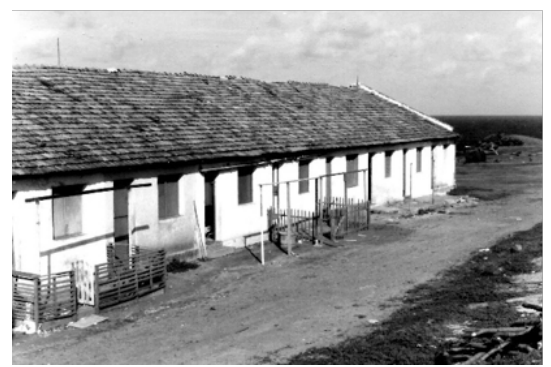

Bairro do Porto, Vila dos Pescadores (frente)

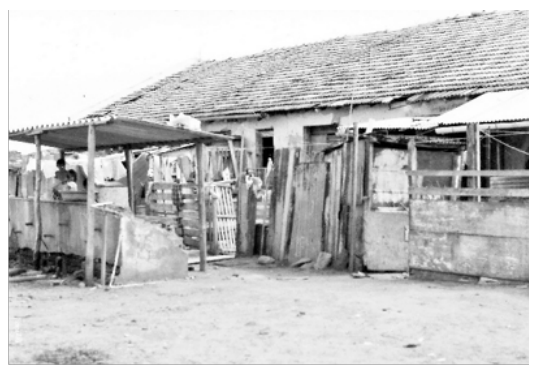

Fundos da Vila dos Pescadores, onde fica o tanque coletivo para limpar os peixes, lavar louças e roupas.

Retornei ao campo em 1982 para complementar as anotações que fizera nas férias anteriores, e que deram origem a dois ou três trabalhos de curso no Museu. Dessa vez, durante três meses, e sem família, mergulhei na vida cotidiana dos moradores de Noronha para melhor perceber como se estruturava a organização social do Território. As imagens são, novamente, ricas na apresentação da estrutura hierárquica expressa na feira mensal 
de alimentos perecíveis não cultivados na ilha, e transportados por aviões militares. Os primeiros são os oficiais de mais alta patente militar ou seus representantes, em seguida os demais escalões e, por último, os moradores civis.

A divisória da feira. A fila de espera pela 'chegada da vez'.

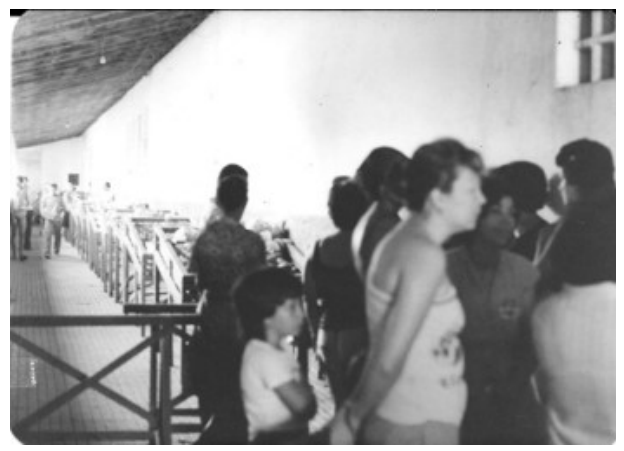

Ao fundo, o taifeiro do coronelgovernador é o primeiro a escolher e comprar. As mulheres dos oficiais, ou as suas cozinheiras/os, esperam na fila atrás do portão.

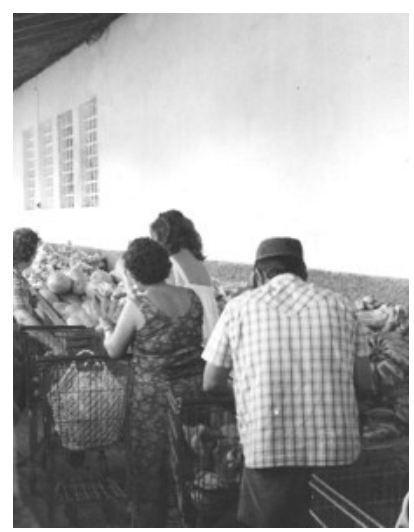

O terceiro grupo a entrar para fazer a feira é o dos militares subalternos ou suas mulheres.

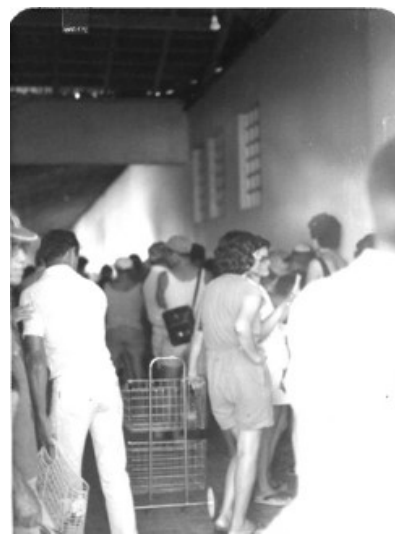

Os civis aguardam na fila até os últimos militares comprarem.

A maioria dos legumes, frutas e verduras acabou, o que sobra está amassado ou estragado.

Resta tentar a sorte no mês seguinte, ou pedir aos parentes para enviarem de Recife nos aviões militares. 
Tem governo que quer ver a gente sempre no pé. Com um governo assim a gente aqui vive assombrado, não sabe? Nunca falam, chamam a gente só prá dar carão, prá fazer queixa. (pescador)

Com esta epígrafe dou início à dissertação 'Fernando de Noronha: ilha de sonho e de assombração' $(1988)^{18}$, indicando os caminhos trilhados, as vicissitudes do trabalho de campo, as dúvidas e certezas, os medos e alegrias que permitiram a realização desta pesquisa, cuja intenção era compreender os princípios que regiam a organização social de Fernando de Noronha no período da administração militar. A estrutura de relações sociais ali criada envolvia o controle das produções pesqueira, agrícola e pecuária e da circulação mercantil de bens de consumo da população e apontava para traços característicos dos princípios integradores de organização econômica propostos por Karl Polanyi (1947): a reciprocidade e, mais especificamente, a redistribuição. A canalização dos bens para o Armazém e a Feira, administrados pelo governo territorial, determinava sua distribuição hierárquica, como vemos nas fotografias. A reciprocidade entre os produtores era a principal estratégia de sobrevivência. Michel Foucault $(1977,1979)$ também foi uma inspiração na leitura desse espaço territorial fechado como prisão e governado pelas forças armadas que, de fato, é a instituição mais propícia ao desenvolvimento de técnicas disciplinares específicas de vigilância para controlar as mínimas parcelas da vida de seus subjugados.

\section{Descoberta e encantamento por um novo campo: a antropologia visual}

Desde as pesquisas de campo ibegeanas despertara para o potencial e a riqueza das imagens para uma melhor compreensão das realidades sociais estudadas. Isto porque fiquei convencida de que a produção de imagens amplia o campo de observação, cria uma outra relação com os sujeitos e permite uma leitura repetida e minuciosa das atividades realizadas, principalmente, aquelas que a observação direta, quase instantânea, não pode acompanhar nem repetir. Mais do que isso, a leitura das imagens permite refletir sobre o nosso próprio olhar.

O doutorado em Antropologia Visual na 'escola de Jean Rouch' (Paris

${ }^{18}$ Dissertação de mestrado. Museu Nacional, PPGAS-UFRJ, 276 p. 
X-Nanterre) foi uma opção para descobrir esse novo campo, já que o IBGE fechava as portas para as pesquisas etnográficas.

Setembro de 1988. Desembarco na Europa pela primeira vez. Mala e cuia, e muitos dicionários já que não falava a língua local! Paris, cidade exótica ou a exótica sou eu ${ }^{19}$

O primeiro ano foi dedicado à aprendizagem da língua francesa e das técnicas e linguagens cinematográficas [em película Super8], no DEA de Anthropologie Visuelle, Télévision et Audiovisuel. Pela primeira vez tive contato com uma câmera cinematográfica e aprendi a perceber o mundo por meio de imagens, e das imagens que eu produzia. Em Nanterre, Jean Rouch criou, com uma ginasta do grupo de mímica de Marcel Marceau, um curso de técnicas corporais para os cineastas adquirirem maior flexibilidade e resistência física nas filmagens com a câmera na mão. Claudine de France e et al ministravam os cursos de produção e análise fílmica. Um dos mais aprazíveis era o de visionamento de documentários: nenhum professor em sala de aula e uma pilha de filmes para assistir e analisar durante três horas! Uma sinopse crítica sobre cada um deles era depositada na secretaria. Outro curso que nos encantava era o de prática de filmagem no qual realizávamos ensaios fílmicos quinzenais, com especificações técnicas diversas: $3 \mathrm{~min}^{20}$, mudo, $\mathrm{P} \& \mathrm{~B}$, montagem à prise de vue; $6 \mathrm{~min}$, som, cor, montagem à prise de vue; e assim até a produção final (máximo de $20 \mathrm{~min}$, som e montagem) para a obtenção do diploma. Eles eram apresentados em sala aos professores e colegas. Muitas críticas e debate. Sem dúvida, um curso que me ensinou muito sobre linguagens e técnicas.

Logo após obter o Diplôme d’Etudes Approfondies/DEA decidi dar continuidade ao doutorado na EHESS, pois pretendia aprofundar os conhecimentos teóricos no campo da antropologia visual, o que Nanterre não oferecia ${ }^{21}$. Nova escola, novo tema de pesquisa \& filme etnográfico: a

${ }^{19}$ Estas duas indagações são analisadas no primeiro capítulo da tese: Uma questão de estranhamento (2000).

${ }^{20}$ Duração de uma bobina Super8. A Universidade não tinha equipamentos e cabia aos estudantes a sua aquisição. Um curso caro que nos levou a criar uma 'cooperativa': uns entravam com câmeras, outros com microfones, outros ainda com a moviola para Super8. Nossa turma foi repreendida por Claudine de France porque o compartilhamento de equipamentos não era autorizado. Para esta diretora de Nanterre, cada estudante deveria ter seus próprios equipamentos, e desobedecemos. Do mesmo modo que não acatamos a interdição para assistir outros cursos similares fora de Nanterre, como o primeiro curso de antropologia visual da EHESS, ministrado por Marc Piault, Eliane de Latour e Jean Paul Colleyn, em 1989.

${ }^{21}$ A Escola de Nanterre estava mais voltada para análise da cinematografia e o uso dos conceitos 
sociabilidade dos velhos nos espaços públicos das cidades.

A questão do envelhecimento me intrigou desde que cheguei em Paris: nunca vira tantos velhos pelas ruas! Eles constituíam um percentual importante neste país e $20 \%$ da população parisiense em 1990. No Brasil, os demógrafos já alertavam para o rápido crescimento desse grupo etário. Velhos parisienses e cariocas invadiam os espaços públicos dessas cidades, construindo territórios de pertencimento nos quais estabeleciam relações intergeracionais e entre camadas sociais.
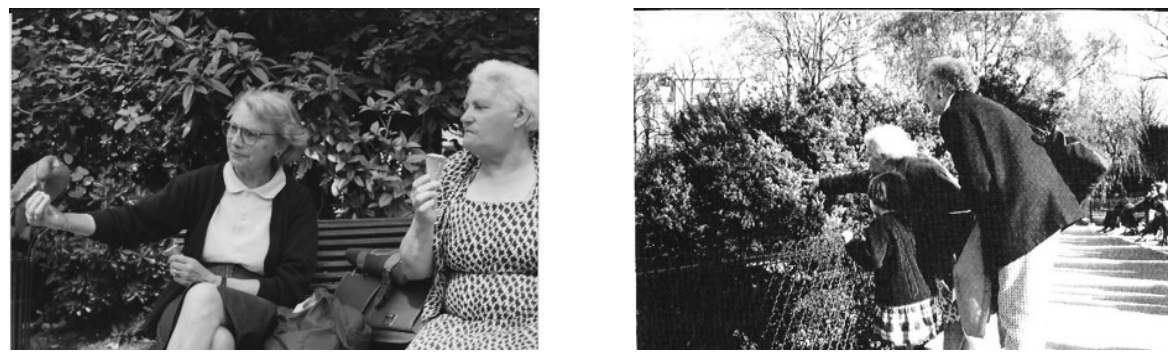

Odette e Andrea na praça Batignolles, território de pertencimento e de relações intergeracionais. Alimentar os animais da praça era a estratégia para atrair crianças e jovens.

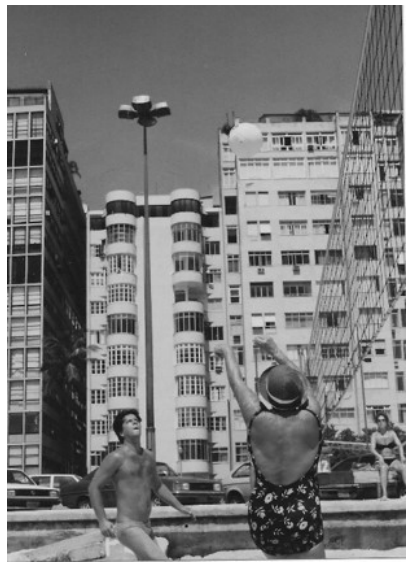

A rede de vôlei da tia Leah, em Copacabana.

Território de relações intraclasse e intergeracionais ${ }^{22}$.

ali criados sobre o modo de filmar, e menos para uma reflexão sobre pesquisa antropológica com imagens. A escola tinha regras bem rígidas de filmagem que não consideravam os preceitos antropológicos da relação com os sujeitos. A regra era interferir o menos possível na cena filmada, buscando a invisibilidade daquele que filma, e jamais falar com as pessoas filmadas durante as tomadas: questão de profilmia! Ou seja, estava mais próxima do cinema de observação inglês do que do cinema compartilhado de Jean Rouch, o idealizador deste curso! O que ele propunha não era seguido por seus colegas e interditado aos estudantes.

${ }^{22}$ Como filmei sozinha (imagem \& som) dei pouca atenção às fotografias, só fotografando duas das quatro cenas sociais analisadas: a praça Batignolles e a rede de vôlei da tia Leah. Nenhuma foto do baile na praça e do clube do Posto 6. 
A intenção era analisar as manifestações e percepções de pertencimento a um espaço, um território, permitindo uma melhor apreensão do processo de construção de uma identidade ligada à velhice. Suas práticas e comportamentos, gostos e hábitos estão sempre marcados pelos valores mais gerais do grupo ao qual pertencem e que condicionam seu comportamento social. De fato, estes indivíduos estão sujeitos às mesmas normas morais que definem as práticas coletivas do comportamento público, expressas nos contatos face a face (Peixoto 2000: 17). Sem dúvida, Erving Goffman foi a principal inspiração para entender que "os valores culturais de uma instituição determinarão em detalhe o modo como os participantes se sentirão a respeito de muitos assuntos, e ao mesmo tempo estabelecerão um quadro de referência de aparências que devem ser mantidas, quer existam, ou não, sentimentos por detrás delas" (1975: 221).

Assim, "estes espaços públicos têm um papel fundamental nas estratégias de sociabilidade dos aposentados na medida em que permitem o estabelecimento de relações sociais com as gerações mais jovens - o que os clubes e associações de terceira idade não o fazem. Para alguns, estas instituições de terceira idade possibilitam a manutenção de relações com seus pares, permitindo que troquem confidências sobre os fatos da vida cotidiana. Mas para outros, estes espaços restritos aos velhos têm uma imagem de isolamento, quase como um 'gueto de velhos'. Para alguns dentre eles, a família mora distante, outros nem têm família, principalmente entre os franceses. As relações com as gerações mais jovens tornam-se, assim, particularmente necessárias e os jardins, praças e praias facilitam esta aproximação. Estas fronteiras marcadas por calçadas ou grades, barracas ou bancos, cordas ou arbustos que demarcam a praia, o clube ou a praça, marcam também um limite entre o público e o privado. Estes espaços constituem, na verdade, um território suspenso entre a rua e a casa pois as relações que lá se estabelecem, ainda que mais estreitas do que aquelas que têm lugar 'no meio da rua', não chegam a entrar na intimidade da casa". (Peixoto 2000: 22).

Portanto, comparar essas duas sociedades tão distantes social e economicamente foi um desafio, mas também, um encantamento descobrir esses novos campos de pesquisa, entrelaçando-os: envelhecimento \& imagens; imagens do envelhecimento ${ }^{23}$ (1993). Sem dúvida, a utilização da

${ }^{23}$ A la reencontre du petit paradis: une étude sur le rôle des espaces publics dans la sociabilité des retraités à Paris et à Rio de Janeiro. Tese de de doutorado. Ecole des Hautes Etudes en Sciences Sociales, Paris, 485pp. Publicada no Brasil com o título Envelhecimento e Imagem. As 
imagem fílmica permitiu uma análise repetida e minuciosa dessas relações sociais e ampliou o campo de observação. Nesta pesquisa sobre os velhos parisienses e cariocas, a linguagem fílmica permitiu mostrar não apenas as marcas do envelhecimento e do isolamento por meio do registro do ritmo do corpo, mas sobretudo, a localização no espaço em que se inserem e as relações ali criadas. (Peixoto 2000). Filme Em busca do pequeno paraíso em www.inarra.com.br

Neste período de doutoramento busquei interlocução com vários pesquisadores franceses e portugueses no campo da família e do envelhecimento, mas também da antropologia visual, com vistas ao estabelecimento de intercâmbios futuros.

\section{A escolha pela vida acadêmica}

Agosto de 1993. Retorno ao Brasil com o primeiro diploma de doutorado em antropologia social e visual da EHESS, sob orientação de Marc-Henri Piault. Mala \& cuia, algumas publicações em periódicos franceses ${ }^{24}$ e a participação em vários festivais de filme documentário e etnográfico. Trouxe, também, na bagagem, muitos filmes etnográficos e documentários.

Quanto aos estudos sobre o envelhecimento, a sociologia e a antropologia brasileiras já iniciavam pesquisas sobre o tema. Eis que o IBGE e suas estatísticas me esperavam, dada minha recente especialização em processos de envelhecimento. Sem ter lugar para os estudos antropológicos, decidi mudar de rumo.

1994. Rosilene Alvim me indicou para uma vaga de professora visitante na Escola de Serviço Social da UERJ, que buscava antropólogos (as) para conduzir pesquisas com professores (as) e alunos (as). Nesse momento, a Uerj inaugurava a sua Universidade da Terceira Idade/UnATI, a primeira em uma universidade pública brasileira. Sorte grande!

A primeira pesquisa uergiana foi realizada com colegas e estudantes do Serviço Social, pois a orientação era introduzi-los às técnicas quantitativas e qualitativas de pesquisa. Elaboramos um questionário e entrevistamos 250 alunos da UnATI. O objetivo da pesquisa era traçar o perfil destes velhos

fronteiras entre Paris e Rio de Janeiro. Annablume/Faperj, 2000. Filme: A la rencontre du petit paradis, $20 \mathrm{~min}, 1993$.

${ }^{24}$ Ver na bibliografia as publicações em Gérontologie et Société, Ethnologie Française, Journal des Anthropologues, Cahiers d’Études Africaines, Cahiers du Brésil Contemporain. 
estudantes para entender o que buscavam nesse espaço: sociabilidade ou reciclagem de conhecimentos? Observamos que, "ainda que os níveis de instrução predominantes entre os alunos da UnATI sejam o primeiro e segundo graus, os cursos que menos os atraem são aqueles que requerem uma maior dedicação no aprendizado como história da arte, gerontologia, história do Brasil, línguas (...). Nesse sentido, embora o projeto inicial de criação da UnATI esteja baseado no modelo de terceira geração das Universidades da Terceira Idade francesas, de fato, ele ainda não saiu da segunda geração. Assim, pensar as universidades da terceira idade sem as práticas de sociabilidade é o mesmo que fundar uma escola sem dispor de professores. Já foi demonstrado que as pessoas vêm em busca de novas amizades, assim como para vencer a solidão (...). O que há de específico nas universidades da terceira idade é a oferta de atividades voltadas para a educação permanente, mas principalmente, a possibilidade de estabelecer relações com as gerações mais jovens. A identificação do peso que a solidariedade tecida nestas instituições adquire na vida cotidiana das pessoas de mais idade, permite também a reflexão sobre as transformações nas relações familiares". (Peixoto 1997a:73). O conhecimento adquirido nos anos ibegeanos foi fundamental para a criação do universo da pesquisa e elaboração do survey.

Nesse primeiro ano de Uerj, na Faculdade de Serviço Social, ainda não havia lugar para as pesquisas com imagens, menos ainda para cursos de antropologia visual. Como o Serviço Social ficava no $8^{\circ}$ andar e as Ciências Sociais no $9^{\circ}$ andar dessa bizarra estrutura vertical da Uerj, logo encontrei colegas da antropologia. O convite honroso foi feito num espaço curioso: Valter Sinder me chamou na copa do $8^{\circ}$ andar e convidou para dar uma disciplina eletiva de antropologia visual nas Ciências Sociais, no segundo semestre de 1994. Sala de aula lotada: 65 alunos e grande expectativa! "Na bagagem, vários filmes sobre a história do cinema, desde as cronofotografias de Etienne-Jules Marey, Eadweard Muybridge e Felix-Louis Regnault aos filmes dos primeiros cineastas (irmãos Lumière, Georges Méliès, Robert Flaherty, Dziga Vertov, Jean Vigo). E muitos filmes etnográficos clássicos e contemporâneos (Franz Boas, Marcel Griaule, Jean Rouch, Georges Rouquier, Yolande Zauberman, Dennis O'Rourke, Bob Connoly, Eliane de Latour, entre outros). (...). Muitas imagens e nenhum texto em português! Convencida de que não poderia transformar esse primeiro curso de antropologia visual em um intervalo de distração cinematográfica entre as disciplinas consideradas mais "sérias", eu comecei a traduzir vários textos 
fundamentais à compreensão da constituição desse campo, à pesquisa e produção de imagens em antropologia" (Peixoto 2014: 133). Essas traduções iniciais, junto com outras, deram origem, em 1995, à primeira revista brasileira especializada nesse campo: Cadernos de Antropologia e Imagem ${ }^{25}$. Sem dúvida, Cadernos foi peça fundamental para a constituição do campo e uma ferramenta importante para o ensino da antropologia visual brasileira, e para a divulgação do que era produzido internacionalmente, além das nossas produções nacionais.

1995. Iniciei a pesquisa qualitativa sobre mulheres de mais de 60 $\operatorname{anos}^{26}$, selecionando vinte e cinco mulheres dentre os 250 entrevistados na pesquisa anterior sobre a UnATI. Há que assinalar que as Universidades da Terceira Idade são um universo majoritariamente feminino, pois "os estudos demográficos sobre envelhecimento indicam que entre 1958 e 2025, o total da população mundial de mais de 60 anos deverá sextuplicar e a de 80 anos e mais será dez vezes maior. Esses números apontam ainda para as importantes disparidades entre os sexos: as mulheres constituem a maior parte da população idosa mundial. Assim, mais avançam na idade mais elas são numerosas e o envelhecimento pode ser visto como um fenômeno particularmente feminino". (Peixoto 1997: 148).

Dessas conversas e informações obtidas na pesquisa anterior surgiram histórias de vida fascinantes. Decidi, então, aprofundá-las. Ao analisar essas múltiplas estórias, encontrei relatos que apresentavam etapas ou momentos da trajetória de vida bem precisos: tempo de criança, de menina-moça, de moça solteira; tempo de casamento, de amor e desamor, de maternidade, de trabalho para muitas e, finalmente, tempo da velhice, da aposentadoria e da viuvez para várias delas. São tempos perdidos, tempos ganhos. Algumas sabem se liberar do tempo anterior, mas outras precisam "preencher o tempo" para não deslizar na solidão, afastando-se do tempo social. Tentando correr atrás do tempo da pesquisa propus entrar nesses tempos femininos, tempos de passagem da infância à maturidade e à velhice. Maurice Halbwachs (1968) foi o principal inspirador ao identificar a memória coletiva da família como um lugar de elaboração de uma memória afetiva. Diria que "as gerações se sucedem e a transmissão de um vasto patrimônio simbólico lhes confere unidade e identidade. E são as histórias de vida, em

${ }^{25}$ Em coeditaria com Patrícia Monte-Mór até 2005 quando me desliguei da editoria. Cadernos publicou 25 números, e encerrou as publicações em 2008. Todos os exemplares estão disponíveis em www.ppcis.com.br.

${ }^{26}$ Histórias de mais de 60 anos. Estudos Feministas 5(1): 148-158, 1997. 
geral carregadas de emoção, que melhor ressaltam os conteúdos sociais da memória familiar, permitindo descobrir as normas e valores transmitidos, os lugares de vida e as relações familiares". (Peixoto 1997: 152). Assim, "nesses relatos sobre a vida na velhice, é imensa a vontade de realizar os desejos até então sufocados; algumas recusam viver sexualmente com os maridos que não escolheram ou não amaram e sublimam a sexualidade em atividades e cursos longe de casa; outras mantém o contrato de casamento, mas buscam novas emoções fora do casamento ... amorosas ou não" (idem, p. 158).

\section{De volta às imagens}

Em 1993, ainda em Paris, fui convidada por Patrícia Monte-Mór para participar, como produtora associada, da I Mostra Internacional do Filme Etnográfico. Estava na hora de propor parcerias e dar largada aos intercâmbios França-Brasil já acionados. Além de propor filmes que trouxe na bagagem também participei da mesa redonda sobre filme etnográfico e documentário: meu primeiro contato com o mundo audiovisual brasileiro e com Ana Maria Galano ${ }^{27}$. Apresentei um brevíssimo texto sobre o tema, no qual afirmava que "a possibilidade de apresentar aos personagens suas próprias imagens e leva-los a comenta-las, explica-las e discuti-las durante as filmagens, ou mesmo posteriormente (...) - processo que alguns chamam de feedback, outros de effet miroir e Jean Rouch de antropologia compartilhada os associa diretamente ao processo de pesquisa. (...). Filmar é, assim, muito mais uma exploração do processo de conhecimento do que um instrumento para descrever uma dada situação social. O filme passa a fazer parte integrante do dado antropológico, mesmo que seu estatuto científico não seja, ainda, reconhecido" (1994:13).

No ano seguinte, 1994, entrei mais fundo na organização da II Mostra Internacional do Filme Etnográfico, participando da programação geral e da coordenação do Fórum de Antropologia e Cinema. Momento de internacionalizar a nossa antropologia visual. Sugeri, então, uma mesa redonda com Marc-Henri Piault e David MacDougall, ainda desconhecidos no Brasil, e propus que Piault também realizasse um workshop sobre cinema

\footnotetext{
${ }^{27}$ Neste evento, Galano fez o convite para apresentar meu filme-tese na Anpocs em outubro desse mesmo ano. O campo da antropologia visual iniciava: Etienne Samain, antropólogo solitário da Pós-graduação em Multimeios/Unicamp já desenvolvia pesquisas com fotografia e Ana Galano/IFCS/UFRJ coordenava um projeto com imagens no Navedoc.
} 
e antropologia. Ele fora meu orientador, e MacDougall conheci no Atelier International d'Anthropologie Visuelle de Marseille, onde apresentei meu filme-tese A la rencontre du petit paradis, em janeiro 1993.

Ainda em 1994, propus à Ana Maria Galano (Navedoc/UFRJ), membro da Comissão da Imagem e Som da Anpocs, convidar Sylvain Maresca (INRA-Universidade Paris III) para uma conferência. Auditório lotado para assistir o primeiro conferencista da Anpocs a falar sobre a imagem nas ciências sociais: Refletir as ciências sociais no espelho da fotografia ${ }^{28}$. Neste seu séjour carioca, convidei Maresca para apresentar seu trabalho 'As figuras do desconhecido' no meu curso de Antropologia Visual, publicado em Cadernos de Antropologia e Imagem 2.

1996. Organização do primeiro Seminário de Antropologia Visual na Uerj: Imagens da África. Além das mesas e debates organizamos dois eventos paralelos: uma exposição de fotografias de Pierre Verger, na Uerj, e o lançamento do seu livro Ewé. O uso das plantas na sociedade Iorubá na Casa França-Brasil, com a presença do autor ${ }^{29}$ !

Um evento sobre imagens e não produzimos nenhuma imagem!

Novembro 1997. Chega ao Rio, para férias, a amiga Christine Fayot, camerawoman do canal de televisão francês FR3. Propus realizar um curso de Extensão já que a demanda para uma formação mais prática em realização de filmes etnográficos aumentava. 'Com a câmera na mão: Oficina de iniciação às técnicas e à linguagem audiovisual aplicadas ao vídeo documentário', foi organizada em parceria com o Centro Tecnológico Educacional (CTE-Uerj), e ministrada por nós duas. A Oficina teve a duração de três semanas nas quais apresentamos alguns postulados da teoria cinematográfica, tendo como base sequências de filmes (Eisenstein, Welles, Hitchcock...) e ministramos aulas sobre composição gráfica, diferentes valores dos planos, movimentos de câmera e as principais regras de enquadramento para realização de um filme documentário. Orientamos na elaboração de um roteiro, discutindo questões como "por que filmamos?", "o que procuramos expressar através da imagem e do som?". Foram ainda abordados os problemas da mise en scène, de edição/montagem, continuidade, paralelismos e a edição realizada

${ }^{28}$ S. Maresca é um amigo parisiense e era professor visitante no Museu Nacional. Sua conferência foi publicada em Pluralismo, Espaço Social e Pesquisa. São Paulo: Hucitec/Anpocs, 1995. Também nessa coletânea o artigo de Etienne Samain ‘Bronislaw Malinowski e a fotografia antropológica'.

${ }^{29}$ Nesse dia conheci Gisèle Omindarewá Cossard. Dois anos depois desembarco em seu terreiro em Santa Cruz da Serra/RJ para as filmagens do seu portrait. 
no decorrer da filmagem - à prise de vue.

Sessenta inscritos para quinze vagas. Dividimos em três equipes de cinco pessoas para a realização de três ensaios fílmicos. Os estudantes se revezaram na captação de imagem \& som e na edição dos filmes Um dia, um gato ${ }^{30}$; Na Glória ${ }^{31}$ e Pescadores Urbanos ${ }^{32}$, realizada no início de 1998.

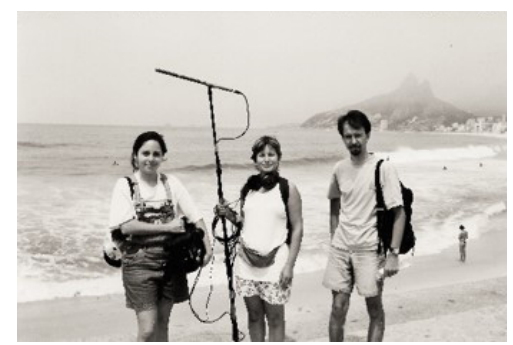

Christine Fayot ao centro

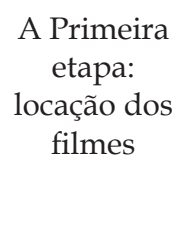

etapa: ocação dos filmes

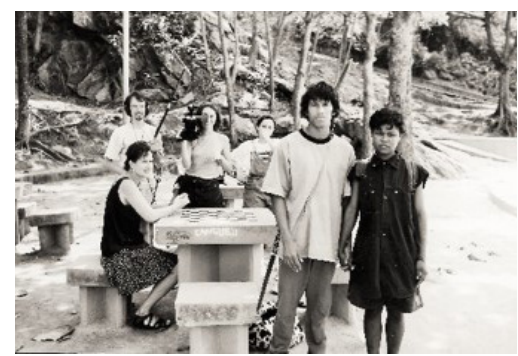

Na praça dos gatos, um jovem casal indígena entra em cena e pede para ser fotografado.

1998. Ano de atividades em várias frentes. Nosso programa de pós graduação criou o doutorado e, para fortalece-lo, decidimos lançar uma revista que expressasse a nossa proposta de interdisciplinaridade nas ciências sociais - Interseções. Revista de Estudos Interdisciplinares. Valter Sinder, Myrian S. dos Santos e eu assumimos a editoria. Interseções lançou o primeiro número em 1999 e passei a acumular a coeditoria das duas revistas - Cadernos e Interseções - me desligando delas no mesmo ano, 2005.

1998 foi também o ano das gravações do filme portrait Gisèle Omindarewá, de março a dezembro. Todo mês era mês de festa de orixá e nós registrávamos a preparação e a festa. A curiosidade inicial era entender o que levara esta burguesa parisiense, até então agnóstica, a optar pela vida religiosa na Baixada Fluminense. Compreender sua história cheia de contrastes, de mundos diversos e tentar transpor para imagens. As filmagens foram atravessadas por muitos imbróglios e muitas substituições de operadores de câmeras e de assistentes. Dizia Gisèle que sua Yemanjá queria ser conhecida por meio do filme, apesar da contrariedade do Xangô da casa.

\footnotetext{
${ }^{30}$ Direção: Clarisse Rath, Jacqueline Szczupak, Marcos Roberto Pereira.

${ }^{31}$ Direção: Martha Nogueira, Bárbara Copque, Lucia Maria Gutierrez.

${ }^{32}$ Direção: Karina Ribeiro de Andrade, Kelly Russo, Guapi Góis.
} 

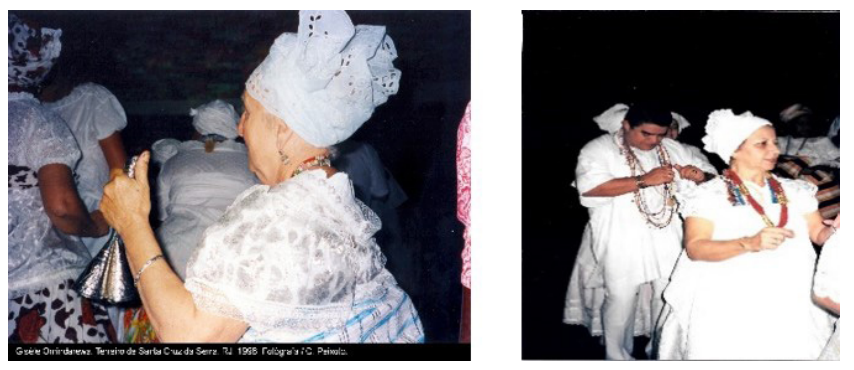

Ao fundo, o Xango

que detestava

câmeras e flashes

e apavorou meus

cameramen, que

interrompiam as

filmagens.

Lembro que o Inarra ainda não possuía equipamentos de filmagem. Uma parceria com o Centro Tecnológico Educacional/Uerj permitiu filmar Gisèle Omindarewa, em $1998^{33}$. Finalizadas as gravações, segui para Paris para um encontro com ela e, juntas, seguirmos ao Benin. Ela faltou ao rendez-vous e só aterrissei nas terras africanas em $2005^{34}$. Uma aventura achar seus caminhos. Milton Guran indicou Ogoulala, tradutor de Gisèle, que com seu filho me levou aos povoados de Saketé, Pobé, Kétou, seguindo a Route de Vaudours.

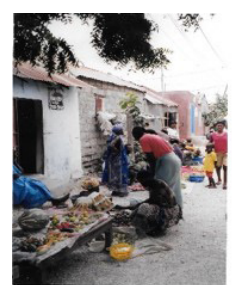

Cotonou, comércio de rua

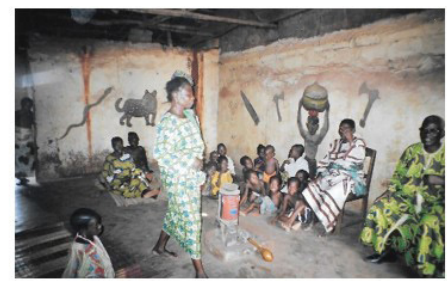

Sakété, casa de Sango

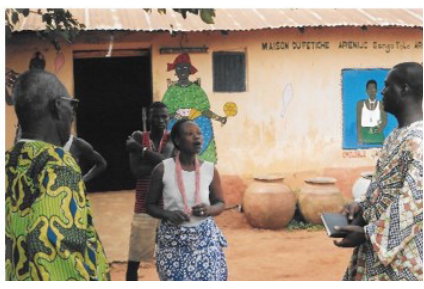

Pobé, casa de Sango

Dez anos de distanciamento das imagens do terreiro de Gisèle, uma edição conturbada e a finalização em $2009^{35}$. Filme em www.inarra.com.br

\footnotetext{
${ }^{33}$ Em 2005, um auxílio da Faperj financiou a edição do filme e a aquisição de uma câmera Sony PDX10, com a qual filmei no Benin. Uma câmera pequena e versátil para filmar en solo: imagem \& som.

${ }^{34}$ Gisèle viajava ao Benin anualmente para visitar suas Yás e comprar produtos religiosos que vendia na sua rede de candomblé. Ela dizia que seguia os passos de Verger. Alguns anos depois tive a oportunidade de participar das $6^{\text {ème }}$ Journées Scientifiques du Réseau Démographique de l'Agence Universitaire de la Francophonie, em Cotonou/Benin, onde apresentei o trabalho Ségrégation spatiale et inégalités sociales: trajectoires de jeunes de Rio de Janeiro. E, claro, aproveitei para seguir os passos de Gisèle na Route de Vaudours!

${ }^{35}$ Este filme ganhou dois prêmios - melhor documentário no III Festival de Filme Etnográfico de Recife (2011), e melhor edição no III Bahia Afro Film Festival (2010) - e foi selecionado para $13^{\circ}$ Brazilian Film Festival de Paris (2011), para o Festival du Film Brésilien de Montreal (2011)
} 
Certa vez, no retorno de Santa Cruz da Serra, paramos na Casa Gerontológica do Galeão para filmar minha avó que lá morava. Foi a partir dessa entrevista filmada que decidi retomar as filmagens de Bebela e a revolução gaúcha de 1923 (2004), iniciadas em 1991 quando realizei o campo carioca da tese de doutorado. Outro filme que levou dez anos para ser concluído! Em www.inarra.com.br

1998 foi um marco para a antropologia visual brasileira: lançamento do primeiro livro coletânea - Desafios da Imagem. Fotografia, iconografia e vídeo nas Ciências Sociais ${ }^{36}$. Organizado por Bela Feldman-Bianco e Miriam Moreira Leite, o livro reunia os trabalhos apresentados em GTs e MR (Anpocs e RBA). Livro que já é um clássico da nossa antropologia visual!

\section{De volta à família \& envelhecimento}

2000. Um ano marcante para quem teve todos os seus trabalhos arquivados pelo IBGE. Lançamento do meu primeiro livro Envelhecimento e Imagem. As fronteiras entre Paris e Rio de Janeiro - fruto da tese e financiado pela Faperj. O evento foi na livraria do Museu da República e lá também apresentamos o filme da tese Em busca do pequeno paraíso. Poucos meses depois lançamos Família e Individualização, organizado com François de Singly e Vincenzo Chiccelli, presentes no lançamento assim como Anália Torres e Jean-Claude Kaufmann, também autores.

1997-2000. As pesquisas anteriores, mais focadas nas questões do envelhecimento, atraíram minha curiosidade antropológica para as relações intergeracionais. Tudo indicava que a qualidade do processo de envelhecimento tinha ligação direta com as relações estabelecidas no âmbito familiar. Assim, me candidatei à bolsa Prociência/Uerj com o projeto de pesquisa 'Trocas e transmissões entre gerações: valores, bens e serviços', para melhor entender as relações familiares na contemporaneidade, e dar prosseguimento aos estudos comparativos internacionais. Rio de Janeiro e Paris novamente em foco, agora para estudar as transmissões entre gerações. As sessenta entrevistas com pessoas de mais de 60 anos foram realizadas por estudantes de ciências sociais da Uerj, e de sociologia da Universidade Paris V-René Descartes, sob a coordenação de Michel Bozon. Inspirada em

\footnotetext{
e para o Brazil Film Fest de Toronto (2011). Apresentado na TV Futura e na TV Sesc, além de outras mostras e festivais brasileiros.

${ }^{36}$ Publiquei o artigo 'Caleidoscópio de imagens: o uso do vídeo e sua contribuição à análise das relações sociais'. $2^{\mathrm{a}}$ edição em 2001.
} 
Claudine Attias-Donfut \& Martine Segalen (1998) e Myriam Lins de Barros (1997) observei que "os laços entre avós e netos se tecem pouco a pouco e surgem as preferências como, aliás, nas relações entre pais e filhos. (...). Mesmo afirmando amar todos os netos igualmente, no final das contas tem sempre um que é mais querido do que os outros. Em geral, a eleição afetiva se constrói ao longo da infância dos netos e raros são os avós que escolheram seu preferido a partir da adolescência, fase da vida caracterizada por uma redefinição das relações familiares. A passagem desta etapa à vida adulta é acompanhada de perto por muitos dos avós entrevistados uma vez que esta transição pode levar a uma aproximação ou a uma perturbação nas relações entre estas duas gerações." (Peixoto 2000: 98). Os primeiros resultados dessa pesquisa foram apresentados em 1999 no Colóquio Internacional Famille et Individualisation ${ }^{37}$, organizado pelo Centre de Recherches sur les Liens Sociaux/Cerlis, da Universidade Paris V-René Descartes.

Animada com a ampliação do campo de estudos sobre as questões ligadas às relações intergeracionais, e com a perspectiva analítica de François de Singly, enveredei por essa direção teórica para estudar o processo de individualização da família contemporânea, pois como ele afirma, "inversamente às aparências, os indivíduos que compõem as sociedades contemporâneas (ocidentais) não se parecem com os indivíduos das gerações precedentes. (...). O período do final dos anos 1960, no qual ainda vivemos, corresponde à instauração de um compromisso entre as reivindicações dos indivíduos em se tornarem autônomos e seus desejos de continuar a viver, na esfera privada, com uma ou várias pessoas próximas. (...). A família se transforma em um espaço privado a serviço dos indivíduos. (...). A independência, e principalmente a independência econômica, é a maneira pela qual o indivíduo pode, graças aos seus recursos pessoais retirados diretamente de sua atividade, depender menos dos próximos; a autonomia é o conhecimento do mundo no qual essa pessoa vive: mundo definido pela elaboração tanto de regras pessoais quanto, no caso da vida em comum, de regras construídas na negociação entre várias pessoas" (Singly 2000: 13-19).

No Brasil ainda discutíamos sobre a "crise" na família, em decorrência da baixa taxa de fecundidade, do aumento da esperança de vida, do

\footnotetext{
${ }^{37}$ François de Singly, sociólogo e diretor do Cerlis, organizou as coletâneas Être soi parmi les autres (tomo 1) e Être soi d'un âge à l'autre (tomo 2) em 2001, compostas dos artigos apresentados nesse colóquio. Meu artigo Les préférences familiales. L'individualisation de l'affection dans les générations âgées faz parte do tomo 2. Nesta versão francesa, a citação acima está na p. 196.
} 
declínio do casamento e da banalização do divórcio. O que se observava nessas pesquisas era, de um lado, a caracterização de aspectos da vida familiar nas diferentes classes sociais ou nos setores produtivos (família favelada, família de camadas médias, família camponesa, etc.) e, de outro, uma forte tendência a tratar a "família" tanto como uma instituição social quanto e, principalmente, como um valor. Estava na hora de propor uma outra perspectiva analítica para os estudos de família no Brasil. Assim, buscando fortalecer esta interlocução, em 2000, organizei com Myriam Lins de Barros (ESS/UFRJ) e Maria Luiza Heilborn (IMS/Uerj), o Colóquio Internacional Análises Contemporâneas sobre Comportamentos Familiares. Convidamos F. de Singly e sociólogos do Cerlis, a socióloga Anália Torres do ISCTE (Lisboa) e antropólogos brasileiros (Gilberto Velho, Parry Scott, Guita Debert, entre outros) para discutir pesquisas e orientações teóricas. Três dias que marcaram nossas reflexões sobre a família contemporânea. Neste momento de efervescência dos debates lançamos o livro Família e Individualização (Peixoto, Singly e Cicchelli 2000), composto de artigos selecionados naquele colóquio francês de 1999. Pontaria certeira, o livro se esgotou em pouco tempo!

Este evento nos levou, Myriam Lins de Barros, Malu Heilborn e eu, à criação do Grupo de Estudos sobre a Família Contemporânea/Grefac, inscrito no Diretório de Pesquisas do CNPq e à criação das coleções Família, Gênero e Cultura e Análises Sociais Contemporâneas na editora FGV ${ }^{38}$. A primeira coleção já publicou oito livros e o primeiro deles ${ }^{39}$ foi, justamente, o de F. de Singly Sociologia da Família Contemporânea, tradução minha.

1999 não acabou! Ano do meu primeiro pós-doutorado. Seria em antropologia visual $^{40}$ (EHESS) para retomar os estudos nesse campo, mas fui atraída pela proposta de Françoise Clavairolle para participar de um edital do Ministère de l’Emploi et de la Solidarité Sociale/MiRE ${ }^{41}$

\footnotetext{
${ }^{38}$ O GREFAC promoveu vários seminários e destaco apenas o Seminário Relações Familiares, sexualidade e religião (2004), organizado com L.F. Duarte do Museu Nacional. Os trabalhos foram publicados em duas coletâneas: Sexualidade, Família e Ethos Religioso (2005) e Família e Religião (2006).

${ }^{39}$ Lançamos a coleção em 2000 já com a publicação de três livros: Sociologia da Família Contemporânea de F. de Singly, Sociologia da Sexualidade de M. Bozon e a coletânea Família e Envelhecimento, por mim organizada.

${ }^{40}$ Pretendia dar seguimento à pesquisa para o portrait de Gisèle Omindarewá, consultando seu acervo pessoal de fotografias e filmes Super 8 que deixara no interior da França, e filma-la no Benin.

${ }^{41}$ Esta pesquisa de pós-doutorado foi realizada no âmbito do Laboratório Techniques
} 
sobre envelhecimento \& novas tecnologias. Nosso projeto 'Política social do envelhecimento: poder da tecnologia, tecnologia do poder: estudo de um município francês' foi um dos vinte selecionados dentre mais de cem apresentados. Embarquei para a França para iniciar o trabalho de campo. Analisamos o uso de novas tecnologias pela população de mais de 60 anos em uma pequena cidade ao sul de Paris: Verrières-Le-Buisson ${ }^{42}$. Consideramos que as "novas tecnologias são sistematicamente associadas à juventude, dando a impressão de que somente os jovens teriam mais competência para lidar com o universo tecnológico. O que leva a pensar que as pessoas de idade avançada são refratárias às inovações tecnológicas, seja por questões econômicas ou por dificuldades de uso? Será que os valores que lhe são atribuídos, vinculados ao universo da juventude, são completamente opostos aos valores que caracterizam o envelhecimento? Sabemos, de antemão, que os valores que acompanham as novas tecnologias raramente estão associados a uma visão de mundo onde cada indivíduo teria o seu lugar; onde a experiência, a maturidade, a memória e a própria história não cederiam lugar, facilmente, às percepções construídas pelas tecnologias da comunicação e da informação. Ao interrogar sobre os estereótipos que identificam a "rejeição" das pessoas de idade às técnicas inovadoras e/ou sua suposta "incompatibilidade", procuramos investigar seu nível de "autonomia" e de "dependência" e sua capacidade para mudar comportamentos face às tecnologias disponibilizadas nos espaços público e privado" (Peixoto \& Clavairolle 2005: 15). Analisar a maneira como as pessoas envelhecidas utilizam (ou são levadas a usar) as tecnologias da vida cotidiana é refletir sobre a contribuição das tecnologias aos processos de construção identitária. (idem, p. 16). Os exemplos são maravilhosos!

Uma senhora francesa incluiu entre os seus pertences tecnológicos a lixeira com pedal que acabara de comprar para provar ao filho que já sou um pouco moderna. Outra afirmou que o forno microondas não é bem uma nova tecnologia, é só um aperfeiçoamento porque o princípio é sempre o mesmo: serve para esquentar! Há também aqueles que recusam usar os distribuidores

et Culture/CNRS para o programa "Evoluções tecnológicas, dinâmica das idades e envelhecimento populacional", do Ministério do Emprego e da Solidariedade/DREES/MiRE e da Caixa Nacional de Seguros da Velhice/CNAV (Caisse Nationale d'Assurance Vieillesse), em 1999.

${ }^{42}$ Politique de la vieillesse dans une municipalité de l'Essonne et développement technologique. Cahiers de recherches de la Mire 10, 2001. Uma versão mais extensa foi publicada na Vibrant 3(2), 2006 sob o título ‘Politique de la vieillesse et développement technologique en France'. 
automáticos dos bancos e correios porque nada substituirá o contato humano. Eu não quero ser robotizada!

Ainda que não estivesse desenvolvendo pesquisas no campo da antropologia visual, ela estava presente no meu dia a dia acadêmico seja nos cursos de Antropologia e Imagem (pós-graduação) e de Antropologia Visual (graduação) oferecidos anualmente, nas atividades do Grupo Imagens, Narrativas e Práticas Culturais/Inarra, nas orientações nos dois níveis, seja nas participações em congressos nacionais e internacionais e nas publicações. Na verdade, os anos 1990-2000 foram de grande investimento na construção desse campo na Uerj e no Brasil. (Koury 1999; Peixoto 1992, $1995,1999)$.

2000-2003. No retorno do pós-doutorado as baixas pensões das aposentadorias eram manchetes nas mídias impressas e televisivas do país e os aposentados protestavam nas ruas. A pesquisa 'Trabalhando... sempre: um estudo sobre aposentados que permanecem ou que se reinserem no mercado de trabalho' revelou que, para muitos brasileiros, a aposentadoria não significa o fim da atividade profissional. $\mathrm{O}$ retorno ao trabalho ou o trabalho jamais interrompido é consequência de aposentadorias irrisórias e de um sistema de previdência precário, incapaz de atender a população demandante. Coexistem várias razões e maneiras para recusar a saída do mercado de trabalho seja ele formal ou informal. São, principalmente, fatores socioeconômicos e culturais (sexo, nível de instrução, condições de saúde, trajetória profissional e contexto familiar) que determinam a situação de cada indivíduo que atinge a idade da aposentadoria.

Esta pesquisa fez parte do curso Trabalho de Campo, e o interesse dos estudantes era estimulado pela pressão das ruas. O objetivo da pesquisa, que entrevistou sessenta e oito aposentados (homens e mulheres), era analisar os aspectos que caracterizavam a trajetória dessas pessoas e seus contextos familiares. Interessante que as questões e reivindicações apresentadas naquela época permanecem e são, agora, novamente discutidas diante do projeto do governo Bolsonaro ${ }^{43}$ para a reforma da previdência. No artigo, publicado no livro que organizei Família $\mathcal{E}$ Envelhecimento, já dizia que "uma das preocupações maiores é a 'crise da previdência social', consequência do déficit do sistema previdenciário, [sendo que] o Estado brasileiro controla a revalorização do salário mínimo e, consequentemente, das aposentadorias. Além disso, há vários anos que esse sistema não atende mais ao seu

${ }^{43}$ N.A. Atualização para esta publicação (março de 2019). 
objetivo primeiro, que determinava que os trabalhadores pudessem dispor, no momento da aposentadoria, de um nível de vida próximo àquele do seu período de atividade. A degradação das suas condições de vida os obriga, então, a retornar ao trabalho: esta é a realidade cotidiana de mais de um terço das pessoas aposentadas. Isto explica porque, para um bom número de brasileiros, a aposentadoria não significa o fim de uma atividade profissional e o início do uso do tempo livre. Ao contrário, ela é uma forma de reconversão, pois, no Brasil, a aposentadoria não representa uma ruptura definitiva com a vida ativa uma vez que o benefício recebido não é suficiente para sobreviver". (Peixoto 2004: 59). Os resultados dessa pesquisa foram apresentados nas $5^{\text {èmes }}$ Journées Scientifiques du Réseau Démographie, em Marsellha 2003, e o trabalho foi selecionado para integrar o livro Familles au Nord, Familles au Sud, publicado em $2005^{44}$.

\section{'Tudo junto e misturado'}

2000. Etienne Samain propõe uma parceria interinstitucional ('nós e outros') para receber o professor Philippe Dubois (Universidade Paris III-Sorbonne Nouvelle). Na Uerj, o professor francês ministrou o módulo Teorias da Imagem, no meu curso Antropologia \& Imagem. Auditório lotado dado que esta disciplina eletiva da pós-graduação é bastante requisitada por estudantes de outras universidades cariocas. Neste mesmo ano, a Faculdade de Comunicação/UERJ propôs uma parceria para oferecer aos seus estudantes uma perspectiva de filme documentário diferente da linguagem televisiva. A experiência foi bem sucedida e, em 2001, fiz a primeira parceria interinstitucional com a Pós-Graduação em Ciências Sociais em Desenvolvimento, Agricultura e Sociedade /CPDA-UFRRJ para a realização do curso "Campo e Cidade com imagens", ministrada com Luiz Flavio de Carvalho e Hector Alimonda (CPDA). Esta experiência mostrou a necessidade de realizar Oficinas práticas para a produção de ensaios fotográficos. Assim, convidamos Miriam Moreira Leite (USP) para participar da primeira Oficina realizada na Uerj, e o fotógrafo Roosevelt Nina para a Oficina do CPDA-UFRRJ.

A parceria com o CPDA se prolongou por alguns anos e, em 2007, organizamos o Seminário Imagens e processos históricos e sociais na América

${ }^{44}$ Publicado originalmente na coletânea que organizei Família E Envelhecimento, em 2004: 'Trabalhando sempre: aposentados que se reinserem no mercado de trabalho e apoio familiar'. 
Latina, no campus da Ilha Grande. Participaram também Carmen Guarini (Universidade de Buenos Aires), Norma Fernandez (documentarista argentina), Etienne Samain e nossos orientandos de pós-graduação. Neste laboratório, no qual discutíamos as nossas pesquisas ao longo do dia e à noite o papo rolava no Bar da Dona Teresa, soubemos que Etienne estava prestes a se aposentar. De pronto, meus alunos ${ }^{45} \mathrm{e}$ eu iniciamos as filmagens de 'Etienne Samain, de um caminho a outro' (2008), que foi apresentado na $26^{a}$ RBA, Porto Seguro (2008). Filme em www.inarra.com.br.

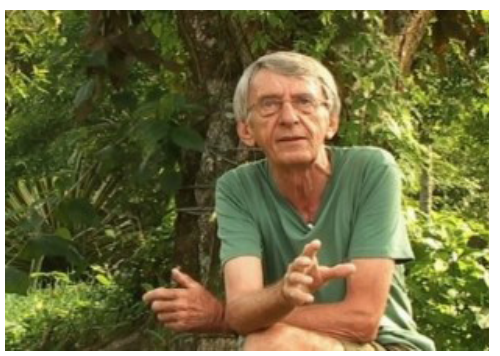

Foi embaixo dessa árvore fogosa da Ilha Grande que Etienne nos revelou seu grande segredo: desembarcou no Brasil como pároco!

Aqui fez antropologia, abandonou a batida, entrou para a Unicamp e casou com Godeliève.

De volta ao ano de 2001, intenso em atividades de toda ordem! A começar com a Coordenação do Programa de Pós-Graduação, com Marcia Contins (2001-2002). Uma experiência sem dúvida estressante, mas que pode ser gratificante quando buscamos construir melhores condições de trabalho, ensino e pesquisa. Um edital Faperj permitiu reformar o espaço das pós-graduações do IFCH (biblioteca, auditórios multimídia, sala de estudos, etc.) e a sala de aula do PPCIS, mas principalmente, adquirir os nossos primeiros equipamentos audiovisuais.

Foi também o ano no qual iniciei a produção e realização do Programa Cinema \& Antropologia, os bastidores do filme etnográfico ${ }^{46}$, na TV Universitária do Rio de Janeiro. Difusão mensal e mil estratégias para entrevistar os pesquisadores que não viviam no Rio. Participei de inúmeros seminários e congressos brasileiros e, sem equipamentos, solicitava o apoio dos colegas locais para gravar as entrevistas. Duas entrevistas internacionais foram realizadas longe dos trópicos: com Virginie de Véricourt (antropóloga francesa) e com Paul Henley (Universidade de Manchester). Um trabalho

\footnotetext{
${ }^{45}$ César Augusto de Carvalho, Gleice Mattos Luz, Barbara Copque e Fabiana Bruno, orientanda de E. Samain..

${ }^{46}$ Consultar, no final do memorial, os títulos dos trinta e sete programas realizados até o momento, disponíveis no site do Inarra www.inarra.com.br .
} 
insano de produção, realização e edição para o programa ir ao ar e não perder o lugar na grade privilegiada das $21 \mathrm{~h}$ de domingo. Cinema $\mathcal{E}$ Antropologia permaneceu na grade televisiva durante quatro anos e produziu programas de entrevistas com pesquisadores que relatam os bastidores da realização e apresenta o filme na íntegra. Em 2005 não resisti às exigências da TV Universitária que se moldava aos canais comerciais e encerrei a 'carreira de apresentadora televisiva'! Mas, não desisti da série. Em 2016, com o Inarra melhor estruturado, reiniciamos Cinema \& Antropologia, os bastidores do filme etnográfico.

Em junho de 2001 embarquei para Göttingen com Sylvia Caiuby para a Conferência Internacional Origins of Visual Anthropology. Putting the Past Together. Objetivo: conhecer e escutar os grandes nomes da antropologia visual. Um momento histórico já que este foi o primeiro reencontro dos pais fundadores da antropologia visual depois da famosa $1^{\text {a }}$ Conferência Internacional de Antropologia Visual de Chicago, em 1973, organizada por Paul Hockings e Margaret Mead! Neste reencontro de 2001, P. Hockings relembrou as escolas fundadoras da antropologia visual: cinéma-vérité e observational cinema. O que diferenciaria uma escola da outra é que o observational cinema surgiu e se desenvolveu no mundo universitário (University of California Los Angeles/UCLA). Ele, Colin Young, Ian Dunlop e outros mantinham uma relação estreita com as ciências sociais, sobretudo com a antropologia. Já o cinéma-vérité, criado por Jean Rouch e Chris Marker, teve maior repercussão junto aos cineasta e pouco se expandiu no mundo universitário europeu, exceto em uma ou outra universidade francesa.

Galeria dos pais fundadores da antropologia visual presentes em Göttingen
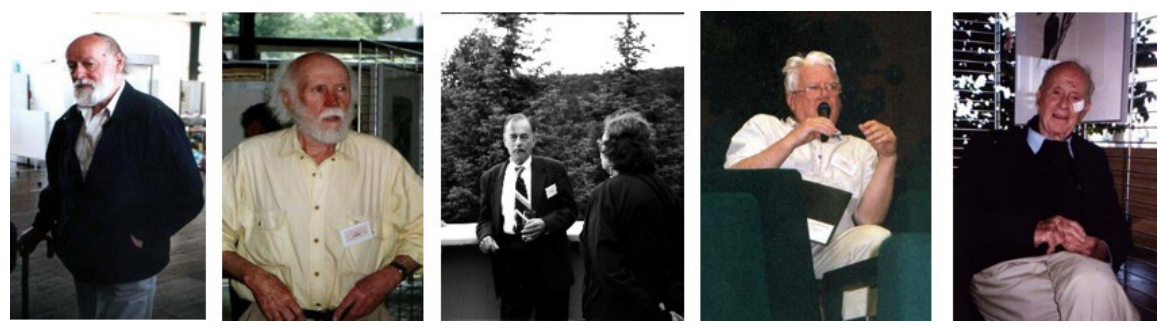


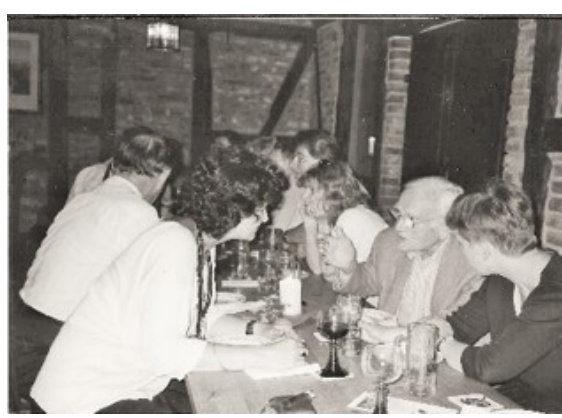

Foto de S. Caiuby

‘Diria que este histórico reencontro terminou em estilo nada latino: um grande jantar fora da cidade, em um restaurante típico, cujas longas mesas de madeira deixavam pouco espaço para a circulação, passamos a noite conversando muito e fazendo projetos para novos encontros já que música não havia e muito menos baile...' (Peixoto 2002).

Conversando com Richard Leacock e ao lado de Paul Hockings. Sem tempo para os talheres, a conversa predominava!

Ainda em 2001 fui indicada pela 'rede'47 de pesquisadores da antropologia visual para compor a Comissão da Imagem da Anpocs. Com Ana Maria Galano/UFRJ e Lisabete Coradini/UFRN organizamos as exposições fotográficas Agudas: os "brasileiros da África, de Milton Guran e Observações fortuitas sobre o Japão, de Fernando de Tacca, e as Sessões de Vídeo: Curtas Urbanos e Documentários sobre músicos e música.

No retorno da Anpocs, me juntei às amigas-colegas para organizar mais um Seminário do Grefac sobre Família, Gênero e Sexualidade (11/2001). Os seminários eram semestrais, com convidados. Em 2001, Michel Bozon e eu apresentamos 'Uma sociedade sem casamento nem paternidade' sobre a etnia chinesa $\mathrm{Na}$, estudada pelo antropólogo Cai Hua. Analisamos o livro e o filme ${ }^{48}$. A sociedade $\mathrm{Na}$, no sudoeste da China, "possui um dos mais absolutos sistemas de matrilinearidade \& matrilocalidade de que se tem conhecimento, no qual o casamento e a paternidade não existem, sendo somente a mãe quem legitima os filhos". A ideia de mostrar em imagens esse aspecto é, sem dúvida, interessante, e a análise dos dois produtos da tese de Cai Hua foi estimulante. (Peixoto \& Bozon 2003: 81).

2001 parecia não acabar! Em dezembro fui convidada pela Universidade de La Plata, Argentina, para dar um curso concentrado de Antropologia Visual na pós-Graduação da Facultad de Ciencias Naturales y Museo. Era a

47 Nos anos 1993-1994, no âmbito da reunião da Anpocs, organizamos uma rede de pesquisadores com o objetivo de criar espaços para a construção do campo da antropologia visual no Brasil.

${ }^{48}$ Artigo publicado em Cadernos de Antropologia e Imagem 17, 2003. 
primeira vez que este Programa oferecia um curso de antropologia visual. Foram dez dias de atividades intensas, envoltas em uma crise política e econômica colossal: sem pagamento e sem o reembolso da passagem que adquiri, os professores e alunos se desdobraram para me convidar para 'comidas, cervezas, paseos y debates políticos'! De La Plata segui para a Universidade de Buenos Aires, convidada por Carmen Guarini, para dar uma palestra sobre a antropologia visual brasileira. Volto para o Brasil sem um tostão e mais trabalho: uma coorientação de doutorado e membro do corpo de pareceristas ad hoc do Conicet.

2002 inicia com a preparação do Prêmio Pierre Verger de Filme Etnográfico para o qual fui convidada a presidir (2002). Minha primeira proposta para a ABA foi a criação do concurso para Ensaio Fotográfico, afinal Pierre Verger era fotógrafo e não cineasta! Criamos, assim, o I Prêmio Pierre Verger de Ensaio Fotográfico, e na 23 ${ }^{a}$ Reunião da Associação Brasileira de Antropologia (Gramado) organizamos uma exposição fotográfica com os cinco vencedores.

Este foi um ano de preparação de vários seminários nos campos da antropologia visual e da família. Dentre eles destaco um do Grefac ‘Família e redes sociais no espaço urbano', no qual discutimos questões sobre as redes de solidariedade familiar: como elas se manifestaram nas últimas décadas e que ligações teriam com as transformações dos padrões familiares. $O$ outro, do Inarra foi 'Cinema \& Ciências Sociais' ${ }^{49}$. Era ano de lançamento de dois filmes que marcaram a história do documentário: Edifício Master, de Eduardo Coutinho, e Cidade de Deus, de Fernando Meirelles e Katia Lund. Participaram das mesas: Eduardo Coutinho, Katia Lund, Wladimir Carvalho, Geraldo Sarno, Consuelo Lins, Ivanna Bentes, Sylvia Caiuby e Paulo Lins. Dois dias de debates acirrados sobre real \& ficção e cinema \& violência ${ }^{50}$. Auditório lotado (250 lugares)!

Quanto às pesquisas, fui convidada por Clara Araújo e Celi Scalon a integrar um grupo de dez pesquisadores brasileiros para realizar a pesquisa Gênero, Trabalho e Família em perspectiva comparada, do International Social Survey Program/ISSP (2002-2005). Tratava-se de um programa internacional de investigação e criação de banco de dados internacionais

${ }^{49}$ Nessa época, a linha de pesquisa Imagens, Narrativas e Práticas Culturais era formada por Helena Bomeny, João Trajano Sento-Sé, Myrian S. dos Santos, Valter Sinder e eu. Junto com nossos estudantes organizamos este Seminário.

${ }^{50}$ Os artigos e debates foram publicados em Interseções. Revista de Estudos Interdisciplinares 5(1), 2003. 
sobre estes temas sociológicos, e fiquei responsável pelas relações intergeracionais ${ }^{51}$.

2002. Recebi um convite da Reitoria da Universidade para participar da $3^{\text {a }}$ Convenção Internacional de Educacão Superior, em Havana, e apresentar a antropologia visual que desenvolvíamos na Uerj ${ }^{52}$. Como não aceitar a viagem dos sonhos de juventude?

2003. Foi o ano dos acordos científicos! Embalada pelas relações criadas com o diretor e pesquisadores do Cerlis/Universidade Paris V-RenéDescartes e com pesquisadores portugueses do ISCTE, propus à Uerj a elaboração de convênios internacionais com os dois centros. Foram os dois primeiros acordos realizados pelas Ciências Sociais da Uerj, e que duraram quase dez anos de trocas entre pesquisadores e de oportunidade de estágios 'sanduíche' para nossos estudantes, inclusive para os de outros institutos da universidade.

Nesse mesmo ano elaborei o projeto 'Indivíduo e Memória Social', cujo objetivo era estudar a memória individual como um ponto de vista da memória coletiva (Halbwachs) e realizar filmes portrait, pois considero que as biografias são fontes metodológicas eficientes para a compreensão dos processos de construção da memória social já que revelam o passado por meio da memória de seus personagens. Os filmes portraits podem ser vistos como um recurso fecundo para a reconstituição dos lugares e tempos de memória porque eles permitem uma composição mais completa e complexa entre textos visuais (fotografias, iconografias, filmes de arquivo, etc.) e textos escritos (jornais, cartas, documentos diversos, etc.) quando ordenados em consonância aos gestos, emoções e falas dos indivíduos, transformados em personagens principais desses filmes portraits. Nesse sentido, a inserção de imagens fixas nestes filmes não deixa de ser "um convite metafórico para sentar no banco ao lado e contemplá-las", como diz B. Stiegler (2009: 15). Ao atuar como artefato de memória essa miscelânea de imagens pressiona os mecanismos de rememoração, aflorando a expressão dos sentimentos. É a memória afetiva desse passado fixado em imagens que vemos manifestarse na tela. Mais do que isso, "a memória, na qual cresce a história, que por sua vez a alimenta, procura salvar o passado para servir ao presente e ao futuro. Devemos trabalhar de forma que a memória coletiva sirva para a

\footnotetext{
51 'Solidariedade familiar intergeracional', publicado em Araújo C \& Scalon C. Gênero, Família e Trabalho no Brasil, 2005.

${ }^{52}$ Apresentei o trabalho 'Antropologia Visual: reflexiones sobre el uso de imágenes en la enseñanza y la investigación antropológica' .
} 
libertação e não para a servidão dos homens" (Le Goff 2003: 471).

A memória em imagens tem sido muito explorada pela antropologia visual através do feedback, um instrumento que incita as pessoas filmadas a discorrerem sobre as imagens projetadas: imagens do Outro, imagem de si. O pesquisador põe em evidência o universo social do filme e desenvolve o argumento central nos agentes da história, focalizando nas relações do tempo com a história, a história do tempo, tempo e memória (Peixoto 2012: 348). Seria este o mesmo exercício de elaboração de um memorial?

Este projeto não tinha data para acabar já que o meu tempo de filmagem é sempre longo por conta das inúmeras atividades que vou encampando. Diria que a maioria dos meus filmes foi realizada no âmbito desse projeto e do projeto de Extensão 'A imagem na pesquisa social: percepção e memória nos filmes e fotografias etnográficas'.

2004. 'Trajetórias juvenis: construção da autonomia e apoio familiar' (2004-2005). Fruto de uma disciplina na graduação - Trabalho de Campo - o tema foi escolhido pelos alunos e a pesquisa desenvolvida com alguns deles ${ }^{53}$ : aprender a elaborar um projeto, construir o universo, realizar e analisar as entrevistas, redigir um artigo. A literatura indicava que os processos de autonomia parental são diferenciados conforme os pertencimentos sociais, sendo múltiplas as estratégias para obter a independência familiar. Pois, "nas sociedades contemporâneas, a passagem de uma etapa da vida a outra é mais rápida e mais direta, mesmo se o prolongamento dos estudos e a entrada tardia na vida ativa leve a coabitação mais longa com os pais. Isso não impede os jovens a serem autônomos" (Peixoto at al 2009). Ou seja, "o princípio da escolha inscreve no vínculo (lien) a expressão da liberdade individual, ele concilia assim o individual e o coletivo. Ele não regula o problema da fragilidade [do vínculo], mas consegue fazer com que o individualismo seja relacional" (Singly 2003: 19).

Selecionamos jovens estudantes de 17 a 27 anos, moradores das Zonas Norte, Sul e Oeste do Rio de Janeiro, pertencentes às camadas populares e médias. A população de jovens pobres universitários cresceu muito nos últimos anos. Para ela, os estudos universitários ou as especializações técnica, esportiva ou artística são os meios de aceder a um mercado de trabalho cada vez mais exigente. Ela se depara, contudo, com inúmeras dificuldades para continuar estudando. Muitas foram as razões apontadas: eles têm um

${ }^{53}$ Os estudantes Eduardo Ribeiro, Isis R. Martins, Júlio Cesar V. Ferreira, Kelly Pedroza Santos, Mariana Leal, Margareth Maria Mendes e Paulo Gustavo Tavares participaram das etapas finais (análise e redação artigo). 
déficit escolar em relação aos jovens das camadas médias e superiores, o que cria uma desvantagem na aprendizagem; as universidades públicas estão localizadas longe da moradia e o custo do transporte é muito alto. Além disso, eles não têm meios para adquirir livros (predomina o sistema de xerox) e as bibliotecas não dispõem de vários exemplares. Comparamos as estratégias dos jovens de camadas médias e populares para continuar estudando e/ou trabalhando, com vistas à construção de sua autonomia. (Peixoto et al. 2009).

Experiência de um ano que resultou na publicação de um artigo. Ainda estudantes de graduação eles já eram coautores em publicação francesa ${ }^{54}$ !

A divulgação dessa pesquisa resultou em um convite para participar do grupo de trabalho Pauvreté, solidarités et transferts intergénérationnels, do Centre Population et Développement/CEPED, Paris 2005-2006. As pesquisas e os debates deste grupo giravam em torno dos levantamentos demográficos e me traziam de volta à análise de estatísticas. No final de um ano trabalho decidi me desligar do CEPED.

Ainda em 2004 fui convidada pelo Mestrado de Economia Doméstica, da Universidade Federal de Viçosa, a dar um minicurso sobre Família e Relações Intergeracionais, abordando também a produção e análise de imagens. O curso 'Imagens da e sobre a Família' ${ }^{55}$ permitiu aliar os interesses de professores e estudantes, e os meus também. Esse foi o primeiro de muitos outros cursos sobre essa temática, e que estimularam a edição do filme Bebela e a revolução gaúcha de 1923, que iniciara em 1991. Naquela época queria apenas registrar as histórias da minha avó sobre a sua participação, e a de meu avô, nessa revolução. Um filme de família. Mas, as conversas com minha avó me levaram a pesquisar esse momento da história do Rio Grande do Sul nos arquivos públicos, garimpando documentos deste período (jornais, relatórios e fotografias) que "objetivassem" seus relatos e suas imagens "subjetivas", apoiadas no seu álbum de fotografias, e que permitissem encontrar as relações possíveis entre sua memória e a memória coletiva (Peixoto 2008). O filme de família se transformou em um documento histórico, pois revelou a participação feminina nas revoluções gaúchas de 1923 e 1930, raramente declarada na história oficial brasileira.

\footnotetext{
${ }^{54}$ Trajectoires des jeunes de Rio de Janeiro. Diversités et enjeux sociaux? (2009).

55 Acabara de editar Cadernos de Antropologia e Imagem 17, Famílias em imagens, que foi fundamental para o curso. Levei uma mala cheia de exemplares! Aliás, além de editora era também vendedora da revista, levando exemplares para todos os congressos que participava.
} 


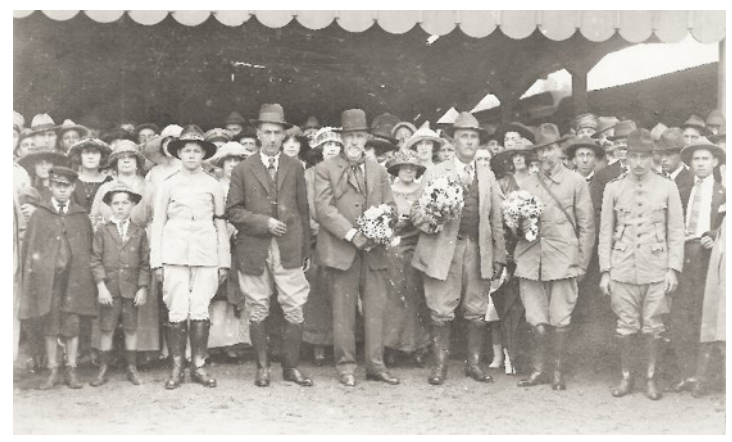

Estação ferroviária de Cruz Alta, recebendo os líderes 'maragatos'.

Ao mostrar a foto para Bebela, ela lembrou o nome de cada um deles e, de repente, 'mas essa sou eu, de chapéu! Naquela época a gente não saía sem chapéu.

'E olha aí, os gaúchões de buquê de flores na mão! Essa tá boa!'

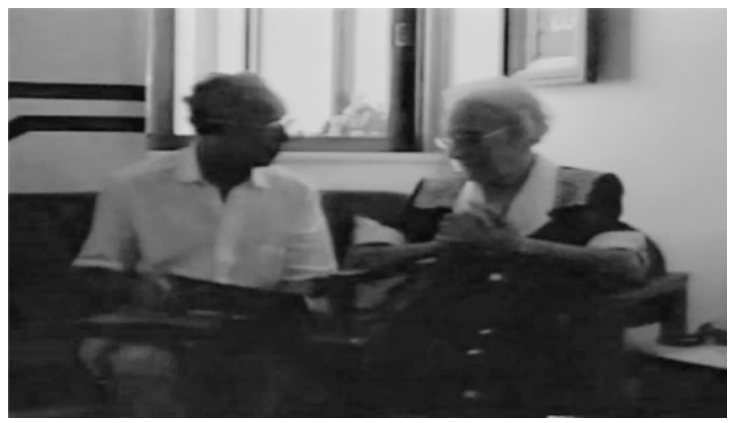

Cada fotografia remetia Bebela ao seu passado, agora revisitado no presente, e revelava que sua memória estava nitidamente vinculada às imagens fotográficas.

2005 - Ano de provação! Defesa de tese dos meus três primeiros orientados de doutorado. A primeira delas no campo da família, a segunda no da antropologia visual e a terceira inserida nos dois campos. Passei na prova.

Ainda neste ano fui convidada pela socióloga colombiana Yolanda Puyana, da Universidade Nacional de Colômbia, para participar do Seminário Internacional Familias, Cambios y Estrategias, promovido pela Prefeitura de Bogotá e Faculdade de Ciências Humanas. Um evento voltado para a discussão de políticas sociais para a família. Cinco especialistas internacionais foram convidados para apresentar um panorama das políticas sociais de seus países, e fui uma delas ${ }^{56}$. Me debrucei novamente

${ }^{56}$ Proferi duas conferências: 'Brasil: transiciones demográficas y urbanas, transformaciones familiares y políticas sociales' e 'Familia y envejecimiento en Brasil: sobre las relaciones intergeneracionales', publicadas em Puyana Y \& Ramírez M-I. Familias, cambios y estrategias, 2007. 
sobre as estatísticas oficiais para apresentar as mudanças demográficas ocorridas no Brasil entre 1960-1990, destacando os desequilíbrios regionais e as desigualdades sociais e afirmando que é por meio da implementação de políticas sociais para a família e da universalização dos serviços públicos e sociais, da proteção integral e da qualificação da mão de obra que o Brasil logrará diminuir as desigualdades sociais.

Este seminário foi cenário de vários encontros e convites. No ano seguinte fui convidada para o Encuentro de Antropología de la Universidad Nacional de Colombia ${ }^{57}$, em Bogotá, e para o Comitê de seleção de trabalhos do concurso 'La estructura familiar en el contexto cultural y socioeconómico de hoy', em Medellin ${ }^{58}$.

Ainda em 2005, como membro da Agence Universitaire de la Francophonie (AUF) fui estimulada a participar da reunião no âmbito do XXV Congrès International de la Population ${ }^{59}$, na cidade de Tours, França.

As participações em congressos e seminários nacionais e internacionais se desenrolavam ao mesmo tempo em que as pesquisas, e infelizmente os dois campos - Família \& Imagem - nem sempre se conectavam. Por exemplo, o segundo pós-doutorado realizado no Centre de Recherches sur les Liens Sociaux/Cerlis, Universidade Paris V-René Descartes, em 2006, foi uma retomada dos meus estudos comparativos França-Brasil e, novamente, sobre uma questão específica do processo de envelhecimento: a violência contra velhos.

A pesquisa 'Violência doméstica e violência institucional: a vitimização das pessoas envelhecidas' (2005-2010) visava preencher um vazio na grade de estudos sobre violência familiar. Muitas pesquisas sobre violência doméstica (praticada contra mulheres e crianças) e violência institucional, e raras sobre violência contra as pessoas de mais idade, inclusive as estatísticas oficiais sobre esse fenômeno eram precárias. Uma pesquisa comparativa ambiciosa que se propôs analisar os fatores socioeconômicos e culturais que influenciavam os comportamentos familiares violentos e as relações institucionais entre asilados e profissionais, nesses dois países ${ }^{60}$.

\footnotetext{
${ }^{57}$ Apresentei o trabalho Envejecimiento y innovación tecnológica: usos, representaciones y políticas.

${ }^{58}$ Proferi a conferência Políticas sociais e transformações familiares no Brasil.

${ }^{59}$ Inscrevi o trabalho Retour au travail après 60 ans au Brésil: le poids des transferts intergénérationnels privés.

${ }^{60}$ A pesquisa empregou três técnicas: quantitativa (análise das estatísticas produzidas por entidades oficiais - Delegacia do Idoso, Instituto de Segurança Pública no Rio, e por
} 
Na França, governantes, planejadores sociais e pesquisadores buscaram soluções para remediar o que chamam de "choque demográfico"61 - que provoca desequilíbrios diversos nas estruturas econômica e social da sociedade, e criaram políticas sociais para a velhice para além das pensões de aposentadoria e assistência médica gratuita que ofereciam diversos serviços para manter essa população em suas casas com mais autonomia (custo menor que subsidiar casas de repouso ou hospitais gerontológicos). No Brasil, a criação tardia do Estatuto do Idoso (2003) regulou direitos \& deveres e, principalmente, distribuiu as responsabilidades entre o Estado e a família no cuidado dos seus velhos. Contudo, falta fiscalização e vigilância do Estado para coibir o crescente aumento das violências familiares e institucionais contra os velhos, como apontam as estatísticas oficiais - agora atentas ao fenômeno - e as pesquisas sócio antropológicas. Estas revelam que o agressor é sempre um membro da família, em geral, um filho (a), genro/nora, neto (a). Os abusos, negligências e maus-tratos são mais recorrentes nas situações de coabitação entre gerações, pois ela implica em uma contribuição material e financeira, mas também um apoio logístico nas tarefas domésticas cotidianas e suporte moral e afetivo. Difícil manter a boa distância quando duas, três ou até quatro gerações vivem sob o mesmo teto. Existem tensões e conflitos que geram maus-tratos, abusos e abandono. (Peixoto 2009, 2011, 2014, 2015, 2016).

Esta pesquisa visava o reencontro dos dois campos de estudo que me são caros: envelhecimento \& imagem. O projeto propôs o uso de imagens (fotos e filmes) em todos os espaços do universo da pesquisa tanto nas entrevistas com os velhos vítimas de violência e no registro das denúncias nas Delegacias do Idoso quanto nas instituições gerontológicas do Rio e de Paris. Uma proposta pretenciosa, pois sabia que teria dificuldade para obter autorizações dado que as violências não são praticadas diante de câmeras, mas quem sabe (?) os relatos sim. Impossível, considerando que os principais agressores dos velhos são familiares, eles não querem se arriscar e expor seus agressores com medo de represálias. Quanto às instituições gerontológicas: o Hospital francês Charles Richet, no município de Villiersle-Bel (17km de Paris) não permitiu o registro de imagens, mas liberou as

Associações franceses de proteção aos idosos); qualitativa (observação direta e entrevistas), e audiovisual (registro fotográfico e fílmico).

${ }^{61}$ Crescimento elevado da população de mais de 60 anos provocado pela entrada da coorte dos baby boomers na faixa de 60 anos e pela redução da mortalidade nas idades avançadas (mais de 80 anos), gerando uma população aposentada bastante significativa. 
fotografias do seu banco de imagens e abriu as portas para a pesquisa ${ }^{62}$. No Rio, duas instituições (uma pública e uma privada) foram estudadas. A privada negou o registro de imagens, e após o início da pesquisa, interditou nossa entrada na clínica geriátrica. A saída foi trocar o crachá de estudante ${ }^{63}$ para o de visitante a um senhor residente interessado em relatar sua história e os maus tratos ali cometidos ${ }^{64}$. A instituição pública não só tudo autorizou como estimulou a divulgação dos resultados da pesquisa. À nova direção interessava mostrar as reformulações e a política de 'bem tratar' dirigida aos velhos asilados. Com os portões escancarados para pesquisa ali permanecemos ${ }^{65}$ uns quatro anos: entrevistas com residentes, agentes de saúde (médicos, enfermeiros \& cuidadores, psicólogos, geriatra, nutricionista), agentes administrativos (setores de cozinha, serviço social, recreação, etc.) e com a direção. $\mathrm{O}$ objetivo era conhecer a dinâmica da instituição asilar e o significado da institucionalização para agentes e residentes, pois "a vida em instituição é um microcosmo à parte, que modifica as regras sociais e induz a uma distorção das relações entre os indivíduos, implicando em uma restrição da liberdade das pessoas institucionalizadas, da sua possibilidade de escolha e da realização dos seus desejos". (Peixoto 2015: 95).

\footnotetext{
${ }^{62}$ Trabalho de campo realizado no pós-doutorado no Cerlis/Paris V, sob supervisão de François de Singly, que mediou o contato e a autorização para estudar este hospital gerontológico. $\mathrm{O}$ artigo 'Nova política francesa para o envelhecimento: le bien vieillir' (2008) analisa essas fotos institucionais.

${ }^{63}$ Trabalho de campo realizado em 2005 pelo então estudante PIBIC, hoje doutor, Michel Alcoforado.

${ }^{64}$ Os artigos 'Sobre a institucionalização da velhice e as condições de asilamento' (2011) e 'The body of the Other: to treat well or mistreat? Tensions and mistreatment at the end of life' (2014) analisam as instituições de asilamento. Dois outros artigos revelam e analisam as imagens do asilamento: 'As coisas não são como a gente quer... Viver e morrer em instituição asilar" (2015) e "Images et récits sur l'entrée en institution" (2016).

${ }^{65}$ A pesquisa foi realizada com bolsistas PIBIC que se revezaram ao longo dos anos. Barbara Copque, pesquisadora do Inarra, produziu as fotografias. Os estudantes e eu realizamos o filme IntraMuros (2015).
} 
Nos quartos, para duas ou quatro pessoas, o canto de cada um é o entorno da cama
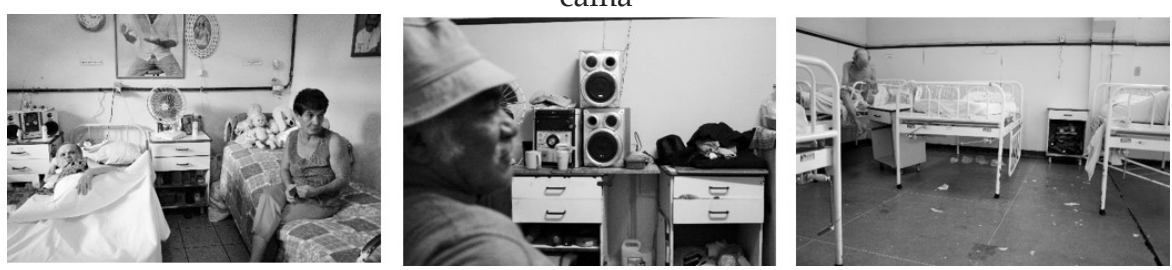

Espaços coletivos, de negociações de lugares e programas de TV
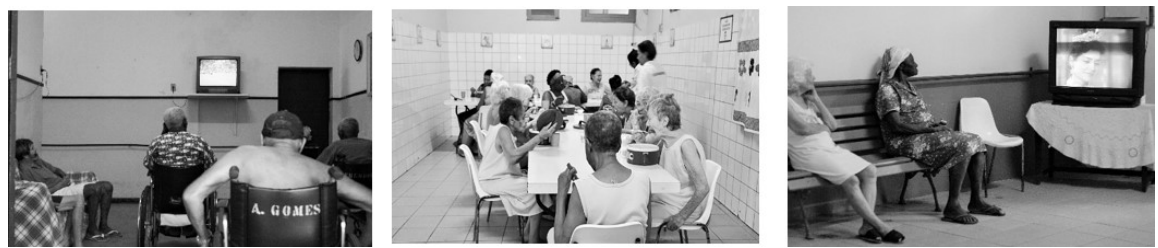

Fotos da antropóloga Barbara Copque

Ao longo da pesquisa percebi que uma conjunção de diversos fatores induz as pessoas a viverem em instituição pública: estado de saúde, relações familiares, conjunturas sociais, precariedade financeira, ausência de soluções alternativas entre outros. Rupturas para uns, nova etapa da vida para outros. De todo modo, a maioria dessas pessoas institucionalizadas vive em isolamento social e familiar. (Peixoto 2016). O filme IntraMuros pretendia mostrar essa violência institucional silenciosa que se revela em imagens por meio das expressões, gestos e emoções, possibilitando assim analisar o sentido da violência sofrida e suas representações. Entrevistas filmadas que revelariam a construção das diversas relações entre os atores da cena gerontológica. Mas, ao longo das filmagens percebi que seus relatos acentuavam as razões da institucionalização e o abandono familiar. Mudei o foco, deixando que contassem suas histórias, as razões do seu asilamento e a vivência no Abrigo, alguns desde a infância. Filme em www.inarra.com. br

Ainda no período do pós doc parisiense (2006) tive a oportunidade de visitar Paul Henley em Oxford, Inglaterra, onde realizei, com Sylvia Caiuby Novaes, uma entrevista filmada sobre o seu filme Faces in the crowd para a série 'Cinema e Antropologia: os bastidores do filme etnográfico'. Parte desta entrevista, sobre sua trajetória como antropólogo visual, foi publicada na Revista de Antropologia (2008). 
Paralelamente à esta pesquisa ${ }^{66}$ desenvolvi duas outras vinculadas à Extensão: 'A imagem na pesquisa social: percepção e memória nos filmes e fotografias etnográficas' (2007-2010); e 'A imagem nas ciências sociais: pesquisa \& extensão'67 (2011-2015). Estes foram períodos nos quais o Inarra desenvolvia várias atividades (produção de filmes, construção de acervo fílmico, realização de workshops e oficinas de imagem, seminários anuais Imagens \& Narrativas, entre outras) e a inserção de estudantes era fundamental para a realização de todas elas. O primeiro projeto foi desenvolvido no âmbito de duas linhas de pesquisa: a) produção e análise de imagens; b) memória \& imagens. Na verdade, ele retomava o espírito da pesquisa anterior 'Indivíduo e Memória Social' e alavancava a realização de outros filmes como Ilha Grande em outros tempos (2010) e o filme portrait Roberto DaMatta e seus carnavais, malandros e heróis (2013). Os estudantes vinculados ao Inarra participam na produção dos filmes e nas pesquisas em arquivos públicos que estes demandam, mas também, no aprendizado da organização de eventos.

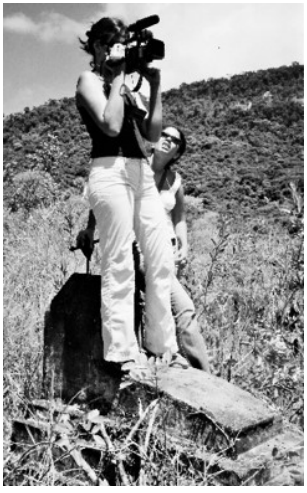

Oficina para as filmagens de Ilha Grande em outros tempos.

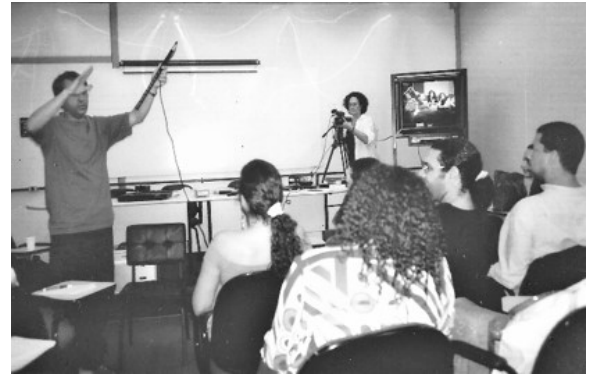

$1^{\text {a }}$ Oficina de imagens \& som do Inarra, 2001.

Ilha Grande em outros tempos. Um filme de memória que procura reconstruir um conjunto de elementos constitutivos da história prisional desse lugar: acontecimentos, indivíduos, ruínas. A ideia, aqui, era a de recuperar os fragmentos da memória de alguns daqueles que viveram no presídio da Ilha Grande, no Rio de Janeiro, e que ainda moram nesse lugar. O narrador principal dessa história é Seu Júlio, um ex-detento.

\footnotetext{
${ }^{66}$ Financiada pelo CNPq e pelo Prociência Uerj.

${ }^{67}$ Pesquisa foi financiada pelo programa EXTPESQ (2010) da Faperj.
} 


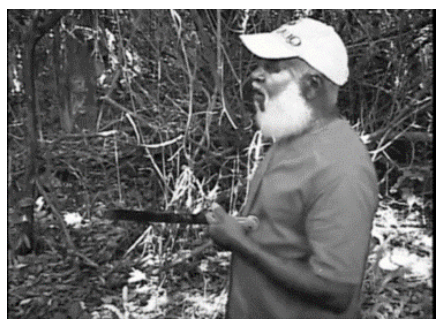

Seu Júlio nos conduziu por esses lugares de memória, contando as suas histórias sobre o cárcere.

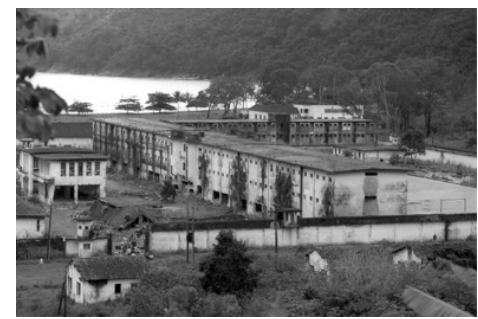

Sua fala é entrecortada pelos relatos de alguns daqueles que foram os seus algozes: os agentes penitenciários e os policiais. Os personagens do filme guardam objetos (facões e escudos improvisados pelos detentos, cartas e mapas, recortes de jornais e revistas, etc.) e, fundamentalmente, a memória de certos acontecimentos. São seus relatos, objetos e as ruínas do presídio que evocam esse momento da história carcerária do Rio de Janeiro. Mas não só. Os trechos de filmes encontrados no Arquivo Nacional da Cidade reforçam os testemunhos do tempo passado e apresentam, no tempo presente, a história em imagens. São pequenos filmes produzidos pela Agência Nacional para difusão pública, e que não somente alternam o enquadramento fixo das entrevistas filmadas como são imagens que testemunham essa realidade que emana do relato do narrador. (Peixoto 2012). Um filme realizado com meus orientandos. Em www.inarra.com.br

Como apontei acima, a realização do portrait Roberto DaMatta e seus carnavais, malandros e heróis ${ }^{68}$ era um projeto antigo com o colega e amigo Valter Sinder. A narrativa fílmica foi então construída nas conversas de DaMatta com seu interlocutor e amigo. Através delas ele esboça sua trajetória: desde a admissão ao Museu Nacional, e coordenador do Programa de PósGraduação/Museu Nacional (1972-1976) num dos períodos mais violentos da ditadura militar, até a chegada à PUC do Rio, onde hoje leciona. O projeto fílmico tinha uma dupla motivação: focalizar tanto na persona do antropólogo fluminense quanto nas reflexões publicadas em sua ampla obra, especialmente no livro clássico Carnavais, malandros e heróis (1979), que se tornou referência nas Ciências Humanas posto que é uma matização de nossos paradoxos, fraturas societárias e dinâmicas sociais.

${ }^{68} \mathrm{O}$ projeto fílmico recebeu financiamento da Faperj para a edição. 

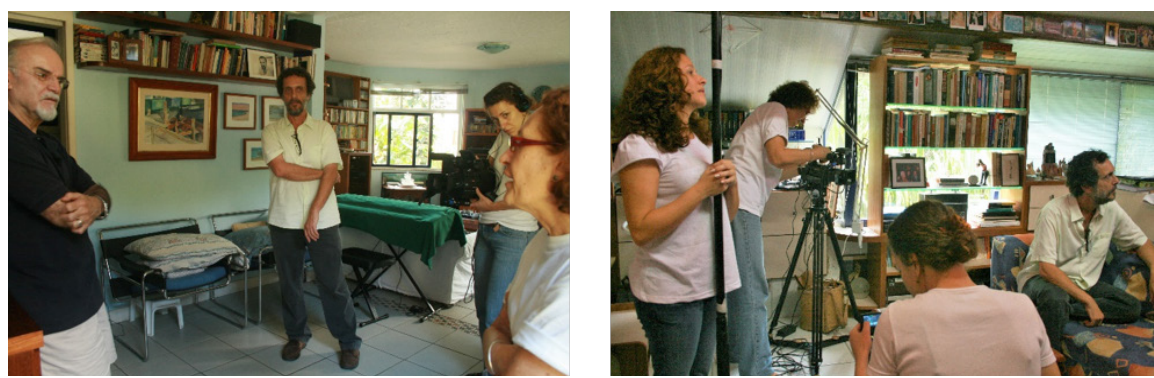

Roberto DaMatta, Valter Sinder e pesquisadores do Inarra: Gleice Mattos Luz, Mariana Leal e Barbara Copque

O filme procura mostrar a visão desse antropólogo iconoclasta sobre a sociedade brasileira caracterizada, por ele próprio, "de viés aristocrático, escravocrata e capitalista". Ele apresenta suas instigantes interpretações e corrosivos comentários sobre as situações brasileiras cotidianas, bem como revela os atos rotineiros e curiosidades como seu lado cantor, só revelado entre amigos. Em www.inarra.com.br

Estes projetos de pesquisa \& extensão visavam duas propostas que me são caras: a realização dos filmes portrait e a elaboração de VídeoAulas de antropologia visual para a divulgação no site do Inarra. A proposta dessas aulas virtuais objetiva ampliar os instrumentos de formação em antropologia visual, criando uma ferramenta de amplo acesso. Elas permitiam, ainda, analisar as diversas experiências de uso de imagens (fixas e em movimento) e suas situações particulares, pois acredito que ao aprofundar a reflexão teórico-metodológica da linguagem imagética criamos narrativas visuais que possibilitam uma dupla apresentação dos resultados da pesquisa: textos escritos e textos visuais.

As primeiras VídeoAulas foram realizadas para o curso à distância de Especialização em Gênero e Sexualidade, uma parceria com o Centro Latino Americano em Sexualidade e Direitos Humanos/CLAM, do Instituto de Medicina Social-UERJ. Produzimos oito VídeoAulas sobre os temas de Gênero, Sexualidade e orientação sexual, Direitos sexuais e reprodutivos, A construção do conhecimento em gênero e sexualidade.

Experiência e tanto para avaliar como realizaríamos as VídeoAulas de Antropologia Visual. 


\section{No meio do caminho}

2008-2013. Mesmo sem pertencer a um Programa de Pós-Graduação em Antropologia fui convidada pela Coordenação dessa área, na Capes, para compor a Comissão de elaboração do Roteiro de Avaliação da Produção Audiovisual (Qualis Imagem), juntamente com Sylvia Caiuby Novaes, Carmen Rial e Ana Luiza Rocha. Um trabalho que demandou muitas consultas, discussões e tensões até ser aprovado pelo CTC da Capes. Sem dúvida, uma vitória para a antropologia visual brasileira. Em 2010, também fiz parte da Comissão de Avaliação trienal da produção audiovisual de 2010-2013. Contudo, como não pertenço a um programa de antropologia, minha produção audiovisual e a dos membros do Inarra ainda não é avaliada como produção intelectual!

2008-2010. Em 2008 assumi a coordenação do Comitê de Antropologia Visual/CAV ${ }^{69}$, da Associação Brasileira de Antropologia. Tinha pela frente a organização de todas as atividades ligadas à antropologia visual e ao Concurso Pierre Verger na 27 $7^{\mathrm{a} B A}$ (Belém 2010). Sylvia Caiuby Novaes presidiu o Prêmio Pierre Verger de Vídeo Etnográfico e Ensaio Fotográfico. Novamente, nossa parceria entrava em cena.

No início dessa coordenação propus à Diretoria da ABA, com Claudia Turra-Magni, a produção de uma coleção composta de oito DVDs contendo vinte filmes etnográficos e quatorze ensaios fotográficos premiados pela ABA nos concursos Pierre Verger, entre os anos de 1996-2008. Esta coleção (2010) foi distribuída aos vencedores dos concursos promovidos pela ABA na $27^{a}$ RBA. Ao produzir esta coleção comemorativa dos doze anos do Prêmio Pierre Verger, me dei conta de que nunca tinha participado desse concurso, mesmo já tendo realizado dois filmes nesse período!

Em 2008 decidi investir em parcerias para além de nossas fronteiras para melhor conhecer a antropologia visual latinoamericana e divulgar a nossa. Assim, como era membro da Comissão de Imagem e Som da Anpocs (20072009), no $32^{\circ}$ Encontro desta associação (2008) organizei o Simpósio Ciências Sociais e Pesquisa com imagem na América Latina, convidando Carmen Guarini (Universidade de Buenos Aires), Gastón Carreño (Universidade de Humanismo Cristiano, Chile), Renato Athias (UFPE) e Sylvia Caiuby Novaes (USP). Nesse mesmo ano, retribuindo o convite, Carmen Guarini propôs uma parceria para coordenar o GT 'Investigação Audiovisual: de lo 'crudo' a lo 'cosido', no IX Congresso Argentino de Antropologia Social,

${ }^{69}$ Fui membro do CAV nos biênios 2007-2009 e 2010-2012. 
Posadas 2008. A partir daí coordenamos a mesa redonda Imagem e Pesquisa na América Latina, na VIII Reunião de Antropologia do Mercosul, Buenos Aires 2009; e a mesa redonda Antropología y Visualidades, na X Reunião de Antropologia do Mercosul, Córdoba 2013.

\section{Seguindo nessa rubrica}

2011. Ano de realização do primeiro Seminário Imagens \& Narrativas a nível internacional ${ }^{70}$. Convidamos Bill Nichols (EUA), Catarina Alves Costa (Portugal), Irène Jonas (França), Carmen Guarini (Argentina), Lourdes Roca (México), Gastón Carreño (Chile) e nossos parceiros brasileiros: Sylvia Caiuby Novaes e Paula Morgado (USP); Cornélia Eckert e Ana Luiza Rocha (UFRGS), Lisabete Coradini (UFRN), Marco Antônio Gonçalves e Eliska Altmann (UFRJ). Dois dias de intensos debates, exposições fotográficas e apresentação de filmes; um DVDRom produzido com artigos e ensaios fotográficos ${ }^{71}$; a realização da primeira VídeoAula de antropologia visual: O Cinema Documentário, por Bill Nichols. Três anos depois, com o apoio da organização do Seminário PPCIS 20 Anos, realizamos mais três VídeoAulas: Produção e Realização do Filme Etnográfico, por Catarina Alves Costa; A fotografia na Antropologia, por Sylvia Caiuby Novaes e Filmes de Memória, por Carmen Guarini. Dois anos depois produzimos O cinema moçambicano, por Lisabete Coradini e Teorias Antropológicas da Cultura e sua tradução imagética, por Marcos Albuquerque.

Já que o tema é VídeoAulas seguimos produzindo: Imagens do mundo rural, por José Roberto Novaes e A fotografia de João Roberto Ripper. Outras virão, inclusive Imagens da e sobre a Família que pretendo realizar. Disponíveis no site do Inarra.

Com recursos do projeto de Extensão financiado pela Faperj, acima referido, organizamos o Workshop Antropologia Visual: Introspecção,

\footnotetext{
${ }^{70}$ Os Seminários Imagens \& Narrativas começaram em 2008, tendo como objetivo promover debates sobre a antropologia audiovisual. No I Seminário realizamos um duo com a Universidade de Laval/Quebec, apresentando os trabalhos de Francine Saillant e Pedro Simonard e dos membros do Inarra. No II Seminário (2009) o debate foi com Marco Antônio Gonçalves e seu grupo NextImagem (PPGSA/UFRJ); no III Imagens \& Narrativas obtivemos financiamento das três agências de fomento para a realização do I Seminário Internacional. Continuamos nos anos seguintes: IV Inarra sobre Antropologia Visual Fluminense com participação da UENF, UFF, UFRJ, UFRRJ (2013); o V Inarra discutiu as questões de Direito Autoral de Imagens, Sons e Web (2015), um debate com especialistas da área do direito e da antropologia visual \& direito. Caminhamos para VI Imagens \& Narrativas.
}

${ }^{71}$ DVDRom Imagens e Narrativas, 2012. ISBN 978-85-86065-10-1. 
Exclusão e Isolamento (2011): 81 inscritos para 25 vagas! Gleice Mattos Luz (PNPD) e Barbara Copque (recém doutora) coordenaram o workshop sob minha supervisão.

Inspirada nessas experiências de cursos de curta duração, ao ser convidada pelo Departamento de Antropologia da UFRN para participar da Semana de Iniciação Científica, em 2011, propus a realização de um minicurso de Antropologia Visual. Retornei em 2014 e 2015 para realizar outros dois: Workshop I: Antropologia e Imagem e Workshop II: Imagens da Família.

2011 foi também o ano de lançamento dos livros Antropologia E Imagem. Narrativas diversas, contendo artigos dos meus orientandos de doutorado e mestrado; e Antropologia \& Imagem. Os bastidores do filme etnográfico que reuniu as entrevistas completas realizadas na série Cinema \& Antropologia e resenhas de cada filme elaboradas por estudantes dos cursos de antropologia visual (graduação e pós graduação). Um projeto idealizado há tempos: publicar artigos e resenhas de estudantes interessados em antropologia visual, sedimentando mais ainda esse campo.

\section{De volta à família, à pesquisa e à sociologia!}

2012-2014. Fui convidada por duas amigas sociólogas para participar da pesquisa ‘Onde é o futuro? Lá ou aqui? Ou aqui e lá? Uma investigação sobre a nova classe média brasileira'72. O projeto de Helena Bomeny (PPCIS), Celi Scalon (IFCS-UFRJ) e Letícia Veloso (UFF) "tinha como principal objetivo compreender em que medida a ideia de futuro, tida sociologicamente como fundamental na constituição das classes médias "tradicionais" desde a década de 1950, se mantém presente nas auto definições, práticas, e expectativas da chamada 'nova classe média brasileira'. A proposta era trabalhar com "três eixos explicativos principais: (1) a noção de futuro em relação à categoria sociológica de 'classe média', num sentido amplo, (2) os modos como projetos de futuro participam (ou não) de planejamentos e trajetórias de grupos definidos como pertencentes à 'nova classe média', e (3) as percepções e auto identificações desses mesmos sujeitos como sendo ou não 'classe média', bem como as práticas e experiências acompanham e definem tais percepções, constituindo os cotidianos desses sujeitos e abrindo caminho para produções de futuros" (Projeto, 2012). Muitas reuniões para discutir amostragem e questionário para a produção do survey. Outras

${ }^{72}$ Financiada pela Faperj. 
tantas para decidir o universo da pesquisa qualitativa e a elaboração do roteiro de entrevistas, que foram realizadas na Zona Sul do Rio - e volto a estudar a relação 'morro e asfalto'. Eu conhecia bem os Morros da Babilônia e do Chapéu Mangueira, meus vizinhos, e para lá fomos. Nosso lugar de encontro era o Bar do David - um botequim já conhecido do 'povo do asfalto' por seus quitutes - que logo se tornou um filme portrait, de curtíssima metragem! Em www.inarra.com.br

A formação em antropologia nunca me afastou da sociologia. A maioria dos meus temas de pesquisa se inspirou em pesquisas demográficas porque acredito que elas informam sobre as transformações da sociedade e 'dão o alarme' para as questões sociais prementes, sobretudo, aquelas do meu campo de interesse. Assim, as estatísticas sobre o aumento da expectativa de vida \& crescimento da população de mais de 60 anos; o crescimento dos espaços de sociabilidade dessa população \& das universidades de terceira idade; a queda no valor das aposentadorias \& o retorno dos velhos ao trabalho; o crescimento da taxa de desemprego dos jovens \& aumento do número de avós que cuidam dos netos e da coabitação intergeracional; aumento da coabitação intergeracional \& a violência contra velhos, me instigaram a estudar essas questões. Mas, não só. Meus principais interlocutores internacionais no campo da família pertencem às sociologias francesa e portuguesa e, aqui no Brasil, Alda Britto da Motta (UFBA) sempre foi interlocutora, parceira e amiga. Talvez tenha sido por esta razão que fui convidada pela diretoria da Sociedade Brasileira de Sociologia a prestar homenagem à Alda na abertura do XVI Congresso Brasileiro de Sociologia (2013) e a compor a Comissão da Imagem desse evento.

\section{Retorno às imagens}

Nos anos 2010 surge um debate sobre autoria nas ciências humanas diante dos parâmetros quantitativistas do $\mathrm{CNPq} \&$ Capes, que privilegiam as ciências exatas e seu modelo de produção fundamentalmente coletiva. Passamos, então, a considerar timidamente a coautoria nas publicações de orientandos, posto que a orientação não deixa de ser um trabalho de coautoria (desde a indicação bibliográfica até as correções ortográficas!). Só faltava coragem para propor aos orientandos uma coautoria, principalmente, àqueles que demandavam um trabalho mais consistente de revisão. A surpresa foi receber o convite de Acácia Dias, primeira orientanda de doutorado, para assinar um artigo fruto de sua tese, defendida em 2005 
(publicado em 2009). Alguns anos e muitas orientações depois, Aline Gama de Almeida, me propôs uma coautoria nos artigos inspirados da tese por mim orientada (2014), um deles para a Revista de Antropologia. Mas, ainda falta coragem para propor a coautoria, nestas duas experiências o convite veio da parte delas.

2010-2017. Elaborei o primeiro projeto para o CNPq e para o Prociência totalmente focalizado em uma questão que me aflige há anos: que antropologia visual é essa que fazemos no Brasil? ${ }^{73}$ Havia decidido encerrar os estudos sobre as relações familiares e processos sociais de envelhecimento para evitar me tornar sujeito das minhas próprias pesquisas! O objetivo principal deste projeto - Antropologia \& Imagens: o que há de particular na antropologia visual brasileira? - era analisar os usos de imagens na antropologia e as bases de reprodução desse conhecimento no ensino e na pesquisa. Tarefa árdua, uma vez que a produção brasileira de textos escritos e textos audiovisuais nesse campo é extensa! Impossível analisar a produção de todos os centros brasileiros uma vez que, hoje, cerca de trinta grupos de pesquisa, núcleos \& laboratórios estão inscritos na página do Comitê de Antropologia Visual, da ABA. Na tentativa de construir um breve panorama da nossa antropologia audiovisual selecionei dois grupos coordenados pela que considero a 'primeira geração' de antropólogas visuais e dois da 'segunda geração'74. Elaborei genealogias, nos parâmetros da antropologia clássica, para visualizar a trajetória dos doutores formados pela primeira geração dada a curiosidade em descobrir se já estão inseridos institucionalmente. Para entender como esse conhecimento é transmitido analisei a formação dos coordenadores dos centros estudados, os programas dos cursos de pós-graduação e bibliografias, as oficinas práticas, a dinâmica de atividades. E, por fim, os trabalhos de conclusão de doutorado de seus orientandos. À indagação inicial - será que produzimos narrativas metodológicas próprias? - diria que temos uma antropologia visual híbrida, pois ela ainda muito se inspira dos ares europeus e americanos na tentativa de construir uma escola própria ${ }^{75}$. Uma pesquisa sobre a antropologia visual brasileira, sem imagens!

\footnotetext{
${ }^{73}$ Este projeto foi prorrogado por mais um triênio, nas duas agências.

${ }^{74}$ Lisa \& Gravi (USP) e Navisual \& Biev (UFRGS), cujas coordenadoras pertencem à primeira geração e Navis (UFRN) e Iris (UNB), da segunda geração. Como pertenço à primeira geração, o Inarra foi incorporado à análise.

${ }^{75}$ Artigo 'Antropologia \& Imagens: o que há de particular na antropologia audiovisual brasileira?'. Cadernos de Arte e Antropologia 8(1): 5-20, 2019.
} 
2015. Ano de lançamento do livro Etnografias Visuais. Análises Contemporâneas ${ }^{76}$, uma coletânea que expressa parcerias \& amizades construídas ao longo dos anos com algumas colegas da primeira geração de antropólogas visuais - Sylvia Caiuby Novaes, Catarina Alves Costa, Carmen Guarini, e com outros da segunda geração, principalmente, os meus/minhas ex-orientandos Barbara Copque, Mariana Leal, Aline Gama, Gleice Mattos Luz e Edney C. de Souza.

A antropologia nos ensina que as parcerias são construídas através da reciprocidade. Essa lição atravessa a nossa vida acadêmica, inclusive nos convites para participação em eventos e bancas de conclusão de curso. Como em 2013 C. Guarini e eu convidamos Antonio Zirión (Universidade Autônoma do México) para participar da mesa redonda Antropología y Visualidades (X RAM, Córdoba), em 2015 ele retribuiu nos convidando para participar do Foro de Cine Etnográfico Latinoamericano do IV Congresso Latinoamericano de Antropologia (ALA), na cidade do México. Fiz também parte do Comité de Selección de la Muestra de Cine Documental desse evento. Dom e contra dom como nos ensinou Marcel Mauss.

Em 2016 a parceria foi com as colegas-amigas Myriam Lins de Barros e Andrea Moraes Alves na organização do dossiê 'Ageing and Anthropology' (Vibrant 13/1), composto de artigos de gerontólogas tradicionais e de jovens pesquisadores. Neste dossiê reuni, novamente, meus dois diletos campos de pesquisa publicando o ensaio fotográfico 'Images et récits sur l'entrée em institution', que veio somar ao anterior 'As coisas não são como a gente quer... Viver e morrer em instituição asilar', publicado na coletânea organizada por Sylvia Caiuby Novaes (2016).

Assim, nessa trajetória, construí uma rede de relacionamentos, cujos diálogos \& interlocuções foram determinantes na minha vida acadêmica, e muitos deles se consolidaram em amizades que me são muito caras. Impossível retratar essa galeria de parceirxs e amigxs.

\section{Página final do Memoriale}

Voltando à primeira página vejo que meus interesses de pesquisa sempre estiveram inseridos nos debates sobre as desigualdades sociais e, desde o doutoramento, mais focalizados nos processos diferenciados de envelhecimento \& políticas sociais, determinados ao mesmo tempo pelas

${ }^{76}$ Nessa coletânea publiquei o artigo 'Filme etnográfico: as escolhas do fabricante de imagens'. 
distintas formas de expressão dos relacionamentos familiares. Percebo, principalmente, por meio deste memorial estruturado em cronologia, que essas reflexões sobre envelhecimento \& relações intergeracionais foram acionadas pelas transformações da sociedade brasileira e suas projeções nos comportamentos familiares. Apenas segui esse fio condutor.

Quanto ao interesse pelo uso da imagem vejo agora que, desde sempre, ele esteve presente na minha trajetória de pesquisadora. Revendo as fotografias entendo sua origem: meu pai sempre fotografou nossa vida familiar! Começou com as fotos analógicas em preto \& branco e registrou sem parar, com o surgimento do slide, todos os encontros de família e as viagens que fez com minha mãe (encontrei inúmeras caixas de slides guardadas em sua casa). Só deixou de fotografar quando surgiram as câmeras digitais!

Dele herdei a sua câmera Yashica Electro 35 e, quando fiz o doutorado em Paris, ele me presenteou com uma câmera Super8 Cannon 814XL-S com a qual realizei os ensaios fílmicos para o DEA da escola de Rouch (Paris X-Nanterre), e meu primeiro filme etnográfico para a conclusão desse curso: Point de reencontre aux Battignolles. Parênteses. Jean Rouch estava na minha banca do DEA e, já aposentado, não gostou da imagem da velhice que viu projetada na tela: criticou a linguagem porque os enquadramentos e ângulos acentuavam as marcas e o ritmo do envelhecimento, mas elogiou a construção narrativa. Ufa!

Impossível finalizar esse memorial sem apresentar as minhas duas primeiras câmeras de registro de imagens (fotográfica e Super8), e meu primeiro computador Macintosh Classic com o qual redigi a tese de doutorado, os artigos que seguiram e meu primeiro currículo acadêmico!

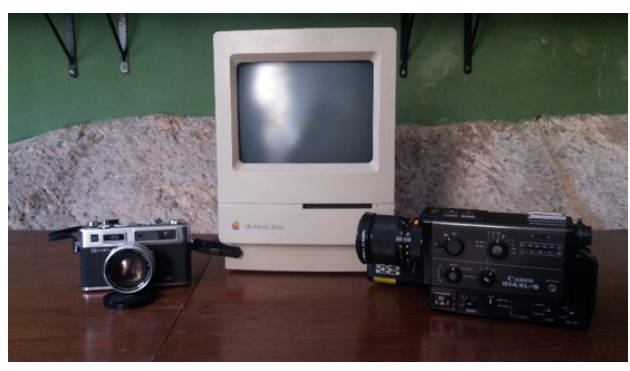




\section{Bibliografia citada no memorial}

ATTIAS-DONFUT, Claudine \& SEGALEN Martine.

(1998). Grands-parents: la famille à travers les générations. Paris: Odile Jacob, 1998.

FERREIRA DOS SANTOS, Carlos Nelson.

(1981). Movimentos urbanos no Rio de Janeiro. Rio de Janeiro: Zahar.

FERREIRA DOS SANTOS, Carlos Nelson e VOGEL, Arno.

(1980). Quando a rua vira casa: A apropriação de espaços de uso coletivo em um centro de bairro. Rio de janeiro: IBAM.

FOUCAULT, Michel.

(1977). Vigiar e punir. Petrópolis: Vozes.

(1979). A microfisica do poder. Rio de Janeiro: Graal.

GOFFMAN, Erving.

(1973). La mise-en-scène de la vie quotidienne. Tomos I e II, Paris: Minuit.

HALBWACHS, Maurice.

(1968). La mémoire collective. Paris : PUF.

LEEDS, Anthony e LEEDS, Elizabeth.

(1978). A sociologia do Brasil urbano. Rio de Janeiro: Zahar.

LE GOFF, Jacques.

(2003). História e Memória. Campinas: ed. UNICAMP.

LINS DE BARROS, Myriam.

(1997). Autoridade e Afeto: avós e netos na família brasileira. Rio de Janeiro: Vozes.

PERLMAN, Janice.

(1977). 0 mito da marginalidade urbana. São Paulo: Paz e Terra.

POLANYI, Karl.

(1947a). Our obsolet market mentality. Commentary 13(3).

(1947b). El sistema económico como proceso institucionalizado. In GODELIER,
M. Antropología y Economía. Barcelona: Anagrama.

RAMOS E.

(2002). Rester enfant, devenir adulte. La cohabitation des étudiants chez leurs parents. Paris: L'Harmattan.

SINGLY, François.

(2000). 0 nascimento do 'indivíduo' individualizado e seus efeitos na vida conjugal e familiar. Prefácio. In PEIXOTO C.; SINGLY F.; CICCHELLI V. Família e Individualização. Rio de Janeiro: ed. FGV, pp.13-19. Tradução C. Peixoto

VALLADARES, Lícia

(1978). Passa-se uma casa. Rio de Janeiro: Zahar.

. (org.).

(1980). Habitação em questão. Rio de Janeiro: Zahar.

STIEGLER, Bernd.

(2009). Quand une vue d'arbres est presque un crime: Rodtchenko, Vertov, Kalatozov. Etudes Photographiques 23: 6-20.

\section{Bibliografia pessoal}

\section{Artigos e capítulos de livro}

PEIXOTO, Clarice.

(1992). Anthropologie visuelle au Brésil. Journal des Anthropologues 47/48 : 47-58.

(1992). Les religions afro-brésiliennes: filmographie. Cahiers d'Études Africaines XXXII: 125-126.

(1994). Une question d'étrangeté: le va-etvient entre l'exotique et le familier. Cahiers du Brésil Contemporain 25/26 : 109-126. 
(1994). Les personnes âgées dans l'espace public et le désir de plaire. Gérontologie et Société 69: 139-149.

(1995). France-Brésil: modes d'appellation dans les lieux publics. Ethnologie Française XXV: 559-568.

(1995). Kaléidoscope d'images: les contraintes et les contributions de l'audiovisuel à l'analyse des relations sociales. Journal des Anthropologues 59: 117-125.

(1995). A sociabilidade dos idosos cariocas e parisienses: em busca de estratégias para preencher o vazio da inatividade. Revista Brasileira de Ciências Sociais 27:138-149.

(1995). Antropologia Visual no Brasil. Cadernos de Antropologia e Imagem 1:75-80. Tradução atualizada do artigo publicado na França.

(1995). 0 jogo dos espelhos e das identidades: as observações comparada e compartilhada. Horizontes Antropológicos 2: 69-84.

(1996). Do diário de campo à câmera na mão ou de como virar antropólogo cineasta. Revista de Antropologia 39: 255-273.

(1997). De volta às aulas ou de como ser estudante aos 60 anos. In VERAS, Renato (org). Terceira idade: desafios para o próximo milênio. Rio de Janeiro: Relume Dumará, pp. 41-74.

(1997). Histórias de mais de 60 anos. Estudos Feministas 5(1): 148-158.

(1997). Os jardins ao longo dos séculos: notas sobre as ideologias paisagísticas na França e no Brasil. Cadernos de Antropologia e Imagem 4: 57-70.
(1998). Caleidoscópio de imagens: o uso do vídeo e sua contribuição à análise das relações sociais. In BIANCO, Bela \& MOREIRA LEITE, Miriam. Desafios da imagem: iconografia, fotografia e vídeo nas ciências sociais. São Paulo: Papirus, pp. 213-224.

(1998). Entre o estigma e a compaixão e os termos classificatórios: velho, velhote, idoso, terceira idade. In LINS DE BARROS, Myriam (org). Velhice ou Terceira Idade? Rio de Janeiro: ed. FGV, pp. 69-84.

(1999). A imagem da velhice nas telas do cinema documentário. Cadernos Pagu 13: 357-369.

(1999). 'Les Archives de la Planète': imagens da coleção Albert Kahn. Cadernos de Antropologia e Imagem 8: 117-132.

(1999). Antropologia e filme etnográfico: um travelling no cenário literário da antropologia visual. BIB. Revista Brasileira de Informação Bibliográfica C. Sociais 48:91-115.

PEIXOTO, Clarice \& MORGADO, Paula.

(2000). Os bastidores dos festivais internacionais de filmes documentários. Cadernos de Antropologia e Imagem 11: 71-88.

PEIXOTO, Clarice.

(2000). Histórias de mulheres, de envelhecimento e sexualidade. In DEBERT, Guita \& GOLDSTEIN, Donna. Políticas do corpo e o curso da vida. São Paulo: Sumaré, pp. 293299.

(2000). Avós e netos na França e no Brasil: a individualização das transmissões afetivas e materiais. In PEIXOTO C., SINGLY F., CICCHELLI V. (org.). Família e Individualização. Rio de Janeiro: ed. FGV, pp. 95-111.

(2001). Les préférences familiales. L'individualisation de l'affection dans 
les générations âgées. In SINGLY, François (org). Être soi d'un âge à l'autre. Paris: L’Harmattan, T.1: 193-207.

(2001). Memória em Imagens: uma evocação do passado. In KOURY, Mauro. Imagem $e$ memória. Ensaios em Antropologia Visual. Rio de Janeiro: GAramond, pp. 173-186.

PEIXOTO, Clarice \& SZTUTMAN, Renato. (2001). Parceria e comunicação por meio de imagens: entrevista com Dominique Tilkin Gallois. Cadernos de Antropologia e Imagem 12: 139-140.

PEIX0T0, Clarice \& CLAVAIROLLE, Françoise.

(2001). Politique de la vieillesse dans une municipalité de l'Essonne et développement technologique. Cahiers de Recherches de la Mire 10/11: 143-148.

PEIXOTO, Clarice.

(2002). Aconteceu em Göttingen... Revista Studium 9.

PEIXOTO, Clarice \& BOZON, Michel.

(2003). Os Na da China, uma sociedade sem casamento nem paternidade: sobre livro e vídeo de Cai Hua. Cadernos de Antropologia e Imagem 17(2): 173-183.

PEIXOTO, Clarice.

(2004). Trabalhando sempre: aposentados que se reinserem no mercado de trabalho e apoio familiar, 2004. In PEIXOTO C. (org.). Família \& Envelhecimento. Rio de Janeiro: ed. FGV, pp. 57-84.

(2004). Jean Rouch:subvertendo fronteiras. In CAIUBY NOVAES, Sylvia et al (org). Escrituras da Imagem. São Paulo: EDUSP, pp. 199-205.

(2005). Retour au travail après 60 ans et cohabitation entre les générations: deux aspects de la solidarité familiale chez les Brésiliens. In VIGNIKIN, Kokou \& VIMARD, Patrice. Familles au Nord, familles au Sud. Louvain-la-Neuve: Academia Bruylant, pp.507-526.
(2005). Solidariedade familiar intergeracional. In ARAÚJ0, Clara \& SCALON, Celi. Gênero, Família e Trabalho no Brasil. Rio de Janeiro: ed. FGV, pp. 225-240.

(2005). Tecnologias e envelhecimento na França: ofertas, opções e interações. In BRITTO DA MOTTA, Alda et al. (org). Reparando a falta: dinâmica de gênero em perspectiva geracional. Salvador : Coleção Bahianas, pp. 187-199.

(2006). Politique de la vieillesse et développement technologique en France. Vibrant 3(2). 67-88.

(2006). Videoteca da Mulher. Mas Afinal, vídeos para quem? In MONTEIRO Simone \& VARGAS, Eliane. Educação, Comunicação e Tecnologia Educacional: interfaces com o campo da saúde. Rio de Janeiro: Fiocruz, pp. 113-127.

(2007). Les parents âgés:de la solidarité à la maltraitance. Informations Sociales 144:4854.

(2007). Brasil: transiciones demográficas y urbanas, transformaciones familiares y políticas sociales. In PUYANA Y \& RAMÍREZ M-I. Familias, cambios y estrategias. Bogotá: CIES/UNC, pp. 79-88.

(2007). Familia y envejecimiento en Brasil: sobre las relaciones intergeneracionales. In PUYANA Y \& RAMÍREZ M-I. Familias, cambios y estrategias. Bogotá: CIES/UNC, pp. 89-102.

PEIXOTO, Clarice e MATTOS LUZ, Gleice.

(2007). De uma morada à outra: processos de re-coabitação entre as gerações. Cadernos Pagu 29: 171-191.

PEIXOTO, Clarice e SZTUTMAN, Renato.

(2007). Pasantía y comunicación por medio de imágenes: entrevista con Dominique Tilkin 
Gallois. Revista Chilena de Antropología Visual 10.

PEIXOTO, Clarice.

(2008). Family Film: From Family Registries to Historical Artifacts. Visual Anthropology 21(2): 112-124.

(2008). Nova política francesa para o envelhecimento: 'le bien vieillir'. Ciência \& Trópico 32(2): 163-182. Fundação Joaquim Nabuco.

PEIXOTO, Clarice e CAIUBY NOVAES, Sylvia. (2008). Paul Henley, o antropólogo-cineasta que faz cineastas. Revista de Antropologia 51: 765-785.

PEIXOTO C., FERREIRA J.C., LEAL M., LIMA A., MARTINS I., MENDES M., RIBEIRO E., SANTOS K., TAVARES P.G.

(2009). Trajectoires des jeunes de Rio de Janeiro. Diversités et enjeux sociaux? In AMADOU SANI M., KLISSOU P., MARCOUX R. TABUTIN D. (orgs.). Villes du Sud. Dynamiques, diversités et enjeux démographiques et sociaux. Paris: Éd. des Archives Contemporaines-AUF, pp. 311-326.

PEIXOTO, Clarice \& DIAS, Acácia.

(2009). Jovens baianos: conjugalidades, separações e relações familiares. In HEILBORN, Maria Luiza et al. (org.). Sexualidade, Reprodução e Saúde. Rio de Janeiro: ed. FGV, pp.123-144.

PEIXOTO, Clarice.

(2009). Relações intergeracionais: da solidariedade aos maus-tratos. Interseções. Revista de estudos interdisciplinares 11(2): 407-421.

et al.

(2009). Trajetórias juvenis: processos de autonomização de jovens cariocas e desigualdades sociais. Anuário Antropológico 1, junho 2010: 175-198.

(2011). Sobre a institucionalização da velhice e as condições de asilamento. In GOLDENBERG, Mirian. Corpo, Envelhecimento e Felicidade.
Rio de Janeiro: Civilização Brasileira, pp. 341356.

(2011). Filme (vídeo) de família: das imagens familiares ao registro histórico. In PEIXOTO, Clarice (org). Antropologia \& Imagem. Narrativas diversas. Rio de Janeiro: Faperj/ Garamond, pp. 11-25.

(2012). The Photo in the Film Public and private collections in video-portrait. Vibrant 9(2): 344-360.

(2014). The body of the 0ther: to treat well or mistreat? Tensions and mistreatment at the end of life. Vibrant 11(2): 184-203.

(2014). Antropologia visual: como transmitir esse conhecimento? In FERRAZ, Ana Lúcia \& MENDONÇA, João Martinho (org.). Antropologia Visual: perspectivas de ensino e pesquisa. Brasília- DF: ABA.

ALMEIDA, Aline e PEIXOTO, Clarice.

(2014). Imagens de guerra: uma leitura sociológica do fotojornalismo. Interseções. Revista de Estudos Interdisciplinares 16(2):245-264.

PEIXOTO, Clarice.

(2015). 'As coisas não são como a gente quer...' Viver e morrer em instituição asilar. In CAIUBY NOVAES, Sylvia (org). Entre arte e ciência. A fotografia na antropologia. São Paulo: Edusp, pp.93-108.

(2015). Filme etnográfico: as escolhas do fabricante de imagens. In PEIXOTO, Clarice \& COPQUE, Barbara (org). (2015). Etnografias Visuais. Análises Contemporâneas. Rio de Janeiro: Garamond.

(2016). Images et récits sur l'entrée en institution. Vibrant 13(1): 176-185. 
(2017). La domination masculine (verbete). In CATANI A. et al. Vocabulário Bourdieu. Belo Horizonte: Autêntica.

(2019). Antropologia \& Imagens: o que há de particular na antropologia audiovisual brasileira?. Cadernos de Arte e Antropologia 8(1): 5-20.

\section{Livros e organização de livros}

PEIXOTO, Clarice.

(2000). Envelhecimento e Imagem. As fronteiras entre Paris e Rio de Janeiro. São Paulo: Annablume.

PEIXOTO, Clarice; SINGLY, François e CICCHELLI, Vincenzo (orgs.).

(2000). Família e Individualização. Rio de Janeiro: ed. FGV.

PEIXOTO, Clarice (org).

(2004). Família e Envelhecimento. Rio de Janeiro: ed. FGV.

PEIXOTO, Clarice e CLAVAIROLLE, Françoise. (2005). Envelhecimento, políticas sociais e novas tecnologias. Rio de Janeiro: ed. FGV.

HEILBORN M-L., DUARTE L-F., PEIXOTO C., LINS DE BARROS M. (orgs.).

(2005). Sexualidade, Família e Ethos Religioso. Rio de Janeiro: Garamond.

DUARTE L-F., HEILBORN M-L., LINS DE BARROS M., PEIXOTO C. (orgs.). (2005).

PEIXOTO, Clarice (org).

(2011). Antropologia \& Imagem. Narrativas diversas. Rio de Janeiro: Faperj/ Garamond.

PEIXOTO, Clarice (org).

(2011). Antropologia \& Imagem. 0s bastidores do filme etnográfico. Rio de Janeiro: FaperjGaramond.

PEIXOTO, Clarice et al. (orgs).

(2012). Imagens e Narrativas. DVDRom. ISBN 978-85-86065-10-1.

PEIXOTO C., COPQUE B., MATTOS LUZ G. (orgs).
(2013). Famílias em Imagens. Rio de Janeiro: ed. FGV.

PEIXOTO, Clarice e COPQUE, Barbara (orgs).

(2015). Etnografias Visuais. Análises Contemporâneas. Rio de Janeiro: Garamond.

\section{Filmografia pessoal.}

In www.inarra.com.br

1992. Point de rencontre aux Batignolles, $15 \mathrm{~min}$, Super 8, França. (não disponível)

1993. À la reencontre du petit paradis (Em busca do pequeno paraíso), $20 \mathrm{~min}$, França.

2004. Bebela e a revolução gaúcha de 1923, $40 \mathrm{~min}$, Brasil.

2008. Etienne Samain, de um caminho a outro. Direção: C. Peixoto et al., 35min, Brasil.

2009. Gisèle Omindarewá, 70min., Brasil.

2010. Ilha Grande em outros tempos. Direção: C. Peixoto et al., 40min, Brasil.

2013. Roberto DaMatta e seus carnavais, malandros e heróis. Direção: C. Peixoto, M. Leal Rodrigues, B. Copque, 40min., Brasil.

2013. Bar do David, 3min, Brasil.

2015. IntraMuros, 36min., Brasil.

Catálogo de Cinema \& Antropologia. Os bastidores do filme etnográfico 2001-2005.

Em www.inarra.com.br

1. Os segredos da mata, Dominique Gallois, 28 min., 1998, Br.

2. Arca dos Zo'é, de Dominique Gallois e Vincent Carelli, 22 min., 1993, Br.

3. Os velhos na propaganda, Guita G. Debert, 18 min., 1998, Br.

4. Em busca do pequeno paraíso, Clarice Ehlers Peixoto, 19 min., 1993, Br.

5. Jean Rouch, subvertendo fronteiras, Ana Lucia Ferraz, Edgar Teodoro da Cunha, 
PaulaMorgado, Renato Sztutman, 41 min., 2000, Br.

6. Habitantes de rua, Claudia Turra Magni, 52 min., Br.

7. Meninas Mulheres, José Roberto Novaes, 23 min., 1999, Br.

8. Sonhos de criança, José Roberto Novaes, 17 min., 1994, Br.

9. Conversas de crianças, José Roberto Novaes e Paulo Pestana, 22 min., 1998, Br.

10. Meninos da roça, José Roberto Novaes, 18 min., 1994, Br.

11. Pomba Gira, Maja Vargas e Patrícia Guimarães, 13 min., 1998, Br.

12. E por aqui vou ficando..., Pedro Simonard, 20 min., 1993, Br.

13. 0 Arco e a Lira, de Priscilla Ermel, 18 min, 2001, Br.

14. Saudade, Bela Feldman-Bianco, 57 min., 1991, Br.

15. A Palavra que me leva além: estórias do Hip Hop Carioca, de Emilio Domingos, Bianca Brandão e Luisa Pitanga, 30min, 1999, Br.

16. Mauss, segundo suas alunas, de Carmem Silvia Rial e Miriam Grossi, 45min, 2002, Br. OK

17. O resto é o dia a dia, de Andréa Barbosa, 11 min, 2002, Br.

18. Microfone, senhora, de Rose Satiko Hikiji, $16 \mathrm{~min}, 2003, \mathrm{Br}$.

19. Ponteio, de Francisco Simões Paes e Camilo Morano Vannuchi, 54min, 2001, Br.

20. Mulheres de luta, de Patrícia Gouveia, $17 \mathrm{~min}, 1998, \mathrm{Br}$.

21. Surumi: as metamorfoses da Virgem, Virginie de Véricourt, 36 min., 1998, Fr.

22. Maria Lacerda de Moura - trajetória de uma rebelde, de Miriam Moreira Leite e Ana Lucia Ferraz, 33 min., 2003, Br.

23. Guariba - 1984, de José Roberto Novaes, 11 min., 2002, Br.
24. A memória em nossas mãos, de José Roberto Novaes, 16 min., 2002, Br.

25. Família Tetra, Emilio Domingos, Fabiene Gama, Lucia Albuquerque e Maria de Andrade, 50 min, 2003, Br.

26. Vulgo Sacopã, André Reyes Novaes e Pedro Urano, 26min, 2002

27. Bebela e a revolução gaúcha de 1923, de Clarice E. Peixoto, 40 min, 2004, Br.

28. Jon Joqu-Ne. Territórios da loucura, Denise Dias Barros \& Gianni Puzzo, 22min, 2000, Br.

29. A morada das águas, de Ana Luiza C. Rocha e Rafael Devos, 25 min, 2003, Br.

30. Ciranda, cirandinha, Claudia Fonseca, 27 min., 1994, Br.

31. Santos Dumont, de Henrique Lins de Barros, 60 min., 1999, Br.

32. Senhora Aparecida, de Catarina Alves Costa, 55 min., 1994, Portugal.

33. 0 arquiteto e a Cidade Velha, de Catarina Alves Costa, 72 min., 2003, Portugal.

34. Regresso à terra, de Catarina Alves Costa, 35 min., 1993, Portugal.

35. Um casamento no Paquistão, de Sylvia Caiuby Novaes, $46 \mathrm{~min}, 1994$.

36. Faces in the crowd, de Paul Henley, 40min, 1994.

37. Os seres da mata e sua vida como pessoas, de Rafael Devos, 30min, 2010

38. As Sementes, de Beto Novaes, 30min, 2015

39. Nuvens de Veneno, de Beto Novaes, $23 \mathrm{~min}$, 2015 


\section{Memorial $^{1}$}

Myrian Sepúlveda dos Santos

\section{Introdução: a memória como objeto}

Pode ser que a continuidade da tradição seja somente uma
aparência. Mas se este é o caso, então é precisamente a
persistência desta aparência da permanência que estabelece
continuidade. Walter Benjamin

Para quem fez da memória seu objeto de estudo, a escrita de um memorial se apresenta como um grande desafio, pois quanto mais estudamos os processos de rememoração, mais cientes ficamos de que há falhas, bloqueios, interpretações variadas e conflituosas em lembranças do passado. Além do mais, a memória é tanto forma de pensamento como produto deste último.

A partir dos estudos do sociólogo Maurice Halbwachs, ainda nas primeiras décadas do século passado, nós nos tornamos mais conscientes de que as reconstruções do passado ocorrem no presente, relacionadas às memórias constituídas em grupos sociais. Para o sociólogo, memórias individuais são constituídas com o suporte de estruturas sociais mais amplas, chamadas por ele de quadros sociais da memória, como a linguagem; trazem com elas o contexto social em que foram produzidas. Não por acaso, portanto, grande parte dos estudos sobre memória social no campo das Ciências Sociais apoia-se nas abordagens e caminhos metodológicos indicados por Halbwachs e analisa memórias constituídas por grupos sociais, como famílias, operários e partidos políticos.

Contudo, embora não enfatizado por Halbwachs, como qualquer outra forma de pensamento e interpretação, o processo de reconstrução do passado não pode ser considerado a partir de um único parâmetro, o quadro social. Halbwachs foi discípulo de Durkheim e procurou dar aos estudos sobre as lembranças do passado a concretude de um fato social. Por um lado, podemos dizer que as memórias são influenciadas por aspectos

\footnotetext{
${ }^{1}$ Este memorial foi defendido, com o título Entre memória e esquecimento: Um depoimento, em 27 de abril de 2018. A banca examinadora foi composta pelos Profs. Helena Bomeny (presidente), Patrícia Birman, Glaucia Villas Bôas, Maria Paula Nascimento Araújo e José Reginaldo Santos Gonçalves.
} 
emocionais e subjetivos que diferem de indivíduo a indivíduo, e, por outro lado, que construções coletivas são repletas de vazios e não ditos. Esses são aspectos bem importantes em estudos sobre memória que enfatizam tanto conflitos entre diferentes versões do passado como intrusões de sentido relacionadas à influência de estruturas de poder sobre memórias consolidadas. Esquecimentos, má interpretação, e condicionamentos de estruturas mais amplas mostram que o retorno do passado pode não estar presente em narrativas, mas em emoções e imagens. Assim sendo, embora considerando que memórias são constituídas de acordo com motivações do grupo e com estruturas sociais que as antecedem, é preciso considerar que a memória também é definida por outros aspectos como subjetividade e relações de poder. Atualmente a memória é estudada em um campo interdisciplinar, em que Filosofia, História, Biologia, Psicanálise, Direito, Ciências Políticas e Sociais, entre outras disciplinas, contribuem para sua melhor compreensão.

No campo da Psicologia, estudos têm mostrado que há certos padrões no que concerne ao lembrar e ao esquecer. Não obstante o pouco consenso relacionado ao seu funcionamento, alguns aspectos são estabelecidos e aceitos. Em relação ao esquecimento, sabe-se que há uma perda contínua natural e biológica das memórias ao longo do tempo, e, também, que elas obedecem ao primeiro momento de apreensão. Se no momento da apreensão não houver a atenção necessária, as lembranças subsequentes serão muito frágeis ou inexistentes. Em outras palavras, nós só nos lembramos daquilo que foi importante e fez sentido para nós no momento em que vivenciamos certo evento. Na Psicanálise, estudos sobre a memória reiteram as observações realizadas por Sigmund Freud e apontam que aqueles que passaram por processos traumáticos podem sofrer com imagens de memórias indesejáveis ou podem ainda ter determinadas lembranças totalmente bloqueadas. A reação a acontecimentos de extrema violência, sofrimento e dor depende da fragilidade de cada um àqueles acontecimentos específicos. O evento traumático é definido em termos da incapacidade de um indivíduo em elaborar o que foi vivenciado por ele.

Voltando à sociologia, podemos associar essas últimas reflexões à percepção de que os fatores incidindo sobre a memória são múltiplos e nem sempre podem ser descartados. O desafio apresentado nessas observações, nas quais procuro sintetizar alguns dos aspectos mais destacados dos processos de rememoração, marcou minha trajetória acadêmica, senão meu próprio percurso existencial. Não se trata, portanto, apenas de situarmos 
nossa narrativa profissional entre a estrutura, a sorte e a intenção do sujeito. Mais do que isso, é preciso também considerar que as construções do passado, memorialistas ou não, ocorrem a partir de fatores que extrapolam nossa disciplina, e que o passado pode estar presente apenas em emoções e imagens difíceis de serem transmitidas e/ou traduzidas para uma linguagem narrativa. Acrescentar essas dimensões às análises sociais sobre a memória foi desde muito cedo o desafio que foi enfrentado ao longo da minha profissão e que será por mim assumido neste memorial. Nosso ponto de partida, como apontado por Benjamin, é precisa e contraditoriamente a aparência da permanência que a memória pode apresentar.

\section{Formação: Rio de Janeiro, Nova York e Cambridge}

Embora não recorde quem eram os membros da banca de seleção do mestrado do antigo Instituto Universitário de Pesquisas do Rio de Janeiro (IUPERJ/Cândido Mendes), lembro que me perguntaram quais eram minhas leituras recentes relacionadas ao campo das Ciências Sociais. Eu estava apaixonada pela leitura de uma coletânea de textos de Walter Benjamin que acabara de ser publicada. Benjamin sempre representou para mim uma fonte de inspiração. Ele procurou compreender a memória como parte da experiência humana da modernidade, e, como sabemos, ele foi um crítico da perda de laços e tradições entre indivíduos que se tornavam cada vez mais autocentrados. Esta foi a questão que orientou minha formação no mundo acadêmico.

Embora tenha respondido satisfatoriamente à pergunta para fins de seleção, meu interesse pela memória enquanto objeto de estudo não teve acolhida imediata na Instituição. Apenas, um ano depois, com a chegada do professor Ricardo Benzaquén de Araújo, consegui uma orientação adequada e pude desenvolver minha dissertação sobre narrativas de História presente em dois museus históricos do Rio de Janeiro, o Museu Histórico Nacional e o Museu Imperial. Meu interesse pelos museus não estava relacionado ao papel social das instituições, mas aos discursos relacionados ao passado.

A erudição de meu orientador me abriu um leque imenso de questões e de possibilidades de pesquisa. As lembranças dos encontros, da gentileza e cuidado, e dos livros emprestados que se sucediam, são muitas.

Outra lembrança forte deste período foi quando o meu antigo professor de História do Brasil, Ilmar Rohloff de Mattos, pediu para que eu fosse encontrar com ele na PUC, onde também dava aulas, e me emprestou um 
livro que havia acabado de comprar: o primeiro volume (La République) da coletânea Les lieux de mémoire, com artigos sobre a história da nação francesa, organizada por Pierre Nora. A apresentação desta coletânea - um texto de 13 páginas escrito por Nora e denominado Entre Mémoire et Histoire, em que História e Sociologia se aproximam na análise de objetos e significados contextualizados e transmitidos entre gerações - tornou-se uma referência obrigatória aos estudos sobre memória. Sem dúvida, historiadores se interessavam por novas diretrizes em seu campo, que surgiam sob a forma de desafio e novidade.

Como resultado da imersão em novas leituras e da defesa da dissertação História, Tempo e Memória: Um Estudo sobre Museus, IUPERJ, publiquei dois artigos sobre o tema: Objeto, Memória e História e o Pesadelo da Amnésia Coletiva em duas conceituadas revistas acadêmicas de Sociologia, Revista Dados e Revista Brasileira de Ciências Sociais, em 1992 e 1993, respectivamente. Estes devem estar entre os primeiros artigos sobre Memória Social a serem publicados em revistas especializadas de Ciências Sociais no Brasil.

Embora essas publicações refletissem o período de formação no IUPERJ, elas foram escritas no período em que me encontrava em Nova York fazendo meu doutorado. Em 1989, fui aprovada para o curso de doutorado no Departamento de Sociologia, da New School for Social Research. Ao chegar lá também não encontrei com facilidade uma orientação acadêmica que se voltasse para o estudo da memória social. Este, decididamente não fazia parte dos objetos da sociologia. No entanto, a efervescência intelectual e cultural da cidade, que sedia duas outras importantes universidades (New York University e Columbia University) e um número grande de bibliotecas, que podem ser utilizadas por estudantes inscritos num sistema universitário único, permitiu que meu objetivo fosse cumprido. No primeiro ano, recebi a sugestão de obter os créditos necessários à formação não só nos cursos regulares exigidos, mas também nos de outros departamentos, o que foi feito com imenso interesse e prazer.

Os créditos obrigatórios diziam respeito às correntes teóricas da Sociologia e eles foram fundamentais em minha formação. Agradeço a dois professores, José Casanova e Andrew Arato, pela formação sólida que obtive em teoria sociológica, responsável por minha inserção nos debates acadêmicos que se sucederam. Os estudos sobre Jürgen Habermas e sua tentativa de síntese teórica e defesa de uma linguagem comum na esfera pública, densamente construída em The Theory of Communicative Action, livro publicado em 1984, nos levaram a ter controle sobre as propostas e 
limites inerentes às correntes teóricas sociológicas.

Das palestras e cursos realizados fora do departamento, gostaria de destacar as aulas de Richard J. Bernstein e Agnes Heller, que me proporcionaram, respectivamente, uma compreensão dos desafios da pós-modernidade e a de um legado marxista aberto e pouco ortodoxo que seguem me acompanhando até os dias atuais. Da mesma forma, Charles Tilly, em História; Nancy Fraser e Seyla Benhabib, em Política; Vera Zolberg e Jeffrey Goldfarb, este último meu orientador, no campo da Cultura Política, possibilitaram a defesa da tese Memory: Social Construction and Critique e a obtenção do título de $\mathrm{PhD}$ em ciências sociais e políticas.

Destaco ainda na minha formação a atmosfera intelectual e de incentivo aos alunos, que era muito grande na New School for Social Research. Palestras e cursos com professores convidados eram frequentes na instituição e, desta forma, tive a possibilidade de entrar em contato com o pensamento de Reinhart Koselleck que muito me instigava desde o mestrado. A palestra de Eric Hobsbawm foi outra que ficou na memória, pois a facilidade com que respondia às perguntas sobre as condições econômicas e sociais de países espalhados por todos os continentes, com estatísticas e dados precisos, foi impressionante.

Alguns meses após a defesa de tese, eu estava de volta ao Rio de Janeiro e, em março de 1994, comecei a dar aula como professora visitante no departamento de Ciências Sociais da UERJ. Em 1996, tive a oportunidade de fazer um curso de especialização de três meses sobre memória e textualidade, na School of Criticism and Theory (SCT), na época sediada pelo Dartmouth College, em New Hampshire, Estados Unidos, graças à bolsa recebida pela Faperj. Atualmente a SCT é sediada pela Cornell University e tem em seus cursos professores de diversas áreas disciplinares como Benedict Anderson, Roger Chartier, Judith Butler, Gayatri Spivak, Susan Stewart, Marianne Hirsch, Mary Jacobs e Susan Buck-Morss. No ano citado, os professores que trabalharam os temas do silêncio textual e do trauma, foram, principalmente, Stephen Greenblatt e Dominick La Capra. Essa experiência, formada por um curso extremamente especializado, com professores reconhecidos na área de desconstrução social e crítica literária, foi fundamental às minhas reflexões sobre memória e violência. Stephen Greenblatt, três anos depois, integrou o conselho editorial da Revista Interseções, criada pelo nosso Programa de Pós-Graduação. A convite da professora Clarice Peixoto, eu me agreguei a ela e ao professor Valter Sinder na produção editorial da revista. 
Ainda em 1996, fiz concurso e passei a ser professora adjunta do Instituto de Filosofia e Ciências Humanas (IFCH) da UERJ. A partir de minha entrada na universidade, aulas, pesquisas e orientações fizeram parte de minha trajetória profissional. Fiquei responsável pelos cursos de teoria social da graduação e da pós-graduação. Paralelamente às formulações sobre memória, tradição e modernidade, que encontraram espaço no grupo de trabalho sobre teoria social da Anpocs (Associação Nacional de PósGraduação e Pesquisa em Ciências Sociais), desenvolvi uma pesquisa sobre a permanência e usos da tradição em duas escolas de samba do Rio de Janeiro, Mangueira e Império Serrano. Ao investir nos jogos travados entre tradição e modernidade pelas escolas de samba, a questão da herança africana na construção nacional ficou evidente, tema que vem sendo elaborado ao longo dos anos e que, recentemente, aproxima-se de abordagens historiográficas do sistema escravista que priorizam o protagonismo dos antigos escravos e libertos do período nas construções históricas.

Como resultado da pesquisa, alguns artigos foram publicados nesse período, procurando problematizar tanto questões teóricas como aquelas relacionadas às memórias do carnaval. Sobre a autonomia das novas identidades coletivas: alguns problemas teóricos, artigo publicado na Revista Brasileira de Ciências Sociais, investiga os limites de abordagens funcionalistas e interacionistas aos temas da memória e da identidade coletiva e A Luta da Memória Contra o Esquecimento, publicado na Revista Síntese de Filosofia, analisa as contribuições de Walter Benjamin e Jacques Derrida às teorias da memória. Dois outros artigos, O Batuque Negro das Escolas de Samba (Revista de Estudos Afro-Asiáticos) e Orfeu Negro: entre fantasia e realidade (Caderno de Antropologia e Imagem) foram escritos sobre a relação entre tradição e modernidade em escolas de samba. O artigo Mangueira e Império: A Carnavalização do Poder pelas Escolas de Samba do Rio de Janeiro traz uma análise mais ampla sobre os conflitos entre cultura, política e indústria cultural nas escolas de samba e foi publicado no livro Cem Anos de Favela, organizado por Alba Zaluar e Marcos Alvito. Minha primeira publicação em inglês foi neste período, quando, após apresentação do trabalho Samba Schools: The Logic of Orgy and Blackness in Rio de Janeiro no Congresso Internacional de Americanistas (ICA), fui convidada a contribuir com a coletânea organizada pelo professor Jean Rahier, que tem o sugestivo título de Representations of Blackness and the Performance of Identities.

Como dito anteriormente, as construções não são contínuas e não são construídas em linha reta. Algumas destas reflexões foram desenvolvidas e 
estão presentes em artigos mais recentes como Carnaval e política, publicado na coletânea organizada por Leonardo Avritzer et alii, Corrupção: Ensaios e Críticas (Editora UFMG/2008) e O Samba é meu dom publicado no livro Nos quintais do samba da Grande Madureira (Editora Olhares/2016).

Entre 1994 e 2000, os trabalhos de pesquisa produzidos foram apresentados em diversos congressos nacionais e internacionais, entre eles: Encontros da Sociedade Brasileira de Sociologia (SBS); Reuniões da Associação Brasileira de Antropologia (ABA); os Congressos da Associação Internacional de Sociologia (ISA), da Latin American Studies Association (LASA); e os Encontros da Associação Nacional de Pós-Graduação e Pesquisa em Ciências Sociais (ANPOCS). Neste último, tive participação ativa na formação do Grupo de Trabalho em Teoria Social, que não existia anteriormente, contribuindo com o debate sobre teorias da memória e modernidade. Fez parte deste primeiro momento um grupo de recémdoutores, entre eles, José Maurício Domingues, Leonardo Avritzer e Josué Pereira da Silva, com os quais eu já debatia informalmente os rumos da modernidade a partir, principalmente, das teorias de Jürgen Habermas e Anthony Giddens. Ao longo da consolidação do GT, fiquei conhecendo outros sociólogos, como Hector Leis e Sérgio Costa, com os quais também mantive fortes laços acadêmicos. A comunidade acadêmica é essencial para as nossas formulações. Devo ao grupo de teoria social da ANPOCS a consolidação de minha formação teórica, bem como seus desdobramentos futuros. Data também deste período a organização do I Seminário Afrocarioca, na UERJ, por mim coordenado.

Em 2000, após cumprir seis anos de ensino e pesquisa na universidade, obtive minha primeira licença, e realizei meu primeiro pós-doutoramento no exterior, com o projeto de pesquisa "Políticas da Memória: Museus e Globalização", tema que consolidaria minha pesquisa. Voltava, portanto, ao tema da dissertação de mestrado, museus e memória, com interesse em avaliar variantes narrativas que estivessem acompanhando transformações sociais e políticas na contemporaneidade.

Depois de passar seis meses no Theory, Culture \& Society Centre, da Nottingham Trent University, onde o Prof. Mike Featherstone me recebeu como professora visitante, passei mais seis meses no Centre of Latin American Studies, em Cambridge, onde igualmente tive boa acolhida pelos professores Charles Jones e David Lehmann. Tive então a oportunidade de apresentar minha pesquisa em diversos fóruns e centros acadêmicos. Finalmente, passei três meses no Centre de Recherche sur les Liens Sociaux (CERLIS), na 
Université de Paris $V$. Conheci diversos museus europeus nesse período e ampliei minha pesquisa, mantendo contato com pesquisadores dessa área. Em Paris, conheci a pesquisadora Luciana Sepúlveda e seu estudo sobre público de museus, o qual serviu de modelo para avaliação dos museus brasileiros nos anos seguintes. O objetivo de analisar as novas práticas e narrativas que estavam sendo criadas nos museus europeus foi cumprido. O pós-doutorado permitiu a troca acadêmica e formação de vínculos e parcerias que têm sido mantidos.

Como resultado da pesquisa desenvolvida no pós-doutorado, diversos artigos foram publicados em revistas e coletâneas analisando narrativas de museus brasileiros e sua adequação às transformações políticas e sociais:

- Os Museus Brasileiros e a Constituição do Imaginário Nacional (Sociedade e Estado/2000);

- Teoria da Memória, Teoria da Modernidade (In Teoria Social e Modernidade, UFMG/2000);

- The New Dynamic of Blockbuster Exhibitions (Bulletin of Latin American Research/2001);

- Brazilian Museums, Public Policy and the Missing Public (Journal of Latin American Cultural Studies/2001);

- Memory and Narrative in Social Theory (Time \& Society/2001);

- Black Orpheus and the Merging of Two Brazilian Nation (European Review of Latin American and Caribbean Studies/2001);

- Museums and Memory: The Enchanted Modernity (Journal for Cultural Research/2003);

- Museums without a Past: The Brazilian Case (International Journal of Cultural Studies/2003);

- The Brazilian Remake of the Orpheus Legend: Film Theory and Aesthetic Dimension (Theory, Culture E Society/2003);

- Museus brasileiros e política cultural (Revista Brasileira de Ciências Sociais/2004).

O período de pesquisa passado na Inglaterra e na França me mostrou que o tema da memória já constava da pauta acadêmica no campo das Ciências Sociais, embora, no Brasil, a recepção ainda fosse tímida. Ao comentar a formação de um campo de estudos em torno do conceito de memória, a historiadora francesa Marie-Claire Lavabre ressaltou que na década de 1970 não havia qualquer menção à "memória" nos debates relativos à 
reformulação da disciplina da História. Análises recentes marcaram uma mudança importante na escrita da História, pois construções do passado passaram a ser consideradas como parte de práticas sociais do presente.

Nos últimos vinte anos houve uma explosão de estudos sobre a memória. A princípio, o aumento de estudos sobre testemunhos, narrativas autobiográficas e lugares da memória foi explicado pelo novo ritmo da vida moderna. No artigo Entre Mémoire et Histoire, que se transformou em referência para os estudos sobre memória, o historiador francês Pierre Nora sugeriu que se falava tanto de memória, porque ela não existia mais. Para ele, bem como para um grupo significativo de filósofos e sociólogos, a experiência do tempo de forma acelerada seria responsável pelo fim, ou, no mínimo, pelo enfraquecimento das tradições anteriormente constituídas. Sempre opondo-me às teorias muito radicais sobre o fim das tradições, desenvolvi pesquisas que identificaram, no Brasil, permanências e transformações ocorridas em diversos museus, que acompanhando tendências mais gerais, substituíam discursos nacionalistas, fortemente calcados em crenças tradicionalistas, por exposições interativas mais voltados para o mercado e para as múltiplas iniciativas que se configuravam socialmente. As modernizações não implicavam necessariamente na mudança de sentido inerente às narrativas anteriores, pois algumas vezes se restringiam às formas e não aos conteúdos.

A dissertação de mestrado, sobre as narrativas históricas, e a tese de doutorado, sobre teorias da memória, foram publicadas em 2003 e 2006, com os títulos de A Escrita do Passado nos Museus Históricos (Editora Garamond) e Memória Coletiva e Teoria Social (Editora Annablume), com o apoio financeiro da Faperj. Em tempos em que o Estado reduz drasticamente os investimentos em educação, ciência e tecnologia, acho importante registrar que financiamentos públicos possibilitaram não só a publicação de artigos, livros, edição de revistas científicas, como também minha formação desde a educação primária até o pós-doutoramento.

\section{Antecedentes: medicina, história e gênero}

Somos treinados a separar a vida privada da pública, divisão esta que tem sido central no pensamento político ocidental. De acordo com minha própria formação, fortemente influenciada pelas teses de Jürgen Habermas e seu conceito de esfera pública, estas são esferas separadas e diferentes, que podem ser problematizadas cada uma em seus próprios termos. Dentro 
de minha própria formação, contudo, acompanhei a crítica de Nancy Fraser ao conceito de esfera pública defendido por Habermas e passei a considerar firmemente o argumento feminista que questiona a demarcação clara entre estas esferas, e que também denuncia a associação entre esfera privada e formas de patriarcalismo. Ao problematizarem a dicotomia entre vida pública e doméstica, estudos feministas de diferentes tradições teóricas trazem à tona a divisão de trabalho entre os sexos, a natureza política da família e a relevância da justiça na vida pessoal.

Relembrar o passado à luz de teorias feministas consiste em, no meu caso, reinterpretar todo um conjunto de eventos e emoções. Consiste, ainda, em seguir Halbwachs de ponta cabeça, pois não se trata apenas da consolidação das novas memórias a partir de um novo grupo de pertencimento, mas, sim, da descoberta de rupturas, emoções e sofrimentos muitas vezes sublimados ou não percebidos. Passado e presente se encontram a partir da possibilidade de reinterpretação de eventos vivenciados, que, no relato a seguir, será dada pela condição de gênero.

Neta de imigrantes portugueses pobres, eu sou a única dentre os 28 filhos e netos que seguiu uma carreira acadêmica universitária. Meu avô, oriundo de uma região de camponeses do norte de Portugal, veio para o Brasil, com sua família, nas primeiras décadas do século passado. Com pouca ou nenhuma instrução, ele e seus irmãos conseguiram se estabelecer como pequenos comerciantes em Campo Grande, região da zona oeste do Rio de Janeiro. Minha avó, com um pouco mais de instrução, veio de Coimbra para se casar com meu avô, após arranjos de família. Dos seis filhos do casal, os quatro homens estudaram, chegaram à Faculdade e conseguiram, através de concursos públicos, carreiras estáveis e ascensão social. As duas mulheres tornaram-se mães de família e continuaram a morar em Campo Grande. Uma delas, viúva muito cedo, ficou sob o teto de meu avô até que seus filhos pudessem the dar abrigo. Dentre os 22 netos, a maioria alcançou o ensino universitário. A família, contudo, desde que dela me recordo, sempre foi dividida entre as famílias dos filhos, que têm suas moradias nas regiões mais ricas da cidade, e aquelas das filhas, que, com poucas exceções, continuaram a morar em regiões menos nobres da cidade. Dentre os bisnetos, observa-se uma menor divisão social. De qualquer forma, sou oriunda de uma família pobre, para a qual a educação, que sempre esteve atrelada à ascensão social, foi inicialmente garantida apenas àqueles do sexo masculino.

A família de minha mãe é bem menor. Fiquei órfã com um ano de 
idade e meu contato com suas duas irmãs foi mais esporádico. Do meu avô materno, sei apenas que, era descendente de espanhóis e/ou portugueses. Dos ascendentes de minha avó materna, eu nada sei. De família mais estabelecida na cidade, minhas tias, assim como minha mãe, embora sem ensino superior, estudaram, trabalharam como professoras de ensino básico, e casaram-se com funcionários públicos, conquistando ascensão social.

Embora minha geração seja caracterizada pela ruptura, em termos políticos e de costumes, pois tinha 15 anos nos anos 1970, quando o movimento estudantil se organizava contra a ditadura militar, a herança familiar não desaparece. Falar de tios e primos em termos de número é difícil e desconfortável, senão penoso. As pertenças se sucedem, mas as antigas não desaparecem. Retomando minhas trajetórias estudantil, militante, e profissional, é fácil perceber que o papel de esposa e mãe sempre esteve presente enquanto desejo, atravessando todos os outros. Ao lidarmos com lembranças, sabemos que quando palavras nos faltam e a razão tem dificuldade em produzir narrativas, imagens nos ajudam a seguir um percurso.

A saída do curso de medicina não foi uma escolha fácil. $\mathrm{O}$ ano de pré-vestibular exigiu muito estudo e dedicação e o curso de Medicina na Universidade Federal do Rio de Janeiro tinha bastante prestígio. A atitude de meu pai, ao dar suporte a qualquer escolha a ser feita por mim, inclusive o abandono da carreira médica, até hoje me emociona e é uma marca positiva no rol das lembranças. Eu hoje me pergunto, contudo, o quanto influenciou nesta postura o fato de eu ser mulher. Meu pai, como outros homens de sua geração, assumia a total responsabilidade pelo sustento das mulheres da família. Em seu ímpeto protetor, ele me isentava de tal peso.

Ser mãe e estudante no curso de História foi outro desafio, sobretudo porque a opção estava mais ligada à politização do curso do que a seu conteúdo propriamente dito. Em 1978, vivíamos sob a repressão da última fase do regime militar, que ainda aprisionava e torturava as lideranças estudantis. Nos centros acadêmicos tínhamos um aprendizado paralelo: as diferentes táticas e estratégias defendidas pelos diversos partidos de esquerda, em sua maioria, clandestinos, que se organizavam dentro do movimento estudantil. Do curso, meu interesse maior era sobre a História do Brasil, e nele me concentrei com o suporte de excelentes professores. De qualquer forma, as noites de reunião e enfrentamento com forças da ditadura requeriam uma liberdade que eu já havia perdido pelo fato de ser 
mãe. Institucionalmente, consegui licenças pela gravidez e alguns cursos e leituras foram feitos em casa, o que certamente não era muito fácil. Por outro lado, colegas combativos tinham muito pouca noção do que fazer com uma criança pedindo atenção em meio a uma reunião política. E eu, muito menos.

A entrada no mestrado não foi resultado de um projeto de vida bem delineado. Ao contrário, surgiu do gosto pela leitura, influenciado pela educação dada por minha madrasta (professora primária formada pelo antigo Instituto de Educação e ávida leitora, que ocupou o lugar de mãe em minha vida) e também pela vontade de escapar de um trabalho burocrático. Silencio sobre este último porque pouco acrescentou à minha carreira acadêmica. Ao longo do mestrado, meu terceiro filho nasceu e desse período mais uma imagem se consolidou, o comentário de um dos professores do Programa: "Nas estatísticas realizadas, não há mulheres com três filhos neste curso de pós-graduação". O Iuperj construía, nesse período, um perfil social e econômico de seus estudantes. A vocação profissional acadêmica ainda não existia para mim, e devo às amizades encontradas na Instituição, principalmente nas figuras de José Maurício Domingues e Monica Herz, a percepção de novos horizontes.

A opção pelo doutorado, por mais especializada que pareça ser, também não fez parte de um projeto próprio, mas de uma tentativa de acompanhar o chefe de família em sua especialização profissional. A chegada em Nova York com três filhos e marido volta à memória através de cenas congeladas. Colegas se perguntavam até onde eu conseguiria dar sequência ao curso de doutorado. Apostas se faziam. A situação se complicou, após o segundo ano do curso, porque precisei mudar de cidade para acompanhar o chefe de família, primeiro para Rochester, Minnesota, a mais de 1.500 quilômetros de distância. No ano seguinte fomos para Califórnia, a mais de 5.000 quilômetros. Nem eu nem meu marido considerávamos a possibilidade de eu continuar na cidade com os filhos. Eu fazia meu doutorado, mas o papel principal ainda era o de acompanhar o cônjuge em sua formação no exterior. Vivíamos de bolsas e o dinheiro era curto. À distância, a escrita da tese me pareceu, muitas vezes, sem sentido. Outras brasileiras em situações menos desfavoráveis abandonaram suas teses. Ainda assim, foi graças a essa conjuntura que o doutorado foi possível. A família sempre cumpriu o papel de me fornecer segurança e realização pessoal. No que diz respeito à profissão, devo, novamente, às amizades formadas, em especial a Josué Pereira da Silva, a finalização do curso. Nesse ambiente acadêmico, em que 
encontros com outros pós-doutorandos e amigos se consolidaram - e aqui destaco a importância de Celia Maria Marinho de Azevedo, Marco Antonio Pamplona, Leonardo Avritzer, e Ana Caetano - novas expectativas profissionais se formaram.

Ao retornar ao Brasil já tinha por objetivo me consolidar na vida acadêmica. O desafio não foi menor. A competição entre jovens professores sempre foi acirrada e nossa produção requer sacrifícios. Desta vez, minha família ficou em segundo plano, talvez pela primeira vez, o que trouxe fraturas significativas, problemas entre filhos já adolescentes e o sentimento crescente de culpa, que é aquele que acompanha todas as mulheres que se movem entre família e profissão.

A percepção de que não lidamos apenas com a memória constituída entre pares, mas que há outros tipos de memória, como aquela que resulta de tradições herdadas, mais ligadas à emoção e à reprodução de comportamentos do que à razão, ampliou o escopo teórico e o campo de estudos sobre a relação entre passado e presente. A perda da minha mãe com um ano de idade me marcou pela ausência. A responsabilidade feminina pela esfera doméstica reproduz comportamentos. No meu caso, ela une passado e presente; os cuidados cotidianos com os idosos do presente se unem àqueles anteriores destinados aos filhos. Embora a questão de gênero não seja meu objeto de estudo, devo aos estudos feministas a ampliação teórica com que trabalho não só os conceitos de memória, mas também as diferentes questões sociológicas das quais me aproximo.

\section{Atividades de orientação e extensão: Ecomuseu Ilha Grande, Museu do Cárcere, Museu Afrodigital Rio}

Ao longo de minha carreira foram muitas as orientações; é difícil relembrar algumas sem esquecer outras e sem fazer injustiças. Se contarmos as centenas de participações em bancas de qualificação, a tarefa de rememoração estaria irremediavelmente perdida. Orientações, em seus diversos níveis, fazem parte de nossa formação, aprendemos com aqueles que orientamos, com os comentários dos outros professores das bancas de qualificação e de trabalho de conclusão. Podemos dizer que orientação e pesquisa são as duas faces da mesma moeda, elas se complementam. Além disso, em minha trajetória na UERJ, os trabalhos de extensão sempre estiveram atrelados à pesquisa $\mathrm{e}$ à orientação. 
Gostaria, contudo, de destacar as três primeiras orientações de doutorado, pois elas foram fundamentais aos projetos que desenvolvi ao longo da carreira. Em 1999, comecei a orientar três doutorandos de Ciências Sociais, Mario de Souza Chagas, Joana D'Arc Fernandes Ferraz e Joselina Silva. Eles logo defenderam suas teses e, além de grandes amigos, tornaramse profissionais extremamente competentes e, companheiros de profissão. Seus trabalhos e pesquisas entrelaçam-se com minha trajetória profissional através de encontros acadêmicos em diversos momentos e espaços comuns.

No ano 2000, enquanto fazia meu pós-doutorado na Inglaterra, recebi um convite da então sub-reitora de Pós-Graduação, Maria Andréa Loyola, para apresentar um projeto de um museu para o campus que estava sendo construído na Ilha Grande. A grande preocupação da sub-reitoria era cumprir uma cláusula presente no Termo de Cessão emitido pelo governo do Estado, em 1994, que transferia toda a área anteriormente ocupada pelo antigo Instituto Penal Cândido Mendes para a Universidade do Estado do Rio de Janeiro. Para assumir a cessão, a Universidade, em contrapartida, deveria assumir alguns compromissos, como a manutenção de algumas atividades da vila, que tinha em torno de trinta casas cedidas a antigos funcionários do IPCM, e a construção de um museu no local das ruínas do IPCM. Os limitados recursos obtidos pela Universidade foram investidos na reforma do prédio do antigo batalhão da Polícia Militar, tendo sido lá instalados laboratórios e um dormitório para professores e alunos. A vila, em tempo muito curto, perdeu o traçado geométrico das ruas e dos canteiros. As casas perderam suas tintas e rebocos caíram. Os recursos para realização do museu deveriam ser obtidos através de projetos submetidos às agências financiadoras.

Para elaboração do projeto, convidei meu orientando Mario de Souza Chagas, que tinha a formação de museólogo e já era professor do Programa de Pós-Graduação Memória Social, da Universidade Federal do Estado do Rio de Janeiro (UNIRIO). Mario faz parte de um grupo de profissionais que traz novos conceitos para a Museologia e eu já o conhecia, desde o tempo da pesquisa de mestrado, por sua destacada atuação no campo. $\mathrm{Na}$ área da museologia, foi ele meu orientador. Juntos, idealizamos a proposta de criação do "Ecomuseu Ilha Grande", cuja principal meta seria a da preservação da natureza, da história e da cultura local, a partir da participação direta de moradores, das organizações não governamentais, de associações e de instituições comprometidas com o museu.

O projeto "Ecomuseu Ilha Grande" apontava a necessidade de criação de 
quatro unidades, para cumprimento de seus objetivos: o Museu do Cárcere, a ser localizado nas ruínas do Instituto Penal Cândido Mendes; o Museu do Meio Ambiente, no prédio que abrigava o antigo presídio feminino, na época ainda em boas condições; o Centro Multimídia, no prédio do antigo cinema; e o Parque Botânico, no pátio do Instituto Penal. Os museus serviriam para preservar meio ambiente, história e cultura, como também para divulgar as diversas pesquisas em andamento realizadas pelos biólogos, geógrafos, oceanógrafos e demais profissionais associados ao campus. Essencial a estas propostas era a participação da população local.

No que dizia respeito às ruínas, inicialmente eu e Mario Chagas estranhávamos e até nos divertíamos quando nos pediam que o projeto apresentado fosse capaz de expulsar os fantasmas do presídio. Algumas propostas já apresentadas procuravam eliminar traços dos antigos presídios, recompondo a arquitetura "harmônica" da vila militar, ou, ainda, utilizando cores vivas, como o vermelho, para as construções no interior da vila, que embora atraíssem insetos e criassem um forte contraste com a vegetação, geravam a esperança de que o local, marcado por cem anos de violência e desrespeito à dignidade humana, pudesse adquirir novos contornos. Meu passado de historiadora e a veia poética de Mario Chagas foram responsáveis pelo maior comprometimento com o passado no projeto apresentado.

Sem medo de fantasmas, mas com grande dificuldade, pois os diversos órgãos do Estado que procurávamos não se interessavam pelo projeto, obtivemos um financiamento da Faperj para abrir ao público as ruínas do antigo presídio. O primeiro módulo do museu foi inaugurado em 2009, quase uma década após o início do projeto. A partir da pesquisa realizada sobre as prisões da Ilha Grande, a exposição Cem Anos de Prisão se concretizou. Duas museólogas se integraram à equipe e foram determinantes na execução do projeto, Viviane Wermelinger e Gabriela Farias.

Associou-se também ao projeto o arquiteto João Calafate, na época, diretor da Faculdade de Arquitetura da Universidade Santa Úrsula. O projeto arquitetônico visava preservar algumas ruínas, recuperar outras, e criar novas estruturas para modernizar o complexo e atender as necessidades dos visitantes. Havia a proposta de construção de passarelas suspensas, que permitiriam ao visitante visualizaras ruínas de muros e guaritas. A ideia era combinar preservação, restauração e funcionalidade. Sem perder funcionalidade, o novo complexo deveria preservar muros, guaritas, prédios, e, dentro deles, vigas, ferragens e parte dos tijolos 
originais, elementos capazes de permitir que o visitante tivesse acesso à passagem do tempo. Estávamos todos interessados na preservação de algumas das ruínas existentes, devido ao impacto que causava o seu testemunho sobre a presença de mais de cem anos de cárceres na Ilha. A nova Museologia tem acenado para diversas estratégias expositivas através das quais, além da informação, procura-se transmitir emoções, conflitos e provocações. As ruínas e testemunhos, assim como a produção artística, cumprem um importante papel nessa nova linguagem. $\mathrm{O}$ "Museu do Cárcere", coordenado atualmente pelo historiador Gelsom Rozentino e sua equipe, está em plena atividade, e já é um dos mais visitados do Rio de Janeiro.

Por ocasião da inauguração deste primeiro módulo do "Ecomuseu Ilha Grande", uma série de acontecimentos mostrou que a preservação do passado não é uma tarefa tão simples. Novos projetos surgiram, colocando em questão a ideia original. Nós nos confrontamos com a construção de quiosques e paisagens caribenhas no interior do espaço do antigo presídio, e até mesmo com a demolição de muros da penitenciária, que foram utilizados como entulho para fins de pavimentação da estrada que liga a vila Dois Rios à vila do Abraão. Em alguns casos foi possível defender a ideia original, em outros não.

A experiência, portanto, de criar o projeto do "Ecomuseu Ilha Grande" foi uma tarefa interdisciplinar sempre ligada à reflexão teórica. No caso do "Museu do Cárcere", a percepção da dificuldade de representação de práticas violentas foi imediata. $\mathrm{O}$ contraste entre representação e as funções de informação e entretenimento provoca uma tensão constante, ampliada pelo ambiente paradisíaco da Ilha Grande e sua vocação turística. Alguns trabalhos sobre o tema foram publicados em revistas e coletâneas, como O Conflito entre Natureza e Cultura (História, Ciências, Saúde Manguinhos/2005).

Em 2010, passei a coordenar um segundo projeto de extensão, o "Museu Afrodigital Rio" (www.museuafrodigitalrio.org), também no âmbito da Universidade do Estado do Rio de Janeiro (UERJ). O museu, que é um sítio eletrônico (site) digital, faz parte de uma rede nacional inaugurada pelo Prof. Lívio Sansone, cujo objetivo é a salvaguarda de fontes documentais e a divulgação de pesquisas da cultura afro-brasileira e africana no Brasil, propiciando a democratização do acesso àqueles interessados. Esse projeto nacional é constituído por iniciativas e temáticas regionais, que se organizam de forma autônoma. Atualmente, a rede "Museu Afrodigital" é 
composta por unidades formadas por grupos de pesquisadores vinculados a universidades estaduais e federais, envolvendo iniciativas em Salvador, Recife, Natal e São Luiz. Duas coletâneas foram publicadas com as experiências desenvolvidas pelos museus: A Política do Intangível: museus e patrimônios (UFBA) e Museus Afrodigitais e Política Patrimonial (EDUFMA). Os museus digitais são coordenados, respectivamente, pelos professores e pesquisadores Livio Sansone (UFBA), Antonio Motta (UFPE), e Julie Cavignac (UFRN). O professor Sergio Ferretti (UFMA), presente desde o início do projeto, faleceu em 2018, deixando em todos nós um profundo sentimento de dor e perda.

Como parte deste conjunto maior, o "Museu Afrodigital Rio" tem por objetivo contribuir para a inclusão da população negra, a qual tem tido suas produções culturais e representações tradicionalmente excluídas de espaços institucionais formais. A digitalização de informações é um instrumento que pode facilitar a repatriação de documentos, e divulgar outros de difícil acesso. Propomos práticas que democratizem o acesso ao saber acumulado, descentralizando formas de conhecimento. Partimos da ideia de que o aprimoramento do sistema poderá incentivar a maior participação dos usuários. Disponibilizamos em exposições e arquivos um conjunto amplo de registros, tais como: recortes de jornais, documentos pessoais, cartas, textos publicados ou não, poesias, fotos, vídeos, depoimentos, cantigas, danças e reproduções de objetos ou artefatos da cultura material. Incentivamos a interação, pretendemos que o usuário possa ser produtor de conhecimento ao contribuir com seleção, identificação e classificação de documentos.

O “Museu Afrodigital Rio" recebeu seu primeiro financiamento em 2010, por meio do Edital Pensa Rio/FAPERJ, o que permitiu sua expansão em termos de tecnologia e pesquisa. Além do apoio recebido da Universidade do Estado do Rio de Janeiro/UERJ que cedeu o espaço, a infraestrutura necessária e bolsistas de extensão, alguns projetos apresentados pela equipe sob minha coordenação foram contemplados pela Faperj e por outros órgãos de financiamento (Edital Humanidades/2011, Edital Apoio a Projetos Temáticos no Estado do Rio de Janeiro/2013, Edital 450 anos da cidade do Rio de Janeiro/2014, Edital Programa de Treinamento e Capacitação Técnica/2015, 2016, 2017 e Edital Preservação e Acesso aos Bens do Patrimônio Afro-brasileiro/2014/ MINC/PROEXT). Os recursos permitiram equipar o espaço físico e potencializar o sítio eletrônico que representa o museu.

Dada a característica do projeto de lidar com novas tecnologias de 
comunicação em grande quantidade de informação num meio digital, foi necessária a aquisição de um servidor que está localizado na sala do Departamento de Informática com temperatura e energia controladas. O museu tem obtido financiamento para bolsistas de apoio técnico, organizações de seminários nacionais e estrangeiros, desenvolvimento de projetos e publicação de livros. Dois seminários foram realizados na UERJ e outro em Havana, este último efetivou-se a partir do convênio realizado com a Casa de África, em Havana, e da parceria com seu diretor, o Prof. Alberto Granado. A partir de 2015, o museu passou a ter uma coordenação colegiada e interdisciplinar constituída pelos Profs. Ana Paula Alves Ribeiro, Gabriel Cid, Guilherme Vargues, Maria Alice Rezende Gonçalves, Maurício Barros de Castro, e por mim. O museu tem cumprido seus objetivos e o número de visitantes tem sido crescente.

A divulgação de pesquisa através da internet é para nós da academia um desafio, o número de pessoas que tem contato com a pesquisa é imenso. Observamos o crescimento contínuo de usuários que acessam o "Museu Afrodigital Rio" desde a sua fundação, o que pode ser associado não só à expansão da internet no país, como também ao interesse específico pelo tema tratado. Se em março de 2012, iniciamos com 39 usuários, 91 visitantes, 4.046 páginas visitadas e $196.92 \mathrm{MB}$ de arquivos copiados, atualmente temos mais de 7 mil usuários, 15 mil visitantes, 100 mil páginas visitadas e 100 GB de arquivos copiados por mês. Embora considerando que a navegação na internet tem suas especificidades, pois o hipertexto é acessado de forma fragmentada e descontextualizada, é inegável a democratização do acesso para aqueles que têm interesse e competência técnica adquirida.

Nos últimos anos, organizei dois livros com os outros membros da coordenação do "Museu Afrodigital Rio", Nos quintais do samba da grande Madureira: memória, história e imagens (Ed. Olhares/2016) e Relações raciais e políticas do patrimônio (Ed. Azougue) e publiquei alguns artigos sobre a especificidade da linguagem digital, suas potencialidades e limites, bem como sobre a importância da mídia digital na democratização da memória das populações negras e africanas:

- Museu digital da memória afro-brasileira: algumas questões (In $O$ Caráter Político dos Museus, MAST/ 2010);

- Museu digital da memória afro-brasileira: um ato de resistência (In A política do intangível: museus e patrimônios em nova perspectiva, EDUFBA/2012); 
- Museu Afrodigital: políticas culturais, identidade afro-brasileira e novas tecnologias (In Museus Afro Digitais e política patrimonial, EDUFMA/2012);

- Museu Afrodigital: desafios na representação do passado (Revista Z Cultural/ 2015).

Os dois museus, um físico e outro virtual, são projetos de extensão que estão conectados a projetos de pesquisa e que têm permitido a dezenas de bolsistas de graduação e de pós-graduação o trabalho integrado desenvolvido pela universidade. Ambos, cada um com suas especificidades, articulam-se às definições e propósitos da nova Museologia Social. Volto a destacar que os resultados do acompanhamento e da análise do funcionamento destes museus foram, como ainda são, parte de estudos constantes que têm sido apresentados em congressos, artigos e livros. Eles geram reflexões, e são exemplos de que extensão e pesquisa se entrelaçam.

\section{Desdobramentos: memória e violência no sistema carcerário}

À medida que o projeto de extensão Ecomuseu Ilha Grande era desenvolvido, foi ficando evidente que muito pouco se sabia sobre as prisões que haviam sido instaladas na Ilha Grande. O que encontramos documentado em biografias, como Memórias do Cárcere, de Graciliano Ramos, apontava para situações dantescas de aprisionamento, mas tínhamos poucos dados oficiais. A partir desta constatação, dei início a um novo projeto de pesquisa, desta vez envolvendo memória e violência.

Na primeira fase da pesquisa, foram feitos levantamentos de processos, relatórios, boletins de ocorrência, e documentos em geral. É importante ressaltar que a documentação sobre instituições penitenciárias não é um bem preservado, e também que não há interesse do Estado em manter arquivos que evidenciam o mau funcionamento e a arbitrariedade das práticas lá desenvolvidas. Depois de dois anos de pesquisa e muitas idas à vila Dois Rios, minha equipe e eu encontramos um galpão em ruínas, com teto parcial, repleto de documentos que haviam sido deixados no local após a desativação e implosão da penitenciária. Diversos processos e documentos oficiais foram encontrados em mãos de guardas e moradores da vila, que os salvaram das ruínas e os guardaram em suas casas. Os arquivos têm coleções incompletas, e mesmo quando os documentos estão sob suas guardas, eles acabam por se deteriorar por falta de verbas 
públicas aplicadas em sua higienização e catalogação. $\mathrm{O}$ acesso nem sempre é possível.

O trabalho de pesquisa documental feito sobre as prisões da Ilha Grande não foi fácil e nem pequeno. A pesquisa se prolongou e, ao longo de dez anos, foram feitos levantamentos de diversos documentos, como decretos, leis, regulamentos, processos, relatórios anuais, boletins de ocorrência, artigos publicados em órgãos oficiais, cartas e fotografias. A busca por esses registros foi feita em arquivos públicos e privados, bibliotecas, museus, centros de estudo e internet. Dentre as instituições visitadas, destacamos o Arquivo Nacional, a Biblioteca Nacional, o Arquivo Público do Estado do Rio de Janeiro, o Centro de Estudos e Pesquisas da Escola de Gestão Penitenciária do Estado do Rio de Janeiro, o Instituto Histórico e Geográfico Brasileiro, a Fundação Getúlio Vargas, a Casa Rui Barbosa, a Biblioteca do Fórum, e a Biblioteca da OAB. A legislação relacionada às instituições penitenciárias foi levantada a partir de diferentes fontes (arquivos e sites especializados).

Os levantamentos feitos em arquivos nos levaram à primeira prisão estabelecida na Ilha Grande, Colônia Correcional de Dois Rios, criada nos primeiros anos da República, que submetia a condições indizíveis aquelas pessoas pobres e miseráveis que perambulavam pelas ruas da capital federal desde finais do século XIX até as primeiras décadas do século XX. Também foi analisada a proposta idealizada ao longo do Estado Novo de criação de duas colônias agrícolas, voltadas para a recuperação através do trabalho de presos de bom comportamento.

Essa pesquisa trouxe à tona diferentes estruturas e políticas de encarceramento instaladas na Ilha Grande entre 1894 e 1945, sendo que em praticamente todas elas os guardas fizeram uso da violência para estabelecimento da ordem. As prisões tinham por característica a manutenção de um regime semiaberto, no qual internos eram obrigados a trabalhar em serviços pesados, como cortes de árvores e carregamento de troncos em terreno irregular. A possibilidade de fuga estava sempre presente e a forma de contenção eram as torturas e mortes, que faziam parte da manutenção do funcionamento das instituições. Durante a maior parte do período estudado as prisões serviram como lugar de isolamento e exclusão dos segmentos mais pobres da população, alijados do mercado de trabalho formal. Os internos da Ilha Grande eram aqueles classificados como contraventores, ou seja, os vagabundos, vadios e capoeiras.

Os resultados da pesquisa estão presentes em relatórios de pesquisa, 
em trabalhos apresentados pelos bolsistas de iniciação científica, alguns deles premiados com menção honrosa (Manuela Castilho Coimbra da Costa, Thatiana Sant'Anna Gonçalves, Yasmim Issa e Marcelo Carvalho), no livro Os Porões da República: barbárie nas prisões da Ilha Grande 1894-1945 (Garamond/EDUERJ/2009), e também em artigos:

- História e Memória: o caso do Ferrugem (Revista Brasileira de História /2003);

- A Prisão dos Ébrios, Capoeiras e Vagabundos no Início da Era Republicana (Topoi/2004);

- A Violência que se Repete no Interior dos Presídios (Revista Interseções/2005).

- Lazareto da Ilha Grande: isolamento, aprisionamento e vigilância nas áreas de saúde e política" (História, Ciências e Saúde Manguinhos/2007);

- Prisões da Ilha Grande (In O Ambiente da Ilha Grande EDUERJ/2009).

Num segundo momento de trabalho, as pesquisas em arquivos continuaram, mas é importante destacar que quanto mais recentes forem as prisões, menos documentos são disponibilizados ao público. Como a pesquisa tinha por objeto um passado recente, ou seja, de acontecimentos ocorridos entre 1938 e 1970, nossa equipe pôde contar com os relatos daqueles que vivenciaram o cotidiano das colônias agrícolas. As entrevistas de maior profundidade, com coleta de informações sobre história de vida, foram realizadas com três funcionários do antigo presídio e um expresidiário, todos do sexo masculino. Os moradores de Dois Rios estão sempre dispostos a colaborar e a esclarecer as dúvidas que vão surgindo ao longo da pesquisa. Mantivemos contato também com familiares de funcionários da Colônia Agrícola do Distrito Federal que residiram em Dois Rios na década de 1940, e que guardam com eles recordações muito positivas.

A análise das entrevistas considerou ensinamentos da história oral e de teorias da memória. Podemos dizer que as lembranças estão atravessadas por esquecimentos, traumas, discursos padronizados e estratégias narrativas diversas. Trazem datas trocadas, versões consolidadas socialmente e, ainda, o lugar do narrador supervalorizado. Em alguns casos, construímos tabelas com informações sobre cada contexto histórico, para podermos localizar no tempo e espaço tudo aquilo que nos era contado. Percebemos discursos 
consolidados coletivamente, com poucas variações entre os entrevistados. Contudo, há nesses depoimentos, sentimentos, emoções, valores, e julgamentos. As lembranças foram capazes de revelar também estratégias de ação frente ao arcabouço institucional criado, até então invisíveis, permitindo uma interpretação mais ampla do que lá acontecia.

Entre 1942 e 1962, a Colônia Agrícola do Distrito Federal (CADF) e a Colônia Penal Cândido Mendes (CPCM), localizadas, respectivamente, na Vila de Dois Rios e na Vila do Abraão, dominaram a cena local. Vinte anos depois, o modelo estava falido, e a Colônia Penal foi desativada. Em 1966, a Colônia Agrícola do Distrito Federal tornou-se uma prisão de segurança máxima, passando a ser denominada Penitenciária Correcional Cândido Mendes. Em 1970, a penitenciária passou a se chamar Instituto Penal Cândido Mendes. Apesar da legislação vigente, das normas estabelecidas e das diversas mudanças, a violência e os maus tratos continuaram. Termos como ilha da Maldição, ilha do Diabo e Caldeirão do Inferno eram utilizados para indicar o que lá se passava.

Assim sendo, paralelamente ao levantamento de processos, boletins de ocorrência, relatórios, ofícios, cartas, notícias de jornais, e debates parlamentares, foram consideradas como elementos condutores dos capítulos apresentados as narrativas de um morador, um guarda e dois internos, quatro personagens que tiveram partes importantes de suas vidas relacionadas às prisões instaladas na Ilha Grande. Através deles, procuramos descrever as práticas de encarceramento em duas colônias agrícolas que foram instaladas na Ilha Grande, com o objetivo de recuperar presos de bom comportamento pelo trabalho. Os relatos analisados trazem experiências de vida particulares, que mostram sentimentos, mentalidades de época e de corporações, e opções de sobrevivência em situações de violência extrema. Embora o foco da pesquisa seja o período entre 1938 e 1966, quando funcionaram na Ilha Grande as colônias agrícolas, à medida que os relatos foram sendo obtidos os períodos analisados se estenderam.

Em 2015, uma licença foi tirada em forma de pós-doutorado, junto ao Núcleo de Estudos da Violência (NEV) da Universidade de São Paulo. A orientação de Marcos Cesar Alvarez e o acompanhamento de algumas atividades do Núcleo, que conta com especialistas de excelência na área de estudo como Sergio Adorno, coordenador do núcleo, e pesquisadores associados como Fernando Salla e Luiz Claudio Lourenço, foram fundamentais para a atualização do debate sobre prisões e finalização do livro Quatro histórias, duas colônias e uma ilha (Garamond/2017). A parte de 
edição de imagens desse livro foi feita por Yves Ribeiro, filho de um antigo médico da Colônia Agrícola que, a partir de um contato inicial para coleta de dados, tornou-se parceiro da pesquisa. O material de pesquisa encontrase disponível no site do grupo de pesquisa Arte, Cultura e Poder (http:/ / artecultpoder.org).

Os resultados dessa segunda fase da pesquisa estão presentes no livro acima citado, nas diversas monografias e dissertações de orientandos, bem como em artigos publicados em revistas de Antropologia, História e Sociologia:

- A invisibilidade da pena: Dois Rios como imagem do paraíso (Tempo Social/2016);

- Madame Satã e as prisões da Ilha Grande (Vibrant/2017);

- Entre militância e vadiagem (Topoi/2017).

Duas reflexões sobre os paradoxos inerentes às destruições sistemáticas de estabelecimentos penais, como Instituto Penal Cândido Mendes, Carandiru e Frei Caneca, através de processos midiáticos, estão presente nos artigos Ruinas e testemunhos: o lembrar através das marcas do passado (UFPB) e $O$ espetáculo da destruição e a manutenção do sistema, que fazem parte, respectivamente, da coletânea organizada pelo Prof. Antonio Motta na Revista Política e Trabalho da UFPB, bem como por aquela organizada por Patrícia Birman et allii no livro Dispositivos urbanos e tramas dos viventes: ordens e resistências. Diante da constatação de que o passado, ao ser marcado pela violência, passa por processos muitas vezes inibidores da representação, procurou-se valorizar a multiplicidade de fatores e elementos que incidem sobre sua representação.

A pesquisa sobre memória e violência tem considerado tanto elementos inerentes à natureza do sistema prisional em sociedades modernas, como também elementos constituintes da sociedade brasileira. Algumas questões centrais atravessam as análises sobre os dois períodos (1894/1945 e 1945/1994): a ineficiência do sistema e a violência intramuros. Reiteradas sempre, essas são questões abordadas por praticamente todos os estudiosos do tema. A primeira fase da pesquisa, com dados mais historiográficos, apresentada no livro Porões da República, foi capaz de mostrar a reiteração da violência sobre uma população negra e pobre em diversos contextos políticos e regimes carcerários. Na segunda fase, presente em Quatro histórias, duas colônias e uma ilha, tive por base entrevistas e histórias orais 
e procurei mostrar que aqueles que estão do lado de fora das prisões não compartilham os mesmos códigos daqueles que estão do lado de dentro. Ao entrar na cadeia, o indivíduo recorre a alternativas que não pertenciam ao mundo a que antes pertencia. É preciso ainda ressaltar que o estudo da violência nas prisões envolve dificuldades de compreensão. Enquanto pesquisadora, senti, em vários momentos, necessidade de afastamento de um mundo cujas regras agridem o senso comum.

O impacto do trabalho acadêmico sobre a opinião pública ainda é um desafio a ser enfrentado, principalmente em questões estruturais como políticas carcerárias, em que as narrativas dos meios de comunicação se alinham às preocupações mais imediatas de segurança pública e de controle da ordem social. Nesse sentido, a abordagem ao mundo carcerário através da história e da memória cumpre o papel de ampliar as dimensões de sentidos sobre uma das instituições mais perversas da sociedade contemporânea.

Todo esse processo foi desenvolvido com muitas parcerias e a muitos devo agradecer as contribuições. Colaboraram com lembranças e depoimentos os antigos guardas e policiais militares que trabalharam em Dois Rios, bem como suas esposas, filhos e filhas, que ainda hoje moram em Dois Rios: Júlio de AlmeidaF, Lupércio de AlbuquerqueF, Hotair da Silva Souza, Maria José Pereira de Souza, Getúlio Cantuária da Silva, Tereza Pimenta, Luiz Carlos Alves Pereira, Margarida Augusta, Pedro dos Santos, José do Ribamar, e Marilene da Silva Campos. Um grupo de moradores de Dois Rios nas décadas de 1940 e 1950 foi fundamental à compreensão da prisão naquele período: Oli Demutti Moura, Edonée Esteves Demutti, Sergio Esteves Demutti, e Yves Ribeiro Filho, este último se tornou parceiro na organização final do livro. Os bolsistas de iniciação científica foram fundamentais nesse percurso. Inicialmente trabalharam comigo Fabio Cardoso Ponso, Ingrid Borges Lemos, Denise Almeida Rodrigues, Marcela Marques Serrano. A partir da maior estruturação do projeto, contribuíram Cintia Guimarães, Thatiana Sant'Anna Gonçalves, Inês Nogueira, Thaís Lemos e Thaís Cavalcante. Em 2004, junto a Marcelo Castañeda, Manuela Castilho e Carolina Gonçalves Alves fizemos algumas entrevistas com antigos presos políticos. Meus agradecimentos a todos os entrevistados do período: André Borges, Carlos Eduardo Ulup, Fernando Palha Freire, e Nelson Rodrigues Filho. A partir de 2010, Amanda Riodades, Clarisse Silveira, Inoã Pierre Carvalho Urbinati, Raquel Glória Moreira, Renata Moreira Fontoura, e Rafaely Camilo Costa estiveram presentes no levantamento de dados em arquivos públicos e entrevistas. Nos últimos 
anos, minha equipe de trabalho foi composta pelos bolsistas Marcelo Carvalho, Weslley Matos e Yasmim Issa. Novas entrevistas foram feitas com André Borges e William da Silva. Sara Dias, chegada de Moçambique, me deu apoio com a transcrição de entrevistas realizadas com Júlio de Almeida. Muitos destes bolsistas desenvolveram suas próprias pesquisas sobre o tema e contribuíram para a realização deste trabalho.

Difícil pensar em Ilha Grande, sem lembrar de Simonne Martins de Carvalho, que foi orientanda de graduação e acompanhou a pesquisa, enriquecendo as reflexões, principalmente sobre as dificuldades e maus tratos por que passam os familiares daqueles que são encarcerados. Nas idas à Ilha Grande, encontrei muitos moradores que me deram informações importantes sobre o período das prisões e fiz amigos: Antonio Simplício, Constantino Cokotós (falecido), Alexandre de Oliveira e Silva, Graciela Cuellar, Renato Motta, Maria Rachel Sousa, Nair Mattoso, e Renato Buys. Aprendi bastante, com minhas companheiras antropólogas e grandes amigas, Patrícia Birman e Rosane Prado, que também fizeram suas etnografias e estudos na Ilha Grande.

\section{Atividades de ensino e administração}

As atividades de ensino e gestão se entrelaçam. Entrei para a UERJ em março de 1994 e imediatamente comecei a lecionar na graduação. Dois anos depois passei a membro do corpo docente do Programa de Pós-Graduação em Ciências Sociais. Na UERJ os professores são responsáveis por três cursos por semestre. No antigo Instituto de Filosofia e Ciências Sociais, e no atual Instituto de Ciências Sociais, os membros do colegiado têm o acordo de ministrarem apenas um curso por ano na pós-graduação. Assim sendo, exceto pelos anos de afastamento em pós-doutorado, fui responsável por três cursos por semestre, que somam mais de 50 cursos ao longo de 23 anos de profissão.

Nos primeiros anos fui responsável pelas disciplinas de Teoria Social Contemporânea para os alunos de graduação, especialização, mestrado e doutorado. Esses cursos alimentaram minhas pesquisas e publicações sobre teorias da memória. Ao retornar do primeiro período de pós-doutoramento com uma pesquisa sobre memória, museus e modernidade, passei a oferecer cursos sobre estas temáticas específicas. O mesmo aconteceu após a realização das pesquisas sobre memória e violência em sistemas carcerários.

As pesquisas propiciam cursos reflexivos, os quais, por sua vez 
contribuem com o que estamos produzindo academicamente. É inegável que a transmissão de conhecimento e o aprendizado usufruído com essa experiência representam a gratificação diária em nosso cotidiano acadêmico. A diversidade de disciplinas ministradas acompanhou as pesquisas realizadas e os interesses dos alunos. Foram cursos, na maioria das vezes, de teoria social, memória social e sociologia da cultura.

As tarefas de administração não são poucas ao longo da carreira de professores universitários. Devido às carências de estrutura básica presente em universidades públicas, é importante ressaltar que estas tarefas requerem qualificações, como as de administração e de contabilidade, que às vezes fogem de nossas competências, para que objetivos sejam cumpridos.

Assumi a vice-coordenação do Programa de Pós-Graduação em Ciências Sociais (PPCIS) a convite do Prof. Luiz Eduardo Soares, em 1998, com o objetivo de criar o projeto de doutorado interdisciplinar para o Programa. Poucos meses depois, a Universidade entrou em greve. A tarefa de manter o Programa funcionando, coordenar eventos internacionais relacionados ao novo projeto, e adequar o projeto idealizado aos perfis do conjunto de professores foi uma experiência, senão traumática, bastante trabalhosa e de difícil realização. Ainda como parte da consolidação do Programa, e em conjunto com os Profs. Clarice Peixoto e Valter Sinder, fui responsável pela edição da Revista de Estudos Interdisciplinares Interseções, do PPCIS, desde sua criação em 1999 até 2010, quando uma nova equipe assumiu. De qualquer forma, estas atividades foram apenas as primeiras de uma série de comprometimentos profissionais desenvolvidos na área administrativa.

Entre 2000 e 2009, foram muitas as funções assumidas junto à SubReitoria de Pós-Graduação (SR-2) para que o Ecomuseu Ilha Grande fosse inaugurado. Em dois momentos obtive licença parcial no PPCIS a que pertencia para poder dar prosseguimento ao projeto. Atualmente, faço parte do Comitê Científico do museu.

A partir de 2003, o Departamento de Museus do IPHAN, e, mais tarde, o recém-criado Instituto Brasileiro de Museus (IBRAM) tomaram uma série de iniciativas no sentido de democratizar o acesso, o conhecimento e a administração dos museus públicos. Foram criados fóruns nacionais, dos quais participei como relatora, e editais. Tive a oportunidade de colaborar com as novas políticas culturais que estavam sendo implementadas nessa área sendo relatora nos Fóruns Nacionais e participando como membro do Conselho do Sistema Federal de Cultura, entre 2009 e 2014.

Algumas atividades se destacam no campo administrativo pela 
dedicação necessária ao seu bom desenvolvimento. Uma delas é a participação em comitês de avaliação de bolsistas de iniciação científica (PIBIC), tarefa que venho realizando tanto no âmbito da UERJ, bem como nos de outras universidades públicas. Da mesma forma, a participação em bancas de admissão à carreira docente é uma atividade que requer bastante compromisso e responsabilidade. Participei na seleção de professores da área de Sociologia em diversas instituições (FIOCRUZ, UFSCAR, UFRJ, UNIRIO, UNICAMP, UERJ)

Cabe ainda destacar os diversos pareceres emitidos para organizações e instituições governamentais (USP, Secretaria de Ciência e Tecnologia do Estado de Tocantins); agências de fomento (CNPq, CAPES, FAPERJ, FAPESP, FFLCH/USP, FAPESPA, FAPEMA, FACEPE; editoras (Edições UESB; EDUFMA; Scielo); e revistas acadêmicas internacionais e nacionais (Theory, Culture and Society; Time \& Society; Trames; Journal of Latin American Anthropology; Latin American Research Review; Luso-Brazilian Review; Revista Cadernos CES; Cadernos CRH UFBA; Revista Brasileira de Ciências Sociais; Tempo Social; História, Ciências, Saúde-Manguinhos; Revista Estudos Históricos (FGV); BIB: Sociedade e Estado; Sociologia e Antropologia; Política e Trabalho; Religião e Sociedade; Revista Psicologia Política; Interseções; Musas; Museologia e Patrimônio; Revista CPS/USP; Anais do Museu Emílio Goeldi, entre outras)

Em suma, foram diversos os cargos de coordenação assumidos ao longo dos anos na instituição de pertencimento e em agências e órgãos governamentais: Universidade do Estado do Rio de Janeiro (Coordenadora de Graduação, Coordenadora de Pós-Graduação, Coordenadora de Área, Coordenadora de Projetos de Extensão, Assessora da Sub-Reitoria de PósGraduação, Membro do Conselho Consultivo do Ecomuseu Ilha Grande, Membro dos Comitês de Avaliação do PIBIC e do PROCIÊNCIA); Capes (Projeto Qualis); IPHAN (relatora em encontros nacionais); e IBRAM (membro do Conselho do Sistema Federal de Cultura). Destaco a coordenação do Museu Afrodigital Rio e do Grupo de Pesquisa Arte, Cultura e Poder, com cadastro no CNPq. Este último é um grupo interdisciplinar que reúne professores brasileiros e estrangeiros no desenvolvimento de estudos sobre arte, cultura e suas interseções com o poder. Ambos os projetos têm sítios eletrônicos, pelos quais sou responsável (www.museuafrodigitalrio. org e www.artecultpoder.org). 


\section{Desenvolvimento da pesquisa: museus e memória}

(...) necessitamos de uma crítica dos valores morais, o próprio valor desses valores deverá ser colocado em questão - para isto é necessário um conhecimento das circunstâncias e condições nas quais nasceram, sob as quais se desenvolveram e se modificaram

(...) Friedrich Nietzsche

A preocupação em perceber a historicidade das construções sociais e suas transformações ao longo do tempo está sempre presente entre filósofos, sendo que os pensamentos de alguns deles - Friedrich Nietzsche, JeanFrançois Lyotard, Martin Heidegger, Michel Foucault, Jacques Derrida, Hans-Georg Gadamer e Paul Ricoeur, entre outros - têm tido enorme impacto nos estudos sociais e políticos das últimas décadas. Em que pese as distinções entre posições interpretativas e hermenêuticas e outras desconstrutivistas, estes são autores que trazem a questão do movimento do tempo para os estudos da sociedade. Gadamer trabalhou com o conceito de tradição em movimento, Foucault procurou resolver o problema através de uma abordagem denominada por ele de genealogia do poder, e Jacques Derrida foi autor do conceito de différance. Em todos eles, a fluidez e transitoriedade do tempo é um aspecto crucial de análise.

A percepção da memória como processo e produto que se transformam continuamente traz imprevisibilidade e incerteza às narrativas sobre o passado, pois sabemos que algo está sempre escapando do campo interpretativo e das memórias que elegemos como objeto. Esta já era uma questão central no início de minha carreira acadêmica, quando procurei analisar as narrativas da história em museus. A pesquisa de doutorado foi sobre teorias da memória, e aquela desenvolvida no pós-doutorado voltou seu foco para os novos discursos e práticas presentes em museus contemporâneos, que se adaptavam às novas demandas de público e consumo na era da globalização. A partir da pesquisa de pós-doutorado, procurei trabalhar não apenas com os processos da memória, mas com seus produtos.

A partir dos anos 1970, a chamada Nova Museologia questionou a centralidade dos objetos nas exposições e foi responsável pela criação de museus voltados para a questão social. As instituições museológicas se diversificaram, tanto em termos de produção e financiamento, como em 
temática. No que diz respeito às técnicas de representação, muito pode ser dito. Dos antigos expositores educativos que procuravam reproduzir o mundo real, chegou-se a uma diversidade de iniciativas, dentre as quais a produção de novas experiências, que agregam imaginação, emoções e sentidos, ganha fôlego. A ênfase dos museus na consolidação dos estados nacionais foi substituída por uma diversidade de temas e pela adequação às novas políticas de identidade. As pesquisas realizadas procuraram apontar transformações ocorridas nas narrativas de grandes museus nacionais, considerando transformações sociais e políticas mais gerais.

Os estudos sobre museus e memória foram apresentados em encontros, seminários e congressos, nacionais e internacionais. No Brasil, participei e coordenei grupos de trabalho temáticos da ANPOCS,SBSe ABA. Esses fóruns possibilitaram o intercâmbio e formação de um grupo de intelectuais que desenvolvem pesquisas nesta área. Embora seja difícil nomear companheiros nesta trajetória sem fazer injustiças a partir de esquecimentos, gostaria de destacar a parceria com Mario Chagas, Joana D’ Arc Ferraz, Rogério Ferreira de Sousa, Regina Abreu, Reginaldo Gonçalves, Manoel Ferreira e Carlos Gadea. Com Mario Chagas e Regina Abreu foi organizada a coletânea Museus, coleções e patrimônios: narrativas polifônicas (Garamond/2007). Com Joana D'Arc Ferraz e Rogério Ferreira de Sousa, Deserdados: dimensões das desigualdades sociais (Editora H. P. Comunicações/2007). Paralelamente a essas reflexões, trabalhei ainda com o conceito de interdisciplinaridade, tão caro aos estudos sobre a memória, em Integração e diferença em encontros disciplinares (Revista Brasileira de Ciências Sociais/2007) e com o conceito de aura, em À procura da alma encantadora da cidade (In Museus, Coleções e Patrimônios: narrativas polifônicas, Garamond/2007).

Em 2009, obtive uma licença para capacitação docente para realização do segundo pós-doutorado. No Centro de Estudos Sociais, coordenado pelo Prof. Boaventura dos Santos, na Universidade de Coimbra, fui recebida pelo Prof. Paulo Peixoto, com quem diversas parcerias acadêmicas foram desenvolvidas. Em 2011, ele veio ao Brasil como professor visitante do Programa de Pós-Graduação em Ciências Sociais (PPCIS) e como consultor do Museu Afrodigital Rio. Firmamos um convênio entre o PPCIS/UERJ e o CES/Universidade de Coimbra, e através dele desenvolvemos pesquisas conjuntas, incentivando o intercâmbio entre docentes e discentes das duas universidades.

Acompanhando o maior interesse pela memória na área da Sociologia da Cultura, criei, também em 2009, o grupo de pesquisa "Arte, Cultura 
e Poder", que agrega pesquisadores de diversas áreas disciplinares. As pesquisas trabalham com o entrelaçamento entre memória, arte e cultura nas dinâmicas de poder. Destaco aqui a parceria com os Profs. Victor Hugo Adler, Geraldo Pontes e Carmem Lucia do curso de Pós-Graduação em Letras da UERJ. A partir de discussões sistemáticas, dois seminários foram organizados por nós envolvendo pesquisadores de instituições nacionais e estrangeiras. As linhas de pesquisa se consolidaram com a entrada de pesquisadores de instituições parceiras (CPDOC/FGV, UNIRIO, UFG, UFBA, CES/Universidade de Coimbra e IL/Universidade Livre de Berlim).

Nesse período, as pesquisas realizadas no campo das políticas da memória já eram bem significativas. Autores como Walter Benjamin, Eric Hobsbawm e Michel Pollak, por diferentes caminhos, tornaram-se referências para as críticas à utilização e à imobilização do tempo enquanto uma política de controle da cultura ocidental. Partindo da consideração de que a relação entre passado e presente é complexa e dinâmica, tendo sempre que considerarmos os dois polos da equação, minha pesquisa procurou mostrar a presença não só de uma política da memória, mas de diversas políticas da memória em museus brasileiros. Significados e valores veiculados em nome da tradição ou da modernidade atenderam interesses de grupos sociais de múltiplas formas.

Muitas mudanças ocorreram nos museus brasileiros nas últimas décadas. As novas práticas culturais que surgiram em torno do tema da preservação da memória ampliaram e democratizaram as iniciativas já existentes. Uma das novidades do campo foi o surgimento de políticas de preservação de patrimônios imateriais ou intangíveis, que procuraram valorizar práticas culturais de populações menos privilegiadas. Podemos ainda destacar o surgimento de iniciativas que partiram de populações subalternas. Alinhados a movimentos sociais diversos, entre eles àqueles constituídos por afrodescendentes e populações indígenas, os novos museus e lugares da memória procuram garantir o direito de constituírem suas próprias narrativas. Os conflitos resultantes de guerras culturais se fortaleceram, criando novas demandas por autodeterminação.

Questões relacionadas às políticas da memória têm ocupado não apenas o centro de debates acadêmicos, mas têm também marcado movimentos sociais e políticos, em esferas locais, nacionais e transnacionais. A escritora e crítica literária argentina Beatriz Sarlo tem afirmado com certa preocupação que nunca, como nos tempos atuais, foi a memória um tema tão espetacularmente social. Inegavelmente, nós pesquisadores nos 
voltamos cada vez mais tanto para as práticas de construção das memórias, na formação de identidades do presente, como para as que procuram o dever da justiça em relação ao passado.

As repercussões das pesquisas realizadas sobre políticas da memória ocorreram a partir da formação de bolsistas de iniciação científica, mestres, doutores e pós-doutores; organização de seminários; e publicações. Em 2010, o primeiro seminário internacional do grupo foi organizado, tendo como um de seus resultados a publicação do livro Memória, cultura e poder (EDUERJ). Em 2011, um grupo de trabalho foi organizado no âmbito da SBS. Como atividade para 2013, o grupo organizou o segundo seminário internacional. Um de seus resultados foi a publicação do livro Diálogos Interdisciplinares: literatura e políticas culturais (EDUERJ). Nessa fase da pesquisa, alguns artigos e o livro Memória coletiva e identidade nacional (Garamond/2013) foram publicados. Sobre o livro, gostaria de reproduzir a apresentação feita por Mario Chagas, que, em muito sintetiza o esforço realizado:

O livro Memória coletiva e identidade nacional é ele mesmo um exercício de memória e identidade. Myrian Sepúlveda dos Santos debruça-se sobre sua própria produção nos últimos vinte anos e de modo crítico reescreve e reafirma sua conexão com o presente. Ao defender abordagens críticas e interdisciplinares, Myrian favorece a compreensão da existência de vários caminhos de aproximação e afastamento do passado, da memória e da identidade. Mas no livro de Myrian também estão, à sua revelia, as nossas memórias e identidades de leitores, de estudantes, de pesquisadores, de companheiros de jornada e as possibilidades de novas construções de memória e identidade. Os textos aqui reunidos nos ajudaram e continuam nos ajudando a pensar, sentir e agir. Mario Chagas

Dentre os artigos, gostaria de destacar o artigo História, Memória e Esquecimento: implicações políticas, escrito em parceria com a Profa. Maria Paula Nascimento, sobre a politização do uso da memória por setores subalternos da população. O artigo teve grande repercussão e foi publicado pela revista Estudios Sociales (2007), pela Revista Critica em Ciências Sociais (2007) e, novamente pela RCCS Annual Review (2009). Outro artigo que também obteve repercussão foi aquele publicado pela Revista da USP, em 2014: Memória coletiva, trauma e cultura: um debate. Ainda no campo teórico, apresentei em congresso e publiquei algumas reflexões sobre o crescimento 
da influência pós-estruturalista nas Ciências Sociais:

- O prefixo pós nas Ciências Sociais (In A questão pós nas Ciências Sociais, Appris/2013).

No que diz respeito às mudanças observadas em museus brasileiros, os quais, a partir dos anos 2000, adaptaram-se às novas demandas de mercado e de movimentos sociais identitários, alguns dos textos produzidos podem ser destacados:

- Museus, liberalismo e indústria cultural (Revista Ciências Sociais Unisinos/2011).

- Brazilian culture as a category of public intervention (In Brazil emerging: Inequality and emancipation, Routledge/2013).

- A mundialização e fragmentação do patrimônio (In Patrimônios do Brasil, Azougue / 2013).

- Naturalists in Nineteenth-Century Brazil (Archiv für Völkerkunde /2014).

- New Initiatives Emerging in the Brazilian Museum Field (Museum International/ 2014).

- Por uma sociologia dos museus (Cadernos do CEOM/2015).

Ao longo desse período, o grupo obteve auxílio financeiro da UERJ e de agências de fomentos para compra de equipamentos e montagem do sítio eletrônico. Auxílios foram recebidos do CNPq (Edital MCT/CNPq 02/2009 - Ciências Humanas, Sociais e Sociais Aplicadas), da CAPES (Organização de eventos 2010 e 2013) e da FAPERJ (Edital Humanidades/2011, Edital Apoio a Projetos Temáticos no Estado do Rio de Janeiro/2013). Os recursos permitiram a montagem de um espaço físico para o grupo de pesquisa Arte, Cultura e Poder, no âmbito da Universidade do Estado do Rio de Janeiro, bem como sítio eletrônico para divulgação dos projetos. O terceiro seminário foi organizado para o ano de 2016, mas não chegou a se realizar devido à crise pela qual passa a Universidade do Estado do Rio de Janeiro (UERJ). Continuamos com a intenção de realizá-lo em 2018.

Entre 2009 e 2017, a pesquisa sobre políticas da memória enfatizou alguns temas, como narrativas constituídas sobre a escravidão e aquelas que compõem hoje diversos museus da Rede de Museologia Social do Rio de Janeiro (REMUS). A Rede define seu objetivo como sendo o de 
trocar experiências entre comunidades populares, movimentos sociais e instituições que atuam no campo da memória, patrimônio e cultura, com o intuito de potencializar a memória como fator de inclusão e transformação social. Fazem parte da rede museus: o Museu da Maré, no Complexo da Maré (RJ); o Museu Sankofa, na Rocinha (RJ); a Vila do Horto, no Jardim Botânico (RJ); o Museu Vivo do São Bento, em Duque de Caxias (RJ); e o Museu de Favela (MUF), no Pavão-Pavãozinho e Cantagalo (RJ).

As representações do negro e da escravidão nos museus brasileiros lidam com questões de poder e discriminação. Em grande parte de museus subsidiados pelo Estado observamos ainda hoje silêncio, representações estereotipadas e vitimização. Diferentemente, as representações que reforçam a identidade negra surgem em um grupo de nos novos museus afro-brasileiros, sem que velhos discursos sejam refeitos nos museus tradicionais. As narrativas sobre a escravidão são bastante delicadas e trazem polêmicas, pois elas lidam com uma memória de sofrimento e dor, plena de conflitos e relações de poder, que permanece em disputa. A representação exacerbada e unilateral do indivíduo escravizado como vítima, em correntes e sendo espancado, pode aparecer como denúncia, mas pode também negar a ele seu lugar de protagonista da história. Cito alguns dos artigos publicados em revistas e coletâneas sobre narrativas da escravidão:

- Entre Troncos e Atabaques (In Projeto Unesco no Brasil, EDUFBA/ 2007);

- The Repressed Memory of Brazilian Slavery (International Journal of Cultural Studies/2008);

- A Representação da Escravidão (Anais do Museu Histórico Nacional/2008);

- The Legacy of Slavery in Contemporary Brazil (In African Heritage and Memories of Slavery in Brazil and the South World, Amherst/2014);

- \& Castro, M.B. Um Verger, Dois Olhares: a construção da africanidade brasileira por um estrangeiro (Caderno CRH/2016).

Observamos, nas últimas décadas, o surgimento de uma diversidade de iniciativas vinculadas à preservação da memória nos museus brasileiros. Muitas dessas iniciativas vincularam-se aos pontos de memória incentivados pelo Instituto Brasileiro de Museus (IBRAM). Outras podem ser associadas ao Movimento Internacional para uma Nova Museologia (MINON), 
criado em 1985, que se define a partir de práticas interativas e voltadas para transformações sociais e culturais. Questões relacionadas às políticas da memória têm ocupado não apenas o centro de debates acadêmicos; elas estão presentes em movimentos sociais e políticos, de esferas locais, nacionais e transnacionais. Novas iniciativas no campo da memória se associam aos movimentos sociais e à defesa de direitos humanos.

\section{Perspectivas futuras}

Desde 2001 tenho recebido apoio da Universidade do Estado do Rio de Janeiro às pesquisas realizadas por meio da infraestrutura e da bolsa PROCIÊNCIA. A partir de 2003, obtive apoio do CNPq aos projetos de pesquisa e, em 2016, da FAPERJ, através do programa Cientista do Nosso Estado (CNE). Essas bolsas permitem o trabalho de campo, a obtenção de apoio técnico, a compra de material de pesquisa, e viagens relacionadas à pesquisa. Elas também possibilitam a manutenção de sítios eletrônicos dos grupos de pesquisa. Atribuo, portanto, os resultados das pesquisas apresentadas a todo o suporte recebido ao longo da carreira acadêmica. cujo desenvolvimento dependerá da continuidade desses apoios

Como já mencionado, podemos relacionar a memória a diferentes contextos históricos e sociais, e, nesse sentido, a obsessão pela memória no mundo moderno pode ser vista como consequência de um conjunto de fenômenos, desde enfraquecimento de tradições e referências morais até fragmentação das esferas sociais. Nas últimas décadas, contudo, a memória passou a ser percebida não apenas como preservação do passado, mas a partir de movimento e de relações de poder. Embora nas ciências sociais, a tendência tenha sido o abandono de discussões filosóficas e psicanalíticas, a partir da tentativa de redução da complexidade das relações sociais a um único vetor, abordagens interdisciplinares redefiniram o campo de estudos da memória. Emoções e sentimentos deixaram de ser negligenciados. Nesse sentido, o passado se apresenta em meio às experiências do presente, não como construção ou invenção, mas como intervenção ativa. Essas considerações nos levam a analisar a natureza de museus e sítios de consciência, que se definem em termos de intervenção social.

O projeto "Museus de consciência, um novo desafio" busca analisar as transformações ocorridas nas últimas três décadas na área de museus e memória. Ao longo do século XX, a multiplicação de museus e de sítios da memória aparece relacionada às novas demandas de consumo, turismo 
e formação de novas identidades. O projeto agora apresentado aponta para uma nova guinada nesses sítios relacionados à memória, pois neles $\mathrm{o}$ passado se atualiza levando a novas missões como reparação e justiça. As mudanças nas áreas de memória e patrimônio acompanham mudanças na relação espaço - tempo, presente nas diversas áreas do conhecimento. $\mathrm{O}$ argumento que vem sendo desenvolvido é que o horizonte de expectativas, tão característico da modernidade, vem dando lugar a uma percepção de passado que se atualiza em práticas políticas que atualizam o passado continuamente. $\mathrm{O}$ projeto em questão tem a intenção de analisar quatro temas nos sítios de consciência: escravidão, sistema penitenciário, habitação precária e regimes militares da América Latina.

A International Coalition of Sites of Conscience é uma organização criada em 1999, em Nova York, Estados Unidos, e financiada por fundações como a Ford Foundation e o United States Department of State Bureau of Democracy, Human Rights, and Labor. A missão da organização é engajar o público na conexão entre passado e presente, a fim de moldar uma sociedade mais justa e humana. No sítio eletrônico, a organização se apresenta como sendo a única rede mundial dedicada à transformação dos lugares que preservam o passado em espaços dinâmicos que promovem a ação cívica nas lutas atuais pelos direitos humanos e por justiça. A organização conta com 200 membros, denominados de sítios de consciência, espalhados pelos cinco continentes. A maior parte desses sítios está localizada na América do Norte (117); os demais estão distribuídos entre América do Sul (24), África (12), Europa (42), Ásia (16) e Oceania (9).

As instituições associadas à Coalizão estão organizadas em torno da denúncia de questões diversas como o regime escravocrata imposto aos africanos nas Américas; as torturas e mortes ocorridas no período dos regimes militares na América Latina; a ocupação nazista e a formação dos campos de concentração na Europa; o apartheid na África do Sul; e o regime do Khmer Vermelho na Camboja; e a violência contra mulheres. Dentre as ações cívicas propostas, encontramos: gravação da história de um sobrevivente do genocídio em Bangladesh pelo seu neto; divulgação da opinião dos recém-chegados aos EUA sobre a definição de nacionalidade; e recriação da paisagem urbana na Cidade do Cabo por ex-moradores de um bairro destruído pelo apartheid. Museus são conectados entre si e enfrentam violações que se entrelaçam, como, por exemplo, desemprego, racismo, e maus tratos no regime penitenciário. Comissões de justiça e reparação são formadas para dar suporte e oferecer alternativas. Garantir aos cidadãos 
direitos humanos é garantir o direito à vida e à morte dignas. Contudo, esses são direitos que cada vez mais se confundem com direitos civis.

A importância de sítios da memória na vida política das cidades e das nações continua a ser grande. Em plena era Trump, no dia 12 de agosto de 2017, o mundo observou atônito a marcha de centenas de extremistas norte-americanos em Charlottesville, Virgínia (EUA), devido à retirada da estátua de Robert E. Lee, um general confederado que lutou na Guerra Civil Americana, a favor da manutenção da escravidão. A reação chegou por parte de ativistas - como aqueles pertencentes ao movimento Black Lives Matter - e o resultado foi o confronto violento. Torna-se evidente que os monumentos não estão relacionados apenas ao passado, mas aos conflitos raciais do presente.

A recente guinada que observamos em sítios de consciência não se resume às guerras de representação. As práticas existentes afastam-se de questões de identidade e representação e se voltam para uma intervenção direta nos conflitos existentes. De domínio quase exclusivo de lideranças políticas e intelectuais, a defesa de sítios históricos e memorialísticos passa a ser realizada por moradores de favelas, quilombolas, populações indígenas, refugiados e movimentos organizados de diferentes matizes. A proposta é a de acompanhar as novas iniciativas de construção memorialística para avaliar seu alcance e repercussão. Em suma, essa pesquisa pode ser vista como parte do crescente interesse sobre memória, contribuindo para a compreensão da centralidade que o passado tem assumido nas demandas recentes não só por identidade, como também por reparação e justiça.

\section{Referências}

Abreu, Regina Maria do Rego Monteiro de. (1996). A Fabricação do Imortal. Rio de Janeiro: Rocco/Lapa.

Adorno, Sérgio.

(1995). “Discriminação racial e justiça criminal em São Paulo". Novos Estudos. Cebrap, 43, pp. 45-63.

Alvarez, Marcos César.

(2002). "A criminologia no Brasil ou como tratar desigualmente os desiguais". Dados Revista de Ciências Sociais, v. 45, n.4, pp. 677704.
Arato, Andrew.

(1977). The Antinomies of the Neo-Marxian Theory of Culture. In International Journal of Sociology, p 3-25.

Benjamin, Walter.

(1968). Illuminations, ed. Hannah Arendt. Nova Iorque: Harcourt Brace \& World.

Benjamin, Walter.

(1978). Reflections: Walter Benjamin Essays, Aphorisms, Autobiographical Writings, ed. Peter Demetz. Nova York: Harcourt, Brace, Jovanovich. 
Bernstein, Richard J.

(1983). Beyond Objectivism and Relativism: Science, Hermeneutics, and Praxis. Philadelphia: University of Penn-sylvania Press.

Butler, Judith.

(2003). Problemas de gênero: feminismo e subversão da identidade. Rio de Janeiro: Jorge Zahar.

Chagas, Mario de Souza.

(1994). Novos Rumos da Museologia. Lisboa: Universidade Lusófona de Humanidades e Tecnologias (ULHT), 1994.

Gonçalves, José Reginaldo Santos.

(1996). A Retórica da Perda: os discursos do patrimônio cultural no Brasil. Rio de Janeiro: Universidade Federal do Rio de Janeiro.

Habermas, Jürgen.

(1984/7). The theory of communicative action (vol.1/2): Boston: Beacon Press.

Habermas, Jürgen.

(1989). The New Conservatism: Cultural criticism and the Historians' Debate. Studies in Contemporary German Social Thought. Cambridge, Mass.: MIT Press.

Halbwachs, Maurice.

(1968 [1950]). La mémoire collective. Paris: Presses Universitaires de France.

Halbwachs, Maurice.

(1994 [1925]). Les cadres sociaux de la mémoire. Paris: Albin Michel.

Heller, Agnes.

(1990). Can Modernity Survive? Berkeley e Los Angeles: University of California Press.

Hobsbawm, Eric \& Terence Ranger (eds.).

(1983). The Invention of Tradition. Cambridge: Cambridge University Press.

Koselleck, Reinhart.

(1985). Futures Past: On the Semantics of Historical Time. Studies in Contemporary German Social Thought. Cambridge, Massachussetts: The MIT Press.
La Capra, Dominick.

(1994). Representing the Holocaust: History, Theory, Trauma. Ithaca, NY: Cornell University Press.

Lourenço, Luiz Claudio.

(2010). Batendo a tranca: Impactos do encarceramento em agentes penitenciários da Região Metropolitana de Belo Horizonte. Dilemas: Revista de Estudos de Conflito e Controle Social, v. 3, n.10, pp. 11-31.

Nietzsche, Friedrich.

(2007 [1887]). Genealogia da Moral: uma polêmica. São Paulo: Companhia das Letras.

Nora, Pierre (ed.).

(1984, 1986, 1992). Les Lieux de Mémoire. La République.1; La Nation 2; Les France 3. Paris: Éd. Gallimard.

Pollak, Michael.

(1989). Memória, Esquecimento, Silêncio. Estudos Históricos 2 (3): 3-15.

Sansone, Lívio.

(2004). Negritude sem etnicidade: o local e o global nas relações raciais e na produção cultural negra do Brasil. Rio de Janeiro: Pallas; Salvador: EDUFBA.

Sarlo, Beatriz.

(2007). Tempo passado: cultura do passado e guinada subjetiva. São Paulo: Companhia das Letras; Belo Horizonte: UFMG.

Spivak, Gayatri.

(2010). Pode o subalterno falar? Belo Horizonte: Editora UFMG. 